\title{
Overgangsrecht nieuw Burgerlijk Wetboek : systematiek, uitgangspunten en toepassingen
}

Citation for published version (APA):

van der Beek, H. L. (1992). Overgangsrecht nieuw Burgerlijk Wetboek : systematiek, uitgangspunten en toepassingen. [Doctoral Thesis, Maastricht University]. Kluwer. https://doi.org/10.26481/dis.19920626hb

Document status and date:

Published: 01/01/1992

DOI:

10.26481/dis.19920626hb

Document Version:

Publisher's PDF, also known as Version of record

\section{Please check the document version of this publication:}

- A submitted manuscript is the version of the article upon submission and before peer-review. There can be important differences between the submitted version and the official published version of record.

People interested in the research are advised to contact the author for the final version of the publication, or visit the DOI to the publisher's website.

- The final author version and the galley proof are versions of the publication after peer review.

- The final published version features the final layout of the paper including the volume, issue and page numbers.

Link to publication

\footnotetext{
General rights rights.

- You may freely distribute the URL identifying the publication in the public portal. please follow below link for the End User Agreement:

www.umlib.nl/taverne-license

Take down policy

If you believe that this document breaches copyright please contact us at:

repository@maastrichtuniversity.nl

providing details and we will investigate your claim.
}

Copyright and moral rights for the publications made accessible in the public portal are retained by the authors and/or other copyright owners and it is a condition of accessing publications that users recognise and abide by the legal requirements associated with these

- Users may download and print one copy of any publication from the public portal for the purpose of private study or research.

- You may not further distribute the material or use it for any profit-making activity or commercial gain

If the publication is distributed under the terms of Article $25 \mathrm{fa}$ of the Dutch Copyright Act, indicated by the "Taverne" license above, 
OVERGANGSRECHT

NIEUW BuRgerLiJK Wetboek 



\title{
OVERGANGSRECHT NIEUW BURGERLIJK WETBOEK
}

\author{
Systematiek, uitgangspunten \\ en toepassingen
}

\section{PROEFSCHRIFT}

ter verkrijging van de graad van doctor aan de Rijksuniversiteit Limburg te Maastricht, op gezag van de Rector Magnificus, prof. mr. M.J. Cohen, volgens het besluit van het College van Dekanen, in het openbaar te verdedigen op vrijdag, 26 juni 1992 om 16.00 unur

door

Hendrik Laurens van der Beek 
Beoordelingscommissie: $\quad$ Prof mr. G.R. de Groot (voorzitter)

Prof. mr. A.S. Hartkamp (Rijksuniversiteit Utrecht)

Prof. mr. G.E. van Maanen

Prof. mr. A.Q.C. Tak

De totstandkoming van dit proefschrift werd mede mogelijk gemaakt door een subsidie van het Ministerie van Justitie.

Van dit proefschrift is een handelseditie verschenen in de Serie Recht en Praktijk, deel 60 , onder ISBN 9026822928.

\section{(C) 1992, H.L. van der Beek, Maastricht}

Alle rechten voorbehouden. Niets uit deze uitgave mag worden verveelvoudigd, opgeslagen in een geautomatiseerd gegevensbestand, of openbaar gemaakt, in enige vorm of op enige wijze, hetzij elektronisch, mechanisch, door fotocopieën, opnamen, of enige andere manier, zonder voorafgande schriftelijke toesterming van de uitgever.

Voor zover het maken van kopieen is toegestaan op grond wan artikel $16 \mathrm{~B}$ Auteurswet 1912 jo. het Besluit van 20 juni 1974, Stb. 351, zoals gewijzigd bij het Besluit van 23 augustus 1985, Stb. 471 en artikel 17 Anteurswet 1912, dient men de daarvoor wettelijk verschuldigde vergoedingen te voldoen aan de Stichting Reprorecht (Postbus 882, 1180 AW Amstelveen). Voor het overnemen van gedeelte(n) uit deze uitgawe in bloemlezingen, readers en andere compilatiewerken (artikel 16 Auteurswet 1912) dient men zich tot de vitgever te wender. 
'Er is altijd strijd tussen oud en nieuw recht. Het nieuwe recht is, omdat het nieuw is, voor zijn tijd het betere - toch mag het nimmer vergeten, dat het oude recht ook recht was. In de moeilijkheden, die daardoor ontstaan, de weg te vinden is niet eenvoudig - het is her zoeken van recht, gebonden aan alle eisen, die de rechtsvinding steeds stelt."

Asser-Seholten, Algemeen deel, p. 146. 


\section{Voorwoord}

Het schrijven van een proefschrift moge een (zeer) solistische bezigheid zijn, zon-der de bijstand van anderen is de voltooiing van zo'n werk een onmogelijke zaak. Dat geldt zeker voor dit proefschrift, dat in een relatief korte tijd tot stand moest komen. Een aantal personen die op de een of andere wijze waren betrokken bij deze totstandkoming wil ik hier graag noemen. Aan mijn promotores, prof. mr. E.H. Hondius, prof. mr. G.J. Rijken en prof. mr. J.B.M. Vranken betuig ik mijn dank voor hun stimulerende begeleiding. De leden van de beoordelingscommissie, prof. mr. G.R. de Groot, prof. mr. A.S. Hartkamp, prof. mr. G.E. van Maanen en prof. mr. A.Q.C. Tak, zeg ik dank voor hun bereidheid om het lidmaatschap van deze commissie op zich te nemen. Mijn ouders ben ik zeer erkentelijk voor de hulp en steun van diverse aard, die zij mij hebben geboden. Student-assistente Silvia Kersemakers heeft belangrijke ondersteunende werkzaamheden verricht, waarvoor ik haar veel dank verschuldigd ben. Een woord van dank is ook op zijn plaats voor mw. C.J. Forder LL.B. (Nottm.), LL.B. (Cantab.), prof. dr. G.W. Mincke en mw. A.J. Winsemius, die in een krap tijdsbestek de vertalingen van de samenvatting hebben verzorgd.

Nog anderen hebben de totstandkoming van dit proefschrift mogelijk gemaakt, bij voorbeeld door bepaalde werkzaamheden van mij over te nemen. Ook hen ben ik daarom dankbaar.

Het manuscript van dit boek werd voltooid op 1 januari 1992. Na deze datum gepubliceerde wetgeving, rechtspraak en literatuur kon slechts incidenteel worden verwerkt. 



\section{Inhoud}

Voorwoord

Lijst van afkortingen

Hoofdstuk 1

Introductie

1.1 Doel- en probleemstelling

1.2 Afbakening van het onderwerp

1.3 Wijze van behandeling

VII

XVII

Hoofdstuk 2

Algemene aspecten van het overgangsrecht woor het nieuwe $B W$

2.1 Inleiding

2.2 Enkele prealabele terminologische kwesties 5

2.2.1 Overgangsrecht en Overgangswet 5

2.2.2 Vereiste en rechtsgewolg 7

2.2.3 Inwerkingtreding, invoering, van kracht worden, gelden 8

2.2.4 Toepasselijk zijn, werken en van toepassing zijn 8

2.3 De aard van het overgangsrecht voor het nieuwe BW

2.3.1 Het overgangsrecht voor het nieuwe BW: "wegwerprecht"? 10

2.3.2 Het overgangsrecht voor het nieuwe BW: dwingend recht? 14

2.4 Wanneer rijzen vragen van overgangsrecht? 16

2.4.1 Overgangssituaties 16

2.4.1.1 De bestaande rechtstoestand en de vereisten van de nieuwe wet 17

2.4.1.2 De relevantie van anterieure feiten $\quad 19$

2.4.1.3 Telt alleen het invoeringstijdstip? 21

2.4.1.4 Invoering van een nieuwe wet 23

2.4.1.5 De rol van de woorden van de nieuwe wet 25

$\begin{array}{ll}2.4 .2 & \text { Vragen van owergangsrecht }\end{array}$

2.5 Regels voor de oplossing van vragen van overgangsrecht 26

$\begin{array}{lll}2.5 .1 & \text { Verwijzingsregels } & 27\end{array}$

$\begin{array}{ll}2.5 .1 .1 & \text { Onmiddellijke werking } \\ & 28\end{array}$

a. Begripsomschrijving; terminologie 28

b. De hoofdregel van de onmiddellijke werking; algemeen 30 
c. De hoofdregel van de onmiddellijke werking en de vereisten van de neuwe wet $\quad 32$

c.1 Toestanden 32

c.2 Feiten 32

c.3 Juridische warderingen 36

d. De hoofdregel van de onmiddellijke werking en de rechtsgevolgen van de nieuwe wet

e. Uitzonderingen op de hoofdregel van de onmiddellijke werking

2.5.1.2 Eerbiediging van oud recht

a. Begripsomschrijving; terminologie 37

b. Handhaving van de toepasselijkheid van het oude recht 38

c. Eerbiediging van het oude recht en de vereisten $\begin{array}{ll}\text { van de nieuwe wet } & 38\end{array}$

c.l Toestanden 38

$\begin{array}{lll}c .2 \text { Feiten } & 39\end{array}$

c.3 Juridische waarderingen 40

d. Eerbiediging van het oude recht en de rechtsgevolgen
van de nieuwe wet

e. De 'eerbiediging van verkregen rechten' 40

f. 'Kruisingen' tussen onmiddellijke werking en eerbiediging van het oude recht 41

2.5.1.3 Uitgestelde werking 42

a. Begripsomschrijving; terminologie 42

b. (Tijdelijke) handhaving van de toepasselijkheid

c. Uitgestelde werking en de vereisten van de nieuwe wet $\quad 44$

c.1 Toestanden : 44

c.2 Feiten $\quad 45$

c.3 Juridische waarderingen 46

d. Uitgestelde werking en de rechtsgevolgen van de nieuwe wet 46

2.5.1.4 Terugwerkende kracht : 46

a. Begripsomschrijving; terminologie 47

b. De regel van het ontbreken van terugwerkende kracht 47

2.5 .2 Overbruggingsregels : : 48

2.5.3 De ontsnappingsmogelijkheden wan artikel 75 Ow I 50

2.6 De verhouding tussen overgangsrecht en anticipatie 55

2.6.1 De betekenis van (afwijzing van) anticipatie voor de keus van de overgangsregel door de wetgever $\quad 56$

2.6.2 De betekenis van overgangsregels voór (afwijzing van) anticipatie vóor de inwerkingtreding $\quad 59$

2.6.3 De betekenis van overgangsregels voor (afwijzing van) anticipatie na de inwerkingtreding 62

$\begin{array}{ll}2.7 & \text { Een strategie voor de beantwoording van vragen van overgangsrecht } 63\end{array}$ 
Hoofdstuk 3

Inschrijvingen betreffende registergoederent

3.1 Inleiding

3.2 Ontstaan van overgangskwesties bij inschrijvingen betreffende registergoederen

3.3 Consequenties van onmiddellijke werking van het nieuwe BW ten aanzien van overgangssituaties bij inschrijvingen betreffende registergoederen

3.4 De Overgangswet en inschrijvingen betreffende registergoederen

3.5 De gefingeerde inschrijving conform afdeling 3.1.2 BW

3.5.1 Kenbaarheid uit de openbare registers uit een 'oude" in- of overschrijving

3.5.2 Kenbaarheid uit de openbare registers uit een 'oude' aantekening

3.6 De rangorde van inschrijwingen in de registers 80

3.7 Uitgestelde derdenbescherming 81

3.8. Enige andere overgangsbepalingen inzake inschrijvingen betreffende registergoederen

3.8.1 Rangorde van vorderingen 84

$\begin{array}{ll}3.8 .2 & \text { Oude zakelijke rechten } \\ 3.34\end{array}$

3.8.3 Buurwegen 84

3.8.4 Door bestemming of herleving ontstane erfdienstbaarheden $\quad 85$

3.8.5 Kwalitatieve verplichtingen $\quad 85$

3.9 Slot

Hoofdstuk 4

Geldigheid van rechtshandelingen

4.1 Inleiding

4.2 Ontstaan van overgangskwesties bij de geldigheid van rechtshandelingen

4.3 Consequenties van onmiddellijke werking van het nieuwe BW ten aanzien van overgangssituaties bij de geldigheid van rechtshandelingen .88

4.4 De Overgangswet en de geldigheid van rechtshandelingen 90

4.5 Onaantastbaar-(ver)nietig(baar) 92

$\begin{array}{lll}4.5 .1 & \text { Algemeen } & 92\end{array}$

4.5.2. Handelingsonbevoegdheid 94

4.5.3 Wilsgebreken 94

$\begin{array}{lll}4.5 .4 & \text { Beperkte rechten } & 95\end{array}$

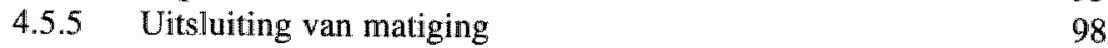

4.5.6 Algemene voorwaarden 98

4.5.7 Rechtsgevolgen van overeenkomsten 102

4.5.8 Bijzondere overeenkomsten 102

4.6 De niet-werking van nieuwe (ver)nietig(baar)heden ten aanzien van voorheen reeds gebrekkige rechtshandelingen 
4.7 Vernietigbaar-onaantastbaar

4.7.1. Algemeen

4.7.2 Koopovereenkomsten 105

4.8 Vernietigbaar-nietig

\subsubsection{Algemeen}

106

4.8.2 Handelings- en feitelijke onbekwaamheid 107

4.8.3 Koopovereenkomsten

4.9 Nietig-onaantastbaar

108

4.9.1 Algemeen

4.9.2 Handelingsonbevoegdheid

4.9.3 Derdenbescherming; de zaak Bunde-Erckens

4.9.4 Beperking van verhaal op vermogen debiteur

4.9.5 Beperkte rechten

116

4.9.6 Derdenbedingen

$\begin{array}{ll}4.9 .7 \text { Bijzondere overeenkomsten } & 116 \\ \text { Nietig-vernietigbaar } & 117\end{array}$

4.10 Nietig-vernietigbaar

4.10.2 Handelings- en feitelijke onbekwaamheid

4.10.3 Misbruik van omstandigheden

4.10.4 Verdeling van gemeenschappen

120

4.10.5 Voortbouwende overeenkomsten

4.11 Rechtshandelingen met een dubbel gebrek

\section{Hoofdstuk 5}

Zekerheidseigendom en stil pandrecht

$5.1 \quad$ Inleiding

5.2. Enkele terminologische kwesties

5.2.1 Zekerheidsoverdracht en zekerheidseigendom 124

5.2.2 Stil pandrecht 124

5.3 Ontstaan van overgangskwesties bij zekerheidseigendom 125

5.4 Consequenties van onmiddellijke werking van het nieuwe BW ten aanzien wan bestaande zekerheidsverhoudingen

$\begin{array}{ll}\text { 5.5 De Overgangswet en de zekerheidseigendom } & 128\end{array}$

5.6 Omzetting van zekerheidseigendom in pandrecht 130

5.6.1 Het goed is aan een ander tot zekerheid overgedragen 130

5.6.2 Een voor verpanding vatbaar goed 130

5.6.3 Geen uitwinning (aangezegd) of faillissement 131

5.6.3.1 Moet de aanzegging vớr of na de inwerkingtreding zijn geschied?

5.6.3.2 Is van belang hoe lang vór de inwerkingtreding de aanzegging is geschied?

5.6.3.3 Welke maatstaf geldt voor de bepaling van het moment van de aanzegging? 
5.6.3.4 Is de omzetting ook opgeschort in geval van een aanzegging zonder tekortschieten van de debiteur?

5.6.3.5 Vanaf welk tijdstip gaat de zes maanden-termijn lopen?

5.6.3.6 Wanneer is sprake van het overgaan tot uitwinning?

5.6.3.7 Is 'een lopende uitwinning zonder voorafgaande aanzegging denkbaar?

5.6.3.8 Toepasselijkheid van het nieuwe procesrecht op de gehandhaafde zekerheidseigendom

5.6.3.9 Staat van faillissement van de debiteur ten tijde van de inwerkingtreding

5.6.4 Geen lopend bodembeslag 142

5.6.5 Overgang van het goed en belasting met pandrecht 144

5.6.6 Aard van het uit zekerheidseigendom voortgekomen pandrecht 146

5.6.7 Een inbreuk op de eerbiediging van verkregen rechten? 147

5.7 Het wettelijke pandrecht nader bezien 148

5.7.1 Verschillen tussen het wettelijke pandrecht en een door vestiging ontstaan pandrecht

5.7.2 Voor het wettelijke pandrecht geldende regels 149

5.7.2.1 Burgerlijk Wetboek 149

5.7.2.2 Faillissementswet $\quad 151$

5.7.2.3 Wetboek van Burgerlijke Rechtsvordering 152

5.7.3 Toepasselijkheid van bestaande bedingen op het wettelijke pandrecht 154

5.8 Hoe sterk is het uit zekerheidseigendom voortgekomen pandrecht? 157

5.8.1 Collisie buiten verhaalssituaties tussen het wettelijke pandrecht en bestaande rechten

5.8.1.1 Collisie tussen het wettelijke pandrecht en 'gewone' eigendom 160

a. Anterieure 'gewone' eigendom 160

b. Posterieure 'gewone' eigendom 161

5.8.1.2 Collisie tussen het wettelijke pandrecht en voorbehouden eigendom

5.8.1.3 Collisie tussen het wettelijke pandrecht en een uit ontbinding voortvloeiend recht

5.8.1.4 Collisie tussen het wettelijke pandrecht en een uit uitoefening van het recht van reclame voortvloeiend recht

5.8.1.5 Collisie tussen het wettelijke pandrecht en een uit uitoefening van het verlengstuk van het recht van reclame voortvloeiend recht

5.8.1.6 Collisie tussen het wettelijke pandrecht en een pandrecht ten gevolge van zaaksvervanging

5.8.1.7 Collisie tussen wettelijke pandrechten onderling 168

5.8.2 Collisie binnen verhaalssituaties tussen het wettelijke pandrecht en bestaande (voor)rechten

5.8.2.1 Collisie tussen het wettelijke pandrecht en een verkopersprivilege 
5.8.2.2 Collisie tussen het wettelijke pandrecht en een privilege ten gevolge van zaaksverwanging

5.8.2.3 Collisie tussen het wettelijke pandrecht en een privilege ter zake van kosten tot behoud

a. Anterieur privilege ter zake van kosten tot behoud

b. Posterieur privilege ter zake wan kosten tot behoud

5.8.2.4 Collisie tussen het wettelijke pandrecht en een privilege ter zake van kosten wegens bearbeiding

a. Anterieur privilege ter zake van kosten wegens bearbeiding

$b$. Posterieur privilege ter zake van kosten wegens bearbeiding

5.8.2.5 Collisie tussen het wettelijke pandrecht en een privilege ter zake wan schadevergoeding

5.8.2.6 Collisie tussen het wettelijke pandrecht en een privilege van de fiscus ex artikel 21 Invorderingswet 1990

5.8.2.7 Collisie tussen het wettelijke pandrecht en een retentierecht

a. Anterieur retentierecht

b. Posterieur retentierecht

5.8.3 Collisie buiten verhaalssituaties tussen het wettelijke pandrecht en rechten daterend van na de inwerkingtreding 184

5.8.3.1 Collisie tussen het wettelijke pandrecht en eigendom 186

5.8.3.2 Collisie tussen het wettelijke pandrecht en een uit ontbinding voortvloeiend recht

5.8.3.3 Collisie tussen het wettelijke pandrecht en een uit uitoefening van het (verlengstuk van het) recht van reclame voortvloeiend recht

5.8.3.4 Collisie tussen het wettelijke pandrecht en een stil pandrecht

5.8.3.5 Collisie tussen het wettelijke pandrecht en een pandrecht ten gevolge van zaaksvervanging

5.8.4 Collisie binnen verhaalssituaties tussen het wettelijke pandrecht en (voor)rechten daterend van na de inwerkingtreding

5.8.4.1 Collisie tussen het wettelijke pandrecht en privileges

5.8.4.2 Collisie tussen het wettelijke pandrecht en retentierecht

5.8.4.3 Collisie tussen het wettelijke pandrecht en beslag

5.8.5 Gehandhaafde zekerheidseigendom en collisieproblemen

5.9 Blokkering van het ontstaan van zekerheidseigendom na de inwerkingtreding

5.9.1 Verbintenissen tot zekerheidsoverdracht

5.9.2 Levering bij voorbaat tot zekerheidsoverdracht

5.9.3 Dubbele leveringen bij voorbaat

5.9.4 Aanpassing van tot zekerheidsoverdracht verplichtende overeenkomsten aan titel $3.9 \mathrm{BW}$

5.10 Omzetting in pandrecht van zekerheidseigendom van rechten uit een levensverzekering 
Hoofdstuk 6

Onrechtmatige daad

6.1. Inleiding

6.2 Ontstaan van overgangskwesties bij onrechtmatige daad

6.3 Consequenties van onmiddellijke werking van het nieuwe BW ten aanzien van overgangssituaties bij onrechtmatige daad

6.4 De Overgangswet en de onrechtmatige daad

6.5 Aansprakelijkheid tot schadevergoeding

6.5.1 Aansprakelijkheid reeds aanwezig

210

6.5.1.1 Schrapping van aansprakelijkheden

6.5.1.2 Verschuiving van aansprakelijkheden

6.5.1.3 Wijziging van de omvang van aansprakelijkheden

6.5.1.4 Bijzondere regel voor verzuim

6.5.1.5 Blokkering van de "paardesprong"

214

6.5.2 Aansprakelijkheid 'in statu nascendi'

214

6.5.2.1 Schade met vertraging; ontstaanstijdstip bekend

6.5.2.2 Schade met vertraging; ontstaanstijdstip niet bekend

6.5.2.3 Het schadeveroorzakende voorval als alternatief criterium

a. Vergelijking van stelsels

6.5.3 Aansprakelijkheid niet aanwezig

6.5.4 Oplopende en opeenvolgende schaden $\quad 222$

6.6 Verbod

$\begin{array}{ll}6.7 & \text { Verklaring van recht } \\ 6.8 & 227\end{array}$

$\begin{array}{ll}6.8 \text { Rectificatie } & 227\end{array}$

$\begin{array}{lll}6.9 \text { Slot } & 227\end{array}$

Hoofdstuk 7

Tekortkomingen in de nakoming van verbintenissen

7.1 Inleiding

7.2 De begrippen 'niet-nakoming" en 'tekortkoming in de nakoming'

7.3 Ontstaan van overgangskwesties bij tekortkomingen in de nakoming

7.4 Consequenties van onmiddellijke werking van het nieuwe BW ten aanzien van overgangssituaties bij tekortkomingen in de nakoming

7.5 De Overgangswet en tekortkomingen in de nakoming

7.6 De debiteur is vór de inwerkingtreding tekortgeschoten in de nakoming

7.6.1 Algemeen

$\begin{array}{lll}7.6 .2 & \text { Bijzondere regel voor verzuim } & 236\end{array}$

7.6.3 De vordering tot nakoming 238

7.6.4 De vordering tot schadevergoeding 239

7.6.5 De (vordering tot) ontbinding 241

$\begin{array}{ll}\text { 7.6.6 Opschortingsrechten } & 242\end{array}$

7.7 De debiteur is eerst bij of na de inwerkingtreding tekortgeschoten in de nakoming 
7.8 Tekortkomingen in de nakoming bij enige beperkte rechten en bij de koopovereenkomst

7.8.1 Vruchtgebruik, gebruik en bewoning 245

$\begin{array}{lll}7.8 .2 & \text { Erfpacht } & 246\end{array}$

$\begin{array}{lll}7.8 .3 \text { Koop } & 248\end{array}$

7.9 De uiteenlopende overgangsregimes bij tekortkomingen

in de nakoming en bỉj de onrechtmatige daad

252

7.10 Slot

Hoofdstuk 8

Tot besluit

Samenvatting

Summary

263

Zusammenfassung

Sommaire

Lijst van aangehaalde Kamerstukken

Lijst van aangehaalde literatuur

Trefwoordenregister

Wetsartikelenregister

305

Jurisprudentieregister 


\section{Lijst van afkortingen}

\begin{tabular}{ll} 
AA & Ars Aequi \\
aant. & aantekening \\
A-G & Advocaat-Generaal \\
AGB-Gesetz & Gesetz zur Regelung des Rechts der Allgemeinen \\
& Geschäftsbedingungen (Duitsland) \\
AMvB & Algemene Maatregel van Bestuur \\
art. & artikel \\
AVP & Aansprakelijkheidsverzekering voor particulieren \\
AWT & Aanwijzingen voor de wetgevingstechniek \\
Bb & Bedrijfsjuridische berichten \\
BR & Bouwrecht \\
BW & Burgerlijk Wetboek \\
c.a. & cum annexis \\
c.s. & cum suis \\
d.d. & de dato \\
DD & Delikt en Delinkwent \\
diss. & dissertatie \\
d.w.z. & dat wil zeggen \\
EG & Europese Gemeenschappen \\
EK & Eerste Kamer der Staten-Generaal \\
etc. & et cetera \\
e.v. & en volgende \\
FW & Faillissementswet \\
HR & Hoge Raad der Nederlanden \\
Inv. & Invoeringswet \\
jo. & juncto \\
KB & Koninklijk Besluit \\
KNB & Koninklijke Notariële Broederschap \\
m.n. & met noot \\
NBW & Nieuw Burgerlijk Wetboek \\
NJ & Nederlandse Jurisprudentie \\
NJB & Nederlands Juristenblad \\
NJV & Nederlandse Juristen-Vereniging \\
nr(s). & nummer(s) \\
o.a. & onder andere(n) \\
Ow 1829 & Overgangswet 1829 \\
& \\
\hline
\end{tabular}


Ow I

Ow II

Ow Kadasterwet

p.

Parl. Gesch.

PbEG

preadv.

q.q.

Rb.

RMTh

r.o.

Rv

RvdW

SER

Stbl.

t.a.p.

TK

TVC

TVVS

VA

vgl.

WAM

WCK

Wet $A B$

WPNR

WvK

Z.j.

z.p.
Aanvulling van de Overgangswet nieuw

Burgerlijk Wetboek

Overgangsrecht, tweede stuk

Invoeringswet Kadasterwet

pagina

Parlementaire Geschiedenis

Publicatieblad van de Europese Gemeenschappen

preadvies

qualitate qua

Rechtbank

Rechtsgeleerd Magazijn Themis

rechtsoverweging

Wetboek van Burgerlijke Rechtswordering

Rechtspraak van de Week

Sociaal Economische Raad.

Staatsblad

ter aangehalder plaatse

Tweede Kamer der Staten-Generaal

Tijdschrift voor Consumentenrecht

Maandblad voor ondernemingsrecht en rechtspersonen

Het Verzekerings-Archief

vergelijk

Wet aansprakelijkheidswerzekering motorrijtuigen

Wet op het consumentenkrediet

Wet Algemene Bepalingen

Weekblad voor priviatrecht, notariaat en registratie

Wetboek van Koophandel

zonder jaar van uitgave

zonder plaats wan witgave 


\section{HOOFDSTUK 1}

\section{Introductie}

Ook aan wetten knaagt de tand des tijds. Vroeg of laat zullen zij moeten worden gewijzigd of zelfs geheel vervangen. Als oude wettelijke regels door nieuwe worden afgelost, zal waak behoefte bestaan aan de tussenkomst van overgangsregels. De oude wet laat zich, ook al is zij afgeschaft, nu eenmaal niet zo maar verjagen uit het rechtsleven. Zij heeft gedurende kortere of langere tijd gegolden. In die tijd heeft zij haar sporen doen ontstaan. Daarvan zullen er in de loop der tijd wel de nodige zijn uitgewist. Bij het aantreden van de nieuwe wet zijn echter doorgaans nog well degelijk door de oude wet nagelaten sporen aamwezig.

De nieuwe wet is uiteraard niet voor niets in het leven geroepen. De oude wet paste niet meer bij gewijzigde opvattingen, had lacunes, vertoonde gebreken qua structuur en terminologie of was om een andere reden niet meer bij de tijd. Daarom moest zij plaats maken voor iets beters. Uiteraard ziet de wetgever het liefst dat zijn produkt zo snel mogelijk de alleenheerschappij heeft. Maar dat gaat niet zo maar: als gezegd plegen uit de regeerperiode van de oude wet nog restanten over te blijven. Daarmee zal in principe rekening moeten worden gehouden. De schok die de nieuwe wet voor de justitiabelen kan betekenen moet voor zover mogelijk worden gedempt. Uitstel van de invoering en anticipatie kunnen aan die demping bijdragen. De schokbrekerfunctie van overgangsregels zal evenwel ook dan meestal niet kunnen worden gemist.

De invoering van het nieuwe vermogensrecht op 1 januari 1992 past in bovenstaande probleemschets. Wel is het zo dat de schaal van een en ander hier vele malen groter is dan gebruikelijk. Daardoor zijn de overgangsbepalingen ver over de honderd in getal en telt de parlementaire geschiedenis een veelvoud daarvan aan bladzijden. De jurist wordt aldus geconfronteerd met drie verschillende en onderling samenhangende omvangrijke complexen: de oude en de nieuwe wetgeving en daartussenin als "smeerolie" de overgangswetgeving. Hij wordt daardoor gedwongen tot 'rechtswetenschappelijke scheelkijkerij'. Behalve de omvang is ook de moeilijkheidsgraad van de onderhavige overgangsproblematiek nogal eens bovengemiddeld. Er is dus alle reden voor om het overgangsrecht dat de invoering van de Boeken 3 e.v. BW begeleidt op een aantal hoofdpunten te ontleden. Daarmee raak ik al aan de doelstelling van mijn onderzoek. Deze zet ik uiteen in nr. 1.1 hierna, evenals de probleemstelling. Daarna volgen de afbakening van het onderwerp en de wijze van behandeling (respectievelijk nrs. 1.2 en 1.3). 
De doelstelling van mijn onderzoek is tweeëriei. Het eerste doel is blootlegging en bespreking van de fundamenten waarop de overgangswetgeving behorende bij het nieuwe vermogensrecht is gebouwd. Deze fundamenten zijn door de overgangswetgever in belangrijke mate nieuw ontwikkeld. Wie er te weinig aandacht aan besteedt, loopt het risico van gebrekkig inzicht in en verkeerde toepassing van vele overgangsbepalingen en van de parlementaire geschiedenis. Het vergt echter diepgaande bestudering van deze geschiedenis en van een aantal publicaties van de ontwerper van de overgangswetgeving on de grondslagen van deze wetgeving voldoende scherp in het vizier te krijgen. Zo"n bestudering was gewenst, ondanks het feit dat er reeds literatuur bestond over het overgangsrecht voor het nieuwe vermogensrecht. Als gevolg van vrij aanzienijke wijzigingen in de oorspronkelijk voorgestelde wetsteksten is deze literatuur ook niet steeds meer bij de tijd.

Het nagestreefde zicht tracht ik in het volgende hoofdstuk te verkrijgen door in te gaan op de volgende probleemstelling: wanneer rijzen vragen van overgangsrecht en hoe kunnen deze worden opgelost?

Als tweede doel heb ik mij gesteld de (consequenties van de) overgangsregels ten aanzien van een aantal, ook in de praktijk belangrijke, rechtsfiguren uiteen te zetten en te bespreken. Voor een goed begrip en voor een juiste toepassing wan het overgangsrecht voor het nieuwe vermogensrecht is uiteraard niet alleen inzicht in de fundamenten daarvan, maar ook analyse van concrete overgangsgevallen onontbeerlijk. Ook een dergelijke analyse was ondanks de reeds verschenen literatuur gewenst.

Leidraad bij de in de hoofdstukken 3-7 plaatsvindende beschouwing van de overgangsregels inzake verschillende rechtsfiguren is de vraag of, en zo ja, in hoeverre het nieuwe vermogensrecht toepasselijk wordt en behoort te worden op concrete overeenkomsten, zekerheidseigendomsrechten en andere rechtsverhoudingen, rechtsposities etc. die bestonden bij zijn inwerkingtreding, alsmede wat de gevolgen zijn van dat al dan niet toepasselijk worden.

Nu zou men kunnen zeggen - en het wordt meestal gezegd - dat het hier gaat om doeleinden die slechts gedurende relatief korte tijd van belang zijn, namelijk voor de periode dat het overgangsrecht voor het nieuwe BW zich doet gelden. Hierop valt evenwel het nodige af te dingen, zoals zal blijken in nr. 2.3.1 hiema. Ik durf daarom de hoop uit te spreken dat ook bij volgende overgangsexercities wetgever en praktijk iets aan dit boek zullen hebben.

\subsection{AFBAKENING VAN HET ONDERWERP}

Om de omvang van dit boek enigszins in de hand te houden en een tijdige verschijning ervan te waarborgen, moest ik beperkingen in acht nemen ten aanzien van de te behandelen stof. Overgangsrecht dat niet betrekking heeft op de op 1 januari 1992 ingevoerde delen van het nieuwe BW heb ik goeddeels buiten beschouwing gelaten. Maar ook van het overgangsrecht dat binnen de aldus getrokken grens valt, moest een niet onaanzienlijk deel onbesproken blijven. Als selectiecriterium heb ik 
hier in de eerste plaats gehanteerd, of een bepaalde rechtsfiguur overgangsrechtelijk gezien zowel dogmatisch als praktisch van meer dan gemiddeld belang is. Voorts heb ik getracht een zekere spreiding over diverse onderwerpen uit het nieuwe goederen- en verbintenissenrecht te bewerkstelligen.

Een andere beperking die ik op bovenstaande gronden heb aangebracht, is dat ik heb afgezien van vergelijking met buitenlands recht. Ik verwijs daarvoor naar twee tamelijk recente proefschriften, namelijk dat van Polman ${ }^{2}$, die uitvoerig ingaat op publicaties van met name Roubier over het Franse overgangsrecht, en dat van Knigge $^{3}$, die aandacht besteedt aan meerdere buitenlandse rechtsstelsels.

Internationaal privaatrecht heb ik slechts hier en daar aangestipt, namelijk waar dlat nuttig is bij het uiteenzetten van overgangsrechtelijke thema's. Voor het overige verwijs ik naar de dissertatie van Joppe ${ }^{4}$.

\subsection{WIJZE VAN BEHANDELING}

Het onderzoek geschjedt in de eerste plaats aan de hand van (voorgestelde) wetgeving en literatuur. Jurisprudentie is uiteraard van minder belang, nu de onderhavige overgangswetgeving pas onlangs in werking is getreden. Jurisprudentie komt met name aan bod in het onderdeel over de verhouding tussen overgangsrecht en anticipatie (nr. 2.6 hierna) en hier en daar bij de beantwoording van de vraag wat het oude recht inhield. Bij de diverse bijzondere onderwerpen werk ik regelmatig met concrete voorbeelden. Aan de hand daarvan tracht ik overgangsregels 'door te rekenen'.

$\mathrm{Na}$ het algemeen deel (hoofdstuk 2) volgt een behandeling van een aantal bijzondere onderwerpen. Ik heb deze gerangschikt aan de hand van de volgorde waarin zij in de Overgangswet zijn geregeld. Deze volgorde is op haar beurt ontleend aan die van de Boeken 3 e.v. BW. Aldus komen in de hoofdstukken 3-7 achtereenvolgens aan de orde: inschrijvingen betreffende registergoederen, geldigheid van rechtshandelingen, zekerheidseigendom en stil pandrecht, onrechtmatige daad en tekortkomingen in de nakoming van verbintenissen.

Wellicht ten overvloede merk ik tot slot nog het volgende op. Ondanks mijn streven naar volledigheid bij de behandeling van transitoire kwesties van enig belang bestaat de mogelijkheid dat ik zulke kwesties over het hoofd heb gezien. Dit kan zich bij het overgangsrecht voor het nieuwe BW licht voordoen, immers:

'Bij een zo omvangrijk project als de vernieuwing van het gehele vermogensrecht blijft het moeilijk alle verschillen te overzien en alle gevolgen daarvan te voorzien. ${ }^{5}$

2. Temporele werkingen van wetten (1984).

3. Verandering van wetgeving (1984).

4. Overgangsrecht in het internationaal privaatrecht en het fait accompli (1987).

5. Aldus de toelichting op artikel 75 Ow I, Parl. Gesch. Overgangsrecht, p. 68. 



\section{Algemene aspecten van het overgangsrecht voor het nieuwe BW}

\subsection{INLEIDING}

Voor het overgangsrecht geldt in bijzondere mate dat toepassing ervan een nogal hachelijke zaak is voor wie niet vertrouwd is met de (theoretische) uitgangspunten en met de grondbegrippen daarvan. Het overgangsrecht voor het nieuwe BW vormt hierop zeker geen uitzondering. Pièce de résistance van dit hoofdstuk is de kartering van deze uitgangspunten en grondbegrippen. Het gaat daarbij met name om het afgrenzen van het overgangsrechtelijke strijdperk en om de wapens die er gangbaar zijn. Daarnaast krijgen nog enkele andere algemene aspecten aandacht, zoals de wijze waarop men de strijd het beste kan voeren.

\subsection{ENKELE PREALABELE TERMINOLOGISCHE KWESTIES}

Aan de behandeling van de zojuist aangekondigde onderwerpen moet een korte ronde langs enkele basisbegrippen voorafgaan. Dit zijn de termen 'overgangsrecht' en 'Overgangswet' (nr. 2.2.1), "vereiste' en 'rechtsgevolg' (nr. 2.2.2), "inwerkingtreding' c.a. (nr. 2.2.3) en 'toepasselijk zijn' c.a. (nr. 2.2.4),

\subsubsection{Overgangsrecht en Overgangswet}

Onder 'overgangsrecht' kan worden verstan het geheel van beginselen ${ }^{1}$ en regels, waarin oplossingen worden aangedragen voor de transitoite kwesties die de vervanging van oud recht door nieuw recht kan oproepen. Aan de hand van overgangsrecht wordt witgemaakt of, en zo ja, in hoeverre het nieuwe recht overgangs ituaties zal gaan beheersen ${ }^{2}$. Owergangsrecht is derhalve "meta-recht", recht over recht. Het behoort niet tot de inhoud van de nieuwe regel waarvan het toepassingsgebied wordt afgepaald $^{3}$; de vergelijking met het internationaal privaatrecht dringt zich dan ook op ${ }^{4}$. Het

1. Zie over beginselen wan overgangstecht met name De Die, AA 1991, p. 818-829.

2. Wgl over de term "overgangstecht' ook Polman, disw. p. 16-19.

3. Vgl. De Die, RMTh 1979, p. 256 257,259; anders Knigge, diss.,p. 121-123. 1k laat in het midden of overgangsrecht van 'hogere" orde is dan de nieuwe regel waarop het betrekking heeft. Zie daarover De Die, RMTh 1979, p. 257 (bevestigend). Na oppositie door Knigge diss., p. $121-123_{\text {„ is }}$ De Die van zijn mening teruggekomen in DD 1989, p. 883. Zie ook FI. Stein, preadv, p. 260-262.

4. Al wan oudsher worden vergelikingen tussen beide disciplimes gemalkt. Zie nr. 2.5 .1 hiema en o. a. Hijmans van den Bergh, diss, p. 354-359; Polman; diss, p. 85; H. Stein, preadv., p. 260-262, Joppe, diss, p. $1-14$. 
internationaal privaatrecht zelf kent ook overgangsproblemen, namelijk als gevolg van wijziging van de inhoud van een bepaalde aanknopingsfactor, zoals de nationaliteit (er is dan een zogenoemd 'conflit mobile'), wijziging van het door de conflictregel aangewezen recht en wijziging van de conflictregel zelf ${ }^{5}$. Bij de oplossing van deze overgangsproblemen kan inspiratie worden ontleend aan het interne overgangsrecht:

'The present discussion in the Netherlands concerning the intertemporal problems caused by the revision of the Civil Code will have its influence on the question of the time factor in private international law.' 6

Behalve tussen het overgangsrecht en het 'materiële' recht ${ }^{7}$ moet ook onderscheid worden gemaakt tussen de vraag naar het al dan niet toepasselijk zijn van nieuw recht en de vraag of toepasselijkheid daarvan in het algemeen wenselijk is of niet. Op de latatste vraag ga ik in dit hoofdstuk niet in. Beantwoording daarvan zou veel ruimte vergen, terwiil elders reeds de nodige aandacht an bedoelde vraag is besteed. Een en ander geldt in mindere mate voor de regels van de Overgangswet nieuw $\mathrm{BW}$ inzake bijzondere onderwerpen. Bij de behandeling van deze bijzondere onderwerpen zall ik daarom wel iets zeggen over de al dan niet wenselijkheid, overgangssituaties binnen de werkingssfeer van het nieuwe BW te trekken.

Als synoniemen van de term 'overgangsrecht' worden ook wel de aanduidingen 'intertemporeel recht' en 'transitoir recht' gebruikt. Ik zal ter afwisseling deze termen ook af en toe hanteren. Ontbreekt een nadere aanduiding, dan gaat het steeds om het overgangsrecht voor het nieuwe vermogensrecht.

De Overgangswet nieuw BW duid ik in het vervolg aan als 'Overgangswet' (afgekort 'Ow I'). In dit boek staat centraal de Wet van 2 april 1991, Stbl. 1979, tot aanvulling van de Overgangswet met de artikelen 68-220, die betrekking hebben op de Boeken 3-7 BW. De Overgangswet is met ingang van 1 januari 1992 voorts nog aangevuld met de artikelen 251-258 inzake Boek 8 BW 1011

Hier en daar noem ik nog overgangsregels die niet in de Overgangswet zijn opgenomen. In de eerste plaats betreft het hier het zogenoemde 'Overgangsrecht,

5. Zie hieromtsent bij woorbeeld H. Stein, Plats en tijd; Van Erp, studiepocket, p. 14-17, 29-30, 68-81, Joppe, diss., o.a. p. 15 e.v.

6. Aldus Van Roojj en Polak, Private International Law (1987), p. 243.244.

7. "Materiete" recht wordt hier gebruikt als tegenstelling tot overgangsrecht, niet tot formeel recht.

8. Zie hicromirent onder anderen Huimans yan den Bergh, preadv. p. 17-29; Leijten, NIB 1972, p. 364-373, $389-400$ (met nane p. 397-400); De Die, RMTh 1979, p. 267-285; Brumer, preadv., p. 3.54; De Die, AA 4991, p. $818-829$.

9. Zie voor de inwerking treding van dit elfde gedeelte van de Invoringswet Boeken 3,5 en 6 nieuw $B W$ het KB van 17 april 1991, Stbl. 1991,200. De artikelen 68-75. OW I zijn in werking getreden met ingang van 14 mei 1991; zij werken terng tot en met I april 1991 in verband met de inwerkingtreding met ingang wan deze datum wan Boek $8 \mathrm{BW}$ (zie hierover nr. 2.5 hiema). De overige artikelen (76-220 Ow D) zijn in werking getreden met ingang van 1 januari 1992.

10. Dit is geschied krachtens artikel I van Hoofdstuk III van de Wer van 25 februari 1991. Stbl. 75, houdende invoering van Boek 8 van het nieuwe B urgerlijk Wetboek, vierde gedeelte. Deze wet is met een aan de definitieve nummering van het nieuwe BW aangepaste tekst in het Staatsblad geplaatst als bijlage bij de beschikking van de Minister van Justitie van 22 maart 1991. Stbl. 129.

11. De met ingang van 1 januari 1992 geldende tekst wan de Overgangswet is in het Staatsblad geplaatst als bijlage bij de beschikking van de Minister van Justitie van 28 november 1991, Stbl. 601 . 
tweede stuk' (afgekort 'Ow II') ${ }^{12}$. Dit heeft betrekking op de in verband met de invoering van het nieuwe $\mathrm{BW}$ aangebrachte wijzigingen in de wetgeving zoals deze ten tijde van de invoering bestond. Voorts verwijs ik, met name in hoofdstuk 3 (inschrijvingen betreffende registergoederen $)$, af en toe naar de overgangsregels inzake de Kadasterwet ${ }^{13}$, welke wet evenals de Boeken 3 e.v. BW met ingang van 1 januari 1992 in werking is getreden.

\subsubsection{Vereiste en rechtsgevolg}

Een essentieel uitgangspunt in de Overgangswet is dat een rechtsregel een rechtsgevolg verbindt aan de vervulling van de vereisten die deze rechtsregel daarvoor stell $^{14}$. 'Vereiste' is dan al datgene dat nodig is om het rechtsgevolg teweeg te brengen, 'rechtsgevolg' is het in de rechtsregel vastliggende resultatat. Een voorbeeld uit vele levert artikel 3:84 lid 1 BW: voor het rechtsgevolg 'overdracht wan een goed' wordt vereist een levering krachtens geldige titel, verricht door een daartoe beschikkingsbevoegde 15 .

Om enige analytische helderheid te brengen, onderscheidt de ontwerper van de Overgangswet verschillende soorten vereisten en rechtsgevolgen. De vereisten deelt hij in drie categorieën in:

- (rechts)feiten (zoals (niet-)nakoming, (onrechtmatige) daad, het tot stand komen van een overeenkomst, de overgang van een recht $\left.{ }^{16}\right)$;

- (rechts)toestanden (zoals toebehoren aan, als konijn in een konijnenwarande zitten (artikel 563 (oud) BW), eigenaar of schuldeiser zijn);

- (juridische) waarderingen/vereisten (zoals geldigheid van een titel, onrechtmatigheid van een daad, causaliteit en toerekening). Het gaat hier niet om zelfstandige vereisten: zij 'bepalen nader het vereiste van toestand of feit' 17 .

De rechtsgevolgen verdeelt de ontwerper van de Overgangswet in zeven soorten:

- absolute rechten (zoals eigendom, erfpacht);

- verbintenissen (rechten met ertegenover staande schulden);

- verplichtingen buiten verbintenissen ('Obliegenheiten', zoals de verplichting ex artikel 3:67 BW tot het noemen van de naam van de volmachtgever);

- bevoegdheden (rechten zonder ertegenover staande schulden, zoals het recht om te ontbinden, op te schorten, op te zeggen, te vernietigen);

- werkingen (zoals die van een tweede levering bij voorbaat);

- hoedanigheden, eigenschappen (zoals roerend, bevoorrecht (van vordering), opeisbaar of hoofdelijk zijn);

12. Wet van 2 april 1991, Stbl. 198, houdende invoering van de Boeken 3,5en 6 van het meuwe Burgerlijk Wetboek houdende het overgangsrecht, tweede stuk (Inwoeringswet Boeken 3,5 en 6 nieuw BW (twalfde gedeelte)). De met ingang van 1. januari 1992 gelldende tekst van deze wet is in het Staatsblad geplaatst als bijlage bij de beschilking vain de Minister van Justitie van 6 december 1991, Stbil. 610.

13. Zie voor nadere gegevens hoofdstuk 3 , noten 1 en 4 .

14. Zie Parl. Gesch. Overgangsrecht; p. 15, 37; De Die, Spoedcursus; p. 2; vgl, ook Parl. Gesch. Irv. Boek 1, p. 1678-1679, 1683-1684; Knigge, diss., p. 20-21; Verheij, RegelMaat 1986,p. 144.

15. Aldus De Die, Spoedcursus, p: 2-3.

16. Zie voor andere voorbeelden Polman, Overgangswet, deel 1, p. 30.

17. Aldus De Die, Spoedcursus, p. 15. 
- omschnjwingen, definities (zoals die van goederen, zaken, bezit en eigendom, waarbij de "vereisten' de elementen van de definitie zijn en de "rechtsgevolgen" het gedefinieerde $)^{18}$.

Wat dan de zijde van de rechtsgevolgen staat (de totstandkoming van een koopovereenkomst) kan tevens aan die van de vereisten staan (zonder koopovereenkomst ontstalan er geen verbintenissen tot het geven van een zaak en het daarvoor betalen van een koopprijs) ${ }^{19}$.

\subsubsection{Inwerkingtreding, inwoering, van kracht worden, gelden}

Een wet begint eerst met ingang van het tijdstip waarop zij in werking treedt daadwerkelijk te gelden. Eerst vanaf dat tijdstip worden de regels uit die wet verbindend, komen zij in alanmerking voor toepassing. Indien op of na het moment van inwerkingtreding de vereisten van de wet worden vervuld, verbindt zij daaraan haar rechtsgevolgen ${ }^{20}$. Dit "gelden" van een nieuwe wet vanaf haar inwerkingtreding zegt op zichzelf nog niets over het antwoord op de vrag of, en zo ja, in hoeverre ook voor overgangssituaties de rechtsgevolgen wan de nieuwe wet (zouden moeten) intreden. Dat is immers een vraag van overgangsnecht. Wel is het unteraard zo dat aan die vraag pas kan worden toegekomen, indien een wet het tot inwerkingtreding heeft gebracht. Ik gebruik in het navolgende meestal de term 'inwerkingtreding'. Ter afwisseling gebruik ik de equivalente begrippen "invoering" en "van kracht worden".

Vanaf haar inwerkingtreding "geldt" de wet. De term "gelden" wordt in de Overgangswet en in de parlementaire geschiedenis in verschillende betekenissen gebruikt. De betekenis die ik zoëven bedoelde, komt bij voorbeeld voor in de artikelen 121 lid 2 en 150 lid 3 Ow I. Daarnaast kan men het begrip 'gelden' ook in andere betekenissen tegenkomen:

- toepasselijk zijn (artikelen $85,88 \mathrm{lid}$ l en 100 OW I);

- van toepassing zijn (artikelen 150 lid 7 en 192 Ow I) ${ }^{21}$ en

- worden aangemerkt als (fictie in overbruggingsregel, artikelen 78 lid 1, 81 lid 2 , 86 lid 7,150 leden 4 en 5 Ow I) $)^{22}$.

\subsubsection{Toepasselijk zijn, werken en van toepassing zijn}

Men zou, als gezegd, overgangstecht als "meta-recht' kunnen kenschetsen: het geeft

18. Zie voor dit alles De Die, Spoedcursus, p. 3-5, die - terecht - waarschuwt tegen het krampachtig toepassen $y$ han deze onderscheidingen.

19.2 te De Bie, RMTh 1979, p. 261-265, in het bijzonder p. 264-265; De Die, Spoedcursus, p. 15, noot 1.

20. Vgl. in verschillende zin Polman, diss,, 3. 483; Knigge, diss., p. 39 41; H. Stein, preadv:, p. 231, 259; vgl, ook Verheij, RegelMaat 1986, p. 144, 145, wolgens wie sommige bepalingen, bij voorbeeld die inzake de inwerkingtreding, al wel vớr de inwerkingtreding rechtsgevolg hebben. Uiteraard treedt een wet niet in werking dan nadat zij op de daarvoor voorgeschreven wijze is bekend gemaakt (zie de Bekendmakingswet, Stbl. 1988,18 ).

21. Zie over de begrippen 'toepasselijk zijn' en 'van toepassing zijn' het wolgende nn.

22. Zie over overbruggingsregels $\mathrm{nt} .2 .5 .2$ hiema en over de eerstgenoemde drie overgangsbepalingen respectievelijk nrs. 3.5, 4.10 en 4.11 , en 5.9.2-3 hierna. 
aan, of, en zo ja, in hoeverre een nieuwe rechtsregel ook bepalend is (en behoort to zijn) voor de rechtstoestand die bestaat op het moment van zijn inwerkingtreding, het is recht over recht ${ }^{23}$. De nieuwe materiële rechtsregel zelf geeft daarover geen uitsluitsel:

"welke inhoud een regeling heeft, is een andere vraag dan de - daaraan voorafgaande -, of zij op een bepaald soort gevallen wel màg worden toegepast. ${ }^{24}$

Hierbij past het om onderscheid te maken tussen de toepasselijkheid van een materièle wetsbepaling en haar van toepassing zijn ${ }^{25}$. De toepasselijkheid, het werken (denk aan bij voorbeeld onmiddellijke werking), is gesitueerd op het "meta-niveau van het overgangsrecht, het van toepassing zijn op het niveau van bedoelde wetsbepaling zelf $^{26}$. In het systeem van de Overgangswet moet men in transitoire casus eerst "afdalen" naar het niveau van de nieuwe materiële wetsbepaling om te zien of de vereisten zijn vervuld, die deze voor een rechtsgevolg stelt. Slechts indien deze vereisten zijn vervuld en derhalve de nieuwe materiële wetsbepaling zonder meer van toepassing zou zijn als er niet een overgangsgeval aan de orde was, kan men toekomen aan de door het overgangsrecht te beantwoorden "meta-vraag". Deze vraag is of, en zo ja, in hoeverre het rechtsgevolg van de nieuwe regel ook daadwerkelijk intreedt, met andere woorden of, en zo ja, in hoeverre de nieuwe regel toepasselijk is ${ }^{27}$.

Wellicht valt hier een parallel te trekken met de algemene voorwaarden. Vraagstukken van aanvaarding van en daarmee gebondenheid aan, gelding van algemene, voorwaarden (uiteraard: in een concreet geval) betreffen de toepasselijkheid van die voorwaarden op een overeenkomst ('meta-niveau', zie met name de artikelen 6:231 sub $c$ en 232 BW). Kwesties van uitleg en van toetsing van de inhoud zijn er pas als die gebondenheid, die gelding een gegeven is: dan gaat het om de (aanvaardbaarheid van de) toepassing, ofwel de toepasbaarheid van de algemene voorwaarden (zie met name de artikelen 6:233 sub a, 236 en $237 \mathrm{BW}$ ).

In de Overgangswet en de bijbehorende toelichtende stukken worden de begrippen 'toepasselijk' en 'toepassing' door elkaar heen gebruikt. Daarbij valt uit het zinsverband wel op te maken in welke betekenis deze woorden worden gebruikt. Vaak wordt het 'meta-niveau' bedoeld (is een bepaling uit het nieuwe vermogensrecht toepasselijk?): zie bij voorbeeld de artikelen 92, 173 lid 1 ("toepasselijk(heid)) en $68 a, 69,73$ lid 1,74 leden 1,3 en $4,88,101-106$ Ow I ('(niet) van toepassing'). Ook komt echter wel voor dat het gaat om het niveau wan de toepassing van een 'materiële' wetsbepaling ('toepasselijk' in artikel 12॥ lid 2 Ow I); of om de afpaling van het toepassingsgebied van een overgangsbepaling ("(niet) van toepassing' in de artikelen 81 lid 2, 89 lid 3 en 150 lid 6 Ow I).

\section{Zie nr. 2.2.1 hierwór.}

24. Aldus De Die, RMTh 1979 p. 257; zie ook p. 259.

25. Vgl. voor het internationaal privatatrecht Jessurund'Oli weira, diss., p. 25.

26. In andere zin Polman, diss., p. 483; H. Stein, Plaats en tijd, p. 41 e., w, en preadv, p. 259-260. In 'inwerkingtreding' versta ik onder "werken" wat ik in het vorige nr. "gelden" heb genoemd.

27. Zie Parl. Giesch. Overgangsrecht, p. 25, en de nrs. 2.4.1, 2.5.1 en 2.7 hierna, vgl. ook Knigge, diss i, p. 2021. 
Waast de tracering en oplossing van owergangsrechtelijke kwesties lijken mij ook van belang de duur wan het leven dat het overgangsrecht voor het nieuwe $B W$ beschoren zal zijn en het al dan niet dwingende karakter van dit recht. Daarom sta ik bij beide punten stil.

\subsubsection{Het overgangsrecht voor het nieuwe BW: "wegwerprechr"?}

In de toelichting op de Overgangswet valt te lezen:

'Men mag niet verwachten dat het overgangsrecht met evenveel aandacht zal worden bestudeerd als her nieuwe wetboek zelf. Veeleer is het een "wegwerprecht" dat voor het overgrote deel slechts kort dienst zal doen en over het algemeen alleen incidenteel $z a l$ worden geraadpleegd door de rechispraktijk." 28

Deze opmerking ower het wegwerpkarakter van de overgangsregels voor het nieuwe BW heeft in de literatuur een warm onthaal gekregen. Daarbij zal de wens wel de vader van de gedachte zijn geweest. Zo schrijft $\mathbf{H}$. Stein:

'Overgangswetgeving dient steeds een tijdelijk beperkt doel: iedere overgangswet is een wegwerp-pocket, waarvan de praktijk zich zo spoedig mogelijk hoopt te kunnen ontdoen.' 29

Voor zover de karakterisering "wegwerprecht" betrekking heeft op het overgangsrecht voor thet nieuwe $\mathrm{BW}$ acht $\mathrm{ik}$ haar in haar algemeenheid onjuist ${ }^{30}$. Ik veroorloof mij in dit verband een klein uitstapje naar de Overgangswet 1829 (Stbl. 29). Deze heeft betrekking op de in 1838 ingevoerde wetboeken. Zelfs na de Tweede Wereldoorlog moest de Overgangswet 1829 nog in rechterlijke uitspraken worden toegepast ${ }^{31}$. In de memorie van toelichting bij de Invoeringswet Boek $1 \mathrm{BW}$ wordt dan ook opgemerkt:

'Op het eerste gezicht zijn overgangsbepalingen voorschriften welke naar hun aard slechts gedurende korte tijk na het in werking treden van de nieuwe wetgeving behoeven te worden toegepast. De ervaring leert echter dat vragen

28. Parl. Gesch. Overgangsrecht, p. 18.

29. Preadw, p. 265. In gelijke zin onder anderen: Jansen, Kwartaalbericht Nieuw BW 1985, p. 58; De Vries Lentsch-Kosterise, in: BW-k.rant jaarboek 1990, p. 77.

30. Spier, Kwartaalbericht Nieuw BW 1985, p. 54, nuanceert de kwalificatie "wegwerprecht", evenals R.S. Meijer, preadv, p. 27, en De Vries Lentsch-Kostense, in: Quod licet (1992), p. 469-470.

31. Voorbeelden uit (gepubliceerde) rechtspraak:

- Rb. Almelo 7 aprill 1948, NJ 1949, 50 (inzake testamentaire beschikking; artikel 50 Ow 1829);

- HR 30 matart 1951, NJ 1952, 697, vernietigend Hof "s-Gravenhage 15 maart 1950, NJ 1950, 764 (inzake recht wan windvang; artikel 1 Ow 1829 );

- Rb. Breda 24 december 1957, NJ 1958, 383 (inzake (onder)erfpachtsnecht; artikelen 1 en 3 Ow 1829); 
van zgn. overgangsrecht zich nog zeer gerume tijd na hel in werking treden van een nieuwe wetgeving blijven voordoen. ${ }^{3}$,

Nu behoeft wat geldt voor de Overgangswet 1829 natuarlijk niet per se tevens te gelden voor de Overgangswet nieuw BW. Het wil mij echter voorkomen dat ook deze laatste genoeg elementen bevat woor een langere levensduur dan menigeen lief is. De mate waarin een owergangswet eerbiediging wan het oude recht ${ }^{\text {s3 }}$ voorschrijft speelt hierbij een belangrijke rol. In de Overgangswet nieuw BW liggen de voorbeelden van eerbiediging van het oude recht voor het oprapen. Het belangrijkst is artikel $690 \mathrm{OW}$, waarin het beginsel van de eerbiediging van verkregen rechten wondt geconcretiseerd ${ }^{34}$. Als wettelijke norm is dit beginsel opgenomen in artikel 1 Overgangswet 1829 . Het laat zich raden dat juist een dergelijke bepaling frequent en nog vele jaren na de inwerkingtreding zal worden ingeroepen ${ }^{35}$. De voorbeelden in de toelichtende stukken bij artikel 69 Ow I wijzen ook in deze richting ${ }^{36}$ :

Ook in het bijzonder deel van de Overgangswet komen nogal wat bepalingen voor, die eerbiediging van het oude recht gebieden. Voorbeelden hiervan zijn:

- artikel 79 OW I (onaantastbare rechtshandelingen worden niat gebrekkig op grond van nieuwe (ver)nietig(baar)heden) ${ }^{37}$;

- artikel 100 Ow I (artikel 3:177 lid $3 \mathrm{BW}$ is niet toepasselijk op pand- en hypotheekrechten daterend wan vóór de inwerkingtreding);

- artikel $103 \mathrm{OW}$ I (artikel 3:194 lid $2 \mathrm{BW}$ is niet toepasselijk op gemeenschappen als bedoeld in artikel 3:189 lid $2 \mathrm{BW}$, die ten tijde van de inwerkingtreding reeds bestonder);

- artikel 104 Ow I (eerbiediging van artikel 804 (oud) BW inzake het oneigenlijke vruchtgebruik");

- artikel 111 OW I (eerbiediging van artikel 1205 lid 2 (oud) BW inzake het "Gordiaanse retentierecht");

- artikel 114 OW I (eerbiediging van artikel 1229 (oud) BW inzake mede tot zekerheid van bedongen rente strekken van hypotheekrecht daterend van vór de inwerkingtreding);

- Rb. Middelburg 3 februari 1960. NJ 1960, 467, bekrachtigd door Hof' 's-Gravenhage 16 mei 1962 , NJ 1963, 203 (inzake plantrecht; artikel 1 Ow 1829);

- Rb. Rotterdam 1.5 mei 1962, NJ 1962,433 (inzake liefdadige instelling; artikelen 1, 2 en 30 w 1829);

- Hof Arnhem 23 juni 1964, NJ 1965, 378 (inzake waterrecht; artikel 10 w 1829);

- Rb. Utrecht 25 mei 1966, kenbaar uit HR 25 april $1969, N J 1970,3$ (inzake recht van de dertiende pennilng; artikel I Ow 1829):

- Rb. Utrecht 17 november 1971, bekrachtigd door Hof Amsterdam 16 mei 1974, beide kenbaar uit HR 10 oktober 1975, NJ 1976,567, het cassatieberoep tegen het arrest van het hof werwerpend (inzake recht van de dertiende penning; artikelen 1 en $47 \mathrm{Ow}$ 1829) en

- Rb. Alkmaar 25 mei 1978, NJ 1979, 33 I (inzake tiendrechi; artikel 3 0w 1829).

32. Parl. Gesch. Inv. Boek 1, p. 1657. Deze memorie van toelichting, alsmede de ontwerp-overgangsbepalingen voor Boek $\mathbb{B}$ BW, waren ge baseerd op een ontwerp wan L.J. Hijmans van den Bergh; zie Parl. Gesch. Inv. Boek 1, p. 1656.

33. Zie over eerbiediging van het oude recht nader mr, 2.5.1.2 hiema.

34. Zie over artikel 69 OW I in het bijzonder nr. 2.5.1.2 hierna.

35. Zie de in noot 31 hiervóór genoemde rechtspraak.

36. Zie Parl. Gesch. Overgangsrecht, p. 15-16, 38-46.

37. Zie over artikel 79 Ow I de nrs. 4.5 en 4.6 hierna. 
- artikel 118 Ow I (artikel 3:283 BW is niet toepasselijk op ten tijde van de inwerkingtreding reeds bestaande vergoedingsvordering);

- artikel $1190 \mathrm{OW}$ (handhaving verkopersprivilege ten aanzien van ten tijde van de inwerkingtreding reeds bestaande verkopersvorderingen);

- artikel 150 leden 2 en 3 OW I (eerbiediging van oud recht inzake gehandhaafde oude zakelijke rechten);

- artikel 160 Ow I (eerbiediging van het oude recht inzake buurwegen die zijn ontstaan vór de inwerkingtreding);

- artikel 163 OW I (artikel $3: 24$ lid $1 \mathrm{BW}$ is onder bepaalde voorwaarden niet toepasselijk op vo6r de inwerkingtreding door bestemming of herleving ontstane entidienstbaarheden);

- artikel 170 Ow I (artikel 5:99 BW is niet toepasselijk op ten tijde van de inwerkingtreding reeds bestaande erfpacht);

- artikel 178 OW I (artikel 6:41 aanhef en sub b BW is niet toepasselijk op verbintenissen tot aflevering van soortzaken, die voortvloeien wit een vóor de inwerkingtreding ontstane rechtsbetrekking);

- artikel $182 \mathrm{OW}$ I (eerbiediging van het oude recht inzake tekortschieten in de nakoming van een verbintenis vóor de inwerkingtreding) ${ }^{38}$;

- artikel $183 \mathrm{OW}$ I (artikel 6:83 BW is niet toepasselijk op rechtsverhoudingen die ten tijde van de inwerkingtreding reeds bestaan) ${ }^{39}$;

- artikel 190 OW I (de afdelingen 6.4.2 en 6.4.3 BW zijn niet toepasselijk op door het oude recht beheerste vorderingen)

- artikel 193 Ow I (de artikelen 6:253 lid 2 en 254-256 BW zijn niet toepasselijk op derdenbedingen die ten tijde van de inwerkingtreding reeds bestonden);

- artikel 196 lid 2 OW T (de consumentenkoopbepalingen uit titel 7.1 BW zijn in beginsel (zie lid 3) niet toepasselijk op vóor de inwerkingtreding gesloten consumentenkoopovereenkomsten);

- artikel 220 Ow I (eerbiediging van het oude recht inzake borgtocht).

Waar het nieuwe recht wordt buitengesloten, blijft op grond van artikel $68 \mathrm{a}$ lid 2 Ow I het oude recht toepasselijk.

Ook de overgangsbepalingen die voozien in uitgestelde werking 40 van nieuw vermogensrecht zullen niet direct zijn "uitgewerkt"; zij het uiteraard sneller dan de zojuist genoemde eerbiedigende artikelen. Ook uitgestelde werking neemt in de Overgangswet een belangrijke plaats in. Ik noem de volgende voorbeelden:

- artikel 73 lid 1 Ow 1 (uitgestelde werking gedurende een jaar van bepaalde nieuwe termijnregels, indien volgens deze regels de termijn vóór de inwerkingtreding zou beginnen);

- artikel 78 lid 3 Ow I (uitgestelde werking gedurende drie jaar van de artikelen $3: 24$ lid 1,25 en 26 BW ter zake van inschrijfbare feiten geschied vór de inwerkingtreding $)^{4 !}$;

- artikel 88 lid 1 Ow 1 (uitgestelde werking gedurende een jaar van artikel 3:86

38. Zie over artikel 182 Ow 1 hoofdstuk 7 hierna.

39. Zie over artikel 183 Ow I de nrs. 6.5.1.4 en 7.6.2 hierna.

40. Zile over uitgestielde werking nader $\mathrm{nr} .2 .5 .1 .3$ hierna.

41. Zix over artikel 78 lid 3 Ow Int 3.7 hierna. 
BW ter zake van vóór de inwerkingtreding gestolen zaken);

- artikel 93 Ow I (uitgestelde werking gedurende een jaar van artikel 3:105 BW met betrekking tot degene die ten tijde van de inwerkingtreding een goed bezat, in geval van voltooiing van de verjaring van de rechtsvordering tot beèindiging wan het bezit);

- artikel 115 lid 1 Ow I (uitgestelde werking gedurende drie jaar van artikel 3:264 leden 4-8 BW ter zake van vóór de inwerkingtreding gemaakte huurbedingen);

- artikel 115 lid 2 OW I (uitgestelde werking gedurende drie jaar van artikel 3:266 $\mathrm{BW}$ ter zake van vón de inwerkingtreding gevestigde hypotheken);

- artikel 151 lid $4 \mathrm{Ow} I$ (in beginsel uitgestelde werking gedurende een jaar van artikel 3:86 BW ter zake van vóor de inwerkingtreding verloren zaken);

- artikel 191 lid 1 Ow I (uitgestelde werking gedurende een jaar van afdeling 6.5.3 BW ter zake van algemene voorwaarden die ten tijde van de inwerkingtreding reeds in overeenkomsten werden gebruikt);

- artikel 196 lid 1 Ow I (in beginsel (zie leden 2 en 3) uitgestelde werking gedurende een jaar van titel 7.1 BW ter zake van koop-en ruilovereenkomsten die zijn gesloten vớr de inwerkingtreding).

Gedurende de uitsteltermijn is er sprake van "nawerking" van het oude recht (artikel $68 a$ lid 2 Ow I).

Ook bij onmiddellijke werking (de hoofdregel van artikel $68 a$ lid 10 o $\mathrm{I}^{42}$ ) en bij terugwerkende $\mathrm{krach}^{43}$ behoeft de toepassing van de Overgangswet niet beperkt te blijven tot de eerste jaren na de inwerkingtreding. Het is immers, met name in goederenrechtelijke verhoudingen, mogelijk dat geschillen die betrekking hebben op. overgangssituaties waarvoor onmiddellijke werking of terugwerkende kracht geldt pas jaren na 1 januari 1992 rijzen.

Overbruggingsregels ${ }^{44}$ kunnen al evenzeer nog jaren na de inwerkingtreding toepassing vinden. Ik denk bij voorbeeld aan het ingewikkelde artikel $860 \mathrm{OW} \mathrm{l} \mathrm{l}^{45} \mathrm{inza}-$ ke de zekerheidseigendom, die onder het oude recht zeer vaak voorkwam en vak onderdeel uitmaakte van langlopende kredietrelaties.

Ook al neemt het belang van de Overgangswet af naarmate de jaren verstrijken, dit neemt gezien het bovenstaande niet weg dat de kwalificatie "wegwerprecht" voor de Overgangswet een valse schijn van snelle vergankelijkheid wekt ${ }^{46}$.

Genoemde kwalificatie is voorts om nog een andere reden ongelukkig. Het belang van de onderhavige overgangswetgeving is niet beperkt tot het nieuwe BW en satelliet-wetten alleen. Onderdelen van deze overgangswetgeving zijn ook elders bruikbaar. Dit geldt niet alleen voor grondslagen ervan, maar ook voor concrete overgangsregels. Met 'elders' bedoel ik andere delen van het Nederlandse (privaat)recht, zoals de delen van Boek 7 , die nog moeten worden vastgesteld en ingevoerd, de Aanwijzingen voor de regelgeving over het overgangsrecht en het internationaal privaatrecht $t^{47}$. Uit de met name voor wetgevingsambtenaren bestemde

42. Zie over onmiddellijke werking nr. 2.5.1.1 hierna.

43. Zie over terugwerkende kracht nr. 2.5.1.4 hierna.

44. Zie daarover nr. 2.5 .2 hierna.

45. Zie daarover hoofdstuk 5 hierna.

46. De Owergangswet kent zelfs het verschijnsel "permanente overgangsbepaling": zie artikel 156.

47. Zie nir. 2.2.1 hiervótr. 
nota van De Die 'De aanpak van het overgangsrecht - een spoedcursus' zou men kunnen afleiden dat de systematiek van het overgangsrecht voor het nieuwe vermogensrecht is voorbesternd om ook buiten dat wermogensrecht gebruikt te gaan worden $^{48}$ "Het onderhavige overgangsrecht zou zelfs wel eens een "exportartikel' kunnen worden. Van Dijk meldt in zijn bijdrage aan het Liber amicorum NBW ${ }^{49}$ dat dit overgangsrecht ook internationaal de aandacht heeft getrokken.

\subsubsection{Het overgangsrecht woor het nieuwe BW: dwingend recht?}

In tekst en parlementaire geschiedenis van het overgangsrecht nieuw BW zijn geen duidelijke en algemeen geldende aanknopingspunten te vinden voor de beantwoording van de vraag of dit recht dwingend dan wel regelend van aard is ${ }^{50}$. Wel is in de parlementaire geschiedenis een zeer verwante kwestie aan de orde geweest. Deze betrof het vraagstuk of het in de macht van partijen lag om onder het oude recht af te spreken dat hun rechtsverhouding onttrokken zou zijn aan toekomstig dwingend recht. Volgens de toelichting op het oorspronkelijke artikel 71 lid $1 \mathrm{OW}$ I is dit niet mogelijk: het ligt bij voorbeeld

"buiten de macht van partijen een andere wijze van levering van een goed te voorzien dan die welke op het tijdstip van die levering geldend recht zal zijn. '51

$\mathrm{Na}$ in de literatuur geuile kritiek bleef de minister, daarnaar gevraggd in het voorlopig verslag van de Tweede Kamer, bij zijn standpunt ${ }^{52}$. Daarbij merkte hij op dat de onderhavige kwestie niet op het terrein van het overgangsrecht ligt. Men zou hierin de opvatting kunnen lezen dat aan de vraag of het overgangsrecht dwingendrechtelijk van aard is niet kan worden toegekomen, omdat het toepasselijke materiële recht zelf daarvoor beslissend is. Is dat materiële recht dwingend, dan zou er dus om die reden niet vóor de invoering van dat recht van kunnen worden afgeweken: vanaf het toepasselijk worden van de nieuwe dwingende materiële regel zou het afwijkende beding nietig of vernietigbarar zijn. Is het regelend, dan zou afwijking

48. Vgl, in het bijzonder p. I van genoemde nota. In de toelichting op de Overgangswet wordt overigens over de antikelen 68-75 Ow I gezegd:

"Als richthijnen van algemene inliowd lenen zij zich uiteraard in beginsel wel voor analogische toepassing

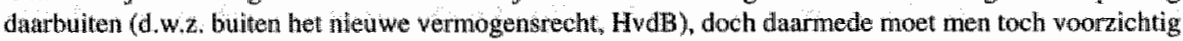
zijn." (Pail. Gesch. Ovengarggsecht, p. 6-7).

Reinsma, Overgangswet, deel 1, p. 67, merkt op dat het denkbaar is "dat de niewwe overgangswetgeving, ,ok door de grondige theoretische fundering, ook buiten het vermogensrecht invloed zal hebben."

49. P. 5 .

50. Slechts hier en daar blijkt uitdrukkelijk uit tekst of parlementaire geschiedenis van een overgangsbepaling, of deze dwingend recht bevat of niet. Zo artikel $185 \mathrm{Ow}$ I en Parl. Gesch. Overgangsrecht, p. 144, 145 (ad artikelen 166 en 167 Ow I). Artikel 75 Ow I geeft op de onderhavige vraag net zo mim een antword als de artiketen $6: 2$ lid 2 en 248 lid 2 BW dat doen ten aanzien van de vraag of het materiele recht dwingendrechtelijk van aard is of niet.

51. Parl. Gesch. Overgangsrecht, p. 46.

52. Zie respectievelijk Spier, Kwartaalbericht Nieww BW 1985, p. 54 en Van der Beek, Kwartaalbericht Nieuw BW 1986, p. 81; Parl. Gesch. Overgangsnecht, p. $48,50$. 
door het materiële recht zelf worden toegelaten. Qua resultaat komt deze benadering mij aanvaardbaar voor. Dat geldt echter niet voor de weg waarlangs dat resultaat wordt bereikt. Men kan immers in het geheel niet toekomen aan toepassing vain materieel nieuw dwingend recht, indien het mogelijk zou zijn om de overgangsregel die daarnaar verwijst weg te contracteren. De vraag is dus nog steeds of het overgangsrecht voor het nieuwe BW dwingend van aard is of niet.

Als uitgangspunt bij de beantwoording van deze vraag neem ik dat gezien moet worden naar de bedoeling van de wetgever en de aard en strekking van de wettelijke regeling ${ }^{53}$. Op grond van deze factoren acht ik het overgangsrecht nieuw $\mathrm{BW}$ dwingendrechtelijk van aard ${ }^{54}$. Juist dit recht dient immers ter bevordering van rechtszekerheid ${ }^{55}$ en duidelijkheid en ter voorkoming van procedures. Niet voor niets heeft de wetgever zich ertoe gezet om iedere nieuw BW-bepaling overgangsrechtelijk door te lichten, teneinde het meest wenselijke overgangsregime voor die bepaling vast te kunnen stellen ${ }^{56}$. Hij heeft daarbij telkens een afweging gemaakt tussen enerzijds het individuele belang dat bestaande rechtsposities en rechtsverhoudingen na de inwerkingtreding zoveel mogelijk ongestoord kunnen worden voortgezet, en anderzijds thet algemene belang dat het nieuwe recht over de gehele linie wordt ingevoerd ${ }^{57}$. Dit heeft geleid tot een gedetailleerde overgangswetgeving en tot een uitgebreide toelichting, waarin onder meer bij in beginsel elke nieuwe bepaling eventuele overgangsproblemen en oplossingen daarvoor worden aangegeven. De parlementaire behandeling van de voorgestelde overgangswetgeving heeft nog eens tot heroverweging, wijziging en nadere toelichting geleid. Bij deze stand van zaken is wel zeer onaannemelijk dat het de justitiabelen zou vrijstaan om het zorgvuldig door de wetgever gekozen evenwicht te verstoren door van overgangsbepalingen naar believen af te wijken.

Men zou de vraag kunnen stellen of een regel uit de overgangswetgeving niet regelend is, indien deze verwijst naar materieel recht dat een regelend karakter bezit, of een brug slaat naar materieel nieuw recht (overbruggingsrege ${ }^{58}$ ). Als men van het materiële recht kan afwijken, waarom zou men dan niet ook van de overgangsregel kunnen afwijken? Gelet op het hierboven betoogde moet mijns inziens worden geoordeeld dat ook hier de overgangsregel dwingendrechtelijk is ${ }^{5 \%}$. Voorop staat dat helder moet zijn welk materieel recht op een bepaalde casus toepasselijk is. Van dàt recht kan men afwijken voor zover ${ }^{60}$ het niet dwingendrechtelijk is. Desgewenst kan men dan datgene overeenkomen wat zou hebben gegolden, indien het door de overgangsregel 'afgewezen' recht toepasselijk zou zijn geweest. Een voor-

53. Vgl. (voor wettelijke voorschriften in het algeneen) Asser-Harkamp II, nr. 247.

54. Behoudens uitdrukkelijke annwijzingen voor het tegendeel, zoals in het reeds genoemde artikel $1850 \mathrm{~W}$ I.

55. Vgl. Asser-Hartkamp II, nr. 247: 'Bij het creëren van dwingend recht kan de wet hebben beoogd de zekerheid in het rechtswerkeer te dienen (...)'.

56. Zie Parl. Gesch. Overgangsrecht, p. 18; De Die, A.A 1991, p. 827.

57. Vgl. Parl. Gesch. Overgangsrecht, p. 5, 11.

58. Zie over verwijzings- en overbruggingsregels nr. 2.5 hierna.

59. Tenzij het tegendeel uitdrukkelijk zou blijken, bij voorbeeld uit de tekst van de Overgangswet; zie ald dus het reeds genoemde artikel $1850 \mathrm{OW}$.

60. Zoals bekend bestaan er verschillende gradaties dwingend recht, zie bij voorbeeld Parl. Gesch. Inv. Boek 3,p. 1020-1021. 
beeld hiervan levert artikel 170 Ow I, op grond waarvan artikel 5:99 BW inzake de vergoedingsplicht van de grondeigenaar bij het einde van de erfpacht niet toepasselijk is op erfpachtsrechten die ten tijde van de inwerkingtreding reeds bestonden. Krachtens artikel $68 a$ lid 2 Ow I blijft het oude recht op zulke erfpachtsrechten in zoverre toepasselijk. Dit oude recht was regelend van aard (zie de artikelen 773 jo. 782 (oud) $\mathrm{BW}$ ). Niets belet partijen om een vergoedingsregeling overeen te komen, die overeenstemt met die van artikel 5:99 BW. Hun verhouding blijft op grond van de artikelen 170 jo. 68 a lid 2 Ow I evenwel ook dan beheerst door genoemde buiten werking getreden bepalingen.

Er zijn mij maar weinig auteurs bekend, die zich hebben uitgesproken over de vraag of het overgangsrecht nieuw BW dwingend van aard is of niet. $H$. Stein schrijft dat het niet erg waarschijnlijk lijkt

dat de Overgangswet boeken 3,5 en 6 aan contractanten de vrijheid laat om op hun overeenkomsten de oude BW-bepalingen toepasselijk te verklaren. Voor zover die vrijheid aan partijen al zou toekomen, zouden daardoor de dwingende NBW-bepalingen niet uitgesloten worden. De contractanten zouden dus bedacht worden met een ratjetoe van BW-bepalingen, geflankeerd door daarop slecht aansluitende dwingende NBW-voorschriften. ${ }^{61}$

Deze opvatting komt dicht in de buurt van de hierboven verdedigde.

Het is op zijn zachtst gezegd opmerkelijk dat van de inmiddels toch reeds tamelijk talrijke auteurs over het overgangsrecht nieuw BW er zo weinig zijn, die zich over de hier aan de orde zijnde vraag uiten. De dwingendheid van het overgangsrecht nieuw BW ligt voor deze auteurs kennelijk zó voor de hand dat zij er daarom geen aandacht aan besteden.

\subsection{WANNEER RIJZEN VRAGEN VAN OVERGANGSRECHT?}

Wil zich een overgangsrechtelijke vraag voordoen, dan moeten er enkele vereisten vervuld zijn: éen aan de feiten en één aan het recht. Er moet sprake zijn van een overgangssituatie en van een 'opeenvolgen van rechtsregels'. Het begrip 'overgangssituaties' licht ik toe in nr. 2.4.1. Enkele vragen waartoe het opeenvolgen van rechtsregels in overgangssituaties kan leiden noem ik in $\mathrm{nr}$. 2.4.2.

\subsubsection{Overgangssituaties}

Het is geen eenvoudige zaak om uit te maken bij welke elementen van een casus men in het overgangsrecht het best kan aansluiten. Ik zet hierna de 'vondist' van de

61. Plaats en tijd, p. 20. Stein makk de geciteerde opmerkingen bij de beantwoording van de vraag of de lex causae ( het krachtens de verwijzingsnegel toepasselijke materiele recht', aldus de omschrijving van Stein op p. 2) aan partijen de vrijheid Iaat om toekornstige wijzigingen van de lex causae uit te sluiten. Joppe, diss., p. 67, noot 80, merkt over de geciteerde passage op dat deze "op het interinechtelijke vlak (min of meer) juist" is. 
overgangswetgever uiteen en voorzie deze van kanttekeningen. Tenzij anders vermeld, ga ik daarbij uit van onmiddellijke werking ${ }^{62}$ van de nieuwe wet:

\subsubsection{De bestaande rechtstoestand en de vereisten van de nieuwe wet}

Een overgangssituatie is er in beginsel niet, indien de nieuwe wet een rechtstoestand (een recht, een rechtsbetrekking) eist, die op het tijdstip van de inwerkingtreding niet meer aanwezig was ${ }^{63}$. "In beginsel", omdat bij terugwerkende kracht denkbatar is dat de toepasselijkheid van een nieuwe regel zelfs wordt uitgestrekt tot rechten etc., die vóor de inwerkingtreding bestonden maar bij de inwerkingtreding niet meer64. 'In beginsel' ook, zo voeg ik hieraan toe, ondat sprake kan zijn van "schijndood': de aannemingsovereenkomst die tot tevredenheid van partijen lijkt te zijn afgewikkeld kan jaren later, als het door de aannemer gebouwde als gevolg van emstige verzakkingen teniet dreigt te gaan, alsnog tot een actie uit wanprestatie aanleiding geven, terwijl tussentijds het nieuwe recht is ingevoerd. En zelfs wanneer dit alles zich vóor de inwerkingtreding heeft afgespeeld en het geschil toen reeds op enigerlei wijze is beslecht, is een vervolggeschil niet onmogelijk ${ }^{65}$.

Een overgangssituatie is er in beginsel evenmin, indien de feiten die de wet vereist zich onder het oude recht al hebben voorgedaan en hun rechtsgevolg toen al hebben gehad: de zogenaamde 'voldongen feiten' 66 .

Ook het omgekeerde kan zich voordoen: de toestand of de feiten die de nieuwe wet vereist worden pas na de inwerkingtreding 'geboren'. Dan betreedt men evenmin het terrein van het overgangsrecht: een in werking getreden wet geldt uiteraard voor wat na de inwerkingtreding aan rechten op goederen, overeenkomsten en andere rechtsbetrekkingen ontstaat ${ }^{67}$.

Het overgangsrecht komt in de opvatting die aan de Overgangswet ten grondslag ligt slechts in actie ten aanzlen van de ten tijde van de inwerkingtreding bestaande rechtstoestand. Deze is samengesteld uit netwerken van rechtsposities en rechtsverhoudingen, zoals bestaande vermogensrechten en bestaande verbintenissen ${ }^{68}$. Het woord 'rechtstoestand' wordt hier als verzamelnaam gebruikt. Het is het opmerken waard dat deze verzamelnaam een zo nuime betekenis heeft dat daaronder zelfs al die feitelijke omstandigheden vallen, waaraan de oude wet geen en de nieuwe wet wel rechtsgevolg verbindt ${ }^{69}$. Hiernaast gebruikt de wetgever het woord (rechts)toe-

62. Zie over de onmiddellijke werking nr. 2.5.1.1 hierna.

63. Zoals hierna zal blijken, is de overgangssituatie in het systeem wan de Overgangs wet een kwestie van de vereisten wan de niev we wet.

64. Zie Parl Gesch. Owergangsrecht, p. 8, noot 1 .

65. Vgl. Btunner, WPNR 6007 (1991) p. 342.

66. Dit lijkt mij althans de strekking te zijn wan: Parl. Gesch. Overgangsrecht, p. 13-14. Vgl. ook De Die, Spoedcursus, p. 13-14,23. Zie nader over het belang wan feiten voor het overgangsrecht nt. 2, 4. 1.2 hierna. 67. Vgl. Parl: Gesch. Overgangsfecth, p. 7, bekritiseerd door H. Stein, in: Liber amicorum NBW, p: 159, noot 1.

68. Zie Parl. Gesch. Overgangsrecht $\mathrm{p}$. 7-8.

69. Zie Parl. Gesch. Overgangstecht, P.9. 
stand woor individuele gevallen, zoals het zijn van eigenaar ${ }^{70}$. Voor bepaalde categorieen (rechts)toestanden komt men in de parlementaire stukken ook wel termen tegen als 'recht', '(rechts)betrekking", '(rechts)positie', '(rechts)verhouding', "schuld" etc.".

Van groot belang is nu hoe in een overgangsregel aansluiting wordt gezocht bij de voorliggende feitelijkheden, met andere woorden: waaraan de overgangsregel de (niet-)werking van het nieuwe recht wastknoopt. De overgangswetgever noemt dit aanknopingspunt in overgangsregels de 'overgangssituatie'. Of er zo'n situatie is hangt naar zijn mening hiervan af, of in de ten tijde van de inwerkingtreding bestaande rechtstoestand de vereisten zijn vervuld, die de nieuwe regel stelt voor het intreden van een rechtsgevolg (vgl. artikel $68 a$ lid 10 ow $)^{72}$.

Uitgaande van de driedeling zoals ik deze in nr. 2.2.2 hiervóór heb uiteengezet, geldt voor de vereisten het volgendle. In de eerste plaats kan de nieuwe wet een zekere, min of meer duurzame, toestand (zoals het zijn van eigenaar) eisen. Deze moet dan bestaan hebben ten tijde van de inwerkingtreding. Mogelijk is ook aanknoping bij een door de nieuwe wet vereist feit in de zin van een gebeurtenis (zoals het toebrengen van schade). Dit feit moet dan vóor de inwerkingtreding zijn voorgevallen en in beginsel onder het oude recht nog niet zijn rechtsgevolg hebben gehad. In verband met de eigenaardige rol, die feiten in thet overgangsrecht voor het nieuwe BW spelen, besteed ik daaraan apart aandacht in nr. 2.4.1.2 hierna. Ten slotte kan mede van belang zijn de vereiste juridische waardering van toestand of feit (zoals onrechtmatigheid van de daad en geldigheid van de titel). Om relevant te zijn in het overgangsrecht moet zo'n juridisch vereiste

"zijn vervuld in de overgangssituatie, d.w.z. op gelijke wijze als de toestand of het feit waarbij het behoort: in geval van onmiddellijke werking bij (toestand) of vóór (feit) de inwerkingtreding. Wordt aan een anterieure onrechtmatige daad een nieuw rechtsgevolg toegekend, dan is dat alleen het geval ten aanzien van daden die onder het tevoren geldende recht, toen ze werden gepleegd, reeds als onrechtmatig moesten worden angemerkt. ${ }^{\text {.73 }}$

De Overgangswet gaat er, zoals zoëven reeds vermeld, van uit dat er een overgangssituatie aanwezig is, indien ten tijde van de inwerkingtreding de vereisten van de nieuwe materiële regel voor het intreden van een rechtsgevolg reeds waren vervuld (vgl. artikel $68 a$ lid 1 Ow I). De overgangssituatie wordt hier dus bezien vanuit de vereisten van de nieuwe wet. Deze vereisten kunnen overigens worden vervuld door rechtsgevolgen (eigendomsrechten, overeenkomsten, aansprakelijkheden etc.) uit hoofde van de oude wet, voor zover deze bij de inwerkingtreding nog steeds bestonden. Zo werken tussen de eigenaars van naburige erven vanaf de inwerkingtreding voor het vervolg de nieuwe regels voor de verplichtingen uit het burenrecht (artikel 159 Ow I).

70. Zie bij voorbeeld Parl, Gesch. Overgangsrecht, $\mathrm{p}, 37$.

71. Vgl. Polman; Overgangswet, deel 1, p. 10-11.

72. Zie Parl Gesch. Overgangsrecht, p. 23, alsmede De Die, DD 1989, p. 882; De Die, Spoedcursus, p. 8-9. 73. Aldus De Die, Spoedcursus, p. 15; zie ook p. 3-4, 12, 13-14; Parl. Gesch. Overgangsrecht, p. 45. Zie over 
De vereisten van de nieuwe wet kunnen slechts vervuld zijn doordat (kort gezegd) een bepaalde toestand bij de inwerkingtreding bestond of voordien bepaalde feiten waren voorgevallen. De overgangssituatie is weliswaar in eerste instantie een kwestie van de vereisten van de nieuwe wet, zonder een bepaalde feitelijke grondslag komt men er niet: zonder wanbetaling door een debiteur geen (aanzegging van) uitwinning, zonder geleden schade geen vordering tot schadevergoeding ${ }^{74}$.

In het kader van een bepaalde toestand (zoals een bij de invoering aanwezige overeenkomst) kan een kluwen van overgangssituaties bestaan, zoals ter zake van wanprestatie, recht van reclame, privilleges, verjaring en opschortingsrechten. Deze overgangssituaties moeten uiteen worden gehaald en hebben elk hun eigen overgangsrecht ${ }^{75}$.

\subsubsection{De relevantie van anterieure feiten}

Geheel klare wijn schenkt de overgangswetgever niet waar het gaat om het belang van zogenoemde anterieure feiten voor het overgangsrecht. Een enkele keer lijkt het erop alsof zulk belang ontbreekt:

'Het ontwerp gaat (...) niet uit van (het zoeken naar) 'anterieure feiten'. Voorop staat de vraag, of ten tijde van het in werking treden van een regel van de nieuwe wet de vereisten die deze voor het intreden van zijn rechtsgevolg stelt, reeds zijn vervuld; moet deze vraag bevestigend worden beantwoord, dan is er sprake van een overgangssituatie $(. . .)^{76}$.

Deze passage uit het Nader Rapport aan de Koningin maakt onderdeel uit van een betoog waarin de aan de leer van Hijmans van den Bergh ontleende regels van punt 74 van de Aanwijzingen voor de wetgewingstechniek worden bestreden. In deze regels vormen vóór de inwerkingtreding voorgevallen feiten het aanknopingspunt ${ }^{77}$. Bovenstaand citaat wijkt echter af van wat elders in de parlementaire stukken wordt gesteld: voor zover anterieure feiten vervulling van vereisten uit een nieuw BW-bepaling opleveren, spelen zij wel degelijk mee in het overgangsrecht, zoals uit onderstaande passage blijkt:

"Veelal knoopt men in definities van overgangsrecht aan bij de feiten die vóór het tijdstip van inwerkingtreding zijn voorgevallen (anterieure feiten) - onmiddellijke werking verbindt dan aan deze feiten vanaf dat tijdstip de gevolgen der nieuwe wet.

Deze zienswijze is niet onjuist - zij ligt ook ten grondslag aan het nieuwe voorgestelde artikel 69 onder $d$-, maar voor een algemene regel is zij te be-

het in de laatste zin van het citaat gestelde nr. 6.5.2.1 hierna.

74. VgL. Parl. Giesch. Overgangsrecht, p. 45; Polman, Owergangswet, deel 1, p. 14.

75. Zie De Die, Spoedeursus, p. 13; Pollman, Overgangstwet, deel 1, p. 18.

76. Aldus Parl. Gesch. Overgangsrecht, p. 23. Vgl. hierbij met name artikel 68a lid 1 Ow I.

77. Zie hierover nader Van der Beek, RegelMaat 1986, p. 159-160. 
perkt. De wet verbindt immers niet alleen rechtsgevolgen aan feiten, gebeurtenissen, maar ook aan een bepaalde toestand, zoals het zijn van eigenaar, schuldeiser, schip, enz. enz. (...)

Als voor het rechtsgevolg een bepaald feit is vereist, moet dat vóor dit tijdstip zijn geschied, en onder het oude recht zijn rechtsgevolg nog niet hebben

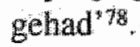

Zo geeft in het stelsel van de Overgangswet het voorheen geschiede feit van een onrechtmatige daad een overgangssituatie, indien de veroorzaakte schadle volgens het oude recht niet vergoedbaar was, maar volgens het nieuwe wel, zoals kan worden afgeleid uit artikel 69 aanhef en sub d OW I. Feitelijke omstandigheden, voorgevallen vóór de inwerkingtreding, die onder de oude wet geen rechtsgevolg hebben gehad, kunnen onder het nieuwe recht alsnog rechtsgevolg hebben. Deze gedachte wordt echter genuanceerd doordat de ontwerper elders aangeeft dat soms anterieure feiten (zoals niet-nakoming) wel degelijk krachtens de nieuwe wet rechtsgevolg kunnen hebben, ook al hebben zij onder het oude recht al rechtsgevolg gehad: als voorbeeld noemt hij bevoegdheden (zoals die tot opschorting), die (bij onmiddellijke werking) in beginsel gaan en komen met de wet die hen toekent ${ }^{79}$. Zoals uit artikel 69 sub a Ow I kan worden opgemaakt, is in de visie van de overgangswetgever tevens sprake van een overgangssituatie, indien aan feiten door het oude recht een rechtsgevolg werd verbonden, dat het nieuwe recht voor die feiten niet kent ${ }^{80}$.

Ook kan zich het geval voordoen dat feiten naar oud recht wel rechtsgevolg hebben, maar dat naar nieuw recht niet zouden hebben, omdat dat een nieuw vereiste stelt, waaraan niet is voldaan. Een voorbeeld daarvan levert de cessie van vorderingen op naam. Het ontstaan van het rechtsgevolg onder het oude recht wordt met rust gelaten: de ontstaansfeiten leveren geen overgangssituatie op ${ }^{\$ 1}$. De rechtsgevolgen (hier: de overgang van de vordering) die zulke 'voldongen feiten' onder het oude recht hebben gehad, kunnen in de visie van de overgangswetgever echter wel een overgangssituatie geven, met name als zij zelf weer als vereisten van de nieuwe wet fungeren ${ }^{82}$. Zo kunnen de verplichtingen uit hoofde van artikel $6: 143 \mathrm{BW}$ ook in geval van overgang van een vordering, die onder het oude recht heeft plaatsgevonden, vanaf de invoering voor het vervolg gaan werken ${ }^{83}$.

Kumnen ook bij de invoering aanwezige toestanden onder het nieuwe recht in beginsel geen rechtsgevolg hebben, als zij onder het oude recht reeds tot rechtsgevolg hebben geleid, zoals bij anterieure feiten het geval is? Het valt immers op dat de wetgever de clausulering van het 'onder het oude recht zijn rechtsgevolg nog niet hebben gehad' wel bij de anterieure feiten noemt, maar - zonder motivering - niet

78. Aldus Parl. Gesch. Overgangsrecht, p. 36-37. Ook op p. 8, 9, 11-14 en 45 wordt aan 'anterieure feiten' overgangsrechtelijke betekenis toegekend. Zie tevens De Die, Spoedcursus, p. 3-4, 13-14.

79. De Die, Spoedcursus, p. 14.

80. Zie hierover ook de nrs, $2.5 \% 1.1$ sub c. 2 en 2.5 .1 .2 sub c. 2 en sub e hierna.

81 . Zie echter inzake de werking van de cessie jegens de debitor cessus artikel $900 \mathrm{~W}$ I.

82. Zie voor dit alles Parl. Gesch. Overgangsrecht; p. 9, 13-14, 37; De Die, Spoedcursus, p. 13-14.

83. Zie Purl. Gesch Overgangsrecht, p. 312. Zie over "voldongen feiten" de nrs. 2.5.1.1 subc $2,2.5,1.2$ sub c.2en 2.5.1.4 sub b hierna. 
bij de op het moment van de invoering bestaande toestanden ${ }^{84}$. Zoals ook de wetgever kennelijk van oordeel is, moet naar mijn mening het antwoord op de gestelde vraag ontkennend luiden. Een bij de invoering aanwezige toestand zal dus geen "voldongen toestand' zijn. Het wezenlijke verschil tussen anterieure feiten en bij de invoering bestaande toestanden is immers dat de eerste niet meer aanwezig zijn onder de gelding van de nieuwe wet en de tweede wel. Voor de periode vanaf de inwerkingtreding kan de toestand (bezit, overeenkomst) derhalve tot rechtsgevolg leiden, ook als hij voordien reeds rechtsgevolg heeft gehad. De bezitter die vór de inwerkingtreding krachtens de artikelen 630-636 en 658-660 (oud) BW vorderingsrechten heeft verkregen (die in het systeem van de Overgangswet gehandhaafd blijven op grond van artikel $69 \mathrm{sub}$ a) kan heel goed vanaf de inwerkingtreding vorderingsrechten verwerven op grond van de artikelen 3:120 123 BW'.

\subsubsection{Telt alleen het invoeringstijdstip?}

Zoals inmiddels is gebleken, dringt de overgangswetgever de overgangssituatie terug tot een nogal beperkt gebied. Slechts indien ten tijde van de inwerkingtreding de vereisten - niet enkele, maar alle vereisten - van de nieuwe wet voor een bepaald rechtsgevolg reeds waren vervuld, is er volgens hem een overgangssituatie. Die is er in deze visie dus bij voorbeeld niet, indien bij een erfpacht die reeds bestond bij de invoering pas nadien wordt voldaan aan de vereisten die artikel 5:97 lid $1 \mathrm{BW}$ stelt voor opheffing van de erfpacht op grond van onvoorziene omstandigheden. Toch kent de Overgangswet hiervoor een overgangsbepaling: artikel 169 Ow I. Ook het na de invoering verstrijken van een termijn die is bepaald voor de nakoming van een verbintenis daterend van vóór de invoering zou in de opvatting van de overgangswetgever niet een overgangssituatie opleveren: op het moment van de inwerkingtreding was immers niet voldaan aan de vereisten van artikel $6: 83$ sub a BW. Toch ziet op dit laatste geval een overgangsbepaling, namelijk artikel $183 \mathrm{OW}$ ${ }^{86}$. Net als bij artikel 169 Ow I is voor de toepassing van artikel 183 Ow I onverschillig, of bij de inwerkingtreding de vereisten van het nieuwe recht reeds waren vervuld. Illustratief is de toelichting bij laatstgenoemdle bepaling:

'Artikel 183 heeft, anders dan artikel 182, mede betrekking op de gevallen warin ten tijde van de inwerkingtreding der nieuwe wet van niet nakoming nog geen sprake is, m.a.w., het gaat verder in de eerbiediging van oud recht." 87

Al helemaal geen overgangssituatie lijkt de overeenkomst op te leveren, die in 1992 wordt gesloten met toepasselijkwerklaring van algemene voorwaarden. Toch bevat de Overgangswet hiervoor een overgangsbepaling: gaat het bij die overeenkomst om algemene voorwaarden die bij de inwerkingtreding reeds in overeenkomsten

84. Zie met name Parl. Gesch. Overgangsrecht; p. 37.

85. Zie met betrekking tot artikel $3: 122 \mathrm{BW}$ artikel $96 \mathrm{OW} \mathrm{I}$.

86. Zie hierover nr. 7.6.2 hiena.

87. Parl. Gesch. Overgangsrecht, p. 163 (mijn cursiwering). 
werden gebruikt, dan is tot 1 januari 1993 afdeling $6.5 .3 \mathrm{BW}$ inzake allgemene voorwaarden niet toepasselijk. Dit geldt zelfs, indien in het jaar 1992 wijzigingen worden aangebracht in die algemene voorwaarden ${ }^{88}$.

Naar aanleiding van deze voorbeelden zou men het begrip overgangssituatie ruimer kunnen opvatten, zodat daaronder ook die situaties vallen waarin pas ná de invoering ten aanzien van een "overstaande' rechtspositie, rechtsverhouding etc. wordt voldaan aan de vereisten die het nieuwe $B W$ voor het intreden van een rechtsgevolg stelt ${ }^{89}$. Een andere mogelijkheid zou zijn, te aanvaarden dat overgangsbepalingen ook op niet-overgangssituaties betrekking kunnen hebben. Ik kies voor de eerste optie. Het lijkt mij wenselijk om de inhoud van het begrip "overgangssituatie' te laten aansluiten bij het door de Overgangswet bestreken terrein. Ik illustreer dit met nog enkele andere voorbeelden.

De overgangswetgever besteedt in zijn beschouwingen over de betekenis van de onmiddellijke werking onder meer aandacht aan de zogenoemde 'onvolledige complexen van rechtsfeiten'. Onder deze abstracte benaming verstaat hij het in de tijd gespreid plaatsvinden van een samenstel van feiten die vereist zijn voor een bepaald rechtsgevolg, en wel zodanig dat een gedeelte van die feiten vóór de invoering is voorgevallen en de rest pas daarna. Bij onrechtmatige daad bij voorbeeld kan het zich voordoen dat nieuw recht in werking treedt tussen het begaan van de onrechtmatige gedraging en het daardoor ontstaan van schade in. Ten tijde van de inwerkingtreding waren nog niet alle vereisten van de oude wet voor aansprakelijkheid vervuld. De overgangssituatie was ten tijde van de inwerkingtreding nog slechts in statu nascendi, aldus de wetgever ${ }^{90}$. Zodra (na de inwerkingtreding) aan alle vereisten is voldaan, is de overgangssituatie zijns inziens 'volwassen' geworden. Dat is in de opvatting van de wetgever omtrent het begrip 'overgangssituatie' juist. Het toont echter tevens aan dat met alleen het tijdstip van de inwerkingtreding als peilmoment voor de vervulling van de vereisten van de nieuwe wet niet kan worden volstaan. Ik zou ook hier een overgangssituatie in eigenlijke zin willen aannemen.

Op welk(e) tijdstip(pen) de overgangssituatie zich bevindt, hangt mede af van de verwijzingsregel waarmee men wordt geconfronteerd. De Die schrijft:

'Bij onmiddellijke werking en eerbiediging van oud recht is de overgangssituatie de toestand op het tijdstip van i.w.t., bij terugwerkende kracht en uitgestelde werking gaat ze verschuiven." 91

Bij terugwerkende kracht is de overgangssituatie die van het tijdstip (T) tot waar wordt teruggewerkt. Alles wat vanaf het tijdstip $\mathrm{T}$ is voorgevallen wordt volgens De Die gegrepen door de nieuwe wet. Dit moet naar mijn mening echter wel worden genuanceerd, zoals ook in de toelichting op de Overgangswet ${ }^{92}$ geschiedt: in-

88. Zie over artikel 191. OW I de nrs. 2.6.2 en 4.5.6 hierna.

89. In deze zin De Vries Lentsch-Kostense, in: Liber amicorum NBW, p. 171-172; Mon. Nieww BW A-25 (De Wries Lentsch-Kostense), p. 27.

90. Zie Parl. Gesch. Overgangsrecht, p. 12; De Die, Spoedcursus, p. 10, 22. Zie over de "schadle met vertraging" bij onrechtmatige daad nr. 6.5.2 hierna.

91. Spoedcursus, p. 10. Zie over de genoemde temporele werkingen nr. 2.5:1 hierna.

92. Parl. Gesch, Overgangsrecht, p. 8, noot 1 . 
dien de rechtsverhouding, rechtspositie etc. op het tijdstip T aanwezig was, maar op het ogenblik dat de nieuwe wet in werking trad niet meer, zal doorgaans zelfs bij terugwerkende kracht de nieuwe wet zo'n rechtsverhouding etc. niet meer bereiken. Behalve op het tijdstip $T$ wordt het peillood alsdan ook op het tijdstip van de invoering naar beneden gelaten; pas als de rechtsverhouding of -positie op beide momenten wordt aangetroffen (en daarmee is voldaan aan de vereisten van de nieuwe wet), kan de terugwerkende kracht zich doen gelden. De overgangssituatie moet er dus zowel op het tijdstip $T$ als op dat van de inwerkingtreding zijn geweest.

Ook zonder dat er terugwerkende kracht in het spel is kan in een overgangsregel zijn voorzien, terwijl de overgangssituatie zoals de wetgever deze opvat 'bij de i.w.t. als het ware all achter de rug' is ${ }^{93}$. Een voorbeeld hiervan is het 'voldongen feit' van een zekerheidsoverdracht die dateert van vóór de inwerkingtreding: deze valt onder artikel $86 \mathrm{Ow} \mathrm{I}^{94}$. Bij de inwerkingtreding aanwezige zekerheidseigendom levert echter naar mijn mening wel een overgangssituatie op.

Een dubbele meting is er ook bij uitgestelde werking: niet alleen bij de inwerkingtreding, maar ook na afloop van het uitstel van de werking van de nieuwe regel moet de rechtsverhouding etc. er zijn, wil die nieuwe regel toepasselijk kunnen worden. Geeft de meting alleen bij de inwerkingtreding een positief resultaat, dan wordt de nieuwe regel in beginsel niet meer ingeschakeld. Beide gevallen merk ik als overgangssituatie aan ${ }^{95}$.

\subsubsection{Invoering van een nieuwe wet}

Geen overgangsrecht zonder overgangssituatie. Dit impliceert in de visie van de overgangswetgever dat er een nieuwe wet is ingevoerd. Immers, zijns inziens is er pas een overgangssituatie, indien op het ogenblik van de inwerkingtreding alle vereisten van die nieuwe wet voor een bepaald rechtsgevolg waren vervuld.

Het opgevolgde oude ${ }^{96}$ en het opvolgende nieuwe recht kunnen zich op verschillende manieren tot elkaar verhouden ${ }^{97}$. Zonder te streven naar volledigheid onderscheid ik enkele mogelijkheden; de onderscheidingen zijn slechts bedoeld om enig overzicht over die mogelijkheden te scheppen. Uitgangspunt is de structuur van een rechtsregel, zoals deze door de wetgever wordt gezien: een rechtsregel verbindt een rechtsgevolg aan de vervulling van bepaalde vereisten die hij daarvoor stelt $t^{98}$. Voor het overgangsrecht nieuw BW is het van belang te weten hoe zich de oude en de nieuwe wet totelkaar verhouden wat betreft hun vereisten en de bijbehorende rechtsgevolgen:

93. In de woorden van De Die, Spoedcursus, p. 23.

94. Zie hoofidstuk 5 hierna.

95. De Die, Spoedcursus, p. 11, merkt alleen het eerste geval als overgangssituatie aan.

96. Een oude rechtsregel kan ontbreken, aldus Polman, diss.. p. 19, 25.

97. Hartkamp, redie p. 7, wijst erop dat door voortbouwen van het nieuwe recht op thet oude en door anticiperende interpretatie van het oude recht door de rechtspraak "een zodanige verstrengeling tussen oud en nieuw recht (is) ontstaan dat men het ene veelal niet zonder kennis van het andere kan uitleggen en toepassen."

98. Zie mr. 2.2 .2 hiervóór. 
'In de praktijk rijzen de problemen van overgangsrecht wanneer de nieuwe wet voor het ontstatin van een rechtsgevolg andere vereisten stelt dan de oude, of aan de elementen van de bestaande rechtstoestand andere rechtsgevolgen verbindt." 99

Een reẹel probleem van overgangsrecht is dus niet waarschijnlijk, indien vereiste en rechtsgevolg naar ond en nieuw recht (nagenoeg) identiek zijn, zoals op het vlak van de overdracht (artikelen 639 (oud) en 3:84 lid $1 \mathrm{BW}$ ) en dat van de onrechtmatige daad (artikelen 1401 (oud) en 6:162 en 163 BW). Men moet dan toch het overgangsirecht raadplegen om te weten te komen of het nieuwe recht werkt voor overgangssituaties. Doorgaans zal, alls oud en nieuw recht met elkaar overeenstemmen, onmiddellijke werking het parool zijn.

Er is wel betoogd dat men het overgangsrecht buiten beschouwing zou kunnen laten, ingeval oud en nieuw recht tot hetzelfde resultaat leiden. Zo stelt Hartkamp dat er dan overgangsrechtelijk geen moeilijkheden zijn en dat eenvoudig het nieuwe recht kan worden toegepast. Men zou hier volgens genoemde auteur kunnen spreken van "de overgangsrechtelijke anti-kiesregel' ${ }^{100}$. Volgens de Commissie-Van Schendel ${ }^{101}$ geldt: leidt toepassing van oud en nieuw BW tot hetzelfde resultaat, dan kan de rechter besluiten de anti-kiesregel toe te passen; alsdan laat hij 'gemotiveerd in het midden welk recht hij toepast.'

Deze opvattingen acht ik niet juist. Het overgangsrecht nieuw BW dwingt ook dan tot het maken wan een keuze tussen oud en nieuw recht, indien beide tot hetzelfde resultaat leiden. Dit volgt uit de aard van het overgangsrecht. Telkens indien in een overgangssituatie de vereisten van het nieuwe recht zijn vervuld maakt het overgangsrecht de dienst uit ${ }^{102}$. Dáárin is nu eenmaal geregeld of het rechtsgevolg van het nieuwe recht in die overgangssituatie intreedt, en zo ja, in hoeverre.

Wel is het zo dat de kans op een reeeel probleem van overgangsrecht aanzienlijk groter is, indien oud en nieuw recht wèl uiteenlopen. Zo kan er verschil zijn bij de vereisten, terwijl de rechtsgevolgen op hetzelfde neerkomen. Hiervan is sprake

- bij cessie van vorderingen op naam (artikelen 668 lid 1 (oud) en 3:94 lid 1 BW), waar een extra vereiste wordt gesteld;

- bij het derdenbeding, waar een vereiste is geschrapt (artikelen 1353 lid 1 (oud) en 6:253 lid $1 \mathrm{BW}$ ) en

- bij diverse verjaringstermijnen, waar in het nieuwe BW dikwijls in een kortere termijn is voorzien dan in het oude, zodat een vereiste voor bij voorbeeld verkrijging door verjaring is vervangen door een ander vereiste.

Vervolgens kan het zijn dat er niet bij de vereisten, maar bij de rechtsgevolgen verschil is tussen oud en nieuw recht. Hierbij kan worden gedacht

99. Aldus Parl. Gesch. Overgangsrecht, p. 10, zie ook De Die, RMTh 1979, p. 261-265, in het bijzonder p. 264: De Die, AA 1991, p. 827; Polman; Owergangswet, deel 1, p. 8 .

100. Zie Hartkamp, rede, p. 6. Zie over de antikiesregel in het international priwaatrecht Jessurun d'Oliveirail diss o, p. 176 e.v.

101. Trema special 91-2, p. 63 (zie ook p. 53,55).

102. Vgl. nr. 2.4.2 hierna. 
- aan misbruik van omstandigheden (artikelen 1371 jo. 1373 (oud) en 3:45 leden 1 en $4 \mathrm{BW}$ ), waarbij in een ander rechtsgevolg is voorzien;

- aan de (niet-)aansprakelijkheid van kinderen die de leeftijd van veertien jaren nog niet hebben bereikt (artikelen 1401 (oud) en 6:164 BW), waarbij thans een rechtsgevolg ontbreekt waar dit vroeger wel kon bestaan ${ }^{103}$ en

- aan de (niet-)aansprakelijkheid van ouders voor de onrechtmatige daden van hun kinderen, voor zover deze de leeftijd van veertien jaren nog niet hebben bereikt (artikelen 1403 leden 2 en 5 (oud) en 6:169 lid $1 \mathrm{BW}$ ), waarbij thans een rechtsgevolg bestaat waar dit vroeger afwezig kon zijn.

Ten slotte kunnen zowell vereisten als rechtsgevolgen uiteenlopen al naar gelang oud dan wel nieuw recht toepasselijk is. Dit doet zich bij voorbeeld voor bij het tot zekerheid dienen van roerende zaken niet-registergoederen (stil pandrecht in plaats van zekerheidseigendom, artikelen 3:237 en $239 \mathrm{BW}$ ) en bij de ontbinding van wederkerige overeenkomsten op grond van een tekortkoming in de nakoming (artikelen 1302 en 1303 (oud) en 6:265 BW) ${ }^{104}$.

\subsubsection{De rol van de woorden van de nieuwe wet}

Hebben de woorden van de nieuwe wet betekenis bij de beantwoording van de vraag of een casus een probleem van overgangsrecht oplevert? Volgens de overgangswetgever geeft inderdaad in eerste instantie de redactie van de nieuwe bepaling de doorslag bij de beantwoording van deze vraag. Aan de hand van die redactie moet worden bezien of het nieuwe artikel in beginsel toepasselijk kan worden op de toestand aanwezig bij de inwerkingtreding, dan wel of het in beginsel rechtsgevolgen kan verbinden aan feiten die voordien zijn geschied; zo ja, dan is de volgende vraag of dat ook wenselijk zou zijn ${ }^{105}$.

Vormen feiten de vereisten, dan kan een kwestie van uitleg zijn of de keuze van de werkwoordstijd in de nieuwe wet van belang is in die zin dat bij gebruik van de onvoltooide tijd geen overgangssituatie bestaat en bij gebruik van de voltooide tijd wel. Doorgaans is bedoelde keuze toevallig, zodat daarop niet snel een argument voor of tegen het bestaan van een overgangssituatie kan worden gebaseerd ${ }^{106}$.

\subsubsection{Vragen van overgangsrecht}

De minister merkt in de toelichting op:

103. Tenzij men het niet aansprakelijk zijn ook als rechtsgewolg zou willen zien.

104. Het owergangsrecht ter zake van een aantal van de genoemde verschillen tussen het oude en het nieuwe recht zal ik hierna bespreken. Zie over de onrechtmatige daad (inclusief de "gewone' van de artikelen 1401. (oud) en 6:162 en $163 \mathrm{BW}$ ) hoofdstuk 6; over het derdenbeding nr. 4.9.6; over misbruik wan onstandigheden nr. 4.10.3; over zekerheidseigendom en stil pandrecht hoofdstuk 5 en over ontbinding nr. 7.6.5.

105. Zie nader Parl. Gesch. Overgangsrecht, p. 8-9.

106. Aldus De Die, Spoedcursus, p. 14-15. Zie woor een uitzondering Parl. Gesch. Owergangsrecht, p. 141 ad artikel 162 lid 10 W I. In andere zin dam De Die: Knigge, diss $\ldots$, p. 113-114. 
'De vraag die het overgangsrecht zoekt te beantwoorden, is of en in hoever$r e$ de nieuwe rechtsregels de elementen van een bij de inwerkingtreding der nieuwe wet bestaande toestand gaan beheersen: gaan inderdaad de (...) rechtsgevolgen van de nieuwe regels voor de bestaande toestand gelden? Hier gaat het om de vraag naar de werking van de nieuwe regels op de bestaande rechtstoestand.' 107

Behalve in termen van de bestaande rechtstoestand kan men vragen van overgangsrecht ook formuleren met behulp van het begrip 'overgangssituatie' 108 . Zoals bekend is er volgens de wetgever een overgangssituatie, indien op het moment van de inwerkingtreding was voldaan aan de vereisten die de nieuwe wet voor een zeker rechtsgevolg stelt ${ }^{109}$. De wetgever dient zich voor zulke situaties

"af te vragen of de nieuwe regel inderdaad daarop toepasselijk moet worden, dat wil zeggen of zijn rechtsgevolg moet intreden, en zo ja, van welk tijdstip af.' 110

Hier worden enkele andere vragen gesteld: behoort de nieuwe regel op overgangssituaties toepasselijk te worden of niet ${ }^{111}$, en bij bevestigende beantwoording van deze vraag, wanneer begint die toepasselijkheid? Men kan dit laatste ook ruimer nemen ${ }^{112}$ : in hoeverre wordt de nieuwe regel toepasselijk?

\subsection{REGELS VOOR DE OPLOSSING VAN VRAGEN VAN OVERGANGSRECHT}

Het is nu tijd om de gereedschapskist van het overgangsrecht te openen en de inhoud daarvan te ontleden: hoe heten de diverse werktuigen en hoe werken ze precies? Aan de hand van hun werkwijze laten zij zich in twee groepen verdelen, te weten verwijzingsregels en overbruggingsregels. Na de analyse van deze instrumenten schenk ik aandacht aan de in artikel 75 Ow I neergelegde correctiemechanismen met behulp waarvan onder bepaalde voorwaarden het resultaat van toepassing wan overgangsregels kan worden gecorrigeerd ${ }^{113}$.

Vooraf wijs ik er nog op dat de diverse gereedschappen ook zelf voorwerp van 'bewerking' kunnen zijn: een overgangsregel voor overgangsrecht dus. Een voorbeeld hiervan is de wel heel opmerkelijke terugwerkende kracht die is toegekend aan de artikelen 68-75 Ow I in verband met de inwerkingtreding met ingang van 1 april 1991 van Boek $8 \mathrm{BW}$. De Aanvulling van de Overgangswet werd tot wet verheven op 2 april 1991 (Stbl. 197) en de algemene overgangsbepalingen daaruit, die

107. Aldus Parl. Gesch. Overgangsrecht, p. 8. Zie ook De Die, RMTh 1979, p. 256, 257-258, 259.

108. Vgl. Polman, Overgangswet, deel 1, p. 14-15.

109. Zie hierover nader nr. 2.4 .1 hiervóor.

110. Parl. Gesch, Overgangsrecht, p. 23. Zie ook De Die, DD 1989, p. 882; De Die, Spoedcursus, p. 7, 8-9.

111. Zoals ik in nr. 2.2.1 hiervór heb opgemerkt, ga ik in dit hoofdstuk niet in op het al dan niet toepasselijk: behoren te zijn van mieuw recht op overgangssituaties. Dit neemt niet weg dat ook dit een vtaag van overgangsirecht is, die hier dient te worden vermeld.

112. In verband met de overbruggingsregels, waarover $\mathrm{nr} .2 .5 .2$ hiema.

113. Zie resp. de nrs. 2.5.1 (verwijzingsregels), 2.5.2 (overbruggingsregels) en 2.5 .3 (artikel 75 Ow I). 
ook op Boek 8 BW betrekking hebben, traden eerst op 14 mei 1991 in werking. Om nu toch vanaf 1 april 1991 deze algemene bepalingen toepasselijk te laten zijn is erin voorzien dat zij terugwerken tot en met 1 april $1991^{114}$. Ook voor een wijziging van artikel 39 OW II is voorzien in terugwerkende kracht, maar dan tot en met 1 januari $1992^{1115}$.

\subsubsection{Verwijzingsregels}

Verwijzingsregels zijn indirecte regels: zij bevatten zelf geen materieel recht, maar verwijzen naar de materiële regel die toepasselijk is op een bepaalde overgangssituatie. Er moet dus een twee fasen-procédé worden gevolgd om te weten te komen wat rechtens is in $z 0^{\prime} \mathrm{n}$ situatie: eerst moet men bezien welk recht door de overgangsregel als het toepasselijke wordt aangewezen en vervolgens moet men de aangewezen "materiële" regel toepassen. Verwijzingsregels zijn ook keuzeregels: zij kiezen voor beheersing van zo' $n$ situatie door het oude dan wel door het nieuwe recht ${ }^{116}$. Tot zo"n keuze zal het in het overgangsrecht voor het nieuwe BW steeds moeten komen, dus ook als oud en nieuw recht niet verschillen ${ }^{117}$. Een 'antikiesregel' als in het internationaal privaatrecht is in het onderhavige overgangsrecht onbekend ${ }^{118}$.

Een overeenkomst tussen internationaal privaatrecht en overgangsrecht is wel dat beide verwijzingsregels kennen. Maar daarmee is nog niet gezegd dat verwijzingsregels in beide rechtsgebieden op dezelfde manier werken. H. Stein ${ }^{119}$ is een andere mening toegedaan. Volgens hem wijst de overgangsregel in de rechtsverhouding een aanknopingsmoment aan; de ten tijde van dat moment geldende wet beheerst de rechtsverhouding. Als voorbeeld noemt Stein de regel 'tempus regit actum':

'de wet, geldende ten tijde van een (rechts-)handeling, bepaalt haar geldigheid en rechtsgevolgen',

waarvoor hij verwijst naar artikel 4 Wet $A B$. Stein wekt de indruk dat alle verwij-

14.Zie hel tweede lid van het enig artikel wan het Besluit van 17 april 1991, Stbl. 200, tot inwerkingtreding wan het elfde, twallfde en dertiende gedeelte van de Inwoeringswet Boeken 3,5 en 6 Nieuw Burgerlifk Wett boek. Dat eventueel de terugwerkende kracht te hulp zou worden geroepen, werd reeds angekondigd in $\mathrm{EK}$, wergader jaar 1990-1991,21265, nr. 90a (memorie van antwoond) p. 1 , met de motivering dat dartegen uit mechtszekerheidsoogpunt geen be zwar bestrat, "omdat de bepalingen goeddeels zijn te beschouwen als uitwerking wan beginselen welke ook woor het hüdige recht reeds worden gehulligd en voor het overige, zoals voor verjarings- en vervaltermijnen, praktische regels voor de overbrugging tussen oud en nieuw recht bewatten.' Voorts werd nog opgemerkt: "Uit de parlementaire behandeling is gebleken dat over de artikelen wam die titel overeenstemming is bereikt."

115. Zie artikel WI lid I van wetswoorstel 22442 als aamgevuld bij nota wan wijziging (TK. vergaderjaar 1.991-1992, nr. 4). Zie over de woorgestelde wijziging van artikel 39 Ow ll de nis. 5.6 .4 en 7.8 .3 hierna.

116. Vigl Parl, Gesch. Overgangsrecht, p. 5; Joppe, diss. p. 8, 10.

117. Diit geldt ook woor owerbruggingstregels: de materiele regel die zij bevatten dient ertoe om toepasselijkheid van het nieuwe BW mogelijk te maken.

118. Zie nr. 2.4.1.4 hiervớr. Zie over de antikiesregel in het internationail privaatrecht Jessurun d Olvei$\mathrm{ra}_{\text {, diss }}$ p. 176e.w... Anders voor het onderhavige overgangsrecht de Commissie-Van Schendel, Trema special $91-2$, p. $53,55,63$; Hartkamp, rede, p. 6 .

119. Preadv., p. 233 . 
zingsregels volgens deze sjabloon zijn opgezet. Dit gaat mij te wer. lk zie niet hoe bij voorbeeld de figurur van de uitgestelde werking in Steins verwijzingsprocédé zou passen. Hetzelfde geldt voor de hoofdregel van de onmiddellijke werking, zoals deze in artikel 68 a lid 1 Ow $I$ is geformuleerd.

De overgangsrechtelijke verwijzingsregels vallen in twee groepen uiteen: of zij verklaren dat niet het nieuwe, maar het oude recht bepalend blijft woor overgangssituaties, of zij verklaren (in enkele varianten) het tegendeel. In het eerste geval is er eerbiediging van het oude recht, in het tweede onmiddellijke werking, uitgestelde werking of terugwerkende kracht ${ }^{120}$. Het inwerkingtredingstijdstip is voor de Boeken 3,5 en 6 en de titels $1,7,9$ en 14 van Boek 7 BW een vaste datum: 1 januari 1992. Met de aanvang van de toepasselijkheid van de nieuwe regels op overgangssittuaties echter kan worden geschoven: deze aanvang hangt ervan af welke vorm van "werking" men kiest: ${ }^{121}$. De grenzen tussen de in verwijzingsregels neergellegde "werkingen" zijn overigens soms vloeiend, zoals in de artikelen 102, 182 en 195 Ow I, waarin een soort combinatie tussen eerbiediging van het oude recht en onmiddellijke werking is neergelegd ${ }^{122}$.

Ik maak een laatste algemene opmerking over verwijzingsregels. De neiging bestaat wel om van het resultaat van toepassing van de 'materiële' regel die door de verwijzingsregel is aangewezen te laten afhangen met wat woor soort verwijzingsregel men van doen heeft. Een voorbeeld: als een 'verkregen recht' wordt aangetast is er terugwerkende kracht. Dit is onjuist: Niet het toepassingsresultaat bepaalt het label van de verwijzingsregel, maar het antwoord op de viaag, of zij de nieuwe wet toepasselijk verklaart op de toestand ten tijde van de inwerkingtreding en zo ja, vanaf welk tijdstip ${ }^{123}$. Evenmin is voor het benoemen van een verwijzingsregel relevant of, en zo ja, in hoeverre het oude en het nieuwe recht inhoudelijk met elkaar overeenstemmen ${ }^{124}$.

De weg is nu vrij om het kwartet verwijzingstegels nader te bezien. Ik begin met de onmiddellijke werking, omdat deze tot hoofdregel van het overgangsrecht voor het nieuwe vermogensrecht is verkozen (nr. 2.5.1.1). Daarna volgen de eerbiediging van het oude recht, de uitgestelde werking en de terugwerkende kracht (respectievelijk nrs. $2.5 \cdot 1.2-4)$.

\subsubsection{Onmiddellijke werking}

\section{a. Begripsonschrijuing; terminologie}

Onmiddellijke werking dient zich aan bij het samenvallen van de tijdstippen van de

120. Vgl. Part. Gesch. Overgangsrecht, p. 9; De Die, RMTh 1979, p. 258.

121. Vgl. Parl. Gesch. Overgangsrecht, p. 41-42.

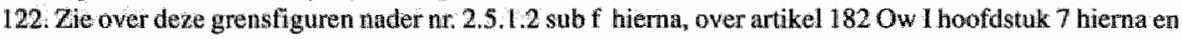
over artikel 1950 W I nr. 2.6 .1 hiena.

123. Vgl, Parl Gesch: Overgangsrecht, p. 9, anders Biruner, preadv.,p. 20-22, waartegen De Die, in: Verslag NJV-vergadering, p. 27-28, beantwoord door Brunner, ta.p. p. 34-35. Zie over de betekenis wan het beginsel van de eerbiediging van verkregen rechten woor het mieuw $B$ W-overgangsrecht nr. 2.5.1.2 sube hierna.

124. Aldus ook Polman, diss., p. 483. 
inwerkingtreding en het toepasselijk worden ${ }^{225}$ van een nieuwe regel. Dat wil zeggen dat voor de rechtstoestand die bestaat op het moment van de inwerkingtreding direct vanaf dat moment die nieuwe regel bepalend wordt. Geformuleerd met behulp van het koppel vereiste-rechtsgevolg ${ }^{126}$ :

'Van het tijdstip van haar in werking treden af is de wet van toepassing, indien op dat tijdstip is voldaan aan de door de wet voor het intreden van een rechtsgevolg gestelde vereisten, tenzij uit de volgende artikelen iets anders voortvloeilt."

Zo luidt artikel 68 a lid 10 w $\mathrm{I}$, warin de hoofdregel van de onmiddellijke werking voor de Boeken 3-8 BW is neergelegd ${ }^{127}$ "Het gewicht van deze regel rechtvaandigt nadere bestudering 128 , te beginnen met een opmerking over de term "onmiddellijke werking'. De wetgever heeft deze yerkozen boven de vroeger gebruikelijke term "exclusieve werking'. De Raad van State opperde tegen deze keuze bezwaar in zijn advies over het toenmalige wetsvoorstel ${ }^{129}$. De minister toonde zich evenwel niet overtuigd. Hij stelde dat de term 'onmiddellijke werking' in tegenstelling tot de term "exclusieve werking" exact het bedoelde tijdseffect aangeeft: gelijktijdig met de inwerkingtreding wordt de nieuwe wet toepasselijk op overgangssituaties, haar rechitsgevolg treedt direct in. Daardoor geschiedt tevens de afbakening ten opzichte van de terugwerkende kracht duidelijker. Bij terugwerkende kracht is net als bij onmiddellijke werking sprake van exclusiviteit in die zin dat na de inwerkingtreding slechts éen rechtsregime bestaat, zodat de term 'exclusieve werking" niet bepaald scherp de grens met terugwerkende kracht markeert ${ }^{130}$. In de toelichting op aanwijzing 164 van de concept-Aanwijzingen voor de regelgeving wordt gezegd dat

'de hoofdregel van overgangsrecht (...) wordt aangeduid als onmiddellijke werking (ook wel: exclusieve werking)." 131

125. Zie over de begrippen inwerkingtreding, toepasselijk zijn en werken de nrs. $2.2 .3 \mathrm{en} 2.2 .4$ hiervoor.

126. Zie over "De bestaande rechtstoestand en de vereisten wan de nieuwe wet" nr. 2.4.1.1 hiervóon. Ik grijp hierna, in beginsel zonder verwijzing, regelmatig terug op hergeen ik in de nrs. 2.4.1.1.3 hicrvoót heb behandeld.

127. Zie Part. Gesch. Overgangsrecht, p. 10-12. Zoals uit het a-nummer al kan worden afgeteid, was dit attikel aanwankelljk op gronden die ta.p. zijn aangegeven niet in de Overgangswet opgenomen. Na andrang van verschillende zijden (zie onder meer (de auteurs nat wie wordt verwezen in) mijn bijdrage in Kwartalbericht Nieuw BW 1986, p. 79-80) is alsnog een wetsbepaling aan de hoofdregel van de onmiddellijke werking gewijd. Zie over deze bepaling Parl. Gesch. Overgangsrechi, p. 35, 36-38.

128. In de navolgende hoofdsfukken is de behandeling van bijzondere onderwerpen telkens geplatist tegen de achitergrond van wat zou gelden, indien de hoofdregel wan de onmiddellijke werking van toepassing zou zijn: zie de nrs, 3.3, 4.3, 5.4, 6.3 en 7.4. Zie ower "het beginsel van onmiddellijke werking der wet' De Die, AA 1991, p. $820-821,824-826,828$.

29. Parl. Gesch. Owergangstecht, p. 20.

130. Zie Parl. Gesch. Overgangsrecht, p. 24.

131. Op de omschrijwing van de onmiddellijke werking un de Aanwijizingen voor de wetgevingstechniek (AWT; deze spreken owerigens nog wan "exclusieve werking") en in de concept-Aanwijzingen voor de regelgeving ga ik hier niet in. Met betrekking tot die in de AWT verwijs ik naar inijn bijdrage in RegelMaat 1986 , p. $158-160$. 
Een tweede terminologische opmerking betreft de in artikel 68 a lid 1 Ow I voorkomende woorden 'de wet'. Opheldering over de betekenis hiervan wordt verschaft in artikel 68 Ow I. Daaruit blijkt dat 'de wet' niet betekent de Overgangswet zelf:

'In de volgende artikelen worden onder 'de wet' verstaan de in werking getreden bepalingen van de Boeken 3-8.'

Vermeldenswaard is de toelichting, waar wordt verduidelijkt dat, afhankelijk van de context, met "de wet' wordt bedoeld het geheel van die bepalingen dan wel afzonderlijke bepalingen, naar gelang die in werking treden ${ }^{132}$. Het praktische belang hiervan kan treffend worden geillustreerd aan de hand van artikel 191 lid 1 Ow I. De eerste zin kent kort gezegd aan 'Afdeling 3 van titel 5 van Boek 6' (inzake algemene voorwaarden) een uitgestelde werking van een jaar toe. De tweede zin laat daarop volgen dat gedurende het jaar van uitstel "de wet" evenmin toepasselijk is op wijzigingen in de daar bedoelde algemene voorwaarden na de inwerkingtreding van 'de wet'. Zonder de zojuist aangehaalde toelichting lijkt artikel 191 lid 1 Ow I 'een foutje' van de overgangswetgever ${ }^{133}$ : op wijzigingen is niet slechts afdeling 6.5.3 BW, maar het gehele nieuwe vermogensrecht niet toepasselijk tot 1 januari 1993. Uit de toelichting op artikell 68 Ow I volgt evenwell dat hier met "de wet" afdeling 6.5.3 BW wordt bedoeld.

\section{b. De hoofdregel van de onmiddellijke werking; algemeen}

In termen van het in nr. 2.2.4 hiervór gemaakte onderscheid tussen toepasselijk zijn en van toepassing zijn betreft artikell $68 a$ lid 1 OW I de vraag of een nieuw BWbepaling al of niet toepasselijk is op (werkt voor) de bij de invoering aanwezige rechtstoestand. Waren de vereisten voor toepassing van die bepaling op het moment van de invoering vervuld, dan is zij toepasselijk, 'werkt' zij, en wel vanaf dat moment voor het vervolg. Artikel $68 a$ lid 1 Ow I lijkt daarmee het prototype van een verwijzingsregel, een regel van indirecte aard ${ }^{134}$. 'Lijkt', want als anterieure feiten zich aandienen, zou men er ook een soort overbruggingsregel in kunnen zien (zie hierna onder $c .2$ ).

Duidelijk herkenbaar in artikel $68 a$ lid 1 Ow I is het begrip "overgangssituatie' zoals dit wordt omschreven in de parlementaire geschiedenis:

'Voorop staat de vraag, of ten tijde van het in werking treden van een regel
van de nieuwe wet de vereisten die deze voor het intreden van zijn rechtsge-
volg stelt, reeds zijn vervuld; moet deze vraag bevestigend worden beant-
woord, dan is er sprake van een overgangssituatie, en behoort de overgangs-
wetgever zich af te vragen of de nieuwe regel inderdaad daarop toepasselijk

132. Zie Parl. Gesch. Overgangsrecht " p. 35, alwaar ook wordt opgemerkt dat het oude, afgeschafte recht meestal wordt aangeduid als "(de artikelen... van) het tevoren geldende recht".

133. In deze zin Wessels, Advocatenblad 1991, p. 324.

134. Zie daarover nr. 2.5.1 hiervóór. 
moet worden, dat wil zeggen of zijn rechtsgevolg moet intreden, en zo ja, wan welk tijdstip af." 135

Ik heb er in nr. 2.4.1.3 hiervóor op gewezen dat de overgangswetgever, zoals ook uit dit citaat blijkt, de overgangssituatie beperkt opvat: zij is er alleen dan, als alle vereisten van de nieuwe wet op het moment van de imoering al waren vervuld. Deze enge opvatting werkt door naar de omvang van het toepassingsveld van de verwijzingsregels, waaronder de onmiddellijke werking. Deze laatste is volgens de wetgever niet aan de orde, indien bij de inwerkingtreding nog niet alle vereisten van de nieuwe wet waren vervuld (denk aan de 'onvolledige complexen van rechtsfeiten'). Hetzelfde gaat op, indien alle vereisten van de nieuwe wet voor bij voorbeeld een ingrijpen van de rechter wegens onvoorziene omstandigheden pas na het ogenblik van de inwerkingtreding worden vervuld, ook al gaat het om een reeds op dat ogenblik bestaand(e) recht of overeenkomst. Dat in zulke gevallen toch overgangsbepalingen zijn opgenomen (zie bij voorbeeld de artikelen 173 en 195 Ow I) laat zich slecht rijmen met de enge opvatting van de wetgever omtrent het begrip "overgangssituatie". Anders dan de overgangswetgever zie ik in gevallen als de onderhavige wel een overgangssituatie, waar zich dan ook de onmiddellijke werking kan doen gelden ${ }^{136}$.

De onmiddellijke werking is tot uitgangspunt verkozen, omdat zij de "normale werking' van een nieuwe wet is, aldus de overgangswetgever. Het is een overweging van systematiek die pleit

"voor de aanvaarding van de onmiddellijke werking van een wet als de meest algemene en voor de hand liggende: met de inwerkingtreding van de nieuwe wet is deze in beginsel het geldend recht geworden en is het oude recht afgeschaft. Wanneer na het tijdstip van inwerkingtreding dan toch nog het oude recht een beperkte gelding blijft behouden, dan is dat de uitzondering die veeleer regeling behoeft." 137

Wel is het zo dat dit uitgangspunt van de wetgever er een is van enkel formele aard. Telkens is afgewogen wat voor het rechtsleven de beste keuze lijkt ${ }^{138}$ "Ook voor de wijzigingen in de bij de invoering van het nieuwe $\mathbb{B W}$ bestaande wetgeving is onmiddellijke werking als uitgangspunt verkozen: artikel $68 \mathrm{a}$ lid 1 Ow I word daar op van overeenkomstige toepassing verklaard in artikel $₫$ lid 2 OW II.

De hoofdregel van de onmiddellijke werking van het nieuwe BW zoals deze is geformuleerd in artikel $68 a$ lid 1 Ow I laat zich analyseren aan de hand van de verschillende soorten vereisten en rechtsgevolgen van nieuw $\mathrm{BW}$-regels. Ik doe hierna een poging tot zo'n analyse. Daarbij leg ik in verband met hum bijzondere rol de nadruk op 'anterieure feiten' als vereisten.

135. Aldus Parl. Gesch. Overgangsrecht, p. 23.

136. Zie nr: 2.4.1.3 hiervóót. In soortgelijke zin als hier verdedigd ook De Vries Lentsch-Kostense, in: Liber amicorum NBW (1991), p. 171-172, en Mon. Nieuw BW A-25, p. 25, 27.

137. Parl. Gesch. Overgangsrecht, p. 36. Evenzo p. 10-11.

138. Aldus Parl. Gesch. Owergangsrecht, p. 11. 


\section{c.1 Toestanden}

Een bij het van kracht worden van de nieuwe wet aanwezige toestand (een min of meer duurzame gesteldheid) kan bij voorbeeld zijn een zakelijk recht, vorderingsrecht of aansprakelijkheid. De bevoegdheden en verplichtingen van de zakelijk gerechtigde, de schuldeiser en de schuldenaar worden bij onmiddellijke werking uit hoofde van artikel $68 \mathrm{a}$ lid $1 \mathrm{OW}$ I vanaf de inwerkingtreding door het nieuwe recht bepaald: waren de vereisten van het nieuwe recht op het moment van de invoering vervuld, dan is dat vanaf genoend moment in beginsel bepalend voor die bevoegdheden en verplichtingen. Hetzelfde geldt voor bij voorbeeld eigenschappen (zoals opeisbaar- en hoofdelijkheid) en omschrijwingen (zoals van (register)goederen). De toestand wordt dus.

"als het ware in twee stukken (...) gebroken: eén dat nog door het oude recht wordt beheerst, één dat van de inwerkingtreding af onder het regime van het nieuwe valt. ${ }^{\prime} 39$

Het bovenstaande gaat alleen op, indien de toestand door de nieuwe wet wordt gehandhaafd. Die handhaving kan voortvloeien uit artikel 69 Ow I of uit een andere overgangsbepaling.

In vele gevallen zal zo'n overgangsbepaling er niet zijn, namelijk ingeval een recht of een aansprakelijkheid zowel in het oude als in het nieuwe recht bekend is. Waarop berust dan hun handhaving na de invoering? Uit de toelichtende stukken op de Overgangswet blijkt dit niet. Polman zegt hierover met een fraaie formulering:

'Het bestaan van het recht wordt door de nieuwe wet verdergedragen; zij kent dit recht" ${ }^{\prime 140}$.

Dat lijkt mij in overeenstemming met het stelsel van de Overgangswet. Een andere vraag is of een recht het voor zijn voortbestaan inderdaad nodig heeft dat de nieuwe wet dat recht verder draagt; zie het nu volgende onderdeel.

\section{c. 2 Feiten}

Op het onder de oude wet totstandgekomen zijn van rechtsgevolgen als het ontstaan, de overgang etc. van bij de inwerkingtreding aanwezige zakelijke rechten, vorderingsrechten, aansprakelijkheden en dergelijke komt de nieuwe wet niet terug. Dit geldt ook indien zij nieuwe ontstaansvereisten bevat en deze niet vervuld zijn, zoals bij de cessie van vorderingen op naam kan voorkomen: de eenmaal totstandgekomen cessie is een 'voldongen feit' ${ }^{\prime 44}$.

139. Aldus Parl. Gesch. Owergangsrecht, p. 14; zie ook p. 16,30,38-40, 299; De Die, Spoedcursus, p. 12-13. 140. Zie (met nadere vitleg) Overgangswet, deel 1, p. 40, alsmede p. 36-37.

141. Vgl. Parl. Gesch. Overgangsrecht, p. 13-14; De Die, Spoedcursus, p. 13-14; Polman, Overgangswet, deel 1, p. 36-37. 
Een andere mogelijkheid is dat feiten onder het oude recht "rechtsgevolgloos" waren, maar datt volgens het nieuwe recht niet zouden zijn. In het stelsel van de Overgangswet kan dan bij onmiddellijke werking vanaf de invoering voor het vervolg aan anterieure feiten het rechtsgevolg van het nieuwe recht worden verbonden. Zo zou het (los van andere overgangsbepalingen) kunnen gebeuren dat degene die vór het ogenblik van het van kracht worden van de nieuwe ausprakelijkheidsregels schade leed, vanaf dat ogenblik een vorderingsrecht tot vergoeding van de daardoor ontstane schade heeft. Het anterieure feit levert dan dus wel een overgangssituatie op.

Anders is het echter, indien het oude recht wel aansprakelijkheid aan het anterieure feit verbond. Dan geeft dat feit zelf geen overgangssituatie en blifft het beheerst door het oude recht; het ontstaan van de aansprakelijkheid word niet op losse schroeven gezet. De bij de invoering aanwezige aansprakelijkheid waartoe deze feiten hebben geleid levert (nog steeds: in het systeem van de Overgangswet) daarentegen wel een overgangssituatie op. Dit heeft onder meer praktisch belang, indien het nieuwe recht $z^{\prime}$ 'n aansprakelijkheid niet kent ${ }^{142}$.

Hoe de wetgever hier over de mogelijke effecten van onmiddellijke werking denkt, kan het best aan de hand van enkele citaten worden geillustreerd. Uitgangspunt is; ook voor het aansprakelijkheidsrecht, dat het nieuwe recht niet terugwerkt ${ }^{43}$. Daaruit volgt:

'Stelt de oude wet een reeks van vereisten aan de vervulling waarvan zij aansprakelijkheid verbindt; en is onder de gelding van die wet aan al die vereisten voldaan, dan bepaalt de oude wet de aansprakelijkheid.'

Uit artikel 4 Wet A.B. volgt dat voor het al of niet aansprakelijk worden uit onrechtmatige daad beslissend is onder welk regime de vereisten daartoe zijn voltooid. Bij de aansprakelijkheid uit onrechtmatige daad is dat hetgeen geldt op het tijdstip waarop de schade is ontstaan. Is dat geschied onder de wer'king van het oude recht, dan is dit in beginsel van toepassing. '144

Het betreft hier het ontstaan van aansprakelijkheid wór de inwerkingtreding. De in de citaten bedoelde regel is er én die volgens de wetgever voor het overgangsrecht in het algemeen geldt:

"als alle wereisten die de oude wet woor een rechtsgevolg stelt, vóór de inwerkingtreding van de nieuwe zijn wervuld, dan is oud recht van toepassing, is dat niet het geval, dan het nieuwe." 145

142. Artikel 69 sub a en d Ow I verhindert dan het tenietgan respectievelijk ontstan van aturgprakelijkheid, zie $\pi$ r. $2.5: 1: 2$ sub e hierna.

143. Zie over terugwerkende kracht ne. 2.5.1.4 hiema.

144. Zie Part. Gesch, Overgangsrecht, p. 149 respectievelijk p. 315.

145. Zie Parl Gesch. Overgangsrecht, p. 159. 
Deze regel neemt evenwel in de zienswijze wan de overgangswetgever niet weg dat de onmiddellijke werking ex artikel $68 a$ lid $\mathbb{O} \mathrm{Ow}$ I zonder nadere voorziening wèl het bij de inwerkingtreding voor het vervolg wegvallen van de aansprakelijkheid voor anterieure feiten tot gevolg zou hebben ${ }^{146}$. Artikel $69 \mathrm{sub}$ a Ow I voorkomt dit resultaat: bestaande aansprakelijkheden die het nieuwe $\mathrm{BW}$ niet kent blijven gehandhaafd.

Omgekeerd doet het nieuwe recht evenmin aansprakelijkheid ontstaan voor feiten, voltooid vó́r de inwerkingtreding (artikel 69 sub d OW I):

'Artikel 70 lid 1 (thans artikel $69, \mathrm{HvdB}$ ) sluit uit dat de regels van titel 6.3 met hun vernieuwingen aansprakelijkheid scheppen voor schade die vóór de inwerkingtreding is ontstaan, of dat die regels een aansprakelijkheid voor zulke schade teniet doen gaan: de artikelen 1401 e.v. van het oude recht blijven daarvoor gelden." ${ }^{147}$

Enerzijds is dus volgens de overgangswetgever voor het al of niet ontstaan van aansprakelijkheid uit onrechtmatige daad vóor de inwerkingtreding beslissend onder welk regime de vereisten daartoe zijn voltooid. Anderzijds echter kan uit de onmiddellijke werking sec volgen dat vanaf de inwerkingtreding een aansprakelijkheid voor tevoren voltooide feiten kan ontstaan of juist vervallen.

Naar mijn mening is hier de vestiging, het ontstaan van de aansprakelijkheid aan de orde: artikel 6:164 BW verhindert het totstandkomen van aansprakelijkheid, artikel 6:169 BW geeft aan wanneer ouders aansprakelijk kunnen worden voor de onrechtmatige gedragingen van hun kinderen ${ }^{148}{ }^{149}$. Ik citeerde hierboven de door de wetgever gehanteerde regel dat als alle vereisten die de oude wet voor een rechtsgevolg stelt, vóor de inwerkingtreding van de nieuwe waren vervuld, oud recht toepasselijk is en anders het nieuwe. Hieruit zou mijns inziens moeten volgen dat vragen inzake de vestiging van de aansprakelijkheid moeten worden beantwoord met behulp van het oude recht; indien onder dat recht alle vereisten voor aansprakelijkheid waren vervuld. Een vór de inwerkingtreding verrichte daad zou dan voltooid verleden tijd zijn en derhalve in de regel zelf geen overgangssituatie creëren, ongeacht of die daad volgens het oude recht nu wel of niet tot rechtsgevolg (aansprake-

146. Dat de overgangswetgever dit uitgangspunt hanteent blijkt ook uit Parl. Gesch. Overgangsrecht, p. 14, 39.

147. Zie Parl. Giesch. Owergangsrecht, p. 315, alsmede p. 11-14.

148. Vgl، in soortgelijke zin Mon. Nieuw BW A-25 (De Vries Lentsch-Kostense), p. 29.

149. Volgens de minister (Parl. Gesch. Overgangsrecht, p. 13 ) betreft de discussie hier in wezen de aard van de materiele rechtsfiguur: Ik denk dat hier ook wel degelijk een kwestie van overgangsrecht aan de orde is (kan bij onmiddellijke werking met vertraging een rechtsgevolg worden verbonden aan anterieure feiten?). Vgl. ook Polman, Overgangswet, deel 1, p. 27. Vermeldenswaard is nog dat de wetgever toestanden die bij de inwerkingtreding niet meer bestaan in beginsel niet door de nieuwe wet bestreken acht:

'Volledigheidshalve zijer nog op gewezen dat het in geval van terugwerkende kracht denkbaar is dat de nieuwe wet van toepasssing wordt, niet alleen op rechten en rechts betrekkingen, bestaande ten tijde van haar inwerkingtreding, maar ook op die welke voordien bestonden; meestal zal dat echter ook dan rechtsverhoudingen enz. betreffen, die bij de inwerkingtreding nog niet geheel zijn witgeblust.' (Parl. Gesch. Overgangsrecht, p. 8, noot 1) 
lijkheid) heeft geleid. Doordat het feit al was "afgelopen" vớr de invoering, kan het nieuwe recht dat feit niet 'bereiken': ten tijde van het voorvallen van het feit was het nog niet in werking getreden; evenmin is het krachtens overgangsrecht (terugwerkende kracht) op dat feit toepasselijk. Het vanaf de inwerkingtreding wel of juist niet hechten van aansprakelijkheid aan zo'n daad lijkt mij derhalve gezien het bovenstaande met behulp van de onmiddellijke werking niet mogelijk ${ }^{150}$. Met artikel $68 a$ lid 1 Ow I wordt dit door de wetgever wel beoogd, ook al spreekt de wetstekst over het voldaan zijn aan de vereisten van de nieuwe wet $o p$ het tijdstip van inwerkingtreding, hetgeen zich bij feiten niet gemakkelijk laat denken. Voor zover artikel $68 a$ lid 1 Ow I 'anterieure feiten' betreft zou het daarom als koppelregel ${ }^{151}$ kunnen worden bestempeld.

In de ogen wan de ontwerper van het overgangsrecht is ook in de hier bedoelde situaties (verbinden van rechtsgevolg aan anterieure feiten vanaf de inwerkingtieding) onmiddellijke werking aanwezig: welke temporele werking de nieuwe wet heeft, hangt zijns inziens

'niet af van het tijdstip waarop de vereisten zijn vervuld, maar van dat waarop het nieuwe rechtsgevolg daaraan wordt gehecht. ${ }^{152}$

Uiteindelijk is hier niet meer, maar ook niet minder aan de orde dan een definitiekwestie: hoe omschrijven we de onmiddellijke werking? Uit het voorgaande blijkt dat in de Overgangswet de onmiddellijke werking nogal ruim wordt opgevat. Beslissend voor de temporele werking van de nieuwe wet is met ingang van welk móment haar rechtsgevolgen ingaan. Of de vereiste feiten al (ver) vóor de inwerkingtreding vervuld waren, doet niet ter zake. Toestanden zijn hierop dan kennelijk een uitzondering: een zakelijk recht, tenietgegaan vóór de inwerkingtreding, kan niet leiden tot het vanaf de invoering ontstaan van wettelijke bevoegdheden ${ }^{153}$ :

Deze laatste zijn meteen voorbeelden van rechtsgevolgen die volgens de overgangswetgever bij onmiddellijke werking 'gaan en komen met de wet die hen schept.' ${ }^{154}$ De toelichting noemt naast wettelijke bevoegdheden: werkingen, eigenschappen en omschrijvingen ${ }^{155}$. Aan anterieure niet-nakoming als feit kan dus vanaf de invoering voor het vervolg de exceptio non adimpleti contractus van artikel $6: 262 \mathrm{BW}$ worden verbonden (zie artikel $180 \mathrm{OW} \mathrm{I})^{156}$.

De overgangswetgever onderscheidt nog een aparte categorie van feiten, de zogenoemde 'onvolledige complexen van rechtsfeiten'. Hiervan is sprake, indien de voor

150. Anders Polman, Owergangswet, deell 1, p. 38-39.

151. Zie over koppelregels nr. 2.5 .2 hierna. Terugwerkende kracht is er niet, ondat hier het rechtsgevolg vam de nieuwe regel niet tot een moment vór de inwerkingtreding wordt "teruggeschoven', maar aanvangt op dat moment.

152. Aldus De Die, DD 1989, p. 882; zie ook De Die, Spoedcursus, p. 7.8.

153. Ik ga overzichtelijkheidshalve in het verwolg uit van de visie wan de owergangswetgever.

154. Aldus Parl. Gesch. Overgangsrecht, p. 17.

155. Parl. Gesch. Overgangsrecht, p. 17-18. Zie ook nur. 2.2.2 hiervóor.

1.56. Zie hierover nr. 7.6 .6 hierna. 
een bepaald rechtsgevolg vereiste feiten bij de invoering nog slechts ten dele waren geschied. De overgangssituatie is dan volgens de wetgever in statu nascendi: pas na de invoering worden de ontbrekende vereisten vervuld. Voorbeeld: de onrechtmatige gedraging die pas na de invoering schade tot gevolg heeft ${ }^{157}$. Dan is de vraag naar de aansprakelijkheid te beantwoorden aan de hand van de nieuwe wet, met dien werstande dat deze niet terugkomt op door haar gestelde vereisten die al vóór de inwerkingtreding waren vervuld en waarop het oude recht toepasselijk was. De oude wet geldt niet meer als uiteindelijk alle vereisten vervuld zijn; haar rechtsgevolg kan daardoor niet meer intreden. Dit laatste laat zich wel denken, indien er sprake is van eerbiediging van het oude recht of wan uitgestelde werking. Iets dergelijks geldt voor rechtsfiguren onder een voorwaarde of tijdsbepaling, die bij de inwerkingtreding bestonden 158 . Overigens biedt artikel 68 a lid 10 w I in zulke gevallen strikt genomen geen uitkomst: er was immers niet ten tijde van de inwerkingtreding reeds voldaan aan 'de" (lees: alle) vereisten van de nieuwe wet ${ }^{159}$. Het lijkt erop alsof hier door de overgangswetgever wordt uitgegaan van een ongeschreven hoofdregel van overgangsrecht.

\section{c.3 Juridische waarderingen}

De juridische waarderingen, door de overgangswetgever ook wel juridische vereisten genoemd; betreffen steeds een toestand of een feit. Bij onmiddellijke werking moet daarom het vereiste bij de invoering zijn vervuld als het een toestand betreft en vóór de invoering als het een feit betreft. Een woorbeeld:

'Wordt aan een anterieure onrechtmatige daad een nieuw rechtsgevolg toegekend, dan is dat alleen het geval ten aanzien van daden die onder het tevoren geldende recht, toen ze werden gepleegd, reeds als onrechtmatig moesten worden aangemerkt." 160

\section{d. De hoofdregel van de onmiddellijke werking en de rechtsgevolgen van de} nieuwe wet

In de toelichting wordt een viertal soorten rechtsgevolgen genoemd, die in het stelsel van de Overgangswet in beginsel 'gaan en komen met de wet die hen schept': wettelijke bevoegdheden, werkingen, eigenschappen en omschrijvingen. Ik verwijs hiervoor verder maar de toelichting ${ }^{161}$. Voor die rechtsgevolgen die bestaan uit absolute rechten en verbintenisrechtelijke betrekkingen geldt dit 'gaan en komen' niet als. gevolg van de doorbreking van de hoofdregel van de onmiddellijke werking (de "eerbiediging van verkregen rechten') op grond van artikel $69 \mathrm{Ow} \mathrm{I}^{162}$. Iets anders is, dat

157. Zie hierover nader ne. 6.5 .2 hierna.

158. Zie de parlementaire geschiedenis als weergegeven door Polman, Owergangswet, deel 1, p. 54-59.

159. Hartkamp, Conpendium, ni $32 c$, schaart de hier aan de orde zijnde gewallen wel onder antikel $68 a$ lid I OWI:

160. Aldus De Die, Spoedoursus, p. 15 Evenzo Parl. Gesch. Overgangsrecht, p. 152 sub a.

161. Parl. Gesch Owergangseelat, $p$, 16-18; De Die, Spoedcursus, p. 4, 5, noemt in dit verband ook 'Obliegenheiten'. Zie ook Polman Overgangswet, deel 1, p. 52, woor beperkingen die voor het 'gaan en komen' gelden.

162. Zie daarover nr. $2,5,1,2$ sub e hierna. 
voor de inhoud van deze gehandhaafde rechten en betrekkingen genoemde hoofdregel wel kan opgaan.

\section{e. Uitzonderingen op de hoofdregel van de onmiddellike werking}

Tot slot nog dit. Zoals uit het slot van artikel 68 a lid 1 Ow I al blijkt, bevat de Overgangswet uitzonderingen op de hoofdregel van de onmiddellijke werking. In de toe lichting wordt opgemerkt dat de regel van onmiddellijke werking als een louter for meel uitgangspunt is aanvaard. In tientallen gevallen heeft de wetgever voor een andere oplossing gekozen ${ }^{163}$. Een aantal van die uitzonderingen heb ik genoemd in nr. 2.3.1 hiervöor. Voor de vraag of het nieuwe $\mathrm{BW}$ onmiddellijk werkt, indien geen bijzondere overgangsregel valt aan te wijzen, verwijs ik naar nr: 2.7 hiema.

\subsubsection{Eerbiediging van oud recht}

\section{a. Begripsowschrijving; terminologie}

Eerbiediging van oud recht houdt in dat de mieuwe wet niet vanaf de invoering en ook niet vanaf een later tijdstip gaat werken voor de rechtstoestand zoals deze bij de inwerkingtreding bestond; in plaats daarvan blijft daarop het oude recht toepasse$\mathrm{lijk}^{164}$. Niet bezien vanuit de bestaande rechtstoestand, mar vanuit de nieuwe rechtsregel (vereiste-rechtsgevolg): ook al was op het moment van de inwerkingtreding voldaan aan de vereisten van de nieuwe wet voor een bepaald rechtsgevolg, toch blifft dat rechtsgevolg uit; het oude recht blijft bepalend ${ }^{165}$.

Het feit dat in geval van eerbiediging de nieuwe wet in het geheel niet werkt voor de bestaande rechtstoestand, brengt met zich mee dat de uitdrukking "eerbiediging van oud recht' de voorkeur verdient boven de ook wel gebruikte term "eerbjedigende werking'. In de (toelichting op de) concept-Aanwijzingen voor de regelgeving wordt, evenals in de huidige Aanwijzingen voor de wetgewingstechniek (AWT), nog van "eerbiedigende werking" gesproken ${ }^{166}$.

Uiteraard blijft de eerbiediging van het oude recht in beginsel beperkt tot de bij de inwerkingtreding bestaande rechtstoestand. De rechtsverhoudingen, rechtsposities etc. die eerst nadien worden geboren horen thuis onder het nieuwe recht, dat nu eenmal in werking is getreden. Wel kan een woorval na de invoering een binding hebben met een 'overstaande' rechtsverhouding, rechtspositie etc. en daardoor nog onder oud recht vallen. Dat is bij voorbeeld het geval bij de niet-nakoning na het moment van de inwerkingtreding van een op dat moment reeds aanwezige over

163 , Zie over de achtergronden wan een en ander Parl. Gesch. Overgangsrecht, p. 11; zie ook p. 6-7, 18,62. 164. Zie over de begrippen inwerkingtreding, thepasselijk zijn en werken de nrs. 2.2 .3 en 2.2 .4 hiervoór. 165. Zie voor de verschillende wijzen waarop de eerbiediging van het oude recht in de Overgangswet is ge. formuleerd Polman, Overgangswet, deel 1, p. 70.

166. Op de omschrijving van de eerbiediging van het oude rech in de AWT en in de concept-Aanwijzingen voor de regelgewing ga ik hier niet in. Met betrekking tot die in de AWT verwijs ik naar mign bijdrage in RegelMaat 1986, p. 158-161. 
eenkomst. Eerbiediging van het oude recht kan zich ook tol zo'n 'posterieur feit' uitstrekken (zie in casu artikel 183 ow $\mathrm{I}^{167}$ ).

Om door de niet-toepasselijkheid van het nieuwe recht op een overgangssituatie niet in het 'luchtledige' terecht te komen, is het noodzakelijk dat er wordt voorzien in handhaving van de toepasselijkheid van het oude recht. Daarover nu eerst enkele woorden.

\section{b. Handhaving van de toepasselijkheid van het oude recht}

Nu eenmaal het oude recht met ingang van de datum van inwerkingtreding van het nieuwe is vervallen, zou het niet werken voor een overgangssituatie, indien niet zou zijn voorzien in "nawerking" 16 "van het oude recht. In de Overgangswet is deze 'nawerking' geregeld in lid 2 van artikel $68 a$ Ow I, dat luidt als volgt:

'Voor zover en zolang op grond van de volgende artikelen de wet niet van toepassing is, blijft het vóor haar in werking treden geldende recht van toepassing."

Dat 'vór haar in werking treden geldende recht' kan behalve uit de vervangen delen van het BW ook bestaan uit vervallen bepalingen uit het Wetboek van Koophandel, het Wetboek van Burgerlijke Rechtsvordering etc., alsmede 'de daaromheen geweven rechtspraak." 169

Evenals de onmiddellijke werking kan ook de eerbiediging van het oude recht nader worden bestudeerd aan de hand van de vereisten en de rechtsgevolgen van de nieuwe wet. Dat geschiedt thans onder $\mathrm{c}$ en $\mathrm{d}$.

\section{c. Eerbiediging van het oude recht en de vereisten van de nieuwe wet}

\section{c.l Toestanden}

Zakelijke rechten, vorderingsrechten, aansprakelijkheden etc., die op het tijdstip van het van kracht worden van de nieuwe wet voorhanden waren en die toen op zichzelf genomen voldeden aan de vereisten van de nieuwe wet, worden bij eerbiediging van het oude recht niet binnen de werkingssfeer van de nieuwe wet gehaald, maar blijven binnen die van het oude recht. Dit betekent bij voorbeeld niet alleen dat zij de inwerkingtreding hebben overleefd (zie artikel 69 sub a Ow I, waarover meer onder c. 2 en onder e hierna), maar ook dat zij voor wat betreft hun inhoud (bevoegdheden, verplichtingen van de zakelijk gerechtigde etc.) door het voorheen geldende recht geregeerd blijven. De cesuur zoals die bij onmiddellijke werking valt aan te wijzen is in geval van eerbiediging dus afwezig.

167. Waturover meer in nr. 7.6.2 hierna.

168. Zie woor deze term bij voorbeeld Versteeg preadv, $0, a_{n}$, p. 4,6,7.

169. Zie Parl. Gesch, Overgangsrecht, p. 35-36. Zie voor enkele voorbeelden Polman, Overgangswet, deel 1., $70-71$. 
Aan eerbiediging van het oude recht kan bij gebreke van een overgangssituatie in beginsel niet worden toegekomen, indien ten tijde van de invoering een feit al "voldongen" was: het ontstaan van het rechtsgevolg wordt niet teruggedraaid, indien de nieuwe wet een nieuw ontstaansvereiste stelt, dat niet in acht is genomen. Het is om deze reden en niet op grond van eerbiediging dat de vór de invoering (zonder mededeling aan de debitor cessus) voltooide cessie niet meer wordt "geraakt" door de extra eis van mededeling aan de debitor cessus, die artikel 3:94 lid 1 BW stelt ${ }^{170}$. Dit is anders als het rechtsgevolg er eén is, dat - bij onmiddellijke werking - vervalt of ontstaat al naar gelang de wet wordt ingetrokken dan wel ingevoerd. Dan kan de eerbiediging wel te hulp worden geroepen, zoals bij de bevoegdheid tot ontbinding wegens anterieure niet-nakoming van een wederkerige overeenkomst (artikelen 182 en 183 OW $\mathrm{I}^{17}$ ) en (bij wijze van uitzondering) bij de bevoorrechting van

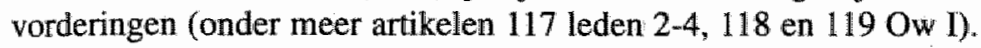

Vervolgens de feiten die onder het oude recht zonder rechtsgevolg bleven. Stel de nieuwe regel heeft voor zulke feiten wel een rechtsgevolg in petto, en wel een $a b-$ soluut of relatief recht. Zou deze nieuwe regel gaan werken voor zulke anterieure feiten, dan kan in de denklijn van de Overgangswet alsnog het rechtsgevolg ontstaan (met ingang van het werkingstijdstip). Bij eerbiediging van het oude recht wordt zulks echter geblokkeerd (zie voor vorderingsrechten - en daarmee ook voor de daartegenover staande aansprakelijkheden - artikel 69 sub d Ow ${ }^{172}$ ).

Een blokkade is er ook voor het omgekeerde geval dat de feiten onder het oude recht een rechtsgevolg hebben gehad in de vorm van een absoluut of relatief recht, dat in het nieuwe BW vergeefs zal worden gezocht. Het toepasselijk worden van het nieuwe BW op zo'n geval zou in de optiek van de overgangswetgever betekenen dat het recht en de verbintenis zouden sneuvelen. Dit wordt gedwarsboomd door de 'eerbiediging van verkregen rechten' ex artikel 69 sub a Ow ${ }^{173}$. Wel is het zo dat de gehandhaafde rechten in beginsel voor wat betreft hun inhoud (bevoegdheden, eigenschappen etc.) vanaf de invoering voor het vervolg onder het nieuwe recht vallen op grond van de hoofdregel van de onmiddellijke werking (artikel $68 a$ lid $\$ Ow I).

Ook feiten die pas na de inwerkingtreding voorvallen kunnen worden bestreken door eerbiediging, namelijk ingeval zij in verband staan met 'overlopende' rechts-

170. Anders Hartkamp, Compendium, nr. 32d; Brunner, WPNR 6007 (1991), p. 345; Van Mierlo, preadv., p. 44, die stellen dat artikel 69 sub a $O$ w I hier eerbiediging teweegbrengt: Aan deze bepaling komt men ech ter in het systeem dat aan de Overgangswet ten grondslag ligt bij cen 'voldongen feit" niet toe; zie de nrs.

2.4. 1.2 en 2.5.1.1 sub c.2 hiervóór.

171. Zie daarover hoofdstuk 7 hierna.

172. Zie voor enkele algemene opmerkingen over artikel 69 Ow I hierna onder e. Zie over de asansprakelijkheid uit onrechtmatige daad in dit verband nr. 6.5 .3 hierna. Het voorbeeld inzake artikel $6.83 \mathrm{BW}$ (intreden verzuim zonder ingebrekestelling) dat Brumer, WPNR 6007 (1991), p. 345, geeft bij artikel 69 sub d OW I is niet juist, ondat de Overgangswet terzake een bijzondere owergangsbepaling bevat: artikel 183. Zie over deze laatste bepaling de urs. 6.5 .1 .4 en 7.6 .2 hierna.

173. Waarover meer onder e hierna. Zie in dit verband over de aansprakelijkheid ust onrechtmatige daad nr. 6.5.1.1 hierna. 
betrekkingen, rechtsposities etc.. Zo wordt na het tijdstip van inwerkingtreding de vraag, of de stipulator een op dat moment bestaand derdenbeding wel kon herroepen, niet beheerst door artikel 6:253 lid $2 \mathrm{BW}$, maar door het oude recht (zie de artikelen 193 jo. 68 a lid 2 Ow 1 ).

Eerbiediging van het oude recht kan ook van invloed zijn op 'onvolledige complexen van rechtsfeiten'. Zou bij de onrechtmatige daad zijn gekozen voor eerbiediging ter zake van schadeveroorzakende gebeurtenissen, gepleegd vóór de invoering ${ }^{174}$, dan zou ook bij schade die zich eerst nadien voordoet krachtens overgangsrecht het oude recht toepasselijk zijn.

\section{c.3 Juridische waarderingen}

De juridische vereisten volgen hetzelfde overgangsrechtelijke regime als de toestand of het feit, walarop zij betrekking hebben. De onrechtmatigheid van een daad (een feit), die leidt tot oplopende of opeenvolgende schaden als geregeld in artikel 173 lid 2 Ow $I^{175}$, moet naar oud recht worden beoordeeld, hetgeen overigens bij onmiddellijke werking niet anders zou zijn geweest.

\section{d. Eerbiediging van het oude rechten de rechtsgevolgen van de nieuwe wet}

Zoals uit het voorgaande al blijkt, blijven in geval van een overgangssituatie bij eerbiediging van het oude recht de rechtsgevolgen geheel uit dat oude recht voortvloeien, zowel wat hun ontstaan als wat hun bestaan betreft en ongeacht de aard van het rechtsgevolg (absoluut recht, verbintenis, bevoegdheid etc.).

\section{e. De 'eerbiediging van verkregen rechten'}

Uitgangspunt van de wetgever is dat de toestand van het al dan niet bestaan van absolute en relatieve rechten niet wordt beïnvloed door het toepasselijk worden van de nieuwe wet:

'ook al zijn vóór of ten tijde van de i.w.t. der nieuwe wet haar vereisten voor het hebben of ontberen wan een vermogensrecht vervuld, die nieuwe wet mag dat rechtsgevolg daaraan niet verbinden. Anders gezegd: of men op het tijdstip van het in werking treden der nieuwe wet een vermogensrecht heeft of niet, wordt in beginsel door het oude, niet door het nieuwe recht bepaald.' 176

Beter dan over (de leer of het beginsel van) de 'eerbiediging van verkregen rechten' zou men dan ook kunnen spreken van 'de eerbiediging van het bestaan en niet bestaan van verkregen rechten' ${ }^{177}$.

174. Op enkele deelterreimen wordt deze regel overigens wel gehanteerd, zie nr. 6.5.2.3 hierna.

175, Zie daarover n. 6.5.4 hiertia.

176. Aldus De Die, Spoedcursus, p. 20.

177. Vgl. Parl. Gesch. Overgangsrecht, p. 40, 41. 
Concretiseringen van bedoeld beginsel zijn in de Overgangswet neergelegd in artikel 69 . In het systeem van de Overgangswet ${ }^{178}$ vormt deze bepaling een uitzondering op de hoofdregel van de onmiddellijke werking van artikel $68 a$ lid 1 (en soms op uitgestelde werking): zo blijven de rechten die bij onverkorte onmiddellijke of uitgestelde werking zouden sneuvelen gespaard krachtens artikel 69 sub a. Dit blijkt ook uit de aanhef van het artikel:

"Wanneer de wet van toepassing wordt, heeft dat niet tot gevolg dat alsdan: (...)"

Artikel 69 Ow I werpt dus een blokkade op tegen bepaalde gevolgen die onmiddellijke of uitgestelde werking zou hebben, waardoor in zoverre een uitzondering op deze werkingen wordt gemaakt ${ }^{179}$. Voor het overige blijven deze werkingen overeind, uiteraard behoudens uitzonderingen op de hoofdregel van de onmiddellijke werking in andere overgangsbepalingen ${ }^{180}$.

Over (de leer of het beginsel van) de 'eerbiediging van verkregen rechten' en de regeling terzake in de Overgangswet zou nog veel meer te zeggen zijn, zoals over de verhouding tussen deze eerbiediging en de terugwerkende kracht en over het op de achtergrond staande algemene rechtszekerheidsbeginsel. Dat zou echter het $\mathrm{ka}-$ der van een behandeling van de diverse verwijzingsregels verre te buiten gaan. Ik volsta daarom met het vermelden van literatuur ${ }^{181}$.

\section{f. 'Kruisingen' tussen onmiddellijke werking en eerbiediging van het oude recht}

Er zijn overgangsregels die zich onttrekken aan de indeling in verschillende soorten verwijzings- en overbruggingsregels. Bij wijze van voorbeeld wijs ik hier op enkele overgangsbepalingen die een combinatie van onmiddellijke werking en van eerbiediging van het oude recht tonen.

In artikel 102 Ow I $^{182}$ wordt artikel 3:181 BW met ingang van de inwerkingtre-

178. Waarop kritiek mogelijk is, zie mr. 2.5 .1 .1 sub. 2 hiervór.

179. In deze zin ook: Parl. Gesch. Overgangsrecht, p. 15; Bruner, pread v, p. 57; Hartkamp, Compendium, nr. 32d: Brunner, WPNR 6007 (1991),p. 344: Reinsma, AA 1991, p. 654; Vriesendorp, WTNR 6025 (1991), p. 770. Volgens De Vries Lentsch-Kostense, in: Liber amicorum NBW, p. 170, 171, zouden de artikelen 69 en 790 w I eerder neverigeschikt moeten $2 \mathrm{ijn}$ aan het in artikel $68 \mathrm{O} \mathrm{OW}$ I neergelegde beginsel. Zie ook Mon Nieuw BW A-25 (De Vries Lentsch Kostense), p. 30-32, 35, en De Die; AA 1991, p. 824, met noot 28.

180. Zie Parli. Gesch. Overgangsrecht, p. 14, 16-18, 38-40, en woor een uitwerking hiervan ten aanzien van de onrechtmatige daad n: 6.3 hierna.

181. Zie onder c hiervoór en nrs. 6.5.1.1.3 en 6.5.3 hierna, en vororts onder meer: Hijmans van den Bergh diss., p. 234-262: Folmer, diss., p. 15-17, 27 e. v.; Hijmans van den Bergh, preadw. p. $7,9-10,12,14,19-22$; Polmann diss, , o.a. p. 66 e.v., 161-162; Knigge, diss., o.a. p. 7 e.v.; Parl. Gesch. Overgangsrecht, p. 9, 14, 15 17, 38-46; Reinsma, Kwartaalbericht Nieuw BW 1985, p. 45; Brunner, preadv., p. 12-19; Stein, preadv, p. 249-258; De Die, in: Verslag NJV-vergadering, p. 26-27, beantwoord door Brunner, t.a,p, p. 34-35; Joppe, diss., p. 119-123; De Die, Spoedcursus, p. 18-21, die op p. 18 terecht opmerkt dat eerbiediging wan verkregen rechten zich niet zozeer richt tegen terugwerkende krachi, maar juist tegen onmiddellijke werking; Brunner, WPNR 6007 (1991), p. 344-345.

182. Toegelicht in Parl. Gesch. Overgangsrecht, p. 110. 
ding toepasselijk verklaard op een krachtens artikel 1117 (oud) BW benoemd onzijdig persoon. Een eerbiedigend element wordt echter ingebouwd door de toevoeging dat de voor de onzijdig persoon geldende beloning wordt gehandhaafd. Hier zou men ook wel van 'gemitigeerde onmiddellijke werking' kunnen spreken.

In de artikelen 182 jo. $68 a$ lid $\mathbb{1}$ Ow I wordt het oude recht geëerbiedigd ter zake van de gevolgen van vó́r de inwerkingtreding plaatsgevonden hebbende tekortkomingen in de nakoming. Deze eerbiediging strekt zich dus niet uit tot tekortkomingen van na het moment van de inwerkingtreding, ook al betreffen deze een verbintenis die op dat moment reeds bestond: daarvoor geldt onverkort de onmiddellijke werking ${ }^{183}$.

Artikel 195 Ow I schrijft de rechter voor bij de toepassing van de artikelen 6:258 en $259 \mathrm{BW}$ geen rekening te houden met wijzigingen in de omstandigheden van vó́r de inwerkingtreding, ingeval hij moet beslissen omtrent een vordering tot wijziging of ontbinding van een overeenkomst als bedoeld in genoemde BW-artikelen. Posterieure wijzigingen in de omstandigheden kunnen dus wel grond opleveren voor toepassing van de artikelen 6:258 en $259 \mathrm{BW}$, ook al betreffen zij een "overstaande" overeenkomst ${ }^{184}$.

\section{2:5.1.3 Uitgestelde werking}

\section{a. Begripsomschrijuing; terminologie}

Bij uitgestelde werking wordt de nieuwe wet - in tegenstelling tot hetgeen eerbiediging van het oude recht te zien geeft ${ }^{185}$ - wèl toepasselijk op de toestand die bestond bij haar inwerkingtreding, maar niet direct: de werking van de nieuwe wet neemt pas een aanvang enige tijd nadien ${ }^{186}$. Met behulp van het begrippenpaar vereiste-rechtsgevolg kan dit ook aldus worden gezegd: ook al was bij de inwerkingtreding reeds voldaan aan de vereisten die de nieuwe wet stelt voor het intreden van een rechtsgevolg, dit rechtsgevolg treedt vooralsnog niet in. Het treedt slechts in, indien (ook) bij het toepasselijk worden van de nieuwe wet (dus na afloop van de 'overgangstermijn') nog aan deze vereisten is voldaan. Gedurende deze termijn blijft het oude recht bepalend. Het kenmerkende verschil met de eerbiediging van oud recht is dat de nieuwe wet in beginsel wel degelijk op de bij de inwerkingtreding bestaande toestand toepasselijk kan worden, zij het dan dat dit pas na enige tijd kan geschieden; gedurende de 'overgangstermijn' leidt dus ook uitgestelde werking tot niet-toepasselijkheid van de nieuwe wet ${ }^{187}$.

Zoals uit het bovenstaande al kan worden afgeleid, is het wel mogelijk dat in concrete gevallen het effect wan uitgestelde werking hetzelfde is als dat van eerbie-

183. Zie de nrs: 2.4 .1 .3 en 2.5.1.1 sub b hiervo6r en 7.6. I. slot hierna.

184. In soortgelijke zin ten aanzien van enkele zakelijke rechten de artikelen 165, 169 en 171 OW I. Zie over deze materie nader de nrs. 2.4.1.3 en 2.5.1.1 sub b hiervóór en 2.6 .1 hierna.

185. Vgl. De Die, RMTh 1979, p. 259.

186. Zie over de begrippen inwerkingtreding, toepasselijk zijn en werken de nrs. 2.2 .3 en 2.2 .4 hiervóor.

187. Zie Parl. Gesch. Overgangsrecht, p. 24-25. 
diging, namelijk dat het nieuwe recht helemaal niet toepasselijk wordt ${ }^{188}$.

De wetgever noemt de hier aan de orde zijnde werking "uitgestelde werking". Deze aanduiding is wat vaag. Niet ondenkbaar is immers dat zij het misverstand oproept, dat de nieuwe wet ondanks haar inwerkingtreding voor een bepaalde tijd naw dien in het geheel niet toepasselijk is, waardoor ook datgene wat na de inwerkingtreding ontstaat buiten het "schootsveld" van de nieuwe wet blijft 1.89 . Dit moge een vreemde figuur lijken, zij komt in de praktijk wel degelijk voor. Voor een voorbeeld ervan behoeft niet eens het terrein van het overgangsrecht voor het nieuwe BW te worden verllaten. Artikel $23 \mathrm{OW} \mathrm{II}^{190}$ houdt namelijk in dat in beginsel het oude recht tot een nader bij $\mathrm{AMvB}$ te bepalen tijdstip toepasselijk blijft op het beslag op en de executie van (beperkte rechten op) schepen en luchtvaartuigen. Ook zulke beslagen en executies die pas na de inwerkingtreding aanvangen zouden volgens deze bepaling dus in beginsel door het oude recht beheerst blijven ${ }^{191}$. Dat is wat men zich bij de term "uitgestelde werking' zou kunnen voorstellen: wolledig uitgestelde werking. Teneinde tot uitdrukking te brengen dat de "uitgestelde werking' in de Overgangswet niet ook posterieure toestanden en feiten bestrijkt, zou een term als partieel uitgestelde werking gezien het bovenstaande beter zijn ${ }^{192}$.

Ook al is 'uitgestelde werking' naar mijn mening niet een erg gelukkige term, toch gebruik ik hem in dit boek. Doorslaggevend hiervoor is geweest dat het mij niet wenselijk lijkt het rechtsleven met een tweede term op te zadelen en daardoor wellicht het tegendeel (misverstand) te bereiken van wat ik beoog. Ook is van belang dat de benaming 'uitgestelde werking' inmiddels wel bestaansrecht lijkt te hebben verworven als aanduiding woor het gedeeltelijk uitstellen van de werking van een nieuwe wet, en dat volledig uitstel van die werking in het burgerlijk recht niet frequent voorkomt.

\section{b. (Tijdelijke) handhaving van de toepasselijkheid van het oude recht}

Evenals bij eerbiediging van oud recht wordt bij uitgestelde werking de leegte die ontstaat door de (voorlopige) niet-toepasselijkheid van het nieuwe recht opgevuld door het (tijdelijk) toepasselijk verklaren van het buiten werking getredlen oude recht: zie artikel $68 a$ lid 2 Ow I, waarover ik reeds schreef in ar. $2.5 .1 .2 \mathrm{sub} \mathrm{b}$ hiervóor.

188. Zie voor een voorbeeld onder $c_{n} 1$ hierna.

189. In deze zin wordt het begrip 'uitgestelde werking' ook wel gebruikt: zie Knigge, disss., p. 87.88 .

190. Toegelicht in Parl. Gesch. Overgangsrecht, p. 215-216. Andere voorbeelden van "volledig nitgestelde werking' worden genoemd door De Die, Spoedcursus, p. 11; Verheij, Regellaat 1986, p. 145, noot 15. Zie ook de artikelen X, XV en XVII Ow Kadasterwet, Stbl. 1991, 376, en de toelichting, TK, vergaderjaar 19901991,21830 , nr. 3 . p. $10,18,20$.

191. Deze handhaving van de toepasselijkheid van het oude recht over de gehelle linie heeft geen doorgang gevonden, omdat de wet houdende aanpassing van het Wetboek van Burgerlijke Rechtswordering en de Wet teboekgestelde Luchtvaartuigen, voor wat betreft beslag op en executie van schepen en luchtwaartuigen, aan de regels betreffende executie en besllag, in dat wetboek opgenomen bij de Wet van 7 mei 1986, Stbl. 295 , nog tijdig wór 1 januari 1992 is totstandgekomen (zie Stbl. 1991, 583: de aanpassingswet is in werking getreden met ingang van 1 januari 1992 (KB van 16 d december 1991 , Stbl. 690)).

192. Ik heb deze term voorgesteld in Kwartaal bericht Nieuw BW 1986, p. 79; RegelMaat 1986; p. 160; AA 1988, p. 406.Zie instemmend Verheij, RegelMaat 1986, p. 145 en Waaldijk, RegelMaat 1987, p. 7 . 


\section{c. Toestanden}

Zakelijke rechten, vorderingsrechten en aansprakelijkheden die de nieuwe wet bij haar inwerkingtreding aantrof, worden bij uitgestelde werking vooralsnog aan het regime van het oude recht overgelaten. De bevoegdheden en verplichtingen van de zakelijk gerechtigde, de schuldeiser en de schuldenaar blijven voorlopig bepaald door het oude recht. Wel is dan noodzakelijk dat een overgangssituatie aanwezig was. Daarvoor moeten in de eerste plaats in beginsel de vereisten van het nieuwe recht op het moment van de invoering (1 januari 1992) vervuld zijn geweest. Maar dat is bij uitgestelde werking niet genoeg. Wil immers het nieuwe recht na afloop van het uitstel toepasselijk kunnen worden, dan zal ook op het moment dal zijn werking aanvangt (bij een uitgestelde werking wan een jaar: 1 januari 1993) moeten zijn voldaan aian zijn vereisten ${ }^{193}$.

Hiermee dienen zich meerdere mogelijkheden aan. De overgangssituatie kan er op 1 januari 1992 èn 1 januari 1993 zijn. Dan gaat na het verstrijken van de 'overgangstermijn" het nieuwe recht werken. De anterieure handelskoop die op 1 januari 1993 nog steeds bestaat, wordt vanaf genoemde datum beheerst door titel 7.1 BW (artikel 196 lid 10 O $)^{194}$. Daarbij zal in de visie van de overgangswetgever op 1 januari 1993 voldaan moeten zijn aan de vereisten die de nieuwe wet voor een rechtsgevolg stelt. Zouden deze vereisten pas later worden vervuld., dan zou men in deze visie niet meer met een transitoir geval van doen hebben ${ }^{195}$. Voor de betekenis van de werking van de nieuwe regels voor een bestaande toestand verwijs ik naar wat ik daarover bij de onmiddellijke werking heb opgemerkt in nr. 2.5.1.1 onder c. 1 .

Ook kan het voorkomen dat de overgangssituatie er alleen op 1 januari 1992 was: in 1992 houdt de handelskoop op te bestaan, doordat zij definitief is afgewikkeld. Titel 7.1 BW krijgt dan niet meer de kans om deze koop te gaan beheersen: er is nu eenmaal op 1 januari 1993 geen koopovereenkomst meer te bekennen. Bij deze stand wan zaken wordt dus hetzelfde resultaat bereikt als bij eerbiediging van oud recht het geval zou zijn geweest.196.

Het bovenstande $k a n$ tevens betekenis hebben voor andere rechtsgevolgen dan de hierboven genoemde, zoals omschrijwingen. Zo is in artikel 224 Ow I aan artikel $8: 160$ lid $1 \mathrm{BW}$, dat een omschrijving van het begrip 'rederij' bevat, een uitgestelde werking toegekend van drie maanden, derhalve tot 1 juli 1991.

193. Zie nr. 2.4.1.3 slot hiervớor.

194. Zie echter lid 3 van artikel 196 Ow 1 , warover meer in mr. 7.8 .3 hierna.

195. Zte in andere (mijns inziens juiste) zin Mon. Nieuw BW A-25 (De Vries Lentsch-Kostense), p. 38.

196. Dat is geen weval: hell verdient naar de mening van de overgangswetgever de voorkeur "in het bijzonder de kortlopende overeenkomsten niet nodeloos aan een wisseling wan rechtsregels te onderwerpen', alldus Parl. Gesch. Overgangsrecht, p. 178; evenzo p. 180. 
'Voldongen feiten' zullen ook bij uitgestelde werking zonder belang voor het overgangsrecht zijn. Bijzonder bij de uitgestelde werking is wel dat ook gedurende de periode van uitstel - dus na de inwerkingtreding - er nog "voldongen feiten" kunnen ontstaan. Ik illustreer dit met een voorbeeld dat betrekking heeft op algemene voorwaarden. De regeling terzake in het nieuwe $\mathrm{BW}$ heeft een uitgestelde werking van een jaar (artikel 191, lid 1 Ow 1). Het aanknopingspunt wordt hierbij gevormd door algemene voorwaarden die op het tijdstip van de inwerkingtreding reeds door een partij in haar overeenkomsten werden gebruikt. De uitgestelde werking strekt zich dus ook uit tot overeenkomsten die gedurende het jaar 1992 worden afgesloten en waarop dergelijke allgemene voorwaarden toepasselijk worden verklaard ${ }^{19}$.

In het arrest inzake Holleman-De Klerk ${ }^{198}$ liet de Hoge Raad de mogelijkheid open, dat in algemene voorwaarden bedingen voorkomen met een zodanige inhoud dat de toestemming van de wederpartij niet kan worden geacht, op de toepasselijkheid ook daarvan gericht te zijn geweest. In het systeem van afdeling 6.5.3 BW bestaat deze mogelijkheid niet meer: de wet voorziet enerzijds in snelle toepasselijkheid van algemene voorwaarden (artikelen 6:231 sub c en $232 \mathrm{BW}$ ) en anderzijds in inhoudstoetsing van algemene voorwaarden (artikelen $6: 233$ sub a, 234 en 235 $\mathrm{BW}^{199}$. In $1992 \mathrm{kam}$ derhalve een overeenkomst worden gesloten, waarbij partijen de toepasselijkheid van "oude" algemene voorwaarden overeenkomen, waarin een beding is verscholen als door de Hoge Raad bedoeld in genoemd arrest. Ervan uitgaande dat deze overeenkomst nog steeds bestaat als op 1 jantari 1993 afdeling 6.5.3 BW toepasselijk wordt op overgangssituaties, rijst de vraag of dan ook de incorporatie wan het 'Holleman-De Klerk-beding' in deze bestaande overeenkomst vanaf dat tijdstip door de artikelen 6:231 sub c en $232 \mathrm{BW}$ wordt beheerst. Zo ja, dan zou dit beding vanaf 1 januari 1993 ineens wel onderdeel van de contractsinhoud gaan uitmaken. Dit nu is in het systeem van de Overgangswet niet het geval, en wel omdat het geincorporeerd zijn van dit beding in de overeenkomst een "voldongen feit" vormt. De nieuwe wet stelt namelijk een ander ontstaansvereiste dan onder het oude recht gold. Artikel $6: 232 \mathrm{BW}$ werkt niet ten aanzien van het overeenkomen van het onderhavige beding; het oude recht blifft maatgevend ${ }^{200}$. Daarmee is hier dus een 'voldongen feit' van na de inwerkingtreding aanwezig.

Ook de "onwolledige complexen van rechtsfeiten" verdienen hier enige aandacht ${ }^{201}$. Aan de derdenbescherming krachtens de artikelen $3: 24$ lid 1,25 en $26 \mathrm{BW}$ wordt ter zake van vór de inwerkingtreding geschiedle en volgens afdeling 3.1 .2

197. Zie nr, 2.4.1.3 hiervóor. Zie over artikell 191 Ow I ook de nrs. 2.6.2 en 4.5.6 hierna.

198. HR 20 nowember 1981, NJ $1982,517$.

199. Zie Parl. Gesch. Inv. Boek 6, p. 1573; Rijken, TVVS 1986, p. 266; Asser-Hartkamp 11, nrs. 352, 353; Rijken, in: Wegwijzer nieuw BW, deel 2, p. 33; Hartkamp, rede, p. 13. Zie echter ook Verbintenissenrecht (Hondius), artikel 232, aant. 3.

200. Zie Parl. Gesch, Overgangsrecht, p. 167-168.

201. Voor het overige verwijs ik naar hetgeen ik in nr. 2.5.1.1 sub c 2 hiervoór bij de onmiddellijke werking heb gezegd over feiten. Het verschil met uitgestelde werking is dat het daarbij woor het 'werken' wan de nieuwe wet noodzakelijk is, dat (niet alleen bij de inwerkingtreding, maar) ook op het daarna gelegen tijdstip wan het toepasselijk worden van de nieuwe wet is voldaan aan de wereisten die zij woor een rechtsgevolg stelt. 
BW voor inschrijving vatbare feiten een uitgestelde werking verleend van drie jaar (artikel 78 lid 30 w ${ }^{202}$ ). Stel dat met betrekking tot een bepaald registergoed zo' $n$ feit op het tijdstip van de inwerkingtreding niet was ingeschreven en dat dit nadien zo blijft. In 1992 wordt het goed krachtens koop overgedragen, ter zake waarvan een transportakte wordt ingeschreven. Het rechtsgevolg van artikel 3:24 lid 1 BW (de uitzonderingen van de leden 2 en 3 zijn niet van toepassing), de niet-werking van het niet ingeschreven feit tegen de onwetende derde-verkrijger, kan pas vanaf 1 januari 1995 intreden (artikel 78 lid 3 Ow D). Ook al waren bij de inwerkingtreding nog niet alle vereisten van artikel 3:24 lid $1 \mathrm{BW}$ vervuld en wordt aan de ontbrekende pas voldaan tijdens de 'overgangstermijn', toch komt bij dit ten tijde van de inwerkingtreding 'onvolledige complex van rechtsfeiten' de uitgestelde werking in actie. Wil het rechtsgevolg van artikel 3:24 lid $1 \mathrm{BW}$ met ingang van 1 januari 1995 intreden, dan zal op dat moment aan alle vereisten van deze bepaling moeten zijn voldaan. Stel nu dat aan het ontbrekende vereiste van inschrijving van de transportakte niet in 1992, maar pas op 1 februari 1995 wordt voldaan. Op 1 januari 1995 zijn nog niet alle vereisten vervuld van artikel 3:24 lid $1 \mathrm{BW}$; dit is pas op 1 februari 1995 het geval. Met ingang van deze laatste datum treedt het rechtsgevolg van artikel 3:24 lid $1 \mathrm{BW}$ in, nu de 'uitsteltermijn' van artikel 78 lid 1 Ow I verstreken is.

\section{c.3 Juridische waarderingen}

Wat betreft de juridische vereisten volsta ik met een verwijzing naar wat ik hierover bij de onmiddellijke werking in nr. 2.5.1. I sub c.3 hiervór heb geschreven. Ik herhaal dat bij uitgestelde werking de regel is, dat de overgangssituatie niet alleen bij dle inwerkingtreding, maar ook bij het toepasselijk worden van de nieuwe wet aanwezig moet zijn.

\section{d. Uitgestelde werking en de rechtsgevolgen van de nieuwe wet}

De uitgestelde werking heeft als effect dat het intreden van de rechtsgevolgen van de nieuwe wet voor kortere of langere tijd wordt geblokkeerd, ook al was bij de inwerkingtreding al aan de vereisten daarvoor voldaan. Ook hier verwijs ik voor het overige naar hetgeen ik bij de onmiddellijke werking heb geschreven ${ }^{203}$.

\subsubsection{Terugwerkende kracht}

Over de terugwerkende kracht is van oudsher veel te doen geweest. Toch kan ik er kort over zijn. Slechts tweemaal immers is in de Aanvulling van de Overgangswet gebruik gemaakt van de terugwerkende kracht, namelijk in de overgangsregeling voor de geldigheid van rechtshandelingen (artikelen 80 lid 2 en 81 lid I Ow I). Deze bepalingen komen ter sprake in het aan deze overgangsregeling gewijde 
hoofdstuk 4204; ik laat ze hier in beginsel buiten beschouwing. In het navolgende snijd ik, behalve uiteraard de begripsomschrijving en de terminologie, het belang aan van de regel dat aan het nieuwe BW terugwerkende kracht ontbreekt (respectievelijk onder $a$ en $b)^{205}$.

\section{a. Begripsomschrijving; terminologie}

In geval van terugwerkende kracht wordt vanaf het ogenblik van de inwerkingtreding gefingeerd dat de nieuwe wet op de op dat ogenblik bestaande rechtstoestand ${ }^{206}$ reeds vanaf een daarvóór gelegen tijdstip toepasselijk is geweest. Geformuleerd met behulp van het in de Overgangswet gehanteerde begrip "overgangssituatie': indien op het moment van de invoering de vereisten van de nieuwe wet waren vervuld, zodat toen een overgangssituatie bestond, wordt het rechtsgevolg van de nieuwe wet geacht reeds vóór dat moment te zijn ingetreden. Daarvoor is dan wel noodzakelijk dat aan die vereisten tevens reeds was voldaan op het moment tot waar de nieuwe wet terugwerkt. De overgangssituatie moet er dus op twee momenten zijn ${ }^{207}$.

Zoals uit het voorgaande blijkt, zie ik de terugwerkende kracht als een fictie ${ }^{208}$. De terugwerkende kracht kan immers niet uitvlakken dat in werkelijkheid tot aan de inwerkingtreding nog wel degelijk het oude recht bepalend was voor het aan de orde zijnde geval.

De term 'terugwerkende kracht' is geheel ingeburgerd. Men treft ook wel de term 'retroactieve werking' aan. Ik geef er echter de voorkeur aan het meer gebruikelijke begrip 'terugwerkende kracht' te hanteren.

\section{b. De regel van het ontbreken wan terugwerkende kracht}

Voor het nieuwe vermogensrecht is als uitgangspunt de onmiddellijke werking uitverkoren. Dit uitgangspunt impliceert dat aan het nieuwe vermogensrecht in de re-

204. Zie de nrs. 4.8 en 4.9.

205. Zie over terugwerkende kracht en eerbiediging van verkregen rechten de literatuur die is vermeld in noot 181 hiervór.

206. Ik laat buiten beschouwing de mogelijkheid dat door terugwerkende kracht ook de vóór de inwerking treding reeds tenietgegane rechts betrekkingen, rechtsposities etc. nog door de nieuwe wet worden bestreken (zie hierover kort Parl. Gesch. Overgangsrecht, p. 8, noot 1).

207. Zie hierover nader m. $2.4,1.3$ hiervótr.

208. Ook in aanwijzing 74 van de. Aanwijzingen woor de wetgevingstechniek en wanwijzung 165 lid 2 van de concept-Aanwijzingen voor de regelgeving wordt de terugwerkende kracht met behulp van een fictie om" schreven. Zie voorts onder meer de volgende schrijwers: als in de tekst Joppe, diss ., p. 107; anders Knigge, diss., p. 28-31, de door deze in noot 17 op p. 67 geciteerde schrijvers, en Polman, diss., p. 483-484, Ten aanzien van het materielle recht wordt in Parl. Gesch. Boek 3, p. 185-186, opgemerkt:

"Terugwerkende kracht is een fictie d.w.z. een constructief hulpmiddel, waarmede men aanduidt, dat voor het wervolg de rechtsgevolgen volkomen gelijk zijn als zij zouden zijn geweest, wanneer het betreffende feit op een vroeger tijdstip had plaats gevonden (...)".

Zie hierover Hartkamp, WPNR 6030 (1991), p. 868, die op p. 873 overgangsrechtelijke terugwerkende kracht echter niet met behulp wan een fictie formulleert. 
gel geen terugwerkende kracht toekomt. Dit laatste steunt in de opvatting van de owergangswetgever op artkel 4 Wet AB. Wat het uitgangspunt van het ontbreken van terugwerkende kracht betekent, kan pas blijken indien het domein wan de terugwerkende kracht voldoende duidelijk us gemarkeerd. Met name de arbakening met de onmiddellijke werking is daarbij van belang. In de parlementaire geschiedenis wordt hierover het een en ander opgemerkt. Ik volsta met enkele korte opmerkingen en verwijs voor het overige naar genoemde bron ${ }^{209}$.

De overgangswetgever acht voor het antwoord op de vraag met welke verwijzingsregel men van doen heeft doorslaggevend, of het rechtsgevolg wan de nieuwe wet in een overgangssituatie intreedt, en zo ja, van welk tijdstip af. Dienovereenkomstig is er onmiddellijke werking, ingeval dat rechtsgewolg vanaf de inwerkingtreding intreedt (ik beperk me tot de 'standaardgevallen'), en terugwerkende kracht, ingeval dat rechtsgevolg al vanaf een tijdstip gelegen vóór de inwerkingtreding geacht wordt te zijn ingetreden. Het rechtsgevolg van onaantastbaarheid van een anterieure rechtshandeling neemt krachtens artikel 81 lid 1 OW I niet pas een aanvang bij de inwerkingtreding, maar reeds op het daarvóor gelegen moment dat die rechtshandeling werd verricht ${ }^{210}$.

Als een anterieur feit pas onder de nieuwe wet tot een rechtsgevolg leidt, levert dit volgens de overgangswetgever geen terugwerkende kracht op, zoals bij het vanaf de inwerkingtreding verbinder van aansprakelijkheid aan een feit dat voordien reeds was geschied ${ }^{21}$. Terugwerkende kracht is er evenmin, indien de inhoud van een zakelijk recht of van een andere rechtsfiguur die een min of meer duurzame toestand oplevert vanaf de inwoering wordt bepaald door de nieuwe wet.

Een andere consequentie van het voor het nieuwe BW geldende uitgangspunt van het ontbreken van terugwerkende kracht is, dat andere of extra ontstaansvereisten die het nieuwe BW stelt voor een bepaald rechtsgevolg geen invloed hebben op zo'n rechtsgevolg dat onder het oude recht reeds is totstandgekomen ${ }^{21.2}$.

\subsubsection{Overbruggingsregels}

In het overgangsrecht staan twee belangen tegenover elkaar. De wetgever wenst zo snel en volledig mogelijke doorvoering van de nienwe wet. Daartegenover staat dat het rechtsleven zo min mogelijk overlast mag ondervinden van nieuwe produkten van de wetgever ${ }^{213}$. Het komt woor dat een verwijzingsregel niet volstaat om een aanvaardbaar evenwicht tussen deze twee belangen te bewerkstelligen, iets dat zich met name bij langlopende verhoudingen zal voordoen. Ik citeer de toelichting:

209. Parl. Gesch. Overgangsrecht, p, 12-15. Volgens Brumer vat de owergangswetgever de inhoud vande terugwerkende kracht te bepenkt, en die wan de onmiddellijke werking te ruim op: zie zijn preadw., p, 19-29, waintegen De Die, in: Verslag NJV-vergadering, p. 26-28; beantwoord door Brumner, t.a.p., p. 34-35; zie voorts Brunners antikel in WPNR 6007 (1991), p. 342343 .

210. $2 \mathrm{ie}$ Parl. Gesch. Overgangsrecht, p. 13, watuit hierna enkele punten worden gelicht. Zie over artikel 81 lid 10 i nader nr, 4.9 hierna.

211. Zle hierover nader de nirs. 2,4.1.2,2.5.1.1 onder c., en $2,5,1.2$ onder e hiervóór.

212, 2 ie over "voldongen feiten" en de Overgangswelt Polman, Overgangswet, deel 1, p. 28-31.

213. Zie Parl, Gesch. Overgangstecht, p. 5. 
"Ook hier moet men natuurlijk partijen zoveel mogelijk last besparen, marr eilanden van oud recht temidden van een zee van nieuw recht komen op den duur geissoleerd te liggen: het oude recht past hoe langer hoe minder in de nieuwe omgeving, de kennis ervan gaat teloor en de handhaving ervan gaat problemen opleveren."214

De owergangsproblematiek in verband met de eigendomsoverdracht tot zekerheid kan hier bij uitstek als illustratie dienen. Genoemde vorm van zekerheid kwam onder het oude recht zeer veel voor en maakte vaak deel uit van langlopende kredietrelaties. Het nieuwe $\mathrm{BW}$ stelt voor de eigendomsoverdracht tot zekerheid de stille verpanding in de plaats. Met geen van de vier hierboven besproken verwijzingsiegels valt hier een aanvaardbaar resultaat te bereiken. Onmiddellijke werking bij voorbeeld zou de bestaande eigendom tot zekerheid onverlet laten, maar vanaf de invoering nieuwe eigendomsoverdrachten tot zekerheid op grond van reeds aanwezige verplichtingen daartoe onmogelijk maken. Ook het naast elkaar bestaan van oude zekerheidseigendom en nieuw stil pandrecht zou niet erg aantrekkelijk zijn.

In gevallen als het zojuist geschetste moet de overgangswetgever grover geschut gebruiken. Dat heeft hij tot zijn beschikking in de vorm van overbruggingsiregels ofwel koppelregels. Het belangrijke verschil met verwijzingsregels is, dat overbruggingsregels directe regels zijn: zij verwijzen niet naar oud of naar mieuw recht, maar houden zelf een 'materiêlle' regel in. Deze kan een oplossing voor het aan de orde zijnde overgangsprobleem bevatten of door een 'truc' de weg vrij maken voor toepassing van de nieuwe wet. De wetgever ontleent de diverse overbruggingsinstrumenten aan het gemene burgerlijk recht. In het overgangsrecht voor het nieuwe BW zijn met name de volgende te vinden.

De overgangsproblematiek bij de eigendomsoverdracht tot zekerheid is de wetgever te lijf gegaan met de figuur van de omzetting van oude rechten in hun evenknie uit de nieuwe wet. Oud en nieuw recht worden gekoppeld door de bij de inwerkingtreding voorhanden zijnde eigendom tot zekerheid als regel om te zetten in stil pandrecht (artikel 86 leden 1, 2 en 5 Ow 1). Daarmee is uiteraard de weg woor toepassing van titel $3.9 \mathrm{BW}$ nog lang niet voldoende geëffend, maar zonder genoemde omzetting zou deze toepassing zich wel bijzonder moeilijk laten denken ${ }^{215}$.

Een andere soort overbruggingsregel is de fictie. Anterieure feiten en bestaande toestanden worden op grond daarvan voor het vervolg geacht een bepaalde hoedanigheid, werking, inhoud etc. te hebben, die zij anders niet zouden hebben gehad en die toepasselijkheid van het nieuwe recht mogelijk maakt. Artikel 86 lid 3 tweede zin Ow I laat hiervan een voorbeeld zien: het pandrecht waarin zekerheidseigendom bij de inwerkingtreding is omgezet geldt met betrekking tot de rangorde als gevestigd op het tijdstip waarop het goed in eigendom tot zekerheid is overgegaan ${ }^{216}$.

214. Parl. Gesch. Overgangsrecht, p. 5.

215. Zie over de overgangsperikelen van de eigendom tot zekerheid uitgebreid hoofdstuk 5 hierna. Zie voor een ander woorbeeld van omzetting artikel 89 لid 1 Ow 1 .

216. Zie hierover de nrs. 5.8.2 en 5.8.3 hierna. Andere voorbeeiden van ficties kunnen worden aangetroffen in onder meer de artikelen 71,77 derde en vierde zin, 78 lid 1 en 86 lid 7 Ow $I_{\text {. }}$ 
Ten slotte de bekrachtiging. Deze is te vinden in artikel 81 lid $1 \mathrm{Ow}$ I. Rechtshandlelingen die volgens het oude recht nietig waren, maar naar nieuw BW onaantastbaar zouden zijn, kunnen profiteren van het liberalere nieuwe regime: zij worden op het tijdstip dat dat regime op hen toepasselijk wordt in beginsel bekrachtigd, en wel met terugwerkende kracht tot het moment waarop zij werden werricht ${ }^{217}$.

Er zijn overigens nog andere mogelijkheden. Zo is de eigenaar van een erf in beginsel verplicht op vordering van een nabuur de bij de inwerkingtreding bestaande toestand in overeenstemming te brengen met hetgeen waarop die nabuur nadien op grond van titel $5.4 \mathrm{BW}$ aanspraak kan maken. Voor het geval dat de toestand in overeenstemming is met het oude recht wordt evenwel voorzien in de mogelijkheid dat de nabuur de kosten en schade draagt, die de wijziging teweegbrengt (artikel

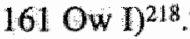

\section{5; De ontsnappingsmogelijkheden van artikel 75 Ow I}

Er is niet veel fantasie voor nodig om zich voor te stellen dat de wetgever onmogelijk alle overgangsproblemen kan voorzien, die de invoering van zo'n omvangrijk regelcomplex als het nieuwe vermogensrecht teweeg kan brengen. De wetgever heeft dit zelf ook ingezien en daarom de volgende bepaling opgenomen in de Overgangswet:

"Artikel 75. 1. De wet blijft, ook buiten de in deze en de volgende titels geregelde gevallen, buiten toepassing in zaken van overgangsrecht, indien de gelijkenis met zulke gevallen daartoe noopt of indien die toepassing onder de gegeven omstandigheden naar maatstaven van redelijkheid en billijkheid onaanvaardbaar zou zijn.

2. Van de artikelen 69-73a wordt, behalve in de volgende titels, afgeweken op dezelfde gronden als in het vorige lid aangegeven.'

Deze bepaling wordt in artikel 1 lid 2 Ow II van overeenkomstige toepassing verklaard op de wijzigingen in de bestaande wetgeving als gevolg van de invoering van het nieuwe $B W$.

Interessant lijken mij vooral de vragen hoe groot de draagwijdte van artikel 75 Ow I is en wat er voor de opzijgezette overgangsregel in de plaats kan worden gesteld.

Wat de draagwijdte betreft het volgende. De eerste grond voor het doorbreken van de toepasselijkheid van het nieuwe BW is, dat de gelijkenis van het aan de orde zijnde geval met wel in de Overgangswet geregelde gevallen, waarvoor het nieuwe $\mathrm{BW}$ niet werkt, daartoe noopt. De toelichting meldt dat op deze grond vooral een beroep zal kunnen worden gedaan,

\section{Zie hierover nr, 4.9 hierna.}

218. Vgl. voorts overgangsbepalingen als die genoend door Polman, Overgangswet, deel 1, p. 63-64. Zie ook De Die, RMTh 1979, p. 269; Polman, diss., p. 149 e.v.; H. Stein, Plaats en tijd, p. 26-29, en preadv., p. 233, die overigens de verwijzingsregel (onmiddellijke werking) van artikel 180 Ow I betreffende opschortingsrechten ten onrechte tot koppelregel bestempelt. Zie over artikel $180 \mathrm{OW}$ I $\mathrm{nr}$. 7.6.6 hierna. 
'indien een geval dat niet in het bijzonder is geregeld, sterk gelijkt op een geval waarvoor een bijzondere regeling is getroffen, welke van de hoofdregel afwijkt."219

De tweede grond is dezelfde als die van de artikelen 6:2 lid 2 en 248 lid 2 BW, namelijk de zogenoemde derogerende werking van de redelijkheid en billijkheid. In de toelichting wordt opgemerkt dat het hier gaat om

"een marginaal criterium om te voorkomen dat al te gemakkelijk op grond van redelijkheid en billijkheid wordt geprocedeerd." 220

Een verschil in formulering tussen de artikelen 6:2 lid 2 en 248 lid 2 BW enerzijds en artikel 75 lid 1 Ow I anderzijds is evenwel, dat in eerstgenoemde bepalingen wordt gezegd dat een regel niet van toepassing is voor zover dat in de gegeven omstandigheden naar maatstaven van redelijkheid en billijkheid onaanvaardbaar zou zijn, terwijl artikel 75 lid 1 Ow I spreekt over indien. Mijns inziens mag aan dit verschil geen betekenis worden toegekend en moet in artikel 75 lid $1 \mathrm{Ow} I$ in plaats van 'indien' worden gelezen 'voor zover'.

Is er voor de redelijkheid en billijkheid eigenlijk wel een rol weggelegd in het overgangsrecht? Men kan immers zeggen dat dit recht met zijn - indirecte - verwijzingsregels

"een hoge abstractiegraad bezit. Het is als het ware een koud recht met een hoog intellectueel gehalte, maar een duidelijke armoede aan gevoel. Kan men in een dergelijk waarde-neutraal verdeelsysteem terecht met normen als redelijkheid en billijkheid?'221

Naar mijn mening wel degelijk. Het zou onwenselijk zijn als men de redelijkheid en billijkheid halt zou laten houden voor de poort van het gebouw dat overgangsrecht heet, juist ook nu zich in dat gebouw zoveel duistere plekken bevinden ${ }^{222}$. Welis-

219. Parl. Gesch. Owergangsrecht, p. 68. Strikt genomen kan het onderhavige gedeelte van artikel 75 Ow I worden gemist; vgl. Van der Beek, Kwartalbericht Neuw BW 1986, p. 81; H. Stein, in: Liber amiconum NBW, p. 164; Brunner, WPNR 6007 (1991), p. 346; enigszins anders Mon. Nieuw BW A-25 (De Vries Lentsch-Kostense), p. 61-62.

220. Parl. Gesch. Overgangsrecht, p. 68. Evenzo het woorlopig verslag van en de memorie wan antwoord aan de Tweede Kamer, t.a.p., p. 68-69. Voor terughoudendheild bij de toepassing van artikell 75 Ow I hebben zich uitgesproken de Commissie Overgangsrecht wan de KNB, Kwartaalbericht Nieuw BW 1985, p. 49; Jansen, Kwartalbericht Nieuw BW 1985, p. 58; H. Stein, in: Liber amicorum NBW, p. 164; Brunner, WPNR 6007 (1991), p. 346-347; Mon. Nieuw BW A-25 (De Vries Lentsch-Kostense), p. 61, 63-64; in andere zin Leijten, NJB 1985, p. 737-738; Hartkamp, in: Liber amicorum NBW, p. 151-155. Zoals uit die tekst blijkt, sta ik niet meer op het standpunt dat artikel 75 Ow I zou moeten worden geschrapt om te woorkomen dat al te gernakkelijk een beroep op de redelijkheid en billijkheid wordt gedaan (vgl. Kwartaalbericht Nieuw BW 1.986, p. 81-82).

221. Aldus inzake het internationaal privaatriecht Van Rijn van Alkemade, in: Liber amicorum NBW, p. 108. Wat Van Rijn van Alkemade in het citaat opmerkt over het internationaal priwaatrecht had even goed over het overgangsrecht gezegd kunnen zijin.

222. Vgl. Hartkamp, in: Liber amicorum NBW, p. 152-153. 
waar is voor het nieuwe BW een uitgebreid arsenaal aan wettelijk vastgelegde overgangsregels voorhanden; er kunnen altijd zulke plekken door de wetgever over het hoofd zijn gezien, zodat hij er geen voorziening voor heeft getroffen. Zo bestaat de mogelijkheid dat de door de hoofdregel van de onmiddellijke werking aangewezen nieuw BW-regel toegepast op een concreet overgangsgeval een onaanvaardbaar resultaat oplevert ${ }^{223}$.

Uit de tekst van artikel 75 lid I Ow I is niet erg gemakkelijk op te maken, hoe ver nu de af wijkingsmogelijkheid op de genoemde twee gronden strekt. Door die formulering van de aanhef zou men kunnen denken dat de in artikel 75 lid 1 Ow I geboden openíngen gelden woor al die gevallen waarin de Overgangswet het nieuxwe BW op enigerler wijze toepasselijk verklaart. Niet alleen dus voor artikel $68 a$ lid 1 Ow I, maar ook woor buiten titel 3 van de Overgangswet geplaatste regels van algemene aard, zoals de artikelen 79-81, 173 en 182 Ow I, ja zelfs voor regels van bijzondere aard, zoals uitgestelde werking (na het uitstel blijft het nieuwe BW immers niet langer 'buiten toepassing'), of voor een overbruggingsregel die de toepasselijkheid van het nieuwe BW mogelijk maakt. Dit alles is afgaand op de toelichting verkeerd gedacht. De wetgever bedoelt in lid 1 slechts afwijking van de in artikel $68 a$ lid 1 Ow I neergelegde hoofdregel van de onmiddellijke werking mogelijk te maken 224 . Deze bedoeling is dan wel tamelijk ongelukkig in de wetstekst tot uitdrukking gebracht. Op grond van zijn tekst lijkt mij toepassing van artikel 75 lid 1 Ow I ook op de hierboven door mij genoemde andere gevallen heel wel verdedigbaar. Aan deze toepassing zou best eens behoefte kunnen blijken te bestaan. Immers, waarom zouden niet door de wetgever geregelde overgangsproblemen of niet door hem voorziene toepassingsresultaten van overgangsregels zich alleen maar kunnen voordoen bij de onmiddellijke werking ex artikel 68 a lid 1 Ow I?

Indien men rechtstreekse toepassing van artikel $75 \mathrm{Ow} \mathbb{I}$ wil beperken tot de door de wetgever bedoelde gevallen, zou analoge toepassing van het artikel buiten deze gevallen een oplossing kunnen zijn. Hartkamp ${ }^{225}$ bepleit deze analoge toepassing. Interessant is hetgeen Reinsma ${ }^{226}$ naar aanleiding van Hartkamps betoog opmerkt. Volgens haar is zeker voor de artikelen 79-81 Ow I iets te zeggen voor analoge toepassing van artikel $75 \mathrm{Ow} \mathrm{I}$ :

'Deze artikelen betreffen een materie die misschien wel slechter te overzien is dan die van de artt. $72-73 \mathrm{a}$ over de verjarings- en vervaltermijnen. Daar staat tegenover dat de wetgever niet voorzien heeft in afwijking van de artt. 79-81 en naar men mag aannemen weloverwogen niet.'

223. Ook woor het internationaal priwatreeht worde dit verdedigd: zo Van Rijn vant Alkemade, in: Liber amicorum NBW, p. 109. Hartkamp, t.a.p., p. 152-153, plaatst zijn stelling dat het overgangsrecht aan het beginsel wan redelijkheid en billijkheid is onderworpen tegen de achtergrond wan degelding wan dit beginsel in het international privanatrecht:

224. Zie Parl. Gesch. Overgangsrecht, p. 68. In Kwartalalbericht Nieuw BW 1986, p. 81-82, dacht ik artikel 75 lid 10 I I op grond van zijn redactie nog een ruimer toepassingsgebied toe.

225. In: Liber aimicorum NBW, p. 153. Zie hierover ook Mon. Nieuw BW A-25 (De Vries Lentsch-Kostense), p. 62-63.

226. Overgangswet, deel 1 , p. 86 . 
Dit laatste neemt niet weg dat als gevolg van de grote omvang en complexiteit van de nieuw BW-overgangsproblematiek ook buiten de door de wetgever aangegeven gevallen wel eens behoefte zou kunnen blijken te bestaan aan het 'vangnet' van artikel 75 Ow I.

Zou men het toepassingsgebied van artikel 75 lid 1 Ow I beperkt willen houden tot de door de wetgever bedoelde omvang, dan zou (overeenkomstige) toepassing van de artikelen $6: 2$ lid 2 en 248 lid 2 BW uitkomst kunnen bieden. Dit laatste is geen probleem voor wie met Harkkamp ${ }^{227}$ aanneemt dat de redelijkheid en billijkheid alle vermogensrechtelijke rechtsbetrekkingen mede beheersen. Ik merk op dat artikel 75 OW I gezien het zojuist gezegde in wezen overbodig is: het nieuwe BW zelf biedt al de mogelijkheid om een bepaling daaruit (en uit de Overgangswet) in een concreet geval buiten toepassing te laten ${ }^{228}$.

Vervolgens de reikwijdte van lid 2. Hierover kan ik kort zijn. Van welke overgangsbepalingen afwijking mogelijk is wordt er in aangegeven, namelijk van de artikelen 69-73a Ow I. Overigens zal er hier niet altijd behoefte aan bestaan. lk denk dan vooral aan artikel $71 \mathrm{Ow}$ I, waarin al een ontsnappingsmogelijkheid is ingebouwd ${ }^{229}$. De gronden waarop kan worden afgeweken zijn dezelfde als in lid 1 van artikel 75 OW I. Voorts wordt in de tussenzin van lid 2 nog aangekondigd dat ook in de bijzondere overgangsregels afwijkingen van de zoẻven genoemde algemene regels te vinden zijn.

Opmerkelijk is dat in artikel 75 Ow I niet de mogelijkheid wordt geopend om af te wijken van de toepasselijkheid van oud recht op overgangsgevallen. De PvdAfractie in de Tweede Kamer heeft in het voorlopig verslag het oordeel gevraagd van de minister over een daartoe strekkend voorstel van $\mathrm{H}$. Stein ${ }^{230}$. De minister heeft daarop geantwoord dat aan het mogelijk maken van afwijking van het eigenlijk toepassselijke oude recht 'minder behoefte' bestaat:

'De gelding van het nieuwe recht berust in het ontwerp op een algemene regel, waarvan de consequenties in alle bijzonderheden buitengewoon moeilijk zijin te overzien. De toepasselijkheid van het oude recht daarentegen berust op een welbewuste keuze binnen een beperkt gebied, waarvan de gevolgen duidelijker zijn.'231

Ik ben er niet zo zeker van dat het optimisme van de minister gerechtvaardigd is. Het was veiligheidshalve beter geweest om de deur ook voor afwijking van het eigenlijk toepasselijke oude recht op een kier te zetten. Thans zal men $z 0^{\prime \prime} n$ afwijking

227. Asser-Hartkamp II, nrs. 304-305; Hartkamp. AA 1991, p. 1112-1113, rede, p. 25, en, voor het overgangsrecht, in: Líber anicorum NBW, p. 153, alwaar hij opmerkt dat ook de overgangsregel, en zeker de daardoor aangewezen toepasselijke regels, regels zijn die in de zin wan de artikelen $6: 2$ lid 2 en 248 lid 2 BW tussen partijen gelden.

228. Onder meer om deze reden bepleitte ik in Kwartaalbericht Nieuw BW 1986, p. 82 schrapping van artikel 75 Ow I.

229. Verder gaat Brunner, WPNR $6007(1991) ;$ p. 346 .

230. Zie respectievelijk Parl. Gesch. Overgangsrecht, p. 68 en H. Stein, preadw, p. 264; in dezelfde zin: [B]ders, in: Verslag NJV-vergadering, p. 31.

231. Parll. Gesch. Overgangsrecht; p. 69. 
moeten zien te baseren op (de onmiddellijk werkende) artikelen 6:2 lid 2 en 248 lid $2 \mathrm{BW}$. Misschien zou deze weg moeten worden bewandeld in een geval als dat opgevoerd door Spier en Sterk ${ }^{232}$ van de concubine wier partner vóór het tijdstip van de inwerkingtreding is overleden en die vanaf dat tijdstip geen beroep op artikel 6:108 lid 1 sub c BW kan doen. Ook kan in dit verband worden gedacht aan de grondeigenaar die geen bevoegdheid tot opzegging van de erfpacht kan ontlenen aan de erfpachtsvoorwaarden en evenmin aan de toepasselijke oude wet ${ }^{233}$. Wellicht kan hier ook gebruik worden gemaakt van anticiperende interpretatie ${ }^{234}$.

Ik kom toe aan de tweede hierboven opgeworpen vraag: wat kan er voor de opzijgezette overgangsregel in de plaats worden gesteld? Artikel 75 Ow I zwijgt hierover, evenals de parlementaire geschiedenis. Men zou kunnen zeggen dat alleen het oude recht als plaatsvervanger kan optreden. Artikel $68 a$ lid 2 OW I verordonneert immers toepasselijkheid van het oude recht voor zover en zolang op grond van de overige artikelen van de Overgangswet, waaronder dus ook artikel 75 , de nieuwe wet niet werkt. Brunner ${ }^{235}$ is deze mening toegedaan. Andere oplossingen, zoals terugwerkende kracht, uitgestelde werking of een overbruggingsregel, zouden juist niet het door artikel $68 a$ lid 2 Ow I bevolen "buiten toepassing" blijven van de nieuwe wet tot gevolg hebben, aldus Brunner. In de toelichting op artikel $68 a$ lid 2 Ow ${ }^{236}$ wordt echter aangegeven dat het daarin gaat om gevallen waarin de Overgangswet de werking van 'bepaalde artikelen of artikelleden' wit het nieuwe wetboek (tijdelijk) uitsluit (denk met name aan eerbiediging van het oude recht en aan uitgestelde werking). Gezien deze opmerking neem ik met Hartkamp en Reinsma ${ }^{237}$ aan dat artikel $68 a$ lid 2 Ow I betrekking heeft op gevallen waarin de overgangswetgever een probleem heeft onderkend en opgelost, hetgeen bij de in artikel 75 Ow I bedoelde gevallen juist niet zo is.

Indien de gelijkenis met een wel in de Overgangswet geregeld geval ertoe noopt het nieuwe BW 'buiten toepassing' te laten, ligt het voor de hand aan te sluiten bij de desbetreffende overgangsbepaling; deze behoeft niet eerbiediging in te hou$\operatorname{den}^{238}$.

Indien toepassing van de nieuwe wet onder de gegeven omstandigheden naar maatstaven van redelijkheid en billijkheid onaanvaardbaar zou zijn, is het mijns inziens aangewezen bij het opvullen van het ontstane vacuiim ook met die omstandigheden rekening te houden en te zoeken naar de oplossing die het meest passend is voor het aan de orde zijnde geval. Behalve de weg naar toepassing van oud recht kunnen dan ook andere wegen worden bewandeld. Men kan bij voorbeeld denken aan uitstel van de werking van het nieuwe recht, of aan het beperken van het terugwerkende effect van uitoefening van een bevoegdheid die het nieuwe recht toekent.

232. Preadv, p. 97 onder $7 \mathrm{c}$. Zie ook nr. 6.5.4 hierna.

233. Zile ni. 7.8.2 hierna.

234. Zie daarover nu. 2.6 hierna.

235. WPNR 6007 (1991), p. 346. Zo ook Mon. Nieuw BW A-25 (De Vries Lentsch-Kostense), p. 64.

235. Parl. Gesch. Overgangsrecht, p. 35.

237. Respectievelijk in: Liber amicorum NBW, p. 154; Overgangswet, deel 1, p. 87. Hartkamp voert t.a.p. nog andere argumenten an tegen de opvatting dat in de gevallen waarop artikel $750 \mathrm{~W}$ 1 ziet eerbiediging her enige alternatief is.

238. Aldus ook Hartkamp, in: Liber amicorum NBW, p. 154; Reinsma, Overgangswet, deel 1, p. 87. 
Ook zou een brug kunnen worden geslagen tussen het oude en het nieuwe recht ${ }^{239}$. Onjuist is dan ook hetgeen de Commissie-Van Schendel schrijft:

'Het overgangsrecht bestaat uit een 'binair systeem': er kan slechts een keuze uit twee oplossingen - oud of nieuw - worden gemaakit; voor genuanceerde oplossingen of een meer of minder bestaat geen ruimte. (...) van waarderingen en 'vage normen' heeft men geen last." 240241

Mijn bespreking van de (correctiemogelijkheden ten aanzien van de) overgangsregels voor het nieuwe BW is hiermee tot een einde gekomen. In het navolgende ga ik in op de verhouding tussen overgangsrecht en anticipatie (nr. 2.6) en op de wijze waarop men een probleem van overgangsrecht het best zou kunnen aanpakken (nr. 2.7), waarna de slotparagraaf van dit hoofdstuk volgt (nr. 2.8).

\subsection{DE VERHOUDING TUSSEN OVERGANGSRECHT EN ANTICIPATIE}

Vóór de imwerkingtreding van het nieuwe BW is onder meer in de rechtspraak veelvuldig op dit nieuwe wetboek geanticipeerd. Omdat daardoor oud en nieuw recht reeds vóór de inwerkingtreding van dat laatste op één lijn konden komen te liggen, was dit verschijnsel bij de keuze van het overgangsregime bepaald niet zonder belang. Omgekeerd kon dat overgangsregime een rol spelen bij de beantwoording van de vraag of anticipatie op het nieuwe recht wel op haar plats was. Maar ook na de inwerkingtreding kan er nog anticipatie plaatsvinden. Bij uitgestelde werking en iǹ mindere mate bij eerbiediging van het oude recht is de mogelijkheid aanwezig dat na het van kracht worden van het nieuwe recht nog anticipatie plaatsvindt. De zojuist genoemde aspecten van de verhouding tussen overgangsrecht en anticipatie wil ik hierna belichten. Eerst maak ik enkele voorafgaande opmerkingen.

Anticipatie door de rechter is aanwezig, indien hij

"vooruitlopend op de verwachte invoering van een nieuwe weit in zijn vonnis verwijst naar die nieuwe wet als onderbouwing van zijn beslissing' ${ }^{242}$

239. Zie Hartkamp, in: Liber amicorum NBW, p. 153-155, die nog andere concrete mogelijkheden noemt, alsmede Polak, WPNR 5744 (1985), p. 436, die als éen van de omstandigheden als bedoeld in artikel $750 \mathrm{~W}$ I aanmerkt Brunners 'criterium' inzake het vermijden van vermogensverschuivingen (zie daarvoor Brunners preadv., p. 41); Van Mierlo, preadv., p. 49-50; Reinsma, Overgangswet, deel 1, p. 87-88. Anders Brunner, WPNR 6007 (1991), p. 346-347, Mon. Nieuw BW A-25 (De Vries Lentsch-Kostense), p. 64.

240. Trema special "91-2, p. 53. Even later wordt artikel 75 Ow I zonder toelichting genoend als bepaling die meer complicaties kan geven (dan de artikelen 68a, 69 en 173 Ow I).

241. Zie voor enkele gevallen warin toepassing wan artikel $75 \mathrm{Ow} I$ is bepleit: Barendrecht, in: BW-krant jaarboek 1991, p. 116; Van Mierllo, preadw., p. 47; Polak, preadv., p. 65; Tekstra, preadv, p. 105, 107; Mon. Nieuw BW B-78 (Blomkwist), p. 81-82; De Vries Lentsch-Kostense, in: Quod licet, p. 478.

242. Aldus Van Maanen, Kwartaalbericht Nieuw BW 1990, p. 69. Vgll ook Van Driel en Wan Maanen, Kwärtaalbericht Nieuw BW 1985, p. 110; Mon. Nieuw BW A-23 (Van Buchem), p. 1; Verheij, RegelMaat 1986, p. 149. 
Ook na de invoering is anticipatie denkbaar, namelijk indien de nieuwe wet (nog) niet toepasselijk is op het aan de orde zijnde geval. In wezen is bij anticipatie sprake van een beroep op ongeschreven recht. De beslissing van de rechter kan niet worden gegrond op de nieuwe wet zelf. Deze is immers hetzij nog niet in werking getreden; hetzij (nog) niet toepasselijk ${ }^{243}$. Afhankelijk van de mate waarin de rechter een beroep doet op een nieuwe wet ter legitimering van zijn beslissing, groeien oude en nieuwe wet geheel of gedeeltelijk naar elkaar toe. Hierna heb ik het over 'legitimerende anticipatie' in gevallen waarin oud en nieuw recht niet op hetzelfde neerkomen; de fase van de 'heuristische anticipatie' laat ik buiten beschouwing ${ }^{244}$. Dit laatste geldt ook voor de puur terminologische anticipatie en voor de 'consoliderende anticipatie', die zich voordoet bij het vooruitlopen op een nieuwe wetsbepaling die weergeeft wat onder het nog van kracht zijnde recht reeds geld $t^{245}$. Ik wil trachten de volgende vragen te beantwoorden, waarbij ik mij beperk tot anticipatie op het nieuwe BW door de Hoge Raad en waarbij ik voorts overbruggingsregels buiten beschouwing laat:

- welke betekenis heeft (afwijzing van) anticipatie voor de keus van de overgangsregel door de wetgever?

- in hoeverre zijn overgangsregels van belang voor (afwijzing van) anticipatie vór de inwerkingtreding?

- in hoeverre zijn overgangsregels van belang voor (afwijzing van) anticipatie na de inwerkingtreding?

Wat de tweede en derde vraag betreft nog deze opmerking vooraf: niet alleen een overgangsregel kan van belang zijn voor (afwijzing van) anticipatie, ook andere factoren kunnen daarop uiteraard invloed hebben ${ }^{246}$.

lets geheel anders is anticipatie op overgangsrecht. Ook dat komt voor: de Hoge Raad heeft tot twee keer toe geanticipeerd op artikel 74 lid 4 Ow I inzake lopende procedures ${ }^{247}$. Ik laat dit punt verder liggen.

\subsection{De betekenis van (afwijzing van) anticipatie woor de kets van de overgangsregel door de wetgever}

Wordt vó́r de inwerkingtreding door de rechter vooruitgelopen op het nieuwe recht, dan zal eerbiediging van het oude recht als overgangsregel niet spoedig in aanmerking komen. Enigerlei werking van het nieuwe recht ligt voor de hand. Afhankelijk van het geval zijn onmiddellijke werking en uitgestelde werking mogelijk, evenals wellicht bij wijze van uitzondering terugwerkende kracht. Toch komt eerbiediging van oud recht ondanks voorafgaande anticipatie voor. Het volgende voorbeeld kan dat illustreren; vanwege zijn belang werk ik het iets uit. Het voor-

243. Zie Verheij, RegelMaat 1986, p. 149 .

244. Zie over dit onderscheid Van Driel en Van Maanen, Kwartaalbericht Nietw BW 1985, p. H10; Mon. Nieuw BW A-23 (Van Buchem), p. $15-17$; Van Maanen, Kwartaalbericht Nieuw BW 1990, p. 69-70.

245. Zie Mon. Nieuw BW A-23 (Van Buchem), p. 18-2I, respectievelijk p. $21-22$.

246. Zie daarover Mon. Nieuw BW A-23 (Van Buchem), p. $41-53$.

247. HR 14 december 1990, NJ 1992, 20; IRR 8 februari 1991, NJ 1992, 21. 
beeld betreft de materie van de onvoorziene omstandigheden. De Hoge Raad is vooruitgelopen op de regeling terzake in artikel 6:258 BW. De Hoge Raad zelf heeft daaromtrent overwogen:

'Daarnaast (naast de artikelen 6:259 en $260 \mathrm{BW}$, HvdB) staat nog de regeling omtrent onvoorziene omstandigheden (art. 6:258), waarop in het kader van art. 1374 BW reeds is geanticipeerd (HR 27 april 1984, NJ 1984, 679 (NVBHelder, $\mathbf{H v d B}))$. 248

Volgens Hartkamp ${ }^{249}$ is op grond van genoemde arresten van de Hoge Raad uit 1984 en 1987 de conclusie gerechtvaardigd, dat artikel 6:258 BW in beginsel ook het voorheen geldende recht weergeeft. Daaraan staat naar zijn mening niet in de weg, dat het nieuwe wetboek aan de materieelrechtelijke regel nog enige bepalingen van processuele aard toevoegt. Uitgaande van dit standpunt verwacht men wellicht, dat de Overgangswet hier onmiddellijke werking voorschrijt: voor zover oud en nieuw recht in de pas lopen, zal er wel geen reden zijn voor een andere verwijzingsregel. Bevreemdend is dan de mede op artikel 6:258 BW betrekking hebbende overgangsregel van artikel $195 \mathrm{Ow}$ I, luidend:

'In geval van een vordering tot wijziging of ontbinding van een overeenkomst als bedoeld in de artikelen 258 en 259 van Boek 6 houdt de rechter bij de toepassing van die artikelen geen rekening met een wijziging in de omstandigheden die zieh vóor het in werking treden van de wet heeft voorgedaan."

Voor erfdienstbaarheden, erfpacht en opstal zijn in de Overgangswet vergelijkbare bepalingen opgenomen (respeetievelijk artikelen 165,169 en 171$)^{250}$.

Wellicht ten overvloede wijs ik erop dat het arrest inzake NVB-Helder vóor de indiening van het voorstel voor de Aanvulling van de Overgangswet werd gewezen. Terecht wordt dan ook in het voorlopig verslag van de Eerste Kamer ${ }^{251}$ stilgestaan bij bovengenoemde overgangsbepalingen. In het verslag wordt gezegd dat anticipatie bij bovengenoemde zakelijke rechten niet onwaarschijnlijk zou zijn geweest, indien de kwestie aan de rechter zou zijn voorgelegd. Gevraagd wordt of, gezien de anticipatie op artikel 6:258 $\mathrm{BW}$, in ieder geval artikel 195 en wellicht ook de artikelen 165, 169 en 171 Ow I mensen niet op het verkeerde been kan plaatsen. Het

248. HR 8 juli 1991, NJ 1991,691 (Kunst-en Antiekstudio Lelystad), ro. 3.4; zie voorts onder meer HR 16 december 1977. NJ 1978, 156 (Ziekenfonds); HR 12 juni 1987, NJ 1988, 150 (Kriek-Smit).

249. Asser-Hartkamp I, nr. 332; vgl ook Mon. Nieuw BW A-23 (Van Buchem), p. 35-36.

250. H. Stein, preadw, p. 86, oordeelt (reeds in 1985):

'art. $195 \mathrm{OV}$, behoor te vervallen, evenals in zijn yoetspoor artt. $165 \mathrm{en} 1690 \mathrm{~V}$. Er walt geen zimnig woord voor te zeggen.'

Vgl. ook Mon. Nieuw BW B-28 (De Jong), p. 79; alwaar wordt bepleit; voor de vordering tot opheffing dezelfde regels te laten gelden als woot de vordering tot wijziging (opheffing is volgens de in de tekst genoemde overgangsbepalingen in het geheel niet mogelijk, terwijl bij een vordering tot wijziging de rechter geen rekening houdt met omstandigheden die dateren van voór de inwerkingtreding):

251. Parl Gesch. Overgangsrecht, p. 173. 
antwoord van de minister ${ }^{252}$ komt niet erg overtuigend voor. $\mathrm{Na}$ een opmerking over wat in het overgangsrecht in het algemeen geldt voor de rechtsgevolgen van anterieure feiten en een weergave van het gekozen overgangsregime zegt hij:

'Dat het oude recht zich in de richting van het nieuwe beweegt, is daarbij (bij] het gekozen owergangsregime, HvdB) geen bezwaar, doch maakt de overgang des te gemakkelijker. ${ }^{253}$

De artikelen 165, 169,171 en 195 Ow I worden pas begrijpelijk tegen de achtergrond van het volgende. Bij de voorbereiding van de Overgangswet heeft de geraadpleegde Vereniging van Nederlandse Gemeenten bezwaar geuit tegen onverkorte toepasselijkheid van artikel 5:97 BW op lopende erfpachtsrechten. Daarom is ervoor geopteerd deze bepaling niet toepasselijk te laten zijn in geval van anterieure wijzigingen in de omstandigheden. Ter wille van de congruentie van de overgangsbepalingen inzake imprévision is ook op andere terreinen hiervoor geko$\mathrm{zen}^{254}$.

De onderhavige eerbiediging is naar mijn mening van geringe betekenis. Weliswaar verbiedt de Overgangswet rekening te houden met anterieure omstandligheden bij de toepassing van de nieuwe imprévisionbepalingen, gegeven de anticipatie door de Hoge Raad op artikel 6:258 BW zullen anterieure wijzigingen in de omstandigheden bij overeenkomsten kunnen leiden tot toepassing van artikel 6:248 lid 2 BW (derogerende werking van de redelijkheid en billijkheid) ${ }^{255}$.

Uiteraard is de Hoge Raad niet altijd bereid zich tot anticipatie te laten verleiden. Bij afwijzing van anticipatie vóor de invoering zal men moeten zien naar de daaraan ten grondslag liggende redengeving (indien deze uit de uitspraak blijkt of daaruit kan worden afgeleid) als het erom gaat of deze afwijzing van invloed kan zijn op de keuze van de verwijzingsregel. Ik geef een voorbeeld. In zijn arrest inzake CBI-IFN ${ }^{256}$ wees de Hoge Raad anticiperende toepassing van artikel 6:130 BW af, omdat deze bepaling een bewuste uitbreiding vormt van de compensatiemogelijkheden van het oude recht zoals dat door rechtspraktijk en schrijvers placht te worden verstaan. Met de afwijzing van anticipatie op deze grond strookt de eerbiediging van het oude recht op grond van artikel 184 Ow I voor onder meer het geval

252. Parl Gesch. Overgangsrecht, p. 173-174. Vgl, ook De Die, AA 1991, p. 828-829.

253. Zie daartegenover het volgende citaat uit TK, vergaderjaar 1988-1989, 18998, ar. 8 (nota maar aanleiding van thet eindverslag), p. 2 :

'Nieuwe regels, in de Boeken 3, 5 en 6 vervat, zijn dikwijls aan de jurisprudentie onder het oude recht ontleemd, of, omgekeerd, al dan niet door anticipatie, daarin inmiddels opgenomen. Zo bezigt HR 27 apr. 1984, NJ 1984, 679 bij de beoordeling van een beroep op onvoorziene omstandigheden tot verkrijging van wijziging wan een overeenkomst cen formulering die kemelijk aan artikel 6.5.3.11 (6:258) is ontleend."

254. Aldius het antwoord van de ontwerper van het overgangsrecht, De Die, op een vraag terzake van R.S. Meijer, door deze laatste met toestemming van De Die geciteerd op de op 10 oktober 1991 te 's-Gravenhage gehouden jaarvergadering van de Vereniging voor Burgerlijk Recht (Meijer oefent in zijn preadv, p, 26-27. kritiek uit op de eerbiediging ter zake van anterieure omstandigheden in de imprevision-bepalingem in de Overgangswet).

255. Hartkamp, rede, p. 9-10, acht artikel 195 Ow I zelfs 'in wezen een dode letter'.

256. HR 19 oktober 1984, NJ 1985, 213. 
dat een vordering vóór de inwerkingtreding op een ander was overgegaan. De overgangswetgever wil daardoor 'verrassingen' vermijden ${ }^{257}$.

\subsubsection{De betekenis van overgangsregels woor (afwijzing van) anticipatie vö́r de inwerkingtreding}

Een overgangsregel kan een factor zijn, die meespeelt bij de beslissing om wel of niet te anticiperen. In welke richting deze factor wijst, hangt mijns inziens zowel vóor de inwerkingtreding als daarna af van de inhoud van die overgangsregel en van zijn ratio. Onmiddellijke werking en terugwerkende kracht zijn anticipatiebevorderend, eerbiediging van het oude recht en uitgestelde werking hebben juist een remmend effect. Ik beperk mij verder kortheidshalve tot uitgestelde werking 258 :

Is het juist te zeggen dat uitgestelde werking aan anticipatie in de weg lijkt te $\operatorname{staan}^{259}$ ? Volgens de minister ligt de zaak anders:

"De door Hondius uitgesproken mening gaat in zijn algemeenheid te ver. Wel kan het toekennen van uitgestelde werking een indicatie zijn van factoren die meebrengen dat anticipatie niet op zijin plaats is, maar het enkele feit dat voor uitgestelde werking is gekozen is daarvoor niet voldoende.'

Indien uitgestelde werking wordt voorgesteld, omdat geen aanleiding bestaat voor de veronderstelling dat bestaand en nieuw recht een gelijke inhoud hebben,

behoeft dit voorstel niet te verhinderen dat jurisprudentie en litteratuur alsnog naar het nieuwe recht toebuigen. Bezwaren uit een oogpunt van overgangsrecht bestaan daartegen in elk geval niet. Men kan hoogstens zeggen dat de overgangsbepaling, als het oude recht geheel aan het nieuwe gelijk wordt, haar zin verliest en, indien de stand van de parlementaire behandeling dit nog toe laat, beter ingetrokken kan worden, al doet zij geen kwaad. ${ }^{260} 261$

Men zal bij uitgestelde werking naar haar ratio moeten zien als het erom gaat of geanticipeerd zal worden of niet. Behalve de door de minister genoemde reden kan aan uitgestelde werking de gedachte ten grondslag liggen dat het nieuwe recht betrekking heeft op kortlopende verhoudingen. Liever dan partijen bij kortlopende overeenkomsten te confronteren met een wisseling van rechtsregels kan de wetge-

257. In de toelichting (Parl, Gesch, Overgangsrecht, p. 163) wordt overigens niet met zoveel woorden gezegd dat bij de keus voor eerbiediging het onderhavige arrest een rol heeft gespeetd.

258. Zie ower eerbiediging in dit verband Mon. Nieuw BW A-23 (Van Buchem); p. 54.

259. Vg1. Hondius, Kwartaalbericht Nieuw BW 1986, p. 97; Mon. Nieuw BW A-23 (Van Buchem), p. 5354; Abas, WPNR 5970 (1990), p. 495; Sallomons, VA 1990, p. 125, 131; anders HJS in zijn noot sub 1 onder HR 23 maart 1990, NJ 1991, 214 (Botman-Van Haaster).

260. Parl. Gesch: Overgangsrecht, p. 28.

261. Volgens Hartkamp, rede, p. 8-9, is het aan de rechter overgelaten om te beslissen of het oude rechit afwijkt van het nieuwe; cle Overgangswet en de wetsgeschiedenis wan de nieuwe materielle wetsbepalling staan hieraan naar zijn mening niet in de weg. 
ver hen door het gunnen van een "terme de grâce" de kans geven hun overeenkomsten nog onder de werking van het oude recht af te wikkelen ${ }^{262}$. Alsdan lijkt anticipatie mij minder spoedig in aanmerking te komen. Dit kan echter anders zijn als de ratio van uitgestelde werking is, justitiabelen de gelegenheid te geven zich op het nieuwe recht in te stellem. Een goed woorbeeld hierwan levert artikel 191 lid $1 \mathrm{Ow}$ I: bovenop het uitstel van de inwerkingtreding van het nieuwe vermogensrecht met twee jaar ${ }^{263}$ gellt voor ten tijde varn de inwerkingtreding reeds in overeenkomsten gebruikte algemene voorwaarden nog een moratorium van een jaar, dus tot 1 januari 1993. De gebruikers van die algemene voorwaarden krijgen aldus de gelegenheid deze aan de nieuwe regels an te passen ${ }^{264}$. Toch is door de Hoge Raad, nog vórdat artikel 191 Ow I door het parlement was aranvard, vooruitgelopen op afdeling $6.5 .3 \mathrm{BW}$. de mogelijkheid bestaat dat een beding in algemene voorwaarden als onredelijk bezwarend moet worden aangemerkt (zie artikel $6: 233$ sub a BW); is dat $z o$ dan is een beroep op het beding in strijd met de goede trouw ${ }^{265}$. De Hoge Raad wees echter anticipatie op artikel 6:240 BW (collectieve actie) af ${ }^{266}$.

In het voorlopig verslag van de Eerste Kamer is gevraagd hoe reeel de uitgestelde werking van afdeling $6.5 .3 \mathrm{BW}$ met een jaar is tegen het licht van het arrest in. zake Van der Meer-Gemeente Smilde ${ }^{267}$. De minister heeft hierop geantwoord dat toetsing op de wijze van het oude recht gedurende het 'uitsteljaar' mogelijk in een concreet geval lleidt tot een resultaat, vergelijkbaar met dat bij toetsing conform afdeling 6.5.3 BW, maar dat dit geenszins steeds kan worden gezegd, waarbij hij verwijst naar het arrest inzake Hooijen-De Tilburgsche Hypotheekbank. Zijns inziens zet artikel 191 lid 1 Ow I mensen niet 'op het verkeerde been' 268 . Naar mijn mening schat de minister de mate warin anticipatie op afdeling $6.5 .3 \mathrm{BW}$ heeft plaatsgevonden te gering.

Naderhand heeft de Hoge Raad een uitspraak ${ }^{269}$ gedaan, warin zelfs 'turbo-anticipatie' $^{270}$ op afdeling 6.5 .3 (en de artikelen $6: 258-260$ ) BW lijkt plaats te vinden. De uitspraak betreft een wordering van een gemeente tegen een grondgebruiker tot. nakoming van een beding in een koopovereenkomst. De grondgebruiker doet ter af-

262. Zie aldus bj koop de hoofdregel van artikel 196 lid 10 W 1, warover Parl. Gesch. Overgangsreeht, p. $178,179.180$

263. 2tie hierower onder meer"TK, vergaderjar 1988-1989, 18998, nr. 5 (memorie van antwoord), p. 3; Parl. Gesch, Overgungstecht, $1,168,169$. Her uitstel van inwerkingtreding met twee jaar heeft ertoe geleid dat de termijn van uitgestelde werking in onder meer artikel 191 ow I is tenuggebracht van drie tot eén jaar.

264. Zie Parl, Geseh. Overgangsrecht, $p, 167,168,169,170$.

265. Zit voor anticipatie op de inhoudstoetsing ex afdeling 6.5.3 BW en op de constructie van de daarin voorkomende lijgtan onder mer: HR 25 april 1986, NJ 1986, 714, Kwartaabericht Nieuw BW 1986, p.92

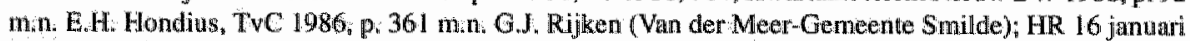
1987, NJ 1987, 553, Kwartadlbericht Nieuw BW 1987, p. 63 m.n. B.H. Hondias, TvC 1987, p. 263 m.n. G.J. Rijken (Hoojen-De Titburgsche Hypotheekbank); HR 23 maart 1990, NJ 1991.214 (Botman-Van Haaster), watrover Rijken, Bb $1991, \mathrm{p}: 96$.

266. Ziv HR 25 april 1986, NJ 1987,742 (Conswmentenbond-Geneente Smilde).

267. Zie Pur. Geseh. Overgangsrecht, p. 170.

268. 2ie Pal. Gesch, Overgangsrecht, p. 170; zie ook p. 169-170 (memorie van antwoord en nota naar aanleiding wan het eindwerslag wande Tweede Kamer).

269. IR 8 juli 1991, NJ 1991, 691 (Kunst- en antiekstudio Lelystud).

270. Aldus Kortmann in zijn noot in A A 1991, p. 1136-1137. 
wering wan deze vordering een beroep op ongeldigheid van het beding. De Hoge Raad overweegt:

"Maakt het beding omtrent grondgebruik deel uit van algemene voorwaarden, hetgeen veelal het geval zal zijn, dan is ook de regeling van afdeling 6.5.3 NBW daarop van toepassing.

Daarnaast kan worden gewezen op de op dit soort bedingen als regel toe-

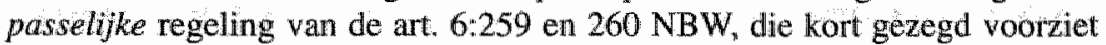
in de mogelijkheid van wijziging of ontbinding van de overeenkomst. Daarnaast staat nog de regeling omtrent onvoorziene omstandigheden (art. 6:258), waarop in het kader van art. $1374 \mathrm{BW}$ reeds is geanticipeerd (HR 27 april 1984, NJ 1984, 679 (NVB-Helder; mijn cursiveringen, HvdB))."

Omdat ten tijde van het wijzen van dit arrest het nieuwe BW nog helemaal niet in werking was getreden, kan er uiteraard geen sprake van zijn dat toen al delen uit het nieuwe BW 'van toepassing' of 'toepasselijk' (hier kennelijk synoniem aan 'van toepassing') waren. Ook valt op dat de Hoge Raad met geen woord rept over het overgangsrecht inzake de aangehaalde regelingen uit het nieuwe BW. $1 \mathrm{k}$ veronderstel dat de Hoge Raad in het onderhavige obiter dictum heeft willen aangeven hoe de toetsing dient plaats te vinden van de inhoud van een beding als hier aan de orde is. Dat is dan wel op onzorgvuldige wijze geschied: men moet maar gissen of de Hoge Raad alleen het oog heeft gehad op situaties die in hun geheel na de invoering van het nieuwe BW spelen of ook op situaties die (zoals in casu) juist in . hun geheel woór de invoering spelen en overgangssituaties. Dit laatste valt niet aan te nemen, omdlat daarmee impliciet de artikelen 191 en 195 Ow I zouden zijn opzijgezet ${ }^{271}$.

Tijdens het op grond van artikel 191 lid 1 Ow I geldende tuitsteljaar' is geen plaats meer voor de goede trouw-toetsing uit het oude recht. Deze is immers vervangen door de toetsing aan de redelijkheid en billijkheild op grond van de onmiddellijk werkende artikelen $6: 2$ lid 2 en 248 lid 2 BW. Wel is het zo dat dit praktisch gesproken geen verschil zal maken ${ }^{272}$. Via bedoelde toetsing kan worden vooruitgelopen op artikel 6:233 sub a BW273.

Met het voorbeeld van de algemene voorwaarden zal duidelijk zijn geworden dat anticipatie niet is uitgesloten, indien is voorzien in uitgestelde werking om justitiabelen de gelegenheid te geven zich in te stellen op het nieuwe recht. Bij de algemene voorwaarden heeft dit geleid tot gedeeltelijke overbodigheid van de desbetreffende overgangsregel ${ }^{274}$. 


\subsubsection{De betekenis van overgangsregels voor (afwijzing van) anticipatie na de inwerkingtreding}

Anticipatie op het nieuwe vermogensrecht is ook na de inwerkingtreding daarvan nog mogelijk ${ }^{275}$. Men moet naar mijn mening zien naar de inhoud van de overgangsregel en naar zijn ratio, indien het erom gaat of, en zo ja, in hoeverre de overgangsregel een 'remmende factor" is voor een dergelijke anticipatie (zie het vorige nr.). Bij onmiddellijke werking en bij terugwerkende kracht laat anticipatie zich na de inwerkingtreding niet denken: het nieuwe recht is op grond van die verwijzingsregels toepasselijk op gevallen van overgangsrecht. Bij uitgestelde werking en eerbiediging wan het oude recht ligt dit anders. Dan is immers het oude recht nog gedurende bepaalde tijd of zelfs onbeperkt toepasselijk op overlopende rechtsverhoudingen etc.. Denkbaar is dat de rechter bij de toepassing van dat oude recht op het - inmiddels in werking getreden - nieuwe recht 'vooruitloopt'. Houdt de overgangsregel eerbiediging van oud recht in, dan zal dat 'vooruitlopen' minder snel geschieden, bij voorbeeld als de eerbiediging in de Overgangswet is opgenomen in verband met gerechtvaardigde verwachtingen van partijen bij voortzetting van hun rechtsverhouding conform het oude recht. Ook bij uitgestelde werking moet de ratio daarvan in de beoordeling worden betrokken. Gaat het erom 'overstaande' rechtsverhoudingen etc. de kans te geven onder de werking van het oude recht af te lopen, dan komt 'anticipatie' natar mijn mening minder spoedig in aanmerking dan wanneer de uitgestelde werking is bedoeld om de justitiabelen de mogelijkheid te bieden zich op de toepasselijkheid van het nieuwe recht voor te bereiden. Waar de Hoge Raad vór de inwerkingtreding ondanks uitgestelde werking al anticipeerde, zoals op het vlak van de algemene voorwaarden, is het waarschijnlijk dat hij dit nadien tijdens het uitstel voortzet.

Het lijkt mij nuttig om ook iets te zeggen over een dicht naast het voorgaande, maar wel buiten het terrein van het overgangsrecht liggend, geval. De rechter zal ook na het tijdstip van de inwerkingtreding moeten oordelen over zaken die worden beheerst door oud recht, omdat zij zich in hun geheel vóór dat tijdstip afspeelden en het nieuwe recht geen terugwerkende kracht heeft. Kan anticipatie dan? Naar mijn mening wel. Ik geef ter verduidelijking een voorbeeld.

Volgens artikel 661 (oud) BW werd de zaaksvormer eigenaar van hetgeen hij 'van eene niet aan hem toebehoorende stof' had gevormd. Het artikel maakte daarbij geen onderscheid tussen de zaaksvormer die voor zichzelf vormde en degene die dat voor een ander deed. In het arrest inzake Breda-Antonius anticipeerde de Hoge Raad op artikel 5:16 lid 2 BW276. Bij zaaksvorming in opdracht van een ander uit materialen die door die ander aan de zaaksvormer ter beschikking waren gesteld, oordeelde de Hoge Raad voor de vraag wie eigenaar wordt van het gevormde bepalend, wat in het licht van de verkeersopvattingen uit de rechtsverhouding van partijen voortvloeide. Stel dat de Hoge Raad in 1992 of daarna over een geval als het onderhavige (zaaksvorming vóór de inwerkingtreding) had moeten oordelen. Hij

275. Evenzo Hartkamp, rede, p. 8. Niet iedereen is deze mening toegedaan; zie de door Hartkamp in noot 8 geciteerde auteurs.

276. HR 5 aktober 1990, RvdW 1990, 167; vgl. hierbij Asser-Beekhuis I, nr. 80. 
had dan artikel 661 (oud) BW moeten toepassen, omdat artikel 5:16 BW niet terugwerkt: het geldt

'in beginsel slechts voor rechtsfeiten die na de inwerkingtreding worden voltooid'27\%.

Bij de toepassing van artikel 661 (oud) BW had de Hoge Raad kunnen anticiperen op artikel 5:16 lid 2 BW op dezelfde wijze als hij in genoemde uitspraak heeft gedaan.

\subsection{EEN STRATEGIE VOOR DE BEANTWOORDING VAN VRAGEN VAN OVERGANGSRECHT}

Meermalen hebben auteurs de rechtspraktijk een handreiking geboden ten behoeve van de rechtsvinding in zaken van overgangsrecht door daarvoor een werkwijze in een aantal stappen aan te geven. Omdat zo'n handreiking mij tot op zekere hoogte wel nuttig lijkt, zal ik er hierna ook één geven. Daaraan voorafgaand past echter wel een aantal opmerkingen ${ }^{278}$.

Men mag uiteraard niet denken dat hantering van een bepaald procédé bestudering van Overgangswet, parlementaire geschiedenis en literatuur (grotendeels) overbodig maakt. De Overgangswet is opgebouwd op een bepaalde theoretische ondergrond die voor een belangrijk deel nieuw is. Daarom moet men in de eerste plaats trachten zich deze theoretische basis eigen te maken. Het achterwege laten van deze bestudering werkt op zijn minst belemmerend bij de kennisname wan de Overgangswet en de bijbehorende toelichtende stukken; over toepassing heb ik het dan nog niet eens. Vervolgens is het van belang inzicht te hebben in de algemene overgangsbepalingen die zijn opgenomen in titel 3 van de Overgangswet. Hetzelfde geldt voor de elders in de Overgangswet te vinden regels van algemene aard. Bij wijze van voorbeeld noem ik:

- de in artikel $68 a$ lid 1 OW I neergelegde hoofdregel van de onmiddellijke werking (die direct al demonstreert hoe belangrijk het is, weet te hebben van de theoretische uitgangspunten die aan de Overgangswet ten grondslag liggen, zie $\mathrm{nr}$. 2.5.1.1 hiervóór);

- de "eerbiediging van verkregen rechten" ex artikel 69 Ow I (zie onder meer nr. 2.5.1.2 onder e hiervớr);

- de (uiterst gecompliceerde) termijnregels van de artikelen 72-73a Ow I;

- de 'hardheidsclausules' in artikel 75 Ow I (zie nr. 2.5.3 hiervóór);

- de algemene regels met betrekking tot inschrijvingen betreffende registergoederen (artikel 78 Ow I, waarover hoofdstuk 3 hierna);

- de algemene regels inzake de geldigheid van rechtshandelingen (artikelen 79-81 Ow I, waarover hoofdstuk 4 hierna) en

277. Aldus Parl. Gesch. Overgamgsrecht, p. 284.

278. Vgl. ook Parl. Gesch. Overgangsrecht, p. 32-33. 
- de met name voor onrechtmatige daad van belang zijnde regels van artikel 173 Ow 1 (zie hoofdstuk 6 hierna).

Stuk voor stuk zijn de hier bij wijze van woorbeeld genoemde overgangsbepalingen van groot belang voor de rechtspraktijk. Zij zullen dikwijls moeten worden toegepast ${ }_{*}$ zodat men zal moeten trachten er vertrouwd mee te raken. Ditzelfde geldt voor een aantal overgangsregels die een minder breed terrein bestrijken. Als voorbeelden noem ik:

- de voorzieningen ten aanzien van zekerheidseigendom (hier treft men een groot aantal overgangskwesties aan, die lang niet altijd gemakkelijk tot een oplossing te brengen zijn; zie artikel 86 Ow I, waarover hoofdstuk 5 hierna);

- de regel van artikel 182 OW I inzake tekortkomingen in de nakoming van verbintenissen (zie hoofdstuk 7 hiema);

- de regels voor de algemene voorwaarden (artikel 191 Ow $\mathrm{I}$, waarover nrs. 2.6 .2 hiervór en 4.5.6 hierna) en

- de overgangsbepaling in verband met koop en ruil (artikel 196 Ow I, waarover mi. 7.8 .3 hiema),

Een andere prealabele opmerking is nog deze. Men mag niet verwachten dat een werkwijze die wordt gesuggereerd voor de oplossing van overgangsproblemen in het algemeen door iedere rechtstoepasser in elk willekeurig geval zonder meer kan worden gevolgd. Steeds moet men zich rekenschap geven van de bijzondere aard van de aan de orde zijnde casus, die zich door die aard mogelijkerwijs niet (geheel) volgens het voorgestelde procédé laat beoordelen en misschien zelfs zodanig gecompliceerd is dat hij

'slechts na zeer diepgaande studie van de grondslagen van het overgangsrecht (kan) worden opgelost.' 279

Met inachtneming van het voorgaande zou men de volgende strategie kumnen volgen om een antwoord te vinden op de vraag, of het nieuwe recht op enigerlei wijze toepasselijk is op overlopende rechtsverhoudingen, rechtsposities etc.

1. Determineer het aan de orde zijnde geval: levert het een overgangssituatie op of niet? Men dient het begrip 'overgangssituatie' ruimer te nemen dan de overgangswetgever doet. Voorts dient men de relevante bepaling(en) uit het nieuwe BW bij de determinatie te betrekken (zie over een en ander de nrs. 2.4.1.1 e.v. hiervóór). Dient zich een overgangssituatie aan, dan komt men toe aan stap

2. Ga na welke uithomst toepassing van het oude recht op de voorliggende casus zou geven en wat rechtens zou zijn bij toepassing daarop van de bij stap 1 gevonden nieuw BW bepaling(en). Oud en nieuw kunnen met elkaar overeenkomen, naar kunnen ook op diverse manieren van elkaar verschillen; zie daarover nr. 2.4.1.4 hiervóor. Ingeval oud en nieuw recht met elkaar overeenkomen, is er geen reeel probleem van overgangsrecht, maar zal wel een overgangsregel (in de regel onmiddellijke werking) moeten worden toegepast om de temporele werking van het nieu-

279. De formulering is afkomstig wit het voorlopig verslag van de Eerste Kamer, Parl. Gesch. Overgangsrecht, $\mathrm{p}, 29-30$. 
we BW te weten te komen ${ }^{280}$. Ingeval oud en nieuw recht niet met elkaar overeenkomen, is er wel kans op een reëel probleem van overgangsrecht; het behoeft geen betoog dat ook dan het overgangsrecht moet worden ingeschakeld ${ }^{281}$.

3. Beoordeel, uitgaande van het nieuwe of gewijzigde materiële artikel, of eén of meer overgangsbepalingen (algemene of bijzondere) in aanmerking komen voor toepassing en pas de gevonden bepaling(en) toe. Daardoor kont in beginsel (zie stap 4) vast te staan of, en zo ja, in hoeverre het rechtsgevolg van de nieuwe regel daadwerkelijk intreedt. Heeft men te maken met (een) artikel(en) uit het nieuwe BW (inclusief Boek 8), dan zal men moeten zoeken in de Aanvulling van de Overgangswet (OW I); heeft men te maken met (een) nieuwe of gewijzigde bepaling(en) uit andere delen van het BW, of het Wetboek van Koophandel, het Wetboek van Burgerlijke Rechtsvordering, de Faillissementswet e.d., dan zal men moeten zoeken in het tweede stuk van het overgangsrecht (Ow II).

Het zoekproces wordt in de eerste plaats vergemakkelijkt doordat de overgangswetgeving in beginsel de nieuwe of gewijzigde regels op de voet volgt: zo is de Aanvulling van de Overgangswet in hoofdzaak conform de structuur van de Boeken 3 e.v. BW opgebouwd. Voorts wordt in deel III van het deel 'Overgangsrecht' uit de reeks Parlementaire Geschiedenis van het nieuwe BW per nieuwe of gewijzigde materiële bepaling verwezen naar de daarvoor van belang zijnde overgangsbepaling(en). Bij gebreke daarvan zijn de desbetreffende passages uit de toelichtende stukken opgenomen, indien deze bestaan. In andere publicaties kan men iets dergelijks aantreffen, zoals in de uitgave Tekst \& Commentaar.

Het zoekproces wordt evenwel bemoeilijkt doordat in de loop van de parlementaire behandeling van de voorgestelde Aanvulling van de Overgangswet nogal wat wijzigingen, waaronder belangrijke, in het voorstel zijn aangebracht. Daardoor wordt bij voorbeeld in de toelichting verwezen naar artikelen die niet meer bestaan of een andere inhoud hebben gekregen.

4. Bezie of het gevonden resultaat eventueel in aanmerking komt voor correctie op grond van artikel $75 \mathrm{Ow} \mathrm{I}$, al dan niet analoog toegepast, of op grond van (analoge toepassing van) de artikelen $6: 2$ lid 2 en 248 lid 2 BW (zie hierover nr. 2.5 .3 hierwóór ${ }^{282}$.

Bij het voorgaande is het van belang te weten

280: Zie nr 2.4.1.4 hierwór. Anders de Commissie-Wan Schended, Trema special ' $91-2,0.53,55,63$; Hartkamp, rede, $p, 6$.

281. Hartkamp, rede, p. 7, wijst erop dat door woortbouwen van het nieuwe recht op het oude en door anticiperende interpretatie van het oude recht door de rechtspraak "een zodanige verstrengeling tussen oud en nieuw recht (is) ontstaan dat men het ene veelal niet zonder kemis van het andere kan uitleggen em toepassen."

282. Zie over de wijze van oplossing van een overgangsrechtelijk probleem ook: Parl Gesch Overgangsrecht, p. 29-30, 32, Reinsma, Kwartaalbericht Nieu wW 1985; p. 46-47; H, Stein, preadv, p. 71-72; Schepel, in: Verslag NIV-vergadering, p. 14; H. Stein, in: Liber amicorum NBW, p. 157-165; Commissie-Van Schendel, Trema special '91-2, p. 54-55, 63; R.S. Meijer, preadv., p. 9-10; Van Mierlo, preadv., p. 48-49 (inzake "'zakelijke' zekerheidscasus"); Polak, preadv., p. 54-58 (inzake de artikelen 72-73a Ow I); Reinsma, Overgangswet, deel 1, p. 4-5; Mon. Nieuw BW A-25 (De Vries Lentsch-Kostense), p. 41-44; Hartkamp, rede. p. 6-7. 
'dat eerbiediging van oud recht, uitgestelde werking en terugwerkende kracht steeds - behoudens in de uitzonderingsgevallen van artikel 75 - in een uitdrukkelijke toepasselijke wetsbepaling hun steun moeten vinden. ${ }^{283}$

Ditzelfde, zo voeg ik hieraan toe, geldt uiteraard voor "directe" regels als fictie, omzetting en bekrachtiging.

Ik geef een voorbeeld ter illustratie van de zojuist geschetste werkwijze.

A verkocht en leverde in 1991 een partij grondstoffen aan fabrikant B. B droeg de grondstoffen over aan bank $C$ tot zekerheid van de voldoening van zijn schulden aan deze bank. De levering geschiedde door middel van constitutum possessorium. Vervolgens trad het nieuwe BW in werking. Daarna bewerkstelligde $\mathrm{A}$ ontbinding van de koopovereenkomst op grond van een tekortschieten van $B$ in de nakoming van zijn betalingsverplichtingen. $\mathrm{Te}-$ genover elkaar staan $\mathrm{A}$ en $\mathrm{C}$, die beiden pretenderen gerechtigd te zijn tot de (nog niet door B verwerkte) grondstoffen ${ }^{284}$.

1. Deze casus levert in tweeërlei opzicht een overgangssituatie (in ruime zin) op. $\mathrm{Bij}$ de inwerkingtreding was voldaan aan de vereisten die artikel 6:265 $\mathrm{BW}$ stelt voor ontbinding van een wederkerige overeenkomst op grond van een tekortkoming in de nakoming van een verbintenis uit die overeenkomst. Voorts was er bij de inwerkingtreding zekerheidseigendom aanwezig. Deze wordt niet geraakt door het verbod van overdracht tot zekerheid, dat artikel 3:84 lid 3 BW bevat. Een overgangssituatie in de betekenis die dit begrip heeft in het overgangsrecht voor het nieuwe BW was er niet ${ }^{285}$. In nr. 2.4.1.3 hiervóór heb ik een ruimere opvatting inzake het begrip 'overgangssituatie' verdedigd, die aansluiting zoekt bij het door de Overgangswet bestreken terrein. In deze opvatting levert bij de inwerkingtreding bestaande zekerheidseigendom wel een overgangssituatie op.

2. Naar oud recht zou $\mathrm{C}$ als gevolg van de ontbinding van een beschikkingsonbevoegde (B) blijken te hebben verkregen. $\mathrm{C}$ werd niet beschermd tegen deze beschikkingsonbevoegdheid. Naar nieuw recht zou de ontbinding geen consequenties hebben voor C's zekerheidsrecht (stil pandrecht). Bij de ontbinding èn bij C's zekerheidsrecht verschillen oud en nieuw recht zowel ten aanzien van de vereisten als ten aanzien van de rechtsgevolgen (zie nr. 2.4.1.4 hiervóór).

3. Op de ontbinding van de overeenkomst A-B is artikel 182 Ow I van toepassing, op de zekerheidseigendom artikel 86 OW I. C's zekerheidseigendom is, zo zou men kunnen denken, op 1 januari 1992 omgezet in stil pandrecht (artikel 86 lid 5 Ow I laat ik buten beschouwing). Omdat de tekortkoming in de nakoming zich in casu vór de inwerkingtreding voordeed, wordt de ontbinding evenwel beheerst door het oude recht. Men moet ook aan de hand van het oude recht bezien of C achteraf beschouwd - zekerheidseigendom heeft verkregen. Dit is een consequentie van de materieelrechtelijke terugwerkende kracht van de ontbinding en van het feit 
dat $\mathrm{C}$ zijn recht vóór de inwerkingtreding heeft verkregen. Bij toepassing van het oude recht blijkt $\mathrm{C}$ achteraf als gevolg van de ontbinding vóor de inwerkingtreding geen zekerheidseigendom te hebben verkregen. Aan omzetting van zekerheidseigendom blijkt dus achteraf niet te kunnen worden toegekomen. A trekt aan het langste eind.

4. $\mathrm{Er}$ is geen aanleiding voor correctie van het gevonden resultaat op grond van artikel 75 Ow I (analoog) of op grond van de artikelen 6:2 lid 2 en 248 lid 2 BW (analoog).

\subsection{SLoT}

Zoals in dit hoofdstuk wel is gebleken, kan men op zijn reis door het overgangsrecht voor het nieuwe $\mathrm{BW}$ alleen zijn reisdoel bereiken met de nodige theoretische bagage. Voor een deel weegt deze bagage zwaar. Maar wie een concreet reisdoel voor ogen heeft, zal haar misschien wat gemakkelijker kunnen tillen. Daar staat tegenover dat zo'n reisdoel zijn eigen barrières kan hebben. In de navolgende hoofdstukken hoop ik een betrouwbare reisgids te bieden voor een aantal van die concrete bestemmingen. 



\section{Inschrijvingen betreffende registergoederen}

\subsection{INLEIDING}

Voor onroerende zaken en voor rechten daarop is de materie van de inschrijvingen ${ }^{1}$ betreffende registergoederen van eminent belang. Dit geldt ook voor teboekgestelde schepen en teboekgestelde luchtvaartuigen ${ }^{2}$. Wel gaat het bij deze vervoermiddelen, met name bij de laatste, om geringere aantallen: de toelichting op de Invoeringswet: Kadasterwet ${ }^{3}$ noemt een aantal teboekgestelde schepen van 'ongeveer 31873 ' en een aantal teboekgestelde luchtvaartuigen van 'ongeveer $141^{\prime}$. Cijfers met betrekking tot (rechtien op) onroerende zaken worden in genoemde toelichting niet gegeven, maar het lijdt geen twijfel dat het daar om zeer aanzienlijk grotere aantallen gaat. Bij de invoering waren derhalve enorme hoeveelheden inschrijvingen, overschrijvingen en aantekeningen aanwezig in de in artikel $3: 16 \mathrm{BW}$ bedoelde openbare registers voor registergoederen. Ik noem deze hierna ook wel kortweg "de registers".

Met name in Boek $3 \mathrm{BW}$, marr ook wel daarbuiten komen ter zake van inschrijvingen betreffende registergoederen regels voor, die op tal van punten verschillen van het tevoren geldende recht. Afdeling 3.1.2 BW bevat een algemene, geheel nieuwe, regeling van inschrijvingen betreffende registergoederen. Zo'n algemene regeling bestond voorheen niet. Van de regels buiten Boek $3 \mathrm{BW}$ noem ik artikel $6: 252 \mathrm{BW}$ inzake kwalitatieve verplichtingen, waarbij inschrijwing in de registers vereist is voor automatische derdenwerking.

Veranderingen als deze moesten wel leiden tot ingrijpen van de overgangswetgever. Hierna ga ik in op de belangrijkste voorzieningen die hij heeft getroffen. Daarbij laat ik om te grote uitwoerigheid te vermijden teboekgestelde schepen en luchtvaartuigen buiten beschouwing. Om dezelfde reden verwijs ik slechts hier en daar naar (het overgangsrecht inzake) de Kadiasterwet.

1. De inschijjwing geschedt door het in bewaring nemen van het afschrift van het ter Insehrijwing anangeboden stuk, bedoeld in artikel 11 lid 1 , aldus artikel 12 lid 1 vatn de Kadasterwet (zie echterook artikel 12 lid 4). De Kadasterwet is de Wet van 3 mei 1989, Stbl. 186, houdende regelen met betrekking tot de openbare registers voor registergoederen, alsmede met betrekking tot het kadaster. De lekst van de Kadasterwet zoals deze luidt met ingang van 1 januari 1992 is in het Staatsbllad geplaatst als bijlage bij de beschikking yan de Minister van Justitie van 14 november 1991, Stb]. 570 .

2. Zie voor een omschrijving van het begrip "registergoederen" artikel 3:10 BW. Onroerende zaken, teboekgestelde schepen en luchtvaartuigen, alsmede aandelen in en beperkte rechten opgenoemde zaken zijn registergoederen in de zin van genoemdle bepaling.

3. TK, vergaderjaar 1990-1991,21830, nr. 3, p. 18.

4. Het overgangsrecht inzake de Kadasterwet is te vinden in de Invoeringswet Kadasterwet. Dit is de Wet varn 6 juni 1991, Stbl. 376, tot wijziging van de Kadasterwet en van enige andere wetten en tegeling wan het overgangsrecht in werband met de inwerkingtreding van de Kadasterwet. 
Nu in hel overgangsrecht de werking van de nieuwe regels voor de bestaande toestand centraal staat, gebruik ik in het navolgende de terminologie van het nieuwe BW.

\subsection{ONTSTAAN VAN OVERGANGSKWESTIES BU INSCHRIJUINGEN BETREFFENDE REGISTERGOEDEREN}

Van de talrijke vernieuwingen die het nieuwe vermogensrecht bevat ten aanzien van inschrijwingen betreffende registergoederen noem ik er hierna enkele. $O p$ een aantal van die vernieuwingen kom ik hierna bij de diverse overgangskwesties nog terug. Voor het overige verwijs ik naar literatuur terzake ${ }^{5}$.

Artikel 3:17 lid $1 \mathrm{BW}$ geeft een opsomming van feiten die in de registers kunnen worden ingeschreven. Te zamen met andere wettelijke bepalingen geeft het artikel een limitatieve opsomming. Deze ontbrak in het oude recht.

Ook nieuw is dat de bewaarder der registers verplicht is een volgens de opsomming inschrijfbaar feit in te schrijven en inschrijving van andere feiten te weigeren (vgl artikel $3: 20 \mathrm{BW}$ ).

Artikel $3: 21 \mathrm{BW}$ regelt de rangorde van meerdere inschrijvingen die op eenzelfde registergoed betrekking hebben. Het verschilt van het voorheen geldende recht, met name waar het gaat om meerdere hypothecaire inschrijwingen ten aanzien van hetzelfde registergoed op eén dag.

Artikel $3: 23 \mathrm{BW}$ geeft een regel omtrent de vraag, wanneer ten aanzien van inschrijfbare feiten sprake is van de goede trouw die vereist is voor de toepassing van met name de artikelen $3: 88$ en $99 \mathrm{BW}$ :

'Artikel 3.1.2.6 (3:23) bevat een regel die nader bepaalt wanneer een verkrijger van een registergoed 'te goeder trouw' is in de zin van de bepalingen waarin aan zijn goede trouw bepaalde rechtsgevolgen worden verbonden, in het bijzonder art. $3.4 .2 .3 \mathrm{~b}(3: 88)$ (bescherming tegen titel of leveringsgebreken in de verkrijging van een rechtsvoorganger) en art. 3.4.3.1 (3:99) (verkrijgende verjaring)."6

Het oude recht kende niet een regel als die wan artikel $3: 23 \mathrm{BW}$. In de artikelen 3:24-26 BW zijn uitbreidingen van derdenbescherming neergelegd.

Nogal afwijkend van wat voorheen gold is ook de nieuwe regelling van de doorhaling van inschrijvingen in de artikelen $3: 28,29$ en $274 \mathrm{BW}$.

De artikelen 1266-1268 (oud) $\mathrm{BW}$ bevatten regels omtrent de verplichtingen en de aansprakelijkheid van de hypotheekbewaarder voor door zijn fouten ontstane schade. Ingevolge artikel 4 van de thans vervallen Wet kadastraal recht rustte genoemde aansprakelijkheid niet meer op de hypotheekbewaarder, maar op de Staat. In het nieuwe $\mathrm{BW}$ is deze aansprakelijkheid neergelegd in artikel 3:30. Vergeleken

5 Zie bij woorbeeld Asser-Beekhuis I, hoofdstuk VIII; De Jong, diss.; Konings, diss.; Snjgers, AA 1991, p. 1089-1091.; Vail Siraaten, Kadaster, met name hoofdstukken III en IV.

6. Aldus Parl. Gesch. Inw. Boek 3, p 1095. 
met het oude recht is de onderhavige aansprakelijkheid van de Staat verruimd ${ }^{7}$. Een terminologisch verschil tussen oud en nieuw recht is dat de term 'overschrijving' is verdwenen: thans wordt steeds van 'inschrijving' gesproken.

Vragen van overgangsrecht zijn ter zake van inschrijvingen betreffende registergoederen onvermijdelijk. Immers, niet alleen geven oud en nieuw recht verschillen te zien, ook bevarten de registers bij de invoering enorme aantallen in- en overschrijvingen en aantekeningen. Worden daaraan de rechtsgevolgen van de nieuwe regels verbonden, en behoren die rechtsgevolgen daaraan te worden verbonden?

Teneinde hierover duidelijkheid te verkrijgen, ga ik als volgt te werk. Eerst bezie ik wat onmiddellijke werking zoal voor gevolgen zou kunnen teweegbrengen ( $\mathrm{nr}$. 3.3). Vervolgens geef ik aan wat de Overgangswet in hoofdzaak voor oplossingen aandraagt voor de diverse problemen (nr. 3.4). Deze werk ik daarna uit in de nrs. 3.5-3.7 voor zover het gaat om vragen van algemene aard. In nr. 3.8 besteed ik aandacht aan enkele meer specifieke kwesties, zoals de betekenis van anterieure inschrijving van bedingen, die voldoen aan de vereisten die artikel 6:252 BW (kwalitatieve verbintenissen) stelt voor werking jegens derden.

\subsection{CONSEQUENTIES VAN ONMIDDELLIJKE WERKING VAN HET NIEUWE BW TEN}

AANZIEN VAN OVERGANGSSITUATIES BIJ INSCHRIJVINGEN BETREFFENDE REGISTERGOEDEREN

Vooropgesteld moet worden dat, wanneer de vereisten van de nieuwe regels inzake inschrijvingen betreffende registergoederen eerst ma het tijdstip van de inwerkingtreding worden vervuld, er in het stelsel van de Overgangswet in beginsel geen overgangssituatie is en daarmee geen vraag van overgangsrecht ${ }^{8}$. Een voorbeeld: de rechtsgevolgen van een inschrijving die na de inwerkingtreding geschiedt worden in beginsel beheerst door het nieuwe recht; ook indien het ingeschreven feit vór de inwerkingtreding is geschied. In het navolgende beperk ik mij tot de BW-bepalingen die ik in het vorige nr. heb genoemd.

Artikel 3:17 BW kan slechts betekenis hebben voor inschrijvingen die na de inwerkingtreding geschieden. Het toepassen van artikel 3:17 BW op anterieure inschrijvingen laat zich niet goed denken. Pas indien deze bepaling terugwerkende kracht zou hebben, zou zij betekenis hebben voor anterieure inschrijvingen\%. Iets dergelijks geldt voor artikel 3:20 BW.

De artikelen 3:21 en 23-26 BW inzake de werking van inschrijvingen behoren volgens de minister in beginsel ook toepasselijk te zijn op (het ontbreken van) anterieure in- en overschrijvingen, evenals de artikelen 3:28, 29 en $274 \mathrm{BW}$ (doorhaling) ${ }^{10}$. Voor artikel 3:30 BW geldt deze wenselijkheid volgens hem evenzeer. Daarbij moet echter wel in het oog worden gehouden

7. Vgll hieromtrent bij voorbeeld Asser-Beekhuis I, nr. 453; Van Dunné c.s., Kosten en tekortkomingen, p. $7,9,12-13$.

8. Zienr. 2.4.1.1 hiervóor.

9. Vgl. Parl. Gesch. Overgangsrecht, p. 249 , alsmede het over 'voldongen feitem' opgemerkte in de nrs, 2.4.1.2.2.5.1.1 sub c.2, 2.5.1.2 subc.2 en 2.5.1.4 sub b hiervó6r.

10. Zie Parl. Gesch. Overgangsrecht, p. 249, 274. 
Zoals hierna in de nrs. 3.6 en 3.7 zal blijken, geldt het "in beginsel" toepasseljik behoren te zijn van de nieuwe regels (bedoeld lijkl te worden: de hoofdregel van de onmiddellijke werking) woor de rangorde en de derdenbescherming (terecht) niet. Voor het overige lijkt de directe toepusseljikheid van het nieuwe recht goed verdedigbaar. Inschrijvingem betreffende registergoederen hebben niet zelden een lang leven en het zou een slechte zaak zijn, indien nog tot in lengte vam jaren zou moeten worden gewerkt met de nieuwe èn met de oude regels, die onderling sterk afwijken. Daar konat bij dat de niewwe regeling met betrekking tot de inschrijvingen betreffende registergoederen nogal wat verbeteringen brengt ten opzichte van het oude recht? ${ }^{2}$. Het valt toe te juichen als dit betere recht ook op ten tijde van de inwerkingtreding reeds bestaande inschrijvingen wordt toegepast.

Voor zover onmiddellijke werking geindiceerd is, zijn er wel enige moeilijkheden op te lossen, onder meer op het terminologische vlak: het nieuwe BW kent naast inschrijvingen geen overschrijvingen meer. Dit betekent dat gegrepen moet worden naar hulpmiddelen om de werking van het nieuwe recht vanaf de invoering voor overgangssituaties mogelijk te maken. Deze hulpmiddelen zijn opgenomen in artikel 78 ow 1 . Dat artikel zou echter niet steeds tot een aanvaardbaar resultaat voeren, bij voorbeeld bij kwalitatieve verplichtingen. Hoe een en ander in de Overgangswet is opgelost, zet ik hiema kort uiteen.

\subsection{DE OVERGANGSWET EN INSCHRUIJINGEN BETREFFENDE REGISTERGOEDEREN}

De toepassing van het nieuwe recht op anterieure in- en overschrijvingen en atekeningen is mogelijk gemaakt met behulp van een overbruggingsregel 13. Deze is neergelegd in artikel 78 lid 10 ow I en houdt een fictie in. Waren feiten bij de invoering kenbaar uit de registers uit een voordien plaatsgevonden hebbende over- of inschrijving of aantekening, dan gelden zij voor de toepassing van het nieuwe recht als feiten die in overeenstemming met afdeling 3.1.2 BW zijn ingeschreven. Hierop wordt een uitzondering gemaakt voor die feiten, die onder de vigeur van het nieuwe recht niet meer hadden kunnen worden ingeschreven. De actieradius van artikel 78 lid 1 Ow I wordt in artikel 1 lid 2 Ow II verruimd tot wijzigingen in de bij de invoering van het nieuwe $\mathrm{BW}$ bestaande wetgeving ${ }^{14}$.

De door lid 1 geopende mogelijkheid tot toepassing van het nieuwe recht wordt elders in de Overgangswet voor enkele deelgebieden weer teruggenomen. Artikel 78 lid 2 Ow I bij voorbeeld voorkomt dat artikel $3: 21 \mathrm{BW}$ verschuivingen in de rangorde van "oude" rechten bewerkstelligt. Voor de derdenbeschermende bepalin-

11. Aldus Parli. Gesch. Overgangsrecht, p. 249.

12 .Zie bij voorbeeld Asser-Beekhuis I, nrs. 440 e.v.

13. Zje daarover ni: 2.5 .2 hiervó́r.

14. Vgl. hieromerent Parl. Gesch. Overgangsrecht, p. 191, alwaar ook het niet noemen van de leden $2 \mathrm{en} 3$ vamurtikel 78.0 I In aurtikel 1 lid 20 w Il wordt verklaard. Een voorbeeld van een geval waarvoor de verniming wan de actieradius van artikel 78 lid 1 Ow I van belang is, is te vinden in genoemde Parl, Gesch., p. 355. 
gen $3: 24$ lid 1, 25 en 26 BW schrijft artikel 78 lid 3 Ow 1 een uitgestelde werking van drie jaar voor. En voor de derdenwerking ex artikel $6: 252 \mathrm{BW}$ is een bij de inwerkingtreding reeds aanwezige inschrijwing "waardeloos", zo volgt uit artikel 192 Ow I.

Hierna zal ik deze en enkele andere overgangsbepalingen onderwerpen aan een nadere beschouwing.

\subsection{DE GEFINGEERDE INSCHRIJVING CONFORM AFDELING $3.1 .2 \mathrm{BW}$}

Bij de behandeling van de fictie die in artikel 78 lid 1 OW I is neergelegd, maak ik onderscheid tussen anterieure in- en overschrijvingen enerzijds (nr. 3.5.1) en anterieure aantekeningen anderzijds (nr. 3.5.2).

\subsubsection{Kenbaarheid wit de openbare registers uit een 'oude' in- of overschritwing}

Zoals ik hierboven reeds aanstipte, is het niet zonder meer mogelijk om aan de nieuwe wettelijke regeling inzake de inschrijvingen betreffende registergoederen onmiddellijke werking toe te kennen. Er zijn namelijk enkele complicerende factoren in het spel. In de eerste plaats gaat de onderhavige afdeling van Boek $3 \mathrm{BW}$ wit van een limitatieve wettelijke opsomming van feiten die in de openbare registers kunnen worden ingeschreven. Artikel $3: 17$ lid $1 \mathrm{BW}$ noemt een aantal inschrijfbare feiten. Inschrijving van feiten in de registers kan ook krachtens andere wetsbepalingen mogelijk zijn. Voorbeelden hierwan zijn de artikelen 3:28 lid 2 en 274 lid 2 BW (verklaring van waardeloosheid van inschrijving respectievelijk verklaring dat hypotheek is vervallen). Daarnaast kan inschrijving in de registers van een akte als vormvereiste gelden woor de totstandkoming van een rechtshandeling, zoals bij de overdracht van registergoederen (artikel 3:89 BW) ${ }^{15}$. Feiten die alleen persoonlijke rechten geven of opheffen kunnen slechts worden ingeschreven, indien een bijzondere wetsbepaling dit toestaat (artikel 3:17 lid 2 BW). Een limitatieve opsomming van inschrijfbare feiten ontbrak in het oude recht. Voorts houdt de nieuwe regeling ten opzichte van het oude recht een witbreiding van het aantal inschrijtbare feiten in 16 .

Het oude recht zweeg ook over de vraag of de bewaarder verplicht kan zijn om tot (weigering van) inschrijving van een felt over te gaan. Wel bracht onder het oude recht een behoorlijke ambtsuitoefening mee dat aan een verzoek tot in of overschrijving niet steeds gevolg kon worden gegeven ${ }^{17}$. De nieuwe wet bevat hier wat men een limitatief-imperatief stelsel zou kunnen noemen: de bewaarder mag slechts èn moet die feiten inschrijven, die volgens de limitatieve opsomming in de wet inschrijfbaar zijn. Lid 1 van artikel 3:20 BW geeft de regel dat de bewarder van de registers weigert een inschrijving te doen, indien een wettelijk vereiste

15. Zie Part. Gesch. Iny, Boek 3, p. 1233.

16. Vgl. Hartkamp, Compendium, nr. 53, Asser-Beekhuis 1, nrs. 441-442.

17. Aldus TK, vergaderjaar 1990- 1991,21830 , nir. 5 (memorie van antwoord), p. 4. 
voor inschrijuing niet is wervuld. De leden 2 tot en met 6 van artikel $3: 20 \mathrm{BW}$ betreffen de situatie dat de bewaarder is overgegaan tot weigering van een inschrijving.

Bovenstaande twee verschillen (wel/geen limitatieve wettelijke opsomming van inschrijfbare feiten en wel/geen regel inzake wat de bewaarder mag en moet inschrijven) roepen de vraag op of er feiten zijn die onder het oude recht wel konden worden ingeschreven, maar onder het nieuwe recht niet. Alleen dan immers zouden de onderhavige verschillen tot een probleem van overgangsrecht kunnen leiden. De gestelde vraag wordt in de memorie van toelichting onbeantwoord gelaten. Wel wordt opgemerkt dat het slot van artikel 78 lid $1 \mathrm{Ow} I$ in verband met de onderhavige twee verschillen een uitzondering maakt

"voor het geval dat een tevoren wellicht inschrijfbaar feit het daarna niet meer is ${ }^{\text {" }} 18$.

Een laatste factor die de toepassing van de nieuwe regels op overgangsgevallen compliceert is de volgende. In het nieuwe BW wordt uitsluitend van inschrijving van feiten en stukken gesproken. In de oude wetgeving werd nogal eens een andere terminologie gebezigd: overschrijving van de transportakte (artikel 671 (oud) BW), overschrijving van de titel wan aankomst wan respectievelijk erfdienstbaarheden, opstal en erfpacht (artikelen 743 (oud), 760 (oud), 767 lid 2 (oud) BW), overschrijving van de titel van vruchtgebruik (artikel 807 lid 1 (oud) BW) en overschrijving van het proces-verbal van inbeslagneming (artikel 505 leden 2,4 en 5 (oud) Rv). Daarnaast werd ook gesproken van inschrijving (van het hypothecaire verband), namelijk in de artikelen 1224 e.v. (oud) $\mathrm{BW}^{19}$.

Wanneer men de nieuwe regeling met betrekking tot inschrijvingen betreffende registergoederen wil toepassen op ten tijde van de inwerkingtreding reeds bestaande inschrijvingen, stuit men gezien het bovenstaande op twee problemen. Het eerste - wellicht zuiver theoretische - probleem is dat deze nieuwe regeling bezwaarlijk kan worden toegepast op - anders dan voorheen - niet meer inschrijfbare feiten, die op het moment van de inwerkingtreding van het nieuwe BW uit de registers kenbaar waren. Het tweede probleem is van terminologische aard: in de nieuwe regeling is steeds van inschrijving sprake, terwijl onder het oude recht ook vaak overschrijwing plaatsvond. De vraag is dan, of de voor inschrijvingen geldende nieuwe regels ook op overschrijvingen kunnen worden toegepast.

De overgangswetgever heeft in verband met laatstgenoemd probleem in artikel 78 lid 1 Ow I cen brug geslagen tussen het oude en het nieuwe recht. Deze bepaling, die een fictie inhoudt, luidt als volgt:

Feiten die op het tijdstip van het in werking treden van de wet kenbaar zijn uilt de openbare registers voor registergoederen uit een in- of overschrijving voordien of uit een voordien door de bewaarder geplaatste aantekening, gelden voor de toepassing van de wet als feiten die overeenkomstig afdeling

19. Vgl. Parl. Gesch. Overgangsrecht, p. 74. Vgl. ook Reinsma, Kwartaallbericht Nieuw BW 1985, p. $45-46$. 
3.1.2 van Boek 3 zijn ingeschreven, tenzij die feiten nadien niet meer hadden kunnen worden ingeschreven.' 20

De toelichting merkt hierover op:

'De regel komt er op neer dat de rechtsgevolgen van het nieuwe recht worden gehecht aan feiten die uit de openbare registers kenbaar zijn uit een vroegere in- of overschrijving., 21

Waarschijnlijk om wille van de eenvoud (het slot van artikel 78 lid 1 Ow I betreft behalve anterieure overschrijvingen ook anterieure inschrijvingen) strekt de fictie van artikel 78 lid $1 \mathrm{Ow}$ I zich tevens uit tot anterieure inschrijvingen ${ }^{22}$.

Artikel 78 lid 1 Ow I brengt bij voorbeeld mee

'dat, wanneer onder het huidige recht tot stand gekomen inschrijwingen of overschrijvingen waardeloos zijn geworden, onder het nieuwe recht de artikelen 3.1.2.10 (3:28) en 3.1.2.10a (3:29) nieuw B.W. toepassing kunnen vinden: ${ }^{23}$

In verband hiermee lijkt het mij nuttig iets meer te zeggen over de verhouding tussen oud en nieuw recht terzake. De artikelen 1239-1241 (oud) BW, die alleen op hypothecaire inschrijvingen betrekking hadden ${ }^{24}$, kwamen op het volgende neer. Een inschrijving kon op kosten van de debiteur worden doorgehaald met toestemming van de daartoe bevoegde belanghebbenden, dan wel op grond van een in hoogste ressort gewezen of in kracht van gewijsde gegaan vonnis (artikel 1239 (oud) BW). Aan de bewaarder moest worden overgelegd een (authentiek afschrift van een) authentieke akte (royementsakte) waarbij tot de doorhaling werd gemachtigd, of een authentiek afschrift van een daartoe strekkend vonnis (artikel 1240 lid 1 (oud) BW). Artikel 1241 (oud) BW regelde de vordering tot doorhaling.

De nieuwe regeling wijkt nogal af van de oude 25 . Volgens artikel 3:28 lid $1 \mathrm{BW}$ zijn degenen ten behoeve van wie een waardeloze ${ }^{26}$ inschrijving zou hebben gestrekt, indien zij wel van waarde zou zijn geweest, verplicht om op hun verzoek aan onmiddellijk belanghebbenden een schriftelijke verklaring van waardeloosheid af

20. Zie ook de artikelen 23 lid 20 II, alsmede IV tweede zin en VII lid 1 Ow Kadasterwet, en woorts artikel VI leden 1-3 van laatstgenoemde wet met de bijbehorende toelichting (TK, wergaderjaar 1990 1991; 21 830, nr. 3, p. 13).

21. Parl. Gesch. Overgangsrecht, p. 74.

22. Artikell VIl lid 10 W Kadasterwet is wel beperkt tot anterieure overschrijvingen. Vgl. TK, vergaderjaar 1990-1991, 21830, nr. 3 (memorie van toelichting), p. 15-16, alwaar onder meer wordt opgemerkt dat, indien het ook in het oude recht om een "inschrijving" ging, ${ }^{2}$ geen terminologische moeilijkheid bestaat daarop de bepalingen van de Kadasterwet betreffende inschrijwingen toe te passen.

23. Allus TK, vergaderjaar 1990-1991, 21 830, nr. 3 (memorie van toellichting), p. 11 .

24. Doothaling van andere inschrijwingen werd in de rechtspraak niett mogelijk geacht; vgl. Parl. Gesch. Boek 3, p. 147 en Asser-Beekhuis I, nr. 446.

25. Zie (ook over de Kadasterwet) Van Straaten, WPNR 5979 (1990), p. 691 e.v., WPNR 5980 (1990), p. 710 e.v. en WPNR 5981 (1990), p. 724 e.v...

26. "Waardeloos' betekent hier 'zonder enig belang rechtens". Een inschrijving kan waardeloos zijn doordat de ingeschreven rechtshandeling van de aanvang af sietig was of naderhand is vernietigd wardeloos is ook de inschrijving van de vestiging van een beperkt recht dat is tenietgegaan. Vgl. Parl. Gesch. Boek 3, p. 149. 
te geven. In deze verklaring moeten de feiten warop de waardeloosheid berust worden vermeld, behalve indien de inschrijwing een hypotheek of beslag betreft ${ }^{27}$. Verklaringen van wardeloosheid kunnen in de registers worden ingeschreven. Gaat het om een inschrijving betreffende hypotheek of beslag, dan machtigen de verkla ringen gezamenlijk de bewaarder tot doorhaling van de inschrijving, aldus artikel 3.28 lid $2 \mathrm{BW}$. Voor het geval dat de verklaringen van waardeloosheid niet worden afgegeven, regelt artikel $3: 29 \mathrm{BW}$ de weg warlangs een rechterlijke verklaring van waardeloosheid kan worden verkregen. Het vonnis dat deze verklaring bevat heeft ook gezag wan gewijsde tegen niet verschenen rechtverkrijgenden van iemand die in de regusters staat ingeschreven, indien deze rechtwerkrijgenden geen nieuwe inschrifving hebben genomen.

In artikel 3.274 BW is een speciale regeling opgenomen voor de doorhaling wan inschrijvingen betreffende tenietgegane hypotheken ${ }^{28}$. De crediteur (en degene die een beperkt recht op de vordering heeft) is in dat geval verplicht om op verzoek van de debiteur en op diens kosten bij authentieke akte ${ }^{29}$ een verklaring af te geven, dat de hypotheek is vervallen (lid 1). Een dergelijke verklaring is inschrijfbaar in de registers en machtigt de bewaarder tot doorhaling (lid 2). In lid 3 wordt artikel 3:29 BW van overeenkomstige toepassing verklaard op het geval dat de vereiste verklatringen niet worden afgegeven. Lid 4 regelt de situatie dat de hypotheek door vermenging is tenietgegaan.

Evenals naar oud recht is de doorhaling van een inschrijving slechts een administratieve maatregel en geen wijze van tenietgaan van het recht waarop de doorgehaalde inschrijving betrekking heeft. Wel bestaat er tussen oud en nieuw recht dit verschil dat de doorhaling onder het oude recht een verwijzing was naar een niet in de registers ingeschreven stuk dat onder de bewaarder berustte, terwijl onder het nieuwe recht de doorhaling een verwijzing is naar een stuk dat (onder de vigeur van dat nieuwe recht) is ingeschreven in de registers en waaruit de waardelloosheid van de inschrijving betreffende een hypotheek of beslag blijkt ${ }^{30}$.

Door artikel 78 lid 1 Ow I wordt, als gezegd, toepassing van de nieuwe doorhalingsregels op vroegere over(- en in)schrijvingen mogelijk gemaakt.

Met het slot van artikel 78 lid 1 Ow I wordt bereikt dat het nieuwe recht niet toe-

27. De achtergrond van dit laatste is dat het bij hypotheek en beslag 'mede kan gaan on vergeten inscltaijvingen waarvan wel de waardeloosheid kan worden erkend, maar niet meer vastgesteld kan worden op welke grond de inschrijuing haar betekenis verloren heeft', aldus Parl. Gesch. Inv. Boek 3, p. 1110.

28. Een hypotheekrecht kan tenietgaan als gevolg van bij voorbeeld

- het tenietgaan wan de vordering van de hypotheekhouder;

- afstand of opzegging van het hypotheekrecht door de hypotheekhouder;

- vervulling van een ontbindende voorwaarde, waaronder het hypotheekrecht is gevestigd en

- zuivering, indien alle belanghebbenden bereid zijn cen verklaring overeenkomstig artikel $3: 274 \mathrm{BW}$ af te geven. Zitjn zij daartoe niet bereid, dan dient de weg van artikel 3:273 BW te worden gevolgd (doorhaling van de inschrijving op grond wan een ingeschreven verklaring van de president van de rechtbank inzake het vervallei van de hypotheek). Zie Part. Gesch Boek 3, p. 840 .

Zie ook Van Strataten, WPNR 5979 (1990), p. 691-692. Deze schrijver is van oordeel dat artikel 3:274 $\mathrm{BW}$ (en niet artikel $3: 28 \mathrm{BW}$ ) geldt voor hypothecaire inschrijvingen die niet naderhand zijn tenietgegaan, maar van de aanvang af waardeloos waren (p. 692).

29. Hier word dus een zwardere eis gesteld dan in artikei 3:28 lid 1 BW (schriftelijke verklaring).

30. Vgl. Parl. Gesch. Inv Boek 3, p. 1112 . Zie voor de doorhaling van de inschrijwing van een beslag artikel 513 a Rw en voor het overgangsrecht terzake de artikelen 20 en 23 lid 4 Ow IL. 
passelik is op feiten die wolgens datzelfde recht helemaal niet in de registers mogen worden ingeschreven. Zonder deze voorziening zou dit anders zijn, ondat reeds wór de inwerkingtreding ingeschreven feiten uit de aard der zaak niet kunnen worden beheerst door de nieuwe regels inzake inschrijfbaarheid in de registers. Op de onderhavige feiten blijft het oude recht toepasselijk (zie artikel $68 \mathrm{a}$ lid $2 \mathrm{OW} \mathrm{I}$ ).

Met het 'kenbaar' zijn uit een vroegere in- of overschrijving wordt in artikel 78 lid $1 \mathrm{OW}$ I het volgende bedoeld:

"Met het woord "kenbaar" wordt aansluiting gezocht bij de gedachte van artikel 3.1.2.6 (3:23). Maar de iets andere redactie, met name de verwijzing naar de in- of overschrijving volgens het oude recht, maakt duidelijk dat de hoofdregel niet geldt voor feiten die bij raadpleging der registers slechts uit het kadaster kunnen worden gekend' 31 .

Met de "gedachte van artikel 3.1.2.6' moet de minister gezien tekst en geschiedenis van het artikel het volgende bedoelen. Uit artikel 3:23 $\mathrm{BW}$ valt af te leiden dat een feit uit de registers kenbatar is, indien dat feit door raadpleging van de registers zou zijn gekend. Het is niet zo dat alle feiten die in de registers zijn geregistreend door het artikel als bekend worden verondersteld. Dit geldt slechts voor die feiten die men door raadpleging van de registers had kunnen kennen. Van dit latste is geen sprake, indien de registers zo onoverzichtelijk worden bijgehouden dat zelfs de zorgvuldige raadpleger een inschrijving niet kan ontdekken ${ }^{32}$.

De tweede zin van bovenstaand citaat veronderstelt als bekend dat de regel van artikel 3:23 BW tevens geldt voor feiten die bij raadpleging van de registers slechts uit het kadaster kunnen worden gekend. De toelichting bij de invoeringswetgeving ten aanzien van Boek $3 \mathrm{BW}$ meldt dat voor de wraag welke feiten door raadpleging van de registers zouden zijn gekend in de zin van artikel $3: 23 \mathrm{BW}$, mede van belang is wat aan ingeschreven feiten bij een zodanige raadpleging uit de kadastrale registratie (die voor degene die de registers wil raadplegen de toegang tot de registers vormt) naar voren komt $^{33}$. In de praktijk zal het hierbij volgens de memorie van antwoord aan de Tweede Kamer ${ }^{34}$ gaan om

'gevallen als die van onder het huidige of het daaraan voorafgaande recht anders dan door een in de openbare registers in- of overgeschreven akte totstandgekomen rechten, die wel in de kadastrale registratie zijn aangetekend, maar waaromtrent in de openbare registers niets is te vinden."

Anders dan in artikel $3: 23 \mathrm{BW}$ blijven die gegevens die uitsluitend uit het kadaster blijken in artikel 78 Ow I (voor zover hier relevant) buiten beschouwing. Het

31. Aldus Parl. Gesch. Owergangsirecht, p. 74. Gezien de context moet de "hoofdregel" de eerder in dezelfde alinea vermelde regel van artikel 78 lid 1.0 I zijn, inhoudende dat an feiten die bij de in werkingtreding uit de registers kenbaar zijn uit een wroegere in- of overschrijving de rechitsgevolgen van het nieuwe recht worden verbonden.

32. Aldus Parl. Gesch. Boek 3, p. 129.

33. Parl. Giesch. Inv. Boek 3.p. 1057-1058.

34. Parl. Gesch. Inv. Boek 3, p. 1096. 
spreekt immers van feiten die kenbaar zijn uit de registers "ü̈t een in- of overschriving (in de registers, HvdB) voordien".

\subsubsection{Kenbaaheid uit de openbare registers uit een "oude" aantekening}

Kort woor de stemming door de Tweede Kamer over de voorgestelde Aanvulling van de Overgangswet nieuw BW is op initiatief van de minister artikel 78 lid 1 Ow I nog aangevuld: Volgens de minister was gebleken dat de regels van artikel 78 Ow I moesten worden uitgestrekt

"tot de aantekeningen die overeenkomstig het huidige recht zonder in- en overschrijwing van een stuk door de bewaarder worden geplaatst in de openbare registers bij de betrokken in- dan wel overschrijving." 35

Het gat hier om feiten die bij de inwerkingtreding uil de openbare registers voor registergoederen kenbaar waren uit een door de bewaarder van deze registers geplaatste aantekening. Bij genoemde aantekeningen ging het met name om doorhalingen van hypotheken en beslagen. In de parlementaire geschiedenis van artikel 78 Ow I worden geen concrete voorbeelden genoemd van aantekeningen-niet-doorhalingen. $\mathrm{lk}$ laat deze categorie ter vermijding van al te grote uitvoerigheid verder buiten beschouwing.

Uitgangspunt bij de doorhaling is dat deze

'een louter administratieve maatregel is, waaraan derden op zich zelf noch positief noch negatief enig recht kunnen ontlenen.' 36

Om iets te weten te komen over de betekenis van artikel 78 Ow I voor doorhalingen moet eerst de volgende vraag onder ogen worden gezien. Kunnen de nieuwe regels inzake de inschrijvingen betreffende registergoederen zonder koppelregel worden toegepast op uit een anterieure doorhaling kenbare feiten? De artikelen 3:17-20 BW niet, omdat zij slechts van belang zijn voor posterieure inschrijvingen. Artikel 3:24 BW ook niet: het gaat uit van niet-inschrijving van een feit dat wel had kunnen worden ingeschreven. Doorhalingen plachten echter onder het oude recht juist niet te berusten op een in- of overschrijwing in de registers. Van toepassing zonder meer van artikelen als 3:25-27 en 30 BW kan ook geen sprake zijn, omdat zij uitgaan van wel in de registers ingeschreven feiten. Artikel 3:23 BW kan wel zonder nadere voorziening worden toegepast op uit een bestaande doorhaling kenbare feiten, nu voor die toepassing niet vereist is dat een inschrijving in de registers aanwezig is $^{37}$. De artikelen $3: 28$ en $29 \mathrm{BW}$ hebben, zo zou men zeggen, ook bij on-

35. Parl Gesch. Overgangsiecht, p. 75. Zie ook artikel Vut lid 2 Ow Kadasterwet.

36. Aldus Parl. Gesch. Kadasterwet, p. 95; evenzo ka.p. p. 33 e.v; Parl. Gesch. Boek 3, p. 152; Parl. Gesch. Inv. Boek 3, p. 1111-1112, 1117 .

37. Registeronderzoek omvat mede de radpleging van onder de bewaarder berustende, niet ingeschreven stukken, op grond waarvan de doorhaling is geschied; vgl. Parl. Gesch. Overgangsrecht, p. 75. 
middellijke werking geen betekenis voor bestaande doorhalingen. Op dit laatste kom ik hieronder terug.

Is nu directe toepasselijkheid van de daarvoor in aanmerking komende nieuwe bepalingen op uit een bestaande doorhaling kenbare feiten wenselijk? De wetgever heeft geoordeeld van we ${ }^{38}$. Deze toepasselijkheid vergt echter een koppeling tussen oud en nieuw recht. Onder het oude recht immers werden de stukken op grond waarvan werd doorgehaald niet in- of overgeschreven. Wel bleven zij doorgaans onder de bewaarder berusten, bij wie zij door het publiek konden worden geraadpleegd. Het nieuwe recht vaart een andere koers. De doorhaling van tenietgegane hypotheken bij voorbeeld geschiedt op grond van een in de registers ingeschreven verklaring (artikel $3: 274 \mathrm{BW}$ ) ${ }^{39}$. Het ingeschreven zijn van die verklaring brengt met zich mee dat bij voorbeeld een derdenbeschermingsbepaling als artikel 3:26 BW kan worden toegepast. Het niet ingeschreven zijn ervan kan aanleiding geven tot toepassing van artikel 3:24 BW.

Ondanks het niet in- of overgeschreven zijn van de stukken op grond waarvan vroegere doorhalingen hebben plaatsgevonden, kan in overgangsgevallen het nieuwe recht daarop toch worden toegepast dankzij de uitbreiding van het toepassingsgebied van artikel 78 lid 1 . Ow I tot zulke doorhalingen. Als gevolg van deze uitbreiding worden ook uit een bestaande doorhaling kenbare feiten geacht te zijn ingeschreven conform afdeling 3.1.2 $\mathrm{BW}^{40}$. Door deze 'truc' van de overgangswetgever worden aan anterieure aantekeningen in het algemeen en aan anterieure doorhalingen in het bijzonder

'de rechtsgevolgen verbonden, die het nieuwe recht toekent aan feiten die kenbaar zijn door raadpleging van de openbare registers. ${ }^{241}$

Opvallend is dat in de tekst van artikel $78 \mathrm{lid} 1 \mathrm{OW}$ I een engere formulering is neergelegd, namelijk dat de desbetreffende feiten gelden als feiten die overeenkomstig afdeling 3.1.2 BW zijn ingeschreven. Zoals ik in nr. 3.5.1 hiervóór reeds uiteenzette kunnen ook niet ingeschreven feiten kenbaar zijn door raadpleging van de registers. Het verschil tussen de wettekst en de parlementaire geschiedenis is om de volgende reden van belang. Op de juistheid van feiten die uit de registers kenbaar zijn door een relaas van doorhaling, maar niet in de registers (geacht worden te) zijn ingeschreven, mag niet worden vertrouwd. Op de juistheid van ingeschreven feiten mag echter op grond van de artikelen $3: 25$ en $26 \mathrm{BW}$ wel worden vertrouw $\mathrm{d}^{42}$.

\section{Zie Parl. Gesch, Overgangsrecht, p. 75.}

39. Zie Parl. Gesch. Kadasterwet, p. 34.

40. De uitzondering van artikel 78 lid 1 slot $O w 1$ ('tenzij die feiten nadien niet meer hadden kunnen worden ingeschrewen") is hier niet van toepassing. Onder het oude recht werden, als gezegd, de stukken waarnaar in de doorhaling werd verwezen zelf niet in de registers ingeschreven, maar bleven zij onder de bewairder berusten. Onder het thans geldende recht daarentegen kunnen, ja zelfs moeten bedoelde stukken wel in de registers worden ingeschreven (zie onder andere de artikelen 3:28, 29, 273 en 274 BWy. Vgl. Parl. Gesch. Kadasterwet, p. 34.

41. Aldus Parl. Gesch. Overgangsrecht, p. 75.

42. Zie bij voorbeeld Parl. Gesch. Inv. Boek 3, p. 1111-1112; Parl. Gesch. Kadasterwet, p. 33-34. Hier is tevens artikel 78 lid 3 Ow I van belang, waarover nr. 3.7 hierna. 
In de toelichting op de aanvulling van artikel 78 lid 1 OW I wordt voorts het wol. gende gesteld:

De voorgestelde aanvulling brengt tevens mee, dat onder het oude recht platisgehad bebbende doorhallingen niet alsmog behoeven te berusten op een verklaring van waardeloosheid als bedoeld in de artikelen $3.1 .2 .10(3: 28)$ en $3.1 .2 .10 \mathrm{a}(3: 29)$ dan wel op een verklaring als bedoeld in de artikelen $3.9 .4 .19(3: 273)$ dan wel $3.9 .4 .20(3: 274)$ N.B.W: ${ }^{: 43}$

De minister acht voor dit resultaat dus een overgangsregel nodig. Hieruit lijkt te moeten worden geconcludeerd dat hij niet ziet naar" de anterieure doorhaling ("voldongen feit), maar naar de toestand van het bij de invoering doorgehaald zijn van een insehrijuing ${ }^{44}$.

\subsection{DE RANGORDE VAN INSCHIIJVINGEN IN DE REGISTERS}

De rangorde van inschrijwingen in ide registers is in het nieuwe BW anders geregeld dan in het oude. Voorheen waren de artikelen 1226-1228 (oud) BW maatgevend. Zij betroffen slechts inschrijving van hypotheken ${ }^{45}$. Behoudens de in de artikelen 1227 en 1228 (oud) BW opgenomen uitzonderingen werd de rang van de hypothecaire inschrijvingen op eenzelfde registergoed bepaald naar hun dagtekening (artikel 1226 lid 1 (oud) BW). Daarbij was volgens lid 2 wan artikel 1226 (oud) BW in geval van inschrijvingen op één en dezelfde dag irrelevant op welk uur de inschrijving was gedlaan ${ }^{46}$. Ging het om een overschrijving ter zake van andere zakelijke rechten dan hypotheek, dan was het tijdstip van overschrijving derhalve wel van belang ${ }^{47}$. Ook volgens artikel $3: 21 \mathrm{BW}$ is het tijdstip van inschrijving wel van belang: de rangorde van op eenzelfde registergoed betrekking hebbende inschrijvingen wordt behoudens wettelijke uitzonderingen ${ }^{48}$ bepald door de volgorde van de tijdstippen van inschrijving ${ }^{49}$, aldus lid 1. Lid 2 geeft zelfs een regeling voor de rangorde in het geval dat er twee inschrijvingen op hetzelfde tijdstip plaatsvinden, die zouden leiden tot onderling onverenigbare rechten van verschillende personen op eén goed.

Indien aan artikel $3: 21$ BW onmiddellijke werking zou worden toegekend, zou dit verandering van de rangorde van bestaande insehrijwingen met zich mee kunnen brengen. Onmiddellijke werking zou hier immers inhouden dat de nieuwe rangorde

43. Parl. Gesch. Overgangsrecht, p. 75 .

44, Zie over "voldongen feiten" de nrs. 2.4.1.2, 2.5.1.1 sub c.2, 2.5.1.2 sub c. 2 en 2.5.1.4 sub b hierwớr, en over de toestand bij de inwerkingtreding (in relatie tot de vereisten van de nieuwe wet) de nrs, 2,4.1.1 en 2.5 .1 .1 sube. 1 hiervóbr.

45. Dit laatste was overigens niet onomstreden; vgl. de door Asser-Beekhuis I, nr. 400, aangehaalde schrijvers.

46. Bij beslag was dit anders zie artikel 505 leden 2 en 3 (oud) Rw:

47. Zie Asser-Beekhuis $\mathrm{I}$, nr. 400; Konings, WPNR 6002 (1991), p. 270.

48. Zie bij voorbeeld lid 2 wan de onderhavige bepaling, alsmede de artikelen $3: 261$ en $262 \mathrm{BW}$.

49. Als tijcstip van inschrijwing wordt aangemerkt het tijdstip van aanbieding van de stukken, die vereist zijn voor de inschrijuing (artikel 3:19 lid 2 BW). 
(rechtsgevolg) vanaf het tijdstip van de inwerkingtreding zou intreden, indien op dat tijdstip zou zijn voldaan aan de vereisten die artikel 3:21 BW daarvoor stelt (artikel $68 a$ lid 1 Ow $\left.1^{50}\right)$. In plaats van dezelfde rang zouden twee bestaande inschrijvingen, beide ter zake van een recht van eerste hypotheek met betrekking tot éen en hetzelfde registergoed, die na elkaar maar op én en dezelfde dag hebben plaatsgevonden, vanaf de inwerkingtreding een verschillende rang hebben. De het eerst ingeschreven hypotheek zou daardoor in rang vóór de als tweede ingeschreven hypotheek komen, mu oudere rechten vóór jongere rechten gaan. Dit zou een niet geringe aantasting betekenen van de positie van de hypotheeknemer wiens recht het latst was ingeschreven. Daarom is het een goede zaak, dat artikel 78 lid 2 Ow I deze verschuiving verhindert door te bepalen:

"Artikel 21 van Boek 3 heeft geen invloed op de rangorde van rechten die reeds vóór het in werking treden der wet bestonden.'

Hier is dus sprake van "eerbiediging van verkregen rangorden'. Het oude recht blijft maatgevend (zie artikel $68 a$ lid 2 OW I) ${ }^{51}$.

\subsection{UITGESTELDE DERDENBESCHERMING}

Artikel 1376a (oud) BW wordt opgevolgd door (onder andere) de artikelen 3:24-26 BW. Over de strekking van artikel: $1376 a$ (oud) BW, het vroegere artikel $1910 \mathrm{BW}$, bestond verschil van mening. Volgens de heersende leer hield deze bepaling in dat de derde die te goeder trouw en om baat een registergoed of een recht op naam had verkregen, werd beschermd tegen onjuistheden of onvolledigheden in de - al dan niet in de registers over- of ingeschreven - akte die de rechtsverhouding tussen de eerste en de tweede hand weergaf. Deze onjuistheid of onvolledigheid moest echter het gevolg zijn van een 'contrelettre', een verzwegen afspraak ${ }^{52}$. De nieuwe artikelen 3:24-26 BW gaan verder. Artikel 3:24 lid $1 \mathrm{BW}$ bewerkstelligt dat de verkrijger van een recht op een registergoed kan worden beschermd tegen inroeping van in de registers inschrijfbare feiten. Deze bescherming geldt, indien zo'n feit op her moment van inschrijving van de rechtshandeling tot verkrijging onder bijzondere titel van zijn recht op het registergoed niet was ingeschreven en de verkrijger er niet van op de hoogte was. Anders dan voorheen is voor bescherming dus niet vereist dat het gaat om in een akte verzwegen informatie. Evenmin geldt het vereiste van verkitijging om baat, dat werd gesteld voor toepassing van artikel $1376 a$ (oud) $\mathrm{BWW}^{53}$. Artikel 3:24 BW geldt voor alle feiten die hadden kunnen worden ingeschreven ${ }^{54}$. Anders dan de artikelen 3:25 en $26 \mathrm{BW}$ heeft artikel 3:24 BW echter alleen betrekking

\section{Zie nr. 2.5. 1. I hiervóór.}

51. Konings, WPNR 6002 (1991), p. 269-271; bepleit toepassing wan artikel 3:21 BW op gevallen waarin onder het oude recht de rangorde onduidelijk was.

52. Vgl. bij woorbeeld Asser-Beekhuis I, nrs, 407-408.

53. Vgl. Parl. Gesch. Boek 3, p. 168; Parl. Gesch. Inv. Boek 3, p. 1099.

54. Vgl. Parl. Gesch. Boek 3 , p. 130. De leden 2 en 3 van het antikel bevatten uitzonderingen op lid $\|$. 
op die feiten, die afzonderlijk in de registers kunnen worden ingeschreven ${ }^{55}$.

De artikelen $3: 25$ en 26 BW betreffen de bescherming van verkrijgers onder bijzondere titel van een recht op een registergoed tegen de onjuistheid van op het moment van de inschrijving van de rechtshandeling ter verkrijging van dat recht in de registers ingeschreven feiten. Tenzij de verkrijger de onjuistheid kende of door raadpleging van de registers de mogelijkheid daarvan had kumnen kennen, kan de onjuistheid van ingeschreven feiten niet aan de derde-verkrijger worden tegengeworpen. In artikel 3:25 BW gaat het om feiten die in een authentieke akte door een ambtenaar met kracht van authenticiteit zijn vastgesteld, in artikel $3: 26 \mathrm{BW}$ gaat het om andere feitem. Volgens dit laatste artikel treft de niet-tegenwerpbaarheid alleen degene die redelijkerwijze voor overeenstemming van de registers met de werkelijkheid had kunnen zorgen. Anders dan bij artikel $1376 a$ (oud) $\mathrm{BW}$ is voor de toepassing van de artikelen $3: 25$ en $26 \mathrm{BW}$ niet vereist dat het gaat om in een akte onjuist weergegeven feiten. Evenals bij artikel $3: 24 \mathrm{BW}$ wordt het vereiste van verkrijging om baat niet gesteld. Een ander verschil tussen oud en nieuw recht is nog dat het toepassingsgebied van artikel $1376 a$ (oud) $\mathrm{BW}$ in een bepaald opzicht ruimer was dan dat van de artikelen 3:24-26 BW: behalve voor registergoederen gold eerstgenoemde bepaling ook voor rechten op naam die geen registergoed zijn, zoals vorderingen op naam.

Het derde lid van artikel $78 \mathrm{Ow} I$ geeft aan de artikelen $3: 24$ lid $1^{56}, 25$ en $26 \mathrm{BW}$ een uitgestelde werking van drie jaar, dus tot 1 januari 1995 :

"De artikelen 24 lid 1, 25 en 26 van Boek 3 worden eerst drie jaren ma het tijdstip van het in werking treden van de wet van toepassing met betrekking tot een voor inschrijving vatbaar feit dat vóor dat tijdstip is geschied.' 57

Voor dit uitstel noemt de toelichting niet alleen de hierboven weergegeven verschillen qua beschermingsomvang als redengevend. Een tweede motief is dat niet vaststaat dat alle feiten die volgens het nieuwe $\mathrm{BW}$ in de registers kunnen worden ingeschreven, ook onder het oude recht reeds inschrijfbaar waren of alsnog juist zijn weergegeven. De minister noemt als voorbeeld de vervulling van een voorwaarde, gesteld in een ingeschreven voorwaardelijke rechtshandeling ${ }^{58}$. Hij acht het billijk om degene die een in de registers inschrijfbaar feit wil inroepen; tijd te geven om die inschrijving(en) te nemen, die noodzakelijk zijn om te voldoen aan de vereisten die het nieuwe recht stelt voor de tegenwerpbaarheid van bedoelde feiten aan derden-verkrijgers ${ }^{59}$. Gedurende de 'overgangsperiode' van drie jaar blijft krachtens artikel $68 a$ lid 2 Ow I het oude recht (artikel $1376 a \mathrm{BW}$ ) toepasselijk.

Het is van belang om in het oog te houden dat de onderhavige uitgestelde werking betrekking heeft op voor inschrijving vatbare feiten die vö́r de inwerkingtre-

55. Aldus Parl. Gesch. Inv. Boek 3, p. 1099.

56. Aangezien de leden 2 en 3 van artikel 3:24 BW feiten opsommen, waarop lid 1 niet van toepassing is, delen eerstgenoemde leden in het overgangsrechtelijke lot van lid 1. Anders W.R. Meijer, WPNR 6007 (1991), p. 351, volgens wie artikel 3:24 lid 2 BW op grond van artikel 78 lid 3 Ow I onmiddellijk werkt:

57 . Zie over artikel 78 lid 3 Ow I Len 'onvolledige complexen van rechtsfeiten' nr. 2.5 .13 sub c.2 hierwó́r.

58. Zie Parl. Gesch, Owergangsrecht, p. 74.

59. Zie Parl. Gesch. Overgangsrecht, p. 74. 
ding zijn geschied. Indien derhalve een voor inschrijving vatbaar feit dat vó́r de inwerkingtreding is geschied bij voorbeeld een half jaar nă de inwerkingtreding wordt ingeschreven, worden de artikelen 3:24-26 BW desondanks pas drie jaar na de inwerkingtreding op dit feit toepasselijk. Hetzelfde geldt, indien het feit vốr de inwerkingtreding reeds is in- of overgeschreven. Geschiedt het voor inschrijving vatbare feit na de inwerkingtreding, dan is geen overgangssituatie aanwezig en komen we dus niet aan artikel 78 Ow I toe.

Ter illustratie van de werking van artikel 78 lid 3 Ow I volgt nu een voorbeeld. In 1989 heeft A een huis verkocht en overgedragen aan B. De koopovereenkomst A-B is echter totstandgekomen onder invloed van misbruik door B van de omstandigheden waarin $A$ ten tijde van het aangaan van die overeenkomst verkeerde. In 1990 daagde A B voor de rechter en vorderde een verklaring voor recht dat de koopovereenkomst A-B nietig was op grond van misbruik van omstandigheden. De rechter wees A's eis in september 1991 toe. B ging niet in hoger beroep. Het nieuwe BW trad op $\mathbb{1}$ januari 1992 in werking. A heeft verzuimd de uitspraak van de rechter in de registers te laten inschrijven (vgl. artikel 3:17 lid 1 sub e BW). B heeft het huis in april 1992 overgedragen aan C, die geen weet heeft van de uitspraak van de rechter. Naar het oude recht werd $C$ in een geval als dit niet beschermd tegen de beschikkingsonbevoegdheid van $\mathrm{B}$, althans volgens de heersende leer inzake artikel $1376 a$ (oud) $\mathrm{BW}$. Volgens het nieuwe recht zou $\mathrm{C}$ zelfs een beroep kunnen doen op twee beschermingsbepalingen, te weten de artikelen $3: 24$ lid 1 en $88 \mathrm{BW}$. In de onderhavige overgangssituatie evenwel zal een beroep door $C$ tegenover $A$ op artikel 3:24 lid 1 BW niet kunnen slagen. Dat zou slechts anders zijn, indien A pas na 31 december 1994 het huis van C zou revindiceren. Dit volgt uit artikel 78 lid 3 Ow I: het voor inschrijving vatbare feit (de rechterlijke uitspraak) is voór de inwerkingtreding geschied, zodat artikel 3:24 BW daarop vanaf 1 januari 1995 toepasselijk wordt. Zou A na de inschrijving van de transportakte B-C, maar vóór 1 januari 1995 alsnog de rechterlijke uitspraak hebben laten inschrijven, dan maakt dit uiteraard voor de uitkomst geen verschil60.

Het uitstel. op grond van artikel 78 lid 3 Ow I deert C niet, indien hij een succesvol beroep op artikel 3:88 BW kan doen. Voor zover het gaat om deze laatste bepaling bestaat er in het systeem van de Overgangswet geen overgangssituatie, nu de overdracht $\mathrm{B}-\mathrm{C}$ na de inwerkingtreding heeft plaatsgevonden.

Ten slotte merk ik nog op dat uit de parlementaire geschiedenis niet blijkt of de lengte van de uitstelperiode volgens artikel 78 lid 3 OW I is heroverwogen na het besluit een 'gewenningstermijn' van twee jaar in te lassen. $\mathrm{Zo}^{\text {" }} \mathrm{n}$ heroverweging heeft in een aantal andere gevallen tot verkorting van de oorspronkelijke uitstelperiode geleid ${ }^{61}$.

60. Artikel 78 lid $30 \mathrm{~W}$ I wormt blijkens het voorgaande een uitzondering op artikel 69 Ow I. Zie ower artikel 69 Ow Inr. 2.5.1.2 sube hierv6or. Zie voor een andere toepassing van artikel 78 lid 3 Ow I. Parl. Gesch. Owergangsrecht, p. 138 (inzake delimitatiecontracten).

61. Voorbeelden: artikelen 115 lid 2 (van vijf naar drie jaar) en 191 Ow I (van drie naar een jaar). Zie Parl. Gesch. Overgangsrecht, respectievelijk p. 119, 120 en 168, 169. 


\subsection{ENIGE ANDERE OVERGANGSBEPALINGEN INZAKE INSCHRUVINGEN BRTREFEENDE REGISTERGOEDEREN}

Behalve de hierboven besproken overgangsregels levert de materie van de inschrijvingen betreffende registergoederen nog enkele andere op. De belangrijkste zal ik hierna kort aan de orde stellen. Zij betreffen de rangorde van vorderingen, en voorts oude zakelijke rechten, buurwegen, erfdienstbaarheden ontstaan door bestemming of herleving en kwalitatieve verplichtingen (respectievelijk nrs. 3.8.1-5).

\subsubsection{Rangorde van worderingen}

Voor de rangorde van vorderingen geldt volgens artikel: $117 \mathrm{lid} 1 \mathrm{Ow}$ I onmiddellijke werking als overgangsregel 'behoudens het elders bepaalde'. Dit laatste betreft onder meer artikel 78 lid $2 \mathrm{OW} \mathrm{I}^{62}$. De niet-werking van artikel 3:21 BW kan bij hypotheekrechten van belang zijin (zie voor een voorbeeld mr. 3.6 hiervór).

\subsubsection{Oude zakelijke rechten}

Bij de inwerkingtreding aanwezige zakelijke rechten die niet voorkwamen in het oude BW, maar die zijn gehandhaafd krachtens artikel 1 OW 1829, zijn op grond van artikel 150 lid $1 \mathrm{OW}$ I registergoederen geworden. Lid 2 schept de mogelijkheid dat het bestaan van deze rechten in de registers wordt ingeschreven. In afwijking van artikel 78 lid 3 OW $I$ is artikel 3:24 lid $1 \mathrm{BW}$ echter niet toepasselijk op het ontbreken van deze inschrijving en op vóór de inwerkingtreding voorgevallen inschrijfbare feiten betreffende niet uit de registers kenbare rechten ${ }^{63}$.

\subsubsection{Butrwegen}

Voor buurwegen houdt artikel $\$ 60 \mathrm{Ow} \mathbb{I}$ in dat de inwerkingtreding van de nieuwe wet rechten, bevoegdheden en verplichtingen met betrekking tot cen reeds bestaande buurweg ongewijzigd laat; voorts is artikel 3:24 lid $1 \mathrm{BW}$ niet toepasselijk op de bestemming tot zo'n butrweg. Ook hier wordt ten aanzien van artikel 3:24 lid 1 BW een uitzondering gemaakt op de uitgestelde werking ex artikel 78 lid 3 OW I $^{64}$.

62. Zie Patl Gesch. Overgangsrecht, p. 121.

63. Zie hierover Parl. Gesch. Overgangsrecht, p. 129-132. Zie woorts artikel 36 lid 2 Kadasterwet, waarin artikel 150 lid 2 Ow 1 nader wordt vitgewerkt.

64: Zie. Part: Giesch. Overgangsrecht, p. 139. 


\subsubsection{Door bestemining of herleving ontstane erfdienstbaarheden}

Voor servituten die in het leven zijn geroepen door bestemming of herleving geeft artikel 163 Ow I enkele regels die overeenkomen met wat in artikel 150 lid 2 Ow I ten aanzien van oude zakelijke rechten is bepaald ${ }^{65}$.

\subsubsection{Kwalitatieve verplichtingen}

In de registers kunnen onder de vigeur van het oude recht notariële akten zijn gepubliceerd met daarin bedingen die naar nieuw recht een kwalitatieve verplichting zouden opleveren, zoals deze is geregeld in artikel 6:252 BW. De fictie van artikel 78 lid 1 Ow I zou voor deze gevallen tot het resultaat leiden dat daarin het rechtsgevolg van automatische derdenwerking zou kunnen intreden; terwijl daarvan onder het oude recht geen sprake was. Het zal niet verbazen dat de overgangswetgever het onbillijk vond om de derdenwerking ex artikel 6:252 BW vanaf de invoering anders dan voorheen ook te verlenen aan de onderhavige reeds 'toevallig' ingeschreven bedingen ${ }^{6.6}$. Hij heeft daarom bepaald:

"Artikel 192. Artikel 78 geldt niet voor een beding als bedoeld in artikel 252 van Boek 6 dat op het tijdstip van het in werking treden van de wet uit de openbare registers kenbaar is; de rechtsgevolgen die artikel 252 en afdeling 2 van titel 1 van Boek 3 aan inschrijving in de openbare registers verbinden, komen slechts toe aan inschrijving na dit tijdstip.'

Indien niet reeds vóór de inwerkingtreding van de schuldenaar-rechthebbende op het registergoed diens medewerking was bedongen aan het nadien opnieuw inschrijven van het beding, zal de schuldeiser om deze medewerking alsnog te verkrijgen zijn aangewezen op onderhandelingen met de schuldenaar-rechthebbende.

Voor de gevallen waarin niet een '252-beding' was overeengekomen, maar een kettingbeding, geldt iets anders. Kettingbedingen worden namelijk niet bestreken door artikel 192 Ow I, ondat artikel 6:252 BW daarop geen betrekking heeft. Kettingbedingen gaan immers niet van rechtswege over op opvolgende rechtsverkrijgers. Alvorens inschrijving van deze bedingen mogelijk is zullen zij-indien dat gelet op artikel 6:252 BW mogelijk is - bij nadere overeenkomst moeten worden omgezet in kwalitatieve verplichtingen als bedoeld in genoemde bepaling ${ }^{67}$.

Het zal onder het oude recht nauwelijks zijn voorgekomen dat partijen onbewust een '252-beding' afspraken, terwijl dit beding werd neergelegd in een notariële akte die vervolgens in de registers werd ingeschreven. Het oude recht kende nu eenmaal

65. Zie Parl. Gesch. Overgangsrecht, p. 141-143. Zie ook artikel 36 lid 3 Kadasterwet, waarin artikel 163 Ow I nader is uitgewerkt.

66. Zie Parl. Gesch. Overgangsrecht, p. 170-171.

67. Zie Parl. Gesch. Overgangsrecht, p. 171. 
geen kwalitatieve verbintenissen als geregeld in artikel 6:252 $\mathrm{BW}$. Hier zal artikel 192 Ow I dus wel niet veel emploøi vinden. Dit kan well het geval zijn, indien partijen bewust met het oog op de nieuwe mogelijkheden van artikel 6:252 BW vór de inwerkingtreding een beding overeenkwamen en dit in een al dan niet in de registers gepubliceerde akte neerlegden, met de bedoeling om de door artikel 192 Ow I geboden inschrijving van het beding na de inwerkingtreding te laten plaatsvinden. In verreweg de meeste gevallen zal echter wel sprake zijn van een kettingbeding. Wil de schuldeiser uit een kettingbeding kunnen profiteren van de automatische derdenwerking ex artikel 6:252 $\mathrm{BW}$, dan is hij aangewezen op de medewerking van de schuldenaar-rechthebbende. Deze zal moeten toestemmen in omzetting van het kettingbeding in een beding houdende een kwalitatieve verbintenis, neerlegging hiervan in een notarièle akte en inschrijving daarvan in de openbare registers. Zoals gezegd is die omzetting (uiteraard) slechts mogelijk, indien het kettingbeding zich, gezien de grenzen die artikel 6:252 $\mathrm{BW}$ trekt, daartoe leent.

Moet ten behoeve van de inschrijving na de inwerkingtreding een nieuwe notariële akte worden opgemaakt? Ervan uitgaande dat het beding vóór de invoering reeds in een notariële akte was neergelegd; hangt het antwoord op deze vraag naar mijn mening hiervan af, met welk geval men precies te maken heeft. Ik zie geen noodzaak tot het opmaken van een nieuwe notarièle akte voor het anterieure beding dat "toevallig" voldoet aan artikel 6:252 BW. Evenmin zie ik deze noodzaak voor het anterieure beding dat door partijen met het oog op het toen nog niet ingevoerde artikel 6:252 BW is overeengekomen. Dit zal anders zijn bij kettingbedingen. Deze zullen, indien zij al in de vorm van een kwalitatieve verplichting kunnen worden gegoten, om te voldoen aan artikel 6:252 $\mathrm{BW}$ inhoudelijk moeten worden aangepast. Het opmaken van een nieuwe notariële akte lijkt dan onvermijdelijk.

\subsection{SLOT}

Schijn bedriegt. Zo ook hier: analyse van het overgangsrecht voor de inschrijvingen betreffende registergoederen leert dat het (praktische) belang en de ingewikkeldheid ervan bepaald groter zijn dan men na een eerste kennisname zou vermoeden. Dit gaat zelfs op, indien men de Kadasterwet met bijbehorend overgangsrecht goeddeels buiten beschouwing laat. Met name artikel 78 lid $1 \mathrm{OW}$ I verdient in dit verband vermelding. Zoals hierboven is gebleken heeft artikel $78 \mathrm{OW}$ I bovendien lang niet altijd het laatste woord. 


\section{Geldigheid van rechtshandelingen}

\section{I INLEIDING}

Het nieuwe $B W$ bevat ten aanzien van de geldigheid van rechtshandelingen vele verschuivingen op allerlei terrein. Nietig- of vernietigbaarheid kan in de plaats van onaantastbaarheid zijn gekomen. Het omgekeerde kan zich even goed hebben voorgedaan. Ook kan vernietigbaarheid in plaats van nietigheid zijn gesteld, of andersom, terwijl zich nog andere varianten laten denken. Voor tal van 'overlopende' rechtshandelingen moet worden uitgemaakt of zij al dan niet zijn geraakt door zo'n verschuiving. In dit hoofdstuk wil ik trachten de belangrijkste overgangskwesties te inventariseren en aan te geven hoe zij moeten worden opgelost. De artikelen 79-81 Ow I voeren daarbij de boventoon.

\subsection{ONTSTAAN VAN OVERGANGSKWESTIES BII DE GELDIGHEID VAN RECHTSHANDELINGEN}

Op het vlak van de geldigheid van rechtshandelingen zijn vele tientallen verschillen tussen oud en nieuw recht te onderscheiden. In het navolgende heb ik een flink aantal van deze verschillen verwerkt. Volledigheid heb ik daarbij niet nagestreefd, zo deze al mogelijk zou zijn op dit tamelijk lastig overzienbare terrein. De gebruikelijke literatuur over verbintenissen- en goederenrecht kan voor het overige de weg. wijzen in het materiële recht. Om de gedachten te bepalen noem ik hierna enkele uiteenlopende resultaten van toepassing van oude en nieuwe regels inzake de onaantastbaarheid, vernietigbaarheid en nietigheid van rechtshandelingen.

Boek $3 \mathrm{BW}$ bevat het bekende voorbeeld misbruik van omstandigheden: de nietigheid uit het oude recht heeft plaats moeten maken voor vernietigbaarheid. Een voorbeeld uit Boek $5 \mathrm{BW}$ : het is onder het nieuwe BW gedaan met de vrijheid ter zake van eenzijdige beëindiging van erfpachtsrechten door de grondeigenaar. Hieraan worden thans grenzen gesteld, die op straffe van nietigheid in acht genomen moeten worden. Voorheen bestond onaantastbaarheid. Van boek $6 \mathrm{BW}$ noem ik de algemene voorwaardenregeling. Daarin wordt paal en perk gesteld aan met name het gebruik van onredelijk bezwarende bedingen in algemene voorwaarden. In vele gevallen is daardoor onaantastbaarheid vervangen door vernietigbaarheid. In boek 7 ontwerp NBW springt in het oog dat het voor de schenking geldende vormvereiste van een notariële akte is verdwenen. Dit betekent dat de nietigheid in de toekomst zal worden verruild voor (in beginsel) onaantastbaarheid. Bij misbruik van 
omstandigheden is er alleen een ander rechtsgevolg, in de andere voorbeelden is er ook verschil ten aanzien van de vereisten.

De variêteit in overgangsgevallen is zodanig groot dat dit wel werk voor de overgangswetgever moest opleveren. Dit blijkt al bij de zojuist genoemde voorbeelden: talloze rechtshandelingen verricht onder invloed van misbruik van omstandigheden, erfpachtsrechten met te ruime bevoegdheden tot eenzijdige beëindiging door de grondeigenaar, al dan niet in contracten geïncorporeerde onredelijk bezwarende algemene voorwaarden en wellicht straks ook nietige schenkingen hebben de inwerkingtreding overleefd. Werkt het nieuwe recht inzake geldigheid op deze anterieure rechtsfiguren in? Het behoeft geen betoog dat het antwoord op deze vraag, ook vanuit praktisch perspectief bezien, van groot belang is.

Het overgangsrecht voor de onderhavige materie is zonder meer als weerbarstig te kwalificeren. Hiervan getuigt ook de opmerking van de minister,

'dat het een terrein is dat de overgangswetgever moeilijk in zijn geheel kan overzien en met algemene regels in zijn macht kan krijgen."

Om het overzicht te bevorderen heb ik de volgende indeling gemaakt, daarbij aansluitend bij de belangrijkste overgangsbepalingen. Eerst bezie ik de voorheen onaantastbare rechtshandelingen, waarvoor het nieuwe $\mathrm{BW}$ vernietigbaarheid of zelfs nietigheid in petto heeft (nr. 4.5). $\mathrm{Na}$ in nr. 4.6 een bijzonder geval te hebben beschouwd, ga ik in de urs. 4.7 en 4.8 in op de vernietigbaarheid die is vervangen door respectievelijk onaantastbaarheid en nietigheid. De nietigheid waarvoor onaantastbaarheid in de plaats is gesteld komt aan de orde in nr. 4.9 , en de nietigheid die vernietigbaarheid is geworden in ar. 4.10. Nog een bijzonder geval staat centraal in nr. 4.11. Eerst geef ik nu echter aan wat de effecten van onmiddellijke werking van het nieuwe BW zouden zijn ten aanzien van de geldigheid van rechtshandelingen (nr. 4.3). Daardoor krijgen de overgangsregels terzake meer reliëf. De belangrijkste van deze overgangsregels beschrijf ik kort in nr. 4.4.

\subsection{CONSEQUENTIES VAN ONMIDDELLUUKE WERKING VAN HET NIEUWE BW TEN} AANZIEN VAN OVERGANGSSITUATIES BH DE GELDIGHEID VAN RECHTSHANDELINGEN

Het is van belang zich steeds af te vragen in welkí(e) opzicht(en) oud en nieuw recht uiteenlopen. Is dit alleen zo ten aanzien van de (ontstaans)vereisten (zoals bij de cessie), is dit alleen zo ten aanzien van het rechtsgevolg (zoals bij misbruik van omstandigheden) of zijn er zowel bij de vereisten als bij het rechtsgevolg afwijkingen (zoals bij de algemene voorwaarden) ${ }^{2}$ ?

Bevindt de afwijking zich (mede) op het vlak van de vereisten (dus de eerste en derde zojuist genoemde mogelijkheid), dan zal men nogal eens in aanraking komen 
met de zogenoemde 'voldongen feiten' ${ }^{3}$. Stelt de nieuwe wet een ander of extra ontstaansvereiste voor een zeker rechtsgevolg, dan heeft dat bij onmiddellijke werking geen consequenties voor die rechtsgevolgen die vóór de invoering zijn verbonden aan feiten, ook al is het nieuwe vereiste niet in acht genomen. Dat zou pas anders zijn als aan het nieuwe recht terugwerkende kracht zou zijn toegekend:

'Geldig - nietig zit meestal in de sfeer der vereisten (bijv. 3.4.2.2 (3:84) lid 1). In dat geval wordt de geldigheid - evenals de onrechtmatigheid van de o.d. - niet door de nieuwe wet beïnvloed."4

Het schoolvoorbeeld van een "voldongen feit" is dat van de cessie die onder de gelding van het oude recht is verricht zonder dat daarvan mededeling aan de debitor cessus is gedaan. De nieuwe regel die wel zo'n mededeling eist, heeft op de geldigheid van de eenmaal totstandgekomen cessie geen invloed. Een ander voorbeeld dat in de toelichtende stukken wordt gegeven is dat van de anterieure overgang van een goed uit een gemeenschap zonder dat er is geleverd. De totstandkoming van de overgang is onberoerd gebleven door het van kracht worden van de nieuwe regel die hier well levering eist, tenzij er terugwerkende kracht in het spel is ${ }^{5}$.

Het vroeger en thans geldende recht kunnen ook uiteenlopen ten aanzien van de rechtsgevolgen (de tweede hierboven genoemde categorie). Die rechtsgevolgen zijn hier uiteraard de onaantastbaarheid, vernietigbaarheid en nietigheid van rechtshandelingen. Dit zijn eigenschappen ofwel hoedanigheden van rechtshandelingen:

'Onaantastbaarheid - nietigheid kan men zien als eigenschappen die slechts bestaan op - en niet langer duren dan - het tijdstip waarop de rechtshandeling is verricht; datarin zit het verschil met vernietigbaarheid, een eigenschap die een rechtshandeling - een tijdlang - begeleidt.' ${ }^{6}$

Bij onmiddellijke werking gaat en komt in deze visie de vernietigbaarheid met de wet die haar schept. Aldus zal een bestaande rechtshandeling vanaf het tijdstip dat de nieuwe wet op haar toepasselijk wordt haar eigenschap van al dan niet vernietigbaarheid ontlenen aain de nieuwe wet. Dit is ook hierom het geval, nu bevoegdheden (tot vernietiging) in beginsel eveneens rechtsgevolgen zijn, waarvoor dit 'gaan en komen' geldt?.

In de ogen van de ontwerper van het overgangsrecht is het bij onaantastbaarheid en nietigheid anders. Wanneer men onaantastbaarheid en nietigheid ziet als 'momentele' eigenschappen, geven bij de inwerkingtreding aanwezige rechtshandelingen in zoverre geen overgangssituatie. De terugwerkende kracht moet dan te

3. Zie daarover ook de nrs. 2.4.1.2, 2.5.1.1 sub c. 2, 2.5.1.2 sub e.2 en 2.5.1.4 sub b hierwór.

4. Aldus B.C. de Die in een brief d.d. 27 februari 1990 ann schrijver dezes.

5. Zie Parl. Gesch. Overgangsrecht, p. 13-14, 76; De Die, RMTh 1979, p. 261 264; De Die, Spoedcursus, p. 13-14: De Die. AA 1991, p. 820-821,824.

6. Aldus B.C. de Die in een brief d.d. 27 februari 1990 an schijiver dezes. Zie ook Parl. Gesch. Overgangsrecht, p. 14, eerste zin.

7. Zie Parl. Gesch. Overgangsrecht, o.a. p. 17,80,82. Zie vovorts de nrs. 2.2 .2 en 2.5.1. I sub d hiervóor. 
hulp worden genoepen om de nieuwe wet deze rechtshandelingen te laten "bereiken".

Ik zie geen goede reden voor het maken van een onderscheid tussen vernietigbaarheid enerzijds en nietigheid en onaantastbaarheid anderzijds. Ik zou nietigheid en onaantastbaarheid evenals vernietigbaarheid willen bestempelen tot eigenschappen die voortduren in de tijd en verdwijnen en verschijnen met de wet die ze voortbrengt (behalve dan bij 'voldongen feiten'). Aldus zou bij voorbeeld een voorheen vernietigbare, volgens de nieuwe wet nietige rechtshandeling bij het toepasselijk worden van die nieuwe wet niet onaantastbaar worden, maar nietig8. Uiteraard zouden op zo'n puur technisch uitgangspunt inzake het verdwijnen en verschijnen van nietigheden ete. als eigenschappen van rechtshandelingen uitzonderingen kunnen worden gemaakt door de werking van de nieuwe wet op enigerlei wijze tegen te gaan of te verzachten. Ter vermijding van verdere complicering zal ik hiema echter de visie van de overgangswetgever aanhouden 9 .

De categorie van de 'voldongen feiten' maakt de materie er niet overzichtelijker op. Niet altijd zal even duidelijk zijn, of men nu via de route van de "voldongen feiten' of via die van artikel 79 OW I moet gaan om tot onaantastbaarheid ook na de invoering te komen ${ }^{10}$.

De al dan niet wenselijkheid van wisselingen in de status van anterieure rechtshandelingen is moeilijk in het algemeen te beoordelen. Ik zal er daarom hierna bij de diverse categorieën afzonderlijk iets over zeggen. De overgangswetgever heeft de statuswisselingen in een aantal gevallen niet aanvaardbaar geoordeeld, zoals uit onderstaand overzicht blijkt.

\subsection{DE OVERGANGSWET EN DE GELDIGHEID VAN RECHTSHANDELINGEN}

Verreweg de belangrijkste overgangsregels voor de geldigheid van rechtshandelingen zijn te vinden in de artikelen 79-81 Ow I. Ik beperk mij hier tot deze bepalingen.

Ik maak enkele algemene opmerkingen vooraf. De artikelen 79-81 Ow I zijn opgenomen onder de overgangsbepalingen in verband met Boek $3 \mathrm{BW}$ en niet onder de algemene overgangsbepalingen in verband met de Boeken 3-8 BW (artikelen 68a-75 Ow l). Deze plaatsing neemt echter niet weg dat de artikelen 79-81 Ow I een (zeer) algemeen karakter dragen, zoals hierna nog wel zal blijken. Dit algemene karakter komt ook tot uiting in de toelichting:

'Ten slotte moge er de aandacht op worden gevestigd dat de artikelen 79-81 niet alleen gelden voor de bepalingen wan titel 3.2, maar ook woor hetgeen elders in de Boeken 3 e.v. ontrent de geldigheid, nietigheid en vernietigbaar-

8. Vgl in soortgelijke zin Mon. Nieuw BW A-25 (De Vries Lentsch-Kostense), p. 69; zie verder nr. 4.8 hierna.

9. Zie voor deze visie Parl. Giesch. Overgangsrecht, p. 76 e.v.; De Die, AA 1991, p. 824.

10. Vgl. in soortgelijke zin Mon. Nieuw BW A-25 (De Vries Lentsch-Kostense) , p. $29,34$. 
heid van rechtshandelingen is bepaald, bij voorbeeld in afdeling 3.7 .3 en de artikelen 6.5.2.11-12a (6:228-230)."

De algemene aard van de artikelen 79-81 Ow I komt ook elders tot uiting. In artikel 1 lid 2 Ow II worden zij van overeenkomstige toepassing verklaard op de wijzigingen in de bij de invoering van het nieuwe BW bestaande wetgeving ${ }^{12}$. In artikel V lid 1 van het wetsvoorstel dat onder meer strekt tot aanpassing van de Wet op het consumentenkrediet aan de Boeken 3, 5 en 6 van het nieuwe BW worden de artikelen 79-81 OW I van overeenkomstige toepassing verklaard op de voorgestelde wijzigingen in de Wet op het consumentenkrediet ${ }^{13}$.

Uitgangspunt in de artikelen 79-81 Ow I is de eigenschap van de bestaande rechtshandeling ${ }^{14}$. Was deze handeling volgens het oude recht onaantastbaar en is dat volgens het nieuwe anders, dan biedt artikel 79 Ow I de helpende hand. Zat er daarentegen naar oud recht een steekje los aan de handeling, dan kan bij een verschil met het nieuwe recht op het punt van haar geldigheid te rade worden gegaan bij de artikelen 80 Ow I (in geval van vernietigbaarheid volgens oud recht) en 81 . Ow I (in geval van nietigheid volgens oud recht).

Een laatste algemene opmerking is deze, dat de artikelen 79-81 Ow I. zien op rechtshandelingen die zijn verricht voordat het nieuwe recht daarop toepasselijk wordt. Zoals bekend behoeft dat toepasselijk worden niet samen te vallen met de inwerkingtreding ${ }^{15}$.

Een rechtshandeling die onaantastbaar was volgens het oude recht kan naar nieuw recht wel met een gebrek behept zijn. Het gaan werken van het nieuwe recht voor zo'n rechtshandeling heeft krachtens artikel 79 Ow I geen gevolgen voor haar onaantastbaarheid. Naar oud recht vernietigbare rechtshandelingen die onder nieuw recht niet aan een onvolkomenheid zouden lijden verliezen hun aantastbaarheid (artikel 80 lid 1 Ow I). Zouden zij daarentegen door het nieuwe recht als nietig worden aangemerkt, dan worden zij wanaf het toepasselijk worden van het nieuwe recht met terugwerkende kracht nietig (artikel 80 lid 2 Ow I). Voorheen nietige rechtshandelingen die volgens nieuw BW onaantastbaar zouden zijn worden op grond van artikel 81 lid 1 Ow I op het moment van het toepasselijk worden van het nieuwe BW met terugwerkende kracht tot onaantastbare bekrachtigd. Bestempelt het nieuwe BW het gebrek van vroeger nietige rechtshandelingen als vemietigbaar* heidsgrond, dan gelden zij vanaf genoemd moment als vernietigbaar (artikel 81 lid 2 OW I). Aldus zien vrij vertaald de hoofdlijnen wan de artikelen 79-81 OW I eruit.

11. Parl. Gesch. Overgangsrecht, p. 77-78. Zie ook p. 7. In KKwartaalbericht Nieuw BW 1986, p. 80, oefende ik kritiek uit op het feit dat de artikelen 79-81 Ow II (die toen anders luidden, maar dat is hier niet relevant) niet onder de allgemene overgangsbepallingen zijn opgenomen. Zie ook Mon. Nieuw BW A-25 (De Vres Lentsch-Kostense), p. 35, 40.

12. Zie woor woorbeelden: Parl. Gesch. Overgangsrecht, p. 237, 239-240, 334, 353-354, 355, 358. De hier voorkomende verwijzingen naar de artikelen 79-81. Ow I zijn niet juist meer alls gevolg van het feit dat deze bepalingen naderhand geheel nieuw zijn opgezet.

13. TK, vergaderjaar 1990-1991, 22 109. Zie de toelichting (stuk nt 3), p; 6-7.

14. Ondler 'rechtshandeling' vallen behalve eenzijdige en meerzijdige rechtshandelingen ook bedingen als onderdeel van een rechtshandeling; zie Parl. Gesch. Overgangsrecht; p. 46 e.v., 81.

15. Zie aver toepasselijkheid en inwerkingtreding respectievelijk de nrs. 2.2 .4 en 2.2 .3 hiervór. 
Thans ga ik over tot het per categorie bespreken van de diverse overgangsvarianten bij de geldigheid van rechtshandelingen ${ }^{16}$.

\subsection{ONAANTASTBAAR-(VER)NIETIG(BAAR)}

\subsubsection{Algemeen}

Stel de nieuwe wet stelt voor een voorheen bestaande onaantastbaarheid vernietigbaarheid of nietigheid in de plaats. Zou zij gaan werken voor overgangssituaties, dan zou dat betekenen dat bij de invoering aanwezige rechtshandelingen hun 'heelheid' zouden kunnen kwijtraken. Het bij de invoering vervuld zijn van de vereisten van de nieuwe wet woor het rechtsgevolg vernietigbaarheid zou leiden tot het intreden van dat rechtsgevolg ${ }^{17}$. In de toelichtende stukken wordt opgemerkt:

"Juist uit de mogelijkheid tot vernietiging, evenals uit die tot bevestiging en bekrachtiging, blijkt dat over de geldigheid van een rechtshandeling niet reeds bij haar geboorte behoeft te worden beslist. Het is denkbaar, haar die eigenschap van vatbaarheid voor vernietiging ook later mee te geven. ${ }^{18}$

De nieuwe wet kan dus nieuwe vernietigbaarheden scheppen, indien zij toepasselijk wordt op overgangssituaties. Voor nietigheid als "momentele" eigenschap zou dit bij afwezigheid van terugwerkende kracht echter niet opgaan in de in or. 4.3 hiervóór uiteengezette gedachtengang van de ontwerper van het overgangsrecht. Elders maakt hij echter een opmerking die wat dit laatste betreft in een andere richting wijst, evenals voorbeelden in de toelichtende stukken bij artikel $79 \mathrm{Ow}$ I (zie de nrs. 4.5.2 e.v. hierna). De nieuwe wet zou bij onmiddellijke werking

'ex nunc (...) een geldige rechtshandeling - bijvoorbeeld een lopende overeenkomst of een beding daarin - nietig of vernietigbaar (kunnen) verklaren.' 19

Ik ga aan dit punt verder voorbij.

Meestal wordt het tornen aan de onaantastbaarheid van anterieure rechtshandelingen niet acceptabel geacht. Dit in weerwil van het feit dat de wetgever niet voor niets bepaalde onder het oude recht onaantastbare rechtshandelingen tot vernietigbaar of zelfs nietig zal bestempelen: deze handelingen zullen in onze rechtsorde om welke reden dan ook niet toelaatbaar worden geacht ${ }^{20}$. Zo kan het

16. Het aspect van de verjaring laat ik buiten beschouwing. Zie daarover het preadvies van Pollak voor de Vereniging voor Burgerlijk Recht (1991).

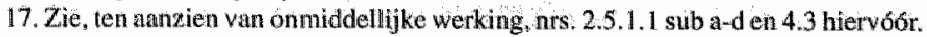

18. Pist. Gesch. Overgangsneeht, p. 81.

19. Aldus De Die, A A 1991, p. 824 (mijn corsivering HudB).

20. Vigl, bij voorbeeld Contuactenrecht I-E (De Loos-Wijker), nr. 149 . 
'gaan om rechtshandelingen die toch als bedenkelijk worden beschouwd, doch die door de formulering van het oude recht aan vernietigbararheid ontsnapten. 21

Daarnaast moeten de nieuwe bepalingen inzake vernietigbaarheid en nietigheid duidelijker, beter en vollediger dan de oudle worden geacht ${ }^{22}$.

Vóór eerbiediging van de onaantastbaarheid van rechtshandelingen pleit dat het nogal eens in strijd met de rechtszekerheid dan well het vertrouwensbeginsel zou zijn, om datgene wat voorheen onaantastbaar was, vanaf de inwerkingtreding plotsklaps (ver)nietig(baar) te verklaren. De justitiabelen hebben de nieuwe strengere bepalingen moeilijk kunnen voorzien of daarmee slecht rekening kunnen houden. Sprekend zijn in dit opzicht gevallen waarin grote financièle belangen in liet geding zijn en waarin tegen de achtergrond van het huidige recht na uitvoerige onderhandelingen afspraken zijn gemaakt, die voor een lange reeks van jaren moeten gelden. Volgens de minister zou de wetgever in zulke gevallen 'licht het gevonden evenwicht verstoren door bepaalde bedingen uit een pakket ongeldig te verklaren, ${ }^{23}$

De afweging kan echter wel degelijk anders uitvailen, zoals bij de algemene voorwaarden: na een periode waarin de gelegenheid bestaat tot aanpassing kunnen de valbijlen van afdeling $6.5 .3 \mathrm{BW}$ hun werk gaan doen (zie nr. 4.5 .6 hierna) ${ }^{24}$.

De in de Overgangswet gekozen benadering doet recht aan de verscheidenheid die de onderhavige materie te zien geeft. Uitgangspunt is de eerbiediging van de onaantastbaarheid van bestaande rechtshandelingen. Daarop wordt bij voorbeeld bij de algemene voorwaarden een uitzondering gemaakt. Genoemd uitgangspunt wordt in artikel 79 OW I als volgt geformuleerd:

"Tenzij anders is bepaald, wordt een rechtshandeling die is verricht voordat de wet daarop van toepassing wordt, niet nietig of vernietigbaar ten gevolge van een omstandigheid die de wet, in tegenstelling tot het tevoren geldende recht, aanmerkt als een grond van nietigheid of vernietigbaarheid:"

Voor zover op grond van zodanige rechtshandeling een absoluut of relatief vermogensrecht is verkregen, komt men als gevolg van deze bepaling niet meer toe aan de eerbiediging van verkregen rechten ex artikel 690 ow $\mathbb{1}^{25}$.

In het navolgende zal blijken waar artikel 790 w I zo al toepassing kan vinden en waar niet.

21. Aldus de minister Parl. Gesch Overgangsrecht, p. 81 .

22. Zie Parl. Giesch. Overgangstecht, p. 77, 78. In Kwartaalbericht Wieuw BW 1986, p. 81, pleitte ik mede met het oog hierop voor minder coulance dan in (thans) artikel 79 Ow I wordt betoond. In deze zin ook Junsen, Kwartaalbericht Nieuw BW 1.985, p. 59.

23. Parl. Gesch. Overgangsrecht, p. 49-50; zie voorts p. 46 en De Die; AA 1991, p. 825.

24. De Die, AA 1991, p. 825-826, 828, 829, noemt nog andere overwegingen die een rolkunnen spelen bij de bepaling van de temporele werking van een tileuwe (wer)nietig(baar)heid. Het hierna an de orde komende artikel $79 \mathrm{OW}$ lis een concretisering van de door De Die, wa.p, onderscheiden beginselen van de geidige rechtshandeling en van de gunstigste bepaling. Zie over dit laatste beginsel ock Polman, diss., $15.77-79$. 25. Vgl. Mon. Nieuw BW A-25 (De Vries Lentsch-Kostense), p. 34. 
In artikel 3:43 lid $\mathbb{B}$ BW worden rechtshandelingen die strekken tot verkrijging van bepaalde goederen door de daar genoemde functionarissen verboden. De toelichting $^{26}$ op het artikel meldt dat de term 'verkrijging' ruim moet worden opgevat. Hieronder vallen behalve verkrijging door overdracht alle wijzen van verkrijging doot middel van een rechtshandeling. Als voorbeeld van zo'n andere wijze van verkrijging wordt onder meer genoemd de verkrijging van een hypotheekrecht door cessie van de vordering waaraan het is verbonden. Ook de vestiging en afstand van beperkte rechten (vgl. artikel 3:98 BW) vallen onder de term 'verkrijging'. Het is twijfelachtig of de artikelen 1504-1506 (oud) BW net zo veelomvattend waren als artikel 3:43 BW27. Mocht dit niet zo zijn geweest, dan is hier door verruiming van de vereisten onaantastbaarheid teruggedrongen ten gunste van nietigheid. Voor de nieuwe nietigheid wordt een bestaande rechtshandeling echter zo nodig behoed door artikel 79 Ow I.

\subsubsection{Wilsgebreken}

Artikel 1361 (oud) BW bepaalde dat geweld (thans: bedreiging) niet slechts een overeenkomst nietig (lees: vernietigbaar) maakte, indien het was gepleegd jegens één der handelende partijen, maar ook wanneer diens echtgenoot of bloedverwanten in de opgaande of nederdalende lijn werden bedreigd. In artikel 3:44 lid $2 \mathrm{BW}$ is deze beperking tot bepaalde groepen derden geschrapt en wordt van 'derde' zonder meer gesproken. Thans kan derhalve ook bedreiging van bij voorbeeld een verloofde, een pleegkind, een broer of een zus grond voor vernietiging wegens bedreiging opleveren ${ }^{28}$. Deze verruiming van de vereisten levert het koppel onaantastbaar volgens oud en vernietigbaar volgens nieuw recht op.

Titel $3.2 \mathrm{BW}$ biedt wellicht nog een voorbeeld. In artikel 1364 (oud) BW werd bedrog gepleegd door een derde niet tot grond voor vernietigbaarheid van de daardoor totstandgekomen overeenkomst bestempeld. In artikel 3:44 lid $5 \mathrm{BW}$ gebeurt dit wel, zij het dat op het gebrek geen beroep kan worden gedaan jegens een wederpartij die geen reden had het bestaan ervan te veronderstellen. Behoudens deze uitzondering zou hier dus sprake zijn van het geval: onaantastbaar naar oud BW en vernietigbaar naar nieuw BW. Het is echter nog maar de vraag of onder het oude recht een overeenkomst onaantastbaar was, indien deze was totstandgekomen door bedrog van een derde, terwijl de wederpartij reden had het bestaan van het wilsgebrek te veronderstellen. Men zou namelijk kunnen aannemen dat in zo'n geval de wederpartij zich zelf aan bedrog schuldig maakte, zodat de overeenkomst vernietigbaar was ${ }^{29}$. De minister noemt de door bedrog van een derde totstandgekomen

26. Parl. Gesch. Irv. Boek 3, p. 1143.

27. Vgl. Asser-Kamphuitsen, p. 47.

28. Deze voorbeelden worden genoemd door Meijers in diens toelichting, zie Parl. Gesch. Boek 3, p. 209. Vgl. voorts Parl. Gesch. Overgangsrecht, p. 251. Hartkamp wil artikel 1361 (oud) BW echter niet als limitatief opvatten, zie Asser. Hiartkamp II, nr. 208.

29. Vgl. Asser-Hartkamp II, nr. 203. 
rechtshandeling als voorbeeld van een onder het oude recht onaantastbare rechtshandeling 30 .

Tegen de eventuele nieuwe vernietigbaarheid worden anterieure rechtshandelingen beschermd door artikel 79 Ow 1 .

\subsubsection{Beperkte rechtien}

Vruchtgebruiker en hoofdgerechtigde kunnen onder het oude recht bedingen zijn overeengekomen inzake de gestanddoening van door de vruchtgebruiker aangegane huur- en pachtovereenkomsten door de hoofdgerechtigde. Deze bedingen kunnen afwijken van artikel 3.217 leden 3-5 BW. Met name lid 5 inzake huur van woonruimte is nieuw ${ }^{31}$.

Sterk afwijkend van het oude recht is de nieuwe regeling van thet hypothecaire huurbeding in artikel 3:264 BW. Aan de leden $4-8$ is in artikel 115 lid 1 OW II een uitgestelde werking van drie jaar toegekend, dus tot 1 januari 1995. Alsdan zullen ongetwijfeld nog anterieure huurbedingen bestaan die afwijken van het nieuwe rechit. Een hypotheekhouder kan voorts vór de inwerkingtreding een beheersen/of ontruimingsbeding hebben gemaakt, dat in strijd is met artikel 3:267 BW. Deze bepaling heeft geen voorloper in het oude wetboek ${ }^{32}$.

Eventuele bedingen in de akte van vestiging van een erfdienstbaarheid inzake de aansprakelijkheid van de verkrijger van (een deel van of een aandeel in) het heersende of dienende erf voor de in artikel 5:77 lid $1 \mathrm{BW}$ bedoelde geldelijke verplichtingen mogen thans niet ten nadele van de verkrijger afwijken van artikel $5: 77$ lid 2 BW (zie lid 3). Vroeger bestond op dit punt een lacune. Het bovenstaande geldt ook voor erfpacht (artikel $5: 92$ leden 2 en $3 \mathrm{BW}$ ) en opstal (artikel 5:104 lid $1 \mathrm{BW}$ ).

De regelling van de erfpacht biedt nog enkele andere voorbeelden. In artikel 5:85 lid $2 \mathrm{BW}$ wordt voor het geval dat in de akte van vestiging van de erfpacht aan de erfpachter de verplichting wordt opgelegd een canon te voldoen, bepaald dat dit een canon in geld moet zijn. Het gaat hier om dwingend recht ${ }^{33}$. In artikel 767 lid 1 (oud) BW werd echter ook een canon in voortbrengselen of in vruchten toegela$\operatorname{ten}^{34}$.

Voor de praktijk wan het nodige belang is het geval van het voorheen onaantastbare beding in akten van vestiging van erfpacht, dat in strijd is met artikel $5: 87$ lid $2 \mathrm{BW}$ (opzegging van de erfpacht wegens wanbetaling van de canon door de erfpachter of het door hem in ernstige mate tekortschieten in de nakoming van zijn andere verplichtingen) en daarom nietig is (artikel 5:87 lid $3 \mathrm{BW}^{35}$. Thans zijn dus,

30. Parl. Gesch. Overgangsreclit, p. 78, 81 .

31. Vgl. Parl. Gesch. Overgangsrecht, p. 269; Mon. Nieuw BW B-10 (Kleijn)» p. 34 e. v..

32. Vgl. Parl. Gesch. Overgangsrecht, p. 274.

33. Vgl. Parl. Gesch. Boek 5, p. 301-302. Op p. 302 wordt opgemerkt dat het op grond van artikel 5:90 lid 1 $\mathrm{BW}$ wèl is toegestaan, in de akte van vestiging te bepalen dat de wruchten en roerende voordelen die de in erfpacht gegeven zaak zelf oplevert, geheel of ten dele niet aan de erfpachter, maar aan de eigenaar toekonen. 34. Vgl. Parl. Gesch. Overgangsreclit, p. 292.

35. Vgl. Part. Gesch. Overgangsrecht, p. 145, alwaar er kennelijk aan wordt voorbijgezien, dat in de praktijk nog all eens van artikel 780 (oud) BW werd afgeweken (zie bij voorbeeld het in de tekst geciteerde beding). Zie over de werking in de tijd van artikel 5:87 lid $2 \mathrm{BW}$ ook nr. 7.8.2 hierna. 
andlers dan voorheen, ongeoorloofd bedingen als het volgende, ontleend aan gemeentelijke erfpachtswoorwaarden die dateren van vóór de invoering van het nieuwe BW:

In afwijking van de bepalingen van de artikelen 780 en 781 van het Burgerlijk Wetboek kan, indien de erfpachter langer dan 6 maanden in gebreke is om de canon te betalen, alsmede in geval niet wordt voldaan aan enige verplichting, de erfpachter opgelegd bij of krachtens deze algemene voorwarden of de afzonderlijke akte van uitgifte, het erfpachtsrecht bij besluit van de gemeenteraad vervallen verklaard worden, onverminderd het recht van de gemeente op schadevergoeding wanneer daartoe termen zijn."

In artikel 5:98 lid 1 BW wordt bepaald dat de erfpacht blijft doorlopen, wanneer de tijd waarvoor zij is gevestigd is verstreken en de erfpachter de zaak op dat tijdstip niet heeft ontruimd, tenzij de eigenaar uiterlijk zes maanden na dat tijdstip doet blijken dat hij de erfpacht als geëindigd beschouwt. De eigenaar en de erfpachter kunnen de aldus verlengde erfpacht conform artikel 5:88 $\mathrm{BW}$ opzeggen. leder beding dat ten nadele van de erfpachter van artikel 5:98 lid $1 \mathrm{BW}$ afwijkt is volgens lid 2 nietig $^{36}$ : Onder het oude recht werd aan partijen de vrije hand gelaten: artikel 779 (oud) BW bevatte regelend recht (zie artikel 782 (oud) BW). Kortom: wat onaantastbaar was onder het oude recht, is nietig onder het nieuwe ${ }^{37}$. Ditzelfde geldt voor bedingen die afwijken van artikel 5:100 lid $1 \mathrm{BW}$ inzake het retentierecht van de erfpachter (zie lid 2) ${ }^{38}$.

Vorenstaande situaties worden als gevolg van artikel 79 Ow I niet beroerd door de wijzigingen die het nieuwe BW heeft gebracht. Bij het erfpachtsrecht kan deze eerbiediging zich nog over vele tientallen jaren doen gevoelen. Dit veelvuldig voorkomende ${ }^{39}$ zakelijke recht wordt immers vaak voor lange duur gevestigd. De vraag kan worden gesteld of eerbiediging van soepeler oud recht hier well geïndiceerd is. Deze eerbiediging heeft namelijk tot gevolg dat erfpachters, in geval van erfpacht die bestaat bij de inwerkingtreding, verstoken blijven - mogelijk gedurende vele jaren - van de bescherming die de artikelen 5:87, 98 en 100 BW bieden. Had hier uitgestelde werking van de nieuwe regels, bij voorbeeld van een jaar, niet meer voor de hand gelegen? In het 'overgangsjaar' zouden partijen dan de erfpachtsvoorwaarden aan de nieuwe regels hebben kunnen aanpassen ${ }^{40}$.

Hiermee is echter ten aanzien van de beperkte rechten het verhaal nog niet compleet. Zo kan bij vruchtgebruik en hypotheek de werking tegenover derden van bedingen in met name akten van vestiging ontbreken, ook al wordt de onaantastbaarheid van die bedingen gecontinueerd. Ik diep dit iets uit voor de werking van het hypothecatire huurbeding jegens een huurder. Als gezegd is de toepasselijkheid van

36. Vgl. voor opstal artikel 5:104 lid 2 BW.

37. Vgl Parl. Gesch. Overgangsrecht, p. 293-294.

38. Vgl Parl. Gesch. Overgangsrecht, p. 294 (krachtens artikel 79 OW I geldt de onmiddellijke werking ex artikel 180 Ow I dus niet voor lid 2 van artikel 5:100 BW).

39. Alleen al door de gemeente Rotterdam waren eind 1987 blijkens een advertentie in Intermediair (d.d. 14 decenber 1987 ) maar liefst 11.000 percelen in erfpacht uitgegeven.

40. Vgl. het in ur. 4.5.6 hierna te behandelen artikel $1.91 \mathrm{OW}$ I inzake algemene voorwaarden: 
de leden 4-8 van artikel 3:264 BW op vroegere hypotheekrechten uitgesteld tot $1 \mathrm{ja}$ nuari 1995 (artikel 115 lid 1 Ow I). Vele van deze hypotheekrechten, voorzien van een met de nieuwe regels strijdig huurbeding, zullen op deze datum nog aanwezig zijn. Tussen hypotheeknemer en -gever blijft de status van zo'n voorheen onaantastbaar beding vanaf 1 januari 1995 gelijk. Bit resultaat kan afhankelijk van de redactie van het huurbeding langs twee wegen worden bereikt.

Een huurbeding kan verwijzen naar het desbetreffende oude wetsartikel (1230 BW), of deze bepaling parafraseren. Artikel $71 \mathrm{Ow}$ I zegt voor zo'n geval dat het beding wordt geacht een verwijzing naar of weergave van 'dle wet' in te houden, tenzij zulks niet in overeenstemming zou zijn met de strekking van het beding. Deze uitzondering zal hier nogal eens van toepassing zijn ${ }^{4}$. Op de vraag van de Tweede Kamer of artikel 71 Ow I ook de situatie betreft dat een beding verwijst naar een regel van de oude wet, die in het systeem van de nieuwe wet juist nietig is, antwoordt de minister namelijk:

'Bij artikel 71 lid 2 (thans artikel $71, \mathrm{HvdB}$ ) is het zaak allereerst na te gaan, wat partijen met hun verwijzing zullen hebben bedoeld, en vervolgens, hoe dat onder het nieuwe recht het best kan worden werwezenlijkt. Sluit het nieuwe recht zelf die weg af, dan zal inderdaad de strekking van het beding gewoonlijk medebrengen dat het beding overeenkomstig het oude recht wordt uitgevoerd.' ${ }^{2}$

De consequentie van deze uitleg van het huurbeding moet zijn dat het ook na 1 januari 1995 onaantastbaar blijft.

Houdt het huurbeding geen verwijzing naar of parafrase van artikel 1230 (oud) $\mathrm{BW}$ in, dan wordt de onaantastbaarheid ervan geëerbiedigd door artikel $790 \mathrm{OW}$ l.

Beide wegen leiden ook in een ander opzicht tot hetzelfde resultaat: vanaf $1 \mathrm{ja}$ nuari $1995 \mathrm{kan}$ het anterieure huurbeding dat ten nadele van de huurder afwijkt van artikel 3:264 leden 4-8 BW jegens hem niet meer worden ingeroepen. De gehandhaafde onaantastbaarheid van het beding in de verhouding tussen hypotheekgever en -nemer doet daaraan niet af. Dit volgt uit het systeem van de Overgangswet. Het rechtsgevolg van werking, zoals hier van een beding tegenover derden, "gaat en komt' met de wet die het schept. Bij het huurbeding vindt dit 'gaan en komen' als gevolg van de uitgestelde werking ex artikel 115 lid $\mathbb{1}$ Ow I pas drie jaar na de inwerkingtreding plaats ${ }^{43}$.

Voor het erfpachts- en opstalrecht kent de Overgangswet nog twee afwijkingen van artikel 79 Ow I. Voor erfpachten gevestigd onder het oude recht blijft de opzeggingsbevoegdheid van de artikelen 766 jo. 783 (oud) BW in stand. De wijze van opzegging die artikel 5:88 lid $1 \mathrm{BW}$ dwingend voorschrijft (exploit) wordt echter ver-

41. Anders nog Parl. Gesch. Overgangsrecht, p. 47, op een moment dat de leden 4-8 nog niet than artikel $3: 264 \mathrm{BW}$ wiren toegevoegd.

42. Parl. Gesch. Overgangsrecht, p. 49, 50.

43. Zie Parl. Gesch. Overgangsrecht, p. 16-17 (algemeen); p. 274 (ten aanzien wam het huurbeding, in een stadium dat nog niet wan de uitgestelde werking ex artikel 115 lid I OW I sprake was) en p. 119120 (inzake artikel 115 lid 1 Ow I). Met betrekking tot vruchtgebruik en erfpacht worden in de toelichtende stukken opmerkingen van soortgelijke strekking gemaakt: zie Parl. Gesch. Overgangsnecht, p: 269 (inzake het hierboven in de tekst genoemde artike $13: 217$ leden 3-5 BW) en p. 292 (inzake erfpacht in bet algemeen). 
plicht gesteld voor het geval van gebruikmaking van de gehandhaafde opzeggingsbewoegdheid (artikel $166 \mathrm{Ow} \mathrm{I).} \mathrm{Artikel} 167 \mathrm{Ow}$ I voorziet in omzetting van bevoegdheden van erfpachters tot eenzijdige afstand in bevoegdheden tot opzegging. Ook voor de gebruikmaking van deze bevoegdheden wordt de genoemde wijze van opzegging bij exploit dwingend voorgeschreven. De artikelen 166 en 167 Ow I worden in artikel 171 Ow I van overeenkomstige toepassing verklaard op opstalrechten in dezelfde gevallen waarin die artikelen op erfpacht van toepassing zijn, en voor zover de opstalrechten aan de daar bedoelde erfpachtsregels onderworpen zijn ${ }^{44}$.

\subsubsection{Uitsluiting van matiging}

Een ander onderwerp waarvoor artikel 79 Ow I van belang kan zijn is het boetebeding. Indien in zo" $n$ beding wordt afgeweken van artikel 6:94 lid $1 \mathrm{BW}$ is het volgens lid 3 nietig. Zo'n afwijkend beding was opgenomen in de bemiddelingsovereenkomst tussen de Nationale Volksbank N.V. en Helder:

'In geval van overtreding van enige bepaling uit deze overeenkomst is de overtredende partij aan de andere partij zonder nadere ingebrekestelling voor iedere overtreding per cliẻnt een niet woor matiging vatbare boete verschuldigd van $f 10000$ : 45

Een beroep op zodanig beding kon in strijd zijn met de goede trouw (artikel 1374 lid 3 (oud) $\mathrm{BW}$ ), maar het beding was niet nietig of vernietigbaar ${ }^{-46}$. Voor overgangssituaties moet echter worden bedacht dat op grond van artikel $182 \mathrm{Ow} \mathrm{I} \mathrm{I}^{47}$ artikel 6:94 BW niet toepasselijk is, indien de schuldenaar vóór de inwerkingtreding is tekortgeschoten in de nakoming van zijn verbintenis, zodat alsdan artikel 79 Ow I niet voor toepassing in aanmerking komt.

In afwijking van het oude rech ${ }^{48} \mathrm{komt}$ de rechter volgens artikel 6:109 lid $1 \mathrm{BW}$ de bevoegdheid toe; een wettelijke verplichting tot schadevergoeding te matigen. leder beding in strijd met lid 1 is nietig (lid 3). Gelet op artikel 182 Ow I kan ook hier niet aan artikel $79 \mathrm{Ow}$ I worden toegekomen in geval van een tekortkoming in de nakoming van een verbintenis vóór de inwerkingtreding.

\subsubsection{Algemene voorwaarden}

De regeling van de algemene voorwaarden in afdeling $6.5 .3 \mathrm{BW}$ staat bol van de nieuwe vernietigbaarheden. Artikel 79 Ow I heeft het hier niet voor het zeggen. Be-

44. Zie Parl. Geseh. Overgangsrecht, p. 144-145 (artikel 1660w 1); p. 145-146 (artikel 167 Ow I); p. 147 (artikel 171 ow I).

45. Het beding wordt geciteerd in de conclusie wan de A-G Mok (NJ 1984, p. 2344) woor het hierna te noemen arrest van de Hoge Raad in deze zaak.

46. Zie HR 27 april 1984, NJ 1984, 679 (NVB-Helder); Parl. Gesch. Overgangsrecht, p. 307.

47. $2 \mathrm{ie}$ daarover hoofdsuk 7 hierna.

48. Zile Asser-Hartkamp II, nr. 493. 
palend is artikel 191 OW L. Omdat voorheen gebruikte algemene voorwaarden met het oog op genoemde afdeling moeten worden 'gescreend' en waar nodig aangepast, geeft lid 1 daarvoor aan de gebruikers (bedrijven, vrije beroepsbeoefenaren, overheidsinstanties etc.) tot één jaar na de inwerkingtreding (dus tot 1 januari 1993) de tijd: werden algemene voorwaarden op het moment van de inwerkingtreding reeds in overeenkomsten gebruikt $t^{49}$, dan wordt afdeling $6.5 .3 \mathrm{BW}$ daarop pas met ingang van genoemde datum toepasselijk. Dit geldt ook, indien partijen na de inwerkingtreding (maar vóór 1 januari 1993) hebben gecontracteerd. De uitgestelde werking geldt eveneens, ingeval tijdens het 'uitsteljaar' wijzigingen in de voorwaarden worden aangebracht. Krachtens artikel $68 a$ lid $2 \mathrm{Ow} I$ blijft gedurende dit jaar het oude recht ter zake van algemene voorwaarden toepasselijk.

Het praktische belang van artikel 191 lid 1 Ow I moet niet worden overschat. Onder het oude recht werd immers tot op zekere hoogte vooruitgelopen op afdeling 6.5.3 BW50 51 .

'Uitstel' betekent hier geen afstel, behalve in geval van een overeenkomst die er bij de invoering nog wel was, maar een jaar later niet meer. Bij een overeenkomst waarin 'oude' allgemene voorwaarden zijn geïncorporeerd en die op 1 januari 1993 nog bestaat, kan vanaf deze datum toetsing aan afdeling $6.5 .3 \mathrm{BW}$ plaatsvinden. Volgens artikel 191 lid 2 Ow I kunnen in zo'n geval bedingen uit de algemene voorwaarden vanaf $\mathbb{1}$ januari 1993 in afwijking van artikel 79 Ow I overeenkomstig de nieuwe afdeling worden vernietigd. De vernietiging heeft echter geen werking over het tijdvak voordat afdeling 6.5.3 BW toepasselijk is geworden, tenzij het beding toen reeds vernietigbaar of nietig was.

Deze overgangsregeling is in meerdere opzichten interessant. Dit geldt bij voorbeeld voor het aanknopen bij ten tijde van de inwerkingtreding reeds in overeenkomsten gebruikte algemene voorwairden. Dit heeft de hierboven al genoemde consequentie dat alle in 1992 gesloten contracten waarop bedoelde algemene voorwaarden toepasselijk worden verklaard in dat jaar niet, althans niet rechtstreeks, worden beheerst door afdeling 6.5.3 BW. Derhalve vallen hier posterieure toestanden en feiten onder het oude recht, en dat betekent een afwijking van het begrip 'overgangssituatie' zoals dit door de overgangswetgever wordt gehanteerd ${ }^{52}$.

Een andere materie die hier bespreking verdient is de volgende. Stel A, gebruiker van algemene voorwaarden, heeft in 1990 een overeenkomst gesloten met wederpartij $\mathrm{B}$. Deze overeenkomst, bij voorbeeld een verzekeringsovereenkomst of een leverantieovereenkomst met een nutsbedrijf, loopt een aantal jaren. A brengt in

49. Uiteraard worden allgemene voorwaarden die na de inwerkingtreding het licht zien, ook al gebeurt dat in het jaar 1992, direct beheerst door het nieuwe recht. Hier is immers niet van een overgangssituatlie sprake.

50. Zie over het overgangsregine inzake algemene voorwaarden in verband met anticipatie nr. 2.6 .2 hiervớr. Tegen de uitgestelde werking ter zake van algemene voorwaarden hebben zich gekeerd: $H$. Stein, preadv., p. 83-84, 238, 239; Paquay, AA 1986, p. 517-524, met naschrift in AA 1987, p. 70-71; Wessels/Jongenteel, Algemene voorwaarden, p. 20, die ondermeer wijzen op de erwaringen met het Duitse AGB-Gesetz. In andere zin Spier, Kwartaalbericht Nieuw BW 1985, p. 54 jo. 53. Genoemde publicaties betreffen overi-

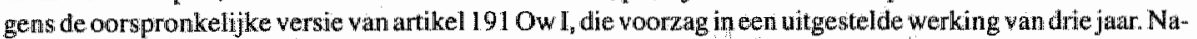
dat besloten was tot de 'gewenningstermign' wan twee jaar is de uitgestelde werking teruggebracht tot eén jaar. Zie Parl. Gesch. Overgangsrecht, p. 168, 169.

511. Zie over de woorden "de wet" in artikel 191 lid 1 Ow I nr. 2.5.1.1 sub a hiervóor.

52. Zie daarover nr. 2.4 .1 hiervóor, met name nr. 2.4 .1 .3 . 
1992 zijin algemene voorwatarden in overeenstemming met afdeling 6.5.3 $\mathrm{BW}$, altharis, dat zegt hij. $B$ vindt dat de aanpassing op een aantal punten lang niet ver genoeg gat om conformiteit met genoemde afdeling te bewerkstelligen. Het door A in 1992 aan B gedane voorstel tot wijziging van de overeenkomst, teneinde daarin de (ver)nieuw(d)e algemene voorwaarden te incorporeren, wijst B dan ook onder opgave van redenen resoluut van de hand. Op 1 januari 1993 bestaat de, ongewijzigd gebleven, overeenkomst nog steeds. Kan B dan bedingen uit de (oudel) algemene voorwaarden vernietigen, waarop gebruiker A zich in 1993 jegens B beroept (zie artikel 19l lid 2 OW I)? Naar mijn mening zal dit inderdaad kunnen, ervan uitgaande dat B het bij het rechte eind heeft met zijn oordeel over de onverenigbaarheid van we desbetreffende bedingen met afdeling $6.5 .3 \mathrm{BW}$.

Stel dat B geen bezwaar heeft gemaakt tegen de toepasselijkverklaring van de aangepaste algemene voorwaarden. Kan B dan vanaf 1 januari 1993 een "fout" beding in die aangepaste voorwaarden vernietigen? Dat zal B inderdaad kunnen doen. Zijn stilzwijgende (of uitdrukkelijke) aanvaarding van de toepasselijkverklaring van de aangepaste algemene voorwaarden brengt niet met zich mee dat hij geen beroep meer kan doen op de vernietigbaarheden in afdeling 6.5.3 $\mathrm{BW}$. Aanvaarding van de toepasselijkheid van algemene voorwaarden impliceert in het systeem van afdeling 6.5.3 BW geen instemming met de onredelijk bezwarende inhoud van bedingen uit die algemene voorwaarden.

Ook de zogenoemde informatieplicht is interessant vanuit overgangsrechtelijk oogpunt. Stel in het hierboven gegeven voorbeeld heeft B wel bezwaar gemaakt tegen toepasselijkverklaring van de (ver)nieuw(d)e voorwaarden, of heeft $\mathrm{A}$ verzuimd om zijn voorwaarden aan te passen aan afdeling 6.5.3 BW. In 1993 beroept $B$ zich in een conflict met $A$ onder meer op de vernietigbaarheidsgrond van de (sterk van het oude recht afwijkende) artikelen 6:233 sub b jo. $234 \mathrm{BW}$ : B vindt dat $A$ de daarin vervatte informatieplicht niet is nagekomen. Zal B's beroep slagen ${ }^{53}$ ?

Artikel 6:234 lid 1 BW geeft aan wanneer de 'redelijke mogelijkheid' tot kennisneming als bedoeld in artikel 6:233 sub b BW is geboden door de gebruiker. In de eerste plaats is dit het geval, indien A aan B de algemene voorwaarden vóór of bij het sluiten van de overeenkomst ter hand heeft gesteld (sub a). Dat heeft A echter niet gedaan; deze eis gold nog niet ten tijde van het sluiten van de overeenkomst (1990). In de tweede plats is de "redelijke mogelijkheid" geboden, ingeval de terhàndstelling redelijkerwijs niet mogelijk was, maar A aan B (kort gezegd) vóór de totstandkoming van de overeenkomst heeft medegedeeld waar de voorwarclen ter inzage lagen en dat zij op verzoek zouden worden toegezonden (sub b). Ook deze eisen golden in 1990 nog niet. Gebruiker A heeft ze niet in acht genomen, of heeft alleen de eerste in acht genomen door slechts aan te geven dat bij voorbeeld de yoorwaarden zijin gedeponeerd bij een Kamer van Koophandel of bij de griffie van een rechtbank. Voor het geval dat, zoals in casu, de voorwaarden niet vór of bij het sluiten van de overeenkomst aan de wederpartij ter hand zijn gesteld, geeft artikel 6.234 lid 2 BW de regel dat de bedingen uit de algemene voorwaarden tevens vernietigbaar zijn, indien de gebruiker de voorwaarden niet op verzoek van de wederpartij onverwijld op zijn kosten aan deze toezendt. De regels ten aanzien van de ver-

53 De toe lichtende stukken op artikel 191 Ow 1 zwijgen over deze vraag. 
plichting tot toezending gelden niet, voor zover toezending redelijkerwijze niet van de gebruiker kan worden gevergd (artikel 6:234 lid 3 BW). Dit laatste zou kunnen opgaan in de situatie dat gebraiker A een nutsbedrijf zou zijn, namelijk indien dit bedrijf zeer omvangrijke complexen van algemene voorwaarden zou gebruiken ${ }^{54}$. Ik zie verder van deze laatste mogelijkheid af.

Het systeem van de Overgangswet laat een beroep (vanzelfsprekend: vanaf 1 januari 1993) op de artikelen 6:233 sub b jo. 234 lid 1 BW ten aanzien van de onderhavige in 1990 gesloten overeenkomst toe. Hier is immers niet een extra eis (ontstaansvereiste) voor het overeenkomen van de toepasselijkheid van algemene voorwaarden aanwezig (het overeengekomen zijn van die toepasselijkheid is een "voldongen feit'55), maar een nieuwe grond voor vernietigbaarheid van (bedingen uit) de algemene voorwaarden ${ }^{56}$. Zoals in nr. 4.3 hiervóór bleek, gaat het bij vernietigbaarheid om een eigenschap van een rechtshandeling en om een bevoegdheid van een partij bij die handeling. Deze rechtsgevolgen gaan teniet en ontstaan met de wet waarop zij berusten.

Artikel 191 lid 1 Ow I maakt geen uitzondering voor de bepalingen inzake de informatieplicht. Uit de toelichting ${ }^{57}$ zou men zelfs kunnen afleiden dat dit ook de bedoeling van de wetgever is geweest. Men zou anders verwachten. De ratio van de uitgestelde werking (gelegenheid geven tot aanpassing van algemene voorwaarden) geldt niet voor de informatieplicht. Bovendien is vervulling van de eisen van artikel 6:234 lid 1 BW hier uit de aard der zaak onmogelijk, nu het sluiten van de overeenkomst met toepasselijkverklaring van algemene voorwaarden reeds enkele jaren vóor het gaan werken van deze bepaling heeft plaatsgevonden. Daarom behoort een beroep op artikel 191 lid 2 Ow I hier te stranden. Analoge toepassing van artikel 75 Ow $1^{58}$ of toepassing van artikel 6:248 lid $2 \mathrm{BW}^{59}$ kunnen hiervoor als grond dienen.

Het valt te verwachten dat vele gebruikers van algemene voorwaarden deze (na aanpassing aan afdeling $6.5 .3 \mathrm{BW}$ ) ter hand stellen of toezenden an wederpartijen met wie zij vóór de invoering of in 1992 hebben gecontracteerd. Uiteraard geldt dan a fortiori dat een beroep op artikel 191 lid 2 OW I jo. de artikelen $6: 233$ sub b en 234 lid $1 \mathrm{BW}$ behoort te stranden. Gebruikers van algemene voorwaarden doen er daarom verstandig aan om hun aan afdeling 6.5.3 $\mathrm{BW}$ aangepaste algemene voorwaarden aan hun wederpartijen ter hand te stellen of toe te zenden.

Stel nu dat gebruiker $\mathrm{A}$ in het voorbeeld terhandstelling of toezending van zijn al dan niet aangepaste voorwaarden nalaat. Artikel 6:234 lid 2 (en daarmee ook lid 3) BW biedt dan uitkomst. Deze bepalingen kunnen namelijk toepassing vinden tijdens het bestaan van de overeenkomst. Buiten overgangssituaties kan men aan lid 2 pas toekomen, indien men lid 1 is 'gepasseerd'. In overgangssituaties zal aan lid 1 vaak niet zijn voldaan. In het systeem van de Overgangswet "past' lid 1 niet voor

54. In Parl. Gesch. Inv. Boek 6; p. 1581-1582, worden de algemente voorwaneden van openbare nutsbedrijwen met bijbehorende normwoorschriften genoemd als woorbeeld wan voorwateden die zeer ornvangrijk zijn en soms boekwerken vullen.

55. Zie nir. $2.5,1.3$ sub c. 2 hiervóor.

56. De Vries Lentsch-Kostense, Mon. Nieuw BW A-25, p. 84, lijkt te opteren voor het 'voldongen feit'.

57. Parl, Gesch. Overgangsrecht; $\mathrm{p}$ : 168, eerste alinea (inzake artikel 6.5.2A.2 lid 2 onder b (oud))

58. Artikel 75 Ow I ziet immers alleen op de artikelen $68 a-73 a \mathrm{OW} \mathrm{L}$, zie ar: 2.5:3 hiervóror.

59. Zie nr. 2.5.3 hiervớr. 
zulke overgangssituaties. Daarom zou ik willen kiezen voor de oplossing, dat in die situaties (uiteraard: vanaf 1 januari 1993) een beroep kan worden gedaan op de vernietigbaarheid van artikel 6:234 lid $2 \mathrm{BW}$, indien gebruiker A de voorwaarden niet op eigen kosten op B's verzoek onverwijld aan deze toezendt. Daarop kan zo nodig de correctie van lid 3 worden aangebracht. Zo wordt met een kleine ingreep toch de informatieplicht hanteerbaar in overgangssituaties ${ }^{60}$.

Er is nog wel meer te zeggen over artikel 191 Ow I. Kortheidshalve moet ik echter voor het overige verwijzen naar de toelichtende stukken ${ }^{61}$.

\subsubsection{Rechtsgevolgen van overeenkomsten}

Een aantal van de bepalingen inzake de rechtsgevolgen van overeenkomsten bevat blijkens artikel 6:250 BW dwingend recht. Ik noem daarvan de artikelen 6:251 lid 3 (kwalitatieve rechten), 252 lid 2 voor zover het de eis van een notariële akte betreft, en lid 3 (kwalitatieve verplichtingen), 253 lid 1 (derdenbedingen), 257 (blokkering "paardesprong") $)^{62}$, en 258-260 BW (onvoorziene omstandigheden c.a.) ${ }^{63}$. De artikelen 6:251 lid 3,253 lid 1,257 en $258 \mathrm{BW}$ komen in beginsel met het oude recht overeen ${ }^{64}$, behalve artikel 6:253 lid $1 \mathrm{BW}$, voor zover daarin ten opzichte van het oude recht de mogelijkheid om een beding ten behoeve van een derde te maken wordt verruimd ${ }^{65}$ : Het is onduidelijk of het in de zojuist genoemde artikelen neergelegde voorheen reeds dwingend recht was. Voor zover dit niet het geval was, kan artikel 79 Ow I in actie komen. Men kan hierbij bij voorbeeld denken aan de volgende situaties. De doorwerking van verweermiddelen ten behoeve van een ondergeschikte als bedoeld in artikel 6:257 BW is uitgesloten. Partijen zijn overeengekomen dat wanneer zich niet in hun overeenkomst verdisconteerde omstandigheden mochten voordoen, de overeenkomst niet met terugwerkende kracht kan worden gewijzigd, maar pas met ingang van het moment van mededeling door de ene partij aan de andere, dat zich naar de mening van eerstgenoemde een zodanige omstandigheid heeft voorgedaan (in strijd met artikel 6:258 lid $1 \mathrm{BW}$ ). Wat naar oud recht onaantastbaar was, is dat in deze gevallen naar nieuw recht niet. Artikel 79 Ow I heeft waar nodig handhaving van voorheen bestaande onaantastbaarheid tot gevolg.

\subsubsection{Bijzondere overeenkomsten}

Ten aanzien van de geldigheid van (bedingen in) bijzondere overeenkomsten bevat

60. Zie hierover ook Barendrecht, in: BW-krant jaarboek 1991, p. 115-116; Mon. Nieuw BW A-25 (De Vries Lentsch-Kostense), p. 83-84.

61. Opgenomen in Parl. Gesch. Overgangstecht, p. 166-170.

62. Vgl. bij dexe bepaling artikel $194 \mathrm{Ow} \mathrm{I}$.

63. Vgl bij deze bepalingen artikel 1950 w I.

64. Vgl. Assen-Hartkanp II, nrs. 422 (artikel 6:253 hid 1 BW); 434,435 (artikel 6:257 BW); 332 (artikel $6: 258 \mathrm{BW}$ ). Zie over deze laatste bepaling in verband met anticipatie nr. 2.6 .1 hierv6or.

65. Zie over deze verruiming nr. 4,9,6 hierna. 
Boek 7 BW een flink aantal vernieuwingen. Tal van nieuwe vernietigbaarheden zijn geschapen in de regeling van de consumentenkoop (zie artikel 7:6 BW). Op grond van artikel 196 lid 2 Ow I worden de bepalingen inzake consumentenkoop, en daarmee artikel 7:6 $\mathrm{BW}$, evenwel niet toepasselijk op bij de invoering bestaande consumentenkoopovereenkomsten. Een uitzondering op deze eerbiediging van het oude recht wordt gemaakt in lid 3 van artikel 196 Ow I: titel $7.1 \mathrm{BW}$ is wèl toepasselijk op de gevolgen van niet-nakoming in het geval dat een partij na de inwerkingtreding tekortschiet in de nakoming van één van haar verbintenissen, tenzij dat tekortschieten een voortzetting is van een eerdere tekortkoming ${ }^{66}$. Dit betekent echter niet dat bedingen ter zake van niet-nakoming door de verkoper, die de rechten verkorten van een consument-koper zoals deze uit met name afdeling 3 van de kooptitel voortvloeien, anders dan vroeger uit den boze zijn. Artikel 79 Ow I verhindert dit; artikel 196 Ow I wijkt daarvan niet af, zoals artikel 191 lid 2 Ow I wel doet.

Ook bij de lastgeving kan artikel $79 \mathrm{Ow}$ I van pas komen. Artikel 7:409 lid $3 \mathrm{BW}$ geeft een regel ter bescherming van 'consument-lastgevers'. Voor een rechtshandeling waarbij de lasthebber als wederpartij van zo'n lastgever optreedt, is op straffe van vernietigbaarheid de schriftelijke toestemming van laatstgenoemde vereist. Dit toestemmingsvereiste gold wellicht wel onder het oude recht, maar in elk geval niet het vereiste van schriftelijkheid van de toestemming ${ }^{67}$. Een lastgever kan de lastgevingsovereenkomst te allen tijde opzeggen, zo bepaalt artikel 7:414 lid $1 \mathrm{BW}$. Eventuele anterieure bedingen die van deze bepaling afwijken en voorheen onaantastbaar waren, worden geěerbiedigd ${ }^{68}$. Artikel $7: 414$ lid $3 \mathrm{BW}$ bevat een regel ter bescherming van de 'consument-lastgever'. Wanneer deze de lastgevingsovereenkomst heeft opgezegd, is hij ter zake van die opzegging geen schadevergoeding verschuldigd, onverminderd het in artikel 7:406 BW bepaalde omtrent vergoeding van kosten. Van artikel 7:414 lid $3 \mathrm{BW}$ kan niet worden afgeweken. Ook voor zover vroeger het beding was toegelaten, dat de lastgevingsovereenkomst in afwijking van artikel 1850 sub 3 (oud) BW niet eindigde door de dood van de lastgever ${ }^{69}$, komt artikel 79 Ow I voor toepassing in aanmerking. Van de overeenkomstige nieuw BW-bepaling (artikel 7:415 lid 1 sub a) kan namelijk volgens lid 2 niet worden afgeweken.

Artikel 7:416 BW betreft de gevallen dat een lastgevingsovereenkonst is geêndigd voordat de last is volbracht of de tijd waarvoor zij is verleend is verstreken, en de verschuldigdheid wan loon afhankelijk is van de volbrenging of van het verstrijuken van die tijd. Het artikel houdt regels in voor het vaststellen van het loon van de lasthebber in de zojuist genoemde situaties. Van deze regels (die het oude recht niet kende) kan volgens artikel 7:416 lid $3 \mathrm{BW}$ niet worden afgeweken ten nadele van een 'consument'-lastgever.

69. Het was omstreden of artikel 1850 sub 3 (oud) BW voor zover het de dood van de lastgever betrof dwingend dan wel regelend recht bevatte. Vgl. Asser-Coehorst, n. 164; Compendium bijzondere overeenkonsten VI(Vetdhuis), ar. II. 
Artikel 79 Ow I heeft nog een andere zijde dan de hiervoor bezichtigde. Het verhindert namelijk, aldus de minister,

'dat naast of in de plaats van een gebrek dat een rechtshandeling reeds aankleeft, een nieuwe grond van nietigheid of vernietigbaarheid ontstaat. 79

Naast de zowel voorheen als thans bestaande vernietigbaarheid op grond van handelingsonbekwaamheid of op grond van een wilsgebrek zoudlen, bij werking van de bepaling met de 'nieuwe grond' voor overgangssituaties, kunnen komen te staan de nietigheden van de artikelen 5:87 lid 3 en 5:98 lid $2 \mathrm{BW}^{71}$. Artikel 79 Ow I belemmert dat. Zou dit artikel alleen betrekking hebben gehad op voorheen onaantastbare rechtshandelingen, dan zou de 'nieuwe grond' wel invloed hebben gehad op anterieure rechtshandelingen die onder oud recht ook al leden aan een gebrek. Dat zou in strijd zijn geweest met de eerbiedigende gedachte achter artikel 79 Ow I.

\subsection{VERNIETIGBAAR-ONAANTASTBAAR}

\subsubsection{Algemeen}

Denkbaar is dat het nieuwe BW een vernietigingsgrond uit het oude recht heeft laten vallen. Het is technisch gesproken geen probleem om een vernietigbare rechtshandeling die (nog) niet is vernietigd vanaf zeker moment de status van onaantastbaarheid te geven. Er zijn twee rechtsgevolgen die alsdan ophouden te bestaan: de eigenschap van vernietigbaarheid dan wel onaantastbaarheid van een anterieure rechtshandeling en de bevoegdheid tot vernietiging. Wanneer aan de vereisten is voldaan, die de nieuwe wet stelt, vervalt de vernietigbaarheid (en dus ook de bevoegdheid tot vernietiging) en komt daarvoor onaantastbaarheid in de plaats. Dit geschiedt zodra de nieuwe wet voor overgangssituaties gaat werken ${ }^{72}$.

Dat onder het oude recht vernietigbare rechtshandelingen inderdaad mogen profiteren van liberaler nieuw recht blijkt uit artikel 80 lid \OW I, dat een toepassing. vormt van het beginsel van de gunstigste bepaling ${ }^{73}$ :

'Een rechtshandeling die vernietigbaar was tot aan het tijdstip waarop de wet op haar van toepassing wordt, kan van dat tijdstip af niet langer worden ver-

70. Aldus Parl. Gesch. Overgingsrecht, p. 81.

71. Zo ook Part. Gesch. Overgangsrecht, p. 84-85. Zoals aldaur wordt opgemerkt moet het "oude" gebrek op zichzelf worden getoetst aan hetgeen volgt uit de artikelen 80 en $81 \mathrm{OWl}$.

72. Zie hiervór de nrs. 2.2 .2 (over vereiste en rechtsgevolg), 2.2 .4 (over toepasselijk zijn en werken) en 4.3 (over tempotele werking en vernietigbaarheid), alsmede Parl. Gesch. Overgangsrecht, p. 16-18 (over de wisseling van rechtsgevolgen met de toepasselijke wet).

73. Zie over het beginsel van de gunstigste bepaling Polman, diss., p. 77-79; De Die ${ }_{4}$ AA 1991, p. 826, 829. 
nietigd op grond wan het gebrek dat haar tevoren aankleefde, indien de wel een zodanig gebrek niet aanmerkt als een grond van wernietigbaarheid."

Wanneer een bepaallde 'overlopende' rechtshandeling die voorheen als het ware gehandicapt door het leven ging volgens de nieuwe wet als kerngezond zou moeten worden beschouwd, komt het als juist voor om $\mathrm{ZO}^{\prime} \mathrm{n}$ rechtshandeling genezen te verklaren. Men zou hiertegen kunnen aanvoeren dat het helen van het gebrek een partij bij de desbetreffende rechtshandeling kan benadelen. Deze tegenwerping legt echter niet veel gewicht in de schaal, omdat degene die werkelijk belang heeft bij vernietiging daarmee niet zal talmen, zodat de vernietiging alsdan vór het toepasselijk worden van het nieuwe recht wel zal zijn geschied. Artikel 80 lid 1 Ow I is dan niet van toepassing (de rechtshandeling is nietig).

Voor de regel van artikel 80 lid 1 Ow 1 pleit voorts dat onder de vigeur van het oude recht niet altijd duidelijk was, of een gebrekkige rechtshandeling nu nietig of vernietigbaar was (zie nr. 4.7.2 hierna). Het verdient geen aanbeveling zo'n onzekere toestand te laten voortbestaan.

Voor een op het moment van het toepasselij $\mathrm{k}$ worden van het nieuwe BW lopende procedure tot vernietiging geldt dat deze als gevolg van het bepaalde in artikel 80 hid 10 W I geen zin meer heeft ${ }^{74}$. Anders is dit, indien in de procedure krachtens artikel $74 \mathrm{OW}$ I het oude recht geëerbiedigd blijft ${ }^{75}$.

\subsubsection{Koopovereenkomsten}

Artikel 80 lid 1 OW I is mogelijk van toepassing op de volgende gevallen. Artikel 1503 (oud) $\mathrm{BW}^{76}$ verbood behoudens drie uitzonderingen koopovereenkomsten tussen echtgenoten. Het nieuwe BW kent zo'n verbod niet. Waren in strijd met het verbod gesloten overeenkomsten voorheen vernietigbaar ${ }^{77}$, dan geldt in overgangssituaties dat de overeenkomst vanaf het moment van het toepasselijk worden van het nieuwe BW niet langer op grond van het oude gebrek kan worden vernietigd.

Artikel 1507 (oud) $^{78} \mathrm{BW}$ verbood de verkoop van eens anders goed. Kamphuisen $^{791}$ meent dat de sanctie op overtreding van deze bepaling niet nietigheid is, zoals het artikel zelf zegt, maar vernietigbaarheid ${ }^{80}$. Wie hiervan thitgaat, moet vervolgens

74. Wel is denkbaar dat partijen doorprocederen over de kosten. Zie Parl. Gesch. Overgangsrecht, p. 82, 85.

75. Aldus ook Mon. Nieuw BW A-25 (De Vries Lentsch-Kostense), p. 68.

76. Krachtens artikel 1582 (ond) BW tevens van toepassing op de ruilovereenkomst; vgl. Asser-Kamphuim sen p. 188.

77. Dit wordt verdedigd door Asser-Schut, p. 77. Zie echter HR 25 mei 1984, RvdW 1984, 110, Kwartaalbericht Nieuw BW 1984, p. 147 (Berggren-De Wit).

78. Krachtens artikel 1582 (oud) BW tevens wan toepassing op de ruilovereenkonst ingl. Asser-Kamphisen, p. 189 .

79. Asser-Kamphuisen, p. 35 .

80. Anders (impliciet): Asser-Schut, p. 132, die echter op p. 100 stelt dat het misschien nog het beste is, de bepaling als niet geschreven te beschouwen, ondat ze op een dogmatische vergigsing berust. 
constateren met de situatie vernietigbaar-onaantastbaar te maken te hebben, omdat een bepaling als artikel 1507 (ond) BW in het nieuwe BW niet voorkont.

\subsection{VERNIETIGBAAR-NIETIG}

\subsubsection{Algemeen}

In elk geval in theorie bestaat de mogelijkheid dat een rechtshandeling krachtens de oude wet vernietigbaar was en op grond van de nieuwe nietig zou zijn. Het is niet gemakkelijk om in de thans ingevoerde delen van het nieuwe vermogensrecht duidelijke voorbeelden hiervan op het spoor te komen. In de hierna (nrs. 4.8.2 en 4.8.3) te noemen gevallen is het de vraag of er volgens het oude recht niet veeleer nietigheid dan vernietigbaarheid was. De rechtszekerheid wordt er dan mee gediend, de nulliteit van de nieuwe wet te laten intreden. Dit zou men voor de periode vanaf de inwerkingtreding kunnen doen, maar ook - vanuit rechtszekerheidsoogpunt nog beter - met terugwerkende kracht. Terugwerkende kracht (maar dan materieelrechtelijke) zou ook verbonden zijn geweest an vernietiging, indien deze zou hebben plaatsgevonden onder het oude recht. Het is de variant met terugwerkende kracht; die de overgangswetgever heeft gekozen in artikel 80 lid 2 Ow I:

'Een rechtshandeling als bedoeld in lid 1, wordt op het daar genoemde tijdstip met terugwerkende kracht nietig, indien de wet een rechtshandeling met hetzelfde gebrek als nietig aanmerkt.'

Zonder deze regel zou volgens de minister het volgende gelden:

'Aan de regel bestaat reeds behoefte, omdat de nieuwe wet in zo'n geval de bevoegdheid tot vernietiging ontneemt aan degene die haar tevoren had zonder nadere voorziening zou de handeling dan niet nietig, doch juist onaantastbaar worden.' ${ }^{81}$

Hier is van belang het verschillende karakter van vernietigbaarheid enerzijds en nietigheid en onaantastbaarheid anderzijds als eigenschappen van een rechtshandeling. Ik verwijs daarvoor naar $\mathrm{nr} .4 .3$ hierboven. De minister vervolgt:

'De tekst brengt tot uitdrukking dat deze nietigheid van rechtswege terugwerkt: hetgeen een partij vóór het toepasselijk worden der wet verschuldigd heeft gepresteerd, kan nadien derhalve als onverschuldigd betaald ongedaan worden gemaakt."

Dit is juist, maar niet volledig. In geval van insolvabiliteit van de schuldenaar heeft de schuldeiser meestal erg weinig aan een persoonlijke ongedaanmakingsverplich- 
$\operatorname{ting}^{82}$. Anders is dit met de revindicatie ${ }^{83}$. Ook deze actie komt de schaldeiser in de door antikel 80 lid 2 Ow I bestreken gevallen onder bepaalde voorwaarden toe ${ }^{84}$. Heeft krachtens een onder het oude recht vernietigbare titel een levering plaatsgevonden en wordt deze titel op grond van artikel 80 lid 2 Ow I met terugwerkende kracht nietig, dan blijkt de vervreemder altijd eigenaar van de geleverde zaak te zijn gebleven. Hij kan deze zaak dan dus revindiceren. Een eventueel faillissement van de schuldenaar deert hem niet, omdat hij separatist is.

De zoëven geciteerde passage zou de gedachte kunnen doen postvatten dat artikel 80 lid 2 Ow I een inbreuk vormt op het beginsel van de eerbiediging van verkregen rechten, zoals dit is geconcretiseerd in artikel 69 Ow 1. Deze gedachte moet echter worden verworpen. Eerstgenoemde bepaling ziet op rechtshandelingen die reeds onder het oude recht aantastbaar waren. Van een verkregen recht in eigenlijke zin kan dan naar mijn mening niet worden gesproken.

Een op het moment van het toepasselijk worden van het nieuwe BW lopende procedure tot vernietiging van een rechtshandeling kan als gevolg van het bepaalde in artikell 80 lid 2 Ow I haar zin verliezen ${ }^{85}$. Anders is dit indien in de procedure krachtens artikel 74 Ow I het oude recht geëerbiedigd blijft ${ }^{86}$.

\subsubsection{Handelings-en feitelijke onbekwamheid}

Voorbeelden van onder artikel 80 lid 2 Ow I vallende rechtshandelingen liggen niet bepaald voor het oprapen. Indien men zou aannemen dat eenzijdige ongerichte rechtshandelingen, verricht door handelingsonbekwamen en geestelijk gestoorden, onder het oude recht vernietigbaar waren ${ }^{87}$, zou men aan toepassing van artikel 80 lid 2 Ow I kunnen toekomen. Dergelijke rechtshandelingen zijn naar nieuw BW immers nietig (artikelen 3:32 lid 2 en 34 lid 2 BW). Waarschijnlijker is echter dat bedoelde rechtshandelingen voorheen ook reeds als nietig haddlen te gelden ${ }^{88}$, zodat artikel 80 lid $2 \mathrm{OW} I$ buiten toepassing blijft.

\subsubsection{Koopovereenkomsten}

Koopovereenkomsten in strijd met de artikelen 1504-1506 (oud) BW werden door-

82. Uit antike 190 Ow I volgt dat de wordering uit onwerschuldigde betalling hiler door het otde reeht wordt beheerst (dit is een consequentie van de terugwerkende krachtex artikel 80 lid 20 W I).

83. Artikel 5:2 BW inzake revindicatie werkt onmiddellijk op grond van artikel $68 \mathrm{a}$ lid 10 w 1 .

84. De geleverde zaken moeten individualiseerbaar zijm, er mag geen natrekking, zaaksvorming of vermenging hebben plaatsgevonden etc..

85. Wel is het nogelijk dat partijen doorprocederen over de kosten, zie Parl. Gesch. Overgatgsirecht, p. 82, 84,85 .

86. Aldus ook Mon. Wieuw BW A-25 (De Vries Lentsch-Kostense), p. 68.

87. Wat hier gold onder het oude recht is onzeker, zie Parl Gesch. Overgangsrecht, p. 78, Aldaar wordt abusiewelijk verwezen nat het niet bestaande lid 2 van artikel $3: 33 \mathrm{BW}$ in plaats varn naar urtike $3: 34$ lid 2 BW. 88. Zie voor rechtshandelingen van handelingsonbekwamen: Asser-Hartkamp $\mathrm{I}$, ne. 95 en voor rechtshan-

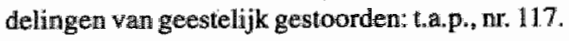


gaans nietig geacht ${ }^{89}$. Voor zover onduidelijk was of de sanctie onder het oude recht nietigheid of vemietigbaarheid was ${ }^{90}$, vallen bedoelde overeenkomsten onder artis kel 80 lid 2 OW 1 . Op grond van artikel 3:43 BW zijn zij immers nietig.

\subsection{NIETIG-ONAANTASTBAAR.}

\subsection{Algemen}

Waar de heengegane oude wet voorzag in nietigheid, kan de in haar plaats gekomen nieuwe wet yoor onaantastbaarheid opteren. De gedachte kan dan opkomen de anterieure nietige rechtshandeling te 'helen'. Omdat het hier gaat om 'momentele' eigenschappen ${ }^{91}$ komt men er eehter niet met werking sec van de nieuwe wet. Bij uitstek geschikt om de helende werking van de nieuwe wet mogelijk te maken is de figuur van de convalescentie. De overgangswetgever heeft dan ook aansluiting gezocht bij de regeling van deze rechtsfiguur in artikel $3: 58 \mathrm{BW}$ :

'Artikel 81. 1. Een nietige rechtshandeling wordt op het tijdstip waarop de wet op haar van toepassing wordt, met terugwerkende kracht tot een onaantastbare bekrachtigd, indien zij heeft voldaan aan de vereisten die de wet voor een zodanige rechtshandeling stelt.

(...)

3. De vorige leden gelden slechts, indien alle onmiddellijk belanghebbenden die zich op de nietigheid hadden kunnen beroepen, de handeling voordien als geldig hebben aangemerkt. Inmiddels verkregen rechten van derden behoeven aan bekrachtiging niet in de weg te staan, mits zij worden geëerbiedigd."

Ook hier is in de Overgangswet derhalve een concretisering van het beginsel van de gunstigste bepaling opgenomen ${ }^{92}$, en wel in de vorm van een overbruggingsregel ${ }^{93}$, door de wetgever 'bekrachtiging' genoemd. Ook al is deze benaming in overeenstemming met artikel 3:58 BW, toch gebruik ik hierna de term 'convalescentie'. Dit om verwarring te vermijden met de bekrachtiging van door een onbevoegde vertegenwoordiger verrichte rechtshandelingen (artikel 3:69 BW).

Dat anterieure nietige rechtshandelingen voordeel hebben van liberalere nieuw $B W$-bepalingen is een goede zaak. Terreinverlies van nulliteiten in overgangssituaties past in het streven van de nieuw BW-wetgever, de nietigheden in het materièle recht terug te dringen ${ }^{94}$. Verder wordt woorheen bestaande rechtsonzekerheid over de vraag of een bepaalde rechtshandeling onaantastbaar dan wel nietig was

89. Vgl. Asser-Kamphuisen, p. 46 (artikel 1504 (oud)), p. 48 (artikel 1505 (oud) en p. 50 (artikel 1506 lid I (oud) voor zover dit de 'bewindvoerders' betreft), Asser-Hartkamp I, nu, 459.

90. Ygl. Parl. Gesch. Overgangsrecht, p. 78, 250; Asser-Kamphuisen, p. 46.48.

91. Zie nr. 4.3 hiervớr.

92. Zie over dit beginsel Polman, diss, p. 7779, De Die, A.A 1991, p. 826, 829 .

93. Zie over overbruggingsregels nr. $2.5,2$ hierwóbr.

94. Vgl, hierover bij voorbeeld Hartkamp, in: Non sine causa , p. 117-118; Mon. Nieuw BW A-1 (Hartkamp), p. $69-70$. 
met terugwerkende kracht opgeheven ${ }^{95}$. Terecht worden voorts aan deze convalescentie grenzen gesteld in lid 3 van artikel 8L OW I: alle onmiddellijk belanghebbenden moeten de rechtshandeling in kwestie tevoren reeds als geldig hebben beschouwd; inmiddels verkregen rechten van derden moeten worden geëerbiedigd. Beide grenzen van lid 3 verdienen nadere aandacht.

Volgens artikel 3.58 lid $1 \mathrm{BW}$ is een vereiste voor convalescentie van nietige rechtshandelingen, dat alle onmiddellijk belanghebbenden die zich op het gebrek hadden kunnen beroepen, in de tussen de handeling en de vervulling van het vereiste liggende tijdsduur de thandeling als geldig hebben aangemerkt. Ook voor de toepassing van artikel $81 \mathrm{Ow}$ I geldt dit vereiste. Wie zijn nu de "onmiddellijk belanghebbenden die zich op de nietigheid hadden kumnen beroepen"? Voor de beantwoording van deze en andere vragen betreffende de uitleg van de onderhavige overgangsbepaling moet te rade worden gegaan bij parlementaire geschiedenis van en literatuur over artikel 3:58 $\mathrm{BW}^{96}$. Het antwoord op de gestelde vraag hangt af van de aard van de rechtshandeling en van de aard van het gebrek ${ }^{97}$. Hartkamp noemt t.a.p. bij de levering door een beschikkingsonbevoegde de eigenaar, de verkrijger, de derde die een recht afleidt van de eigenaar en de schuldeiser van de eigenaar, die op het goed beslag legt. De vervreemder is onmiddellijk belanghebbende, indien de nietigheid van de overdracht op een nietige titel berust.

Een andere vraag is, wanneer kan worden gezegd dat de onmiddellijk belanghebbenden de nietige rechtshandeling vóer het toepasselijk worden van de nieuw BW-bepaling 'als geldig hebben angemerkt'. Dit is het geval, indien de onmiddellijk belanghebbenden niet een beroep op de nietigheid hebben gedaan en evenmin een handeling hebben verticht, die met de nietige rechtshandeling niet te verenigen zou zijn geweest, indien deze laatste onaantastbaar zou zijn geweest. Voorbeelden van zulke handelingen zijn,

'dat iemand beslag op een goed legt of zich een beperkt recht daarop doet verschaffen zonder te weten dat het goed reeds te voren naar de mening van de daarbij betrokken partijen geldig aan een ander was overgedragen of te diens behoeve met een beperkt recht was bezwaard, ofschoon daarbij niet alle voor een geldige levering gestelde vereisten waren vervuld. ${ }^{98}$

De hier besproken overgangsbepaling verhindert toepasselijkheid van artikel 81 lid $1 \mathrm{OW}$ I op gevallen waarin een rechtshandeling nietig is als gevolg van vernietiging. Dan kan immers niet met recht worden gezegd dat alle onmiddellijk belanghebbenden de handeling voorheen als geldig hebben aangemerkt. Artikel 81 leden 1 en 2 Ow I is derhalve alleen van toepassing op van rechtswege nietige rechtshandelingen ${ }^{99}$. Rechtshandelingen die vóor het toepasselijk worden van het nieuwe BW zijn vernietigd, vallen daarmee als het ware tussen de wal en het schip: zij horen niet

95. Aidus ook de minister, zie Parl. Gesch. Overgangsrecht, p. 77.

96. Zie Parl. Gesch. Boek 3, p. 247-250; Parl. Gesch. Inv. Boek 3, p. 1174-1176, en Hijma, diss s, hoofdstuk VIII, met verwijzingen naar andere auteurs.

97. Aldus Asser-Hartkamp II, nr. 504.

98. Parl. Gesch. Boek 3, p. 249, zie voorts Asser-Hartkarnp II, nr. 504.

99. Zie in gelijke zin ten aamzien van artikel $3.58 \mathrm{BW}$ : Asser-Hartkamp II; nr. 503 . 
thuis onder artikel 80 Ow I, omdat zil krachtens oud recht nietig waren in plaats van vernietigbaar; zij horen evenmin thuis onder artikel 81 Ow I, omdat zij niet door alle onmiddellijk belanghebbenden voorheen als geldig zijn aangemerkt. Deze ca tegorie rechtshandelingen zal na het toepasselijk worden van het nieuwe $\mathrm{BW}$ dan ook nietig blijven.

Het feit dat partijen de rechtshandeling als geldig hebben beschouwd rechtwaardigt de terugwerkende kracht van de convalescentie ex artikel 81 lid 10 W ${ }^{100}$. Hetzelfde geldt voor de inbreuk die deze convalescentie maakt op de eerbiediging wan verkregen rechten krachtens artikel 69 Ow II0I.

Naar aanleiding van een vraag van de vaste Commissie voor Justitie van de Tweede Kamer ${ }^{102}$ is aan artikel 81 hd 30 w een regel van derdenbescherming toegevoegd. Deze luidde aanvankelijk als volgt:

"Inmicldels verkregen rechten van derden behoeven aan de toepassing van de vorige leden niet in de weg te staan; mits zij worden geëerbiedigd.' 109

De minister schrijft in de memorie van antwoord ${ }^{104}$ :

"Inderdaad is het denkbaar dat een derde te goeder trouw een recht heeft werkregen, dat ook bij overgangsrechtelijke bekrachtiging eerbiediging behoeft, evenals dat in artikel $3.2 .20(3.58)$ lid 3 geschiedt.'

De bedoeling van de minister kwam in de voorgestelde tekst niet goed tot uitdrukking, omdat daarin sprake was van toepassing van de vorige leden, dus bok lid 2 , dat echter niet op bekrachtiging (lees: convalescentie) betrekking heeft. De Kamercommissie stelde voor de letterlijke tekst van artikel $3: 58$ lid $3 \mathrm{BW}$ over te nemen. Deze zou beter tot uitdrukking laten komen

'dat de onderhavige bepaling een uitzondering is op de eerste zin van het derde lid (en niet zozeer op het eerste en tweede lid).' 105

De minister nam het voorstel zonder commentaar over ${ }^{106}$. Daardoor spreekt de wetstekst nu uitdrukkelijk over 'bekrachtiging' (convalescentie), zodat de uitzondering inzake de "verkregen rechten" geen verband meer lijkt te houden met artikel 81 lid 2 Ow I $^{107}$.

Ik geef een voorbeeld inzake de "verknegen rechten":

100. Zie ten aanzien van artikel $3.58 \mathrm{BW}$ Asser-Hartkampli, nr. 504 ; Hartkamp, WPNR $6030(1991), 1$, 872 .
101. Ik ga hiepop in in nr. 4.9 .3 hiema.

102. Prarl. Qesch, Overgangsrecht, p. 79.

103. Parl. Gesch. Overgangsrecht, p. 83.

104. Parl Gesch. Overgangsrecht, p. 80 .

105. Zie voor artikel 3:58 BW Asser-Hartkamp II, nr. 505: Hid 3 makkt een uitzondering op het wereiste val het "als geldig aammerken".

106. Parl. Gesch. Overgangsrecht, p. 83.

107. Vgl hierover ook Polnain, Overgangswet, deel 1, p. 101. 
A schenkt onder het thans nog geldende schenkingsrecht een zaak aan B zonder het vormvereiste van een notariële akte van schenking (artikel 1719 $B W$ ) in acht te nemen. Vervolgens vestigt $A$, vór de invoering van titel 7.3 ontwerp NBW, op dezelfde zaak een vruchtgebruik ten behoeve van $\mathrm{C}$.

De vestiging van het vruchtgebruik brengt met zich mee dat $A$ en $C$ de overdracht A-B niet als geldig hebben aangemerkt. Zonder nadere voorziening zou nu de overdracht A-B niet kunnen worden geconvalideerd door het toepasselijk worden van titell 7.3 ontwerp NBW, waarin het vereiste van een notariële schenkingsakte niet meer wordt gesteld. De tweede zin van artikel 81 lid 3 Ow I brengt echter met zich mee dat de vestiging van het vruchtgebruik niet aan convalescentie in de weg staat. C's recht wordt geëerbiedigd; B verkrijgt de zaak onder de last van het vruchtgebruik $^{108}$.

\subsubsection{Handelingsonbevoegdheid}

Op de handelingsonbevoegdheid voortvloeiend uit artikel 3:43 lid 1. sub a BW bevat lid 2 een uitzondering. Deze kwam niet voor in de voorloper van genoemde bepaling, artikel 1505 (oud) BW, zodat de mogelijkheid zich voordoet van nietigheid die is opgevolgd door onaantastbaarheid. De convalescentie uit hoofde van artikel 81 lid 1 Ow I kan alsdan plaatsvinden.

\subsubsection{Derdenbescherming; de zaak Bunde-Erckens}

Zonder meer de meest opvallende en verrassende ${ }^{109}$ toepassing van artikel 81 leden 1 en 3 OW I is de categorie van '3:88-gevallen'. Zoals bekend bevat artikel 3:88 BW een ruimere bescherming dan voorheen van derden te goeder trouw tegen beschikkingsonbevoegdheid van hun rechtswoorganger. Hier zijn zowel nieuwe vereisten als een nieuw rechtsgevolg (onaantastbare overdracht) aanwezig. Het "voldongen feit' van de nietige anterieure owerdracht kan door overgangsrechtelijke convalescentie alsnog worden geredresseerd. Het praktische belang hiervan kan worden geillustreerd aan de hand van de zaak Bunde-Erckens. Deze heeft gespeeld van 1961 tot in 1990 en heeft meer dan tien rechterlijke uitspraken opgeleverd, waaronder twee arresten van de Hoge Raad ${ }^{110}$.

Op 21 juni 1961 verkocht Erckens een aantal percelen weiland en boomgaard aan de toenmalige gemeente Bunde (inmiddels gemeente Meerssen) voor de prijs van

108. Vgl. (ten aanzien van artikel 3:58 lid 3 BW) Asser-Hartkamp I, nr. 505.

109. De juiste opmerking van $H$. Stein, preadv., p. 78 , over het woormalige artikel 790 w I geldi ook voor zijn opvolger artikel 81 Ow I: 'Het is een artikel met grote verrassingen.' De onderhavige verrassing bespreekt hij owerigens niet.

110. Onderstaande gegevens ontleen ik aan het ieerste arrest van de Hoge Raad inzake Bunde-Erckens, zOals dit is gepubliceerd in de NJ (HR 17 december 1976, NJ 1977, 241). Zie over deze zaak ook Sijmonsma, in: Om wille van de consument, p. 165-175; Kortmann, in: Met grond verbonden, p. 89-99. 
f $175500^{11}$. In deze koopsom was een bedrijfsschadevergoeding begrepen. Partif en kwamen overeen dat de gemeente de belastingschade, vallende op de bedriffsschadevergoeding, aan Erckens zou vergoeden op basis van een verklaring van de belastinginspecteur terzake. De inspecteur berekende de bedrijfsschadevergoeding op $f 127100$, warover Erckens $f 50840$ aan inkomstenbelasting moest betalen. Volgens de inspecteur bedroeg Erckens" (door de koop veroorzaakte) belasting schade $f 2$ 151,50. Dit was het bedrag dat Erckens als gevolg van de "mirnelije onteigening" neer aan inkonstenbelasting moest betalen dan wanneer hij zijn be driff normaal zou hebben kunnen voortzetten. De gemeente vatte het begrip belastingschade in laatstbedoelde, in het onteigeningsrecht gehanteerde, betekenis op en kwam derhal ve uit op het door de inspecteur berekende bedrag van $f 2151,50$. Erekens echter verstond onder 'belastingschade' het gehele bedrag, dat hij over de bedrijfsschadevergoeding aan inkomstenbelasting moest betalen ( $f 50840$ ).

Erckens stelde eerst op grond van de overeenkomst tegen de gemeente een vordering in tot betaling van $f 50$ 840. Deze vordering werd in eerste aanleg en in hoger beroep afgewezen. Nog voordat de uitspraak in hoger beroep was gedaan, begon hij voor het geval dat zijn vordering zou worden afgewezen een nieuwe procedure. Daarin vorderde hij in hoofdzaak een verklaring voor recht; dat de koopovereenkomst nietig was wegens het ontbreken van wilsovereenstemming over de vergoeding van de belastingschade. Deze vordering werd na jarenlang procederen toegewezen 112 .

De gemeente leverde na de koop een gedeelte van de grond aan particulieren. Op de desbetreffende percelen werden vele tientallen woningen gebouwd. Ook werden door de bewoners van de huizen hypotheekrechten verleend aan financiers. De nietigheid van de overeenkomst tussen Bunde en Erckens had tot gevolg dat aan de eigendomsoverdracht door Erckens aan Bunde geen geldige titel ten grondslag lag, zodlat deze overdracht ongeldig was. Daardoor bleek Erckens steeds eigenaar van de grond (met de naderhand daarop gebouwde huizen!) te zijn gebleven. De gemeente was derhalve niet beschikkingsbevoegd over de grond ten tijde van de levering daarvan aan derden. Het oude recht bood de derden (huizenbewoners en hypotheekhouders) geen bescherming tegen de beschikkingsonbevoegdheid van hun rechtsvoorgangers ${ }^{113}$

Erckens liet op 8 september 1989 de eerder genoemde arresten van het Hof Arnhem en van de Hoge Rad overschrijven in de openbare registers. De tenaamstelling van de grond werd op dezelfde datum gewijzigd. Een door de gemeente Meerssen gevorderde veroordeling om deze overschrijwing te laten doorhalen werd afgewezen 114 . Erckens zond voorts een brief aan de bewoners van 74 woningen die op

111. De transpontakte werd verleden op 15 september 1961.

112. Zie naast het hierboven genoemde arrest van de Hoge Raad wan 17 december 1976, NJ 1977, 241 het door het Hof Arnhem na de verwigzing door de Hoge Raad gewezien arrest van 9 november 1982, NJ 1987, 714. Hetcassatiebercep van de gemeente Meerssen tegen laatstgenoemd arrest werd door de Hoge Raad verworpen bij wrrest van S december 1986, NJ 1987, 382 .

113. Althans volgens de heersende leer: zie bij voorbeeld Drion-Hijma/OHthof, nr. 115. Anders: Schoordijk; Boek 3, $\mathrm{p}, 298-299$. Wel bestond uiteraard de mogelijkheid van verkrijgende verjaring (twintig jaar, artikel 2000 lid 1 ( oud ) B W). Zie Kortmann, in: Met grond werbonden; p. 91-92, 96-97.

114. Pres. Rb. Maastricht 15 november 1989 , rolnummer $498 / 1989$ (niet gepubliceerd). 
de grond gebouwd zijn, waarin hen werd medegedeeld dat ze geen eigenaar meer zijn van de woning' 115 .

Naar aanleiding van het in kracht van gewijsde gaan van bovengenoemd arrest van het Hof Arnhem besloot de ring van notarissen in het arrondissement Maastricht om geen akten te passeren, die betrekking hadden op de in het litigieuze gebied liggende percelen ${ }^{116}$. Behalve de huizenbewoners en hypotheeknemers verkeerde ook de gemeente Meerssen in een lastig parket. Deze had, zoals gebruikelijk, in koopovereenkomsten inzake de grond de verplichting op zich genomen tot vrijwaring wegens uitwinning. Op vordering van de gemeente werd Erckens op 22 december 1987 in kort geding veroordeeld tot (door)onderhandelen over de door de gemeente te betalen koopprijs ${ }^{117}$. Erckens verlangde de actuele waarde van de grond inclusief opstallen. De gemeente was niet bereid zo ver te gaan en spande tegen Erckens een bodemprocedure aan teneinde een veroordeling van Erckens tot medewerking aan het transport van de grond te verkrijgen. In deze procedure wees de Rechtbank Maastricht op 5 januari 1989 vonnis; in hoger beroep wees het Hof Den Bosch op 30 oktober 1989 een tussenarrest ${ }^{118}$. Daarin gelastte het Hof een comparitie van partijen, waarop zij zich konden uitlaten over te benoemen deskundigen, die bericht moesten verschaffen over het door de gemeente aan Erckens te betalen bedrag ${ }^{119}$. Uiteindelijk hebben partijen een minnelijke regeling getroffen, waarop alsnog overdracht van de in het geschil betrokken grond door Erckens aan de gemeente Meerssen heeft plaatsgevonden ${ }^{120}$.

Aan de hand van deze casus kan de werking van artikel 81 Ow I worden gedemonstreerd. Stel de gemeente en de erven Erckens twistten ten tijde van de inwerkingtreding van het nieuwe BW nog steeds over de door de gemeente te betalen koopprijs. Volgens artikel 3:88 BW zouden de rechtsopvolgers van de gemeente anders dan vroeger wel tegen de beschikkingsonbevoegdheid van de gemeente worden beschermd (ik ga uit van de goede trouw van deze rechtsopvolgers) ${ }^{121}$. Hoe zou

115. Aldus een bericht in De Limburger van 23 september 1989.

116. Dit blijkt uit het vonnis ju kort geding van de president van de Rb. Maastricht wain 15 november 1989 , rolnurnmer $498 / 1989$ (niet gepubliceerd).

117. Pres. Rb. Maastricht 22 december 1987, rolnummer 356/87 (niet gepubliceerd).

118. Rolnummer 196/89/Ma (niet gepubiliceerd).

119. Wolgens een bericht in het Limburgs Dagblad van 21 november 1989 gingen partijen op de comparitie akkoord mer benoening van een accountant, een fiscaal jurist en een belastingdeskundige uit de bankwerelld.

120. Zie Kortmann, in: Met grond verbonden, p. 96, 98; Limburgs Dagblad 20 februari 1990. Volgens het bericht in genoemd dagblad zijn partijen betaling door de gemeente Meerssen aan (inmiddels) de erwen Errckens overeengekomen van een bedrag van $f 575340$, alsmede van de wettelijke enkelvoudige rente van $f 101500$. De overeenkomst is gebaseerd op het in de tekst genoemde vonnis van de Rechtbank Maastricht van $\$$ januari 1989 , waarin de gemeente Meerssen werd veroordeeld tot betaling van $f 50840$ en van f 700000 minus het in 1961 reeds betaalde bedrag van $f 175500$. Volgems een bericht in De Limburger van 21 augustus 1990 heeft op grond van dit "compromis" op 18 juli 1990 het notarièle transport van de grond aan de gemeente Meerssen plaatsgehad, op 19 juli 1990 gevolgd door overschrijving van de akte in de openbare registers. Het bericht maakt werder melding van de voorgenomen overdracht van grond door de gemeente Meerssen aan de huizenkopers in de desbetreffende woon wijk.

121. De eventuele toepasselijkheid van derdenbeschermende bepalingen uit afdeling 3.1.2 BW laat ik thier buitten beschouwing. Zie over deze bepalingen ni. 3.7 hiervóór. Ik beperk mij tot de positie van die 
een casus als deze overgangsrechtelijk moeten worden opgelost? De minister ${ }^{2}$ ? zegter dit ower:

'Artikel 3.4.2.3b (3;88) is, omdat het niet terugwerkt, slechts van toepassing op rechtsfeiten die na zijn inwerkingtreding worden voltooid. Of een overdracht die vóor de inwerkingtreding van de nieuwe wet is geschied en waarvoor artikel 2014 niet gold, geldig is tot stand gekomen, moet naar het oude recht worden beoordeeld, watr wellicht soms aan de hand van artikel 1910 (naderhand artikel $1376 a$, HvdB) eenzelfde resultaat kan worden bereikt."

Er waren in casu bij de inwerkingtreding 'voldongen feiten' aanwezig, te weten nietige grondoverdrachten. De inwerkingtreding van een nieuwe regel die niet nietigheid, maar onaantastbaarheid als rechtsgevolg zou meebrengen, kan bij zulke "voldongen feiten" in die nietigheid alleen verandering brengen in geval van terugwerkende kracht ${ }^{123}$. Dat laatste is precies wat hier gebeurt:

"Is de overdracht naar het oude recht ongeldig, dan kan zij evenwel door artikel 79 (thans: artikel 81 lid 1, HvdB) worden bekrachtigd.' 124

De grondoverdrachten door de gemeente zouden dus in beginsel op grond van artikel 81 lid 1 Ow I met terugwerkende kracht zijn geconvalideerd. Erckens zou daardoor de eigendom van de grond met terugwerkende kracht hebben verloren aan de bewoners van de op de grond gebouwde huizen. Dat zou in het onderhavige geval niet een aanvaardbaar resultaat zijn, omdat Erckens de leveringen door de gemeente aan derden niet als geldig heeft aangemerkt. Hij heeft zich immers (in rechte) op het standpunt gesteld, dat de koopovereenkomst met de gemeente nietig was wegens het ontbreken van wilsovereenstemming. Dit standpunt impliceert dat Erckens tevens de overdrachten door de gemeente aan derden en vervreemding en bezwaring door de derden-verkrijgers niet als geldig heeft aangemerkt. Voor deze situatie bevat lid 3 van artikel $81 \mathrm{Ow}$ I dan ook een uitzondering op lid 1: het 'als geldig hebben aangemerkt' van de rechtshandeling. Erckens is als eigenaar van de litigieuze grond onmiddellijk belanghebbende in de zin van artikel 81 lid 3 Ow I. Tk verwijs verder naar de bespreking van deze bepaling in nr. 4.9 .1 hiervóor. Ik wijs hier alleen nog op de verhouding van artikel 81 leden 1 en 3 OW I tot artikel 69 Ow I. Zou Erokens de leveringen aan derden wel als geldig hebben aangemerkt, dan was hij bij de inwerkingtreding de eigendom van de grond kwijtgeraakt met terugwer-

directe rechtsopvolgers van de gemeente, die op 1 januari 1992 nog geen twintig jaar bezitter van de grond waren of om een andere reden niet door verkrijgende verjaring (twintig jaar, artikel 2000 lid 1 (oud) BW) rechthebbende waren geworden, terwijl zij ondler de vigeur van het uieuwe BW zouden worden bescherma door artikel 3:88.

122. Parl. Gesch. Overgangsrecht p. 256.

123. Zie Parl. Gesch. Overgangsrecht p. 13 (met noot 1); nrs. 2.4.1.2, 2.5.1.1 süb c. 2, 2.5.1.2 sub c. 2 en 2.5.1.4 sub b hierv ốr.

124. De minister spreekt over bekrachtiging van een overdracht. Zijns inziens kan de overdracht namelijk miet slechts als rechtsgevolg (artikel $3: 84$ lid $1 \mathrm{BW}$ ), maar ook als rechtshandeling worden aangeduid (Part. Gesch. Inv. Boek 3, p. 1176). Hiertegen Hijma, diss., p. 377-378. Ik volg de zienswijze wan de minister. 
kende kracht tot aan de leveringen aan derden. Het recht had zich dan alsnog en met terugwerkende kracht bij de feiten aangesloten. De convalescentie zou dan dus een afwijking van de 'eerbiediging van verkregen rechten' met zich hebben meegebracht, althans in de visie van de overgangswetgever ${ }^{125}$. Hoe dit ook zij, het verlies wan Erckens' recht zou in dat geval niet zonder goede grond zijn geweest, want ook hier geldt:

'Indien partijen en derden vanaf het verrichten van de rechtshandeling van haar geldigheid zijn uitgegaan en daarop hun gedragingen hebben afgestemd, is het gerechtvaardigd dat deze toestand ex tunc wordt geconsolideerd.' 126

\subsubsection{Beperking van verhaal op vermogen debiteur}

Een schuldeiser zou met zijn schuldenaar kunnen overeenkomen dat eerstgenoemde zich niet op het gehele vermogen van laatstgenoemde zal mogen verhalen (hij mag bij voorbeeld bepaalde vermogensbestanddelen van de debiteur niet uitwinnen). Het was onder het oude recht niet geheel zeker, of een dergelijke overeenkomst tot beperking van het verhaalsrecht van de crediteur wel toelaatbaar was ${ }^{127}$. Deze onzekerheid wordt opgeheven door artikel 3:276 BW, dat uitdrukkelijk een overeenkomst met de zojuist weergegeven strekking toestaat. Voor overgangssituaties kan de convalescentie ex artikel 81 Ow I uitkomst bieden.

\subsubsection{Beperkte rechten}

Vroeger werd wel betwijfeld of het mogelijk was de vruchtgebruiker bevoegdheden tot vervreemding en tot vertering te geven ${ }^{128}$. Door de artikelen 3:212 en $215 \mathrm{BW}$ wordt de verlening van genoemde bevoegdheden aan de vruchtgebruiker echter toegestaan.

Liberaler recht is ook in Boek $5 \mathrm{BW}$ aan te treffen. Zo worden in artikel 5:70 BW in tegenstelling tot in het oude recht (artikel 721 (oud) BW) ten aanzien van erfdienstbaarheden niet meer het naburigheids- en het nutswereiste gesteld. Ook is de mogelijkheid verruimd om een verplichting tot een doen te scheppen (artikel 5:71 BW tegenover artikel 736 (oud) BW) ${ }^{129}$. Voorts is een canon niet langer een essentiale van de erfpacht (artikel 5:85 lid 2 BW tegenover artikel 767 lid 1 (oud)

125. Artikel 81 lid 1 Ow I derogeert zijns inziens aam artikel 690 w I, zie Parl. Gesch. Overgangsrecht, p. 45, 76-77, 101, 102. Daar hier niet van het enkele toepasselijk worden van het nieuwre BW sprake is, zoals in de gevallen waarop artikel 69 Ow I ziet, maar van een rechtstreeks ingrijpen van de overgangswetgever, zie ik hier geen inbreuk op artikel 69 OW I. Ik verwijs naar hetgeen ik in nr. 5.6 .7 hierna schrijf over de verhouding tussen de omzetting van zekerheidseigendom ex artikel $86 \mathrm{OW}$ I tot artikel $69 \mathrm{OW} \mathrm{I}$.

126. Aldus Asser-Hartkamp II, nr. 504. Anders Hijma, diss., o.a. p. 379.

127. Zie Parl. Gesch. Boek 3, p. 856; Parl. Gesch. Overgangsrecht, p. 275; H. Stein, preadw., p. 78.

128. Vgl. Parl. Gesch. Overgangsrecht, p. 267, 268; H. Stein, preadv., p. 79; Commentaar KNB, Kwartaalbericht Nieuw BW 1985, p. 50; Mon. Nieuw BW B-10 (Klejin); p. 28 e.v.

129. Vgl. Parl. Gesch. Owergangsrecht, p. 290. 
BW) ${ }^{130}$. Betwist was voorheen of overdracht, toedeling en splitsing van de erfpacht alan toestemming van de eigenaar konden worden onderworpen ${ }^{131}$. Artikel 5:91 BW staat het maken van $z o^{x} n$ beding toe. Op over de inwerkingtreding heen lopende gevallen van bovengenoemde aard kan zo nodig artikel 81 Ow I toepassing vinden.

Voor appartementsrechten geeft arlikel 172 Ow I een speciale regel. Lid I verklaart artikel 5:110 BW inzake ongeldige splitsingen met onmiddellijke werking toepasselijk op anterieure splitsingen. Anders dan in artikel 81 lid $\mathbb{1}$ Ow I wordt hier nict geopereerd met terugwerkende kracht ${ }^{132}$.

\subsubsection{Derdenbedingen}

Minder streng dan het vroegere recht is ook artikel 6:253 lid $1 \mathrm{BW}$, waarin niet meer het in artikel 1353 lid 1 (oud) BW gestelde vereiste voorkomt dat de stipulator ook iets voor zichzelf moet bedingen ${ }^{133}$. Waar voorheen nietigheid gold kan deze met terugwerkende kracht worden opgeheven door toepassing van artikel 81 OW I.

\subsubsection{Bijzondere overeenkomsten}

Artikel 81. Ow I kan ook van pas komen bij bijzondere overeenkomsten. Een koop waarbij partijen geen prijs hebben bepaald en deze evenmin aan de begroting van een derde hebben overgelaten (zie artikel 1501 (oud) BW) is thans onaantastbaar (de koper is een redelijke prijs verschuldigd, zie artikel 7:4 BW) ${ }^{134}$. Bij anterieure koopovereenkomsten kan in verband met de uitgestelde werking van het nieuwe kooprecht op grond van artikel 196 lid 1 OW I de overgangsrechtelijke convalescentie eerst op 1 januari 1993 plaatshebben. Dit geldt ook bij consumentenkoop. Weliswaar wordt op anterieure consumentenkoopovereenkomsten nieuw consumentenkooprecht niet toepasselijk (artikel 196 lid 2 Ow I), maar voor artikel 7:4 BW is dit niet van belang, omdat het niet een regel voor consumentenkoop alleen bevat ${ }^{135}$.

Het in artikel 1719 (oud) BW gestelde vormvereiste dat schenkingen op straffe van nietigheid bij notariele akte dienen te geschieden zal niet meer gelden, zodra titel 7.3 ontwerp NBW in werking zal zijn getreden ${ }^{136}$. Voorts is thans anders dan in

130. Vgl Part Gesch, Overgangsrecht, p. 292; H. Stein; pread v., p. 79.

131. Vgli Parl. Gesch. Overgangsrecht; p: 293; Asser-Beekhuis II, nrs. 285-286.

132. Ze daarower Part: Gesch. Overgangsrecht, $p .148$.

133. Vgl. Part. Gesch. Overgangsrecht, p. 172; H. Stein, preadv., p. 87, Op het derdenbeding heeft tevens artikel 193 Ow I betrekking. Deze bepaling wordt toegelicht in Parl. Gesch. Overgangsrecht, tap..

134. Zie Parl Gesch, Boek 7, p. 54 .

135. Artikel 7:6 lid $1 \mathrm{BW}$, dat onder meer artikel 7:4 BW tot dwingend recht verklaart voor consumentenkoop, wordt wel bestreken door artikel 196 lid 2 Ow I. Vain praktisch belang is dat niet: er zou dan sprake moeten zijn van een beding dat afwijkt wan artikel $7: 4 \mathrm{BW}$, en dat lijkt miet mogelijk.

136. Vgl. H. Stein, preadv. p. 78; Asser-Kleijn, nr. 253. 
hel oude BW (artikel 1850 sub $3^{137}$ ) het beding toegelaten, dat een lastgevingsovereenkomst niet eindigt door de dood van de lasthebber (artikel 7:415 lid 1 sub b BW).

\subsection{NIETIG-VERNIETIGBAAR}

\subsubsection{Algemeen}

De laatste hier te bespreken categorie is die van de rechtshandelingen ten aanzien waarvan de nietigheidssanctie plaats heeft gemaakt voor die van vernietigbaarheid. (Onmiddellijke) toepasselijkheid van de nieuwe regel op een overgangssituatie zou opleveren toekenning voor het vervolg van het nieuwe karakter aan een rechtshandeling ${ }^{138}$. Een dergelijke overgangsrechtelijke oplossing zou goed passen in het streven van de nieuw BW-wetgever om de nietigheden terug te dringen. Ook eventueel bestaande rechtsonzekerheid onder het oude recht zou hierdoor worden opgeheven. Wel zou mogelijke benadeling van onmiddellijk belanghebbenden moeten worden voorkomen. Een en ander is gerealiseerd in de leden 2 en 3 van artikel 81 Ow I:

'2. Een tevoren nietige rechtshandeling geldt van dat tijdstip (waarop de wet op haar toepasselijk wordt, HvdB) af als vernietigbaar, indien de wet het gebrek dat haar aankleeft, als grond van vernietigbaarheid aanmerkt. Artikel 73a lid 1 is alsdan niet van toepassing, indien het tevoren geldende recht een beroep op de nietigheid niet aan een bepaalde termijn bond.

3. De vorige leden gelden slechts, indien alle onmiddellijk belanghebbenden die zich op de nietigheid hadden kunnen beroepen, de handeling voordien als geldig hebben aangemerkt. (...)'

Terugwerkende kracht is anders dan in lid 1 van artikel 81 Ow I niet aangewezen, omdat een beroep op de vernietigbaarheid in de periode vór het toepasselijk worden van de nieuwe wet feitelijk onmogelijk is. Opvallend is het gebruik van het woord 'geldt' in de tekst van lid 2. Dit kan wijzen op het gebruik van een fictie en daarmee van een koppelregel. In de toelichtende stukken gebruikt de minister het

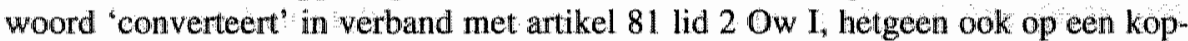
pelregel zou kunnen wijzen (omzetting) ${ }^{139}$. In weerwil hiervan zou men dé bepaling evenzeer als een verwijzingsregel kunnen lezen: zodra de nieuwe wet gaat werken voor een overgangssituatie, wordt het rechtsgevolg vain de vernietigbaarheid (bevoegdheid, eigenschap) verbonden aan het vervuld zijn daarvoor van de vereisten van die nieuwe wet ${ }^{140}$.

137. Deze bepaling bevatte op dit punt dwingend recht, zie Compendium bijzondere overeenkomsten VI (Veldhuis), nr. 11 . Zou onder het oude recht sprake zijn geweest van werntetigbaarheid, dan zou artikel 80 lid 1 Ow I van toepassing zijn.

138. Zie mutatis mutandis nr. 4.5 .1 hierv6or.

139. Parl. Gesch. Overgangsrecht, p. 169.

140. Zie over artikel 81 lid 2 eerste in Ow IParl. Gesch Overgangsrecht, p. 77, 78, 80,81, 82. Zie over verwijzings- en koppelregels respectievelijk de nrs. 2,5.1 en 2.5.2 hiervóór. 
In artikel 81 lid 2 Ow I wordt afgeweken van artikel $73 a$ lid $1 \mathrm{OW} I$, welke bepaling op haar beurt een afwijking bevat van de artikelen 72 en 73 Ow I, waarin de overgangsregeling inzake termijnen is neergelegd. Deze laatste afwijking houdt in dat een wettelijke bewoegdheid niet meer kan worden uitgeoefend, indien de daarvoor bij de wet gestelde termijn reeds op het tijdstip van de inwerkingtreding is verstreken en een bevoegdheid van gelijke aard onder het tevoren geldende recht niet bestond.

Artikel 81 lid 2 tweede volzin Ow I wordt naar verhouding nogal uitvoerig toegelicht in de memorie van antwoord aan de Tweede Kamer ${ }^{141}$. Ik volsta daarom met het citeren van deze toelichting, hier en daar voorzien van een kanttekening.

'Zoals hierboven ${ }^{142}$ opgemerkt, moet bij deze laatste categorie, de van nietig vernietigbaar wordende handelingen worden acht geslagen op de termijnenregeling van de artikelen $72-73 a$. Deze categorie bestaat uit een tweetal groepen.

De eerste daarvan wordt gevormd door die rechtshandelingen waarvan de nietigheid onder het oude recht binnen een bepaalde termijn kan worden ingeroepen, zoals de zgn. paulianeuze handelingen volgens artikel 1377, waarwoor artikel 1490 tweede lid, laatste onderdeel, geldt. Hierop kunnen de artikelen $72-73 a$ zonder beperking toepassing vinden; het inroepen van de nietigheid kan in de zin van artikel $73 a$ als een 'bevoeg(d)heid van gelijke aard' als de bevoegdheid tot vernietiging worden aangemerkt.'

Het voorbeeld van de actio Pauliana lijkt wat ongelukkig gekozen. Onder het oude recht was toch eigenlijk well communis opinio dat het inroepen van de nietigheid waarvan in artikel 1377 lid 1 (oud) BW werd gesproken moest worden opgevat als het vernietigen van de paulianeuze rechtshandeling ${ }^{143}$.

'Anders is het met de tweede groep, de rechtshandelingen die onder het oude recht nietig waren doch waar inroepen van de nietigheid niet aan een bepaalde termijn was gebonden, in tegenstelling tot het nieuwe recht dat de rechtsvordering tot vernietiging en de bevoegdheid tot buitengerechtelijke vernietiging (buiten het geval van artikel 3.2.15 (3:51) lid 3) wèl aan cen termijn bindt: artikel 3.2.17 (3:52). Als voorbeelden kunnen gelden de rechtshandelingen die onder invloed van misbruik van omstandigheden zijn verricht: onder het oude recht zijn deze nietig wegens het ontbreken van een geoorloofde oorzalak, onder het nieuwe worden zij vernietigbaar. Maar ook moet men bedenken dat het oude recht tal van rechtshandelingen als "nietig" aanmerkt, waarvan betwist is of daar niet veeleer vernietigbaar moet worden gelezen, terwijl die rechtshandelingen volgens nieuw recht gewoonlijk vernietigbaar zijn. Wordt op een rechtshandeling van deze groep nu het nieuwe recht van toepassing, dan zijn er ten aanzien van de nieuwe termijn drie mogelijkheden: (1) of die termijn is nog niet aangevangen - zie artikel 3.2.17 (3:52),

141. Parl. Gesch. Owergangsrecht, p. 82-83.

142. Parl. Gesch. Overgangsrecht, p. 81 (noot miet in het origineel, HvdB).

143. Vgl. bij voorbeeld Asser-Hartkamp II, nr, 449. 
bijv. de invloed van het misbruik van onstandigheden duurt nog voort - (2) of de termijn van het nieuwe recht is alsdan reeds aangevangen - bijv. 2 jaar tevoren volgens de omschrijving van artikel 3.2.17 (3:52) - en loopt nog, (3) of de termijn van het nieuwe recht is alsdan reeds voltooid - bijv. 5 jaar tevoren reeds aangevangen.

In het eerste geval zijn de artikelen 72-73a niet van toepassing.

In het tweede geval begint bij een korte termijn volgens artikel 72 deze te lopen op het tijdstip waarop de nieuwe wet van toepassing wordt, en bij een langere wordt krachtens artikel 73 de werking van de termijn een jaar uitgesteld: gedurende dat jaar bestaat er in ieder geval een bevoegdheid tot vernietiging, ook als de tot vernietiging bevoegde zijn voor vernietiging vatbare verbintenis reeds is nagekomen en hij dus niet langer het verweermiddel van artikel $3.2 .15(3: 51)$ lid 3 heeft.'

Wanneer een rechtshandeling krachtens artikel 81 lid 2 eerste volzin Ow I vanaf de inwerkingtreding vernietigbaar is, bestaat er alsdan een bevoegdheid tot vernietiging, die in het "uitsteljaar" 1992 niet kan verjaren.

'Pas na afloop van dat jaar wordt het bepaalde omtrent de termijn van toepassing; blijkt deze op dat tijdstip dan inmiddels verlopen, dan geldt de bevoegdheid tot vernietiging als vanaf dat tijdstip verjaard (art. 73 lid 2).

In het derde geval zou artikel $73 a$ lid 1 de bevoegdheid in het geheel niet doen ontstaan, omdat het oude recht hier niet een bevoeg(d)heid tot vernietiging, maar nietigheid kent.'

Artikel $73 a$ lid 1 Ow I stelt als eis dat een bevoegdheid van gelijke aard als naar nieuw BW volgens het tevoren geldende recht niet bestond. Indien een voorheen nietige rechtshandeling op grond van artikel 81 lid 2 eerste volzin Ow I vernietigbaar wordt; is aan deze eis voldaan. Een bevoegdheid tot vernietiging is niet een bevoegdheid van gelijke aard als een bevoegdheid, zich op nietigheìd te beroepen, althans indien dat beroep onder het oude recht niet aan een termijn was gebonden (zie hierboven).

'Het is evenwel billijker ook in dit geval, evenals in het vorige, de bevoegdheid tot vernietiging nog te gunnen in de, in artikel 72 , resp. artikel 73 voorziene periode. Om die reden wordt in de tweede zin van artikel 81 lid 2 van artikel $73 a$ afgeweken.'

Artikel 81 lid 2 tweede volzin Ow I geldt dus alleen voor dit laatste geval.

Ten aanzien van de achtergrond van artikel 81 lid 3 eerste volzin $O$ w I verwijs $i k$ naar nr. 4.9.1 hiervóór.

\subsubsection{Handelings- en feitelijke onbekwaamheid}

Onzeker was onder het oude recht of door een handelingsonbekwame verrichte eenzijdige rechtshandelingen werden gesanctioneerd door nietigheid dan wel door ver- 
nietigbaarheid ${ }^{144}$. Wanneer men met Bolweg ${ }^{145}$ aanneemt dat zulke rechtshandelingen nietig waren, zal men in overgangsgevallen bij artikel 81 leden 2 en 3 Ow I te rade moeten gaan, indien het cenzijdige gerichte rechtshandelingen betreft (deze zijn volgens artikel 3:32 lid $2 \mathrm{BW}$ vernietigbaar). Anders is dit, zo men er met Hartkamp ${ }^{146}$ van uit gaat dat oud en nieuw recht hier met elkaar sporen.

Onzekerheid was er onder de vigeur van het oude BW ook op het punt van de rechtshandelingen, verricht door geestelijk gestoorden ${ }^{147}$. Hartkamp ${ }^{148}$ meent dat de oplossing van artikel 3:34 lid $2 \mathrm{BW}$ eveneens woor het oude recht kon worden aanvaard. In deze opvatting komt men aan toepassing van artikel 81 Ow I niet toe. Dit is anders, indien men Rutten ${ }^{149}$ volgt, die van oordeel is dat meerzijdige rechtshandelingen in geval van geestelijke gestoordheid van één van de thandelende partijen onder het oude rechr niet vernietigbaar, maar nietig waren.

\subsubsection{Misbruik wan omstandigheden}

De meest in het oog springende toepassing van artikel 81 lid 2 Ow I betreft misbruik van omstandigheden. Was dit voorheen een nietigheidsgrond (ontbreken van een geoorloofde oorzaak wegens strijd met de goede zeden, artikelen 1371 jo. 1373 (oud) BW: ${ }^{50}$ ), thans is misbruik van onstandigheden een wilsgebrek op grond waarvan vernietiging van de rechtshandeling kan plaatsvinden (artikel 3:44 lid 4 BW). Hier is een wisseling van rechtsgevolg aanwezig; de vereisten blijven onveranderd.

\subsubsection{Verdeling van gemeenschappen}

De verdeling van een gemeenschap, waaraan niet alle deelgenoten en andere personen wier medewerking vereist was hebben deelgenomen, is vernietigbaar, indien zij is geschied bij notariële akte (artikel 3:195 lid $1 \mathrm{BW}$; is de verdeling niet geschied bij notariêle akte dan is zij nietig). Volgens het oude recht was het rechtsgevolg steeds nietigheid ${ }^{151}$. Heeft men hier nu niet te maken met een "voldongen feit" waarop het nieuwe recht geen invloed heeft? Naar mijn mening niet, omdat hier geen nieuw vereiste wordt gesteld, maar zich een ander rechtsgevolg manifesteert ${ }^{152}$.

144. Vgl. H. Stein, preadv, p. 75-76.

145. Pitlom Bolweg P. 422423

146. Asser-Hartkamp II, ni, 95 .

147. Vgl. Mon. Nieuw BW A.23 (Van Buchem), p. 43,50, Asser-Hartkamp II, nr. 117.

1418. Asser-Hartkamp II, nr. 117, al watr tevens verwijzïngen naar andere auteurs. In wr. 467 noemt Hartkamp artikel 3:34 lid 2 BW als voorbeeld van een bepaling die wernietigbaarheid voorschrijft waar in het oude recht nietigheid placht te worden aangenomen.

149. Asser-Rutten II, p. 77.

$150 . \mathrm{Vgl}$. Asser-Harkamp II, mr. 212 , alwaar ook enkele schrijwers worden genoemd, die reeds voor het vroegere recht verdedigen dat misbruik vam onstandigheden leidde tot vernietigbaarheid.

151. Vgl. Parl, Gesch Overgangsrecht, p. 266, Asser-Meijers-Van der Ploeg, nr. 489.

152. Zie nur. 4.3 hierv60: 
Indien een overeenkomst (denk bij voorbeeld aan schuldvernieuwing) de strekking heeft voort te bouwen op een bestaande rechtsbetrekking en deze rechtsbetrekking blijkt naderhand niet te bestaan, is de overeenkomst in beginsel vernietigbaar (artikelen 6:229 en $230 \mathrm{BW}$ ). Vroeger was zo'n voortbouwende overeenkomst nietig wegens het ontbreken van een oorzaak (artikel 1371 (oud) BW153).

\subsection{RECHTSHANDELINGEN MET EEN DUBBEL GEBREK}

In de loop van de behandeling door de Tweede Kamer is artikel 81 lid 2 Ow 1 nog iets gewijzigd. Deze wijziging is aangebracht om duidelijker te laten uitkomen dat artikel 81 lid 2 Ow I ook vernietigbaarheid bewerkstelligt van die rechtshandelingen die onder de vigeur van het oude recht aan twee (soorten) gebreken leden, waarvan het ene tot nietigheid en het andere tot vernietigbaarheid leidde, terwijl de nietigheidsgrond onder het nieuwe recht wegvalt. De minister ${ }^{154}$ noemt als voorbeeld een schenking door een minderjarige zonder de vereiste notarielle akte (artikel 1719 (oud) BW). Vernietigbaarheid als uitkomst ligt hier wel voor de hand.

\subsection{SLOT}

Bij een zo veelomvattende overgangsregeling als die voor de geldigheid van rechtshandelingen dringt de behoefte aan een schema zich op. Naar aanleiding van de door H. Stein en schrijver dezes ${ }^{155}$ opgestelde schema"s vraagt de vaste Commissie voor Justitie van de Tweede Kamer in haar voorlopig verslag, of de minister een schematisch overzicht kan geven van de verschuivingen tussen geldigheid, nietigheid en vernietigbaarheid, die het toepasselijk worden van het nieuwe BW teweeg kan brengen, alsmede van de gevolgen die daaraan door het overgangsrecht worden verbonden. De minister voldoet aan het verzoek van de commissie ${ }^{156}$. Ik geef hierna een soortgelijk schema met daarin een alantal detailleringen en uitzonderingen.

Oud recht
onaantastbaar(1)
onaantastbaar(1)
vernietigbaar
vernietigbaar
nietig(3)
nietig(3)(4)

Oud recht onaantastbaar(1) onàntastbaar(1) wernietiguar vernietigbaar nietig(3)(4)

Huidig $B W$
vernietigbaar
nietig
onaantastbaar
nietig
onaantastbaar
vernietigbaar

Overgangswet
onaantastbaar(2)
onaantastbaar(2)
onaantastbaar
nietig
onaantastbaar $(5)(6)(7)$
vernietigbaar(5)(8)

Artikel 79 79 80 lid 1 80 lid 2 81 lid 1 81 lid 2

153. Vgl. Asser-Hartkamp II, hr. 240.

154. Parl. Gesch. Overgangsrecht, p. 84.

155. Respectievelijk preadv, p. 77, 131; Kwartaalbericht Nieuw BW 1986, p. 80 .

156. Parl. Gesch. Overgangsrecht, p. 80, 83. 
Opmerkingen

(1) Artikel 79 OW I verhindert tevens dat naast of in de plaats van een bestaand gebrek een nieuwe grond van nietigheid of vernietigbaarheid ontstaat (zie nr. 4.6 hiervoor):

(2) Deze oplossingen gelden behoudens andersluidende bepaling, zo waarschuwt de aanhef van artikel 79 Ow I (zie voor een belangrijk voorbeeld nr. 4.5.6 hiervóór).

(3) Artikel 81 Ow I geldt alleen voor nietigheid van rechtswege (zie nr. 4.9.1 hiervóóry.

(4) Onder artikel 81 lid 2 Ow I vallen ook die rechtshandelingen die onder het oude recht leden aan twee (soorten) gebreken, walarvan het ene leidde to nietigheid en het andere tot vernietigbaarheid, terwijl de nietigheidsgrond onder het nieuwe recht wegvalt (zie nr: 4.11 hiervóor).

(5) De rechtshandeling is slechts dan onaantastbaar respectievelijk vernietigbaar, indien alle onmiddellijk belanghebbenden die zich op de nietigheid hadden kunnen beroepen haar voorheen als geldig hebben aangemerkt (zie nr. 4.9.1 hiervóor).

(6) Hebben derden inmiddels rechten verkregen, dan behoeven deze niet aan de convalescentie in de weg te staan, mits deze rechten worden geẻerbiedigd (zie nr. 4.9.1 hierv60r).

(7) In artikel 172 Ow I is een afwijking te vinden (zie nr. 4.9.5 hiervóór).

(8) Indien het oude recht een beroep op de nietigheid niet aan een bepaalde termijn bond, is artikel $73 a$ Ow I niet van toepassing (zie nr. 4.10.1 hiervóór). 


\section{Zekerheidseigendom en stil pandrecht}

\subsection{INLEIDING}

Tot de belangrijke veranderingen die het nieuwe BW heeft gebracht; moet ongetwijfeld de vervanging van de fiduciaire eigendom tot zekerheid door het stille pandrecht worden gerekend. De fiduciaire eigendomsoverdracht tot zekerheid (doorgaans met levering constituto possessorio) geschiedde in de regel op grond van duurzame kredietovereenkomsten en kwam zeer vaak voor. Een en ander riep voor de overgangswetgever problemen op, met name of, en zo ja, hoe het nieuwe recht op bestaande zekerheidseigendomsrechten en verbintenissen en leveringen bij voorbaat tot zekerheidsoverdracht kon en moest worden toegepast. Daarbij diende onder meer in het oog te worden gehouden dat het bij overdracht tot zekerheid niet alleen ging om roerende zaken, niet-registergoederen, maar ook om andere goederen, zoals vorderingen op naam. Artikel 86 Ow I strekt ertoe om deze - naar in het onderstaande zal blijken gecompliceerde - problematiek op te lossen. Het is veelzeggend dat artikel 86 het langste is van de meer dan 100 artikelen die de Aanvulling van de Overgangswet nieuw BW telt. Bestudering van de overgangsvragen waarvoor wij ons bij de zekerheidseigendom gesteld zien leert bovendien, dat voor de beantwoording daarvan niet kan worden volstaan met toepassing van één of meer van de acht leden wan artikel 86 Ow I. Daarvoor zijn namelijk niet zelden ook andere overgangsbepalingen onmisbaar, zoals die betreffende de privileges (artikelen 117-119 Ow I) en het bodembeslag van de fiscus (artikel 39 Ow II): In het navolgende zal ik trachten de overgangskwesties met betrekking tot de zekerheidseigendom op overzichtelijke wijze te ontrafelen en tot een oplossing te brengen. Daarbij zal ik mij in beginsel beperken tot de objecten die hier het belangrijkst zijn, namelijk roerende zaken, niet-registergoederen en vorderingen op naam.

Voorbehouden eigendom, die tot op zekere hoogte ook zekerheidseigendom is, laat ik buiten beschouwing. Het praktische belang van de daarvoor gegeven overgangsregels (artikel $89 \mathrm{OW}$ I) is geringer dan die voor de door overdracht geschapen eigendom tot zekerheid. Voorts is artikel 89 Ow I grotendeels een kopie van artikel 86 Ow I.

\subsection{ENKELE TERMINOLOGISCHE KWESTIES}

Alvorens te kunnen overgaan tot de behandeling van het overgangsregime ter zake van de zekerheidsoverdracht dient eerst duidelijkheid te worden verschaft over de 
bij die behandeling gehanteerde terminologie. Omdat de werking van het nieuwe recht voor overgangssituaties centraal staat, gebruik ik in beginsel zijn terminologie. Oude termen zijn echter niet te vermijden, met name uiteraard zekerheidsoverdracht en -eigendom. Ik ga hierna kort in op de begrippen zekerheidsoverdracht en -eigendom en stil pandrecht.

\subsubsection{Zekerheidsoverdracht en zekerheidseigendom}

De fiduciaire eigendomsoverdracht tot zekerheid met levering door middel van constitutum possessorium is de rechtsfiguur waarvoor het nieuwe $\mathrm{BW}$ de stille verpanding in de plaats stelt. Het is echter niet goed werkbaar om telkens deze lange aanduiding te bezigen. Daarom gebruik ik in het verwolg de minder juiste - want onvolledige - termen "zekerheidsoverdracht' en 'overdracht tot zekerheid'. De door zo' 1 overdracht verkregen eigendom zal ik kortheidshalve 'zekerheidseigendom' of "eigendom tot zekerheid" noemen. Bij laatstgenoemde termen dient te worden aangetekend dat deze strikt genomen te ruim zijn, omdat woorbehouden eigendom tot op zekere hoogte ook zekerheidseigendom is 1 .

Naast zaken werden ook vorderingen veelvuldig tot zekerheid overgedragen. Onder het oude recht was het merendeel van de schrijvers de mening toegedaan dat (vorderings)rechten niet het voorwerp van eigendom konden zijn ${ }^{2}$. Kortheidshalwe gebruik ik echter oiok bij worderingen de term 'zekerheidseigendom'.

Wanneer ik het oog heb op zowel zekerheidseigendom als verbintenissen en leveringen bij voorbaat tot zekerheidsoverdracht zal ik om het kort te houden spreken van "zekerheidswerhoudingen".

\subsubsection{Stil pandrecht}

De nieuw BW-wetgever gebrukt nogal eens de omschrijving "bezitloos pandrecht" voor het pandrecht dat wordt gevestigd bij authentieke of geregistreerde onderhandse akte zonder dat de zaak in de macht van de pandhouder of van een derde wordt gebracht (artikel 3:237 lid I BW) ${ }^{3}$. Deze term suggereert ten onrechte dat, wanneer de zatk wel in de macht van de pandhouder of van een derde is gebracht, de pandhouder bezitter van de verpande zaak zou zijn. Daarom is het juister net als voor verpanding van vorderingen op naam zonder mededeling daarvan aan de debiteur van de verpande vordering (artikel $3: 239$ lid $1 \mathrm{BW}$ ) de term "stil pandrecht' te gebruikent". Deze

1. Zie Mezas, diss. p. 8; Asser-Mijnssen, wr. 172; Brahn, studiepocket, p. 134-135.

2. Zie Asser-Beekhuis 1, nor. 89.

3. Zie Prarl. Gesch. Boek 3, p. 746 e.w.

4. In de parlementaire stukken behorend bij de lnvoeringswet wordt de benaming 'still pandrech' niet all leen gebruikt voor pandrechten die zjongevestigd op de wijze van artikel $3: 239$ lid $1 \mathrm{BW}$, maar ook wel voor pundrechten die zijn gevestigd op de wijze van atikel $3: 237$ nid I BW: zie Parl. Gesch. Inw. Boek 3, p, 1329, 1337, 1338. Voor gebritk van de term "stil pandrecht' woor beide soorten pandrechter pleiten Asser Mijnssem, nr. 157; Rethuis, diss, nir 5, Brahn, studepocket, p. 23.24. Wan Mierlo, diss, p. 177, noot 11, kiest voor de onnchlijving 'vuistloos pandrecht' als het gat om het pandrecht als bedoeld in artikel $3: 237$ lid $1 \mathrm{BW}$. 
term brengt tot uitdrukking waar het om gaat, namelijk dat beide zojuist genoemde pandrechten voor de buitenwereld niet kenbaar zijn.

\subsection{ONTSTAAN VAN OVERGANGSKWESTIES BU ZEKERHEIDSIIGENDOM}

In de artikelen 1198 en 1199 (oud) $\mathrm{BW}$ werd voor vestiging van pandrecht als eis gesteld dat het verpande goed, kort gezegd, uit de macht van de pandgever werd gebracht. Dit vereiste werd in de praktijk als te knellend ervaren. Er bestond grote behoefte aan een zekerheidsrecht dat kon worden gevestigd zonder dat het desbetreffende goed uit de macht van de pandgever werd gebracht. Daarvoor werden constructies benut die erop neerkwamen, dat het goed tot zekenheid in eigendom aan de crediteur werd overgedragen, zonder dat dit uit de macht van de zekerheidsgever (doorgaans de debiteur) werd gebracht. In 1929 erkende de Hoge Raad de mogelijkheid van zekerheidsoverdracht zonder feitelijke overgave van het tot zekerheid dienende goed 5 . De titel zekerheid was onder het oude recht derhalve een geldige titel voor eigendomsoverdracht. Het nieuwe BW heeft in deze situatie verandering gebracht. In artikel $3: 84$ lid 3 wordt bepaald:

'Een rechtshandeling die ten doel heeft een goed over te dragen tot zekerheid of die de strekking mist het goed na de overdracht in het vermogen van de verkrijger te doen vallen, is geen geldige titel van overdracht van dat goed:

Omdat ook in het nieuwe BW het causale stelsel voor overdracht wordt gehand. haafd (artikel 3:84 lid 1), brengt het zojuist geciteerde lid 3 met zich mee, dat een overdracht met als titel zekerheid nietig is.

Aan de in de praktijk bestaande behoefte aan een "stil' zekerheidsrecht is tegemoet gekomen door vestiging van pandrecht mogelijk te maken zonder dat het te verpanden goed uit de macht van de pandgever wordt gebracht (antikelen 3:237 lid 1 en 239 lid 1 BW). Volgens de toelichtende stukken is gekozen

"voor regeling van een bezitloos pandrecht waarmee praktisch hetzelfide resultaat als met zekerheidseigendon kan worden bereikt, zij het ook op een duidelijker wijze:

De afdelingen 3.9 .1 en $3.9 .2 \mathrm{BW}$ zijn aldus opgezet

"dat bestaande financieringspatronen, ondanks de wetstechnische andere opzet van de nieuwe regeling, onder het nieuwe recht zonder moeilijkheid kunnen worden gecontinueerd. ${ }^{16}$

5. HR 25 januari 1929, NJ 1929, 616 (Bierbrouwerij) en HR 21 juni 1929, NJ 1929, 1096 (Autoverhuurondernening).

6. Parl. Gesch. Inw. Boek 3, p 1197. Op de p. 1198-1200 geeft de minister een vergelijking opeen aantal purtten tussen zekerheidseigendom en stil pandrecht. 
Voor zover de verschillen tussen zekerheidseigendom en stil pandrecht in overgangsrechtelijk opzicht van belang zijn zullen zij hierna aan de orde komen. Voor. het overige verwijs ik naar literatuur over zekerheidseigendom en stil pandrecht ${ }^{7}$.

De vervanging van eigendom tot zeketheid door stil pandrecht werd in het perspectief van het overgangsrecht pas echt een probleem, doordat zekerbeidsverhoudingen veelvuldig voorkwamen en - wat belangrijker is - vaak onderdeel uitmaakten van langlopende kredietrelaties. Ten tijde van de invoering van het nieuwe BW waren derhalve in groten getale de volgende toestanden aanwezig:

- het bestaan van zekerheidseigendom;

- het bestaan van verbintenissen tot overdracht tot zekerheid;

- het bestaan van leveringen bij voorbaat van toekomstige goederen tot overdracht tot zekerheid.

Kortom, wij hebben hier te maken met zowel een ingrijpende vernieuwing in het recht als met een omvangrijk bestand aan duurzame over de inwerkingtreding heen lopende zekerheidsverhoudingen. Een menigte overgangsvragen doemt op. Een algemene kwestie is hoe pandregels op eigendom tot zekerheid zijn toe te passen; een bijzondere, welke rangorde bestaat tussen zekerheidsrechten van vóór de inwerkingtreding en later totstandgekomen rechten. Hierna bespreek ik deze en andere vragen. Eerst geef ik aan, waartoe onmiddellijke werking zou leiden (nr. 5.4). Daarna volgt een overzicht van de belangrijkste regels die de Overgangswet bevat voor zekerheidseigendom (nr. 5.5). Een analyse van de omzetting van zekerheidseigendom in pandrecht geef ik in $\mathrm{mr}$. 5.6. (De sterkte van) het door de omzetting ontstane pandrecht is voorwerp van beschouwing in de nrs. 5.7 en 5.8 . Hoe het ontstaan van zekerheidseigendom na de inwerkingtreding wordt geblokkeerd blijkt in nr. 5.9. In nr. 5.10 geef ik aan wat geldt voor rechten uit een levensverzekering.

\subsection{CONSEQUENTIES VAN ONMIDDELLIJKE WERKING VAN HET NIEUWE BW TEN} AANZIEN VAN BESTAANDE ZEKERHEIDSVERHOUDINGEN

Voor het in artikel 3:84 lid $3 \mathrm{BW}$ opgenomen verbod van zekerheid als titel voor overdracht geldt de algemene regel van artikel $68 a$ lid 1 OW I, te weten de onmiddellijke werking. Alvorens te kunnen ingaan op de vraag of, en zo ja, welke overgangsvoorzieningen met betrekking tot zekerheidsverhoudingen geïndiceerd lijken, wil ik om de gedachten te bepalen eerst bezien waartoe de regel van de onmiddellijke werking sec zou leiden. In de memorie van toelichting wordt ten aanzien van deze laatste kwestie het volgende standpunt ingenomen:

'De bepaling (artikel 3:84 lid $3 \mathrm{BW}, \mathrm{HvdB}$ ) betekent alleen dat na haar inwerkingtreding geen geldige overdracht meer tot stand kan komen die op zulk een rechtshandeling als titel steunt. Aan een overdracht voordien ontneemt zij de geldige titel niet: de bepaling werkt immers niet terug. In zoverre bestaat er dus strikt genomen geen behoefte aan een overgangsbepaling. ${ }^{2} 8$

7. Zie bij voorbeeld de dissertatie van Reehuis, Stille verpanding, en de zesde en zevende druk van de stur diepocket wan Brahn.

8. Parl. Gesch. Overgangsrecht, p. 89. 
De Die merkt op:

'De overgangssituatie is bij de i.w.t. als het ware al achter de rug. Als belangrijkste voorbeeld in de Overgangswet NBW zie men art: 86, dat de - bij de i.w.t. reeds bestaande - eigendom tot zekerheid converteert in een bezitloos pandrecht. Strikt genomen is hiertoe geen noodzaak: art. 3.4 .2 .2 (3:84) lid 3 keert zich slechts tegen het ontstaan van eigendom tot zekerheid - in gevallen van overgangsrecht bijv. krachtens tevoren gesloten kredietovereenkomsten -, maar niet tegen het bestaan ervan; denkbaar zou zijn geweest bij de Overgangswet daaraan niets te doen $(. . .)^{9}$.

De vór de invoering eenmaal totstandgekomen zekerheidsoverdracht moet worden aangemerkt als een 'voldongen feit' ${ }^{10}$. Haar totstandkoming ondervindt geen invloed van de invoering van het verbod van zekerheid als titel voor overdracht, tenzij daarbij terugwerkende kracht in het spel zou zijn. Deze zou hier echter niet passen. Bestaande verbintenissen tot zekerheidsoverdracht zouden bij onmiddellijke werking gelet op artikel 3:84 lid $3 \mathrm{BW}$ tot een nietige prestatie verplichten; bestaande leveringen bij voorbaat tot zekerheid zouden na de inwerkingtreding niet meer tot een geldige overdracht kunnen leiden. Bij dit alles komt nog, dat het oude recht ten aanzien van de zekerheidseigendom lacunes vertoonde" ${ }^{11}$.

Bij kredietrelaties waarbij werd gewerkt met zekerheidseigendom als zekerheid voor de voldoening van de vorderingen van de kredietverschaffer ging het doorgaans om gedurende langere tijd lopende overeenkomsten, op grond waarvan periodiek zaken en/of vorderingen tot zekerheid aan de kredietverschaffer werden overgedragen. Als gezegd kwamen deze kredietrelaties vaak voor. Indien geen specifieke overgangsregeling voor deze zekerheidsverhoudingen zou worden getroffen, zou men nog gedurende (zeer) lange tijd na de inwerkingtreding met zekerheidseigendom worden geconfronteerd, terwijl dan inmiddels naar mag worden aangenomen ook het stille pandrecht veelvuldig is gevestigd. Het naast elkaar bestaan van beide zekerheidsfiguren zou een weinig aantrekkelijke situatie opleveren.

Gezien het voorgaande moet het treffen van overgangsvoorzieningen voor (de gevolgen van) zekerheidswerhoudingen als noodzakelijk worden beschouwd ${ }^{112}$. Van deze voorzieningen, die zijn neergelegd in artikel $86 \mathrm{OW} \mathrm{I}$, zal ik nu een overzicht geven. Ik merk nog op dat met genoemde overgangsbepaling de wetgever zich heeft ingelaten met een geval dat valt buiten het begrip 'overgangssituatie', zoals hij dit hanteert ${ }^{13}$.

9. Spoedcursus, p. 23.

10. Zie de nrs. 2.4.1.2, 2.5.1.1 sub c. 2, 2.5.1.2 sub c.2 en 2.5.1.4 sub b hierv6ór.

11. Zie voor lacunes in het oude recht bij woorbeeld Reehuis, diss., 0 .a, nrs. $3,14,20$.

12. Vgl. Parl. Gesch. Overgangsrecht; p. 89; Reehuis, diss, nr: 507 ,

13. Zie het lavatste citaat hierboven, alsme de de nrs. 2.4.1.1 e.v. hiervór. 
De tussen het oude en het nieuwe recht ten aanzien van zekerheidsverhoudingen gapende kloof wordt in de Overgangswet overspannen met behulp van de figuur van de orizetting en die van de fictie. De omzetting van bestaande zekerheidseigendom is aldus geconstrueerd. De zekerheidseigendom is op grond van artikel 86 lid 1 Ow I op het moment van de inwerkingtreding van het nieuwe BW teruggevallen aan degene die de goederen tot zekerheid had overgedragen. Tegelijkertijd zijn de goederen belast met cen pandrecht ${ }^{14}$. Vereist is wel dat het gaat om voor verpanding vatbare goederen. Indien de zekerheidsoverdracht is geschied met levering constituto possessorio zal op grond van artikel 86 lid 2 Ow II het pandrecht een stil pandrecht zijn.

Behalve van zekerheidseigendom kon ten tijde van de inwerkingtreding ook sprake zijn van een verbintenis tot zekerheidsoverdracht dan wel van een levering bij voorbaat van een toekomstig goed tot zekerheidsoverdracht. Deze mogelijkheden zijn door de overgangswetgever niet over het hoofd gezien. Zij worden in lid 7 van artikel 86 Ow $I$ aldus geregeld dat zij voortaan gelden als respectievelijk een verbintenis tot vestiging van een pandrecht en een levering bij voorbaat tot vestiging van een pandrecht. Uiteraard moet het ook dan gaan om een voor verpanding vatbaar goed. Verlangt een partij bij een overeenkomst die tot zekerheidsoverdracht verplicht aanpassing van de overeenkomst aan titel $3: 9 \mathrm{BW}$, dan is de wederpartij verplicht om aan deze aanpassing mede te werken, aldus artikel 86 lid 8 Ow I.

Met genoemde koppelregels worden de in nr. 5.4 hiervóór genoemde problemen opgelost, die bij onmiddellijke werking zouden rijzen. De frequent voorkomende en vaak uit duurzame verhoudingen voortvloeiende zekerheidseigendom is geëlimineerd, zodat niet de situatie kan ontstaan van het naast elkaar bestaan van tweeërlei recht. Ook de verbintenis tot zekerheidsoverdracht en de levering bij voorbaat tot zekerheid kunnen thans tot een (aangepast) rechtsgevolg leiden. De regeling van het pandrecht in het nieuwe BW geeft miet de lacunes te zien, die het oude recht ter zake van de zekerheidseigendom kenmerken ${ }^{15}$. Naar mijn mening is het dan ook juist dat ervoor gekozen is, over te gaan tot vervanging van zekerheidsverhoudingen door figuren die passen in het kader van titel $3.9 \mathrm{BW}$.

Met deze omzetting zijn echter nog lang niet alle problemen uit de wereld. Zo is van belang hoe het door omzetting ontstane pandrecht zich verhoudt tot die, vór de inwerkingtreding ontstane, rechten en vorderingen, waartegen de zekerheidseigendom kon worden ingeroepen. Artikel 86 lid 3 Ow I bepaalt hieromtrent dat ook het pandrecht ex artikel 86 lid 1 Ow I tegen deze rechten en vorderingen kan worden ingeroepen. Dit is een tamelijk voor de hand liggende oplossing; het pandrecht zou zonder deze regel minder van waarde zij.j voor de crediteur. Hetzelfde geldt voor de ook in lid 3 van artikel 86 OW I opgenomen regel dat het pandrecht met betrekking tot de rangorde geldt als gevestigd op het tijdstip waarop het goed tot zekerheid is overgegaan.

14. Doorgatans zal de debiteur de zekerheidsverschaffer zijn geweest en de crediteur de eigenaar tot zekentheid/pardhouder. In het navolgende zal ik in beginsel alleen van deze situatie uitgaan.

115. Althans volgens de overgangswetgever: zie. Parl. Gesch. Overgangsrecht, p. 89, Vgl, ook Reehuiis, diss., ar. 19. 
Omzetting van zekerheidseigendom in pandrecht zou een ongewenste verrassing kunnen opleveren in die gevallen, waarin het vóór de inwerkingtreding tot executie van de zekerheidsobjecten kwam dan wel dreigde te komen. In die situaties is een ongestoorde afwikkeling van de zekerheidseigendom te prefereren boven een door ornzetting van zekerheidseigendom in stil pandrecht (waarop de nieuwe regels inzake de uitwinning van toepassing zouden zijn) ontregelde executie ${ }^{16}$. Terecht zijn dan ook in artikel 86 lid $5 \mathrm{OW}$ I uitzonderingen opgenomen op de omzetting van zekerheidseigendom in stil pandrecht. Deze houden het volgende in.

Was vór de inwerkingtreding de uitwinning van het zekerheidsobject aan de debiteur aangezegd, dan heeft de omzetting ex artikel 86 lid 1 Ow I vooreerst niet plaatsgevonden. Indien echter de crediteur op 1 juli 1992 nog niet tot de uitwinning is overgegaan, dan wordt op genoemde datum de zekerheidseigendom alsnog in pandrecht omgezet. Was de debiteur failliet op het moment van de inwerkingtreding, dan vindt de omzetting na afloop van het faillissement plaats, indien de zekerheidseigendom is blijven bestaan.

Ten aanzien van contractuele bedingen inzake zekerheidseigendom wordt in artikel 86 lid 6 Ow I bepaald dat deze bedingen op het pandrecht van overeenkomstige toepassing worden. Hierbij is niet van belang of zij aan een na de inwerkingtreding gevestigd pandrecht zouden kunnen worden verbonden. Een uitzondering geldt evenwel voor die bedingen die worden uitgesloten door de artikelen 3:249-253 BW. Als gevolg van deze regeling behoeft in beginsel geen aanpassing van overeenkomsten aan titel $3.9 \mathrm{BW}$ plaats te vinden ${ }^{17}$.

De zojuist gemaakte instemmende opmerkingen met betrekking tot de hoofdpunten van de overgangsregeling inzake de zekerheidseigendom en het stille pandirecht nemen niet weg dat $i \mathrm{k}$ op andere punten wel kritiek heb. Deze zal ik aan de orde stellen bij de meer diepgaande behandeling van artikel $86 \mathrm{OW}$ I, die hieronder zal plaatsvinden.

Aan het overzicht van de inhoud van artikel 86 Ow I voeg ik nog enkele opmerkingen toe omtrent het toepassingsgebied van deze overgangsbepaling. Voor dat toepassingsgebied is in de eerste plaats van belang dat de leden $2,3,5,6$ en 8 van artikel 86 Ow I in artikel 89 lid 3 Ow I van overeenkomstige toepassing worden verklaard. Artikel 89 Ow I heeft betrekking op voorbehouden eigendom en verbintenissen tot levering onder eigendomsvoorbehoud voor zover het eigendomsvoor behoud zich uitstrekt buiten de grenzen van artikel 3:92 lid 2 BW.

Voorts moet worden gewezen op artikel 39 lid 1 Ow II. Daarin wordt bepaald dat artikel 86 lid $\mathbb{1}$ OW I niet van toepassing is op gevallen waarin een vór de inwerkingtreding door de fiscus gelegd bodembeslag niet is afgewikkeld ${ }^{18}$.

16. Vgl. Paril. Gesch: Owergangsrecht, p. 91.

17. Overigens is zodanige aanpassing wel aan te raden; zie de nrs. 5.7.1-3 hiema.

18. Hierover meer in ni 5.6.4 hierna. Volledigheidshalve wermeld ik nog dat in de toelichtende stukken bij het tweede stuk van het overgangsrecht (Ow II) er bij het nieuwe artikel 49 a Zaaizaad - en Plantgoed wet op wordt gewezen dat artikel 86 Ow I ook van toepassing is op bestaande zekerheidseigendom wan kwekers* redhten (Pari. Gesch. Overgangsrecht, p. 359). 
Startpunt bij het ontleden van (de werking van) artikel 86 Ow I moet uiteraard de omzetting van zekerheidseigendom in pandrecht ingevolge lid 1 zijn. Lid I van artikel 86 Ow I biedt met deze omzetting een voorbeeld van een overbruggingsregel: over het gat tussen het oude en het nieuwe recht wordt als het ware een brug geslagen ${ }^{19}$. Hieronder bezie ik eerst de vereisten voor de omzetting (nrs. 5.6.1-4). Vervolgens (nr. 5.6.5) ga ik in op het rechtsgevolg dat intreedt, indien aan deze vereisten is voldaan. De aard van het pandrecht ex artikel 86 Ow I vormt het onderwerp wan nr. 5.6.6. Ik sluit af met de verhouding van artikel 86 lid 1 OW I tot artikel 69 Ow I (nr. 5.6.7).

\subsubsection{Het goed is aan een ander tot zekerheid overgedragen}

Een eerste vereiste voor de omzetting is, dat ten tijde van de inwerkingtreding een goed aan een ander tot zekerheid is overgedragen. Men denke aan handelsvoorraden, kantoor-, fabrieks- en café-inventaris, auto's en vorderingen op naam die tot zekerheid van de voldoening van schulden aan bij voorbeeld een bank of brouwerij zijn overgedragen ${ }^{20}$.

In de oorspronikelijke tekst van het wetsvoorstel werd gesproken over goederen die aan een schuldeiser tot zekerheid zijn overgedragen ${ }^{21}$. De Raad van State merkte naar aanleiding hiervan in zijn advies op dat

'Betwijfeld kan worden of onder het eerste lid ook de situatie is begrepen dat. degene te wiens laste de zekerheid is gesteld voor het tijdstip van het in werking treden van de wet, een voor verpanding vatbaar goed aan een ander; c.q. een derde, in plaats van aan zijn schuldeiser heeft overgedragen. ${ }^{22}$

De Raad was van oordeel dat in de wetstekst iedere twijfel hieromtrent diende te worden uitgesloten. De minister bleek in het nader rapport ${ }^{23}$ van mening dat de door de Raad bedoelde casus zich vermoedelijk buiten het geval van vertegenwoordiging nauwelijks zal voordoen. Hij had er echter geen bezwaar tegen, het woord 'schuldeiser' te vervangen door 'ander'.

\subsubsection{Een voor verpanding vatbaar goed}

Het ligt voor de hand dat alleen zekerheidseigendom van goederen die voor ver-

19. Zie nader over overbruggingsregelis nu: 2.5 .2 hiervóor.

20. Het kan onder onstandigheden wijfelachtig zijn of sprake is van zekerheidsoverdracht: zie bij woorbeeld hetgeen Van Mierlo, preadv., p. 43-44, schrijft over de zogenoemde "securitisation'. Vgl. ook W.R. Meijer, WPNR 6007 (1991), p. 352, alsmede het door Reehuis over leasing opgemerkte in AA 1991, p. 507 e.v..

21. Parl. Gesch: Overgangsrecht, p. 91 .

22. Parl. Gesch. Overgángsrecht, p. 91 .

23. Parl. Gesch. Overgangsrecht, p. 92. 
panding vatbaar zijn ${ }^{24}$ in aanmerking komt voor omzetting in stil pandrecht. Artikel 86 Ow I heeft betrekking op zowel roerende zaken, niet-registergoederen als op (vorderings)rechten, ook al is in het artikel sprake van eigenaar of eigendom tot zekerheid. Dit blijkt impliciet uit de wetstekst ${ }^{25}$, waarin het woord 'goed' wordt gebruikt, en expliciet uit de toelichtende stukken ${ }^{26}$. Zekerheidseigendom van de in nr. 5.6.1 hiervóór genoemde handelsvoorraden, kantoor-, fabrieks- en cafe-inventaris, auto's en vorderingen op naam zal gezien het bovenstaande in de regel op grond van artikel 86 lid 1 Ow I zijn omgezet ${ }^{27}$.

Het is denkbaar dat onder het oude recht zekerheidseigendom van registergoederen bestond. Deze vorm van eigendom tot zekerheid kwam niet veel voo ${ }^{28}$, onder meer omdat het hypotheekrecht al de mogelijkheid bood een zekerheidsrecht te vestigen zonder dat het goed uit de macht van de zekerheidsverschaffer werd gebracht. Zekerheidseigendom van registergoederen kan uiteraard niet in pandrecht worden omgezet; pandrecht kan nu eenmaal niet op registergoederen worden gevestigd. Volgens de minister leent zekerheidseigendom van registergoederen zich niet goed voor een eenvoudige omzetting, die dan op hypotheek zou moeten zijn gericht ${ }^{29}$. Nu voor eigendom tot zekerheid van registergoederen een specifieke overgangsregeling ontbreekt, is deze na de inwerkingtreding blijven voortbestaan ${ }^{30}$.

\subsubsection{Geen uitwinning (aangezegd) of faillissement}

Autoverhuurbedrijf A droeg in 1989 de eigendom van zijn voor de verhuur bestemde auto's tot zekerheid van de voldoening van zijn schulden aan bank B over. De levering geschiedde door middel van constitutum possessorium. Door het regeringsbeleid werden eind 1991 steeds meer mensen het openbaar vervoer ingedreven. De verhuuractiviteiten van $A$ liepen daardoor een gevoelige klap op. Als gevolg daarvan stokten zijn aflossingen aan B. Laatstgenoemde som-

24. Vgl. de artikelen 3:227 en $228 \mathrm{BW}$.

25. Behalve dan die van lid 4 van artikel 860 w $I$, waarover meer in nr. 5.10 hierna.

26. Parl. Gesch. Overgangsrecht, p. 89,92.

27. In de menorie van toelichting (Parl. Gesch. Overgangsrecht, p. 89) wordt nog naar enkele wetsartikelen verwezen in verband met de mogelijkheid tot verpanding van aandelen op naam in naamloze en besloten vennootschappen, octrooien en andere goederen, alsmede van verzekeringsportefeuilles en vorderingen wan de tussenpersoon op de verzekeraar. In het woorlopig verslag van de vaste Commisste voor Justitie van de Tweede Kamer (Parl. Gesch. Overgangsrecht, p. 92) word gevraagd waarom op evengenoemde plasts in de toelichting "allerlei vereisten voor de westiging van een pandrecht worden genoemd nu de omzetting van rechtswege plaatsvindt". De minister antwoordt hierop (Parl. Gesch. Overgangsrecht, p. 92) dat slechts wordt "aangegeven dat ook een aantal rechten waarvan de overdracht buiten Boek 3 wordt geregeld, voor pand vatbaar is."

Zle over de omzetting vam eigendom tot zekerheid van een aandeel in een verzameldepot als bedoeld in de Wet Giraal Effectenwerkeer: Van Mierlo, preadv., p. 40 41.

28. Aldus Parl. Gesch. Overgangsrecht, p. 89; Asser-Van Velten, nr. 202; Reehuis, diss.., nr. 511. Volgens Schuttevâer-Hermans, p. 79, kwam deze rechtsvorm onder meer woor, indien de debiteur slechts tot een onverdeeld aandeel gerechtigd was, zodat verlening van hypotheek in verband met artikel 1212 (oud) BW minder aantrekkelijk was.

29. Parl. Gesch. Overgangsrecht, p. 89.

30. Zie nr. 5.4 hierv6or ("voldongen feit"). 
meerde A daarom op 15 december 1991 om vóor 15 januari 1992 aan zijn ver plichtingen jegens $B$ te voldoen. Tevens werd aan A medegedeeld, dat B tot executie van A"s auto's zou overgaan, indien A niet aan de sommatie zou voldoen.

Een (negatief) vereiste voor de omzetting van eigendom tot zekerheid is dat niet reeds vóór de inwerkingtreding door de crediteur aan de debiteur de uitwinning van de zekerheidsgoederen was aangezegd ${ }^{31}$. Voor bovenstaand voorbeeld betekent dit dat de zekerheidseigendom (vooralsnog) nief is omgezet in stil pandrecht, maar dat deze de inwerkingtreding heeft "overleefd ${ }^{*} 32$. De ratio van deze eerbiediging van de eigendom tot zekerheid is de volgende. In geval van een op het moment van de inwerkingtreding op handen zijnde dan wel reeds lopende afwikkeling van dit zekerheidsrecht weegt het belang van partijen bij cen ongestoorde uitvoering van de overeengekomen regeling zwaarder dan het belang van het over de gehele linie toepassen van het nieuwe recht ${ }^{33}$. doet:

Stel nu echter dat in het hierboven gegeven voorbeeld zich het volgende voor-

A voldeed op het allerlaatste moment de achterstallige betalingstermijnen aan B; een staking van openbaar vervoerpersoneel in december 1991 bracht een opleving in A's verhuuractiviteiten teweeg, die hem weer even soelaas bood. B zag na de betaling door $\mathrm{A}$ af van de angezegde executie. In september 1992 is A echter weer een aantal maanden achter met zijn aflossingen can B. Omdat het er niet naar uitziet dat in A's financiële situatie binnen aanvaardbare termijn verbetering zal komen, besluit B thans daadwerkelijk tot uitwinning van A's auto's over te gaan.

Wat voor zekerheidsrecht maakt B geldend, zekerheidseigendom of stil pandrecht? Op grond van de tweede zin van artikel 86 lid 5 Ow II luidt het antwoord op deze vraag: stil pandrecht. Deze tweede zin houdt namelijk in dat de omzetting in pandrecht alsnog plaatsvindt, indien de crediteur zes maanden na de inwerkingtreding (dus op 1 juli 1992) nog niet (daadwerkelijk) tot de uitwinning is overgegaan. De ormzetting vindt dan plaats op 1 juli 1992. In de toelichting wordt vermeld dat in overleg met praktijkjuristen is gekozen voor de termijn van zes maanden en het criterium van de "aanzegging" (dit laatste omdat er lang niet altijd een formele ingebrekestelling is $)^{34}$.

Na deze eerste kennismaking met wat zou kunnen worden genoemd een voorwaardelijke blokkade van omzetting van eigendom tot zekerheid in pandrecht dient hierop thans dieper te worden ingegaan. Daartoe citeer ik eerst, voor zover hier relevant, de tekst van artikel 86 lid 5 Ow I.

31. Bij tor zeketheid ovengethagen worderingen gant het on een angezegde inning; aldus ook Mon. Nieu w BW B-12a (Molenar), p:88.

32. Zle nool 30 .

33. Vig. Paw , Gesch. Overgangsmecht, p. 91, 5; H. Stein, preadw, p. 157-158; Reehuis, diss, nrs. $512,516$.

$34 \mathrm{p}$ m. . Gesch. Overgangsrecht, $\mathrm{p} .91$. Deze opmerking heett betrekking op de oorspronkelijke tekst van arthkel 86 lid 5 Ow I, mar geldt on verkort voor de definitieve versie van deze bepaling. 
De leden 1-4 zijn niet van toepassing, indien aan de schuldenaar de uitwinning van het tot zekerheid overgedragen goed was aangezegd ${ }^{35}$. Is de schuldeiser zes maanden na dat tijdstip nog niet tot de uitwinning overgegaan, dan worden die leden alsdan van toepassing. ${ }^{36} 37$

Naar aanleiding van de wetstekst rijzen de volgende vragen, die ik in de nrs. 5.6.3.1-7 aan de orde stel:

- wanneer moet de in de eerste zin bedoelde aanzegging hebben plaatsgevonden, vóor of na de inwerkingtreding?

- indien de aanzegging voór de inwerkingtreding moet hebben plaatsgevonden, is dan nog van belang hoe lang vóor de inwerkingtreding de aanzegging is geschied?

- aan de hand van welke maatstaf wordt bepaald "op welk moment de aanzegging heeft plaatsgevonden: het tijdstip van verzending of het tijdstip van ontvangst?

- is de omzetting van de zekerheidseigendom ook opgeschort, indien de crediteur de uitwinning van de zekerheidsgoederen heeft aangezegd zonder dat de debiteur is tekortgeschoten in de nakoming van zijn verplichtingen?

- vanaf welk tijdstip moet de termijn van zes maanden, genoemd in de tweede zin, worden gerekend: vanaf dat van de inwerkingtreding of vanaf dat van de aanzegging?

- wanneer kan worden gezegd dat de schuldeiser "tot de uitwinning (is) overgegaan'?

- is een lopende uitwinning zonder voorafgaande aanzegging denkbaar?

De materie van artikel 86 lid 5 Ow I is hiermee nog niet uitgeput. In de nrs. 5.6.3.8 en 5.6.3.9 ga ik in op enkele resterende vragen, mamelijk:

- welke regels van procesrecht zijn toepasselijk op (vooralsnog) niet omgezette zekerheidseigendom?

- de tweede grond voor opschorting van de omzetting van eigendom tot zekerheid, te weten het in staat van faillissement verkeren van de schuldenaar ten tijde van de inwerkingtreding.

\subsubsection{Moet de aanzegging vór of na de inwerkingtreding zijn geschied?}

Het antwoord op deze wraag kan niet anders luiden dan: de aanzegging moet vóor de inwerkingtreding hebben plaatsgehad: Immers, op grond van de hoofdregel van

35. In de eerste zin wan artikel 86 lid 5 Ow I wordt niet gezegd, door wie aan de schuldenaar de uitwinning moer zijn aangezegd. Zoals ook uit de tweede zin van artikel 86 lid 50 w I kan worden afgeleid is dit uitei-

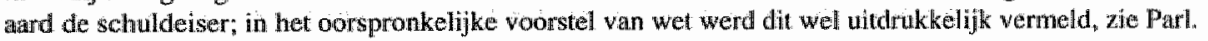
Gesch. Overgangsrechit; p. 88.

36. Deze bepaling is te zien als een concretisering van het door De Die onderscheiden beginsel varn de conserverende werking; zie AA 1991, p. 826-827.

37. Volgens Wessels, Advocatenblad 1990, p. 475 , biedtartikel 86 lid 5 Ow leen voorbeeld van uitgestelde werking, en wel éen van zes maanden. Dit is onjüist: artikel 86 lid 50 w I beval geen verwijzingsregel, maar een tijdelijk geldende uizondering op de overbruggings- of wel koppelregel van artikel 86 lid 1 Ow I. Zie over het onderscheid tussen de genoemde soorten overgangsregels de ars, $2.5,1$ en 2.5 .2 hiervóci. 
artikel 86 lid 1 Ow I heeft op het moment van de inwerkingtreding de omzetting van zekerheidseigendom in pandrecht plaatsgehad. Een nâ dat tijdstip gedane aanzegging kan daar uit de aard der zaak geen verandering meer in brengen. De ratio van artikel 86 lid 50 I (een op handen zijnde dan wel lopende afwikkeling niet verstoren) gaat in een dergelijk geval niet op. Desalniettemin is het een merkwaardige zaak dat in artikel 86 lid 5 Ow I niet wordt aangegewen, wanneer de aanzegging moet hebben plaatsgehad. De yerklaring hiervoor is dat bij het opstellen wan de (eerste) nota van wijziging kennelijk een vergissing is gemaakt. Naar aanleiding van kritiek van Reehuis ${ }^{38}$ op de oorspronkelijke tekst van artikel 86 lid 5 Ow $I$ is deze gewijzigd. In de memorie van antwoord aan de Tweede Kamer wordt gezegd dat als nieuwe tekst wordt voorgesteld:

(De leden $1-4$ zijn niet van toepassing, indien) 'aan de schuldenaar reeds vóor het tijdstip van het inwerkingtreden van de wet de uitwinning van het tot zekerheid overgedragen goed was aangezegd".

In de bijbehorende nota van wijziging"39 echter zijn de woorden "reeds v66r het tijjstip van het inwerkingtreden van de wet' weggevallen. De conclusie uit het voorgaande is duidelijk: de aanzegging moet voor de inwerkingtreding hebben plaatsgevonden, anders is de omzetting van bestaande zekerheidseigendom bij de inwerkingtreding geschied.

\subsubsection{Is van belang hoe lang vóor de inwerkingtreding de aanzegging is geschied?}

Voor het antwoord op deze vraag is in de wet en de parlementaire stukken geen aanknopingspunt te vinden. Uit de tekst van artikel 86 lid $5 \mathrm{OW} \mathrm{I,} \mathrm{zoals} \mathrm{deze} \mathrm{blijkens} \mathrm{ge-}$ noemde memorie van antwoord had moeten luiden ${ }^{40}$, volgt dat het er niet toe doet of de aanzegging nu bij voorbeeld negen dagen of negen maanden vór de inwerkingtreding is geschied. In beide gevallen zou de aanzegging de omzetting van de zekerheidseigendom vooralsnog verhinderen. In de praktijk zal het echter well niet vaak voorkomen dat de aanzegging zo lang voór de inwerkingtreding is gedaan zonder dat korte tijd daarna de uitwinning is ter hand genomen. In de regel zal of de zekerheidseigendom ten tijde van de inwerkingtreding door de witwinning reeds zijn tenietgegaan of de uitwinning op genoemd moment nog aan de gang zijn geweest.

Stel nu echter dat zich het volgende geval voordoet.

Schuldeiser B kondigde op 1 april 1991 aan A wegens achterstalligheid bij het aflossen van een door $\mathrm{B}$ aan $\mathrm{A}$ verleend krediet de uitwinning van door

38. Diss.. nrs. 513.516. De vaste Commissie voor Justitie van de Tweede Kamer vroeg in het voorlopig werslag het oordeel van de minister over het door Reehuis in nr. 516 geformuleerde voorstel (Parl. Gesch, Owergangsrecht, p. 92), Ook H. Stein, preadw., p. 157, liet zich kritisch uit over de oorspronkelijke wersie wan ar thel 86 lid 5 Ow I.

39. Part. Gesch, Overgangsrecht, p. 92 .

40. lk $z$ al in het vervolg wan de in de memorie van anwoord woorkonmende tekst uitgaan. 
deze aan $\mathrm{B}$ tot zekerheid overgedragen goederen aan. De uitwinning volgde evenwel niet, omdat $A$ alsnog aan zijn betalingsverplichtingen jegens $B$ voldeed. A bleef tot 1 februari 1992 stipt op tijd zijn aflossingen aan B voldoen. Daarna raakte hij zo ernstig in gebreke dat $B$ zich genoodzaakt zag tot uitwinning over te gaan. De uitwinning vond in mei 1992 plaats.

Heeft B eigendom tot zekerheid of pandrecht gellend gemaakt? Volgens de letter van artikel 86 lid 5 Ow I eigendom tot zekerheid. Dat ligt echter niet erg voor de hand. De gedachte achter artikel 86 lid 5 Ow I (een ten tijde van de inwerkingtreding op handen zijnde of reeds plaatsvindende uitwinning niet frustreren) gaat in dit geval immers niet op. De uitwinning in mei $1992 \mathrm{zal}$ - ná de inwerkingtreding door een nieuwe aanzegging zijn voorafgegaan. Naar mijn mening zou $B$, indien hij zich op artikel 86 lid 5 Ow I zou willen beroepen, een dergelijk beroep moeten worden ontzegd. De vraag is waarop dit oordeel zou moeten worden gebaseerd. Artikel $75 \mathrm{Ow}$ I, dat immers alleen de artikelen $68 a-73 a$ Ow I bestrijkt, kan er niet toe diemen om dit resultaat te bereiken, behalve indien men deze bepaling hier analoog zou toepassen. Wil men dat niet doen, dan is er nog de mogelijkheid, B een beroep op artikel 86 lid 5 eerste zin Ow I te ontzeggen op grond van artikel 6:248 lid 2 BW41.

Het praktische belang van het al dan niet slagen van een beroep op genoemde overgangsregel kan worden geillustreerdl aan de hand van de toepasselijkheid van de bepalingen uit titel $3.9 \mathrm{BW}$ inzake de executie op het door omzetting ontstane pandrecht. Te denken valt aan een geval waarin het volgende beding is gemaakt:

In de algemene voorwaarden van een grote bank inzake zekerheidsoverdracht van één of meer voertuigen werd bepaald:

'Een daarna (dat wil zeggen: nadat de bank zich uit de opbrengst van de voertuigen heeft voldaan, HvdB) eventueel resterend bedrag zal de Debiteur slechts dan kunnen vorderen, indien generlei engagementen meer bestaan, krachtens welke op de Bank ten laste van de Debiteur enig obligo rust.

Zodra ingevolge engagementen, als in het vorige lid bedoeld, een vordering of vorderingen van de Bank op de Debiteur is of zijn ontstaan, zal de Bank met het resterend bedrag handelen als in de tweede zinsnede van het tweede lid van dit artikel (omtrent het zich uit de opbrengst voldoen door de bank, HvdB $)$ is bepaald. Eerst nadat alle uit die engagementen voortvloeiende worderingen zijn voldaan, zal de Bank hetgeen daarna nog van het resterende bedrag overblijft onmiddellijk aan de Debiteur doen toekomen.'

Ik begrijp het bovenstaande aldus, dat de bank de bevoegdheid bedingt om voor toekomstige vorderingen die uit bestaande rechtsverhoudingen zullen voortvloeien de restant-opbrengst onder zich te houden. Dit gedeelte wordt derhalve (vooralsnog) niet aan de debiteur uitgekeerd.

41. Zie nr. 2.5.3 hiervór. In het algemeen verdedigbaan lijkt mil de stelling, dat hoe langer vór de inwer" kingtreding de aanzegging plaats wond (zonder dat de uitwinning is gevolgd), hoe onaanvaardbaarder toepassing wan artikel 86 lid 5 Ow I wordt. 
Op grond van artikel 86 lid 6 OW $\mathbb{I}^{42}$ is een beding als het zojuist geciteerde niet van overeenkomstige toepassing geworden op het door omzetting ex artikel 86 lid 1 OW I ontstane pandrecht, omdat het in strijd is met artikel 3:253 lid $1 \mathrm{BW}$. Hoogstens zou kunnen worden gedacht aan toepassing van artikel $483 \mathrm{e}$ Rv. Dat betreft de situatie waarin een pand- (of hypotheek)recht strekt tot zekerheid van vorderingen die de pandhouder uit hoofde van een bestaande rechtsverhouding zal verkrijgen. Deze vorderingen kunnen in de rangregeling worden begrepen, hetzij voor het gehele op het tijdstip wan het opmaken van de staat van verdeling reeds verschuldigde bedrag, hetzij, op verlangen van de pandhouder; voorwaardelijk voor het gehele bedrag waarwoor het pandrecht tot zekerheid strekt. Ook indien artikel $483 e \mathrm{Rw}$ in casu zou kunnen worden toegepast, zou de bank niet meer de bevoegdheid hebben; die zij onder het oude recht had ${ }^{43}$. De bank mist dus volgens het nieuwe recht een bevoegdheid die zij, naar mag worden aangenomen, onder het oude recht wel had.

5.6.3.3 Welke maatstaf geldt voor de bepaling van het moment wan de aanzegging?

Deze vraag is van belang voor een geval als het wolgende:

Schuldeiser B zond op 27 december 1991 per post een aanzegging aan zijn schuldenaar $A$, waarin werd aangekondigd dat tot uitwinning van de door $A$ aan B tot zekerheid overgedragen goederen zou worden overgegaan. Als gevolg van vertragingen bij de bezorging, veroorzaakt door de grote hoeveelheden kerst- en nieuwjaarspost, bereikte de aanzegging A pas op 3 januari 1992.

Volgens de hoofdregel van artikel $3: 37$ lid $3 \mathrm{BW}^{44}$ moet een tot een bepaalde persoon gerichte verklaring om haar werking te hebben die persoon hebben bereikt. Dit betekent dat B's aanzegging eerst op 3 januari 1992 haar werking had. Hieruit volgt dan weer dat aan het vereiste voor omzetting van zekerheidseigendom in pandrecht is voldaan, dat niet vóór de inwerkingtreding een aanzegging van uitwinning is geschied. In bovenstaand voorbeeld zal B derhalve als pandhouder executeren, en zijn de nieuwe regels vain titel $3.9 \mathrm{BW}$ toepasselijk.

De onderhavige categorie van gevallen, die echter waarschijnlijk niet omvangrijk zal zijn, valt als het ware tussen de wal en het schip: de beweegreden voor het opnemen van artikel 86 lid 5 Ow I geldt hier, maar toch vindt de omzetting ex artikel 86 lid 1 Ow I doorgang. Dit is precies de omgekeerde situatie ten opzichte van de zoëven in nr. 5.6.3.2 aan de orde gestelde. Indlien men het doorgang vinden van de omzetting onwenselijk zou vinden, zou wellicht artikel 86 lid 5 Ow I bij wijze van analogie kunnen worden toegepast. Voor het praktische belang van de hier bespro-

42. 2ie over deze bepaling nis. 5.7.3 hierna.

43. Vgl, over artikel 483e Rv: TK, zitting $1980-1984,16593$, nr. 3 (memorie van toelichting), p. 65-67, TK, zitting 1981-1982, 16593, nr, 5 (memorie wan antwoord), p. 19-20.

44. Het niew we recht werschilt hier niet van het oude zie Asser-Harkamp 1I, nr. 153. Genoemde bepaling werk $\mathrm{t}$ onaniddellijk op grond van artikel $68 \mathrm{a}$ lid $1 \mathrm{Ow} \mathrm{I}$ 
ken vraag geldt thetzelfde als zojuist in nr. 5.6.3.2 over het praktische belang van de daar behandelde vraag is opgemerkt.

\subsubsection{Is de omzetting ook opgeschort in geval van een aanzegging zonder tekortschieten van de debiteur?}

Artikel 86 lid 5 Ow I zoals dit luidde in het oorspronkelijke ontwerp van wett5 koppelde de voorlopige blokkade van de omzetting van zekerheidseigendom aan het vóór de inwerkingtreding door de debiteur tekortschieten in de nakoming van zijn verbintenis. Naar aanleiding van kritiek van Reehuis ${ }^{46}$ is de tekst van artikel 86 lid 5 Ow I gewijzigd. Daarbij is evenwel niet het door H. Stein en Reehuis ${ }^{47}$ voorgestelde dubbele criterium opgenomen. Dit hield in dat de omzetting zou worden verhinderd, indien de schuldenaar vór de inwerkingtreding in de nakoming van zijn verbintenis was tekortgeschoten en aan hem de uitwinning van het tot zekerheid overgedragen goed was aangezegd. In artikel 86 lid 5 Ow I wordt niet tevens vereist dat de debiteur vóór de inwerkingtreding is tekortgeschoten in de nakoming van zijn verbintenis(sen) jegens de crediteur. Strikt genomen volgt daarom uit de tekst van genoemde bepaling dat omzetting van zekerheidseigendom ook dam (voorlopig) uitgesloten is, indien de debiteur vóór de inwerkingtreding keurig aan zijn verbintenis(sen) jegens de crediteur voldeed en toch (vóór de inwerkingtreding) aanzegging van uitwinning van de zekerheidseigendom is gedaan. De achtergrond van zo"n aanzegging zou bij voorbeeld kunnen zijn dat de schuldeiser een reële kans aanwezig acht, dat hij begin 1992 tot uitwinning zal moeten overgaan. Een beroep op artikel 86 lid 5 Ow I lijkt mij dan wel mogelijk. Naar mijn mening zou echter een aanzegging zonder dat sprake is van een (dreigend) tekortschieten van de debiteur, maar met het oogmerk te ontkomen aan toepasselijkheid van titel $3.9 \mathrm{BW}$, misbruik van artikel 86 lid 5 OW I opleveren. Deze bepaling behoort in zo'n situatie niet te worden toegepast. Dit resultaat zou kunnen worden bereikt door, ingeval het tot een geschil tussen schuldeiser en schuldenaar zou komen over de hier aan de orde zijnde kwestie, de schuldeiser op grond van analoge toepassing wan artikel 75 Ow I of op grond van artikel 6:248 lid 2 BW een beroep op artikel 86 lid 5 eerste zin Ow 1 te ontzeggen ${ }^{48}$. Naar mijn mening geldt hetzelfde voor het geval dat de crediteur vó́r de inwerkingtreding een voorwaardelijke aanzegging aan de debiteur heeft gedaan, inhoudende dat de zekerheidsgoederen zullen worden geèxecuteerd onder de opschortende voorwaarde dat de debiteur zal tekortschieten in de nakoming van zijn verplichtingen.

45. Parl. Gesch. Overgangsrecht, p. 88.

46. Diss., rars. 513-516, waarover de vaste Commissie woor Justitie van de Tweede Kamer in her voorlopig verslag het oordeel van de minister wroeg (Parl. Gesch. Overgangsrecht, p. 92).

47. Respectievelijk preadw., p. 157 en diss., nr. 516.

48. Zie ni. 2.5.3 hiervoór. 


\subsubsection{Vanaf welk tijdstip gaat de zes maanden-termijn lopen?}

'De leden 1-4 zijn niet van toepassing, indien aan de schuldenaar de uitwinning van het tot zekerheid overgedragen goed was aangezegd. Is de schuldeiser zes maanden na dat tijdstip nog niet tot de uitwinning overgegaan, dan worden die leden alsdan van toepassing.'

aldus de eerste twee zinnen van artikel 86 lid 5 OW I. De zinsnede 'zes maanden na dat tijdstip" hangt als het ware in de lucht, omdat in de voorafgaande zin in het geheel geen tijdstip wordt genoemd. Men zou kunnen denken dat het aanvangstijdstip van de termijn wan zes maanden zou zijn het moment waarop de aanzegging van de uitwinning is geschied ${ }^{49}$. Dil is verklaarbaar, maar niet juist. Zoals in nr. 5.6.3.1 hiervóór is aangegeven, had in de eerste zin van artikel 86 lid 5 Ow I de eis moeten voorkomen, dat de aanzegging vóór het tijdstip van het in werking treden van de wet is geschied. Op de hier behandelde vraag moet dus het antwoord luiden, dat de zes maanden-termijn loopt van $\mathbb{1}$ januari 1992 tot 1 juli 1992. Het woord 'alsdan' in artikel 86 lid 5 Ow I betekent: zes maanden na de inwerkingtreding, dat wil zeggen op 1 juli 1992. Omdat artikel 86 lid 1 Ow I met ingang van 1 juli 1992 van toepassing is, vindt de omzetting op deze datum plaats ${ }^{50}$. De omzetting werkt dus niet terug.

\subsubsection{Wanneer is sprake van het overgaan tot uitwinning?}

Het antwoord op deze vraag is hierom van belang, omdat de omzetting ex artikel 86 lid 1 Ow I alsnog plaatsvindt, indien ondanks de aanzegging de schuldeiser vóór 1 juli 1992 nog miet tot uitwinning van de zekerheidsobjecten is overgegaan. Hier moet een onderscheid worden gemaakt tussen roerende zaken en vorderingen op naam, omdat de wijze van uitwinning van beide verschilt. Roerende zaken die tot zekerheid zijn overgedragen zullen meestal zijn geleverd door middel van constitutum possessorium. Alsdan zal de crediteur doorgaans afgifte van de zaken door de debiteur hebben verlangd om deze te gelde te kunnen maken. Mocht een crediteur vö́r 1 juli 1992 afgifte hebben verlangd met als doel het voorkomen van omzetting van de zekerheidseigendom in pandrecht, dan zal een beroep van deze crediteur op artikel 86 lid 5 Ow I wellicht kunnen worden getorpedeerd met behulp van artikel 75 OW I (analoog) of artikel 6:248 lid 2 BW's1.

Het is mogelijk dat niet aan de tweede zin van artikel 86 lid 5 Ow I wordt toegekomen, omdat de zekerheidseigendom op een andere wijze dan door uitwinning teniet gaat, zoals door toeëigening op grond van een daartoe strekkende overeen-

49. Zie in deze zin Van Mierlo, preadv., p. 47; Mon. Nieuw BW A-25 (De Vries Lentsch-Kostense), p. 72. Molenaar, Mon. Nieuw BW B-12a, p. 88, stelt dat voor het al dan niet alsnog doorgang winden van de omzetting matgevend is ol de schuldeiser na de inwerkingtreding nog niet tot uitwinning is overgegaan en ziel dus de zes maanden-termijn over het hoofd.

50. Zie Parl. Gesch, Owergangsrecht, p. 92.

51. Zite nur. 2.5.3 hierq6ór. 
komst aangegaan nadat de crediteur tot uitwinning bevoegd is geworden ${ }^{52}$.

De zekerheidsoverdracht van vorderingen op naam zal doorgaans niet aan de debitor cessus zijn betekend. Vaak was betekening niet nodig, omdat de crediteur een bank was, waarbij meestal betaling door de debitor cessus geschiedde door overschrijuing op de rekening van de cedent bij de bank, gevolgd door verrekening met de vordering van de bank ${ }^{53}$. Ook hier zal - uiteraard slechts in geval van aanzegging vóór de inwerkingtreding - een beroep op artikel 86 lid 5 Ow I kunnen worden verijdeld met behulp van artikel 75 Ow I (analoog) of artikel 6:248 lid $2 \mathrm{BW}$, indien de crediteur enkel met het oog op handhaving van de eigendom tot zekerheid vór 1 juli 1992 tot betekening van de cessie zou zijn overgegaan.

\subsubsection{Is een lopende uitwinning zonder voorafgaande aanzegging denkbaar?}

Wat betreft het tijdstip van de uitwinning van de zekerheidsgoederen in verhouding tot dat van de inwerkingtreding zijn drie mogelijkheden denkbaar:

a. De uitwinning heeft in haar geheel vóór de inwerkingtreding plaatsgevonden.

$b$. De uitwinning was gaande op het tijdstip van de inwerkingtreding.

c. De uitwinning nam eerst na de inwerkingtreding een aanvang.

Ad a.

Deze categorie gevallen is in overgangsrechtelijk opzicht niet van belang. De zekerheidseigendom is door de executie tenietgegaan; van eventueel resterende goederen kan retro-overdracht aan de schuldenaar hebben plaatsgehad. Mogelijk is ook dat deze goederen ten tijde van de inwerkingtreding dienden als zekerheid voor nieuwe schulden, in welk geval omzetting in pandrecht heeft plaatsgevonden op grond van artikel 86 lid 1 Ow I.

$A d b$.

Deze groep situaties levert wel een probleem van overgangsrecht op. Is aan de uitwinning een aanzegging daartoe voorafgegaan, dan kan artikel 86 lid 5 Ow I worden toegepast. Is de aanzegging achterwege gebleven, dan kan analoge toepassing uitkomst bieden. Op dit geval ga ik hierna nog nader in.

Ad c.

Wanneer tijdens de inwerkingtreding eigendom tot zekerheid bestond, zal deze op dat moment zijn omgezet in (stil) pandrecht, tenzij voordien een aanzegging tot executie was gedaan of de schuldenaar toen in stal van faillissement verkeerde (artikel 86 leden 1 en 5 Ow I). Is de omzetting wel geschied en komt het na de invoering tot een uitwinning, dan vindt deze (uiteraard) volgens het nieuwe recht plats.

Wat categorie $b$ betreft: een lopende uitwinning zonder voorafgaande aanzegging is niet ondenkbaar. In akten inzake zekerheidsoverdracht werd steeds bedongen dat de schuldenaar ook zonder ingebrekestelling door de enkele tekortkoming in verzuim raakte ${ }^{54}$. Wilde de schuldeiser echter tot executie van tot zekerheid overgedragen roerende zaken overgaan, die zich (zoals gebruikelijk) onder de debiteur be-

52. Vgll. Reehuis, diss, nr. 198.

53. Vgl. Asser-Mijnssen, nr. 193.

54. Aldus H. Stein, preadv, p. 157. 
vonden, dan zal hiij deze eerst van de debiteur hebben opgevorderd. Aangenomen mag worden dat in de eis tot afgifte al dan niet uitdrukkelijk een aanzegging tot uitwinning opgesloten lag. In dat geval (aanzegging vóór invøering) is artikel 86 lid 5 Ow I van toepassing: de transfonnatie van de eigendom tot zekerheid is opgeschort.

Bij vorderingen op naam ligt de situatie anders. Vaak zall het een bank zijn, waaraan de vorderingen tot zekerheid waren gecedeerd. Voldoening aan de cedent tot zekerheid van de vordering door de debitor cessus zal veelal zijn geschied door overschrijving op de rekening wan de cedent bij de bank, gevolgd door verrekening met de vordering van de bank. Betekening kon dan doorgaans achterwege blijwen ${ }^{55}$. Ook indien betekening wel geschieddle, behoefde gezien bovengenoemd beding betreffende het in verzuim raken van de schuldenaar nog niet tevens aan deze een aanzegging tot inning te worden gedaan. Stel nu dat, zonder voorafgaande aanzegging, vóór het moment wan de invoering een begin was gemaakt met pogingen tot inning en dat deze op dat moment nog voortduurden. Artikel 86 lid 5 Ow I is dan niet van toepassing, tenzij de debiteur-cedent op het moment van de inwerkingtreding in staat van faillissement verkeerde. Wel gaat hier de ratio van artikel 86 lid 5 Ow I op. Analoge toepassing van deze bepaling op dit geval lijkt mij daarom aangewezen.

\subsubsection{Toepasselijkheid van het mieuwe procesrecht op de gehandhaafde zekerheidseigendom}

Kort dient nog te worden stilgestaan bij de vraag, welke regels van procesrecht na de invoering toepasselijk zijn op een (vooralsnog) niet omgezette zekerheidseigendom. In beginsel hebben deze regels onmiddellijke werking (artikelen 1 lid 2 Ow II jo. 68 a lid 1 OW [). Artikel 21 lid 1 OW 11 houdt in dat de nieuwe bepalingen in het Wetboek van Burgerlijke Rechtsvordering betreffende executie door een pand- of hypotheekhouder toepasselijk zijn, voor zover krachtens onder meer artikel 110 OW $I$ de artikelen 3:249-253 BW toepasselijk $z$ ijn ${ }^{56}$. Artikel 110 Ow I betreft echter uitwinning op grond van een ten tijde van de inwerkingtreding reeds bestaand pandrecht en is derhalve niet van toepassing op (voorlopig) in stand gelaten zekerheidseigendom. Men zou er daarom van uit kumnen gaan dat, evenals de artikelen 3:249$253 \mathrm{BW}$, de daarmee verband houdende bepalingen uit Rv niet toepasselijk zijn op deze zekerheidseigendom. Wellicht is evenwel analoge toepassing van genoemde bepalingen op zekerheidseigendom denkbaar.

\subsubsection{Staat van faillissement van de debiteur ten tijde van de inwerkingtreding}

Uit artikel 86 lid 5 Ow I kan nog een tweede negatief vereiste voor de omzetting van bestaande eigendom tot zekerheid worden afgeleid: 
Verkeert de schuldenaar op het genoemde tijdstip in staat van faillissement, dan worden die leden eerst na afloop daarvan toepasselijk, indien de eigendom tot zekerheid is blijven bestaan.'

De ratio van deze regel wordt in de toelichtende stukken niet genoend. Deze moet wel in het verlengde liggen van de ratio van de hiervoor besproken regel inzake aanzegging van uitwinning aan de schuldenaar, namelijk: bij cen lopend faillissement weegt het belang van partijen bij "conservering'57 van het oude recht zwaarder dan het belang van het over de gehele linie toepassen van nieuw recht $t^{58}$.

Door het in nr. 5.6.3.1 hiervóór gesignaleerde ontbreken van een aantal woorden in de eerste zin van artikel 86 lid 5 Ow I is ook hier uit de tekst niet duidelijk, welk tijdstip nu precies wordt bedoeld. Doordat bedoelde woorden ons in de parlementaire geschiedenis zijn overgeleverd, weten we echter dat het ook hier om het tijdstip van de inwerkingtreding gaat.

Indien de schuldenaar eerst ná de inwerkingtreding in staat van faillissement wordt verklaard, is niet zonder meer te zeggen of onzetting van de eigendom tot zekerheid in stil pandrecht heeft plaatsgehad. De volgende mogelijkheden dienen zich aan. Ik stel in het navolgende een faillissementsaanvrage gelijk met een aanzegging; het lijkt mij in overeenstemming met de ratio van artikel 86 lid $5 \mathrm{Ow}$ I, om deze bepaling analoog toe te passen, indien vóór de inwerkingtreding zo'n aanvrage is gedaan.

$a$. Vóór de inwerkingtreding is geen aanzegging en geen faillissementsaanvrage gedaan: omzetting op 1 januari 1992. Faillietverklaring in de eerste helft van 1992 doet daaraan niet af.

$b$. Vóór de inwerkingtreding is een aanzegging gedaan: geen omzetting op 1 januari 1992. Tussen deze datum en 1 juli 1992 wordt faillietverklaring van de debiteur aangevraagd en uitgesproken. Op 1 juli 1992 loopt het faillissement nog, is het niet tot de aangezegde uitwinning gekomen en bevinden de zekerheidsobjecten zich nog in de boedel. Volgens de letter van artikel 86 lid 5 Ow I zou omzetting plaatshebben. Naar mijn mening dient de omzetting alsdan echter geen doorgang te vinden. Het lijkt mij in strijd met de strekking van artikel 86 lid $5 \mathrm{OW} \mathrm{I}_{n}$ indien tijdens het faillissement zekerheidseigendom in pandrecht zou worden omgezet. Ook hier zal die omzetting alsnog geschieden, ingeval bij het einde van het faillissement de eigendom tot zekerheid nog steeds bestaat ${ }^{59}$.

$c$. Als $b$, maar op 1 juli 1992 is wel een uitwinning van de zekerheidsobjecten aan de gang. Tot omzetting komt het niet (artikel 86 lid 5 Ow I).

$d$. Vór de inwerkingtreding is geen aanzegging, maar wel een faillissementsaanvrage gedaan. De faillietverklaring is begin 1992 geschied. De omzetting op 1 januari 1992 heeft dan geen doorgang gevonden.

e. Als $d$, maar vór de inwerkingtredling is ook uirwinning aangezegd. Op 1 juli 1992 loopt het faillissement nog. De uitkomst is, afhankelijk van de toestand op 1 juli 1992, dezelfde als onder $b$, respectievelijk $c$.

57. In gewallen als het onderhavige kan volgens De Die, AA 1991, p. 826-827, 829, het "beginsel wan de conserverende werking' zich doen gelden.

58. Vgl. Parl. Gesch. Overgangsrecht, p. 91, 5; Reehuis, diss, nr. 517.

59. Evenzo Reehuis, diss., nr. 537, die dit echter schreef woondat artikel 86 lid 5 Ow I zijn huidige tekssit kreeg. 
$f$. Indien ten slotte voór de invoering de uitwinning is aangezegd, maar daarmee zes maanden nadien nog geen begin is gemaakt en de faillietverklaring eerst na afloop van genoemde termijn plaatsheeft, wordt de omzetting op 1 juli 1992 uiteraard wiet tegengehouden.

Krachtens artikel 29 lid 1 Ow II zijn de nieuwe bepalingen die in verband met de invoering van het nieuwe BW in de Faillissementswet zijn opgenomen niet toepasselijk op vóór de inwerkingtreding uitgesproken faillissementen. Dit geldt derhalve ook voor uitwinning van zekerheidseigendom die in stand is gebleven krachtens artikel 86 lid 5 laatste zin Ow I.

\subsubsection{Geen lopend bodembeslag60}

Voor het antwoord op de vratg of in een bepaald geval eigendom tot zekerheid op 1 januari 1992 in pandrecht is omgezet, volstaat niet alleen kennisneming van artikel 86 Ow I. In het tweede stuk van het ten behoeve van de invoering van het nieuwe BW opgestelde overgangsrecht is namelijk nog een regel te vinden, die hier van belang is, te weten artikel 39 lid 1 Ow II. Dit luidt als volgt:

'Artikel 86, eerste lid, van de Overgangswet nieuw Burgerlijk Wetboek is niet van toepassing, zolang een vór het in werking treden van de wet, met toepassing van artikel 22 van de Invorderingswet 1990 (Stb. 221) of artikel 156 van de Algemene wet inzake de douane en de accijnzen (Stb. 1961, 31) gelegd bodembeslag niet is afgewikkeld. ${ }^{61} 62$

Deze uitzondering moet worden gezien tegen de achtergrond van artikel 33 Ow II. In deze bepaling wordt artikel 18 Ow II van overeenkomstige toepassing verklaard op beslag- en executieregelingen in bijzondere wetten, die in de Invoeringswet aan het Wetboek van Burgerlijke Rechtsvordering worden aangepast. Artikel 18 Ow II bevat de hoofdregel dat een vór de inwerkingtreding van het nieuwe BW gelegd

60. Zie over de verhouding wan het wettelijke pandrecht tot het privilege van de fiscus ex artikel 21 lnwordetingswet $1990 \mathrm{nr} .5 .82 .6$ hierna.

61. In de zogenoemde "bezemwet" (Stbl. 1991, 199) is artikel 39 lid 1 Ow II aangepast aan de Inworderingswet 1990. Deze aanpassing solut echter nier geheel aan op de oorspronkelijke tekst van deze bepaling. Waar deze sprak van een ingevolge artikel 16 van de Invorderingswet 1845 gellegd bodembeslag, doet de bezemwet het voorkomen alsof in artikel 39 lid 1 OW II stond: een met toepassing van artikel 16 van de Inworderingswet 1845 gelegd bodembeslag: zie Parl. Gesch. Overgangsrecht, p. 229, noot b; p. 232 met noot $b$.

62. Dit is de tekst van artikel 39 lid 1 Ow II zoals voorgesteld in TK, vergaderjaar 1991-1992, 22 442, nr. 2 (wetsvoorstel Correctie en anpassing van de Invoeningswet Boeken 3,5 en 6 nieuw B.W. (dertiende gedeelte) voor zover het fiscale wetgeving betreft en enige andere correcties). Artikel VI lid 1 van het wetsvoorstel voorziet in terugwerkende kracht tot en met l januari 1992.

De wijziging wan artikel 39 lid 10 w II strekt ertoe cen omissie te herstellen: alsnog is woorzien in een overgangsbepaling met betrekking tot een bodembeslag dat is gelegd met toepassing van artikel 156 van de Algemene wet inzake de douane en de accijnzen (memorie van toelichting (stuk ni. 3), p. 5). De tekst van laatstgenoemde wet, zoals deze laatstelijk is gewijzigd bij de Wet van 19 december 1991, Stbl. 741, is in het Staatsblad geplaatst als bijlage bij de beschikking van de Minister van Justitie van 31 januari 1992, Stbl. 54. 
beslag wordt afgewikkeld volgens het oude recht (lid 1). Nu dit krachtens artikel 33 Ow II ook voor bodembeslag geldt,

"is vereist dat ook de zekerheidseigendom blijft bestaan, zolang de executie nog loopt: op het ogenblik dat de zekerheidseigendom krachtens artikel 86 lid 1 in pandrecht zou veranderen en de beslagen zaak in het vermogen van de schuldenaar valt, zou ook het bodembeslag vervallen (vgl. HR 3 oktober 1980, NJ 1981, 60 en 10 april 1987, NJ 1987, 829). Heeft op het tijdstip der inwerkingtreding dan tevens de zekerheidseigenaar de uitwinning aangezegd, of verkeert de schuldenaar dan in staat van faillissement, dan houdt artikel 86 lid 5 Overgangswet de omzetting van de zekerheidseigendom in pandrecht tegen, en is aan het vereiste voor voortzetting voldaan. Denkbaar is echter dat de zekerheidseigenaar op het tijdstip der inwerkingtreding de uitwinning nog niet heeft aangezegd. Alsdan verhindert artikel 86 Overgangswet de omzetting niet. Voor dat geval bestaat voor de ongestoorde afwikkeling van het bodembeslag behoefte aan een bijzondere bepaling $(\ldots)^{963}$.

De minister lijkt gezien het bovenstaande van mening te zijn dat ook buiten faillissement een bodembeslag verviel als gevolg van het in het vermogen van de schuldenaar terechtkomen van de beslagen zaak. Deze mening is niet juist. Verval van het bodembeslag door genoemde oorzaak vond wel plaats binnen faillissement; op die situatie hadden de door de minister genoemde uitspraken betrekking. Buiten faillissement van de schuldenaar zal het beslag als zodanig zijn blijven bestaan. Het verschil met de voorheen bestaande toestand was dat dit beslag niet meer was gebaseerd op het bodemrecht, nadat de beslagen zaak in het vermogen van de schuldenaar was terechtgekomen. Het bodemrecht is immers een uitzondering op het beginsel dat schulden alleen op het vermogen van de schuldenaar zelf kunnen worden werhaald:

"Wanneer derhalve beslag is gelegd ter zake van een belastingschuld en onder de in beslaggenomen goederen bevinden zich goederen die aan derden toebehoren, dan kunnen onder bepaalde voorwaarden de goederen van die derden worden geëxecuteerd ter voldoening van de belastingschuld van de belastingschuldige, bij wie de goederen zich bevinden. Deze bijzondere verhaalsmogelijkheid ten behoeve van de fiscus is neergelegd in het derde lid van artikel 23 (thans: artikel 22, HvdB) en staat bekend als het bodemrecht van de fiscus. 64

Voor handhaving van het door de fiscus gélegde beslag acht ik gezien het bovenstaande een bijzondere overgangsbepaling overbodig voor het geval dat de debiteur ten tijde van de inwerkingtreding niet in staat van faillissement verkeerde. In de omgekeerde situatie (debiteur wel failliet op het moment van de inwerkingtreding)

63. Aldus de minister, Parl. Gesch. Overgangsrecht, p. 229-230.

64. Aldus TK, vergaderjaar 1987-1988, 20588, ar. 3 (memorie van toelichting), p. 64. 
zou zo'n bepaling wel nodig zijn. Omzetting van de eigendom tot zekerheid in pandrecht zou dan als consequentie hebben, dat het op grond van het bodemrecht gelegde beslag zou tenietgaan op grond van artikel 33 lid 2 Fw. Zoals de minister in bovenstaand citaat terecht opmerkt, houdt artikel 86 lid 5 Ow I de omzetting van de zekerheidseigendom in dit geval al tegen.

Artikel 39 lid 1 Ow II heeft wel een ander effect. Het buiten het vermogen wan de schuldenaar blijwen van de bodemzaken heeft tot gevolg dat de artikelen 21 lid 2 Invorderingswet 1990 en 152 lid 2 Algemene wet inzake de douane en de accijnzen ${ }^{63}$ betreffende de rangorde geen betekenis hebben voor zover zij de verhouding tot de pandhouder regelen. Op grond van de artikelen $68 a$ lid 2 Ow I jo. 1 lid 2 Ow II blijft het oude recht toepasselijk ${ }^{66}$.

Volledigheidshalve wijs ik op de zogenoemde horizonbepaling van artikel $70 \mathrm{In}$ vorderingswet 1990. Deze houdt in dat artikel 22 lid 3 van genoemde wet vervalt op 1 januari 1993, tenzij voordien een wetsvoorstel houdende een definitieve regeling van het fiscaal bodemrecht bij de Tweede Kamer is ingediend, dan wel een wetsvoorstel dlat strekt tot verlenging van de geldigheidsduur van artikel 22 lid 3 met maximaal een jaar. De Algemene wet inzake de douane en de accijnzen bevat eenzelfde horizonbepaling (artikel $220 \mathrm{c}$ ) voor het in artikel $156 \mathrm{lid} 4$ van die wet geregelde bodemrecht:

\subsubsection{Overgang van het goed en belasting met pandrecht}

Bij de inwerkingtreding van het nieuwe BW is in die gevallen waarin aan de hierboven besproken vereisten is voldaan de eigendom van zekerheidsobjecten krachtens artikel 86 lid 1 Ow I van de zekerheidseigenaar (dit zal doorgaans de schuldeiser zijn) overgegaan op degene te wiens laste de zekerheid is gesteld (dit zal doorgaans de schuldenaar zijn geweest). Tegelijkertijd zijn deze objecten op grond van dezelfde wetsbepaling belast met pandrecht ten behoeve van de voormalige zekerheidseigenaar ${ }^{67}$. Deze uit kracht van de wet plaatsvindende eigendomsovergang en vestiging van pandrecht wordt in artikel $108 \mathrm{OW} \mathrm{I}$ en in de toelichtende stukken 'omzetting' genoemd ${ }^{68}$; in artikel $860 \mathrm{OW}$ I zelf komt deze term evenwel niet voor ${ }^{69}$.

Men kan zich afvragen hoe deze omzetting nu eigenlijk in haar werk gaat. Is sprake van een 'samenval van rechtsmomenten', of gaat eerst de eigendom van de goederen over op de schuldenaar en worden de goederen direct daarna belast met

65. Beide als gewijzigd bij de 'bezenwet' Stbl. 1991, 199.

66. Vgl. Parl. Geseh. Overgangsrecht, p. 230, alwaar wordt gesproken over het destijds nog geldende artikel 12 Invorderingswet 1845 .

67. De omzetting krachtens artikel 860 w 1 betreft ook in het kader van consumentenkfediettransacties totstandgekomen zekertheidseigendom. Op grond van artikel V lid 2 van de Wet strekkende tot onder meer aanpassing van de Wet op het consumentenkrediet (WCK) aan de Boeken 3,5 en 6 van het nieuwe Burgerlijk Wetboek, Stbl. 1991,630, zijn de gewijzigde artikelen $40-43$ WCK ook toepasselijkk op de wettelijke pandreehten ex artikel 86 Ow I. Zie hierover TK, vergaderjaar $1990-1991,22109, \mathrm{nr}$. 3 (memorie van toelich(ing), p. 7.

68. Zie Parl. Gesch. Overgangsrecht, p. 89 e.v..

69. In artikell 89 lid 1 Ow I wordt wel gesproken over eigendon die wordt 'omgezet'. 
"dat de zekerheidseigendom eerst terugvalt uit het vermogen van de schuldeiser in dat van de schuldenaar en dat daarna op de aldus herkregen eigendom onmiddellijk een pandrecht ten behoeve van de schuldeiser ontstaat."

'De datum van ontstaan van het pandrecht (...) is niet de datum van de invoering van Boek 3, maar de datum waarop de fiduciaire overdracht is geschied ${ }^{70}$.

Brahns zienswijze lijkt mij niet juist. Brahn moet bij het schrijven van de hierboven geciteerde passage het oog hebben gehad op artikel 86 lid 3 Ow $\mathrm{I}^{71}$. Daarin wordt bepaald dat het pandrecht met betrekking tot de rangorde geldt als gevestigd op het tijdstip waarop het goed in eigendom tot zekerheid is overgegaan. Men zou hoogstens kunnen stellen dat voor zover het gaat om de rangorde van het pandrecht de fictie geldt, dat dit is ontstaan vór de inwerkingtreding en dat in zoverre sprake is van terugwerkende $\mathrm{kracht}^{72}$. In de tekst wan artikel 86 lid 10 W I en in de toelichting daarop is echter geen aanknopingspunt te vinden voor de opvatting dat het pandrecht ex artikel 86 lid 1 OW I zonder genoemde beperking wordt gevestigd met terugwerkende kracht tot het moment waarop de zekerheidseigendom is ontstaan. Uit de tekst van artikel 86 lid 1 Ow I volgt juist dat de goederen op het tijdstip van de inwerkingtreding worden belast met pandrecht. De opvatting van Brahn levert ook de vraag op welk recht over de periode voorafgaand aan de inwerkingtreding op het pandrecht toepasselijk is. Dit zou alleen maar titel 3.9 BW kunnen zijn. Voor een dergelijke terugwerkende kracht van titel 3.9 BW zou een overgangsbepaling nodig zijn geweest. Die is er echter niet.

Volledigheidshalve merk ik nog op dat in de toelichting, anders dan in de tekst van artikel 86 lid 3 Ow I, zonder beperking wordt gesteld dat het pandrecht geldt als gevestigd op het tijdstip van de zekerheidsoverdracht ${ }^{73}$. Dit moet hieruit worden verklaard, dat oorspronkelijk de woorden 'met betrekking tot de rangorde" niet in het artikel voorkwamen. Deze zijn pas na het advies van de Raad van State ingevoegd $^{74}$. De toelichting is daaraan kennelijk niet aangepast.

De vraag hoe de conversie ex artikel 86 lid 1 Ow I precies in haar werk gaat moet naar mijn mening als volgt worden beantwoord. De overgang van de eigendom van schuldeiser op schuldenaar en de belasting met pandrecht vinden beide plaats op het tijdstip van de inwerkingtreding. Genoemde bepaling zegt immers:

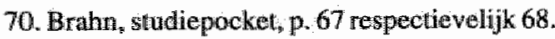

71. Vgl. Brahns weergave van de tweede zin wan artikel 86 lid 3 Ow I op p. 67: Met betrekking tol hun rang fingeert art. 86 lid 3 dat de nieuwe pandrechten zijn ontstaan ten ijde van de indertijd verrichte zekerheidsowerdracht."

72. $\mathrm{Vgl}$. in deze zin ten aanzien van de overgangsregeling voor het eigendomswoorbehoud (artikelen 89 lid. 3 jo. 86 lid 3 Ow I): Vriesendorp, Advocatenblad 1985, p. 438. In soontgelijke zin H. Stein, preadv., p. 158, volgens wie het pandrecht met het oog op de rangorde bij verhaal als het ware terugwerkend in de plaats treedt van de zekerheidsowerdracht (bedoeld moet zijn: zekerheidseigendom).

73. Piarl. Gesch. Overgangsrecht, p: 90.

74. Zie het overzicht wan wijzigingen in het oorspronkelijke voorstel wan wet, Parl, Gesch. Overgangsrectht, p. 91. 
'Op het tijdstip van het in werking treden van de wet gaat een goed dat voor. verpanding vatbaar is en aan een ander tot zekerheid is overgedragen, over op degene te wiens laste de zekerheid is gesteld, en wordt het belast met pandrecht ten behoeve van de voormalige eigenaar tot zekerheid".

Het goed is derhalve $o p$ het tijdstip van de inwerkingtreding belast met pandrecht; zodat van een 'samenval van rechtsmomenten' kan worden gesproken. Slechts ten aanzien van de rangorde geldt het pandrecht als gevestigd op het tijdstip waarop de zekerheidseigendom is ontstaan (artikel 86 lid $3 \mathrm{Ow} \mathrm{D}$ ).

Een andere vraag is of de rechten die afhankelijk zijn van een tot zekerheid overgedragen vordering (pand, hypotheek, borgtocht) met de vordering mee overgaan op de voormalige cedent tot zekerheid. Ik verwijs naar hetgeen Vriesendorp onlangs over deze vraag heeft geschreven ${ }^{75}$.

\subsubsection{Aard wan het uit zekerheidseigendom voortgekomen pandrecht}

Artikel 86 lid 2 Ow I geeft uitsluitsel over de vraag welke de aard van het pandrecht ex artikel 86 lid 1 Ow I is. Deze aard is afhankelijk van die van de voormalige zekerheidseigendom. Bij overdracht van roerende zaken in eigendom tot zekerheid zal de levering vaak door middel van constitutum possessorium zijn geschied. De zaken bleven berusten onder de debiteur. Ging het om een vordering op naam, dan zal doorgaans betekening van de zekerheidscessie achterwege zijn gelaten. In die gevallen was de strekking van de eigendom tot zekerheid dezelfde als die van de stille pandrechten van de artikelen 3:237 lid 1 en 239 lid $1 \mathrm{BW}^{76}$. Op grond van artikel 86 lid 2 Ow I is in bovengenoemde gevallen de zekerheidseigendom geconverteerd in een stil pandrecht.

Het is echter ook mogelijk dat de zekerheidsobjecten zich buiten de macht van de debiteur bevonden, of dat de zekerheidscessie was betekend aan de debitor cessus. Dit kan van de aanvang af zo zijn geweest ${ }^{77}$, dan wel eerst naderhand zijn geschied in verband met (dreigend) tekortschieten van de schuldenaar. Bestond een dergelijke situatie ten tijde van de inwerkingtreding, dan kwam de strekking van de zekerheidseigendom overeen met die van het 'gewone' pandrecht van artikel 3:236 BW, respectievelijk met de strekking van een stil pandrecht waarbij de crediteur op grond van de artikelen 3:237 lid 3 of 239 lid $3 \mathrm{BW}$ het 'stille' karakter van het

75. WPNR 6025 (1991), p. 767-772. Vriesendorps beschouwingen lijken mij, op een enkel punt na (zie nir. 5.6.7 hierna), juist: Zie over het in de tekst genoemide probleem ook Van Mierlo, preadv, p. 46-47.

76. Aldus ook Prarl. Gesch. Overgangsrecht, p. 89; Reehuis, diss., nr. 522.

77. Zoals mogelijkerwijs bij de zogenoemde "warrantage". Zie daarover Van Harinxma thoe Slooten, NJB 1990, p. $1447-1451$. Een voor de hand liggende maar door gencende schrijwer niet gestelde vraag is, waarom hier (onder het oude recht) niet direct een pandrecht werd gevestigd. Op deze vraag wordt wel ingegaan door Fesevur in zijn bijdrage in Advocatenblad 1990, p. $537-540$ (p. 539). Fesevur geeft het antwoord dat zekerheidseigendom anders dan pandrecht de bank beschernde tegen de hoog gerangsehikte (semi-)fiscale privileges. Voorts zal naar nieuw BW in geval van "warrantage'doorgaans niet de weg van artikel 3:237 lid 3 kunnen worden bewandeld, zonls eerstgenoemde schrijver stelt (p. 1449), maar zal een vuilstpandrecht moeten worden gevestigd (artikel 3:236 lid I BW; aldus ook Fesevur, p. 539). 
pandrecht heeft beëindigd. Het door omzetting ontstane pandrecht zal deze zelfde strekking hebben ${ }^{78}$. Hierbij dient echter wel te worden aangetekend dat de zaak anders ligt, indien het 'stille' karakter van de zekerheidseigendom vóór de inwerkingtreding is beëindigd met het oog op een executie. Op grond van (analoge toepassing ${ }^{79}$ van) artikel 86 lid $5 \mathrm{OW} \mathrm{I}$ is de omzetting in pandrecht daardoor tijdelijk verhinderd.

\subsubsection{Een inbreuk op de eerbiediging van verkregen rechten?}

Door enkele auteurs ${ }^{80}$ is gesteld dat artikel 86 lid 1 Ow I een vitzondering vormt op het beginsel van de eerbiediging van verkregen rechten, waarvan artikel 69 Ow I concretiseringen bevat. Deze schrijvers hadden het oog op het oorspronkelijk voorgestelde artikel 69 Ow I. Wat er zij van de juistheid van hun mening ten aanzien van artikel 69 Ow I zoals het aanvankelijk luidde, voor artikel 69 Ow I in de uiteindelijke versie gaat deze in ieder geval niet op. Men zou wellicht geneigd zijn te denken dat de omzetting van zekerheidseigendom een mooi voorbeeld oplevert van verlies van een vermogensrecht (zekerheidseigendom) dat iemand onder het tevoren geldende recht had verkregen (artikel 69 sub a Ow I), gecombineerd met het met een beperkt recht (pandrecht) belast worden van een goed (artikel 69 sub e Ow I) ${ }^{81}$. Deze gedachte moet echter worden verworpen. In artikel 69 Ow I wordt immers bepaald dat rechtsgevolgen als de zoëven genoemde niet intreden door het (enkele) toepasselijk worden van de wet. Hiermee wordt volgens de minister ${ }^{82}$ bedoeld dat deze rechtsgevolgen niet intreden doordat het nieuwe BW met onmiddellijke werking, uitgestelde werking of terugwerkende kracht bepalend wordt voor enig vermogensrecht. Welnu, het verlies van zekerheidseigendom en de belasting met pandrecht zijn niet het gevolg van het enkele bepalend worden van het nieuwe BW voor een vermogensrecht ${ }^{83}$, maar van het feit dat dit nu eenmaal zo wordt bepaald in een op dat nieuwe $\mathrm{BW}$ betrekking hebbende overgangsregel, namelijk de overbruggingsregel van artikel 86 lid 1 Ow I. Artikel 86 Ow I kan dan ook mijns inziens niet als een afwijking van artikel 69 Ow I worden bestempeld ${ }^{84}$. Evenmin juist

78. Vgl over de diverse mogelijkheden ook Reehuis, diss., nt. 522; zie voorts (met betrekking tot vorderingen) enigszins anders P.A. Stein, WPNR 6007 (1991), p. 358.

79. Zie nr. 5.6.3.7 huiervoor.

80 . H. Stein, preadv, p. 158 , Reehuis, diss., nr. 518.

81. In deze zin Mon. Nieuw BW B-12a (Molenaar), p. 87 .

82. Parl. Gesch. Overgangsrecht, p. 42.

83. Zie nr. 5.4 hiervóór.

84. Vgl. Parl. Gesch. Overgangsrecht, p. 42 (de reeds onder het oude recht voltooide overdracht tot zekerheid wordt niet getroffen door het verbod van artikel $3: 84 \mathrm{ld} 3 \mathrm{BW}$; artikel 69 sub a $O$ w I is niet valn toepassing). Vriesendorp, WPNR 6025 (1991), p. 770, met noot 14, acht ten onrechte deze passage "enigszins bevreemdend', nu de minister malaat 'melding te maken wan het bepaalde in art. 86 oW waardoor dergelijke overdrachten wel degelijk worden beînvloed door de inwoering van het NBW:' (mijn cursiveringem, HwdB). Volgens Vriesendorp houdt artikel 86 Ow I wel eeri afwijking van artikel 69 Ow I in.

Niet werenigbaar met deze stellingname is het op zichzelf juiste standpunt dar Vriesendorp vervolgens inneemt, dat het verlies yan aan tot zekerheid gecedeerde vorderingen verbonden zekerheidsrechten niet wordt veroorzaakt door het enkele toepasselijk worden van het nieuwe BW, maar door de Overgangs wet, zodat artikel 69 OW I op dat verlies niet van toepassing is: 
acht ik de opvatting van Brumer en Van Mierlo ${ }^{85}$, dat door artikel 86 Ow I een ver kregen recht wordt geéerbiedigd door omzetting in een vergelijkbaar ander recht. Bij de inwerkingtreding bestaande zekerheidseigendom zow zonder artikel 86 OW I worden gecontinueerd $\$$. lets anders is dat men wel zou kumnen zeggen, dal de omzetting van zekerheidseigendom in pandrecht een inbreuk betekent op het beginsel van de eerbiediging van verkregen rechten als zodanig, dus los van de concretiseringen van dat beginsel in artikel 690 w 1 .

\subsection{HET WETTELUKE PANDRECHT NADER BEZIEN}

Na de voorafgaande uiteenzetting over de omzetting van zekerheidseigendom in (stil) pandrecht dient thans dit uit de wet ontstane pandrecht aan een nadere beschouwing te worden onderworpen. Een eerste oriëntatie kan worden verkregen door het in het kort tegen elkar afzetten van het pandrecht 'ex lege' en het stille pandrecht dat door vestiging is ontstaan (nr. 5.7.1). In nr. $5.7 .2 \mathrm{komt}$ aan de orde welke wettelijke regels op het pandrecht toepasselijk kunnen zijn. Wat mek de ten aanzien van de eigendom tot zekerheid overeengekomen bedingen is gebeurd na de ormzetting van die eigendom in (stil) pandrecht bespreek ik in $\mathrm{nr}$ 5.7.3.

De 'sterkte' van het door conversie van zekerheidseigendom ontstane pandrecht ten opzichte wan andere rechten en van vorderingen is een vraagstuk op zichzelf. Daarover zal ik in nr. 5.8 hiema de nodige opheldering proberen te geven.

\subsubsection{Verschillen tussen het wettelike pandrecht en een door vestiging ontstaan pandrecht}

Pandrechten die zijn ontstaan krachtens artikel 86 OW I kunnen bepaald niet op ển lijn worden gesteld met pandrechten die na de inwerkingtreding door vestiging zijn totstandgekomen. Tussen beide soorten pandrechten is een aantal verschillen aan te wijzen. Ik noem ze hieronder, waarbij ik uitga van 'stille' pandrechten ${ }^{87}$.

De artikelen 3:237 lid 1 en 239 lid $1 \mathrm{BW}$ eisen voor de totstandkoming van een pandrecht een authentieke of geregistreerde onderhandse akte. Het door omzetting ontstane pandrecht heeft als ontstaansbron de wet; een authentieke of geregistreerde onderhandse akte met een op het nieuwe recht afgestemde inhoud behoeft niet aanwezig te zijn. Indien een dergelijke akte ontbreekt, verdient het aranbeveling deze alsnog op te (laten) maken. Het ontbreken van een akte als bedoeld heeft een aantal consequenties:

- de datum warop de zekerheidsoverdracht is geschied staat niet met werking tegen derden vast:

85. Respectievelijk WPNR 6007 (1991), p. 344; preadv., p. 39.

86. Zie nr. 5.4 hierworor.

87. Vgl. over deze verschillen ook H. Stein, preadv, p. 158-159; Reehuis, diss., nr. 523; Brahn, studliepocket, p. 68-69, 120; Mon. Nieuw BW B-12a (Molenaar), p. 88. 
- de in de zojuist genoemde artikelen (lid 2) verlangde (on)bezwaardheidsverklaring zal ontbreken ${ }^{88}$;

- de toepassing van artikel $496 \mathrm{Rv}$ levert problemen op (zie nr. 5.7.2 hierna);

- het beding dat de vordering tegen de debiteur onmiddellijk geheel opeisbatar wordt in geval van beslag door een derde op de zaak zall ontbreken (zie nr. 5.7.2 hierna).

Verschillen tussen het (stille) pandrecht ontstaan door vestiging en het (stille) pandrecht ex artikel 86 Ow I zijn voorts aanwezig als gevolg van de voor laatstgenoemd pandrecht geldende regels van de leden 3 en $6^{89}$ van artikel 86 Ow I.

Terzijde kan nog worden opgemerkt dat het pandrecht ontstaan door omzetting wan zekerheidseigendom niet het enige pandrecht is dat uit kracht van de wet ontstaat in plaats van door vestiging. Andere voorbeelden kunnen worden aangetroffen in de artikelen 77 Ow I, 89 lid 1 OW I, 3:229 lid 1 BW en 3:259 lid 2 BW99.

\subsubsection{Voor het wettelijke pandrecht geldende regels}

Het pandrecht dat is ontstaan op grond van artikel 86 lid 10 w I is uiteraard in beginsel onderworpen aan de nieuwe regels in met name Burgerlijk Wetboek, Faillissementswet en Wetboek van Burgerlijke Rechtsvordering. 'In beginsel', want het feit dat het pandrecht is ontstaan door omzetting van zekerheidseigendom laat zijn sporen na. Hierna wordt bezien hoe talrijk en diep deze sporen zijn.

\subsubsection{Burgerlijk Wetboek ${ }^{91}$}

Voor titel $3.9 \mathrm{BW}$ geldt het volgende. Zoals ik in $\mathrm{nr} .5 .6 .2$ hiervór reeds opmerkte, zijn de artikelen 3:227 lid 1 en $228 \mathrm{BW}$ van belang voor het antwoord op de vraag of een goed voor verpanding vatbaar is; deze vraag rijst bij de toepassing van artikel 86 Ow I. In artikel 3:227 lid 2 BW wordt geregeld waarover het pandrecht zich uitstrekt.

De zaaksvervanging ex artikel $3: 229 \mathrm{BW}$ is relevant voor het wettelijke pandrecht. In de eerste plaats kan de wettelijke pandhouder van deze zaaksvervanging profiteren. In de tweede plaats kan hij met zaaksvervanging ten behoeve van andere crediteuren worden geconfronteerd, ingeval hij op bij voorbeeld een vordering op een verzekeraar pandrecht heeft (zie nr. 5.8.3.5 hierna).

De artikelen 3:230-235 BW zijn vanaf de inwerkingtreding op het door omzetting ontstane pandrecht toepasselijk geworden. Op grond van artikel 69 onder d Ow I heeft de inwerkingtreding van artikel $3: 233 \mathrm{BW}$ geen nieuwe aansprakelijkheden met zich mee gebracht woor reeds voltooide feiten ${ }^{92}$.

88. Brahn, studiepocket, p. 68-69, acht het ontbreken van zo'n verklaring niet bezwaarlijk.

89. Zie respectievelijk de nrs. 5.8.1-2 en 5.7 .3 hierna.

90. Met 'wettelijk pandrecht' bedoel ik steeds uitsluitend het pandrecht ex artikel $860 \mathrm{~W} \mathrm{I}$.

91. Voor een bespreking van die hieronder genoemde artikelen uit titel $3.9 \mathrm{BW}$ verwijs ik naar de dissertatie wan Reehuis.

92. Vgli. Parl. Gesch. Overgangsrecht, p. 272. 
De vereisten voor vestiging van een pandrecht, die zijn neergelegd in de artikelen 3:236-239 BW, kunnen uit de aard der zaak niet gellen voor het op grond van artikel 86 OW I ontstane pandrecht. Wel kunnen de regels van de artikelen 3:237 leden 3-5 en 239 lid 3 BW inzake het beëindigen van het stille karakter van het pandrecht vanaf de inwerkingtreding toepassing vinden. Artikel 3:239 lid $4 \mathrm{BW}$ betreft de bescherming van de pandhouder tegen beschikkingsonbevoegdheid van de pandgever ${ }^{93}$.

De artikelen 3:241-243 lid 1 BW werken ook voor het wettelijke pandrecht. Lid 2 van laatstgenoemd artikel bestrijkt alleen na de inwerkingtreding gemaakte kosten. Indien de zekerheidsgever vóór de inwerkingtreding op grond van artikel 1203 lid 2 (oud) BW kosten verschuldigd is geworden, die volgens artikel 3:243 lid 2 $B W$ niet voor vergoeding in aanmerking komen, blijven deze kosten verschuldigd op grond van artikel 69 onder a en c OW $\mathbb{I}^{94}$.

Volgens artikel 3:244 BW strekt een pandrecht tot zekerheid van één of meer bepaalde vorderingen tevens tot zekerheid voor drie jaren rente die over deze vorderingen krachtens overeenkomst of wet verschuldigd is. Partijen kunnen echter anders overeenkomen. De beperking van artikel 3:244 BW kwam onder het oude recht niet voor ${ }^{95}$. Een beding als bedoeld in genoemde bepaling zal onder het oude recht dan ook niet zijn gemaakt. Daarom geldt op grond van artikel 108 Ow I voor bestaande en door omzetting op grond van de artikelen 86 en 89 Ow I ontstane pandrechten artikel 3:244 BW zonder de daar vermelde beperking tot drie jaren. Aanvankelijk gold deze overgangsregel niet ook voor een door omzetting krachtens artikel 86 Ow I ontstaan pandrecht. Dit werd in de toelichting ${ }^{96}$ gemotiveerd met de stelling dat erop mag worden vertrouwd, dat bij de zekerheidsoverdracht steeds een regeling omtrent de rente zal zijn overeengekomen. In het voorlopig verslag van de Tweede Kamer ${ }^{97}$ werd vervolgens onder meer gevraagd wat zich ertegen verzet om artikel $108 \mathrm{OW}$ I ook voor het wettelijke pandrecht te laten gelden, nu het mogelijk is dat bij de zekerheidsoverdracht geen regeling inzake de rente is overeengekomen. De minister is daarop ertoe overgegaan het toepassingsgebied van artikel $108 \mathrm{OW}$ I uit te breiden tot het pandrecht ex artikel 86 Ow ${ }^{98}$.

De artikelen 3:245-248 BW zijn vanaf de invoering toepasselijk geworden op de omgezette eigendom tot zekerheid. Voor het op parate executie betrekking hebbende artikel 3:248 BW geldt artikel 109 OW I. Deze overgangsregel houdt in dat artikel 3:248 BW van overeenkomstige toepassing wordt verklaard op verzuim van een derde-pandgever in de nakoming van verplichtingen die hij voór de inwerkingtreding op zich had genomen, voor zover miet artikel 3:233 BW van toepassing is. De aansprakelijkheid uit hoofde van laatstgenoemde bepaling geldt op grond van artikel 69 onder d OW I niet voor feiten die vóór de inwerkingtreding zijn voltooid; de sanctie van artikel 1201 (oud) BW kan na de inwerkingtreding niet meer worden

93. Zie ower het belang van deze bepaling woor het wettelijke pandrecht Parl. Gesch. Overgangsrecht, p. 272 jo. 256.

94. Vgl. Parl. Gesch. Overgangsrecht, p. 273.

95. Vgl. de artikelen 1201 lid 1 (oud), 1204 lid 1 (oud) en 1205 lid 1 (oud) BW.

96. Parli Gesch. Overgangsteeht, p. 114-1/15.

97. Parl. Gesch. Overgangsrecht, p. 115.

98. Zie Parl. Gesch. Overgangsrecht, p. 115. 
benut. Bovendien is het mogelijk dat op de derde-pandgever nog andere verplichtingen dan de in artikel 3:233 BW neergelegde rusten, waarvoor partijen in verband met artikel 1201 (oud) BW geen sanctie hebben afgesproken ${ }^{99}$.

Artikel 109 Ow I heeft geen betrekking op het door omzetting ontstane pandrecht. Strikt genomen is dat een lacune. Het zal zich echter niet snel voordoen dat een derde goederen tot zekerheid van de voldoening van schulden van een ander aan diens crediteur heeft overgedragen en deze derde tekortschiet in de nakoming van een op hem als derde-zekerheidsgever rustende verplichting, terwijl artikel 3:233 BW geen soelaas biedt en partijen evenmin een sanctie hebben afgesproken. Wanneer dit eens anders mocht zijn en de crediteur geen sanctie tot zijn beschikking zou hebben, kan wellicht artikel 109 Ow $\mathbb{I}$ analoog worden toegepast.

De regels van de artikelen 3:249-253 BW zijn vanaf de inwerkingtreding gaan werken voor het wettelijke pandrecht. Op grond van artikel 86 lid 6 OW I (waarover meer in nr. 5.7.3 hierna) worden tussen partijen ten aanzien van de zekerheidseigendom overeengekomen bedingen die afwijken van deze bepalingen niet toepasselijk op het wettelijke pandrecht. Artikel 110 Ow I, dat enige overgangsregels voor genoemde bepalingen bevat, geldt alleen voor ten tijde van de inwerkingtreding reeds bestaande pandrechten.

Op een door omzetting van zekerheidseigendom ontstaan pandrecht zal artikel 3:254 BW geen toepassing kunnen vinden. Deze bepaling betreft immers voornamelijk objecten die onder het oude recht als zaken onroerend door bestemming (ofwel hulpzaken) moesten worden aangemerkt ${ }^{100}$ en daardoor op grond van artikel 1210 sub 1 (oud) BW onder een op de onroerende hoofdzaak gevestigde hypotheek vielen $^{101}$. Zekerheidseigendom van deze hulpzaken was mogelijk in het geval dat de onroerende zaak die deze hulpzaken dienden (onder het oude recht) in eigendom tot zekerheid was overgedragen. Deze zekerheidseigendom is blijven bestaan (zie daarover nr. 5.6.2 hiervóór), zodat aan toepassing van artikel 3:254 BW op deze gevallen niet kan worden toegekomen.

Vanaf de inwerkingtreding zijn de artikelen 3:255-258 BW op het wettelijke pandrecht toepasselijk geworden. Deze en de andere artikelen uit titel 3.9 BW, ten aanzien waarvan hierboven hetzelfde is gezegd, hebben immers onmiddellijke werking op grond van artikel $68 a$ lid 1 Ow I.

\subsubsection{Faillissementswet}

Aan de bepalingen die in de Faillissementswet zijn opgenomen in verband met de inwerkingtreding van het nieuwe BW komt in overgangssituaties in beginsel geen werking toe op grond wan artikel 29 Ow II (vgl. de in nr. 5.6.3.9 hiervoór besproken handhaving van de zekerheidseigendom ingeval de debiteur bij de invoering in staat van faillissement verkeerde). Het zou te ver voeren om hier in te gaan op de 
voor na de invoering uitgesproken faillissementen relevante vraag welke nieuwe: bepalingen in de Faillissementswet voor het pandrecht van belang zijn. Hiervoor raadplege men de dissertatie van Reehisis ${ }^{102}$.

\subsubsection{Wetboek van Burgerlijke Rechtswordering}

Het Wetboek van Burgerlijke Rechtsvordering heeft de nodige wijzigingen ondergaan in het kader van de invoering van het nieuwe BW. Evenals bij de vernieuwingen in de Faillissementswet moet ik voor een beschrijwing van de voor het wettelijke pandrecht relevante nieuwe regels van procesrecht volstaan met een verwijzing naar de dissertatie van Reehuis 103 .

Voor enkele nieuwe bepalingen uit Rv maak ik een uitzondering. Ik geef eerst een voorbeeld, dat ik naderhand enkele malen verander.

A heeft op 15 januari 1991 tot zekerheid van de voldoening van zijn schulden al zijn huidige en toekomstige fabrieksinventaris, voorraden gereed produkt en vorderingen op afnemers door middel van levering constituto possessorio overgedragen aan bank B. Op 1 januari 1992 is de op dat moment bestaande zekerheidseigendom omgezet in stil pandrecht. In de lente van 1992 heeft A te kampen gekregen met een plotselinge scherpe daling in de hoeveelheden afgezet produkt. Dit leidt ertoe dat hij vanaf juni 1992 in emstige mate tekortschiet in de nakoming van zijn betalingsverplichtingen jegens B. Daarom zegt B op 1 september 1992 aan A aan op 1 oktober 1992 tot uitwinning van verpande goederen over te gaan. $B$ verlangt daartoe dat A de aanwezige voorraad gereed produkt aan B afgeeft. A voldoet aan dit verlangen.

Omdat het hier gaat om een executie na de inwerkingtreding kunnen de nieuwe Rvbepalingen die voor de executie van belang zijn toepassing vinden. Bij wijze van voorbeeld kan worden genoemd artikel $490 b$ Rv (inzake de verdeling van de opbrengst).

In het zojuist gegeven voorbeeld weigert A thans om de door B opgeëiste voorraden af te geven. Van de zekerheidsoverdracht is vóór de inwerkingtreding een onderhandse akte opgemaakt.

Ook nu komen uiteraard de relevante nieuwe procesrechtelijke bepalingen voor toepassing in aanmerking. Van deze bepalingen komt vooral artikel $496 \mathrm{Rv}$ in het vizier. Hierin wordt de pandhouder een eenvoudige mogelijkheid geboden om zijn recht op afgifte geldend te maken, dat hem toekomt op grond van artikel 3:237 lid $3 \mathrm{BW}$. Is van de zekerheidsoverdracht een geregistreerde onderhandse akte opgemaakt, dan kan bij verzoekschrift aan de president van de rechtbank binnen welker rechtsgebied zich het

102. Zie in het bijzonder het deel zaken, hoordstuk 5 en het deel vorderingen, hoofd stuk 5 :

103. 2 ie in het bijzonder het deel zaken, hoofdstukken 4 en 5 en het deel vorderingen, hoofdstuk 4 . 
goed bevindt verlof worden gevraagd om de deurwaarder de zaak onder zich te laten nemen (artikel 496 lid $2 \mathrm{R}$ ). Ook kan verlof tot inbeslagneming worden gevraagd ${ }^{104}$. In plats van een rechterlijk vonnis is voor het kunnen afdwingen van het recht op afgifte door treële executie verlof van de president voldoende.

De mogelijkheid is echter bepaald niet uit te sluiten, dat de onderhandse akte die van de zekerheidsoverdracht is opgemaakt niet is geregistreerd. In dat gevall rijst de vraag of artikel 496 lid 2 Rv wel toepassing kan vinden. Omdat deze bepaling een procesrechtelijk complement is van artikel $3: 237$ lid $3 \mathrm{BW}$ zal bij haar toepassing worden uitgegaan van het bestaan van een authentieke (zie lid 1) of geregistreerde onderhandse akte (zie lid 2). Zal de president genoegen nemen met een niet geregistreerde akte (waarvan de datum tegenover derden dus niet vaststaat)? Doet hij dit niet, dan zal de pandhouder een rechterlijk vonnis moeten zien te werkrijgen om de afgifte te kunnen afdwingen ${ }^{105}$. Het is mede om deze reden dat het alsnog (laten) opmaken van een authentieke of geregistreerde onderhandse akte aanbeveling verdient, indien dit nog niet mocht zijn geschied (zie nr. 5.7.1 hiervóór). Overigens moest ook onder het oude recht een crediteur die niet beschikte over een executoriale titel in de vorm van de grosse van een authentieke akte de rechter adièren, ingeval de debiteur afgifte van de zekerheidsobjecten weigerde: hij moest revindicatoir beslag leggen, gevolgd door een vanwaardeverklaringsprocedure, dan wel in kort geding afgifte vorderen ${ }^{106}$.

In het hierboven gegeven voorbeeld weigert A ook nu om de door B opgeêiste voorraden af te geven. Van de zekerheidsoverdracht is vóor de inwerkingtreding echter een authentieke akte opgemaakt:

Thans heeft $\mathrm{B}$ de beschikking over een executoriale titel in de grosse van de authentieke akte ${ }^{107}$. Hij kan op grond van artikel 496 lid 1 Rv afgifte van de voorraden bewerkstelligen. Ook kan hij eerst beslag tot verkrijging van afgifte leggen (artikel $492 \mathrm{Rv})^{108}$.

Een tweede nieuwe regel van procesrecht die vermelding verdient is artikel $461 a$ $\mathrm{Rv}^{109}$. Volgens lid 1 van dit artikel kan de pandhouder in geval van beslag op de verpande zaak de executie overnemen, mits hij bevoegd is tot executie over te gaan. Dat is hij echter niet, indien de vordering waarvoor het pandrecht is gevestigd nog niet opeisbaar is. Daarom is het van belang dat de pandhouder bedongen heeft (of alsnog met de schuldenaar overeenkomt), dat de schuld onmiddellijk geheel opeisbaar wordt ingeval een derde beslag legt op de verpande zaak.

104. Vgl. artikel $492 \mathrm{R} v$. Zie Reehuis, diss., nr. 116 voor een opsomming van gewallen waarin deze mogelijkheid van belang kan zijn.

105. Vgl. Reehuis diss., nr. 535. De schuldeiser kan dan conservatoir beslag tot afgifte leggen (artikel 730 e. $\mathrm{V}, \mathrm{R}$ ( $)$.

106. Vgl. Reehuís, diss:, nr. 197.

107. Aldus Reehuis, diss., nr. 114, die ook enkele auteurs noemt, dic een andere mening zijn toegedaan, namelijk dat de akte niet in executoriale vorm behoeft te zijn opgemaakt.

108. Vgl. artikel 220 w IL: een executie tot afgifte van een roerende zaak geschiedt naar het recht waaronder de executie is aangevangen. In casu is de executie onder het nieuwe recht aangevangen.

109. $\mathrm{Vgl}$. hierbij artikel 496 lid $3 \mathrm{R} v$, dat ziet op de situatie dat een executie tot af gifte plaatsvindt teñ áanzien wan een beslagen zaak. 


\subsubsection{Toepasselijkheid van bestaande bedingen op het wettelijke pandrecht}

Voor het pandrecht ex artikel 86 Ow I zijn niet alleen wettelijke maar ook contractuele regels van belang. Artikel 86 lid 6 Ow I heeft betrekking op deze contractuele regels. In deze overgangsbepaling wordt rekening gehouden met het feit dat de inhoud van hetgeen partijen bij een zekerheidsoverdracht zijn overeengekomen is toegespitst op zekerheidseigendom en niet op pandrecht. Met het oog daarop wordt het volgende bepaald:

'Overeengekomen bedingen worden op het pandrecht van overeenkomstige toepassing, ongeacht of zij aan een na het in werking treden van de wet gevestigd pandrecht kunnen worden verbonden, met uitzondering van bedingen die worden uitgesloten door de artikelen 3.9.2.10-14 (3:249-253)."

De contractuele regeling inzake eigendom tot zekerheid wordt behoudens genoemde uitzondering geconverteerd in éen inzake pandrecht ${ }^{110}$.

Aangenomen moet worden dat artikel 86 lid 6 Ow I slechts betrekking heeft op bedingen die onder het oude recht onaantastbaar waren. Dat waren volgens de beersende leer bij voorbeeld niet die bedingen, waarin de schuldeiser de bevoegdheid werd toegekend zich de zekerheidsobjecten toe te eigenen voor het gevall dat de schuldenaar tekortschoot in de nakoming van zijn verplichtingen, tenzij deze afspraak werd gemaakt op een moment dat de schuldeiser tot executie bevoegd was geworden. De grond hiervoor was analoge toepassing op eigendom tot zekerheid van het op pandrecht betrekking hebbende artikel 1200 (oud) BW'111.

Door lezing van artikel 86 lid 6 Ow I kan men nieuwsgierig worden naar voorbeelden van bedingen die bij zekerheidsoverdrachten werden gemaakt en die bij vestiging van pandrecht op grond van titel $3.9 \mathrm{BW}$ uit den boze zouden zijn. De parlementaire geschiedenis van artikel 86 lid 6 OW $\mathrm{I}$ helpt ons niet deze nieuwsgierigheid te bevredigen. Een voorbeeld zou kunnen zijn het geval waarin de crediteur een bevoegdheid tot het eisen van afgifte van de tot zekerheid over te dragen zaken dan wel tot het betekenen van de zekerheidscessie heeft bedongen, die de grenzen van de artikelen 3:237 lid 3 respectievelijk 239 lid $3 \mathrm{BW}$ te buiten gaat ${ }^{112}$. Een dergelijk beding is krachtens artikel 86 lid 6 Ow I van overeenkomstige toepassing op het door omzetting ontstane pandrecht, ook al kan het niet rechtsgeldig worden gemaakt ter zake van een na de inwerkingtreding gevestigd stil pandrecht.

Bij de zekerheidsoverdracht gemaakte bedingen die worden uitgesloten door de artikelen 3:249-253 BW worden niet van overeenkomstige toepassing op het door transformatie ontstane pandrecht, aldus artikel 86 lid 6 OW I. De vermelding van de artikelen $3: 249,251$ lid $\mathbb{1}$ en $252 \mathrm{BW}$ wekt verbazing. Zoals uit deze artikelen blijkt ('Tenzij anders is bedongen (...)') bevatten zij regelend recht en sluiten zij dus geen bedingen uit. Is voor het omgezette pandrecht dwingend recht wat voor het onder

110. Aldus Purl. Gesch. Overgangsrecht, p. 91.

111. Vgl. Reehuis, diss., nr. 196, met verwijzingen naar andere auteurs, waaraan kan worden toegevoegd Van Mierlo, diss., p. 160.

112. Vgl. Reehuis, diss., nrs. 94,95. 
de vigeur van het nieuwe BW gevestigde pandrecht regelend recht is? Omdat deze artikelen regels van aanvullend recht bevatten, acht Vriesendorp ${ }^{113}$ de verwijzing naar de artikelen 3:249,251 lid 1 en 252 BW zinloos. Hij is voorts van mening dat het uitermate onwaarschijnlijk is, dat een beding op grond van artikel 86 lid 6 Ow I wordt uitgesloten, nu de wet zelf de mogelijkheid biedt anders te bedingen. H. Stein en Reehuis ${ }^{114}$ echter stellen dat de nieuwe regeling ${ }^{115}$ van openbare orde is en dus door de (aldus Stein) 'getransformeerde pandhouder' moet worden toegepast.

De opvatting van Stein en Reehuis lijkt mij niet in overeenstemming met de tekst van de onderhavige BW-bepalingen. Vriesendorp onderkent het feit dat deze bepalingen regelend recht bevatten. Niet juist lijkt mij evenwel zijn stelling dat het, omdat het BW zelf de mogelijkheid biedt anders te bedingen, uitermate onwaarschijnlijk is dat een beding krachtens artikel 86 lid 6 Ow I wordt uitgesloten. Weliswaar worden er, anders dan artikel 86 lid 6 OW I ons wil doen geloven, geen bedingen uitgesloten door de artikelen $3: 249,251$ lid 1 en 252 BW, uit de toelichting op artikel 86 lid 6 Ow I blijkt dat het de wetgever wel degelijk menens is:

'Uitgesloten echter worden de bedingen die een wijze van verhaal voorschrijven of toelaten die afwijkt van die van de artikelen 3.9.2.10-14 (3:249253; mijn cursivering, HvdB).' ${ }^{116}$

Een motivering voor deze strenge regel wordt in de toelichting evenwel niet gegeven. Het is voor partijen niet moeilijk om onder deze artikelen voor zover zij regelend recht bevatten uit te komen. Zij kunnen immers ná de inwerkingtreding van dit regelend recht afwijken. Dàt wordt hen door artikel 86 lid 6 Ow I niet verboden.

Heeft artikel 86 lid 6 Ow I ook betekenis voor bedingen die in strijd zijn met voor het wettelijke pandrecht relevante dwingendrechtelijke regels uit het Wetboek van Burgerlijke Rechtsvordering en de Faillissementswet? De parlementaire geschiedenis zwijgt over deze vraag. De tekst wan artikel 86 lid 6 Ow I luidt heel algemeen ('ongeacht of zij aan een na het in werking treden van de wet gevestigd pandrecht kunnen worden verbonden'). Men zou kunnen veronderstellen dat in elk geval bepalingen uit $\mathrm{Rv}$ of $\mathrm{Fw}$, die verband houden met de artikelen 3:249-253 BW, eenzelfde behandeling krijgen als genoemde BW-bepalingen. Bedingen die worden 'uitgesloten' door deze laatste artikelen worden immers niet van overeenkomstige toepassing op het wettelijke pandrecht. Bij artikel 3:253 BW (dat dwingend recht bevat) kan worden gedacht aan de hiermee verband houdende artikelen $480-490 d$ Rv, die de verdeling van de executie-opbrengst betreffen. De minister merkt bij artikel $110 \mathrm{Ow} I \mathrm{op}^{117}$ dat, ingeval op de verdeling artikel 3:253 BW van toepassing is $^{118}$, dit dan ook geldt voor de nieuwe artikelen $480-490 \mathrm{~d} \mathrm{Rv}$. Hij voegt hieraan toe dat het belang hiervan is, dat de pandhouder een volgende - niet door het pandrecht

113. Advocatenblad 1985, p. 439.

114. Respectievelijk preadv., p. 159 en diss., nr. 534.

115. Stein spreekt wan de nieuwe rangregeling, Reehuis van de nievwe executie- en rangregeling.

116. Parl. Gesch. Owergangsrecht, p. 91.

117. Parl. Gesch. Owergangsrecht, p. 117.

118. Blijkens artikel 86 lid 6 Ow I windt genoend artikel inderdaad toepassing op het wettelijke pandrecht. 
gedekte - vordering dan niet meer kan verrekenen met het saldo van de opbrengst.

Wat heeft echter te gelden voor bepalingen wit $R v$ en Fw, die geen verband houden met de artikelen 3:249-253 BW? Gedacht zou bij voorbeeld kunnen worden aan een beding omtrent de bevoegdheid tot het eisen van afgifte, dat in strijd is met artikel $63 a$ lid $1 \mathrm{Fw}$. Hierin wordt de mogelijkheid geopend dat de rechter-commissaris bepaalt, dat elke bevoegdheid van derden tot onder meer opeising van goederen die zich in de macht van de gefailleerde of van de curator bevinden voor een periode van ten hoogste één maand niet dan met zijn machtiging kan worden uitgeoefend119. Prevaleert het beding boven deze wetsbepaling? Het op dit punt ongeclausuleerde artikel 86 lid 6 OW I wijst in deze richting. De vraag is echter, of de wetgever wel aan deze mogelijkheid heeft gedacht.

De uitleg die men geeft aan artikel 86 lid 6 Ow I is ook van betekenis voor een geheel ander onderwerp, namelijk de verhouding van artikel 86 lid 6 Ow I tot artikel $191 \mathrm{OW}$ I, welke laatste bepaling de overgangsregeling voor bestaande algemene voorwaarden bevat ${ }^{120}$. Bedingen die inzake een zekerheidsoverdracht tussen partijen zijn overeengekomen, zullen veelal onderdeel hebben uitgemaakt van algemene voorwaarden van de kredietverschaffer (vaak een bank). Artikel 191 lid 1 Ow I nu houdt in dat aan afdeling 6.5.3 BW een uitgestelde werking van een jaar wordt verleend ten aanzien van die algemene voorwaarden die bij de inwerkingtreding reeds in overeenkomsten werden gebruikt. Lid 2 bepaalt onder meer dat een beding in algemene voorwaarden die deel uitmaken van een overeenkomst na afloop van genoemd jaar overeenkomstig afdeling $6.5 .3 \mathrm{BW}$ kan worden vernietigd, hetgeen een afwijking oplevert van artikel 79 Ow I. Brengt artikel 86 lid 6 Ow I nu met zich mee dat bedingen in algemene voorwaarden voor zekerheidsoverdracht zijn onttrokken aan het toepassingsbereik van artikel 191 Ow I? Opnieuw geldt dat men op grond van de tekst van artikel 86 lid 6 Ow T deze vraag met " ja' zou kunnen beantwoorden. Daartegen kan worden ingebracht dat het twijfelachtig is, of de wetgever wel aan deze vraag heeft gedacht.

Het belang van de (met een jaar uitgestelde) toepassing van afdeling 6.5.3 BW op algemene voorwaarden inzake zekerheidsoverdracht bestaat kort gezegd wit het volgende. Afhankelijk van de hoedanigheid van de wederpartij (all dan niet handelend in de uitoefening van een beroep of bedrijf, al dan miet een 'grote' partij als bedoeld in artikel 6:235 lid 1 BW) zal deze na het verstrijken van het "uitsteljaar' een beroep kunnen doen op de vernietigingsgronden van de artikelen 6:233 en $234 \mathrm{BW}$, alsmede op de artikelen 6:236 en 237 BW (zwarte en grijze lijst). Wellicht zou met behulp van de open norm van artikel 6:233 sub a BW een beding kunnen worden aangepakt als het hierboven genoemde, op grond waarvan de crediteur een bevoegdheid heeft tot het eisen van afgifte van de verpande zaken dan wel tot het betekenen van de verpanding van een vordering, welke bevoegdheid de grenzen van de artikelen 3:237 lid 3 respectievelijk 239 lid 3 BW overschrijdt.

Het van overeenkomstige toepassing verklaren van ook die bedingen die niet aan een na de inwerkingtreding van het nieuwe BW gevestigd pandrecht kunnen worden verbonden, brengt met zich mee dat woorheen onaantastbare bedingen worden

119. Vgl. hierover Reehuis, diss., nr. 181.

120. Zie over artikel 191 Ow I de nrs. 2.6 .2 en 4.5.6 hiervór. 
behoed voor aantastbaarheid. Wat dit resultaat betreft vertoont artikel 86 lid $6 \mathrm{OW} \mathrm{I}$ overeenkomst met artikel 79 Ow I ${ }^{121}$. Dit geldt echter niet voor het in het slot van artikel 86 lid 6 Ow $\mathbb{I}$ bepaalde: bedingen die afwijken van de artikelen $3: 249-253$ BW 'sneuvelen' wèl.

Artikel 86 lid 6 Ow I neemt uiteraard niet weg dat het de voorkeur verdient on (de vorm van) overeenkomst en leveringshandeling aan het nieuwe recht aan te passen, indien dit vóór de inwerkingtreding niet reeds is gebeurd. In het voorgaande heb ik een aantal factoren genoemd met het oog waarop aanpassing voor de zekerheidseigenaar/pandhouder is aan te bevelen ${ }^{122}$.

\subsection{HOE STERK IS HET UIT ZEKERHEIDSEIGENDOM VOORTGEKOMEN PANDRECHT?}

Hoe het wettelijke pandrecht zich verhoudt tot andere rechten en tot privileges, is wel het meest weerbarstige onderdeel van de overgangsproblematiek die wordt opgeroepen door de omzetting van zekerheidseigendom in pandrecht. De gecompliceerdheid van deze materie wordt met name door de volgende factoren veroorzaakt. Allereerst is er het tamelijk grote aantal rechten en privileges van derden waarmee de pandhouder ex artikel 86 Ow I kan worden geconfronteerd. Daarnaast moet rekening worden gehouden met het vóór dan wel ná de invoering ontstaan zijn van deze rechten en privileges en met de daarmee samenhangende overgangsregels: $\mathrm{Bo}^{-}$ vendien is de collisie ${ }^{123}$ van zekerheidseigendom en pandrecht met deze rechten en privileges - nog afgezien van het kwantitatieve aspeet - ook zonder overgangsrechtelijke verwikkelingen al geen gemakkelijk thema.

Bij de behandeling van de sterkte van het wettelijke pandrecht kan het best aansluiting worden gezocht bij de twee elementen die het pandrecht kenmerken ${ }^{124}$. Deze elementen blijken uit de omschrijving van het pandrecht (en het hypotheekrecht) in artikel $3: 227$ lid $1 \mathrm{BW}$ :

"Het recht van pand en het recht van hypotheek zijn beperkte rechten, strekkende om op de daaraan onderworpen goederen een vordering tot voldoening van een geldsom bij voorrang boven andere schuldeisers te verhalen. $(. . .)^{\prime}$ (mijn cursiveringen, HvdB).

Het pandrecht is in de eerste plaats een beperkt recht Dat is volgens artikel $3: 8 \mathrm{BW}$ een recht dat is afgeleid uit een meer omvattend recht dat met het beperkte recht is bezwaard. Het onderhavige beperkte recht houdt in hoofdzaak de volgende bevoegdheden in. Ingeval het een stil pandrecht is, is de pandhouder onder bepaalde

121. Zie over artikel 790 Ow 1 de nrs. 4.5 en 4.6 hiervoór.

122. Zie de nrs. 5.7.1, 5.7.2 en dit nr.. Vgl. voor overeenkomsten die tot zekerheidsowerdracht verplichten artikel 86 lid 8 Ow 1 .

123. Ik gebruik dit woord in de betekenis zoals die in de 'dikke Van Dale' (elfde, herciene druk, p. 514) wondt gegeven: botsing in figuurlijke betekenis; cen collisie van plichten word tomschireven als een strijd van twee of meer plichten die elkaar schijnbaar of werkelijk uitsluiten.

124. Vgl. over thet tweeledlige karakter wan het pandrecht Reehuis, diss, 0.a. nrs. 7, 8, 11, 201, 241, 395, 396 , 438. 
voorwaarden bevoegd dit stille karakter te beëindigen. Voorts komt de pandhouder de bevoegdheid toe om (ook in faillissement) paraat te executeren (met name van belang indien zaken zijn verpand) en (in geval van verpanding van vorderingen) tot inning over te gaan.

Zolang niet door executie of inning de opibrengst van het verpande goed is verwezenlijkt, wordt de positie van de pandhouder tegenover derden bepaald door het feit dat het pandrecht een beperkt recht is. In dit stadium ontstane collisieproblemen zullen moeten worden opgelost met behulp van de regels inzake de verkrijging en de werking van een beperkt recht op een goed.

Het tweede kenmerkende element van het pandrecht is dat van verhaalsrecht met hoge voorrang, waarin het pandrecht na de executie of inning opgaat. Zijn er meer crediteuren dan alleen de pandhouder met verhaalsrechten op (de netto-opbrengst van) het verpande goed en is deze opbrengst niet voldoende om hun vorderingen te voldoen, dan komt dit verhaalsrecht met voorrang aan de orde. Collisieproblemen die in deze fase rijzen zullen in principe met een rangregeling moeten worden opgelost. $\mathrm{Bij}$ de uit hoofde van artikel 86 lid 1 Ow 1 ontstane pandrechten zal evenwel vaak moeten worden bezien, hoe onder het oude recht de zekerheidseigendom zich tot een bepaald voorrecht verhield. Ook dit zal in het navolgende blijken.

De beide categorieèn collisieproblemen die ik zoèven aanduidde, zal ik in het navolgende in overgangsrechtelijk perspectief aan de orde stellen. Daarbij zal ik nog een tweede onderscheid maken, namelik tussen 'botsing' met concurrerende (voor)rechten van vór en van ná de inwerkingtreding. Het antwoord op de vraag of deze concurrerende (voor)rechten al dan niet voor de inwerkingtreding reeds bestonden, is namelijk van belang voor de oplossing van de diverse collisiekwesties. De hierna volgende behandeling van deze kwesties kan geen aanspraak maken op volledigheid. Collisievragen die mij voor de praktijk niet of nawwelijks van belang leken, heb ik kortheidshalve buiten beschouwing gelaten.

\subsection{Collisie buiten verhaalssituaties tussen het wettelijke pandrecht en bestaande rechten}

In het navolgende zullen collisies aan de orde komen tussen het wettelijke pandrecht en (gepretendeerde) rechten en vorderingen, die dateren van vó́r de invoering van het nieuwe BW, voor zover deze collisies niet binnen een verhaalssituatie plaatsvinden. Voordat hiermee een begin kan worden gemaakt, moet eerst aandacht worden geschonken aan artikel 86 lid 30 w 1 . De eerste zin hiervan luidt als volgt:

'Het pandrecht werkt tegen de, vóror het in werking treden wan de wet ontstane, rechten op het goed en vorderingen, waartegen de eigendom tot zekerheid kon worden ingeroepen." 125

Zoals uit deze tekst blijkt, geldt de bepaling niet voor rechten en vorderingen, die

125. Zie woor een bepaling met nagenoeg gelijke inhoud ten aanzien van zaken die tot de inwerkingtreding onroerend door bestemning waren artikel 77 laatste zin OW I. 
eerst na de inwerkingtreding zijn ontstaan. Verder volgt daaruit dat opnieuw een onderscheid dient te worden gemaakt, en wel tussen enerzijds rechten en vorderingen, waartegen de zekerheidseigendom (uiteraard: wór de inwerkingtreding) wel kon worden ingeroepen en anderzijds rechten en vorderingen, waartegen de zekerheidseigendom niet kon worden ingeroepen. In de eerste situatie zegeviert op grond van de zojuist geciteerde bepaling het wettelijke pandrecht over de concurrerende rechten en vorderingen. Op de vraag wat rechtens is in de tweede situatie geeft deze overgangsbepaling geen antwoord.

Of de eigendom tot zekerheid al dan niet sterker was dan deze rechten en vorderingen moet (uiteraard) worden bepaald aan de hand van het oude recht. Volgens de toelichting moet worden uitgemaakt,

'of - indien het toen (dat wil zeggen: vóór de inwerkingtreding, HvdB) tot een executie was gekomen - die eigendom tegen die andere rechten bestand zou zijn geweest, en of het tot zekerheid overgedragen goed veilig zou zijn geweest tegen verhaal wegens die vorderingen. Moet deze vraag bevestigend worden beantwoord, dan is ook na de inwerkingtreding het pandrecht tegen die rechten en vorderingen bestand:" 126

Heeft de minister hier alleen het oog op verhaalsrechten die met de zekerheidseigendom wedijveren, of ook op andere rechten? Hij noemt beide. Doordat de minister echter als ijkpunt de situatie neemt; dat het tot een executie komt, zou de indruk kunnen ontstaan dat hij alleen doelt op verhaalsrechten. Behalve om verhaalsrechten kon het echter ook gaan om bij voorbeeld (voorbehouden) eigendom die tegen de zekerheidseigendom werd ingeroepen. Daarbij ging het niet om een collisie tussen verhaalsrechten ten aanzien van de opbrengst van het goed in het geval van uitwinning of inning daarvan. De regels betreffende de rangorde van verhaalsrechten kwamen niet voor toepassing in aanmerking 127 .

Kon de in pandrecht omgezette zekerheidseigendom onder het oude recht wel tegen rechten of vorderingen van derden worden ingeroepen, dan biedt, zoals gezegd, artikel 86 lid 3 Ow I uitkomst: wat voor de zekerheidseigendom gold, geldt ook voor het wettelijke pandrecht. Moest echter de zekerheidseigendom het onderspit delven tegen die andere rechten of vorderingen, dan moeten andere overgangsregels te hulp worden geroepen, met name de artikelen 117-119 Ow I inzake de rangorde van vorderingen.

Hierna bezie ik in de nrs. 5.8.1.1-7, welk recht voorgaat in geval van collisie tussen het wettelijke pandrecht en

- 'gewone' eigendom;

- voorbehouden eigendom;

- een uit ontbinding voortvloeiend recht;

- een uit uitoefening van het recht van reclame voortvloeiend recht;

- een uit uitoefening van het verlengstuk van het recht van reclame voortvloeiend recht;

126. Parl. Gesch. Overgangsrecht; p. 90 .

127. Vgl. hierover ook Reehuis, diss, nf. 526 . 
- een pandrecht ten gevolge van zaaksverwanging en

- een ander wettelijk pandrecht.

\subsubsection{Collisie tussen het wettelijke pandrecht en "gewone" eigendom.}

Een eerste 'botsing' die aandacht verdient is die tussen het door omzetting op grond van artikel 86 OW I ontstane pandrecht en "gewone" eigendom ${ }^{128}$. Hier zijn twee varianten mogelijk: de 'gewone' eigendom dateert van vó́r het (beweerde) ontstaan van de zekerheidseigendom en eerstgenoemde (beweerde) eigendom dateert van ná het ontstaan van de zekerheidseigendom.

\section{a. Anterieure 'gewone" eigendom}

Aannemer A gaf in 1991 zijn hijskraan in bruikleen aan zijn collega B. Deze laatste droeg met zijn eigen materieel ook $A^{\prime}$ 's bijskraan over aan bank $C$ tot zekerheid van de voldoening van zijn schulden aan deze bank. De levering geschiedde door middel van constitutum possessorium. Vervolgens trad het nieuwe $\mathrm{BW}$ in werking, waarna $\mathrm{A}$ ontdekte wat er met zijn hijskraan was gebeurd. Hij gaat over tot revindicatie. $\mathrm{C}$ verzet zich daartegen ${ }^{129}$.

Eerst zal moeten worden nagegaan of $C$ zekerheidseigendom heeft verkregen. Daartoe moeten de vereisten voor eigendomsoverdracht (artikel 639 (oud) BW) worden langsgelopen. In casu is niet voldaan aan het vereiste van beschikkingsbevoegdheid van de vervreemder (B). Daarnaast schort het hier ook aan een geldige levering: B kon zich naar analogie van artikel 592 (oud) BW niet buiten A om van houder voor $\mathrm{A}$ tot houder voor $\mathrm{C}$ maken. Omdat artikel 2014 (oud) BW alleen beschermde tegen het ontbreken van beschikkingsbevoegdheid kon $\mathrm{C}$ geen (zekerheids)eigenaar worden 130 .

Het voorgaande betekent dat aan artikel 86 Ow I niet kan worden toegekomen. Er was immers op het ogenblik van de inwerkingtreding helemaal geen zekerheidseigendom die op grond van artikel 86 lid 10 OW in pandrecht kon worden ongezet ${ }^{13 !}$.

Tot nu toe ging het steeds over zaken, Voor vorderingen geldt het volgende:

128. Hierondet versta ik eigendondie geen zekerheidseigendom is en die niet is ontsaran als gevolg van ontbinding wanten wederkerige overeenkomsl op grondwan wamprestatie of als gevolg van uitoefening vam het recht van reclame.

129. Het hieronder opgenerkte geldt uiteraurd ook, indien B op een andere grond dan bruikleen de hijs braan als houder onder zich krijgt (voorbewid: hurr).

130. Vgl, HR 22 mei 1953, NJ 1954, 189 (Sio); HR 29 september 1961, NJ 1962, 14 (Picus-Smallingerland); HR 8 jun 1973, NJ 1974, 346 (Kamphuis-Nationaal Grondbezit), Asser-Mijnssen, ns, 77 , Reehuis, diss nrs. 29, 32, 204, Brahn, sudiepocket (zesde drak), p. 77-78. Nant nieww BW (artikel 3,238) is deze oplos sing miet anders.

131. Ik 2te (ook hierna) af van de gevallen die onder lid 5 van artikel 86 Ow I ressorteren. In die gevallen is de eigendom tox zekerheid immers blij ven bestan en kan asn artikel 86 lid 3 Ow I niet worden toegekomen. Ook lata "lk de mogelijkheid bauten beschouwing dat de schuldeiser afgifte heeft gevorderd zonder executie an te zeggen. Hetzelfde geldt ten slotte voor onvrijwillig bezitsverlies door de (zekerheids)eigenaan. Beide situalties zullen zich natr verhouding wel nief wak woordoen. 
A heeft een vordering op Z. A's broer B cedeerde in 1991 zonder hiertoe bevoegd te zijn de vordering tot zekerheid van de voldoening van zijn schulden aan bank $C$. Mededeling van de cessie aan $Z$ vond niet plaats. Het voorgarande speelde zich voór de inwerkingtteding af. In 1992 komt A achter de cessie. Hij stelt tegenover bank $C$ en $Z$ de ware rechthebbende op de vordering te zijn. C betwist dit.

C kon slechts beschermd worden tegen B's bèschikkingsonbevoegdheid (en daardoor zekerheidseigenaar van de vordering op Z worden), indien artikel 1376 a (oud) BW van toepassing was, hetgeen niet snel het geval was ${ }^{132}$. Doorgaans zal dus niet an artikel 86 Ow I kunnen worden toegekomen.

\section{b. Posterieure 'gewone' eigendom}

Indien de debiteur zekerheidsobjecten aan een derde had vervreemd, terwijl hij dwartoe in zijn verhouding tot de crediteur-zekerheidseigenarar als bevoegd moest worden beschouwd, kon een collisie tussen zekerheidseigendom en "gewone" eigendom zich niet voordoen. De derde was eigenaar geworden van de zaken en de zekerheidseigendom was tenietgegaan. Dit is het geval dat zich wel het meest zal hebben woorgedaan ${ }^{133}$.

Van Mierlo ${ }^{134}$ verdedigde woor het oude recht het ook door anderen ${ }^{135}$ gehuldigde standpunt, dat het in geval van 'onbevoegde nomale bedrijfsvervreemding' redelijk was dat de zekerheidsoverdracht warbij de levering constituto possessorio is geschied, werd gerelativeerd. De derde zou in deze opvatting in beginsel krachtens artikel 639 (oud) BW eigenaar worden. Neemt men dit aan, dan kan (ervan uitgaande dat de eigendomsverkrijging door de derde voor de inwerkingtreding heeft platsgevonden) aan toepassing van artikel 86 Ow I niet worden toegekomen, omdat er ten tijde van de inwerkingtreding geen zekerheidseigendom meer bestond.

Ook in de zojuist genoemde opvatting blijft er een groep gevallen over ${ }^{36}$, warin de debiteur niet bevoegd was tot vervreemding en toch daartoe is overgegaan. Stel dat zich het volgende geval heeft voorgedaan:

Debiteur A, grossier in levensmiddelen, droeg aan crediteur B tot zekerheid over zijn kantoorinventaris en zijn handelsvoorraad levensmiddelen. Vervolgens verkocht en leverde A de kantoorinventaris zonder toestemming wan B aan derde $\mathrm{C}$. Het voorgaande is vór de inwerkingtreding geschied. Na de inwerkingtreding ontdekt $B$ de vervreemding aan $C$ en revindiceert de kantoorinventaris van $C$, die er niet over piekent aan $B$ "s eis te voldoen ${ }^{137}$.

132. Vgl. Reehuis, diss., nir. 441.

133. Zie hierover bij voorbeeld Van Mienlo, diss ., p. 60-76.

134. Diss., p. $76-79$.

135. Zie de door Van Mierlo, diss., p. 77, noot 135, geciteerde sehrijvers, alsmede Parl. Gesch. Inv. Boek 3, p. 1198 . Anders Reehuis, diss., nr. 10.

136. Door Van Mierlo, diss, p. 79 aangeduid als "onbevoegde vervreending, niet zijnde ven otbevoegde normale bedriffs wervreending".

137. Het voorbeeld is ontleend aan Van Mierlo, diss, p. 79 (die het op p. 79-83 uitwerkt) en door mij toegesneden op het overgangsrecht. 
Of $\mathrm{C}$ eigenaar kon worden ondanks de beschikkingsonbevoegdheid van $\mathrm{A}$ hing er in de eerste plaats van af, of aan de overige vereisten voor eigendomsoverdracht was voldaan. Met name was van belang of de levering door middel van constitutum possessorium was geschied. Zo ja, dan was de levering gebrekkig (A was immers houder; $v$ gl. onder a hierboven) ${ }^{138}$. C werd geen eigenaar; de zekerheidseigendom bleef bestaan en is in beginsel op grond van artikel 86 lid 1 Ow I op het moment van de inwerkingtreding omgezet in pandrecht. Aan artikel 86 lid 3 Ow I komen we niet toe.

Was wel aan de overige vereisten voor eigendomsoverdracht voldaan, dan kon artikel 2014 (oud) $\mathrm{BW}$ worden toegepast. Werd $\mathrm{C}$ niet beschermd op grond wan dit artikel, dan werd hij geen eigenaar; artikel 86 lid 1 Ow 1 kan toepassing vinden, lid 3 echter niet. Kon C aan artikel 2014 (oud) BW wel bescherming ontlenen, dan is hij eigenaar geworden en is B's zekerheidseigendom tenietgegaan ${ }^{139}$. Artikel $86 \mathrm{Ow}$ I komt niet in het vizier.

Wat betreft de verhouding tussen een zekerheidscessionaris en een derde aan wie de vordering later is gecedeerd kan het volgende worden opgemerkt:

A heeft een vordering op $Z$. A cedeerde deze vordering in 1991 aan bank B tot zekerheid van de voldoening van zijn schulden aan deze bank. Betekening van deze cessie aan $\mathrm{Z}$ bleef achterwege. Vervolgens cedeerde $\mathrm{A}$ dezelfde vordering op grond van koop aan $C$. Dit alles geschiedde vóor de inwerkingtreding. Na de inwerkingtreding komt $B$ de cessie aan $C$ te weten. $B$ stelt tegenover $\mathrm{C}$ en $\mathrm{Z}$ de ware rechthebbende op de vordering te zijn. $\mathrm{C}$ betwist dit.

Hiervoor geldt mutatis mutandis hetzelfde als hierboven onder $a$ is gezegd over de verhouding tussen een cessionaris en een derde aan wie de vordering later tot zekerheid is gecedeerd. Werd $\mathrm{C}$ niet beschermd tegen A's beschikkingsonbevoegdheid, dan kan artikel 86 lid 1 OW I voor toepassing in aanmerking komen, lid 3 echter niet. In het andere geval is A's zekerheidsrecht tenietgegaan en kan ook aan lid 1 van artikel 86 Ow I niet worden toegekomen ${ }^{140}$.

\subsubsection{Collisie tussen het wettelijke pandrecht en voorbehouden eigendom ${ }^{141}$}

Bouwmaterialenleverancier A leverde in 1991 onder eigendomsvoorbehoud bouwmaterialen aan aannemer B. B droeg vervolgens deze materialen over aan bank $\mathrm{C}$ tot zekerheid van de voldoening van de schulden die hij aan $\mathrm{C}$ had. De levering geschiedde door middel van constitutum possessorium. Na

138. Vgl. woor thet nieuwe BW artikel 3:90 lid 2 .

139. Zie voor thet nieuwe BW artikel.3:86 lid 2 .

140. Vgl. ook Reehuis, diss. mr. 449. Of de zekerbeidscessie aan B in aanmerking kwam voor relativering ten opzichte van het door $C$ gepretendeerde recht inde gevallen dat $C$ de cessie heeft betekend aan $Z$ of $Z$ deze cessie heeft erkend, was een open vraag. Vgl. Parl. Gesch. Inv. Boek 3, p. 1199; Reehuis, L.a.p.

141. Voorbehouden eigendom kan uit de and der zaak slechts collideren met posterieure (gepretendeerde) rechten van derden; vgl. Brahn, studiepocker, p. 150-151. 
de inwerkingtreding van het nieuwe BW komt A hier achter. Omdat B in gebreke is met de betaling van zijn schuld aan $A$ revindiceert $A$ de bouwmaterialen onder $\mathrm{B}$. $\mathrm{C}$ verzet zich tegen deze revindicatie.

Eerst dient weer de vraag te worden beantwoord, of $\mathrm{C}$ onder het oude recht zekerheidseigenaar is geworden. Er kan zonder meer van worden uitgegaan, dat in casu B in zijn verhouding tot A niet bevoegd was tot overdracht tot zekerheid: àls hij ergens niet toe bevoegd was, dan was het wel tot zekerheidsoverdracht. Dit geval moet verder langs dezelfde route worden opgelost als het geval van anterieure 'gewone' eigendom tegenover zekerheidseigendom ${ }^{142}$.

Stel nu dat B na de invoering van het nieuwe BW de vordering van A geheel voldoet. Kan $C$ dan alsnog een zekerheidsrecht op de bouwmaterialen verwerven? Doorgaans zal dit inderdaad het geval zijn. Akten betreffende zekerheidsoverdracht bevatten immers doorgaans clausules inzake levering bij voorbaat tot zekerheidsoverdracht van toekomstige zaken. Krachtens artikel 86 lid 7 tweede zin Ow I geldt zodanige levering na de inwerkingtreding als levering bij voorbaat tot vestiging van pandrecht daarop. Zodra dus de zaken in B's vermogen terechtkomen, komt daarop een stil pandrecht ten behoeve van $C$ te rusten, mits uiteraard $B$ alsdan nog beschikkingsbevoegd is.

Denkbaar is dat het eigendomsvoorbehoud de grenzen van artikel 3:92 lid 2 BW te buiten gaat. Voor zover dat zo is, is de voorbehouden eigendom omgezet in een stil pandrecht (artikel 89 leden 1 en 3 Ow 1). Ook dan geldt het over het gegeven voorbeeld geschrevene.

\subsubsection{Collisie tussen het wettelijke pandrecht en een uit ontbinding voortvloeiend recht $^{1.43}$}

A verkocht en leverde in 1991 een partij grondstoffen aan fabrikant B. B droeg de grondstoffen over aan bank $\mathrm{C}$ tot zekerheid van de voldoening van zijn schulden aan deze bank. De levering geschiedde door middel van constitutum possessorium. Enige tijd hierna bewerkstelligde A op grond van artikel 1302 (oud) BW antbinding van de koopovereenkomst wegens wanprestatie van $B$. Vervolgens trad het nieuwe $B W$ in werking. Tegenover elkaar staan $\mathrm{A}$ en $\mathrm{C}_{4}$ die beiden pretenderen gerechtigd te zijn tot de (nog niet door $B$ verwerkte) grondstoffen.

Heeft $\mathrm{C}$ zekerheidseigendom verkregen? Ten tijde van de overdracht tot zekerheid was $B$ beschikkingsbevoegd. De ontbinding van de koopovereenkomst op grond van artikel 1302 (oud) BW had echter tot gevolg dat aan de overdracht A-B de ver-

142. Zie nr. 5.8.1.1 sub a hiervóór en Parl. Gesch. Overgangsrecht, p. 93 sub a, 94 sub a, alsmede AsserMijnzsen, nr. 177; Reehuis, diss, wr. 206; Van Mierlo, diss, p. 141-142; Brahn, studiepocket (zesde druk), p. $207-208$.

143. Uit de aard der zaak kan een uit ontbinding voortvloeiend recht slechts collideren met posterieure (gepretendeerde) rechten van derden. 
eiste geldige titel met terugwerkende kracht kwam te ontvallen; B werd geach nooil eigenaar te zijn geweest. Achteraf bleek $\mathbb{B}$ beschikkingsonbevoegd te zijn geweest toen hil de grondstoffen tot zekerheid aan $C$ overdroeg. Daar $B$ geen houder was, matar bezitter, was de levering door middel van constitutum possessorium geldig. Ervan uitgaande dat ook wan de overige vereisten woor een geldige overdracht was voldaan, was de vraag of $\mathrm{C}$ werd beschermd door artikel 2014 (oud) BW. Fen beroep op dit artikel kon $C$ echter niet baten. Dit moest worden aangenomen op grond van een aantal uitspraken van de Hoge Raad, waarin werd overwogen dat er arleiding kan bestaan een overdracht tot zekerteid zonder feitelijke overgave van de zaken buiten beschouwing te laten voor zover zulks nodig is voor de erkenning van rechten waarop door derden anspraak wordt gemaakt met betrekking tot bepaalde onder die overdracht vallende zaken ${ }^{144}$. In deze uitspraken was anders dan in het her besproken geval de dercle een geprivilegieerde crediteur. Wat voor een crediteur met een voorrecht opgat moet a fortion opgaan voor iemand, die zich op eigendom kan beroepen. Tegenover de oudere gerechtigde $A$ zal derhalve $C_{s}$ seroep op artikel 2014 (oud) BW tevergeefs zijn geweest 145 . Het tegenover A buiten beschouwing laten van de zekerheidseigendom impliceerde dat $C$ geen zekerheidseigenaar werd. Tegelijkentjd bestaande eigendom van $A$ en zekerheidseigendom van $C$ van dezelfde zaken laat zich "mmers nier goed denken, nu mede-eigendom niet in de rede ligt 46 .

Ten tijde van de inwerkingtreding was gezien het bovenstaande alleen de eigendom van $A$ aanwezig. Voor het overige was er geen overgangssituatie (in ruime zin, zie nr. 5.4 hiervóor); met name bestond er op dat moment geen zekerheidseigendom; artikel 86 Ow I is niet van toepassing. Reehuis schrijft hierover het volgende:

"Moest de eigendon tot zekerheid het afleggen tegen voorbehouden eigendom of tegen op grond van voor de invoering bewerkstelligde ontbinding of ingeroepen reclanerecht herkregen eigendom, dan zal ook onder het NBW het pandrecht "ex lege" het daartegen in beginsel moeten afleggen. In dergelijke gevallen bestaat er geen zekerheldseigendom die krachtens het eerste lid van art. 86 OW NBW wordt omgezet in pandrecht (...) ${ }^{\prime 14}$.

Reehus lijkt hier op twee gedachten te hinken: in de eerste zin gaat hij er kennelijk van uit dat er bij de inwerkingtreding wel zekerheidseigendom bestaat (is dat niet

144. Zie HR 6 maart 1970, NJ 1970, 433 (Van Wessem-Traffic) HR 7 maart 1975, NJ 1976, 91 (Van Gend \& Loos); HR 21 juni 1985, NJ 1986, 306 (LDM-Brock).

145. Zie voor het nieuwe BW artikel $3: 90$ lid 2.

146. Vgl nader Asser-Mijnssen, un 179 Reehwis, diss, nrs. 33, 39 en 218 . Anders Van Mierlo, diss., p. 138139, Brahn, studiepocke ( (esdle druk), p. 101-103. Reehuis schrijft in nr. 39: "Zoals uit nr. 3 I en volgende blijkt moet de vraag of de fiduciatire crediteur door art $2014 \mathrm{BW}$ word bescherm indien hij zonder feitelijke overgave geleverd heeft verkregen on tkennend worden beantwoord. Dit vindt bij levering constituto possessorio door een beschikkingsonbevoegde houder zijn oorzaak in een mislukte levering, in de andlere gevallen in de rellativering van dezekerheidsoverdracht." Vain belang is ook dat de goede trouw die vereist was voor cen geslaggd beroep op artikel 2014 (oud) BW aanwezig moest zijn op het moment dat de crediteur de zaken in thanden kreeg; v6or die feitelijke overgave kon van bescherming krachtens genoende bepaling dan ook geen sprake zajin. Vgl. Reehuis, diss., nir. 39.

147. Diss., nr. 529. 
zo dan kan het pandrecht 'ex lege' immers helemaal niet ontstaan) en vervolgens ontkent hij dat in de tweede zin. Hetgeen in de tweede zin wordt gesteld is naar mijn mening juist.

Een complicatie doet zich voor, indien het hierboven gegeven voorbeeld als volgt wordt gewijzigd:

De ontbinding van de koopovereenkomst wegens het tekortschieten van $\mathrm{B}$ vindt pllaats na de inwerkingtreding.

Is op de ontbinding het oude of het nieuwe recht toepasselijk? Het antwoord op deze vraag is hier van belang, ondat anders dan voorheen de ontbinding van wederkerige overeenkomsten op grond van een tekortkoming in de nakoming onder het nieuwe recht in beginsel niet terugwerkt en nimmer zakelijke werking heeft (artikel 6:269 BW). Artikel 182 OW I (wagrover meen in hoofdstuk 7 hierna) beantwoordt de gestelde vraag aldus, dat het nieuwe BW op de gevolgen van de tekortkoming niet toepasselijk is, ingeval een schuldenaar voór de inwerkingtreding in de nakoming van zijn verbintenis is tekortgeschoten, ook niet indien de tekortkoming nadien wordt voortgezet. Onder de gevolgen van de tekortkoning valt ook de bevoegdheid tot ontbinding ${ }^{148}$. Op de onderhavige ontbinding is dus het oude recht toepasselijk, zodat deze ontbinding terugwerkende kracht en zakelijke werking heeft.

Op het moment van de inwerkingtreding is de eigendom tot zekerheid wan $\mathrm{C}$ omgezet in een stil pandrecht (artikel 86 leden 1 en 2 Ow I). De ontbinding van de koopovereenkomst A-B met haar (materieelrechtelijke) terugwerkende kracht brengt, te zamen met het feit dat $\mathrm{C}$ zijn recht vór de inwerkingtreding verkreeg, met zich mee dat ook nu aan de hand van het oude recht moet worden bezien of $\mathrm{C}$ - achteraf beschouwd - het pandrecht ex artikel 86 Ow I heeft verkregen. Achteraf kàn dus blijken dat $\mathrm{C}$ nimmer het wettelijke pandrecht heeft verkregen, Als gevolg van de ontbinding blijkt hij namelijk vóor de inwerkingtreding geen zekerheidseigendom te hebben verkregen, zodat ook niet aan omzetting daarvan kan worden toegekomen.

Voor gevallen waarin niet zaken maar vorderingen tot zekerheid zijn overgedragen geldt het volgende:

A theeft zijn vordering op $\mathbb{Z}$ verkocht en gecedeerd an $B$. B heeft vervolgens deze vordering tot zekerheid van de voldoening van zijn schulden aan bank $C$ gecedeend. Mededeling van de cessie aan $Z$ vond net plaats. Enige tijd hierna bewerkstelligde A op grond van artikel 1302 (oud) BW ontbinding van de koopovereenkomst wegens wanprestatie van B. Vervolgens trad het nieuwe $\mathrm{BW}$ in werking. Tegenover elkaar staan $\mathrm{A}$ en $\mathrm{C}$, die beiden pretenderen gerechtigd te zijn tot de vordering.

De vraag is weer of $C$ eigendom tot zekerheid heeft verkregen. De ontbinding van de koopovereenkomst A-B had tot gevolg dat B achteraf bleek beschikkingsonbe-

148. Zie Parl. Gesch Overgangsrecht, p. 157. 
voegd te zijn geweest toen hij de vordering tot zekerheid cedeerde aan C. Slechts zelden kon de zekerheidscessionaris (C) bescherming ontlenen aan artikel $1376 a$ (oud) $\mathrm{BW}^{149}$; alsdan kon omzetting van de zekerheidseigendom op het moment van de inwerkingtreding plaatsvinden. Ook indien de koopovereenkomst pas na de inwerkingtreding wordt ontbonden, vindt afwikkeling volgens het oude recht plaats (zie hierboven) ${ }^{150}$.

\title{
5.8.1.4 Collisie tussen het wettelijke pandrecht en een uit uitoefening van het recht van reclame voortvloeiend recht $t^{151}$
}

\begin{abstract}
Kort voor de inwerkingtreding werkocht en leverde A een partij grondstoffen aan fabrikant B. B droeg de grondstoffen over aan bank $\mathrm{C}$ tot zekerheid van de voldoening van zijn schulden aan deze bank. De levering geschiedde door middel van constitutum possessorium. Vervolgens riep A het recht van reclame in op grond van artikel 1191 (oud) BW wegens wanbetaling door B. Daarna trad het nieuwe BW in werking. Tegenover elkaar staan $A$ en $C$, die beiden pretenderen gerechtigd te zijn tot de (nog niet door B verwerkte) grondstoffen.
\end{abstract}

De koopovereenkomst A-B werd door inroeping van het recht van reclame op grond van artikel 1191 (oud) BW ontbonden. Net als bij de ontbinding op grond van artikel 1302 (oud) $B W$ was ook hier sprake van terugwerkende kracht en zakelijke werking. Voor de bescherming van $\mathrm{C}$ tegen de achteraf blijkende beschikkingsonbevoegdheid van $\mathrm{B}$ moest bij artikel $1192 a$ lid 1 (oud) $\mathrm{BW}$ te rade worden gegaan. Toepassing hiervan leverde op dat C niet werd beschermd tegen B's beschikkingsonbevoegdheid ${ }^{152}$. $\mathrm{Er}$ is geen zekerheidseigendom ontstaan; artikel $86 \mathrm{Ow}$ I behoeft niet te worden toegepast. Het feit dat in het zojuist opgevoerde geval het conflict tussen A en B zich na de inwerkingtreding afspeelt, brengt in het zojuist opgemerkte geen verandering. Artikel 196 lid 3 Ow I bepaalt namelijk dat in geval van uitoefening van het recht van reclame vóór de inwerkingtreding het oude recht toepasselijk blijft ${ }^{153}$.

\subsubsection{Collisie tussen het wettelijke pandrecht en een uit uitoefening van het verlengstuk van het recht van reclame voortvloeiend recht}

Kort voor de inwerkingtreding verkocht en leverde $A$ een partij grondstoffen aan fabrikant B. B verkocht en leverde de grondstoffen aan C. B cedeerde

149. Vgl. Reehuis, diss., nrs, 443, 441.

150. Denklkaar is ook dat de overeenkomst A-B niet wordt ontbonden, maar nietig is (van rechtswege of door vernietiging). Dain geldt het hiervoor opgemerkte evenzeer, behalve woor zover dit de overgangsregeling
värn artikel 1820 w l betreft.

151. Uil de aard der zaak kan en uit uitoefening van het recht wan reclame woortwloeiend recht slechts collideren met posterieure (gepretendeerde) rechten van derden.

152. Vgl. Reehuis, diss., nrs. 33, 218; Van Mierlo, diss., p. 140-141; Brahn, studiepocket (zesde druk), p.
101-103.

153. Zie over de vermelding van artikel $1192 \mathrm{a}$ (oud) BW in artikel $119 \mathrm{Ow}$ Inr. 7.8 .3 hierna. 
zijn vordering op $C$ aan bank $D$ tot zekerheid van de voldoening van zijn schulden aan deze bank. Betekening van de cessie bleef achterwege. Vervolgens riep $A$ het recht van reclame in op grond van artikel 1191 (oud) BW wegens wanbetaling door B. Nadat A was gebleken van de doorverkoop aan C verlangde $\mathrm{A}$ van $\mathrm{C}$ dat deze de (nog niet betalide) kooppenningen aan $\mathrm{A}$ voldeed. Daarna trad het nieuwe BW in werking. Tegenover elkaar staan thans A en $\mathrm{D}$, die beiden pretenderen gerechtigd te zijn tot de vordering op $\mathrm{C}$.

Is $\mathrm{D}$ zekerheidseigenaar van de vordering op $\mathrm{C}$ geworden? Ik ga ervan uit dat $\mathrm{C}$ voldeed aan de vereisten voor bescherming op grond van artikel $1192 a$ lid 1 (oud) BW tegen B's beschikkingsonbevoegdheid als gevollg van de inroeping van het recht van reclame door A. A's terugvorderingsrecht verviel daardoor. Artikel $1192 a$ lid 2 (oud) BW gaf A voor die situatie de bevoegdheid om tot het beloop van zijn vordering op $B$ van $C$ de kooppenningen te vorderen die deze aan $B$ verschuldigd was. Aangenomen dat aan de vereisten ook van deze bepaling was voldlaan, was het de vraag of de bevoegdheid van A was tenietgegaan door de cessie van deze vordering aan D. Dat dit niet het geval was, werd in 1954 door de Hoge Raad uitgemaakt in zijn arrest inzake de doorverkochte rogge ${ }^{154}$. Artikel 1192a lid 2 (oud) BW gold volgens de Hoge Raad ook,

'indien op het tijdstip der opvordering het recht op den koopprijs niet meer tot het vermogen van den eersten koper behoort, en met name indien dit recht vóór het tijdstip der opvordering aan een derde is overgedragen'.

De vordering op de tweede koper bleef

'gedurende dertig dagen na de oorspronkelijke aflevering ten behoeve van den oorspronkelijken verkoper belast'.

D trok derhalve aan het kortste eind ${ }^{155}$. Hij kon zijn recht op de vordering niet tegen A inroepen.

$\mathrm{Na}$ de inwerkingtreding van het nieuwe $\mathrm{BW}$ is de situatie als volgt. Zoals in $\mathrm{nr}$. 5.8.1.4 hiervóór is gezegd, blijft de uitoefening van het recht van reclame, die vóór de inwerkingtreding heeft plaatsgevonden, door het oude recht beheerst (artikel 196 lid 3 Ow I). Dit brengt met zich mee dat A's recht op de vordering blijft bestaan. De zekerheidseigendom van D is omgezet in een pandrecht (artikel 86 lid I Ow I). Of dit pandrecht sterker is dan het recht van A blijkt niet uit artikel 86 lid 3 Ow I. Deze bepaling bestrijkt alleen de situatie waarin de zekerheidseigendom vóór de inwerkingtreding, anders dan in casu, wèl tegen het recht van de derde kon worden ingeroepen. Wat geldt indien de zekerheidseigendom voorheen niet tegen het recht van de derde kon worden ingeroepen, moet aan de hand van andere overgangsregels worden bepaald ${ }^{156}$. Nu op grond van artikel 196 lid 3 Ow I het oude recht hier toe- 
passelijk is, moet op grond van het doorverkochte rogge-arrest worden geconcludeerd dat A's recht op de vordering sterker is dan het recht van de derde $C^{157}$.

\subsubsection{Collisie tussen het wettelijke pandrecht en een pandrecht ten gevolge van zaaksvervanging}

A cedeerde vór de inwerkingtreding van het nieuwe BW al zijn tegenwoordige en toekomstige vorderingen aan bank $B$ tot zekerheid van de voldoening van zijn schulden aan deze bank. Deze cessie werd niet medegedeeld aan de debiteuren van de vorderingen. Voorts vestigde $\mathrm{A}$ op zijn bedrijfspand, tegen onder andere brandschade verzekerd bij verzekeringsmaatschappij $D$, een hypotheekrecht ten behoeve van hypotheekbank $\mathrm{C}$. Enige tijd voór de invoering van het nieuwe BW ging A's bedrijfspand in vlammen op. Na de invoering ontstaat tussen $\mathrm{B}$ en $\mathrm{C}$, die beiden vergeefs wachten op betaling van hun vorderingen door $\mathrm{A}$, onenigheid over de vraag, wie van hen (het eerst) recht op de verzekeringspenningen kan doen gelden. Deze zijn niet toereikend om zowel de vorderingen wan $\mathrm{B}$ als die van $\mathrm{C}$ te voldoen.

Onzeker was onder het oude recht de verhouding tussen B's zekerheidseigendom van de vordering op de verzekeraar en het recht van $\mathrm{C}$ op deze vordering ex artikel 297 (oud) WvK ${ }^{158}$. Naar nieuw BW (artikel 3:229 lid 2) geldt dat het pandrecht ten gevolge van zaaksvervanging uit hoofde wan lid 1 van genoemde bepaling gaat boven ieder op de vordering gevestigd ander pandrecht (in casu dat van bank B) ${ }^{159}$.

$B$ 's zekerheidseigendom is op het tijdstip van de inwerkingtreding omgezet in een pandrecht (artikel 86 lid 1 OW I). Uit artikel 69 sub a Ow I volgt dat C's recht ex artikel 297 (oud) WvK blijft bestaan; het oude recht blijft daarop toepasselijk (artikel $68 a$ lid 2 Ow I). De verhouding tussen beide kan niet worden beheerst door artikel 3:229 lid $2 \mathrm{BW}$, omdat lid 1 van deze bepaling niet toepasselijk is ${ }^{160}$. De onzekerheid die onder het oude recht bestond is ook hier aanwezig.

\subsubsection{Collisie tussen wettelijke pandrechten onderling}

Zaken of vorderingen die een eerste keer aan een schuldeiser tot zekerheid waren overgedragen, konden nog een tweede keer aan een andere schuldeiser tot zekerheid zịn overgedragen. Deze gevallen komen hierna aan de orde.

A droeg in 1990 zijn kantoorinventaris over aan bank B tot zekerheid van de voldoening van zijn schulden aan deze bank. De levering geschiedde door

157. Zle ower de vermelding van artikel $1192 a$ (oud) BW in artikel 119 Ow I nr. 7.8 .3 hierna.

158. Ik ga erwan uit dat Chet gebruikelijke assurantiebeding in de hypotheekakte heeft opgenonven.

159. Onder het oude recht werd niet op deze bepaling geanticipeerd, vgl. HR 8 december 1989, NJ 1990, 747 (WUH-Union Allantique), r.o. 3.3. Zie ook de toot sub 2 van KIeijn onder dit arrest.

160. Artikel 69 sub e OW I verhindert dat op de wordering op de verzekeraar het pandrecht ex artikel 3:229

lid 1 BW komt te rusten. Zie Parl. Gesch. Overgangsrecht, p. 271 . 
middel van constitutum possessorium. Vervolgens droeg A dezelfde kantoorinventaris over aan bank $C$, eveneens tot zekerheid van de voldoening van schulden en met levering constituto possessorio. Daarna trad het nieuwe $\mathrm{BW}$ in werking. A betaalt zijn schulden aan $B$ en $C$ niet. Na verloop van enige tijd komt het tot onenigheid tussen $B$ en $C$ over de vraag, wie gerechtigd is tot de kantoorinventaris.

Heeft $\mathrm{C}$ na de inwerkingtreding enig recht op de kantoorinventaris en zo ja, wat voor recht? Ter beantwoording van deze vraag moet cerst worden uitgemaakt, of $\mathrm{C}$ vóor de inwerkingtreding enig recht op de kantoorinventaris kon doen gelden. Men kan zeggen dat dit niet het geval was. A was immers beschikkingsonbevoegd: B zal A nimmer de bevoegdheid hebben gegeven om de zaken nogmaals tot zekerheid over te dragen aan een derde. Daarnaast deugde de levering niet: $A$ kon zich naar analogie van artikel 592 (oud) BW niet buiten B om van houder voor B tot houder voor C maken. Omdat artikel 2014 (oud) BW alleen tegen het ontbreken van beschikkingsonbevoegdheid beschermde is $\mathrm{C}$ geen (zekerheids)eigenaar geworden ${ }^{161}$ : De kous lijkt hiermee af te zijn: op het moment van de inwerkingtreding bestond slechts zekerheidseigendom van B. Deze zekerheidseigendom is omgezet in een stil pandrecht. $\mathrm{C}$ heeft slechts concurrente vorderingen, evenals vór de inwerkingtreding.

Echter, het is de vraag of de zaak zo simpel ligt. De minister vindt van niet: in de toelichting merkt hij op dat geldig wordt

'een z.g. fiduciaire eigendomsoverdracht 'in tweede verband', nl. door de oorspronkelijke, doch door de eerste eigendomsoverdracht tot zekerheid onbevoegd geworden, eigenaar aan een tweede schuldeiser, welke in de praktijk blijkt voor te komen. Op de zaak of vordering kan zo'n zekerheidsrecht, dat door artikel 86 wordt geconverteerd, als tweede (bezitloos) pandrecht komen te rusten.' 162

De minister heeft hier het oog op de voorganger wan het huidige artikel 81 lid $1 \mathrm{OW}$ I. Krachtens laatstgenoemde bepaling wordt een nietige rechtshandeling op het moment waarop het nieuwe BW daarop toepasselijk wordt met terugwerkende kracht tot een onaantastbare bekrachtigd, indien deze rechtshandeling heeft voldaan aan de vereisten die het nieuwe BW voor haar stelt ${ }^{163}$.

De zoêven geciteerde passage heeft in de literatuur kritiek ontmoet. H. Stein schrijft:

"Aan de problemen die daaruit zullen voortwloeien, kan men slechts met huiver denken." 164 ,

zonder de nieuwsgierigheid van de lezer naar deze problemen te bevredigen. De

161. Vgl. bij woorbeeld Reehuis, diss, nr. 89 .

162. Parl. Gesch. Overgangsrecht, p. 78.

163. Zie over artikel 81 lid 10 W I nader ne. 4.9 hiervóór.

164. Preadv.. p. 159. 
huiver wan Stein wordt gedeeld door Reehuis, die wijst op de problematiek van de collisie van het wettelijke pandrecht met rechten op het goed en vorderingen van derden en in verband hiermee op de terugwerkende kracht van de bekrachtiging van de ongeldige overdracht en de verhouding daarvan tot artikel 86 lid 30 ow I ${ }^{165}$. Reehuis heeft voorts kritiek op de constructie voor de omzetting van zekerheidseigendom 'in tweede verband' in (stil) pandrecht ${ }^{166}$. Reehuis' conclusie is dat (thans) artikel 81 lid 1 Ow I niet van toepassing is op een zekerheidsoverdracht "in tweede verband' en dat dat ook niet wenselijk zou zijn 167 .

Met Stein en Reehuis ben ik van mening, dat de minister niet op het goede spoor zit. Ilk wil echter tevens aangeven hoe naar mijn mening het probleem van de dubbele zekerheidsoverdracht vanuit overgangsrechtelijk oogpunt dan wèl moet worden aangepakt ${ }^{16 \%}$.

Zou de tweede zekerheidsoverdracht niet mede een levering bij voorbaat van toekomstige zaken hebben behelsd, dan kon zij voor wat betreft de reeds eerder aan B overgedragen zaken in beginsel $\mathrm{C}$ niet tot zekerheidseigenaar maken. Hier geldt mutatis mutandis wat ik in nr. 5.8.1.1 hiervóór opmerkte over de collisie met "gewone' eigendom.

Gebruikelijk was echter om ook levering bij voorbaat tot zekerheidsoverdracht van toekomstige zaken overeen te komen ${ }^{169}$. De overdracht van toekomstige goederen kan worden gezien als een overdracht onder een opschortende voorwaarde. Deze voorwaarde houdt in dat de vervreemder (A) de goederen in de toekomst zal verkrijgen (hier: door voldoening van $B$ ) en dat hij ten tijde van die verkrijging beschikkingsbevoegd zal zijn ${ }^{170}$.

Bij de inwerkingtreding heeft in gevallen als deze een 'samenval van rechtsmomenten' kunnen plaatsvinden. B's zekerheidseigendom werd omgezet in stil pandrecht (ik ga uit van het "normale" geval). Met het arriveren van de ex-zekerheidsobjecten in het vermogen van de nog steeds beschikkingsbevoegde A werd echter tevens de opschortende voorwaarde vervuld, waaraan de overdracht A-C onderworpen was ${ }^{171}$. De levering bij voorbaat gold op grond van lid 7 van artikel 86 Ow I met ingang van 1 januari 1992 als één tot vestiging van pandrecht en kon dus direct haar werk gaan doen, zodat $\mathrm{C}$ op genoemdle datum een pandrecht verkreeg, gerangschikt na dat van $B$.

Anders was het uiteraard, indien door de voldoening van B reeds vóór de inwer165. Diss، nr. 521. Zie ook P.A. Stein, WPNR 6007 (1991), p. 357; Mon. Nieuw BW B-12a (Molenar), p.
90.

166. Diss., nr. 520 .

167. Diss 168. Vgli ook Vin Mierlo, preadv., p. 41-43, die hier eveneens geen rol ziet weggelegd voor convalescentie
ex artikel 81 Ow I.

169. Vgl hierover in verband met de dubbele zekerheidsoverdracht Brahn, studiepockat (zesde druk), p. 85-

170. Vgl, artikel 35 lid 2 Fw; HR 19 mei 1989, NJ 1990, 745 (IFN-CBI), r.o. 3.6; HR 15 maart 1991, RvdW 1991,79 (Veenendaal q.q. Hogeslag); Asser-Beekhuis I, nr. 325; Hartkamp; WPNR 6030 (1991), p. 869
(met noot 13).

171. Ook al hadden partijen bij het sluiten van hun overeenkomst wellicht niet deze wijze van vervulling van de voorwararde op het oog. 
kingtreding zijn zekerheidseigendom had opgehouden te bestaan. In die situatie was $\mathrm{C}$ wel reeds onder het oude recht zekerheidseigenaar geworden en kan hij op 1 januari 1992 stil pandhouder zijn geworden. Volgens Pabbruwe ${ }^{172}$ werden in de praktijk cok wel de volgende twee oplossingen gebruikt bij zekerheidsoverdracht aan meerdere kredietverleners. De ene oplossing kwam hierop neer dat de zekerheidsobjecten aan de kredietgevers gezamenlijk in mede-eigendom tot zekerheid werden overgedragen, alsmede dat zij onderling afspraken maakten over de verdeling van de netto-opbrengst van de uitgewonnen zekerheden. Dergelijke mede-eigendom tot zekerheid zal in het geval dat deze ten tijde van de inwerkingtreding nog bestond op dat moment in beginsel zijn omgezet in een wettelijk pandrecht ten behoeve van de gezamenlijke crediteuren ${ }^{173}$. De andere oplossing hield in dat de zaken slechts aan één kredietgever tot zekerheid werden overgedragen, terwijl aan de overige kredietgevers bij voorbaat het recht van de debiteur op een eventueel netto-surplus bij uitwinning van de zekerheden tot zekerheid werd overgedragen. In dat geval zal op de zekerheidsobjecten vanaf de inwerkingtreding een (stil) pandrecht zijn komen te rusten. Voor het recht van de debiteur op een eventueel netto-surplus geldt artikel 86 lid 7 tweede zin Ow I: de levering bij voorbaat daarvan geldt vanaf de inwerkingtreding als een levering bij voorbaat tot vestiging van een pandrecht ${ }^{174}$.

Het voorgaande geldt mutatis mutandis ook voor de dubbele cessie tot zekerheid van vorderingen op naam.

\subsubsection{Collisie binnen verhaalssituaties tussen het wettelijke pandrecht en bestaande (voor)rechten}

Ging het tot nu toe om conflicten die zich niet in het kader van verhaal afspeelden, thans komen die gevallen aan de beurt waarin dit wel zo is. Alsdan kan behalve de eerste, in nr. 5.8.1 hiervóór geciteerde, zin ook de tweede zin van artikel 86 lid 3 Ow I van belang zijn. Deze luidt:

'Het (pandrecht, HvdB) geldt met betrekking tot de rangorde als gevestigd op het tijdstip waarop het goed in eigendom tot zekerheid is overgegaan." 175

Deze overgangsregel betreft die gevallen waarin de rang afhankelijk is van de ouderdom ${ }^{176}$. Voorbeelden hiervan komen aan de orde in de navolgende bespreking van diverse collisies:

Bij artikel 86 lid 3 tweede zin Ow I mag niet uit het oog worden verloren dat het daar bepaalde alleen betrekking heeft op de verhouding van het wettelijke pand-

172. RMTh 1985, p. 386.

173. Vgl. Reehuis, diss., nr. 520 .

174. Zie hierover nr. 59.2 hierna.

175. Voor de vraag of artikel 86 lid 3 tweede zin Ow I betekent dat het wettelijke pandrecht met terugwerkende kracht ontstaat verwijs ik naar nr. 5.6 .5 hierv6ór. Zie voor een bepaling met nagenoeg gelijke inhoud betreffende zaken die tot de inwerkingtreding onroerend door bestemming waren artikel 77 laatste zin $\mathrm{OW}$ I.

176. Zie Parl. Gesch. Overgangsrecht, p. 90. 
recht tot (voor)rechten die dateren van wón de inwerkingtreding. Voorts geldt het slechts ingeval de zekerheidseigendom kon worden ingeroepen tegen bestaande (voor)rechten ${ }^{177}$. In de nrs. 5.8.2.1-7 zal ik achtereenvolgens bespreken de collisie tussen het wettelijke pandrecht en

- een verkopersprivilege;

- een privilege ten gevolge van zaaksvervanging;

- een privilege ter zake van kosten tot behoud;

- een privilege ter zake van kosten wegens bearbeiding;

- een privilege ter zake van schadevergoeding;

- een privilege van de fiscus op grond van artikel 21 Invorderingswet 1990;

- een retentierecht.

\subsubsection{Collisie tussen het wettelijke pandrecht en een verkopersprivilege}

Reehuis voert de volgende casus op:

'Onder het oude recht verkoopt en levert importeur A een partij textiel aan grossier B. A is op grond van het verkopersprivilege op de opbrengst van de partij textiel bevoorrecht. B draagt de partij zonder feitelijke overgave tot zekerheid van een vordering uit geldlening over aan bank $C$. Wanneer het NBW in werking is getreden en $A$ noch $C$ betaling van hun vordering hebben ontvangen, willen beiden verhal zoeken op de nog bij $B$ aanwezige partij textiel, waarvan de opbrengst echter onvoldoende is om beiden te voldoen. Wie gaat bij verhaal voor?'178

Vóór de inwerkingtreding kon $\mathrm{C}$ zijn zekerheidseigendom niet tegenwerpen aan $\mathrm{A}_{\text {, }}$ indien deze verhaal wilde nemen op de partij textiel voor zijn met het verkopersprivilege versterkte vordering ${ }^{179}$. Op het moment van de inwerkingtreding is $C^{\prime}$ 's zekerheidseigendom omgezet in een stil pandrecht op grond van artikel 86 leden 1 en $2 \mathrm{OW} \mathrm{I}^{180}$. Onder het nieuwe BW ontbeert de verkoper het verkopersprivilege. Dit betekent evenwel niet dat de voormalige zekerheidseigenaar ineens veel beter af is. De onderhavige overgangskwestie moet namelijk als volgt worden opgelost.

Artikel 86 lid 3 Ow I is in casu niet van toepassing. De eigendom tot zekerheid kon immers v6ór de inwerkingtreding niet tegen de vordering van de verkoper worden ingeroepen ${ }^{181}$. Derhalve moet de oplossing aan de hand van andere overgangsregels worden gevonden; en wel die overgangsregels die de rang van vorderingen betreffen. Uitgangspunt is hier dat de nieuwe bepalingen betreffende de rang van

177. Zie ne. 5.8.1 hierwởr.

178. Diss., ar. 531

179. Zie HR 6 maari 1970, NI 1970,433 (Van Wessem-Traffic, ofwel Pluvier) en onder anderen Reehuis, diss., nr: 256 .

180. Ik gat hierbij vanuit dat de uitzonderingsbepaling vatt artikel 86 lid 5 Ow I in casu niet van toepassing is.

181. Zie nr. 5.8.1 hiervóor. 
vorderingen onmiddellijk werken (artikel $₫ 17$ lid 1 Ow ) $^{182}$. Eén van de uitzonderingen hierop is neergelegd in artikel 119 Ow I. Het verkopersprivilege dat op bestaande vorderingen betrekking heeft is gehandhaafd. Dit gehandhaafde privilege heeft voorts vooirang boven, kort gezegd, een wettelijk stil pandrecht (artikel 119 derde zin Ow I). Zo wordt bij wijze van overgangsbepaling de lijn van het Pluvierarrest voortgezet ${ }^{183}$. Uit het bovenstaande volgt dat $C$ evenals vóór de inwerkingtreding het onderspit delft tegen $\mathrm{A}$.

Stel nu dat C vórr de inwerkingtreding afgifte van de partij textiel door B heeft geëist en verkregen. Hoe ligt de zaak dan? Aangenomen mag worden dat in de eis tot afgifte een aanzegging tot uitwinning besloten $\operatorname{lag}^{184}$. In dat geval is artikel 86 lid 5 Ow I van toepassing: de omzetting van de eigendom tot zekerheid is opgeschort. $\mathrm{Nu} \mathrm{C}$ afgifte van de zekerheidsobjecten heeft verkregen, is niet langer sprake van het verschaffen van zekerheid zonder feitelijke overgave van de zaken. Deze waren niet meer in handen van de schuldenaar in de zin van artikel 1190 (oud) BW. De zekerheidsoverdracht ging boven het voorrecht van de verkoper. Artikel 1190 (oud) BW blijft krachtens de tweede zin van artikel $\$ 19$ Ow I toepasselijk op overgangssituaties. De slotsom moet zijn dat niet $\mathrm{C}$ hier het onderspit delft, maair $\mathrm{A}^{185}$.

Een andere mogelijkheid is nog dat $C$ ná de inwerkingtreding afgifte van de partij textiel door B eist en verkrijgt (vgl. artikel 3:237 lid $3 \mathrm{BW}$ ). Er is hier niet langer sprake van een pandrecht dat ingevolge artikel 86 lid 2 Ow I de gevolgen heeft van een pandrecht dat is gevestigd overeenkomstig artikel 3:237 BW. Artikel 119 derde zin OW $\mathrm{I}$ is daarom niet langer van toepassing. Ook hier geldt op grond van artikel 1190 (oud) $\mathrm{BW}$ dat het verkopersprivilege is geëindigd. C's vordering gaat dus boven die van A. Dit zou anders kunnen zijn, indien C's handelwijze tegenover A als onrechtmatig zou moeten worden beschouwd.

\subsubsection{Collisie tussen het wettelijke pandrecht en een privilege ten gevolge van zaaksvervanging}

In de fabriek van A brak in 1991 brand uit. B en C, eigenaren van een naburig bedrijf, wisten uit de fabriek onder meer de dure kantoorinventaris te redden. Zij gebruikten daartoe enkele van hun voertuigen, namelijk een vorkheftruck en een vrachtwagen. Voorts sloegen zij de inventaris tijdelijk op in hun eigen bedrijf. Enige tijd later, toen de kantoorinventaris weer in bet herstelde bedrijfspand van A was teruggeplaatst, kwam door een enorme wolkbreuk A's fabriek blank te staan, waardoor de kantoorinventaris alsnog verloren ging. Vervolgens trad het nieuwe BW in werking. De vordering van B en $C$ wegens de door hen gemaakte kosten tot behoud werd door $A$ niet voldaan. Hetzelfde geldt voor de vorderingen die bank $\mathrm{D}$ uit hoofde van geldlening op

182. Terzijde merk ik op dall artikel 117 lid 1 Ow I door het later ingevoegde artikel 68 a lid 1 Ow I overbodig is geworden.

183. Aldus Parl. Gesch. Overgangsrecht, p. 90. Artikel 119 Ow I wordt toegelicht op p. 122-123.

184. Zie nr. 5.6.3.7 hierwoor.

185. Vgl. HR 18 september 1987, NJ 1988, 983 (Berg \& Sons-De Bary) en onder anderen Brahn, studie. pocket (zesde druk), p. 91-94. 
A heeft. A blijkt een vordering te hebben op assuradeur $\mathrm{E}$, die onder meer betrekking heeft op de verloren gegane kantoorinventaris. B, C en D willen zich op cleze vordering verhalen. $\mathrm{D}$ beroept zich daarbij op een van vór de inwerkingtreding daterende (verplichting tot) zekerheidscessie van alle tegenwoordige en toekomstige vorderingen van $\mathrm{A}$ aan $\mathrm{D}$.

Onder het oude recht zou alleen $\mathrm{D}$ zich op de vordering op verzekeraar $\mathrm{E}$ kunnen verhalen, omdat deze vordering door de zekerheidscessie uit het vermogen van $A$ was geraakt, waardoor derden-schuldeisers zich niet meer op deze vordering konden verhalen. Aan de vraag of $D^{\prime}$ 's zekerheidsrecht zou moeten worden gerelativeerd zou niet kunnen worden toegekomen, omdat $B$ en $C$ hun privilege ter zake van de kosten tot behoud zouden zijn kwijtgeraakt door het alsnog tenietgaan van de kantoorinventaris. De zaaksvervangingsregel van artikel 3:283 $\mathrm{BW}$ kwam in het oude recht niet voor ${ }^{186}$.

Toepassing van het nieuwe BW zou het volgende resultaat te zien geven. D zou een pandrecht op de vordering op verzekeraar $E$ hebben. Deze vordering zou dus niet uit A's vermogen zijn geraakt. B en $C$ zouden zich kunnen beroepen op artikel 3:283 BW: hun voorrecht wegens de kosten tot behoud op de kantoorinventaris zou zich mede uitstrekken over de vordering tot uitkering van de verzekeringspenningen, die in de plaats van de inventaris is getreden. Aangenomen moet echter worden dat de rang tussen pandrecht en privilege zou moeten worden bepaald aan de hand van de hoofdregel van artikel 3:279 $\mathrm{BW}$ : pand gaat boven voorrecht ${ }^{187}$.

In het gegeven voorbeeld is D's eigendom tot zekerheid op het moment van de inwerkingtreding omgezet in pandrecht (artikel 86 lid 1 Ow I). De vordering op assuradeur $E$ is dus in A's vermogen teruggekeerd. Een beroep van $B$ en $C$ op artikel 3:283 BW zal echter niet kunnen slagen: op grond van artikel 118 Ow I is deze bepaling niet toepasselijk op een vordering tot vergoeding die, zoals hier, bestond op het tijdstip van de inwerkingtreding ${ }^{188}$. Aan artikel 3:279 BW kan dus niet eens worden toegekomen. Pandhouder D kan zich vóór de concurrente schuldeisers B en $\mathrm{C}$ op de vordering verhalen (vgl. artikel 86 lid 3 eerste zin Ow I).

\subsubsection{Collisie tussen het wettelijke pandrecht en een privilege ter zake van kosten tot behoud}

Hier moet onderscheid worden gemaakt tussen de situatie dat het onderhavige voorrecht is totstandgekomen vóor de zekerheidseigendom en de omgekeerde situatie. Uit het navolgende blijkt dat ook met het oog op het hier aan de orde gestelde collisieprobleem registratie van de akte die van de zekerheidsoverdracht doorgaans zal zijn opgemaakt geen overbodige luxe was ${ }^{189}$.

186. Vgl. Asser-Mijnssen, nr. 18.

187. Zie hierover Reehuis, diss., nr. 462; Van Mierlo, diss., p. 201, die voor het onderhavige geval een whettelijke uitzondering op artikel $3: 279 \mathrm{BW}$ bepleit.

188. Zie voor de ratio van deze overgangsbepaling de toelichting. Parl. Gesch. Overgangsrecht, p. 122.

189. Zie over hel belang van registratie van een dergelijke akte nr. 5.7 hiervóór. 
In de fabriek van A brak in 1991 brand uit. B en C, eigenaren van een naburig bedrijf, wisten uit de fabriek onder meer de dure kantoorinventaris te redden. $\mathrm{Zij}$ gebruikten daartoe enkele van hun voertuigen, namelijk een vorkheftruck en een vrachtwagen. Voorts sloegen zij de inventaris tijdelijk op in hun eigen bedrijf. Enige tijd later, toen de kantoorinventaris weer in het herstelde bedrijfspand van A was teruggeplaatst, droeg $\mathrm{A}$ de inventaris over aan bank $D$ tot zekerheid van de voldoening van zijn schulden aan deze bank. De levering geschiedde door middel van constitutum possessorium. Vervolgens trad het nieuwe BW in werking. Betaling door A van zijn schulden aan B, C en D blijft achterwege. Na verloop van tijd willen zowel $B$ en $C$ wegens de door hen gemaakte kosten tot behoud als $\mathrm{D}$ wegens het door haar verleende krediet verhaal nemen op de kantoorinventaris. De opbrengst daarvan is echter onvoldoende om allen te voldoen.

Het privilege wegens de kosten tot behoud is evenals thet verkopersprivilege een bijzonder privilege. Het moet ervoor worden gehouden dat onder het oude recht de zekerheidseigendom in beginsel moest worden gerelativeerd ten opzichte van genoemd privilege. Ook hier ging immers op de overweging van de Hoge Raad in het arrest Van Wessem-Traffic ${ }^{190}$, dat het redelijk is het belang van de zekerheidseigenaar bij de uitoefening van zijn verhaalsrechten op bepaalde zekerheidsobjecten te laten wijken voor het belang van de crediteur(en) (in het arrest: de verkoper; hier: $B$ en C) met een voorrecht bij de uitoefening daarvan. De zekerheidseigenaar zou namelijk, aldus de Hoge Raad, geen recht op de zekerheidsobjecten hebben kunnen doen gelden, als zij niet door de verkoper waren geleverd. Vertaald naar het hier gegeven voorbeeld: $\mathrm{D}$ had geen recht op de kantoorinventaris kunnen doen gelden, indien deze niet door $B$ en $C$ was gered ${ }^{191}$.

Onder het nieuwe BW zou de verhouding tussen $B$ en $C$ enerzijds en D anderzijds niet anders zijn dan voorheen. Het voorrecht ter zake van kosten tot behoud is gehandhaafd (artikel 3:284 BW). De verhouding tussen het privilege en stil pandrecht wordt geregeld in artikel 3:284 lid $2 \mathrm{BW}$. Is het pandrecht gevestigd na het maken van de kosten tot behoud, dan kan het slechts aan de schuldeiser worden tegengeworpen, indien de zaak in de macht van de pandhouder of een derde is gebracht. In casu is van dit laatste geen sprake, zodat ook volgens het nieuwe BW het eerst voor de vorderingen van $B$ en $C$ verhaal zou kunnen worden genomen. Een reëel probleem van overgangsrecht doet zich hier dus niet voor. Toch moet worden bezien of artikel 3:284 BW direct vanaf de inwerkingtreding toepasselijk is. Dit is inderdaad het geval, en wel krachtens artikel 117 lid 1 Ow I. Genoende BW-bepaling is toepasselijk op het wettelijke pandrecht van $\mathrm{D}$, omdat dit op grond van artikel 86 lid 2 Ow I de gevolgen heeft van een conform artikel 3:237 BW gevestigd pandrecht. Voor B, C en D blijft de toestand na de inwerkingtreding derhalve zoals

190. HR 6 maart 1970, NJ 1970, 433 (ook Pluvier-arrest genoemd).

191. Vgl. in deze zin onder anderen Asser-Beekhuis I, nr. 356; Reehuils, diss., nr. 257; Brahn, studiepocket (zesde druk), p. 94; vgl. ook Parl. Gesch. Inv. Boek 3; p. 1198 
deze voordien was. Ervan uitgaande dat de zekerheidseigendom onder het oude recht niet tegen de bevoorrechte vordering kon worden ingeroepen, is artikel 86 lid 3 Ow 1 niet van toepassing ${ }^{152}$.

Het is mogelijk dat D afgifte van het kantoormeubilair door A verkrijgt voordat het tot een vertaalssituatie komt. Dit kan zich zowel vóor als ná de inwerkingtreding voordoen. In het eerste geval zal op grond van artikel 86 lid 50 ow 1 de eigendom tot zekerheid gehandhaafd zijn ${ }^{193}$. Er is dan een zekerheidsoverdracht wet feitelijke overgave van de zaken aanwezig, voor relativering van de zekerheidsowerdracht is in beginsel geen reden meer, zodat $D$ zich het eerst op de zaken zal kunnen verhalen. In het tweede geval is wel een wettelijk pandrecht ontstaan, maar is het resultaat hetzelfde als in het eerste geval op grond van artikel $3: 284$ lid 2 BW (in verband met de artikelen 117 lid 1 en 86 lid 2 Ow I) ${ }^{194}$.

\section{b. Posterieur privilege ter zake van kosten tot behoud}

Ik neem als uitgangspunt het voorbeeld dat ik hierboven onder a gaf, met dit verschil dat de zekerheidsoverdracht van het kantoormeubilair heeft plaatsgehad vóordat de kosten tot behoud zijn gemakkt. Wat onder het oude recht gold voor de verhouding tussen de vordering van de eligenaar tot zekerheid en de bevoorrechte schuldeiser is niet geheel duidelijk. Mijnssen ${ }^{195}$ acht de vordering wegens kosten tot behoud bevoorrecht boven de vordering van de zekerheidseigenaar op grond van analoge toepassing van artikel 1196 (oud) BW. Zijn mening wordt bestreden door Van Mierlo ${ }^{156}$; die pleit voor relativering van de zekerheidsoverdracht, ook al is het privilege ná de zekerheidsoverdracht ontstaan. Reehuis ${ }^{197}$ vindt relativering minder aannemelijk, omdat dan een aanvankelijk volledig geldige zekerheidsoverdracht later tegenover de geprivilegieerde crediteur ongeldig zou worden. Hem lijkt het mogelijk dat de schuldeiser op grond van zaakwarmeming of ongerechtvaardigde verrijking rechtstreeks de eigenaar tot zekerheid aanspreekt tot betaling van de kosten tot behoud ${ }^{198}$.

Het newwe BW brengt helderheid op het hier aan de orde zijnde punt: op grond van artikel 3:284 lid 2 kan de bevoorrechte schuldeiser zijn vordering op het goed verhalen zonder dat hem rechten ${ }^{199}$ van derden op het goed kunnen worden tegengeworpen, tenzij deze rechten na het maken van de kosten tot behoud zün verkre-

192. Hiersan gaat ook de minister stllzwijgend wit: zie Parl. Gesch. Overgangsrecht, p. 90.

193. Zie wi 5.63 .7 hiervoror.

194. Volgens Asser-Mijnssen, nr. 162, kan het pandrecht alleen aan de schuldeiser worden tegengeworpen, indien de pandhouder het voomecht niet kende of behoorde te kennen op het tijdstip waarop de zaak in zijin macht werd gebracht. Hientegen Reehuis, diss, nr, 252, wilens mening wordt onderschreven door Molenaar, K wartaalbericht Nieuw BW 1990, p. 53. Als Reehuis en Molenaar ook de minister, Panl. Gesch. Inv. Boek $3,1331-1332$.

195. Asser Mijnssen, nrs, 63, 180 :

196. Diss.; p. 130-131.

197. Diss... nr. 257.

198. Vgl. in algemene zin over de verhouding tussen zekerheidseigendom en een privilege ter zake van kosten tot behoud Parl. Gesch. Inv. Boek 3, p. 1198: onder het oude recht gold vaak hetzelfde als volgens artikel $3: 284$ lid $2 \mathrm{BW}$.

199. Hitronder vallen ook pandrechten, aldus Parl. Gesch. Boek 3, p. 865. 
gen. In thet gegeven voorbeeld gaat de hoofdregel van het artikel op (het privilege gaat boven pandrecht). Of de verpande zaken inmiddels in de macht van de pandhouder of een derde zijn gebracht is irrelevant.

Voor de rangorde in de onderhavige overgangssituatie maakt het niet uit, welke opvatting men heeft over hetgeen hier onder het oude recht gold. Wel maakt dit uit yoor de weg waarlangs men tot die rangorde komt. De opvattingen van Mijnssen en Van Mierlo voeren tot hetzelfde resultaat, namelijk dat de vordering van de bevoorrechte crediteuren $B$ en $C$ voorgat boven die van zekerheidseigenaar $D^{200}$. Dan is na de inwerkingtreding artikel 86 lid 3 Ow I niet van toepassing op de verhouding tussen de vordering van $B$ en $C$ en die van wettelijk pandhouder $D$. In beginsel is op grond van de artikelen 117 lid 1 en 86 lid 2 Ow I artikel 3:284 lid 2 tweede zin BW toepasselijk. Op grond daarvan kan D's bij de inwerkingtreding ontstane wettelijke pandrecht niet aan $\mathrm{B}$ en $\mathrm{C}$ worden tegengeworpen.

De visie van Reehuis daarentegen leidt wel tot toepassing van artikel 86 lid $3 \mathrm{OW}$ I. Het wettelijke pandrecht is eerst op het tijdstip van de inwerkingtreding ontstaan. Dat is later dan het moment waarop het privilege wegens de kosten tot behoud is verkregen. De zekerheidseigendom was juist eerder dan dit privilege ontstaan. Dit is van belang omdat op grond van het toepasselijke artikel 3:284 lid $2 \mathrm{BW}$ verschillende regels gelden al naar gelang een pandrecht vóór dan wel ná het maken. van de kosten tot behoud is verkregen. Artikel 86 lid 3 tweede zin Ow I geeft deze uitkomst dat het wettelijke pandrecht met betrekking tot de rangorde geldt als gevestigd op het tijdstip waarop het goed in eigendom tot zekerheid is overgegaan: Hieruit vloeit, uitgaande van de hoofdregel voor de privileges (artikel 117 lid $1 \mathrm{OW}$ I), voor de onderhavige casus (posterieur privilege) voort dat artikel 3:284 lid 2 eerste zin BW van toepassing is. Daardoor is de uitkomst een andere dan onder het oude recht: $B$ en $C$ kunnen hun vordering op de kantoorinventaris verhalen, zonder dat hen het wettelijke pandrecht van $D$ kan worden tegengeworpen. Dit zou ook dan gelden, indien D de inventaris inmiddels onder zich zou hebben genomen.

5.8.2.4 Collisie tussen het wettelijke pandrecht en een privilege ter zake van kosten wegens bearbeiding

Ook bij het voorrecht ter zake van kosten wegens bearbeiding moet onderscheid worden gemaakt tussen het geval waarin de kosten zijn gemaakt vó́rdat de eigendom tot zekerheid werd verkregen en het omgekeerde geval. Als voorbeeld kan weer de casus van het kantoormeubilair van fabrikant $A$ worden genomen, met dit verschil dat $B$ en $C$ niet de inventaris voor verbranding hebben behoed, maar er onderhoudswerkzaamheden aan hebben verricht.

\section{a. Anterieur privilege ter zake van kosten wegens bearbeiding}

Wordt na het ontstaan van de geprivilegieerde vordering van B en C het kantoor-

-200. In de memorie van toelichting (Parl. Gesch. Owergangsirecht, p. 90) wordt impliciet van dit resultant uitgegaan. 
meubilair tot zekerheid overgedragen aan $\mathrm{D}$, dan geldt hetzelfde als in nr. 5.8 .23 onder $a$ hierv66r is geschreven over de verhouding tussen het privilege ter zake van de kosten tot behoud en zekerheidseigendom respectievelijk (wettelijk) pandrecht $^{201}$. In plaats van artikel 3:284 $\mathrm{BW}$ moet artikel 3:285 $\mathrm{BW}$ worden toegepast. Uit laatstgenoemde bepaling blijkt dat, anders dan bij de kosten tot behoud, de kring van geprivilegieerde crediteuren naar nieuw recht kleiner is dan voorheen. In artikell 3:285 lid $1 \mathrm{BW}$ wordt namelijk de eis gesteld dat de crediteur persoonlijk aan de uitvoering van in de uitoefening van zijn bedrijf aangenomen werk pleegt deel te nemen dan wel een vennootschap of een rechtspersoon is, waarvan een of meer beherende vennoten of bestuurders dit plegen te doen. Hierdoor is de mogelijkheid aanwezig dat een crediteur vanaf de inwerkingtreding niet langer een voorrecht wegens bearbeiding heeft (vgl. artikel 117 Ow D). Doet dit laatste zich voor; dan is van een collisieprobleem uiteraard geen sprake meer.

Een ander verschil met het privilege betreffende de kosten tot behoud is dat voor het privilege wegens de kosten van bearbeiding een vervaltermijn van twee jaar geldt (artikel 3:285 lid 1 tweede zin BW). Het oude recht kende hier geen termign. Voor het overgangsrecht inzake deze termijnkwestie zie men antikel $73 \mathrm{OW} \mathrm{I}$.

\section{b. Posterieur privilege ter zake van kosten wegens bearbeiding}

Indien de zekerheidsoverdracht dateert van vón het maken van de bearbeidingskosten geldt het volgende. Onder het oude recht bestond geen overeenstemming over de verhouding tussen overdracht tot zekerheid en een nadien ontstaan voorrecht wegens bearbeidingskosten. Volgens Mijnssen ${ }^{202}$ zou de bevoorrechte crediteur zich erop kunnen beroepen dat de eigenaar tot zekerheid door de zaak in de feitelijke macht van de debiteur te laten een situatie heeft geschapen, waarin de aannemer ervan heeft kunnen uitgaan dat de debiteur bevoegd was tot het aangaan van de desbetreffende overeenkomst. De bevoorrechte crediteur kan, aldus Mijnssen, op grond hiervan zijn voorrecht ook tegenover de zekerheidseigenaar staande houden. Van Mierlo ${ }^{203}$ is de mening toegedaan dat de zekerheidsoverdracht moet worden gerelativeerd, ook al is het privilege pas na de zekerheidsoverdracht ontstaan. Hij voert hiervoor dezelfde grond aan als Mijnssen voor zijn opvatting gebruikt. Reehuis ${ }^{204}$ vindt relativering van de zekerheidsoverdracht tegenover een later ontstane bevoorrechte vordering minder aannemelijk, omdat dan een aanvankelijk volledig geldige zekerheidsoverdracht later tegenover de geprivilegieerde crediteur ongeldig zou worden. Hij noemt als mogelijke oplossing een verbintenissenrechtelijke uitweg (een actie van de bevoorrechte schuldeiser tegen de eigenaar tot zekerheid op grond van zaakwaarneming of ongerechtvaardigde verrijking) ${ }^{205}$.

201. Zie bij yoorbeeld Reehuis, diss, nrs. 257 (oud BW), 253 en 255 (BW).

202. Asser-Mijnssen, ar. 180.

203. Diss., p. 130.

204, Diss., nr. 257

205. Vgl. in algemene zin over de verhouding tussen zekerheidseigendom en een privilege ter zake wan kosten wegens bearbeiding Parl. Gesch. Inv. Boek 3, p. 1198: onder het oude recht gold vaik hetzelfde als volgens artikel 3:285 lid 2 BW. 
Naar nieuw BW heeft het voorrecht op de zaak waaraan de arbeid is verricht voorrang boven een stil pandrecht, tenzij dit pandrecht eerst na het ontstaan van de bevoorrechte vordering is gevestigd en de zaak in de macht van de pandhouder of een derde is gebracht (artikel 3:285 lid 2 BW). Deze uitzondering is in het hier behandelde geval (posterieur privilege) niet aan de orde. Niet van belang is hier of de zaak naderhand in de macht van de pandhouder of een derde is gebracht.

Toepassing van het overgangsrecht levert het volgende op. Laat men onder het oude recht met Mijnssen en Van Mierlo de vordering van de geprivilegieerde schuldeisers $B$ en $C$ voorgaan boven die van eigenaar tot zekerheid $D^{206}$, dan is na de inwerkingtreding artikel 86 lid $30 \mathrm{~W}$ I niet van toepassing op de verhouding tussen genoemde vorderingen. In beginsel werkt hier artikel 3:285 lid $2 \mathrm{BW}$, en wel op grond van de artikelen 117 lid 1 en 86 lid 2 Ow I. Op grond van genoemde BW-bepaling kan D's bij de inwerkingtreding ontstane wettelijke pandrecht niet aan B en C worden tegengeworpen. Aan artikel 86 lid 3 Ow I kan wel worden toegekomen, indien men de opvatting van Reehuis aanhoudt. Krachtens deze overgangsregel geldt het wettelijke pandrecht met betrekking tot de rangorde als gevestigd op het tijdstip waarop het goed in eigendom tot zekerheid is overgegaan. Dit brengt, indien artikel 117 lid 1 Ow I van toepassing is, met zich mee dat de hoofdregel van artikel 3:285 lid 2 BW opgaat: het voorrecht van $B$ en $C$ heeft anders dan voorheen voorrang boven het wettelijke pandrecht van $D$. Dit zou ook dan gelden, indien $D$ de inventaris inmiddels onder zich zou hebben genomen.

Ook hier geldt uiteraard het hierboven onder $a$ opgemerkte over de inperking van de kring van geprivilegieerde crediteuren en over de vervaltermijn voor het privilege.

\subsubsection{Collisie tussen het wettelijke pandrecht en een privilege ter zake van schadevergoeding}

A heeft een onrechtmatige daad gepleegd tegenover B. A verkreeg in verband hiermee op grond van zijn aansprakelijkheidsverzekering een vordering op assuradeur C. A had zich eerdler tegenover bank D verbonden om al zijn bestaande en toekomstige vorderingen tot zekerheid van de voldoening van zijn schulden aan de bank te cederen. Zo cedeerde $A$ ook de vordering op $C$ aan D, zonder mededeling aan C. Kort daarna trad het nieuwe BW in werking. $B$ en $D$ wachten thans tevergeefs op betaling en willen zich beiden op de vordering op C verhalen, die echter niet toereikend is om beiden te voldoen. Wie kan zich het eerst verhalen?

Volgens het oude recht zou B slechts een concurrente vordering hebben op $\mathrm{A}^{207}$. De wordering van $A$ op $C$ zou door de zekerheidscessie buiten A's vermogen zijn geraakt, waardoor $B$ zich daarop niet meer zou kunnen verhalen.

206. In de memorie van toelichting (Parl. Gesch. Overgangsreclat, p. 90) wordt impliciet van dit resultaat uitgegaan.

207. Ik ga ervan uit, dat in casu artikel 6 WAM nijet van toepassing is. Zie over het oude recht Asser-Mijnssen, nrs. 72,170 . 
Het nieuwe recht geeft cen ander beeld te zien. In artikel 3:287 lid $1 \mathrm{BW}$ wordt namellik bepaald dat de wordering tot vergoeding van schade bevoorecht is op de wordering die de schuldenaar (in casu A) uit hoofde van verzekering van zijn aansprakelijkheid op de verzekeraar (in casu C) heeft, voor zover deze laaste vordering de verplichting tot vergoeding van deze schade betreft. Rechten van derden op de vordering tot uitkering van de assurantiepenningen kunnen niet aan de schuldeiser (in casu B) worden tegengeworpen, zo bepaalt lid 2 voorts. B zou zich derhalve het eerst op genoemde vordering kinnen verhalen ${ }^{208}$.

Hoe moet nu het opgevoerde owergangsprobleem worden opgelost? De zekerheidseigendom van $D$ is op het moment van de inwerkingtreding omgezet in pandreeht (artikel 86 lid 10 w $)$. Aan het vorderingsrecht van $B$ is ingevolge artikel 117 lid I Ow I vanaf de inwerkingtreding het woorrecht wan artikel $3: 287 \mathrm{BW}$ verbonden. Dit werd mogelijk gemaakt door genoemde omzetting van de eigendom tot zeketheid in pandrecht, waardoor de vordering op $C$ zich weer in $A$ 's vermogen bewond. Ondanks artikel 3:287 lid $2 \mathrm{BW}$ kan D's pandrecht echter wel aan B worden tegengeworpen. Dit volgt uit artikel 86 lid 3 eerste zin Ow I: nu de eigendom tor zekerheid wór de inwerkingtreding tegen $\mathrm{B}$ kon worden ingeroepen, geldt dit nadien ook voor het wettelijke pandrecht ${ }^{209}$.

\subsubsection{Collisie tussen het wettelijke pandrecht en een privilege van de fiscus ex} artikel 21 Invordeningswet 1990

Fabrikant $\mathrm{A}$ heeft vóór de invoering van thet nieuwe BW al zijn tegenwoordige en toekomstige woorraden grondstoffen en gereed produkt, kantoorinventaris, machines, bestelauto's en vorderingen op afnemers tot zekerheid van de voldoening van zijn schulden overgedragen aan bank B. De levering van genoemde zaken is geschied door middel van (geanticipeerd) constitutum posisessorium, van de zekerheidscessie is mededeling aan de debiteurenafnemers achterwege gebleven. Kort voor 1 januari 1992 haperden de betalingen door $\mathrm{A}$ aan $\mathrm{B}$ en alan de fiscus. Na genoemde datum komt het tot een verhaalssituatic. De aanwezige activa zijn onvoldoende om zowel $B$ als de fiscus te kunnen voldoen. Wie kan zich het eerst verhalen?

Giteraard moeten hier de gevallen worden geëcarteerd, waarin de omzetting van de zekerheidseigendom in pandrecht wordt tegengehouden. B mag dus niet vór 1 januari 1992 de uitwinning van de zekerheden hebben aangezegd aan A, A mag op genoemde datum niet in stat van fallissement verkeren (artikel 86 lid $50 \mathrm{~W}$ I) en evenmin mag de fiscus voór 1 januari 1992 bodembeslag hebben gelegd (artikel 39 lid 1 Ow II) 210 .

Onder het oude recht zou het volgende hebben gegolden. Onderscheid zou moe-

208. Vgl. Asser-Mijnssen, nr. 72; Reehuis, diss, nr, 460; Van Mierlo, diss, p. 200-201.

209. Zu Parl. Geseh. Overgangsirecht, p. 90, 276; Reehuis, diss., ni. 528. Volgens Mon. Nieuw BW B-12a (Molenaar), $\mathrm{p}$. 87, kan dit ook worden gebaserd op artikel 69 sub a Ow $I$.

210. 2 ie over dit alles de nus. 5.6 .3 en 5.6 .4 hiervór. 
tem worden gemaakt tussen bodemgoederen en andere goederen ${ }^{211}$. Bodemgoederen zijn volgens artikel 22 lid 3 Invorderingswet 1990 (nog niet) ingeoogste vruchten, roerende goederen tot stoffering van een huis of landhoef, of tot bebouwing of gebruik van het land, die zich ten tijde van de beslaglegging op de bodem van de belastingschuldige bevinden. In casu behoren hiertoe de kantoorinventaris en de machines $^{212}$.

Voor de niet-bodemgoederen zou gelden dat zekerheidseigenaar B zich daarop zou kumnen verhalen. Voor deze niet tot A's vermogen behorende goederen zou de hoofdregel gelden dat een schuldeiser (hier de fiscus) zich niet kan verhalen op goederen van anderen dan de schuldenaar (hier A). Voor de bodemgoederen zou echter de uitzondering op deze regel opgaan, die is te vinden in artikel 22 lid 3 Invorderingswet 1990, waardoor de fiscus zich wel op deze goederen zou kunnen verhalen, ook al behoorden deze niet toe aan debiteur A, maar aan diens crediteur B. Een eventueel bezwaarschrift van $B$ zou hem als zekerheidseigenaar niet baten ${ }^{213}$.

Naar nieuw BW zou B stil pandhouder zijn en zouden de diverse goederen zich derhal ve in A's vermogen bevinden. Daardoor zou zich de vraag voordoen, in welke rang de vorderingen van $B$ en van de fiscus ten opzichte van elkaar staan. Ook hier zou weer het onderscheid tussen bodemzaken en andere zaken moeten worden gemaakt. De andere zaken zouden nu (evenals vorderingen) vallen onder de hoofdregell van artikel 3:279 $\mathrm{BW}$, dat pand boven voorrecht gaat. B zou hier dus aan het langste eind trekken. Voor de bodemzaken zou de uitzondering op deze hoofdregel van artikel 21 lid 2 Invorderingswet $1990^{214}$ gelden: het voorrecht wan de fiscus gaat boven pand, voor zover het pandrecht rust op een zaak als bedoeld in artikel 22 lid 3 Invorderingswet 1990, die zich op de bodem van de bellastingschuldige bevindt en tegen inbeslagneming waarvan derden zich op die grond niet kunnen verzetten.

Thans de hierboven gepresenteerde overgangssituatie. Daarin wordt de eigendom tot zekerheid omgezet in stil pandrecht (artikel 86 leden 1 en 2 Ow I). Gelden de nieuwe rangorderegels? Voor het uiteindelijke resultaat maakt dit niet uit, wel voor de weg waarlangs dit resultaat wordt bereikt (zie het zojuist over het oude en het nieuwe recht gezegde). Voor de vorderingen en de niet-bodemzaken biedt artikel 86 lid 3 eerste zin Ow I uitkomst: het pandrecht kan worden ingeroepen tegen de vordering van de fiscus, nu ook de eigendom tot zekerheid tegen die vordering kon worden ingeroepen ${ }^{215}$. Bij de bodemzaken ligt het anders, ondat daar de eigendom tot zekerheid niet tegen de vordering van de fiscus kon worden ingeroepen; waardoor artikel 86 lid 3 OW I niet van toepassing is. Dit brengt met zich mee dat moet worden uitgeweken naar de artikelen 117 lid $\mathbb{1}^{216}$ Ow I jo. 1 lid 2 Ow II:

211. Vorderingen komen hier niet in beeld, omdat het bodemrecht van de fisc us daaropgeen betrekking kan hebbetn.

212. Zie voor de inhoud van de begrippen "bodem' en "stoffering" de Leidraad Irwordering 1990 ad artikel 22 Inworderingswet 1990 , par. 3 .

213. Zie de Leidraad Invondering 1990 ad artikel 22 Inworderingswet 1990, par. 5 , punt 2.

214. Als gewijzigd bij de "bezemwet" (Stbl. 1991, 199).

215. Artike1 86 lid 3 tweede zin Ow I is niet van toepassing, omdat hier de rangorde niet afhankelijk is van de ouderdom wan het pandrecht.

216. Ik zie af van bespreking van de vraag of de uitzonderingen van de leden 2-4 in casu zouden kunnen gelden. 
'Naar het nieuwe recht zal dus bijvoorbeeld moeten worden beoordeeld of het pandrecht zal kunnen worden ingeroepen tegen een schuldeiser die vóor de inwerkingtreding een beroep op het bodemrecht van verhuurder of fiscus had, waarvoor de eigendom tot zekerheid moest wijken. 217

Ten aanzien van de bodemzaken zal dus $B$ tegen de fiscus het onderspit delven op grond van de nieuwe rangorderegel van artikel 21 lid 2 Invorderingswet $1990^{218}$.

\subsubsection{Collisie tussen het wettelijke pandrecht en een retentierecht}

Voor het bepalen van de verhouding tussen een wettelijk pandrecht op een zaak en een ten aanzien van die zaak uitgeoefend retentierecht moet worden onderscheiden tussen twee mogelijkheden. Het kan zich voordoen, dat het retentierecht is ontstaan voórdat de zaak tot zekerheid werd overgedragen. Ook het omgekeerde is echter denkbaar. Opnieuw zal in het onderstaande het belang blijken van registratie van de akte die doorgaans van de zekerheidsoverdracht zal zijn opgemaakt ${ }^{219}$.

\section{a. Anterieur retentierecht}

Transporteur A liet in 1991 éen van zijn vrachtauto's repareren bij garage B. Nadat de vordering van B inzake de reparatiekosten was ontstaan, droeg A onder meer de zich nog bij B bevindende vrachtwagen over aan zijn kredietverschaffer $C$ tot zekerheid van de voldoening van zijn schulden aan deze laatste. De levering geschiedde door middel van constitutum possessorium. Betaling door $\mathrm{A}$ van de reparatiekosten bleef achterwege; B weigerde daarom afgifte van de vrachtwagen aan A. Nadat korte tijd later het nieuwe BW in werking is getreden, ontstaat onenigheid tussen $B$ en $C$ over de vraag, of $B$ ook tegenover $\mathrm{C}$ gerechtigd is, de vrachtwagen terug te houden.

Dat B onder het oude recht een retentierecht had bleek uit artikel 1652 (oud) BW. Dit retentierecht kon door $\mathrm{B}$ ook aan $\mathrm{C}$ worden tegengeworpen ${ }^{220}$. Het nieuwe $\mathrm{BW}$ heeft op deze punten geen verandering gebracht: zie respectievelijk de artikelen 3:290 juncto 6:52 en 3:291 lid 1 BW. Op grond van dit laatste artikel is voor de inroepbaarheid van het retentierecht ook tegen derden vereist, dat deze derden hun recht op de zaak hebben verkregen nadat de vordering van de schuldeiser was ontstaan èn de zaak in zijn macht was gekomen. Is aan (één van) deze vereisten niet voldaan, dan moet het pandrecht als een ouder recht worden beschouwd.

Een reèell probleem van overgangsrecht is hier niet aanwezig. Is dus het nieuwe recht toepasselijk? Dat is inderdaad het geval. Op grond van artikel 180 Ow I komt

220. Vgl. Asser-Mijnssen, nr. 97; Reehuis, diss., nr. 286; Van Mierlo, diss., p. 146; Brahn; studiepocket (zesde druk), p. 110-111. 
aan de artikelen $3: 290$ en 6:52 BW onmiddellijke werking toe ${ }^{221}$. B heeft dus vanaf de inwerkingtreding een retentierecht krachtens het nieuwe recht. Artikel 86 lid 3 Ow I is niet van toepassing, omdat de zekerheidseigendom van $C$ onder het oude recht niet tegen B's retentierecht kon worden ingeroepen. Uit artikel $68 a$ lid $1 \mathrm{OW}$ $\mathbb{F}^{222}$ volgt dat artikel 3:291 lid $1 \mathrm{BW}$ onmiddellijke werking heeft. Toepassing van deze laatste bepaling geeft hier als resultaat dat B's retentierecht kan worden ingeroepen tegen het wettelijke pandrecht van $\mathrm{C}$.

Een interessantere vraag is, of vanaf de inwerkingtreding aan $B$ de bevoegdheid ex artikel 3:292 BW toekomt om zich op de zaak te verhalen met voorrang boven allen (onder wie in casu $\mathrm{C}$ ) tegen wie het retentierecht kan worden ingeroepen. Naar mijn mening moet deze vraag gezien de hoofdregel van artikel 117 lid $1 \mathrm{OW} I$ in beginsel bevestigend worden beantwoord ${ }^{223}$. Deze hoofdregel houdt immers in dat de nieuwe bepalingen (waaronder artikel 3:292 $\mathrm{BW}$ ) omtrent de rangorde waarin vorderingen uit de opbrengst van een goed moeten worden voldaan, mede gelden voor bestaande vorderingen (waaronder dus ook de vorderingen van B en C). Op de onmiddellijke werking van de nieuwe rangorderegels bestaan wel uitzonderingen, zoals die van de in casu niet van toepassing zijnde leden 2-4 van artikel 117 Ow I.

\section{b. Posterieur retentierecht}

Thans vindt in het hierboven gegeven voorbeeld eerst de overdracht tot zekerheid van de vrachtwagen aan $C$ plaats en wordt pas daarna het voertuig ter reparatie bij B gebracht. Ook hier liggen het oude en het nieuwe recht op éen lijn. Artikel 3:291 lid $2 \mathrm{BW}$ sluit aan bij de voorheen geldende opvattingen ${ }^{224}$. Volgens deze bepaling kan de retentor zijn retentierecht ook inroepen tegen derden met een ouder recht, indien zijn vordering voortspruit uit een door de schuldenaar bevoegdelijk gesloten overeenkomst, of de retentor geen reden had om aan de bevoegdheid van de schuldenaar te twijfelen ${ }^{225}$.

Voor toepassing van het overgangsrecht moet onderscheid worden gemaakt tussen de situatie dat het retentierecht onder het oude recht wel kon worden tegengeworpen aan de zekerheidseigenaar en de situatie dat dit niet zo was. Voor het eerste geval geldt hetzelfde als hierboven onder $a$ is geschreven over de verhouding tussen een pandrecht ex artikel 86 leden 1 en 2 Ow I en een anterieur retentierecht, met dit verschil dat hier uiteraard het al genoemde lid 2 van artikel 3:29! BW toepasselijk is. Zou de schuldenaar niet bevoegd zijn geweest om opdracht te geven tot het verrichten van de reparaties en tevens de retentor wel reden hebben gehad om aan

221. Antikel 180 Ow I moet overigens na het opnemen van artikel $68 \mathrm{a}$ lid II OW I als overbodig worden beschouwd.

222. Artikel $180 \mathrm{Ow} I$ is hier mijns inziens niet van toepassing, omdat deze bepaling (onder meer) de vraag betreft of een retentierecht bestaat. Artikel 32291 lid I BW betreft echter de werking van een reeds bestaand retentierecht tegenover derden met een jonger recht.

223. Anders Reehuis, diss., nr. 528. Hij verliest uit het oog dat artikel 86 lid 3 Ow I niet van toepassing is, indien de eigendom tot zekerheid onder het oude recht niet aan de retentor kon worden tegengeworpen.

224. Aldus de formulering win de minister in Parl. Gesch. Overgangsrecht, p. 277.

225. Zie nader onder anderen Reehuis, diss., nrs. 287 (oud BW), 283 en 285 (BW); Van Mierlo, diss., p. 146148 (oud BW), 206-207 (BW). 
de bevoegdheid van de debiteur te twijfelen ${ }^{225}$, dan ligt de zaak anders. Dan kon immers onder het oude recht het retentierecht wan $B$ niet tegen de zekerheidseigendom van $C$ worden ingeroepen, met als consequentie dat artikel 86 lid 3 tweede zin Ow I wel van toepassing is. Door deze overgangsbepaling geldt het wettelijke pandrecht van $\mathrm{C}$ met betrekking tot de rangorde als gevestigd op het tijdstip, waarop de vrachtwagen in eigendom tot zekerheid is overgegaan. C's recht moet dus worden aangemerkt als een ouder recht in de zin van artikel 3:291 lid 2 BW. Dit oudere recht kan op grond van genoemde bepaling evenals voorheen worden tegengeworpen aan retentor $B$.

Rest nog de vraag, hoe het in de gegeven overgangssituatie staat met de voorrang ex artikel 3:292 BW. Indien B zijn retentierecht kan inroepen tegen $C$, dan geldt hetzelfde als hierboven onder $a$ is gezegd: in beginsel is artikel 3:292 BW toepasselijk (artikel 117 lid 1 Ow I) en kan B zijn vordering op de vrachtwagen verhalen met voorrang boven $\mathrm{C}$. Ingeval B zijn retentierecht niet kan inroepen tegen wettelijk pandhouder $C$ (artikelen 86 lid 3 tweede zin Ow I en 3:291 lid 2 BW), is zijn vordering ook niet bevoorrecht boven die van $\mathrm{C}$ : de voorrang geldt immers alleen ten opzichte van crediteuren tegen wie het retentierecht wel kan worden ingeroepen.

\subsubsection{Collisie buiten verhaalssituaties tussen het wettelijke pandrecht en rechten daterend van na de inwerkingtreding}

Tot nu toe ging het steeds over de verhouding tussen het wettelijke stille pandrecht en (woor)rechten die, evenals de eigendom tot zekerheid die in het pandrecht is getransformeerd, zijn ontstaan vór het tijdstip waarop het nieuwe BW in werking trad. Er kunnen zich echter ook collisieproblemen voordoen tussen het wettelijke pandrecht en (voor)rechten die eerst ná de inwerkingtreding ontstaan. Het zijn deze collisieproblemen die ik hierna onder ogen zal zien. $\Perp k$ begin weer met de collisies buiten verhaalssituaties. In $\mathrm{nr}$. 5.8 .4 hierna komen de collisies binnen verhaalssituaties aan de beurt.

Over de anpak van de onderhavige 'botsings' kwesties kunnen enkele algemene opmerkingen worden gemaakt. Artikel 86 lid 3 Ow I biedt hier geen uitzicht op een oplossing. Het toepassingsgebied van de daarin opgenomen regels is immers beperkt tot (voor)rechten, die zijn ontstaan vóór het in werking treden van het nieuwe $\mathrm{BW}^{227}$. Over de vraag hoe hier een uitweg kan worden gevonden merkt de minister het volgende op:

'Op rechten en vorderingen die na de inwerkingtreding ontstaan is het nieuwe recht van toepassing; hoe het pandrecht met zijn fictie van vestiging vóor de inwerkingtreding ${ }^{228}$, zich daartoe verhoudt, wordt door de regels van het nieuwe recht bepaald, zij het dan met inachtneming van het onderhavige lid

226. In ber hier aan de orde zijnde voorbeeld is deze mogelijkheid niet erg aannemelijk, zie Parl. Gesch. Boek 3 , p. 887.

227. Vgl. Parl. Gesch, Overgangsrecht, p. 90.

228. Deze fictie geldt slechts voor zower het gaat on de rangorde; zie nr. 5.6 .5 hiervór. 
3 van artikel 86 , tweede zin. Men zie hier in het algemeen de artikelen 3.10.1.3 (3:278) en 3a (3:279), en de, aan het zakenrecht ten grondslag liggende, regel dat bij botsing tussen beperkte rechten het oudere voorgaat. Het pandrecht zal echter komen achter te staan bij nieuwe vorderingen met het voorrecht van artikel 3.10 .3 .15 (3:287) en bij een nieuw retentierecht in de gevallen van artikel $3.10 .4 \mathrm{~A} .2(3.291)$ lid 2 jo $3.10 .4 \mathrm{~A} .4(3: 292){ }^{*}{ }^{229}$

Voor na de inwerkingtreding ontstane (voor)rechten geldt uit de aard der zaak het nieuwe BW. Voor zover het uitsluitend on deze (voor)rechten gaat is immers miet van een overgangssituatie sprake. Dat ook de verhouding tot het wettelijke pandrecht door het nieuwe recht wordt geregeerd ligt evenzeer voor de hand, nu ook op dat pandrecht het nieuwe recht toepasselijk is ${ }^{230}$. Verbazing wekt echter de opmerking, dat artikel 86 lid 3 tweede zin Ow I in acht moet worden genomen ${ }^{231}$. Vlak voor bovenstaand citaat is immers in de toelichting te lezen:

'Lid 3 geeft enige regels omtrent de werking van het pandrecht tegenover andere rechten en vorderingen, die ten tijde van de omzetting reeds bestonden. (...) De bovenstaande (in lid 3 opgenomen, $\mathrm{HvdB}$ ) regels geven niet een volledige oplossing voor alle vragen die hier kunnen rijzen. In het bijzonder laten zij twee vragen onbeantwoord: $a$ welke rang komt toe an het pandrecht tegenover rechten en vorderingen die $n a$ de inwerkingtreding ontstaan $(. . .)^{232}$.

Hieruit kan toch moeilijk iets anders worden afgeleid, dan dat artikel 86 lid 3 (inclusief de tweede zin) OW I niet van toepassing is als er (voor)rechten van nä de inwerkingtreding in het spel zijn. Bovendien lijkt mij de tweede zin van artikel 86 lid 3 OW I zonder betekenis voor de verhouding van het pandrecht "ex lege" tot (voor)rechten die dateren van nâ de inwerkingtreding. Indien het tijdstip van ontstaan van het pandrecht van belang is voor de verhouding tot (voor)rechten van derden, dan is toch slechts interessant of het pandrecht al dan niet eerder dan die (voor)rechten is ontstaan, niet hoeveel eerder (zie bij voorbeeld de artikelen 3:284 lid 2, 285 lid 2 en 291 lid 2 BW). In de hier aan de orde zijnde gevallen 1 s het pandrecht inderdaad anterieur: het is ontstaan op het tijdstip van de inwerkingtreding, de (voor)rechten van derden pás daarna.

In de nrs. 5.8.3.1-5 komen achtereenvolgens aan de orde collisies tussen het wettelijke pandrecht en

- eigendom;

- een uit ontbinding voortvloeiend recht;

- een uit uitoefening van het (verlengstuk van het) recht van reclame voortvloeiend recht;

- stil pandrecht en

- het pandrecht ten gevolge van zaaksvervanging. 
Anders dan ini nir. 5.8.1.1 hiervóór behoeft hier niet te worden onderscheiden tussen anterieure 'gewone' eigendom ${ }^{233}$ en posterieure 'gewone' eigendom: het door omzetting ontstane pandrecht is per definitie ouder dan na de inwerkingtreding verworven "gewone" eigendom. De collisie tussen het wettelijke pandrecht en "gewone $^{*}$ eigendom moet naar nieuw recht worden opgelost ${ }^{234}$. Afgezien van de transformatie van eigendom tot zekerheid in pandrecht is hier geen overgangssituatie aanwezig, zodat toepassing van andere overgangsregels dan artikel 86 leden 1 en 2 Ow I niet aan de orde komt ${ }^{235}$.

'Botsingen' tussen het wettelijke pandrecht en na de inwerkingtreding ontstane voorbehouden eigendom kunnen zich niet voordoen ${ }^{236}$.

5.8.3.2 Collisie tussen het wettelijke pandrecht en een uit ontbinding voortvloeiend recht

A verkocht en leverdle in 1991 handelswaar aan B. B droeg de waar over aan bank $\mathrm{C}$ tot zekerheid van de voldoening van zijn schulden aan deze bank. De levering geschiedde door middel van constitutum possessorium. $\mathrm{Na}$ de inwerkingtreding verkrijgt $\mathrm{A}$ ontbinding van de koopovereenkomst op grond van wanprestatie van B. A en C stellen beiden gerechtigd te zijn tot de handelswaar.

Hier moet tussen twee gevallen worden onderscheiden. B's wanprestatie kan reeds vóor de inwerkingtreding zijn aangevangen ${ }^{237}$. Ook is mogelijk dat de wanprestatie zich eerst na de inwerkingtreding heeft voorgedaan. Dan is volgens artikel $182 \mathrm{Ow}$ $\mathrm{I}^{238}$ het nieuwe recht toepasselijk. De ontbinding werkt in beginsel niet terug en heeft geen zakelijke werking (artikel 6:269 BW). A's persoonlijke recht tot teruglevering (artikel 6:271 $\mathrm{BW}$ ) is uiteraard zwakker dan het wettelijke pandrecht. Denkbaar is echter dat $B$ teruglevert zonder te reppen van het op grond van artikel 86 lid 1 Ow I ontstane wettelijke pandrecht van C. A kan dan bescherming tegen B's beperkte beschikkingsbevoegdheid ontlenen aan artikel 3:86 lid $2 \mathrm{BW}$.

233. Met "gewone" eigendom bedoel ik hier eigendom die geen zekerheidseigendom is en die niet is ontstanan als gevolg van ontbinding van een wederkerige oveneenkomst op grond wan wanprestatie of als gevolg wan uitoeftening van het recht van reclame.

234. Zie nit. 5.8.3 hiervóón:

235. Vgl. ten aanzien van vorderingen Parl. Gescli. Overgangsrecht, p. 94 sub g, $94-95$ sub g en 95 (eindvers lag Eerste Kamer en nota maar aanleiding van het eind werslag).

236. Woorbehouden eigendon kan uit de aard der zaak slechts collideren met posterieune (gepretendeerdie) rechten wan derden; vgl. Brahn, studiepocket, p. 150-151.

237. Zie daarover $\mathrm{mr}, 5.8,1,3$ hiervóór.

238. Zie over attikel 182 Ow I hoofdstuk 7 hierna. 
5.8.3.3 Collisie tussen het wettelijke pandrecht en een uit uitoefening van het (verlengstuk van het) recht van reclame voortvloeiend recht

Kort voor de inwerkingtreding verkocht en leverde $A$ een partij grondstoffen aan fabrikant $B$. Vervolgens trad het nieuwe BW in werking. Daarna roept $A$ het recht van reclame in wegens wanbetaling door $B$. Bank $C$ verzet zich tegen de terugvordering van de koopwaar door $\mathrm{A}$ op grond van een vóór de inwerkingtreding totstandgekomen zekerheidsoverdracht aan $C$ van al A's tegenwoordige en toekomstige goederen met levering constituto possessorio.

Op het moment dat het nieuwe BW in werking trad is de zekerheidseigendom van de partij grondstoffen omgezet in een stil pandrecht (artikel 86 leden 1 en 2 Ow I). Op de inroeping van het recht van reclame door A is krachtens artikel 196 lid 3 tweede zin Ow I het nieuwe recht toepasselijk ${ }^{239}$. Beslissend voor de toepasselijkheid van oud respectievelijk nieuw recht is volgens genoemde bepaling namelijk of de uitoefening van het recht van reclame vóór respectievelijk na de inwerkingtreding geschiedt; in casu is sprake van het laatste. Ik ga ervan uit dat A het recht van reclame heeft ingeroepen binnen de daarvoor gestelde termijnen (artikel 7:44 BW; een geval als het hier opgevoerde zal zich waarschijnlijk niet vaak voordoen). Indien aan de vereisten van artikel 7:39 lid $1 \mathrm{BW}$ is voldaan, zal $\mathrm{A}$ in beginsel weer eigenaar worden van de grondstoffen, en wel vanaf het moment dat de inroepingsverklaring haar werking heeft. Daarvoor is dan wel noodzakelijk dat $\mathrm{C}$ geen bescherming kan ontlenen aan artikel 7:42 BW. Deze voorwaarde is in casu vervuld: omdlat de grondstoffen in handen van koper B zijn gebleven, blijft A's terugvorderingsbevoegdheid in stand. Slechts in de situatie dat $C$ vór de inroeping van het recht van reclame afgifte van de grondstoffen door B zou hebben bewerkstelligd, zou de mogelijkheid bestaan dat $\mathrm{C}$ op grond van genoemde bepaling wordt beschermd.

Naar nieuw BW heeft de onbetaalde verkoper niet meer de beschikking over het verlengstuk van het recht van reclame: Dit brengt met zich mee dat een eventueel pandrecht op de vordering tot betaling van doorverkooppenningen aan de oorspronkelijke verkoper kan worden tegengeworpen in het geval dat hij zou proberen zich op deze vordering te verhalen ${ }^{240}$.

\subsubsection{Collisie tussen het wettelijke pandrecht en een still pandrecht}

Indien na de inwerkingtreding een goed waarop een pandrecht ex artikel 86 leden 1 en 2 Ow I rust aan een derde wordt verpand, moet de verhouding tussen het wettelijke pandrecht en het later gevestigde pandrecht aan de hand van het nieuwe recht worden bepaald. Overgangsrecht komt hierbij niet te pas ${ }^{24 !}$. 
5.8.3.5 Collisie tussen het wettelijke pandrecht en een pandrecht ten gevolge van zaaksvervanging

A cedeerde vóór de inwerkingtreding van het nieuwe BW al zijn tegenwoordige en toekomstige worderingen alan bank $B$ tot zekerheid van de woldoening van zijn schulden aan deze bank. Deze cessie werd niet medegedeeld aan $A$ 's debiteuren. Voorts vestigde A op zijn bedrijfspand, tegen onder andere brandschade werzekerd bij verzekeringsmaatschappij $D$, een hypotheekrecht ten behoeve van hypotheekbank $\mathrm{C}$. Enige tijd na de invoering van het nieuwe $B W$ gaat $A^{\prime s}$ bedrijfspand in vlammen op. Tussen $B$ en $C$, die beiden vergeefs wachten op betaling van hun vorderingen door $A$, ontstaat onenigheid over de vraag, wie van hen (het eerst) recht op de verzekeringspenningen kan doen gelden. Deze zijn niet toereikend om zowel de vorderingen van $B$ als die van $C$ te voldoen.

Onzeker is hoe onder het oude recht de verhouding was tussen zekerheidseigendom van de vordering op de verzekeraar en het recht van de hypotheekhouder op deze vordering ex artikel 297 (oud) WvK ${ }^{242}$. Naar nieuw BW (artikel 3:229 lid 2) geldt dat het pandrecht ten gevolge van zaaksvervanging uit hoofde van lid 1 van genoemcle bepaling gaat boven ieder op de vordering gevestigd ander pandrecht (de bank heeft naar nieuw $\mathrm{BW}$ immers geen eigendom tot zekerheid, maar een pandrecht).

In de geschetste situatie zal artikel 297 (oud) WvK niet kunnen worden toegepast. De schade ontstaat op een moment dat uit artikel 297 (oud) WvK geen recht meer kan ontstaan, omdat het is ingetrokken. Ten tijde van de inwerkingtreding bestond er nog geen recht op grond van artikel 297 (oud) WvK, zodat artikel 69 sub a en e OW I ('eerbiediging van verkregen rechten') cok niet voor toepassing in aanmerking komt. Inmiddels is echter de zaaksvervangingsregel van artikel 3:229 BW ingevoerd, die hier uiteraard wel kan worden toegepast. Hoe verhoudt zich nu het krachtens deze zaaksvervangingsregel ontstane pandrecht van $C$ tot het pandrecht ${ }^{243}$ van $B$ ? De pandrechten van $B$ en $C$ zijn na de inwerkingtreding ontstaan en worden dus door het nieuwe recht beheerst. Voor de verhouding tussen beide kan artikel 3:229 lid $2 \mathrm{BW}$ toepassing vinden: het pandrecht van $\mathrm{C}$ gaat boven dat van B. Een overgangssituatie is hier niet aanwezig ${ }^{244}$.

In de toelichtende stukken wordt opgemerkt dat dit laatste anders is, indien men de rechten van A's crediteuren tegenover de assuradeur niet ziet als toekomstige rechten, zolang de schade nog niet is ontstaan, maar als bestaande doch voorwaardelijke rechten. Dan leidt de hoofdregel van artikel $117 \mathrm{OW}$ I tot onmiddellijke werking van de rangordebepaling van artikel 3:229 lid 2 BW 245 .

242. Ik ga erwan uit dat $\mathrm{C}$ het gebruikelijke assurantiebeding in de hypotheekakte heeft opgenomen.

243. Hier geldi artikel 86 lid 7 Ow I (waurover mr. 5.9.2 hiema).

244. Vgl. Parl. Gesch. Overgangsrecht, p. $271-272$.

245. Vgl. parl. Gesch. Overgangsrecht, p. 272. 


\subsubsection{Collisie binnen verhaalssituaties tussen het wettelijke pandrecht en}

(woor)rechten daterend van na de inwerkingtreding

Ook binnen verhaalssituaties kan het voorkomen daf de gerechtigde tot een wettelijk pandrecht iemand op zijn weg treft die zich beroept op een (voor)recht dat na de inwerkingtreding is ontstaan. Voor algemene opmerkungen over de aanpak van deze collisieproblemen verwijs ik naar nr. 5.8.3 hiervóor. In de nrs. 5.8.4.1-3 hierna behandel ik achtereenvolgens de collisie tussen het wettelijke pandrecht enerzijds en privileges, retentierecht en besiag anderzijds.

\subsubsection{Collisie tussen het wettelijke pandrecht en privileges}

Over de sterkte van het pandrecht ex artikel 86 Ow I ten opzichte van privileges die dateren van na de inwerkingtreding behoeven geen uitvoerige beschouwingen te worden gegeven. Ook het maken van een onderscheid tussen de diverse privileges is overbodig. Steeds geldt immers dat de verhouding van het wettelijke pandrecht tot privileges die zijn ontstaan na de inwerkingtreding moet worden bepaall aan de hand van het nieuwe recht ${ }^{246}$. Voor het bereiken van dit resultaat behoeven geen overgangsregels te worden toegepast.

\subsubsection{Collisie tussen het wettelijke pandrecht en retentierecht}

Ontstaat na de inwerkingtreding een retentierecht op een zaak waarop het wettelijke pandrecht rust, dan moet het nieuwe recht worden toegepast ter beantwoording van de vraag, welk recht sterker is. Evenals bij de privileges van na de inwerkingtreding is hier geen overgangskwestie aanwezig: het wettelijke pandrecht valt nagenoeg gehee ${ }^{247}$ onder het nieuwe recht, het van na de inwerkingtreding daterende retentierecht geheel en dit laatste geldt ook voor de verhouding tussen pandrecht en retentierecht ${ }^{248}$.

\subsubsection{Collisie tussen het wettelijke pandrecht en beslag}

Hier geldt hetzelfde als zojuist is opgemerkt over de verhouding tussen het pandrecht ex artikel 86 Ow I enerzijds en privileges en retentierecht anderzijds ${ }^{249}$.

246. Zie Parl. Gesch. Overgangsrech, p. 90, gecteerd in inr 5.8 .3 hierwót:

247. Een uitzondering is opgenomen in artikel 86 lid $6 \mathrm{OW} \mathrm{I}$.

248. Zie Parl. Gesch. Overgangstecht, p. 93 sub h $95 \mathrm{stibh}$.

249. Collisie tussen het wettelijke pandrecht en een vốr de inwerkingtreding doot een derde gelegd beslag op de tot zekerheid owergedragen zaken is niet denkbaar, mu deze zaken niet tot het vermogen wan de zeker heidsgever behoorden. 


\section{8 .5 Gehandhaafde zekerheidseigendom en collisieproblemen}

Hierboven is uifsluitend gesproken over de relatie tussen het pandrecht, ontstaan door omzetting krachtens artikel 86 lid 1 Ow $I_{y}$ en (voor)rechten van derden. Nog niet aangekart zijn evenwel die situaties, waarin de omzetting van zekerheidseigendom (vooralsnog) is tegengehouden door lid 5 van artikel $860 \mathrm{~W}$ I. Hoe moeten collisies tussen de (voorlopig) ongemoeid gelaten zekerheidseigendom en (voor) rechten van derden worden opgelost? Hier moeten twee onderscheidingen worden gemaakt. De eerste is die tussen de twee gevallen, warop artikel 86 lid 5 Ow I ziet, namelijk

a) aanzegging vór de inwerkingtreding door de crediteur aan de debiteur van uitwinning van het tot zekerheid overgedragen goed en

b) het in staat van faillissement verkeren van de debiteur op het moment van de inwerkingtreding.

De tweede onderscheiding is die tussen collisie van de zekerheidseigendom met (voor)rechten

1) vain vór de inwerkingtreding en

2) van na de inwerkingtreding.

Een antwoord op de gestelde vraag kan niet worden gevonden in het hiervór herhaaldelijk ter sprake gebrachte lid 3 van artikel 86 OW I. Deze bepaling geldt immers, indien de zekerheidseigendom juist wel in pandrecht is omgezet.

Collisie van door een aanzegging van uitwinning gehandhaafde zekerheidseigendom met reeds bestaande (voor)rechten (categorie al) kàn door het oude recht beheerst blijven, bij voorbeeld in geval van uitoefening van het recht van reclame vóor de inwerkingtreding (artikel 196 lid $3 \mathrm{Ow}$ I). Dit is het meest in overeenstem-

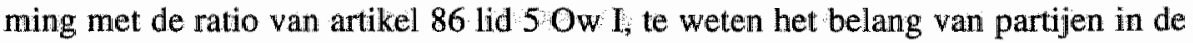
aldaar genoemde situaties bij afwikkeling van de gevolgen van de zekerheidseigendom volgens het oude recht ${ }^{250}$.

Toch kan op reeds bestaande (voor)rechten en op de collisie daarvan met gehandhaafde zekerheidseigendom wel degelijk het nieuwe recht toepasselijk worden. Dit geldt bij voorbeeld voor de nieuwe rangorderegels (artikel 117 lid 10 w $\mathbb{D}$ ), zij het met enkele uitzonderingen (artikelen 117 leden 2-4, 118 en 119 Ow I). Eén van die uitzonderingen is de volgende. Het oude recht wordt geëerbiedigd ten aanzien van de rangorde bij de verdeling van de opbrengst van een goed, dat op het tijdstip van de inwerkingtreding reeds ten behoeve van verhaal is verkocht. Hetzelfde geldt voor de verdeling van wat op een vordering op dat tijdstip teeds is geind (artikel 117 lid 2 Ow I). Als echter de hoofdregel van artikel 117 lid 1 Ow I geldt (onmiddellijke werking), rijst de vraag of bepalingen als de leden 2 van de artikelen $3: 284$ en $285 \mathrm{BW}$ (waarin van overeenkomstig artikel 3:237 BW gevestigde pandrechten wordt gesproken) analoog op eigendom tot zekerheid moeten worden toegepast. De onmiddellijke werking van genoemde bepalingen (zonder uitzondering voor het onderhavige geval) lijkt dit inderdaad met zich mee te brengen. Indien dit juist is, dan zou dus bij in stand gelaten eigendom tot zekerheid toch het nieuwe recht inzake de 
rangorde van vorderingen toepasselijk zijn. Dit wordt hierdoor veroorzaakt, dat de uitzonderingen op de respectievelijke hoofdregels van de artikelen 86 en 117 OW I niet dezelfde zijn.

Ik acht genoemd resultaat in strijd met de ratio van de uitzonderingen op de hoofdregel van de omzetting, die zijn neergelegd in artikel 86 lid 5 Ow I. Deze ratio is dat bij een op handen zijnde dan wel reeds lopende afwikkeling van de eigendom tot zekerheid het belang van partijen bij "conservering"251 van het oude recht zwaarder weegt dan het belang van het over de gehele linie toepassen van nieuw recht $\mathrm{t}^{252}$. Ik zou hier analoge toepassing van artikel $75 \mathrm{Ow}$ II willen bepleiten: tegen de achtergrond van artikel 86 lid 5 OW I noopt de gelijkenis met de in artikel $117 \mathrm{Ow}$ I geregelde uitzonderingen op de onmiddellijke werking ook hier tot zo'n uitzondering; het oude recht kan dan blijven werken 253 .

De tweede categorie (a2) is die van collisies van door een aanzegging van uitwinning gehandhaafde zekerheidseigendom met (voor)rechten die pas na de inwerkingtreding ontstaan. De zekerheidseigenaar die de uitwinning heeft aangezegd zal er doorgaans wel voor zorgen dat hij de tot zekerheid dienende goederen bij het uitblijven van betaling in zijn macht krijgt, om vervolgens tot executie over te gaan. Alsdan is de kans dat er nog (voor)rechten van derden ontstaan op de zekerheidsgoederen niet groot. Het is echter denkbaar dat de aanzegging (vooralsnog) niet wordt gevolgd door uitwinning en een daaraan voorafgaande opeising van de goederen. De schuldenaar kan bij voorbeeld tijdig het verzuim hebben gezuiverd, of de schuldeiser kan van gedachten zijn veranderd ${ }^{254}$. Dan heeft de zekerheidsgever zes maanden de tijd om de zekerheidsgoederen onbevoegdelijk te vervreemden, te bezwaren etc.. Stel dat hij handelsvoorraden stil verpandt aan een derde en dat de zekerheidseigenaar vóór 1 juli 1992 (dus vóór afloop van de zes maanden-termijn van artikel 86 lid 5 OW I) alsnog wil executeren. Moet dan aan de hand van het oude of aan de hand van het nieuwe recht worden uitgemaakt, welk zekerheidsrecht voorgaat?

Een specifieke overgangsregel ontbreekt. Voor de zekerheidseigendom sec geldt het oude recht. Op het (ná de inwerkingtreding gevestigde) stille pandrecht sec is uiteraard het nieuwe recht toepasselijk. Ditzelfde laten gelden woor de collisie tussen de zekerheidseigendom en het stille pandrecht lijkt, gelet op de ratio van artikel 86 lid 5 Ow I, niet goed verdedigbaar. De toelichting zegt over deze ratio immers het volgende. Bij aanzegging van uitwinning vór de inwerkingtreding

'is het beter de gevolgen van de eigendom tot zekerheid af te wikkelen en verdient het de voorkeur partijen niet met het opleggen van een andere regeling dan de overeengekomene lastig te vallen. ${ }^{255}$

Aan de andere kant is het moeilijk denkbaar dat het hier aan de orde zijnde geval

251. In gevallen als deze kan zich volgens De Die, AA 1991 , p. 826-827, 829, het "beginsel van de consertverende werking' doen gelden,

252. Zie de nrs 5.6 .3 en 5.6 .3 .9 hierwór.

253. Zie over artikel 75 Ow I nr. 2.5.3 hiervóór.

254. Vgl. Parl. Gesch. Overgangsrecht, p. 91.

255. Part. Gesch. Overgangsrecht, p. 91. 
moet worden opgelost met behulp van artikel 1198 id 5 (oud) BW in plaats van met artikel 3:238 BW, omdat het oude BW stil pandrecht nu eenmaal verbood. Daar komt nog bij dat de collisie ná de inwerkingtreding plaatsvindt. Al met al vind ik toepassing wan het nieuwe artikel de meest voor de hand liggende optie.

lets soortgelijks geldt voor collisie van voortbestaande eigendom tot zekerheid met andere rechten dan stil pandrecht. Het toepassen van het oude recht op collisie van zekerheidseigendom met rechtsfiguren als beslag en privileges, die zelf door het nieuwe recht worden beheerst, likkt mij niet geindiceerd. Het will mij voorkomen dat een bepaling als die van artikel 3:285 lid $2 \mathrm{BW}$ betreffende de verhouding tussen het voorrecht wegens bearbeiding van een zaak en stil pandrecht analoog kan worden toegepast op de verhouding tussen dit privilege en eigendom tot zekerheid:

Er kan tijdens de zes maanden-termijn waarin de eigendom tot zekerheid blijf bestaan beslag op de zekerheidsgoederen worden gelegd. Zou wel omzetting van de zekerheidseigendom hebben plaatsgevonden, dan zouden nieuwe executiebepalingen als de artikelen $461 a$ en 496 lid 3 Rv rechtstreeks toepassing hebben kunnen winden. Het lijkt mij echter de vraag of, ingeval de omzetting is tegengehouden op grond van artikel 86 lid 5 Ow 1 , de nieuwe executieregels voor analoge toepassing op zekerheidseigendom in aammerking komen.

Ik kom toe aan de tweede grond voor het opschorten van de omzetting van zekerheidseigendom, te weten het in staat van faillissement verkeren van de schuldenaar ten tijde van de inwerkingtreding. De collisie van de eigendom tot zekerheid met (voor)rechten van vóór de inwerkingtreding (categorie b1) kan betrekkelijk kort worden afgedaan. Het over categorie al opgemerkte geldt ook hier. Een werschil is alleen, dat woor faillissement in plaats van lid 2 van artikel $117 \mathrm{Ow}$ I lid 4 wan belang is: Ook deze overgangsregel is niet gelijk aan die van artikel 86 lid $50 \mathrm{~W}$ 1. Hij komt hierop neer, dat het oude recht word geêerbiedigd ter zake van de rang van vorderingen op een failliete debiteur, indien het nieuwe $\mathrm{BW}$ in werking treedt nadat de rechter-commissaris overeenkomstig artikel 108 Fw de dag heeft bepaald, waarop die worderingen uiterlijk ter verificatie moeten zijn ingediend.

Collisie van de zekerheidseigendom met (voor)rechten van ná de inwerkingtreding (categorie b2) is bij faillissement slechts in beperkte mate mogelijk. Zekerheidseigenaren zullen een failliete debiteur wel niet in de gelegenheid stellen om handelingen te verrichten ten aanzien van de tot zekerheid overgedragen goederen, die tot gevolg kunnen hebben dat derden bij voorbeeld privileges op deze goederen kunnen doen gelden. Een belemmerende factor is bovendien de bekendmaking van de faillietverklaring (zie artikel 35 lid 3 Fw) ${ }^{256}$. Een situatie die onder categorie b2 valt is de volgende:

Kort voor de inwerkingtreding heeft A een partij grondstoffen aan fabrikant $B$ verkocht en gelleverd, die vrijwel direct daarna falleerde. Vervolgens trad het nieuwe $\mathrm{BW}$ in werking. Daama riep $\mathrm{A}$ het recht van reclame in wegens wanbetaling door $B$. Hiertegen verzette zich bank $C$, die pretendeerde rechthebbende te zijn op grond van een vö́r de inwerkingtreding totstandgeko- 
men zekerheidsoverdracht van al B's tegenwoordige en toekomstige goederen, met levering constituto possessorio.

Als gevolg van B"s failleren vóor de inwerkingtreding is de eigendom tot zekerheid van $\mathrm{C}$ in stand gebleven (artikel 86 lid $5 \mathrm{Ow}$ I). Voor het overige geldt mutatis mutandis het in $\mathrm{nr}$. 5.8.3.3 hiervóór opgemerkte.

Voor de collisie tussen eigendom tot zekerheid en het (na de inwerkingtreding ontstane) pandrecht ex artikel 3:229 BW geldt het in nr. 5.8.3.5 geschrevene. Op de als gevolg van het faillissement van de schuldenaar voortbestaande eigendom tot zekerheid zal artikel 3:229 lid 2 BW analoog kunnen worden toegepast. Denkbaar is voorts nog dat na de inwerkingtreding een privilege ter zake van kosten tot behoud ontstaat. Ook hier zal waarschijnlijk analoge toepassing van het desbetreffende nieuwe artikel ( $3: 284$ lid $2 \mathrm{BW}$ ) mogelijk zijn om de verhouding van het privilege tot nog aanwezige zekerheidseigendom te bepalen.

\subsection{BLOKKERING VAN HET ONTSTAAN VAN ZEKERHEIDSEIGENDOM NA DE INWERKINGTREDING}

Indien de overgangsregeling voor eigendom tot zekerheid alleen rekening zou houden met zodanige eigendom die bestond op het moment van de inwerkingtreding, zou zij een belangrijke lacune vertonen. Zekerheidsoverdracht vond nu eenmaal vaak plaats in het kader van langlopende kredietwerhoudingen op grond waarvan telkens opnieuw zaken of vorderingen in eigendom tot zekerheid moesten worden. overgedragen. Het kon daarbij gaan om verbintenissen tot zekerheidsoverdracht van goederen en om leveringen bij voorbaat tot zekerheidsoverdracht van goederen. $\mathrm{Na}$ de inwerkingtreding zouden zulke verbintenissen en leveringen bij voorbaat zonder overgangsrechtelijke voorziening zinloos worden. De verbintenissen tot zekerheidsoverdracht zouden verplichten tot een door de wet (artikel 3:84 lid $3 \mathrm{BW}$ ) verboden en derhalve nietige prestatie ${ }^{257}$. Ook de leveringen bij voorbaat zouden niet meer tot het beoogde resultaat kunnen leiden, indien de vervreemder pas na de inwerkingtreding de voor de overdracht vereiste beschikkingsbevoegdheid over de goederen in kwestie zou verwerven. De overdracht zou dan niet tot stand kunnen komen, omdat zekerheid op grond van genoemde wetsbepaling niet langer geoorlloofd is als titel voor overdracht ${ }^{258}$.

In de Overgangswet is echter wel met beide mogelijkheden rekening gehouden. Zij zijn geregeld in lid 7 van artikel $86 \mathrm{OW} \mathrm{I}$, waarover meer in de nrs. 5.9.1-3 hierna. Daarnaast is voor de categorie verbintenissen tot zekerheidsoverdracht een verplichting opgenomen tot het aanpassen van de overeenkomst aan de nieuwe pandbepalingen, indien eén der partijen dat wenst. Deze verplichting behandel ik in nr. 5.9.4 hierna. Ik merk nog op dat hier anders dan bij ten tijde van de inwerkingtreding reeds aanwezige zekerheidseigendom wèl sprake is van overgangssituaties in 
de betekenils die de overgangswetgever aan dit begrip toekent ${ }^{259}$. Er was hier immers bij de inwerkingtreding voldaan aan de vereisten die artikel $3: 84$ lid $3 \mathrm{BW}$ stelt: de overgangssituatie was niet reeds 'achter de rug'.

\subsubsection{Verbintenissen tot zekerheidsoverdracht}

Voor bestaande verbintenissen tot overdracht tot zekerheid wordt in artikel 86 lid 7 eerste zin $\mathrm{O}$ w de volgende overgangsvoorziening getroffen:

"Van het in werking treden van de wet af wordt een alsdan bestaande verbintenis strekkende tot overdracht van een voor verpanding vatbaar goed ${ }^{260}$ tot zekerheid, aangemerkt als een verbintenis tot vestiging van een pandrecht.'

Deze bepaling betreft ten tijde van de inwerkingtreding bestaande verbintenissen tot zekerheidsoverdracht, waaraan op dat moment nog geen uitvoering was gegeven $^{261}$. Ondat zulke verbintenissen vanaf de inwerkingtreding niet langer zin hebben $^{262}$, worden $z i j$ voor het vervolg bestempeld als verbintenissen tot vestiging van een pandrecht. Aangenomen moet worden dat de verbintenis moet worden be schouwd als strekkende tot vestiging van een pandrecht, dat naar zijn aard het meest overeenstemt met de zekerheidseigendom zoals die partijen voor ogen stond (meestal zal dit een stil pandrecht zijn) ${ }^{263}$.

Indien de schuldenaar na de inwerkingtreding goederen verwerft en aan de "nieuwe" verbintenis uitvoering wordt gegeven, zullen alle voor vestiging van pandrecht geldende vereisten, die het nieuwe BW stelt, in acht moeten worden genomen. Wordt een stil pandrecht gevestigd, dan moet derhalve (onder meer) het vereiste worden in acht genomen van een authentieke of geregistreerde onderhandse akte, waarin een (on)bezwaardheidsverklaring is opgenomen (leden 1 respectievelijk 2 van de artikelen 3:237 en 239 BW) ${ }^{264}$. Zoals ook uit de geciteerde wetstekst al blijkt, is er hier anders dan in lid 1 van artikel 86 Ow I derhalve geen sprake wan een pandrecht, dat ontstaat uit kracht van de wet.

De onderhavige overgangsregel is waarschijnlijk in het bijzonder van belang voor tot zekerheid dienende vorderingen. Cessie van toekomstige vorderingen was immers aan de beperking onderworpen, dat deze hun onmiddellijke grondslag

\section{Zue de tris, 2,4.1.1 e. hierw6ón}

260.2 ire omtrent dit element ne. 5.6 .2 biervoor.

261. Indien dat wel zo was en er dardoor ten tijde van de inwerkingtreding zekenheidseigendom aan wezig Was; kan artikel 86 lid I OW I in beginsel toepassing vimelen.

262. Zie ne. 59 hiervóñ.

263. Vgl. Reahuts, diss., nr. 538. Voor het pandrecht ex artikel 86 lid 1 Ow I wordt dit uitdrukkelijk bepaald in antikel 86 lid 2 Ow I.

264. Anders P.A. Stein, WPNR 6007 (1991), p. 358, die geen onderscheid lijkt te maken tussen een wertbintenis tot vestiging van een pandrecht (artikel $\$ 6$ lid 7 eerste zin Ow I) en een lewerirg bij woorbaat tot vestiging wan een pandrecht (iden, tweede zin). 
moesten hebben in een ten tijde van de cessie reeds bestaande rechtsverhouding ${ }^{265}$. In de praktijk werd daarom ten aanzien van die toekomstige vorderingen, die niet aan het zojuist genoemde vereiste voldeden, gekozen voor de weg van een obligatoire verplichting tot periodieke cessie ${ }^{266}$. Ontstaan de vorderingen na de invoering van het nieuwe $\mathrm{BW}$, of wordt na de invoering voldaan aan de eis van artikel 3:239 lid 1 slot $\mathrm{BW}$, dan zullen de vestigingsvereisten van het nieuwe $\mathrm{BW}$ moeten worden vervuld. Met name zal de eis in acht moeten worden genomen, dat de gebruikelijke periodieke opgave door de pandgever geschiedt in een authentieke of geregistreerde onderhandse akte ${ }^{267}$.

Een vraag van theoretische aard die ik niet onaangeroerd wil laten, is of artikel 86 lid 7 eerste zin OW I nu een voorbeeld te zien geeft van fictie of van omzetting ${ }^{268}$. Wie afgaat op de wetstekst zal voor de fictie kiezen, omdat daarin valt te lezen dat de verbintenis tot zekerheidsoverdracht wordt aangemerkt als een verbintenis tot vestiging van een pandrecht ${ }^{269}$. Echter, de toelichting merkt de onderhavige figuur aan als omzetting ${ }^{270}$. Het lijkt mij toe dat deze opvatting niet in overeenstemming is met de zoëven aangehaalde bewoordingen van de wet. Omzetting zou aanwezig zijn geweest, indien (analoog aan artikel 86 lid 1 Ow I) uit kracht van de wet de bestaande verbintenis tot zekerheidsoverdracht zou tenietgaan en daarvoor in de plaats een verbintenis tot vestiging van een pandrecht zou komen. Voor het resultaat maakt het echter niet uit voor welke opvatting wordt gekozen. Beide leiden ertoe, dat de zekerheidsgever na de inwerkingtreding gehouden is tot vestiging van een pandrecht.

Collisieproblemen behoeven hier niet te worden behandeld. Voor zover daaraan overgangsaspecten kleven, betreffen deze namelijk niet het - na de inwerkingtreding ontstane - pandrecht ${ }^{271}$.

\subsubsection{Levering bij voorbaat tot zekerheidsoverdracht}

De tweede in artikel 86 lid 7 Ow I geregelde groep gevallen wordt gevormd door de leveringen bij voorbaat tot zekerheidsoverdracht, die op het moment van de inwerkingtreding nog niet tot daadwerkelijke overdracht hadden geleid ${ }^{272}$. Artikel 86 lid 7 tweede zin Ow I zegt er dit over:

265. Zie HR 24 oktober 1980, NJ 1981, 265 (Solleveld, Romijn \& Co. B.V. II). Overigens geldt voor stille werpanding wan toekomstige worderingen onder het nieuwe BW een soortgelijke beperking (artikel $3: 239$ lid 1 slot); zie daaromtrent Reehuis, diss., nrs. 478-480.

266. Aldus Asser-Mijnssen, nr. 189: Van Mierlo, diss., p. 98 en de door deze latatste geciteerde schrijvers.

267. Zie Parl Gesch. Overgangsrecht, p. 93 sub e, 94 sub e.

268. Beide zijn overbruggingsregels. Zie daarover nr. 2.5 .2 hiervóor.

269. Vgl. Wessells, Kort bestek, p. 42.

270. Parl. Gesch. Overgangsrecht, p. 91. Zo ook Reehuis, diss.; nr. 538.

271. Zie over de onderlinge verhouding van obligatoire verplichtingen tot vestiging van pandrecht op vorderingen Reehuis, diss., wr. 498.

272. Was dat wel zo en was daardoor ten tijde van de inwerkingtreding eigendom tot zekerheid aanwezig. dan kan artikel 86 lid 10 W I in beginsel worden toegepast. 
Levering bij voorbaat tot de overdracht van een zodanig goed (een voor verpanding vatbaar goed, $\mathrm{HudB}^{273}$ ) tot zekerheid, die vóór dat tijdstip (dat van inwerkingtreding, $\mathrm{HvdB}$ ) is geschied, geldt nadien als levering bij voorbaat tot vestiging wan pandrecht daarop."

Deze zin is bij nota van wijziging ingevoegd naar aanleiding van een vraag van de vaste Commissie voor Justitie van de Tweede Kamer ${ }^{274}$. Bestaande leveringen bij voorbaat tot overdracht tot zekerheid konden niet ongeregeld blijven in de Overgangswet, omdat deze na de inwerkingtreding niet meer het door partijen gewenste effect zouden kunnen sorteren alls gevolg van het reeds genoemde verbod van zekerheid als titel van overdracht (artikel 3:84 lid $3 \mathrm{BW}$ ). Aangenomen moet worden dat de levering bij voorbaat moet worden beschouwd als strekkende tot vestiging van een pandrecht dat naar zijn aard het meest overeenstemt met de zekerheidseigendon zoals die partijen voor ogen stond (meestal zal dit een stil pandrecht zijn $^{275}$.

De levering bij voorbaat tot zekerheidsoverdracht zal doorgaans zijn geschied door middel van een geanticipeerd constitutum possessorium ${ }^{276}$. De levering bij voorbat brengt met zich mee dat als eenmaal aan alle overdrachts- of vestigingsvereisten (waaronder (op het moment van de verkrijging) beschikkingsbevoegdheid van degene clie vervreemdt of bezwaart) is voldaan, niet alsnog een leveringshandeling vereist zal zijn, omdat die reeds eerder is verricht. Voor de levering bij voorbaat, die krachtens artikel 86 lid 7 tweede zin OW I geldt als één die strekt tot vestiging van een pandrecht, betekent dit het volgende. Omdat de levering reeds (vóor de inwerkingtreding) bij voorbat is geschied, behoeft na de inwerkingtreding niet opnieuw een levering - ditmaal conform de vereisten voor vestiging van stil pandrecht - te worden verricht. Dit moet worden afgeleid uit de wet, waar gesproken wordt van het nadien gelden van de levering bij voorbaat tot zekerheidsoverdracht als levering bij voorbaat tot vestiging van pandrecht (artikel 86 lid 7 tweede zin Ow 1). Wel dient de pandgever beschikkingsbevoegd te zijn op het moment van de verkrijging van het goed 277 .

Ook voor levering bij voorbaat tot zekerheidsoverdracht van toekomstige vorderingen op naam is de hier aan de orde zijnde overgangsbepaling uiteraard van belang ${ }^{278}$. Indien de vordering na de inwerkingtreding ontstaat, behoeft namelijk niet alsnog de door artikel 3:239 lid 1 BW geëiste authentieke of geregistreerde onderhandse akte te worden opgemaakt. Iets anders is dat de crediteur er verstandig aan doet, alsnog zo'n akte te laten opmaken, indien dit niet reeds is geschied ${ }^{279}$.

273. Zie dakrover nr. 5.6 .2 hiervớr:

274. Zie Parl Gesch. Overgangsrecht, p. 92.

275. Voor thet pandrecht ex artikel 86 lid 1 Ow I word dit uttdrikkelijk bepald in artikel 86 lid 20 w I.

276. Kortheidshalve ga ik hiema uitsluitend van deze rogelijkheid wit.

277. Vgl artikel 35 lid 2 Fw; FR 15 maart 1991 , RvdW 1991, 79 (Veenendaal q. q.-Hogeslag).

278. Dit belang is echter kleiner dan biy roerende zaken, met registergoederen; omdat de mogelijkheid on toekonstige vorderingen (tot zekerheid) te cederen beperkter was dan die om toekomstige roerende zaken, niet-registergoederen bij voorbaat te leveren. Vgl. HR 24 oktober 1980, NJ 1981, 265 (Solleveld, Romijin en Co: B. V. II) en onder anderen Reehuis, diss, nr, 491.

279. Zie ower het belang daarvan nr. 5.7 hiervór. 
Tussen de levering bij voorbaat tot zekerheidsoverdracht en de verbintenis tot zekerheidsoverdracht bestond een belangrijk verschil. Zo"n verbintenis moest eerst zijn nagekomen, wilde er zekerheidseigendom kunnen ontstaan. Dit was in de hier aan de orde zijnde gevallen ten tijde van de inwerkingtreding nog niet geschied (anders is artikel 86 lid 7 OW I niet van toepassing). Daarom zal nadien moeten worden voldaan aan de nieuwe vereisten voor de vestigingshandeling. Bij de levering bij voorbaat heeft de vestigingshandeling reeds vóor de invoering plaatsgehad en behoeft nadien niet de vestigingshandeling voor een stil pandrecht te worden verricht. Een overeenkomst tussen de levering bij woorbaat tot vestiging van een pandrecht en de verbintenis tot vestiging van een pandrecht is weer, dat in beide gevallen het pandrecht eerst ná de invoering ontstaat. Een overeenkomst is ook dat in beide gevallen geen sprake is van een pandrecht dat de wet als ontstaansbron heeft280. Dit is wel zo bij het pandrecht ex artikel 86 lid $10 \mathrm{~W} \mathrm{I}$.

Evenals bij de verbintenis tot zekerheidsoverdracht wil ik hier de theoretische vraag stellen, welke soort overbruggingsregel in de hier aan de orde zijnde overgangsbepaling is opgenomen: én die een fictie inhoudt of één die een omzetting inhoudt ${ }^{281}$. Ook hier wijst de wettelijke terminologie ('geldt nadien als") in de richting van een fictie ${ }^{282}$. Ook hier acht de minister evenwel een omzetting anwezig ${ }^{283}$. Op de in $\mathrm{nr}$. 5.9.1 aangegeven grond meen ik dat in dit geval een fictie is gebruikt. Voor het resultaat maakt dit echter, evenals in nr. 5:9.1, niet uit beide opvattingen leiden ertoe, dat er (na de inwerkingtreding) een levering bij voorbaat tot vestiging van een pandrecht bestaat.

\subsubsection{Dubbele leveringen bij voorbaat}

Collisies van het eenmaal ontstane pandrecht met rechten etc. van derden behoeven hier niet te worden behandeld, omdat eventuele overgangsaspecten daarvan niet het - na de inwerkingtreding ontstane - pandrecht betreffen. Well is aandacht gerechtvaardigd voor dubbele leveringen bij voorbaat. Artikel 3:97 lid 2 BW bepaalt daarontrent dat een levering bij voorbaat van een toekomstig goed niet werkt tegen iemand die het goed ingevolge een eerdere levering bij voorbaat heeft verkregen. Betreft het een roerende zaak, dan werkt de levering jegens deze vanaf het tijdstip dat de zaak in handen van de verkrijger is gekomen. Op grond van artikel 3:98 BW is een en ander van overeenkomstige toepassing op de vestiging van een beperkt recht.

Stel nu dat zich het volgende voordoet.

1. A droeg in 1991 zijn toekomstige kantoorinventaris eerst bij voorbaat over aan $B$ tot zekerheid van de voldoening van schulden en daarna aan $C$ ten titel van koop. De levering geschiedde telkens door middel van geanticipeerd 
constitutum possessorium. Op een gegeven moment verloren de zaken hun toekomstigheid en verkreeg $A$ beschikkingsbevoegdheid daarover. Daarna trad het nieuwe BW in werking. B en C krijgen onenigheid over de vraag. wiens recht voorgaat.

Aan te nemen walt dat artikel 3:97 lid $2 \mathrm{BW}$ het voorheen reeds geldende recht weergeeft ${ }^{284}$. Derhalve werkte ook al wór de inwerkingtreding de levering bij voorbaat aan $C$ niet tegen $\mathrm{B}^{285}$. De op het moment van de invoering van het nieuwe $\mathrm{BW}$ bestaande eigendom tot zekerheid van B is omgezet in stil pandrecht (artikel 86 leden 1 en 20 W I). Indien dit pandrecht anders dan door executie tenietgaat, kan $\mathrm{C}$ alsnog eigenaar worden, mits $A$ op het moment van dat tenietgaan nog beschikkingsbevoegd is. Ook is mogelijk dat het pandrecht weliswaar niet tenietgaat, maar de kantoorinventaris in handen van $C$ komt en hij op dat moment te goeder trouw is: dan is bescherming van $\mathrm{C}$ op grond van artikel 3:86 lid $2 \mathrm{BW}$ mogelijk ${ }^{286}$. Wanneer het in plaats van kantoorinventaris gaat om vorderingen op naam geldt het zojuist opgemerkte evenzeer, behalve voor zover het de bescherming van $C$ betreft. $C$ zal namelijk niet beschermd worden tegen de beperkte beschikkingsonbevoegdheid van $\mathrm{B}^{287}$, behoudens wellicht in een uitzonderlijk geval (artikel 3:36 BW).

2. In het omgekeerde geval (de levering bij voorbaat aan $\mathrm{C}$ geschiedde vóór de levering bij voorbaat aan $\mathrm{B}$ ) geldt dat al wóór de inwerkingtreding de levering bij voorbaat aan $B$ niet tegen $C$ werkte. De op het moment van de inwerkingtreding bestaande levering bij voorbaat tot zekerheidsoverdracht aan B geldt nadien als een levering bij voorbaat tot vestiging van een pandrecht (artikel 86 lid 7 tweede zin Ow I). Ook hier gelden de twee zojuist genoemde uitzonderingen (terugvallen van de eigendom in het vermogen van $\mathrm{A}$ en in handen van $\mathrm{B}$ komen van de kantoorinventaris; in het laatste geval is bescherming op grond van artikel 3:238 lid $1 \mathrm{BW}$ mogelijk ${ }^{288}$ ). Voor vorderingen op naam geldt weer hetzelfde, behalve op het punt van de derdenbescherming 289 .

3. Indien in voorbeeld 1 ook aan $\mathrm{C}$ bij voorbat was geleverd tot zekerheidsoverdracht, zou evenzeer reeds vóór de inwerkingtreding gelden, dat de levering bij voorbaat aan $\mathrm{C}$ niet werkte tegen $\mathrm{B}$. De ten tijde van de inwerkingtreding aanwezige eigendom tot zekerheid is omgezet in stil pandrecht (artikel 86 leden 1 en 2 ow D). De oplossing is hier dezelfde als in nr. 5.8.1.7 hiervór.

4. Stel dat in voorbeeld 1 de kantoorinventaris zijn toekomstigheid eerst na 31 december 1991 verliest. Vanaf genoemde datum geldt de levering bij voorbaat tot zekerheidsoverdracht aan B als een levering bij voorbaat tot vestiging van een pandrecht (artikel 86 lid 7 tweede zin Ow 1). Op het ogenblik dat de kantoorinventaris arriveert in het vermogen van A komt daarop B's pandrecht te rusten, mits A op dat tijdstip nog beschikkingsbevoegd is. Voor de verhouding tussen de rechten

284. Aldus ook Reehuis, diss, nr. 302; Van Mierlo, diss., p. 115-116.

285. Jk ga ervan uit dat $A$ in zijn verhouding tot $B$ niet bevoegd was tot de onderhavige verwreemding.

286. Vgl. Reehuis, diss., ne. 300 .

287. Vgl. keehuis, diss., nr. 495.

288. Zie hiverover Reehuis, diss, , ar 299.

289. Vgl. Reehuis, diss., nr. 495 . 
van $\mathrm{B}$ en $\mathrm{C}$ gelden de artikelen 3:97 lid 2 juncto $98 \mathrm{BW}$. Daaraan komt onmiddellijke werking toe krachtens artikel 68 a lid 1 OW ${ }^{290}$. Het resultaat is dat $C^{*} s$ recht niet werkt tegen $B$, omdat de levering bij voorbaat aan $B$ de oudste van beide is. $C$ heeft dus met pandrecht bezwaarde zaken verkregen. Dit kan anders worden indien B : s pandrecht anders dan door executie tenietgaat, of indien $C$ de zaken in handen $\mathrm{krijgt}^{291}$. Bij vorderingen op naam is het beeld niet anders, behoudens waar het de derdenbescherming betreft 292 .

5. Ook hier is het omgekeerde mogelijk: eerst levering bij voorbat ten titel van koop en vervolgens aan een ander tot zekerheid. Na de inwerkingtreding wordt de tweede levering bij voorbaat aangemerkt als éen tot vestiging van een pandrecht (artikel 86 lid 7 tweede zin Ow I). Ook dan gelden de onder 4 genoemde artikelen, met dien verstande dat thans $\mathrm{C}$ in beginsel aan het langste eind trekt. Voor vorderingen op naam geldt weer hetzelfde, behalve ten aanzien van de derdenbescherming ${ }^{293}$.

6. De gegeven casus kan nog verder worden gevarieerd door in de plaats van de levering bij voorbaat ten titel van koop een tweede levering bij voorbaat tot zekerheidsoverdracht te stellen. In dat geval gelden uiteraard beide leveringen bij voorbaat vanaf de inwerkingtreding op grond van genoemde overgangsbepaling als leveringen bij voorbaat tot vestiging van een pandrecht. Verder is het onder 4 opgemerkte van toepassing, met dien verstande dat hier $C$ een pandrecht verkrijgt, dat ten achter staat aan dat van $B^{294}$.

\subsubsection{Aanpassing van tot zekerheidsovendracht verplichtende overeenkomsten aan titel $3.9 \mathrm{BW}$}

'De partijen bij een overeenkomst die tot overdracht van goederen tot zekerheid verplicht, zijn deswerlangd jegens elkaar gehouden tot medewerking aan aanpassing van die overeenkomst aan de bepalingen van titel 3.9 van Boek 3.",

aldus $\|$ id 8 van artikel 86 Ow I. De minister merkt in de toelichting op, dat lid 8

'de houder/pandgever en de eigenaar/pandhouder jegens elkaar verplicht tot medewerking aan verdere eventuele aanpassingen in de overeenkomst, welke naast en ten gevolge van de omzetting (ex lid 7 eerste zin, HwdB) wenselijk blijken, ook al is de omzetting reeds van rechtswege geschied. "295

290. Vgl. Parl. Gesch. Overgangsrecht; p. 257. Volgens de minister, h. a., p. 94 sub ci en d, gatat dit buiten het overgangsrecht om. Echter, hier is vớr de inwerkingtreding gelewerd bij voorbaat, terwijl pas na de inwerkingtreding de zaken in A's vermogen komen. De toepasselijkheid, daarop wan de artikelen 3:97 er 98 BW zall dan toch op overgangsrecht moeten berusten; vgl. het in de toelichting opgemerkte over rechtsfiguren onder een woorwararde (t.a.p., p. 12) en over het rechtsgevolg weeking (t.a.p., p. 17),

291. Vgl. Reehuis, diss ... nr. 300.

292. Vigl. Reehuis, diss., , 495.

293. $\mathrm{Kgl}$. Reehuis, diss., mr. 495 .

294. Zie ook Reehurs, diss., nrs. 301 (zaken) en 496 (vorderingen).

295. Parl. Gesch. Owergangsrecht, p. 91. Men kan artikel 86.11d8 Ow I zien als een overbruggingstegel (zie daarower nr. 2.5.2 hiervón). Aldus ook Hartkamp, Compendium, nr. $32 a$. 
Welke aanpassingen aan titel $3.9 \mathrm{BW}$ zouden zoal wenselijk kunnen blijken? Gedacht zou kunnen worden aan een beding inhoudende een ruimere bevoegdheid van de crediteur tot het eisen van afgifte van de zekerheidsobjecten respectievelijk tot het betekenen van de zekerheidscessie dan toegelaten door de artikelen 3:237 lid 3 en 239 lid $3 \mathrm{BW} 296$. Op pandrechten ex artikel 86 lid 1 OW I zou een dergelijk beding op grond van lid 6 van genoemd artikel van overeenkomstige toepassing worden, ook al kan het niet rechtsgeldig worden gemaakt ter zake van een na de inwerkingtreding gevestigd pandrecht. Artikel 86 lid 6 Ow I is echter niet van toepassing op pandrechten die na de inwerkingtreding worden gevestigd ter uitvoering van een vóór de invoering ontstane (en door artikel 86 lid 7 eerste zin Ow I gemodificeerde) verbintenis. Ook al zou men bovengenoemd beding na de inwerkingtreding op basis van artikel $79 \mathrm{OW} I$ als volledig rechtsgeldig blijven beschouwen, dan nog valt niet weg te cijferen dat het pandrecht ná de inwerkingtreding is ontstaan. Deze laatste factor is beslissend voor het antwoord op de vraag, of op het pandrecht oud dan wel nieuw recht toepasselijk is. Op dit pandrecht is derhalve titel 3.9 $\mathrm{BW}$ toepasselijk. Daarin wordt de bevoegdheid van de pandhouder tot het beëindigen van het stille karakter van het pandrecht aan banden gelegd (artikelen 3:237 lid 3 en 239 lid 3 BW). Het meergenoemde beding moge dan wellicht verbintenisrechtelijk geldig zijn, de inhoud van een na de inwerkingtreding ontstaan pandrecht kan er naar mijn mening niet door worden bepaald. Aanpassing van het beding aan titel $3.9 \mathrm{BW}$ is aan te raden.

Indien in de overeenkomst van partijen geen voorziening mocht zijn getroffen ten aanzien van het verhaal van rente, zal de crediteur er verstandig aan doen om met de debiteur overeen te komen, dat de beperking van artikel 3:244 BW (pandrecht strekt tot zekerheid van drie jaar rente) niet geldt ${ }^{297}$. Ook kan gebruik worden gemaakt van de mogelijkheden tot afwijking van de wet, geboden in de artikelen 3:249 lid 1 (verplichting pandhouder tot mededeling van voorgenomen verkoop), 251 (mogelijkheid tot verkoop op andere dan de in artikel 250 voorgeschreven wijze dan wel tot verblijven van het pand aan de pandhouder) en $252 \mathrm{BW}$ (verplichting pandhouder tot kennisgeving van de plaatsgevonden hebbende verkoop).

De wederzijdse gehoudenheid ex artikel 86 lid 8 Ow I tot aanpassing van de (immers van voór de inwerkingtreding daterende) overeenkomst aan de bepalingen van titel 3.9 BW bestaat uiteraard pas vanaf 1 januari 1992. Bestaat deze aanpassing uit wijzigingen in allgemene voorwaarden die op de overeenkomst van partijen toepasselijk waren en worden deze wijzigingen in het jaar 1992 aangebracht, dan geldt ook voor deze wijzigingen de uitgestelde werking van afdeling 6.5.3 $\mathrm{BW}$ van een jaar vanaf de inwerkingtreding (dus tot 1 januari 1993; artikel 191 lid 1 tweede zin Ow I). Hetzelfde geldt, indien de toepasselijkheid van wijzigingen of van geheel nieuwe algemene voorwaarden reeds vóór de inwerkingtreding wordt overeengekomen, maar dan op grond van de eerste zin van artikel 191 lid 1 OW I. Worden na de inwerkingtreding geheel nieuwe algemene voorwaarden op de overeenkomst toepasselijk verklaard, dan geldt afdeling 6.5.3 BW daarvoor direct. In dat geval is immers niet meer sprake van een overgangssituatie ${ }^{298}$.

296. Vgl. Reehuis, diss., nurs. 94 en 95.

297. Artikel 108 Ow I is hier miet van toepassing.

298. Vgl. Parl. Gesch. Overgangsrecht, p. 167,9-10. 
Een ander punt dat nadere beschouwing verdient is het toepassingsgebied van artikel 86 lid 8 Ow I. Deze bepaling sluit aan bij artikel 86 lid 7 Ow I ${ }^{299}$. Daarin werd aanyankelijk alleen de verbintenis tot zekerheidsoverdracht geregeld. Later werd daaraan de levering bij voorbaat tot zekerheidsoverdracht toegevoegd ${ }^{360}$. Het toepassingsgebied van artikel 86 lid 8 OW I is echter beperkt gebleven tot de (vanaf de inwerkingtreding geldende) verbintenis tot vestiging van een pandrecht. Een gehoudenheid van partijen uit hoofde van de Overgangswet tot aanpassing van een overeenkomst op grond waarvan vóor de invoering bij voorbaat tot zekerheidsoverdracht is geleverd bestaat dus niet. Het na de inwerkingtreding krachtens een "omgezette' levering bij voorbaat ontstane pandrecht wordt echter wel door titel 3.9 BW geregeerd, evenals een pandrecht dat na de inwerkingtreding wordt gevestigd ter uitvoering van cen verbintenis tof vestiging van (inmiddels) een pandrecht. Voor beide situaties waarop artikel 86 lid 7 Ow I ziet, geldt voorts dat daarop artikel 86 lid 6 OW I niet van toepassing is.

Gezien het bovenstaande zou het voor de hand hebben gelegen dat ook bij bestaande leveringen bij voorbaat tot zekerheidsoverdracht; die vanaf de inwerkingtreding gelden als leveringen bij voorbaat tot vestiging van een pandrecht, de wederzijdse verplichting tot aanpassing van de overeenkomst aan titel $3.9 \mathrm{BW}$ op partijen zou hebben gerust. Men zou dit resultaat kunnen bereiken door analoge toepassing van artikel 86 lid 8 Ow I. Overigens is ook los van een eventuele verplichting daartoe aanpassing van de overeenkomst aan titel $3: 9 \mathrm{BW}$ aan te raden, zoals moge blijken uit de hierboven genoemde voorbeelden van nieuwe wetsbepalingen die in dit verband van belang zijn. Indien tot zodanige aanpassing wordt overgegaan, dient men erop bedacht te zijn dat, zoals ik reeds vermeldde, voor krachtens artikel 86 lid 1 OW I in pandrecht omgezette zekerheidseigendom een ander regime geldt, namelijk dat van artikel 86 lid 6 Ow I. Ook daar is aanpassing van de contractuele verhouding aan de nieuwe regels echter aan te bevelen ${ }^{301}$.

\subsection{OMZETTING IN PANDRECHT VAN ZEKERHEIDSEIGENDOM VAN RECHTEN UIT LEVENSVERZEKERING}

Eén van de acht leden van artikel 86 Ow I moet nog aan de orde worden gesteld. Het is lid 4, luidend:

'De schuldeiser aan wie de rechten uit een levensverzekering met afkoopwaarde tot zekerheid waren overgedragen, kan van het tijdstip van het in werking treden van de wet af als pandhouder die verzekering belenen ter hoogte van zijn opeisbare vordering tot aan die waarde op de bij de verzekeraar gebruikelijke voorwaarden.'

Deze bepaling wordt als volgt toegelicht:

299. Zie Parl. Gesch. Overgangsrecht, p. 91.

300. Zie nur. 5.9 .2 hiervóór.

301. Zie ar. 5.7 hiervóór. 
'Lid 4 geeft een regeling voor de cessie van de rechten uit een levensverzekering. Ook deze wordt tot een pandrecht geconverteerd, dat de pandhouder de bevoegdheid verleent de verzekering tot het bedrag wan de afkoopwaarde te belenen: aldus kan de pandhouder betaling verkrijgen, terwijl niettemin de verzekering in stand blijft. Te verwachten is dat deze oplossing ook zal worden voorgesteld in afdeling 7.17.3 voor verpanding van rechten uit levensverzekering in het algemeen. ${ }^{302}$

Ik volsta met enkele korte opmerkingen hierover. De in de toelichting bedoelde regeling van de verpanding van rechten uit een levensverzekering is opgenomen in de artikelen 7.17.3.20-206 NBW303. Voorts gelden de uitzonderingen van lid 5 van artikel 86 OW I tevens voor zekerheidsoverdracht van de rechten uit een levensverzekering ${ }^{304}$. Of ook de andere leden van artikel $86 \mathrm{Ow}$ I daarvoor gelden, blijkt niet uit de tekst van de wet en de toelichtende stukken.

\subsection{SLOT}

De conclusie uit het voorafgaande kan geen andere zijn dan dat de omzetting van eigendom tot zekerheid in pandrecht een groot aantal kwesties van overgangsrechtelijke aard oproept, die lang niet altijd gemakkelijk tot een oplossing zijn te brengen. Gezien het grote gewicht van niet-registergoederen als zekerheidsobject zou artikel 86 dan ook wel eens één van de belangrijkste bepalingen uit de Aanvulling van de Overgangswet kunnen blijken te zijn. 


\section{HOOFDSTUK 6}

\section{Onrechtmatige daad}

\subsection{INLERIING}

Op het wlak van de (schadevergoeding op grond van) onrechtmatige daad' kunnen in het nieuwe $\mathrm{BW}$ diverse noviteiten worden aangewezen. Zo zijn nieuwe aansprakelijkheden geschapen en oude afgeschaft. Ook zijn de kringen van aansprakelijke personen en die van vorderingsgerechtigden niet steeds identiek gebleven. Afhankelijk van de feitelijke constellatie van een bepaald geval kunnen deze en andere vernieuwingen tot overgangsrechtelijke problemen leiden. Deze laatste zal ik hierna bespreken. Daarbij zullen de artikelen $68 a, 69$ en 173 Ow I centraal staan.

Aan de in afdeling 6.3.5 BW opgenomen 'tijdelijke regeling verhaalsrechten' ga ik voorbij. Zoals de plaatsing in het nieuwe BW zelf al doet vermoeden, gaat het hier niet om een overgangsregeling, maar om een regeling van materieelrechtelijke aard. Daarin wordt op het stuk van de verhaalsrechten globaal de status quo gehandhaafd in afwachting van een meer definitieve oplossing van de problematiek van de verhaalsrechten ${ }^{2}$. Kortheidshalve laat ik ook overigens regres en subrogatie buiten beschouwing, evenals verjaringskwesties.

\subsection{ONTSTAAN VAN OVERGANIGSKWESTIES BIJ ONRECHTMATIGE DAAD}

Ten aanzien van de (schadevergoeding op grond van) onrechtmatige daad brengt het nieuwe BW nogal wat verandering. Ik verwijs hiervoor naar de literatiur over onrechtmatige daad en schadevergoeding ${ }^{3}$. Om de gedachten te bepalen voer ik hier enkele in het oog springende nieuwigheden op, die ook hierna nog een rol zullen spelen.

Titel $6.3 \mathrm{BW}$ bevat nogal wat geheel of gedeeltelijk nieuwe aansprakelijkheden. Deze zijn bij voorbeeld te vinden in de volgende artikelen:

$-6: 165$ (aansprakelijkheid van gehandicapten);

- 6:169 (aansprakelijkheid voor kinderen);

- 6:171 (aansprakelijkheid voor niet-ondergeschikten);

1. Ik gebruik het begrip "onrechtmatige daad' in dezelffe betekenis als het wordt gebruikt in het opschrift van titel $6.3 \mathrm{BW}$, dus inclusief de in deze titel geregelde risico-aansprakelijkheden.

2. Vgl. Parl. Gesch. Inv. Boek 6, p. 1403 e.v.. Zie hierover onder andenen Van Maanen, NJB 1984, p. 173; Hondius, Kwartaalbericht Nieuw BW 1984, p. 6; Bloembergen, in: BW-krant jaarboek 1987, p. 13-36; Van Maanen, Kwartaalbericht Nieuw BW 1988, p. 45-46. Zie woorts de notitie over verkeersaansprakelijkheid, TK, vergaderjaar 1989-1990,21528, nr. 1 .

3. Zie bij woorbeeld de desbetreffende hoofdstukken van Asser-Hartkamp I en III. 
- 6:172 (aansprakelijkheid voor vertegenwoordigers);

- 6:173 (aansprakelijkheid voor gebrekkige zaken);

- 6:174 (aansprakelijkheild voor opstallen).

Ook het omgekeerde komt voor: afgeschaft is de aansprakelijkheid uit onrechtmatige daad van kinderen jonger dan veertien jaar (artikel 6:164 BW). Voorts bevat de bijzondere regel van artikel 6:170 lid $2 \mathrm{BW}$ inzake ondergeschikten in dienst van een natuurlijke persoon een engere maatstaf voor aansprakelijkheid van laatstgenoemde dan voorheen gold.

In plaats van de eigenaar van een opstal en de eigenaar van een dier of degene die het duurzaam ten eigen nutte gebruik $t^{4}$ (artikelen 1405 (oud) respectievelijk 1404 (oud) BW) is in beginsel de bezitter daarvan aansprakelijk (artikelen 6:174 respectievelijk $179 \mathrm{BW}$ ).

In artikel 6:257 BW komt de wetgever de ondergeschikte te hulp, die wordt aangesproken door de wederpartij van zijn werkgever: de ondergeschikte kan in de regel een beroep doen op een door zijn werkgever met diens wederpartij overeengekomen exoneratiebeding.

De nieuwe wet kent hoofdelijkheid (artikel 6:102 BW) waar in het oude recht doorgaans toevallig samenlopende verbintenissen werden aangenomen.

Dat bovenstaande vernieuwingen overgangskwesties oproepen ligt voor de hand. Bij de nieuwe aansprakelijkheden is er een probleem in de situatie dat de vereisten die de wet daarvoor stelt reeds vóór haar inwerkingtreding zijn vervuld. Is door de invoering ook in zo'n situatie aansprakelijkheid ontstaan? Omgekeerd rijst bij de afschaffing van een aansprakelijkheid de vraag, of deze bij de invoering aanwezige aansprakelijkheden heeft tenietgedaan. Andere mogelijke vragen zijn, of het van kracht worden van het nieuwe recht aansprakelijkheden heeft doen verschuiven, een beroep op nieuwe verweermiddelen heeft mogelijk gemaakt en de inhoud van anterieure schadevergoedingsverplichtingen heeft gewijzigd.

Teneinde de nodige orde in de materie te scheppen, maak ik in het navolgende onderscheid tussen diverse rechtsgevolgen die een onrechtmatige daad kan hebben, namelijk:

- de aansprakelijkheid tot en de daartegenover staande aanspraak op schadevergoeding en in het kader daarvan de verplichting tot schadevergoeding (zie de nrs.

6.3-6.5), en de bevoegdheden van gelaedeerde en rechter tot het vorderen respectievelijk toewijzen van:

- een verbod (zie un. 6.6);

- een verklaring van recht (zie nr. 6.7);

- een rectificatie (zie nr. 6.8).

Verder lijkt het dienstig om ten aanzien van de aanspraak op schadevergoeding een onderverdeling an te brengen. Uitgangspunt hierbij is of de nieuwe wet bij haar aantreden op 1 januari 1992 al dan niet een recht op schadevergoeding (in wording) aantrof:

- ten tijde van de inwerkingtreding was reeds een recht op schadevergoeding aan -

4. Vgl. HR 29 november 1985, NJ 1987, 291 (Van Amsterdam-Van den Hurk) en Asser-Hartkamp Ir, mrs. 193 en 1996 . 
wezig met de daartegenover staande op de laedens rustende schadevergoedingswerbintenis. Volgens het nieuwe recht zou zo"n verbintenis niet dezelfde inhoud hebben, niet bestaan, op een ander rusten, of een andere omvang hebben ${ }^{5}$ (zie nr. $6.5 .1)$;

- ten tijde van de inwerkingtreding was het recht op schadevergoeding nog "in statu nascendi', dat wil zeggen: enkele vereisten waren reeds vervuld, aan eśn of meer andere wordt pas nadien voldaan (zie nr. 6.5.2);

- ten tijde van de inwerkingtreding was geen recht op schadevergoeding aanwezig, waar dit volgens de nieuwe wet wel zou bestaan (zie nr. 6.5.3).

Oplopende en opeenvolgende schaden vormen voorwerp van bespreking in nr. 6.5 .4 .

Het geval dat de voor een schadevergoedingsverplichting gestelde vereisten alle pas má de invoering worden vervuld, hoort in deze onderverdeling uiteraard niet thuis, omdat dan geen overgangssituatie aanwezig is.

Aan de hand van bovenstaande onderscheidingen bezie ik nu wat onmiddellijke werking van het nieuwe vermogensrecht zou oplevenen woor transitoire oniechtmatige daadsgevallen.

\subsection{CONSEQUENTIES VAN ONMTDDELLIJKE WERKING VAN HET NIEUWE BW TEN AANZIEN VAN OVERGANGSSTTUATIES BIJ ONRECHTMATIGE DAAD}

Toepassing van de hoofdregel van artikel $68 a$ lid 10 I bij de onrechtmatige daad zou resultaten als de volgende opleveren ${ }^{6}$. Met ingang van het moment van de inwerkingtreding zouden nieuwe aansprakelijkheden zijn ontstaan, indien alsclan aan de vereisten daarvoor reeds zou zijn voldaan. Ook zouden bestaande aansprakelijkheden op genoemd tijdstip zijn tenietgegaam of zijn verschoven, nieuwe verweermiddellen inroepbaar zijn geworden en verbintenissen tot schadevergoeding door de nieuwe regels worden beheerst:

Een geval waarin een onnechtmatige gedraging vór de invoering eerst daarna tot schade leidt, zou worden geregeerd door het nieuwe recht (dat mogelijk - anders dan het oude recht - juist voor die casus een aansprakelijkheid inhoudt).

Sommige van de zojuist genoemde resultaten vragen om correctie, andere niet. Ontstaan, verloren gaan en verschuiving van aansprakelijkheden als gevolg van de invoering van nieuw vermogensrecht is in het algemeen niet aanvaardbaar. Het beginsel van de 'eerbiediging van verkregen rechten' dient zich hier aan:

"Of men een verkregen recht heeft $(.$. ) hangt niet af van de wet van wandaag, maar van die van gisteren."7

5. Bij hel navolgende moet in het oog worden gehouden dat wat woor het worderingsrecht geld t bij voorbeeld het tenietgawn ervany ook geldt vour de andere kant van die medaille, de schuld, of wel de aansptrakelijkheid. 6. Zie woor kritiek op het stelsel van de artikelen 68 a en 69 ow 1 ten anzien van de alansprakelijkheid uit onrechtmatige daad ar. 2.5.1.1 sub c 2 hiervór. in het navolgende ga ilk uit wan bedoeld stelsel.

7. Aldus De Die, AA 1991, p. 824. 
'Behoudens andersluidende, duidelijk kenbare bedoeling van de wetgever, heeft de nieuwe wet niet tengevolge, dat daardoor en vermogensverschuiving plaatsvindt."

Dit betekent niet dat er bij de onrechtmatige daad in het geheel geen speelruimte is woor de onmiddellijke werking, al is deze wel vrij beperkt. Ik merk hierover het volgende op.

De onmiddellijke werking manifesteert zich bij de inhoud (eigenschappen, gewolgen) van een bestaande schadevergoedingsverplichting en de bevoegdheden van de schuldeiser. Zie de volgende citaten uit de parlementaire stukken:

'De regel die in het algemeen terugwerkende kracht aan het nieuwe recht ontzegt, heeft tot gevolg dat een duurzame rechtsverhouding, een bestaand recht of een bestaande rechtspositie, als het ware in twee stukken wordt gebroken: eén dat nog door het oude recht wordt beheerst, eén dat van de inwerkingtreding af onder het regime van het nieuwe valt."

"De regel die inhoudt dat het absolute recht en de verbintenisrechtelijke rechtsbetrekking worden gehandhaafd, verhindert niet dat hun inhoud voor het vervolg door het nieuwe recht wordt beheerst, voor zover de bijzondere overgangsartikelen niet anders bepalen.' 9

In gelijke zin de opsteller van het overgangsrecht voor het nieuwe BW, De Die:*

"Te ver gaat de uitspraak dat de nieuwe wet geen (enkele) invloed op een verkregen recht zou hebben. Het recht zelf blijft weliswaar bestaan, maar, bij onmiddellijke of uitgestelde werking van de nieuwe wet, wordt het wel degelijk voor zijn gevolgen aan haar regime onderworpen (...): een eigenaar, een schuldeiser, die zijn recht uit het ancien régime heeft gered, krijgt "voor het vervolg" bijv. de bevoegdheden die de nieuwe wet hem toekent, "voor het vervolg" wordt een vordlering overeenkomstig het nieuwe recht hoofdelijk enz.." 10

Het gaat hier met name on de al dan niet toepasselijkheid op overgangssituaties wan afdeling $6.1 .10 \mathrm{BW}$. Een wak gegeven voorbeeld is dat van twee of meer personen die uit hoofde van onrechtmatige daad elk verplicht zijn tot vergoeding van eenzelfde schade. Naar oud recht placht te worden aangenomen dat alsdan sprake was van zogenoemde toevallig samenlopende verbintenissen en niet van hoofde-

8. Pready., p. 41. Zie over het beginsel van de eerbiediging van verkregen rechten nader nr. 2.5.1.2 sub e biervoor.

9. Aldus de toelichting, Parl. Gesch. Overgangsrecht, p. 14 respectievelijk. 16; evenzo p. 300-301. Artikel 69 sub c Ow I "verzet er zich niet tegen dat de bestaande vordering of schuld door de nieuwe wet andere eigenschappen krijgt, bijv. opeisbaar of hoofdelijk wordt", aldus Parl. Gesch. Overgangsrecht, p. 43.

10. Spoedcursus, p. 21. 
lijkheid, omdat de wet voor dat laatste doorgaans geen aanknopingspunten bood ${ }^{11}$. Vanaf de inwerkingtreding is dit voor bestaande verbintenissen anders geworden: daarvoor is artikel 6:102 BW gaan gelden, waardoor hoofdelijkheid is ingetreden ${ }^{12}$.

In weerwil van bovenstaande citaten komen in de visie van de overgangswetgever naast artikel 6:102 $\mathrm{BW}$ slechts de artikelen 6:103 en 105 $\mathrm{BW}$ in aanmerking voor toepassing, indien de schade dateert wan voór de inwerkingtreding:

'In de andere gevallen (dan aansprakelijkheid uit niet-nakoming, HvdB), met name bij onrechtmatige daad, zal afdeling 6.1.9 (6.1.10) slechts van toepassing zijn, als de schade, als laatste element van de vereisten voor schadevergoeding, na de inwerkingtreding is gevallen.'

\section{Afdeling 6.1.10 BW blijft}

'buiten toepassing op de vergoeding van schade die vóór de inwerkingtreding is ontstaan (...). Een uitzondering vormen hier de artikelen 6.1.9.8-6.1.9.10 (6:102, 103 en 105), die de ornvang der te vergoeden schade miet beïnvloeden, en die onmiddellijk toepassing kunnen vinden. ${ }^{13}$

Brunner ${ }^{14}$ daarentegen stelt zonder restrictie dat afdeling 6.1.10 BW (op een krachtens artikel $69 \mathrm{sub}$ a OW I gehandhaafde schadevergoedingsverplichting van een kind van twaalf jaar) onmiddellijk toepasselijk wordt.

Ik zou een middenweg willen bewandelen. Zolang niet één van de uitzonderingen op de onmiddellijke werking in het geding is (dat is bij voorbeeld wel zo als het gaat om het al dan niet bestaan en de omvang van de schadevergoedingsverbintenis) zou afdeling 6.1.10 BW voor onmiddellijke toepassing in aanmerking kunnen komen. De in het laatste citaat bedoelde artikelen 6:102, 103 en 105 BW zijn niet de enige uit afdeling 6.1.10 BW die de omvang van de te vergoeden schade niet beinvloeden. Dit geidt bij voorbeeld ook voor artikel 6:101 BW (eigen schuld). Waarom zouden dan alleen de in het citaat genoemde bepalingen onmiddellijk kunnen werken? Genoemde afdeling kan zelfs, afgezien van de artikelen 6:104 en 106$110 \mathrm{BW}$, als voorheen reeds geldend recht worden beschouwd ${ }^{15}$.

De gedachte van de overgangswetgever lijkt te zijn dat in overgangsgevallen afdeling 6.1.10 BW - als geheel ${ }^{16}$ - alleen dan voor toepassing in aanmerking kan ko-

1.1. Zie artikel 1318 (oud) BW eim Asser-Hartkamp I, ni. 98a.

12. Zie: Parl. Gesch. Overgangsrecht, p. 16, 301, alwar ook wordt opgemerkt dat deze wisseling van aard geen bezwaar heeft, "nu in het nieuwe recht de moeilijk aanvatardbare gevolgen van hoofdelijkheid niet zullen terugkeren?. Vgl, vooris artikel $1750 \mathrm{w} \mathrm{I.}$

13. Allus Parl. Gesch. Owergangsrecht, p. 308; evemzo p. 150, alsmede De Vries Lentsch-Kostense, WPNR 6007 (1991), p. 370 .

14. WPNR 6007 (1991), p. 345. Vgl. ook H. Stein, preadv., p. 108, 112.

15. Althans volgens Asser-Hartkamp I, nr. 404. Zie over de artikelen 6:104 en 108 lid 2 BW nr. 6.5.1.3 hierna.

16. Vgl. de door Bakels, Kwartaalbericht Nieuw BW 1985, p. 56 , geciteerde passage uit het departementale antwoord op kritiek wan de Nederlandse Vereniging voor Rechtspraak op de ontwerp-Overgangswet:" 'dat men 6.1.9 (6.1.10) als één pakket moet beschouwen clat alleen aan de orde komt als op de vordering nieuw rechill van toepassing is'. 
men, indien minstens én vereiste voor schadevergoeding pas na de inwerkingtreding is vervuld: Dan is echter niet duidelijk, waarop de uitzondering voor de artikelen 6:102, 103 en 105 BW stoelt.

Naar mijn mening valt te verdedigen dat de inhoud, eigenschappen etc. van een bestaande aansprakelijkheid uit onrechtmatige daad krachtens artikel $68 a$ lid 1 Ow I vanaf de inwerkingtreding worden beheerst door nieuw recht, met name afdeling $6.1 .10 \mathrm{BW}$, voor zover althans niet een andere overgangsbepaling (met name artikel 69 Ow I) daaraan in de weg staat.

Afzonderlijke aandacht verdient artikel 6:109 BW. De daarin aan de rechter gegeven algemene matigingsbevoegdheid bestond naar oud recht niet. Toch leent deze bepaling zich mijns inziens voor onmiddellijke toepassing op overlopende rechtsverhoudingen. Op het eerste gezicht lijkt dat wellicht in strijd met artikel 69 sub c OW I. Dat is echter maar schijn, omdat hier geen sprake is van verandering van de omvang van een schuld door en met het enkele toepasselijk worden van artikel 6:109 BW. Daarin is immers een matigingsbevoegdheid neergelegd; de rechter zal daarvan gebruik moeten maken, voordat een verplichting tot schadevergoeding daadwerkelijk wordt verminderd ${ }^{17}$.

Ik vermeld nog dat Spier en Sterk ${ }^{18}$ hebben bepleit, afdeling 6.1.10 BW toepasselijk te laten zijn op na de inwerkingtreding opkomende schade, ook al zou deze voortvloeien uit een gebeurtenis van vóor de inwerkingtreding. Anders dan genoemde schrijvers doen voorkomen, is hetgeen zij bepleiten in hoofdzaak juist in overeenstemming met het stelsel van de Overgangswet. In de toelichting valt te lezen: bij onrechtmatige daad

'zal afdeling $6.1 .9(6.1 .10)$ slechts van toepassing zijn; als de schade, als laatste element van de vereisten voor schadevergoeding, na de inwerkingtreding is gevallen.' 19

De overgangsbepalingen die in het bijzonder van belang zijn voor de onrechtmatige daad zal ik thans kort beschrijven.

\subsection{DE OVERGANGSWET EN DE ONRECHTMATIGE DAAD}

Artikell $69 \mathrm{OW}$ I strekt tot het eerbiedigen van bestaande vermogensrechtelijke posities. Het is een concretisering van het zojuist reeds genoemde beginsel van de eerbiediging van verkregen rechten en is daarmee direct al een voorbeeld van het 'tenzij uit de volgende artikelen lets anders voortvloeit' van artikel $68 \mathrm{a}$ lid 1 Ow $\mathrm{I}$. Het in overgangssituaties ontstalan van nieuwe aansprakelijkheden en tenietgaan en verschuiven van 'oude' aansprakelijkheden wordt door artikel 69 Ow I verhinderd 20 .

De handhaving van de bestaande toestand die door artikel 69 Ow I op het terrein

17. Vgl. Brunner, WPNR 6007 (1991), p. 345 .

18. Pread w, p. 97-98, 100-101.

19. Parl, Gesch. Overgangsrecht, p. 308 (hierboven reeds geciteerd). Zie verder de nrs. 6.5.2 en 6.5 .4 hiema.

20. Zie over artikel 69 OW I en de onrechtmatige daad ook nr. 2.5 .1 .1 sub c.2 hiervóór. 
van de onrechtmatige daad wordt bewerkstelligd ligt in de rede. De zonder zo"n 'bevriezing' optredende herallocatie van vorderingsrechten en aansprakelijkheden. zal in het algemeen met het oog op de rechtszekerheid niet verdedigbaar zijn.

De algemene overgangsbepalingen $68 a$ en 69 Ow I lenen zich woor toepassing op een breed scala van gevallen. Bij artikel 1.73 Ow II is dit anders. Weliswaar geldt het - in beginsel - voor aansprakelijkheid en schadevergoeding in het algemeen, het betreft tamelijk specifieke gevallen. Lid 1 moet worden gezien tegen de achtergrond van hetgeen geldt voor de zogenoemde "onvolledige complexen van rechtsfeiten' 21 . Stel, op het tijdstip van de inwerkingtreding was een deel van de vereisten voor het ontstaan van aansprakelijkheid al vervuld, maar was het nog wachten op het ontstaan wan schade. Aan dat wachten komt op zeker moment - na de inwerkingtreding - een einde. Gegeven de ook hier opgaande hoofdregel van de onmiddellijke werking zullen aansprakelijkheid en schadevergoeding in beginsel aan de hand van nieuw recht moeten worden beoordeeld. Maar hoe is de oplossing, indien niet kan worden vastgesteld of de schade v6or dan wel na het invoeringstijdstip is ingetreden? Hier nu dient artikel 173 lid 1 Ow I zich aan. Beslissend is, zo zegt het artikel, of de schade vór of na de inwerkingtreding is bekend geworden. Is de schade pas na de inwerkingtreding bekend geworden, dan is het nieuwe BW toepasselijk, waarbij dus niet is uitgesloten dat de schade reeds voordien is ingetreden.

$\mathrm{Er}$ is echter meer. Uit één gebeurtenis kunnen verschillende schaden voortvloeien. De ene schade kan vóór en de andere kan ná de inwerkingtreding vallen: Zonder ingrijpen door de overgangswetgever zou in beginsel op de eerste schade oud en op de tweede nieuw recht toepasselijk zijn. Iets dergelijks zou gelden voor een door een bepaalde gebeurtenis vóór de inwerkingtreding ontstane schade die langzamerhand, ook na de inwerkingtreding, steeds hoger wordt. Artikel 173 lid 2 Ow I bewerkstelligt hier eenheid van recht: de (omvang van de) aansprakelijkheid woor na de inwerkingtreding ontstane of bekend geworden schade wordt naar oud recht beoordeeld, indien deze schade het gevolg is van dezelfde gebeurtenis als een eerdere door het oude recht beheerste schade van dezelfde benadeelde.

Een enigszins vergelijkbaar geval is dat van de persoon aan wie vóór de inwerkingtreding letsel wordt toegebracht, als gevolg waarvan hij nadien komt te overlijden. Volgens de algemene regels zou in beginsel de reeds bestaande letselschade wan de gewonde onder het oucle recht vallen en zou op de naderhand ontstane overlijdensschade van de nabestaanden nieuw recht toepasselijk zijn. Hiervoor wordt een stokje gestoken in artikel 173 lid 2 tweede zin Ow I: ook op de overlijdensschade moet oud recht worden toegepast.

Evenals de algemene overgangsbepaling $69 \mathrm{Ow} I$ is artikel $173 \mathrm{Ow}$ I niet alleen van belang voor het veld van de onrechtmatige daad. Het gaat in artikel 173 OW I om aansprakelijkheid en schadevergoeding in het algemeen. Aan artikell 173 Ow I wordt echter voor wat betreft tekortkomingen in de nakoming van verbintenissen gederogeerd door artikel $182 \mathrm{Ow}$ I. Anderzijds wordt het toepassingsgebied van artikel 173 Ow I en ook dat van artikel 69 Ow I vergroot door artikel 1 lid 2 Ow II: zij gelden mede ter regeling van het overgangsrecht in verband met de wijzigingen in de bij de invoering van het nieuwe BW bestaande wetgeving. 
De hoofdmoot van de iriteenzettingen over de onrechtmatige daad in overgangsrechtelijk perspectief betreft de aansprakelijkheid tot schadevergoeding. Thans zal ik de daamee verband houdende overgangsvragen bespreken volgens de in nu. 6.2 hierwoor weergegeven opzet.

\subsection{Aansprakelikheid reeds aanwezig}

Was ten tijde van het toepasselijk worden van het nieuwe recht reeds een aanspraak op schadevergoeding aanwezig, dan kunnen zich in overgangssituaties vragen van diverse aard voordoen ${ }^{22}$. Wat heeft te gelden als het nieuwe recht zo'n aanspraak niet kent blijkt in nr. 6.5.1.1. Ingeval aansprakelijkheid naar nieuw recht op iemand anders zou rusten dan volgens oud recht, kont de vraag op of daardoor de aansprakelijkheid van de een op de ander overgaat (zie nr. 6.5.1.2). Als naar nieuw recht een hogere of juist lagere schadevergoeding verschuldigd zou zijn dan voorheen, is de vraag welk recht terzake maatgevend is (zie nr. 6.5.1.3). De bijzondere regel voor verzuim die artikel $183 \mathrm{OW}$ I inhoudt; komt ter sprake in nr. 6.5.1.4. Een laatste punt van behandeling is, of de regel van artikel $6: 257 \mathrm{BW}$ al dan niet direct vanaf de inwerkingtreding voor inroeping vatbaar is (zie nr. 6.5.1.5).

\subsubsection{Schrapping van aansprakelijkheden}

De dertienjarige A heeft in de oudejaarsnacht van 1991 nog juist vóór middernacht zijn laatste slechte voomemen van 1991 tot uitvoering gebracht door bij B, zijn gehate leraar lichamelijke opwoeding, vuurwerk door de brievenbus te gooien. Daardoor is een brandje in de hal van $B^{*} s$ woning ontstaan, dat om 23.50 uur is geblust. $B$ heeft vervolgens op 2 januari 1992 zowel $A$ als diens ouders aangesproken tot schadevergoeding.

Een voorbeeld als dit wordt steevast gegeven bij bespreking van artikel 69 sub a Ow 1, huidend:

"Wanneer de wet van toepassing wordt, heeft dat niet tot gevolg dat alsdan: a. iemand het vermogensrecht werliest dat hij onder het tevoren geidende recht had verkregen".

Hierbij kan ook worden gedacht aan het waarschijnlijk minder vaak spelende geval van de kinderoppas, tuinman of soortgelijke werkkracht, die vóor het moment van het toepasselijk worden van artikel 6:170 lid 2 BW onrechtmatig schade teweegbracht bij een derde, welke schade op genoemd moment nog niet was vergoed. In

22. Een darvin kan zijin of de woor de schadevergoedingsvordering geldende verjaringstermiju (artikel 2004 (oud) BW) door de invoering van artikel $3: 310 \mathrm{BW}$ wordt beïnvloed. Zie daarvoor artikel 73 OW I. 
beide situaties is er de mogelijkheid dat aansprakellijkheid naar nieuw recht ontbreekt, waar deze naar oud recht wel aanwezig was. Immers, het kind uit bovenstaand voorbeeld kon voorheen doorgaans, nu het de leeftijd van dertien jaar had bereikt, wel worden aangesproken op grond wan onrechtmatige daad ${ }^{23}$. Krachtens artikel 6:164 BW evenwel zou een vordering tot schadevergoeding tegen het kind tot mislukken gedoemd zijn. Bij het huis- en tuinpersoneel kan zich hetzelfde voordoen: niet uit te sluiten is namelijk dat de 'werkgever' naar oud recht (artikel 1403 lid 3 (oud) BW) wel aansprakelijk was jegens de derde, maar in verband met de in het oude recht onbekende ${ }^{24}$ strengere maatstaf van artikel 6:170 lid $2 \mathrm{BW}$ niet.

Het in de beide veronderstelde gevallen ten tijde van de inwerkingtreding 25 bestaande recht op schadevergoeding van de derde wordt volgens artikel 69 sub a $O w$ I geëerbiedigd, ook als de gelaedeerde vóór de inwerkingtreding nog geen vordering tot schadevergoeding had ingesteld. Met deze eerbiediging van verkregen rechten wordt afgeweken van de hoofdregel van de onmiddellijke werking. Deze zou hier tot effect hebben gehad dat de schadevergoedingsaanspraken beide zouden verdwijnen met het oude recht waaruit zij voortvloeiden. De doorbreking van de hoofdregel van de onmiddellijke werking door artikel 69 sub a OW I heeft tot resultaat dat voor zover het gaat om 'hebben of niet hebben' van een vorderingsrecht alles bij het oude blijft:

'ook al zijn vóór of ten tijde van de i.w.t. der nieuwe wet haar vereisten voor het hebben of ontberen van een vermogensrecht vervuld, die nieuwe wet mag dat rechtsgevolg daaraan niet verbinden. Anders gezegd: of men op het tijdstip van het in werking treden der nieuwe wet een vermogensrecht heeft of niet, wordt in beginsel door het oude, niet door het nieuwe recht bepaald. ${ }^{26}$

\subsubsection{Verschuiving van aansprakelijkheden}

A is erfpachter van een perceel grond met een daarop vóór de vestiging van het erfpachtsrecht gebouwd woonhuis. Als gevolg van een constructiefout bij de bouw van het huis stortte in november 1991 de schoorsteen naar beneden. Deze kwam precies bovenop C's voor het huis geparkeerd staande auto terecht, die daardoor total loss raakte. $C$ 's verzekeraar vergoedde $C$ diens schade en sprak A en grondeigenaar B in februari 1992 aan tot vergoeding daarvan.

Onder de vigeur van het oude recht zou, zo neem ik aan, grondeigenaar B voor de

23. De ouders van het kind zeer waarschijnlijk volgens oud recht niet en volgens nieuw recht jwist wel, maar dat komt in nr. 6.5.3 hierna aan de orde.

24. Zie Asser-Hartkamp III, nr. 142.

25. De artikelen 6:164 en 170 BW komt in beginsel onmiddellijke werking toe op grond van artikel $68 \mathrm{a}$ lid 10 w 1 , zodat inwerkingtreding en toepasselijk worden samenvallen. Zie voor laatstgenoemde begrippen de nurs. 2.2 .3 en 2.2 .4 hiervớor.

26. Aldus De Die, Spoedcursus, p. 20. Zie hierover nader de nrs. 2.5 .1 .1 sub c.2, 2.5.1.2 sub c.2 en sub e hiervóór, alsmede Parl. Gesch. Overgangsrecht, p. 39, 40,42-43. 
schade aansprakelijk zijn geweest (artikel 1405 (oud) BW). Wel placht in erfpachtsvoorwaarden te worden bedongen dat de erfpachter de eigenaar vrijwaarde voor aanspraken uit genoemide bepaling ${ }^{27}$. Volgens artikel $6: 174$ lid $2 \mathrm{BW}$ zou $\mathrm{A}$, bezitter van het erfpachtsrecht, in beginsel aansprakelijk zijn. Resultaat van onmiddellijke werking van artikel $6: 174 \mathrm{BW}$ (zie artikel $68 a$ lid 1 Ow I) zou zijn verspringing van de aansprakelijkheid van B naar A. Immers, op 1 januari 1992 was voldaan aan de vereisten gesteld door artikel $6: 174 \mathrm{BW}$ voor aansprakelijkheid van $\mathrm{A}$, terwijl op $\mathrm{B}$ geen aansprakelijkheid rust volgens deze bepaling. De zienswijze van de wetgever brengt echter met zich mee dat artikel 69 sub b Ow I zich hier doet gelden:

'Wanneer de wet van toepassing wordt, heeft dat niet tot gevolg dat alsdan:

(...)

b. een schuld op een ander overgaat'.

Gevolg hierwan is dat B aansprakelijk is gebleven en A niet aansprakelijk is geworden. Ook hier is niet van belang of de gelaedeerde reeds vóór de inwerkingtreding een wordering tot schadevergoeding had ingesteld ${ }^{28}$.

Brunner noemt als voorbeeld van een geval waarop artikel 69 sub b Ow I wan toepassing zou zijn ${ }^{29}$ :

'De schuld van het kind uit onrechtmatige daad, ontstaan voor 1 januari 1992, gaat niet over op zijn ouders die krachtens art. 6:169 risicoaansprakelijk zijn. Voor de vraag of de ouders aansprakelijk zijn blijft art. 1403 lid 5 beslissend?

H. Stein en Hartkamp ${ }^{30}$ geven ongeveer hetzelfde voorbeeld. Naar mijn mening moet dit voorbeeld echter als onjuist worden aangemerkt. Door artikel 69 sub b Ow I wordt overgang van een schuld op een ander verhinderd. Van zo"n overgang zal alleen sprake kunnen zijn alls het om één en dezelfde schuld gaat. Hier is dat niet zo: een schuld (van het kind) ter zake van eigen onrechtmatig handelen is een andere schuld dan een schuld (van de ouders) ter zake van het onrechtmatig handelen van hun kind. Daarom zal hier in het systeem van de Overgangswet moeten worden geopereerd met artikel 69 sub a (een bestaande schuld van het kind gaat niet teniet, zie nr. 6.5.1.1 hiervó́r) en sub d Ow I (waren de ouders voorheen niet aansprakelijk, dan worden ze dat door het toepasselijk worden van het nieuwe recht niet alsnog, zie nr. 6.5 .3 hierna) ${ }^{31}$.

27. Zie Parl. Gesch. Boek 6, p. 756, noot 8.

28. Zie over artikel 69 subb b Ow I Parl. Gesch. Overgangsrecht, p. 43.

29. WPNR $6007(1991), \mathrm{p} 345$

30. Respectievelijk preadv., p. 257; Compendium, nr. 32 .

$3 \Perp$ In deze zin de memorie van antwoord aan de Tweede Kamer, Parl, Gesch. Overgangsrecht, p. 43. Anders echter, naar het lijkt, de memorie van toelichting, Parl. Gesch. Overgangsrecht, p. 39, alwaar wordt opgemerkt dat artikel 70 ld I (thans artikel 69) Ow I doet "vaststaan dat, ondanks het inwerkingtreden van de mileuwe wet, een bestaand vorderingsrecht jegens ouders of kind wordt geẻerbiedigd, en dat die inwerkingtreding geen nieuwe aansprakelijkheid voor oude feiten meebrengt en dat geen aansprakelijkheid wan het kind naar de ouders verschuift: (....)'. 
A bracht in oktober 1991 dodelijk letsel toe aan B. In maart 1992 sprak B's weduwe $\mathrm{A}$ aan tot schadevergoeding. Zij vorderde vergoeding van schade door het derven van levensonderhoud en vergoeding van de kosten van lijkbezorging.

Stel op A rustte onder oud recht (artikel 1406) aansprakelijkheid wegens het veroorzaken van B's overlijden. Tot vergoeding van de kosten van lijkbezorging kon A niet met succes worden aangesproken ${ }^{32}$. Volgens artikel 6:108 lid 2 BW is dat anders, voor zover deze kosten in overeenstemming zijn met de omstandigheden van de overledene. B's vordering zou dus beoordeeld aan de hand van laatstgenoemde bepaling hoger uitvallen dan met toepassing van het oude recht. Onmiddellijke werking van artikel 6:108 lid $2 \mathrm{BW}$ wordt tegengehouden door artikel 69 sub c Ow I:

'Wanneer de wet van toepassing wordt, heeft dat niet tot gevolg dat alsdan:

(...)

c. het bedrag van een vordering wordt gewijzigd' ${ }^{33}$.

Maatgevend voor de omvang van B's ten tijde van de inwerkingtreding aanwezige recht op schadevergoeding blijft derhalve ook nadien het oude recht. De hoogte van het vorderingsrecht wordt geëerbiedigd: bestaandle vorderingsrechten en schulden

'worden bevroren in de omvang die zij bij - dat wil zeggen vlak vóor - de inwerkingtreding van het nieuwe recht hadden $(. .)^{34}$.

De onmiddellijke werking zou wèl aansprakelijkheid van A voor de kosten van lijkbezorging hebben teweeggebracht.

Artikel 69 sub c Ow I heeft ook betekenis voor degene die uit hoofde van onrechtmatige daad op het moment van de invoering jegens iemand aansprakelijk was en door die daad winst heeft opgestreken. Deze laedens kan na 1 januari 1992 niet op vordering van de gelaedeerde door de rechter worden veroordeeld tot betaling van (een deel van) de winst, voor zover daardoor de omvang die zijn aansprakelijkheid volgens het oude recht had zou worden gewijzigd ${ }^{35}$.

\subsubsection{Bijzondere regel voor verzuim}

Verzuim treedt volgens artikel 6:83 sub b BW zonder ingebrekestelling in, wanneer de verbintenis voortvloeit uit onrechtmatige daad en niet terstond wordt nageko-

32. Zie Asser-Hartkamp I, nr. 481.

33. Zie over artikel 69 sub o Ow I Parl. Gesch. Overgangsrecht, p. 43.

34. Aldus de toelichting, Parl, Gesch. Overgangsrecht, p. 39.

35. Zie over deze in artikel 6: $104 \mathrm{BW}$ neergelegde vernieuwing Asser-Hartkamp I, nr. 447.Zie over de overgangsrechtelijke kant van de zaak Parl. Gesch. Overgangsrecht, p. 63 subi, 308 . 
men. Onder het oude recht was juist wel een ingebrekestelling vereist voor werzuim $^{36}$. Met het oog hierop bepaalt artikel 183 Ow I:

Artikel 83 van Boek 6 is niet van toepassing (...) op het niet nakomen van een op dat tijdstip (dat wan de inwerkingtreding, $\mathrm{HvdB}$ ) bestaande verbintenis als bedoeld in onderdeel b van dat artikel." 37

\subsubsection{Blokkering van de 'paardesprong"}

Krachtens artikel 6:257 BW kan een ondergeschikte, indien hij door een wederpartij van zijn werkgever wordt aangesproken, onder bepaalde voorwaarden een beroep doen op een door zijn werkgever met die wederpartij overeengekomen exoneratiebeding. Aan artikel 6:257 $\mathrm{BW}$ komt onmiddellijke werking toe op grond van artikel 194 Ow I. De tekst hiervan luidt:

'Van het tijdstip van het in werking treden van de wet af is artikel 257 van toepassing op een ondergeschikte wiens gedraging vór dat tijdstip tot aansprakelijkheid heeft geleid'.

Een uitdrukkelijke overgangsbepaling wordt door de minister wenselijk geacht; omdat niet zeker is, of artikel $6: 257 \mathrm{BW}$ wel het oude recht weergeeft ${ }^{38}$. Wijkt deze regel van het huidige recht af, dan houdt dat een inbreuk op artikel $69 \mathrm{Ow} I$ in. De onmiddellijke werking van artikel 6:257 BW geldt ook in een op het moment van de inwerkingtreding reeds lopende procedure ${ }^{39}$.

\subsubsection{Aansprakelijkheid 'in statu nascendi"}

Tot nu toe ging het over gevallen waarin, naar kon worden vastgesteld, schadle als gevolg van onrechtmatige daad reeds bij de inwerkingtreding was geleden. Als gezegd is echter niet ondenkbar dat de vereisten voor schadeplichtigheid uit onrechtmatige daad niet alle voór of ná de inwerkingtreding zijn vervuld, maar dat aan sommige ervoor en aan andere erna is voldaan. Hoe dan het toepasselijke recht wordt bepaald, is voorwerp van bespreking in nr. 6.5.2.1. Welk recht op zulke situaties toepasselijk is, indien de schade het laatst vervulde vereiste was, maar niet is vast te stellen of deze vóor dan wel na de inwerkingtreding is ontstaan, wordt geregeld in artikel $173 \mathrm{OW}$ I (nr. 6.5.2.2). Genoemde overgangsbepaling zet ik in nr. 6.5 .2 .3 af tegen enkele andere.

36. Zie Asser-Hartkamp I, nr. 369.

37. Zie de toelichting, Parl. Gesch. Overgangsrecht ${ }_{\text {p. }}$. 162-163, alsmede H. Stein, preadv., p. 110 en (kritisch) Spier en Sterk, preadv., p. 98-99.

38. Volgens Asser-Hartkamp I, nr. 343, is dit wel het geval.

39. Zle over artikel 1940 w I Parl. Gesch. Overgangsrecht, p. 63 subj, 172-173. 


\subsubsection{Schade met vertraging; ontstaanstijdstip bekend}

Bij de figuur van de gespreide vervulling van vereisten voor schadeplichtigheid op grond van onrechtmatige daad kan met name worden gedacht aan een (onrechtmatig) handelen of ander voorval vóór de inwerkingtreding, dat pas tot schade leidt na verloop van kortere of langere tijd ná de inwerkingtreding ${ }^{40}$. Schade met vertraging, waaronder ook 'sluipende schade' 41 valt, kan bij voorbeeld ontstaan als gevolg van het gebruik van langzaam werkende vergiften, blootstelling aan straling of aan gevaarlijke dampen of stoffen, het mengen van gif in een hoestdrank, waarvan pas later wordt gedronken en lekkages van voor het milieu schadelijke stoffen ${ }^{42}$. Steeds gaat het erom of, en zo ja, in hoeverre de tussentijds van kracht geworden nieuwe wet ook geldt voor deze gevallen, waarin een handelen of ander gebeuren vóór de invoering pas nadien tot schade in juridische zin leidt. Aansprakelijkheid kan hiermee staan of vallen, namelijk daar waar het nieuwe recht anders dan voorheen een aansprakelijkheid kent (of wellicht juist niet kent).

Volgens de overgangswetgever geldt in dit soort gevallen het volgende:

'Is bij de inwerkingtreding van de nieuwe wet nog niet aan al die vereisten (van het oude recht voor aansprakelijkheid, HvdB) voldaan, dan geldt de nieuwe wet; $z i j$ stelt dan de vereisten vast en $z i j$ bepaalt de gevolgen.'

In geval van tussentijdse inwerkingtreding van de nieuwe wet

"zal zij bepalend zijn voor de verbintenissen tot schadevergoeding: de oude wet is ingetrokken voordat zij aansprakelijkkheid kon doen ontstaan - na haar intrekking geldt zij niet meer." ${ }^{43}$

Er is hier sprake van een zogenoemd 'onvolledig complex van rechtsfeiten':

"Voor aansprakelijkheid uit onrechtmatige daad zijn, behalve die daad zelf, ook causaal verband, schuld of toerekenbaarheid en schade vereist. Heeft zo'n complex, voor zover het uit feiten bestaat, zich nog slechts ten dele verwezenlijkt bij de inwerkingtreding van de nieuwe wet, dan bepaalt de nieuwe wet - en zij alleen - aan welke vereisten moet zijn voldaan, i.c. voor (...) de aansprakelijkheid: Daarvoor kunnen andere feiten van vóór de inwerkingtreding relevant worden dan het toen geldend recht aanwees. Voor zover een

40. De wijze watarop de schade wordt berekend ("abstract" of "concreet") kan vain belang zijn voor het antwoord op de vraag, wanneer de schade geacht moet worden te zijn geleden, zie Parl. Gesch. Boek 6, p. 475; Asser-Hartkamp 1, nr. 419. Ik lat dit punt werder buiten beschowwing.

41. Waarover de inaugurele rede van Spier. Zie ook de omschrijving van dit begrip door Spier en Sterk, preadv.. P. 91 .

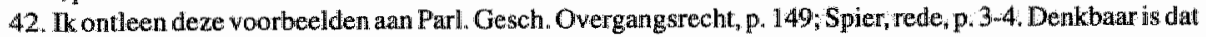
nilet kan worden vastgesteld of de schade nu vóó de in werkingtreding of daarna is ingetreden. Zie daarvoor artikel 173 Ow 1 , waarover ni, 6.5.2.2 hierna.

43. Aldus de toelichting, Parl. Gesch, Overgangsrecht, p. 149-150. Zie ook p. 151-152. 
door de nieuwe wet gesteld vereiste reeds was vervuld vóór de inwerkingtreding en darop het oude recht van toepassing was, komt de nieuwe wet er niet op terug."

Volgens de minister kan de vervulling van vereisten onder de gelding van het oude recht dus ook na de inwerkingtreding nog van belang blijven. Dit blijkt eveneens uit zijn antwoord op een vraag in het voorlopig verslag van de Eerste Kamer ${ }^{4}$ naar welk recht ingevolge onder meer artikel 173 Ow I de onrechtmatigheid van een handeling moet worden beoordeeld, die in december 1991 is verricht en ten gevolge waarvan in januari 1992 schade is ontstaan:

'Indien een nieuwe wet een (nieuw) rechtsgevolg verbindt aan een onrechtmatige daad, en dat rechtsgevolg ook kan worden verbonden aan vóór de inwerkingtreding gepleegde onrechtmatige daden, moet de vraag of $\mathrm{zo}^{\circ} \mathrm{n}$ daad als onrechtmatig behoort te worden beschouwd, worden beoordeeld naar het recht dat gold toen de daad werd verricht." 46

Dat een door de nieuwe wet gesteld vereiste al was vervuld onder de gelding van het oude recht is alleen mogelijk, als oud en nieuw recht hetzelfde vereiste stellen. lets anders is er aan de hand, indien het nieuwe recht een strengere of juist een soepeler eis stelt: Uit bovenstaande citaten vloeit voort dat dan het nieuwe recht bepam lend is. Stel in 1991 ontplofte een gasleiding die lek was geraakt door een korte tijd eerder plaatsgevonden hebbende grondverzakking. Van de door artikel 1405 (oud) BW geëiste fouten in onderhoud of constructie was geen sprake. Wel is voldaan aan de maatstaf van artikel 6:174 lid $1 \mathrm{BW}$, dat de leiding niet voldoet aan de eisen die men in de gegeven omstandigheden daaraan mag stellen, en daardoor gevaar voor personen of zaken oplevert ${ }^{47}$. Zou de schade (bij voorbeeld de geheel onverwachte instorting van een op enige afstand gelegen huis) zich pas na de inwerkingtreding voordoen, dan is laatstgenoemde bepaling maatgevend.

Omdat ten tijde van de invoering nog in het geheel geen recht op schadevergoeding met de daar tegenover staande aansprakelijkheid aanwezig was, kan artikel 69 sub a-c OW I niet in actie komen bij schade met vertraging. Ook onderdeel d van genoemde bepaling is hier niet van toepassing, omdat het ontstaan van het vordewingsrecht niet het gevolg is van het enkelle toepasselijk worden van de nieuwe wet, maar van het nadien zich voordoen van de schade. In het voorbeeld van de ontploffende gasleiding kan derhalve de aansprakelijkheid ex artikel 6:174 BW intreden. Mijns inziens vloeit dit resultaat voort uit de hoofdregel van de onmiddellijke werking, ook al waren bij de inwerkingtreding nog niet alle vereisten vervuld, zoals artikel $68 a$ lid 1 Ow I eist (zie nr. 2.5.1.1 sub b hiervór).

44. Parl. Cesch. Overgangsrecht, p. 12. Zie ower "onvolledige complexen wan rechtsfeiten" ook de nrs; $2,1.3,2.5 .1 .1$ subc. 2 en $2.5,1.2$ subc. 2 hierwớr.

45. Parl. Gesch. Overgangsrecht, p, $151-152$.

46. Parl. Gesch, Owergangstecht, p. 152 sub het gast hier om het vereiste van de juridische waardering (de onrechtnatigheid van de daad), zie de ars. 2.4.1.1 en 2.5.1.1 sub c. 3 hiervór.

47. Het woorbeld is ontleend atan Asser-Hartkanp III, nr. 188. 
Brunner ${ }^{48}$ bestrijdt het systeem van de Overgangswet inzake schade met vertraging door te stellen dat volgens de Hoge Raad

"de verbintenis tot vergoeding van schade ontstaat op het moment van de onrechtmatige daad, ook al wordt de schade eerst in de toekomst geleden."

Naar mijn mening gaat dit echter alleen op voor de in artikel 6:105 BW geregelde nog niet ingetreden schade (vgl. nr. 6.5.4 hierna). Men kan toch moeilijk volhouden dat in een casus als die van de ontploffende gasleiding de verbintenis tot vergoeding wan de schade van de gelaedeerde huiseigenaar reeds is ontstaan op het moment dat de gasleiding ontplofte?

De Vries Lentsch-Kostense ${ }^{49}$ bepleit analoge toepassing van het in nr 6.5 .2 .3 hierna te noemen artikel V lid I van wetsvoorstel 21202 op gevallen van door artikel 6:173 BW beheerste aansprakelijkheid voor milieuschade, voortvloeiend uit een gebeurtenis die dateert van voór de inwerkingtreding,

'zeker indien in casu blijkt dat ook de verzekering niet aanknoopt bij het tijdstip waarop de schade ontstaat.'

Als grondslag voor deze analoge toepassing voert genoemde auteur artikel 75 lid 1 Ow II aan. Haar standpunt komt mij als juist voor.

\subsubsection{Schade met vertraging; ontstaanstijdstip niet bekend}

Soms liggen de zaken nog wat ingewikkelder. Zo komt het voor dat achteraf niet meer valt te achterhalen wanneer nu eigenlijk precies de schade is ingetreden: vór de invoering of daarna, terwijl dit voor de keuze tussen oud en nieuw recht in overgangssituaties wel beslissend is (zie het vorige nr.). Dit kan onder meer voorkomen bij milieu- en produktschade en bij een ziekte die zich pas openbaart enige tijd nadat $\mathrm{zij}$ is uitgebroken (zie ook de voorbeelden genoemd in het vorige nr.). De "aanknopingsverlegenheid" 50 waarin de wetstoepasser dan zou komen te verkeren, wordt in artikell $173 \mathrm{Ow} I$ als volgt voorkomen:

'Is voor de al dan niet toepasselijkheid van de bepalingen der wet omtrent aansprakelijkheid en schadevergoeding beslissend, of een schade vớr of na het in werking treden van de wet is ontstaan, en blijkt dit niet, dan is beslissend, of de schade voor of na het in werking treden van de wet is bekend geworden."

Het behoeft niet juist de benadeelde te zijn, die kennis neemt van de schade; deze kan kort vóor de inwerkingtreding door letsel bewusteloos zijn geworden. Evenmin is nodig dat de schade algemeen bekend werd ${ }^{51}$.

48. In: Verslag NJV-vergadering, p. 34.

49. In: Quod licet, p. $477-478$.

50. Zie Joppe, diss.., p. 13-14.

51. Aldus Parl. Gesch. Overgangsrecht, p. 150. 
Door het tijdstip van het bekend worden wan de schade doorslaggevend te laten zijn voor de situaties waarin niet is vast te stellen of deze nu vóor of na de invoering haar intrede heeft gedlaan, wordt de mogelijkheid geopend dat een in werkelijkheid nog onder de gelding van het oude recht voorgevallen schade wordt behandeld alsof zij nadien was voorgevallen, zodat het nieuwe recht bepalend wordt voor de aansprakelijkheid. Mogelijk is daardoor:

- dat een schade is ontstaan vóor de inwerkingtreding, maar dat dit niet kan worden vastgesteld;

- dat deze schade na de inwerkingtreding is bekend geworden;

- en dat daardoor één van de aansprakelijkheden van titel $6.3 \mathrm{BW}$ is ontstaan, die in het voorheen geldlende recht niet aanwezig waren (aansprakelijkheid voor kinderen, vertegenwoordigers, gebrekkige zaken etc.). In afwijking van artikel 69 sub d Ow I kan hier dus door het toepasselijk worden van de nieuwe wet een vorderingsrecht ontstaan doordat alle feiten die die wet daarvoor vereist reeds voordien waren voltooid ${ }^{52}$. Wel is het (uiteraard) zo dat door de onmogelijkheid het ontstaanstijdstip van de schade te achterhalen, op grond van artikel $173 \mathrm{lid} 1 \mathrm{OW}$ I de aansprakelijkheid pas een aanvang neemt met het bekend worden van de schade (in het veronderstelde geval derhalve na de inwerkingtreding). Artikel 173 lid 1 Ow I kan ook afwijkingen opleveren van de onderdelen a-c van artikel 69 Ow $1^{53}$.

\subsubsection{Het schadeveroorzakende voorval als alternatief criterium}

Niet overal in het overgangsrecht wordt bij de onrechtmatige daad gegrepen naar het moment waarop de schade voorvalt of bekend wordt als criterium voor de bepaling van het toepasselijke recht. Voorbeelden hiervan zijn:

- de overgangsbepaling bij het nieuwe produktenaansprakelijkheidsrecht ${ }^{54}$, op de aansprakelijkheid van producenten ter zake van voór de inwerkingtreding in het verkeer gebrachte produkten is het oude recht toepasselijk;

- artikel $256 \mathrm{OW}$ I: aanvaringen van vóór de inwerkingtreding worden beheerst door het oude recht. Dit geldt ook voor door een schip op andere wijze veroorzaakte schade, indien het ongeval vóór de inwerkingtreding heeft plaatsgevonden;

- artikel V lid 1 wetsvoorstel $21202^{55}$; de nieuwe wet is niet toepasselijk, indien de schadeveroorzakende gebeurtenis vóór de inwerkingtreding heeft plaatsgevonden;

52. Vgl. Parl. Gesch. Overgangsrecht; p. 299.

53. Zie woor het werzekeringsaspect van artikel 173 lid 1 Ow I het volgende nr.

54. Artikell II van de Wet van 13 september 1990 tot aanpassing van het Burgerlijk Wetboek aan de richtlijn van de Raad yan de Europese Gemeenschappen inzake de annsprakelijkheid voor produkten met gebreken, Stbl. 487, en van de Wet van 11 september 1991, Stbl. 470, strekkende tot aanpassing van Boek $6 \mathrm{BW}$ aan genoemde richtlijn. Deze laatste wet is in werking getreden met ingang van 1 januari 1992 (zie het KB valn 16 december 1991, Stb》. 690).

55. Aanvulling van de Boeken 3,6 en 8 nieuw $\mathrm{BW}$ met regels betreffende de aansprakelijkheid voor gevaarlijke stoffen en verontreiniging van lucht, water of bodem; zie echter ook lid 2 van artikel $V$. 
- artikel V lid 1 wetswoorstel $21556^{56}$ : artikel 47 van de Wet bodembescherming is mede toepasselijk, indien de oorzaak van de verontreiniging of aantasting van de bodem zich vóór de inwerkingtreding heeft voorgedaan;

- artikel 11 van het voorstel voor een EG-richtlijn inzake dienstenaansprakelijkheid ${ }^{57}$ : de richtlijn is niet toepasselijk op diensten die zijn verricht vóór de datum waarop de door de Lid-Staten tot stand te brengen uitvoeringsvoorschriften in werking treden.

Voor zover voorhanden houden de toelichtingen op bedoelde overgangsregels het volgende in. De overgangsregel bij het nieuwe produktenaansprakelijkheidsrecht is ontleend aan de EG-richtlijn terzake en is in overeenstemming met het SER-advies over produktenaansprakelijkheid ${ }^{58}$. In dat advies wordt gezegd dat een op risico-aansprakelijkheid gebaseerde regeling met het oog op de rechtszekerheid niet met terugwerkende kracht (bedoeld zal zijn: onmiddellijke werking) mag worden ingevoerd 59 :

Dat aanvaringen van vóór de invoering van Boek $8 \mathrm{BW}$ ook nadien beheerst blijven door het oude recht stemt overeen met de traditie in het overgangsrecht inzake aanvaring. Daarbij sluit de regel over door een schip op andere wijze veroorzaakte schade zich aan met het oog op de artikelen 8:541 en 1002 BW, waarin aanvaringsregels in beginsel van toepassing worden verklaard op door een zee- respectievelijk binnenschip veroorzaakte schade zonder dat een aanvaring plaatshad ${ }^{60}$.

Ten aanzien van de nieuwe risico-aansprakelijkheden voor gevaarlijke stoffen etc. wordt de verzekerbaarheid aangevoerd als argument voor de voorgestelde overgangsregel. Deze zou in gevaar komen, indien ook schadeveroorzakende gebeurtenissen uit het verleden onder de reikwijdte van de nieuwe aansprakelijkheden zouden vallen, omdat de saneringsmaatregelen van de afgelopen jaren vaak uiterst kostbaar waren en moeilijk te voorspellen is waar tot nu toe nog verborgen schaden aan het licht zullen komen. Daarom zou het evenmin aangaan dat de uitbreiding van aansprakelijkheid ter zake van in wezen reeds ontstane schade onder bestaande, daarop niet afgestemde, polissen zou komen te vallen ${ }^{61}$.

\section{a. Vergelijking van stelsels}

De hierboven genoemde overgangsregels hebben gemeen dat daarin ter bepaling van het toepasselijke recht niet, zoals in het systeem van de Overgangswet, wordt aangeknoopt bij het moment van het intreden of bekend worden van de schade, maar bij de schadeveroorzakende gebeurtenis. Van de motieven die daarvoor worden aangevoerd, zijn voor een beoordeling van het systeem van de Overgangswet. vooral interessant het belang van de rechtszekerheid en dat van de verzekerbaarheid van de aansprakelijkheid ${ }^{62}$.

56. Uitbreiding van de Wet bodembescherming met een regeling inzake de sanering van de bodem.

57. PbEG 18 januari 1991 , nr C 12/11.

58. TK. vergaderjaar 1985-1986, 19636, nr. 3 (memorie van toelichting), p. 13.

59. Advies Produktenaansprakelijkheid, Publikatie nr. $4-18$ januari $1980, \mathrm{p} .47$.

60. Zie TK, vergaderjaar 1988-1989,21 265, nr. 3 (memorie van toelichting), p. 7.

61. Aldus TK, vergaderjaar 1988-1989, 21 202, nr. 3(memorie vain toelichting), p. 14-15.

62. Ik ga er uiteraard wan wit dat op het tijdstip van de inwoering de schade nog niet (volledig) is vergoed, omdat anders geen overgangssituatie aamwezig is. 
Troedt de schade direct in na het schadeveroorzakende voorval, dan leiden beide stelsels tot eenzelfde resultaat: bij een voorval en schade van vóór de inwerkingtreding is en blijft op de aansprakelijkheid oud recht toepasselijk. Het is deze categorie gevallen die zich het meest zal voordoen ${ }^{63}$. Eenzelfde resultaat levert ook op het evenement dat pas na enige tijd, maar nog wel vóoúr de invoering, schade tot gevolg heeft gehad. Over blijft de (kleine) minderheid van de gevallen waarin de beide overgangsistelsels verschillende uitkomsten genereren. Dit doet zich voor, ingeval het evenement vớr de invoering plaatsvond en de (juridische) schade pas daama intreedt of bekend wordt: op aansprakelijkheid en schadevergoeding is dan in het stelsel van de Overgangswet in beginsel nieuw recht toepasselijk; in het alternatieve stelsel blijft oud recht toepasselijk.

Stel dat in deze laatste feitenconstellatie vaststaat dat de schade pas na de inwerkingtreding is ontstaan en dat het nieuwe BW voor de casus in kwestie een voorheen niet bestalande wettelijke aansprakelijkheid of een verzwaring van een bestaande wettelijke aansprakelijkheid in petto heeft. Dan zou het systeem van de Overgangswet problematisch kumnen zijn bij een verzekeringspraktijk waarin voor het bestaan van dekking onder een polis bepalend is of het schadebrengende evenement tijdens de contractsduur voorviel (het zogenoemde act committed-systeem). Voor de algemene verzekeringsrisico's is echter een ander stelsel maatgevend, namelijk het loss occurrence-systeem: gedekt wordt schade die ontstaat binnen de contractsduur. Zie bij voorbeeld een beding als het volgende, ontleend aan een zeer recente AVP-polis:

'Verzekerd is de aansprakelijkheid van de verzekerden (...) voor schade veroorzaakt of ontstaan tijdens de periode dat de dekking van deze verzekering van kracht is."

Dit systeem past bij dat van de Overgangswet. De dekking blijft bij toepassing van het loss occurrence-stelsel bestaan bij verandering van de aansprakelijkheidsregeling door de inwerkingtreding ${ }^{64}$. Plausibel is de conclusie van de minister uit het bovenstaande,

'dat het verzekeringsbelang zich niet in het algemeen tegen het gekozen uitgangspunt verzet.'

Daarmee lijkt het belang van de rechtszekerheid in beginsel evenmin aan het stelsel van de Overgangswet in de weg te staan.

De tweede mogelijkheid bij schade met vertraging is dat niet vaststaat of de schade zich vór of na de inwerkingtreding heeft voorgedaan, maar deze pas nadien bekend is geworden. In sommige gevallen zal artikel 173 lid 1 Ow I in afwijking van

63. Zo ook Parl. Giesch. Overgangsrecht, p. 160. Op cen voorval en schade van na de inwerkingtreding is uiteratard nieuw recht voepasselijk; dat is echter geen owergangskwestie.

64. Zle hiervoor Parl, Gesch. Overgangsrecht, p. 161, naar aanleiding van opmerkingen van Spier, Kwartalbericht Niew BW 1985, p. 54 en van Bakels, Kwantaalbericht Nienw BW 1985, p. 55. 
artikel 69 sub b-d Ow $I^{65}$ een nieuwe wettelijke aansprakelijkheid of aen verzwaring van een bestaande wettelijke aansprakelijktheid met zich meebrengen.

Van belang is ten sllotte nog dat het alternatieve criterium (bepalend is wanneer de schade is veroorzaakt) moeilijkheden oplevert, indien niet is vast te stellen of dit voor dan wel na het in werking treden van de nieuwe wet is gebeurd. De toelichtende stukken bevatten het voorbeeld van schade ontstaan door het nallaten van voldoende onderhoud ${ }^{66}$. Volgens de minister $z a l$ in de gevallen van schade met vertraging

"meestal het precieze tijdstip van die gebeurtenis (waarop de aansprakelijkheid berust, HvdB) moeilijk meer zijn te achterhalen, maar het tijdstip waarop de schade is ingetreden of bekend geworden, naar verhouding juist gemakkelijker. Dat zelfde geldt ook, wanneer de schade ontstat ten gevolge van een of meer uit een reeks handelingen zonder dat precies valt aan te geven door welke daarvan het gevolg is veroorzaakt."67

Dit aspect van rechtszekerheid is doorslaggevend geacht om hier aan het voor de onrechtmatige daad gekozen overgangsregime, ondanks bezwaren in de literatuur; vast te houden. In het systeem van de Overgangswet is het moment van de schadeveroorzakende gebeurtenis overigens niet steeds irrelewant ${ }^{68}$.

Spier en Sterk hebben bepleit om ten aanzien van de aansprakelijkheidsvraag in de Overgangswet aan te knopen.

"bij het recht dat gold ten tijde van de gebeurtenis die tot aansprakelijkheid leidt. 69

Op grond van al het bovenstaande acht $\mathrm{ik}$ dit pleidooi niet overtuigend ${ }^{70}$.

\subsubsection{Aansprakelijkheid niet aanwezig}

Zoals reeds bleek in nr. $6: 2$ hiervór is er in het nieuwe BW een aantal aansprakelijkheden opgenomen, dat in het oude recht onbekend was, en zijn andere aansprakelijkheden meer omvattend geworden. Het is heel goed mogelijk dat de vereisten die voor

65. 2 ile het vorige nir.

66. Wgl. Parl Gesch. Overgangsrechti, p. 149.

67. Parl. Gesch. Overgangsrech, p. 160 (het betoog betreft hier de vergchillende aingangspunten wan de armtikelen 173 en 182 Ow 1 , warover kort nr. 7.9 hierma). Ik wijs in dit verband nog op artikel V lid 2 wets woorstel 21 202, warower in de memorie van antwoord aan de Tweede Kamer (vergaderjaar 1990-1991, 21 202 , nr. 6,28 sub ej onder meer wordt opgernerkt dat het moment van het bezwijken van de verpakking zich achteraf moeilijk meer zal laten vaststellen en daarvoor in begingel ook geen afzonderlike nieuwe gebeurteris nodig zal xijn, doch alleern een natuurhijk proces, zoals dootroesten van een sted ien wat."

68. Dit blikt uit Pat. Gesch. Overgangsrecht, p. 151 sub a, 152 sub a (geciteerdin nr. 6.52 hiervorit).

69. Preadv. p. 85-101 (100). Zie eerder in deze zon Spier, Kwartalbericht Nieuw BW J985, p. 53-54.

70. Zie over het betoog vai Spier en Sterk ook (kritisch) De Vries Lentsch-Kostense, in: Quod licet, p. 473 478. Wel bepleit zi woor door artikel $6: 173 \mathrm{BW}$ beheerste milieaschade analoge toepassing van artikel $V$ lid I. wan wetsyoorstel 21202 (zie nr. 6.5.2.1 slot hierworo). 
deze (ver)nieuw(d)e aansprakelijkheden gelden op het tijdstip van de inwerkingtreding reeds waren vervuld. Ter illustratie voer ik het volgende voorbeeld op.

In december 1991 werd door de nieuwe eigenaar van een in 1985 gebouwd huis de vloerbedekking vervangen. De op de eerste verdieping te leggen vloerbedekking werd door de stoffeerders op de plaats van bestemiming gebracht via het op die verdieping aanwezige balkon. Bij het manoeuvreren met één van de omvangrijke rollen tapijt stootten zij tegen de balkonmuur aan. Deze stortte naar beneden, waardoor een toevallige voorbijganger letsel opliep. Oorzaak van de instorting bleek te zijn ondeugdelijk metselwerk door een destijds bij de bouw van het huis betrokken onderaannemer. De voorbijganger spreekt onder anderen de hoofdaannemer aan tot schadevergoeding ${ }^{71}$.

Ik ga ervan uit dat de hoofdaannemer onder oud recht niet aansprakelijk was uit hoofde van artikel 1401 (oud) BW jegens het slachtoffer en dat hij krachtens artikel 6:171 BW (aansprakelijkheid voor niet-ondergeschikten) wel jegens deze aansprakelijk zou zijn, nu de vereisten daarvoor zijn vervuld. Dan zou artikel $68 a$ lid 1 Ow I tot gevolg hebben dat deze aansprakelijkheid vanaf de inwerkingtreding zou bestaan. Dit wordt echter tegengegaan door artikel 69 sub d Ow $\mathbf{I}$, luidend:

'Wanneer de wet van toepassing wordt, heeft dat niet tot gevolg dat alsdan:

(...)

d. een vorderingsrecht ontstaat, indien alle feiten die de wet daarvoor vereist, reeds voordien waren voltooid' ${ }^{72}$.

Resultaat: de hoofdaannemer is op 1 januari 1992 niet aansprakelijk geworden uit hoofde van artikel 6:171 BW. Was de schade na de inwerkingtreding gevallen, dan zou hij wel aansprakelijk zijn geweest (zie nr. 6.5.2.1 hiervóór). Geëerbiedigd wordt in de Overgangswet dus niet alleen het verkregen zijn van rechten, maar ook het niet verkregen zijn daarvan. Niet echter wordt door artikel 69 sub d Ow I tegengegaan dat vanaf het moment van het toepasselijk worden van het nieuwe BW een vorderingsrecht uitsluitend wordt verbonden aan een op dat moment bestaande toestand die in een bepaling daaruit wordt omschreven ${ }^{73}$. Als voorbeeld hiervan wordt in de parlementaire stukken gegeven de 'zorgplicht' die krachtens artikel $6: 27 \mathrm{BW}$ rust op degene die een individueel bepaalde zaak verschuldigd is ${ }^{74}$.

\subsubsection{Oplopende en opeenvolgende schaden}

A. Op oudejaarsavond 1991 nam Arend alvast een voorschot op het nieuw-

71. Het woorbeeld is geänspireerd door de casus die heeft geleid tot Rb. Zwolle 6juni 1990, BR 1990, p. 861.

72. Zie hierover de nrs. 2.5.1.1 sub c.2 en 2.5.1.2 sub e hierwór.

73. Zie over de toestand als vereiste de nrs. 2.4.1.1 en (in verband met onmiddellijke werking) 2.5.1.1 sub 6.1 hỉervớr.

74. Zie hieromtrent nader Parl. Gesch. Overgangsrecht, p. 43-44, 45 . 
jaarswuurwerk en stak een vuurpijl af. Deze trof om 23.45 uur een bedrijfspand dat daardoor in brand vloog. Als gevolg van overspringende vonken vloog om 00.05 uur een belendend pand van hetzelfde bedrijf ook in brand. Voor de door de vuurpijl veroorzaakte schaden wordt verhal gezocht op Arend.

B. lemand "rijdt wlak vóór de inwerkingtreding een auto aan met twee inzittenden, beiden gehuwd en kostwinner; de ene inzittende is op slag dood, de andere overlijdt kort na de invoering; de aannijding vindt plaats op een terrein waar een bord is geplaatst met het opschrift ' $U$ betreedt dit terrein voor eigen risico"75.

C. Fabriek A loosde gedurende de jaren 1991 en 1992 onrechtmatig afvalstoffen in de Rijn. Tuinder B ondervond daarvan grote schade. In 1993 start hij een procedure tegen fabriek $A$ teneinde zijn schade vergoed te krijgen. Vaststaat welke lozingen in 1991 tot schade hebben geleid en welke lozingen in 1992 dit effect hebben gehad.

Eén gebeurtenis kan meerdere achtereenvolgende schaden tot gevolg hebben (voorbeelden A en B) of schade die in de loop der tijd alsmaar hoger oploopt, zoals bij een verwonding door een ongeval (kosten van verpleging, derving van inkomsten etc.). Ook kan het zo zijn, dat een onrechtmatig handelen of nalaten zich over een zeker tijdvak uitstrekt, waardoor gedurende dit tijdvak doorlopend schade wordt geleden (voorbeeld C). Overgangsrechtelijk wordt dit soort casusposities interessant, indien de ene schade vóór en de andere na de inwerkingtreding valt (voorbeelden $\mathrm{A}$ en B), of indien een deel van een oplopende schade vóór en een ander deel na de inwerkingtreding intreedt, of indien voortdurende gedragingen zowel vór als na de inwerkingtreding tot schade leiden (voorbeeld C).

Voorbeeld A valt onder de eerste zin van artikel 173 lid 2 OW I:

'De aansprakelijkheid voor schade die is ontstaan of bekend geworden na het in werking treden van de wet, wordt, ook met betrekking tot haar omvang, naar het tevoren geldende recht beoordeeld, indien die schade voortspruit uit dezelfde gebeurtenis als een eerdere door de benadeelde geleden schade waarop dat recht van toepassing was.'

Het gaat hier om de vraag onder welk recht schaden ressorteren, die na de inwerkingtreding vallen of bekend worden, indien op de daarvór uit dezelfde gebeurtenis voortgevloeide schade(n) het oude recht toepasselijk is. Die 'nieuwe' schaden worden beheerst door het oude recht, zo volgt uit de geciteerde regel. Dit geldt ook in geval van verergering na de invoering van een schade die voortspruit uit een gebeurtenis (bij voorbeeld verwonding) van vó́r 1 januari 1992 en die ook reeds voordien is aangevangen. Het is volgens de minister - en zijn redengeving komt als

75. Dit aan Spier, Kwartaalbericht Nieuw BW 1985, p. 54, ontleende voorbeeld wordt gegeven in het voor lopig verslag vari de Tweede Kamer, Parl. Gesch. Overgangsrecht, p. 158. 
juist voor - niet wenselijk om in dit soort gevallen op aansprakelijkheidsvragen het nieuwe recht toepasselijk te laten zijn:

"Stel dat schade vóór het in werking treden der nieuwe wet is aangevangen en dat iemand daarvoor krachtens artikel 1401 aansprakelijk is geworden; als de schade zich nadien voortzet, is het billijk dat dezelfde persoon aansprakelijk blifft, en niet, volgens de regels van het nieuwe recht, naast of in plaats van hem een ander. Dit geldt ook voor de maatstaven waarnaar de omvang der te vergoeden schade wordt bepaald. ${ }^{76}$

Hiermee worden uitzonderingen gemaakt op de hoofdregel van de onmiddellijke werking: in de eerste plaats blijven de bestaande verbintenissen tot schadevergoeding in de ogen van de overgangswetgever ook na de inwerkingtreding beheerst cloor oud recht. Voor de artikelen 6:102, 103, 104 (in somnige gevallen) en 105 BW bestaat volgens de overgangswetgever echter een uitzondering: deze kunnen wel direct gaan werken voor overgangssitwaties ${ }^{77}$. Ik vraag mij af of dit laatste wel strookt met de tekst van artikel 173 lid 2 eerste (en tweede) zin Ow I.

In de tweede plaats worden verbintenissen tot schadevergoeding, die na de inwerkingtreding uit een voordien voorgevallen evenement ontstaan, onder het oude recht gebracht, terwijl de hoofdregel van de onmiddellijke werking (het uitgangspunt van artikel 173 lid $1 \mathrm{OW}$. ) hier naar het nieuwe recht zou verwijzen.

Op voorbeeld B is artikel 173 lid 2 tweede zin Ow I van toepassing, luidend:

'Hetzelfde geldt voor de aansprakelijkheid wegens iemands overlijden na het tijdstip van het in werking treden van de wet als gevolg van letsel dat vóór dat tijdstip is ontstaan."

Voor de na de inwerkingtreding ontstane aanspraak van de nabestaanden zou zonder de geciteerde bepaling krachtens de hoofdregel van de onmiddellijke werking nieuw recht gelden, terwijl voor de aanspraak van de verwonde oud recht zou blijven gelden. Artikel 173 lid 2 eerste zin Ow I zou daarin geen verandering brengen, omdat hier geen sprake is van schaden van én benadeelde, maar van meerdere benadeelden. De minister acht dit resultaat weinig wenselijk; ook zou het strijden met de aan artikel 173 lid 2 eerste zin Ow I ten grondslag liggende gedachte (zie thierboven). Meer voor de hand ligt het naar zijn mening om de schade door het overlijden hier op te vatten als een vervolg op de schade door het letsel ${ }^{78}$.

76. Purl. Gesch, Overgangsrecht, p. $1.50 \mathrm{~m} 1.51$, al waar ook wordt toegelicht waarom artikel 173 lid 2 eerste zin Ow I (abusievelijk wordt gesproken over het derde lid dat echter niet bestaat) alleen geldt voor schade(n) wan sén benadeelde. Zie echter de tweede zin van artikel $173 \mathrm{lid} 2 \mathrm{Ow}$, die hierna aan de orde komt, alsmedle (kritisch) Spier en Sterk, preadv., p. 88-89,97 e.v. ad voorbeeld 7c. Afwijking van artikel $173 \mathrm{lid} 2$ eerste zin OW II zou hier in sommige gevallen well icht mogelijk zijn op grond van artikel 6.2 lid 2 BW, zie nr: 2.5 .3 hiervóót.

77. Zie Parl. Gesch. Overgangsrecht, p. 308. Of dit ook geldt voor artikel 6:102 BW (hoofdelijkheid bij "medeschuld') is overigens gezien p. 300-30I van genoemde Parl. Gesch., waarnaar op p. 308 wordt verwezen, onzeker:

78. Zie Parl. Gesch. Overgangsrecht, p. 151. 
Overigens ging het in de door Spier en de Tweede Kamercommissie ${ }^{79}$ opgevoerde casus om de ongelijke behandeling wan de beide weduwen zoals die uit het oorspronkelijk ontwerp volgde: de ene weduwe zou wel een uitkering ontvangen ingevolge thet Lemmerboot-arrest ${ }^{80}$, de andere niet op grond van artikel 6:108 lid $3 \mathrm{BW}$. Uit de parlementaire geschiedenis blijkt niet of dit element in de gedachtengang van de minister een rol heeft gespeeld. Het resultaat van de tweede zin van artikel 173 lid $2 \mathrm{OW} I$ is evenwel mede, dat de vorderingen van de weduwen beide naar oud recht worden beoordeeld ${ }^{81}$.

Ten slotte voorbeeld C. Hiervoor geldt

\begin{abstract}
'dat de (on)rechtmatigheid (van, HvdB) de daad, voor zover zij wóór de inwerkingtreding is verricht, moet worden beoordeeld naar oud recht, en voor zover zij nadien is verricht, naar nieuw. Evenzo gelden voor de aansprakelijkheid voor en de omvang van schade de regels van het oude recht, voor zover die schade vóór dat tijdstip is ontstaan, en van het nieuwe, voor zover de schade nadien is ingetreden.' ${ }^{2} 2$
\end{abstract}

Dit gaat slechts op voor zover duidelijk is welke lozingen de schade vóór en welke lozingen de schade na de inwerkingtreding hebben veroorzaakt. Behalve om een serie op elkaar volgende onrechtmatige daden kan het ook gaan on een onrechtmatige toestand, zoals een blokkade, die over de inwerkingtreding heenloopt, voor zover de ontstaanstijdstippen van de schaden kunnen worden vastgesteld. Anders zou het worden, indien niet zou zijn vast te stellen of een bepaalde schade is ontstatan vóór of juist na de inwerkingtreding. Dan bevindt het geval zich weer in het vaarwater van artikel 173 lid 1 Ow I. Leidt een bepaalde lozing van vóór de invoering zowel in 1991 als in 1992 tot schade, dan dient artikel 173 lid 2 eerste zin Ow I zich $\operatorname{aan}^{83}$.

Men zou zich kunnen afvragen waarom nu voorbeeld $C$ niet eenzelfde behandeling krijgt als casusposities waarin een gebeurtenis van vóor de invoering nadien tot schade leidt. Het wil mij voorkomen dat dit eenvoudigweg komt doordat in voorbeeld $\mathrm{C}$ gedragingen ná de invoering schade tớ gevolg hebben. Zou nu ook over deze gedragingen het oude recht de scepter blijven zwaaien, dan zou daarmee de weg geopend zijn voor langdurige heerschappij van dat oude recht over zaken dje na zijn afschaffing voorvallen. Wat na de inwerkingtreding van een nieuwe wet geschiedt, dient echter als regel onder die nieuwe wet te vallen. Is de schade een ge-

79. Respectievelijk Kwartaalbericht Nieuw BW 1985, p. 54 en Parl. Gesch. Overgangsrecht, p. 158.

80. HR 22 december 1950, NJ 1951, 222.

81. Het bezwaar dat in de toelichting (Parl. Gesch. Overgangsrecht, p. 150.151 ) wordt genoend tegen uitbreiding van artikel 173 lid 2 eerste zin $O w$ I tot werschillende schaden van verschillende benadeelden uit éen gebeurtenis (dde uitslag van de ene proced une kan affbankelijk worden van die van een andere, welke nog lang op zich kan laten wachten) is hier klaarblijkelijk niet doorslaggevend geacht. Enige toelichting was hier wel op haar plaats geweest.

82. Aldus Parl, Gesch, Overgangsrecht, p. 152; zie ook p. 151. Ook hier kan vanaf de inwerkingtreding voor alsdan bestaande verbintenissein naar mijn mening in beginsel afdeling $6.1,10 \mathrm{BW}$ gelden.

83. Zie Parl. Gesch. Overgangsrecht, p. 150" De Die, Spoedcursus, p. 10. 
volg van een gebeurtenis die zich onder de gelding van het oude recht heeft voorgedaan, dan is er de zeis van de verjaring (indien artikel 3:310 BW toepasselijk is: in ieder geval verjaring door verloop van twintig jaar na de schadeveroorzakende gebeurtenis), die op een gegeven moment een eind aan de gelding van het oude recht maakt. Gevallen als dat van voorbeeld $\mathrm{C}$ moeten dus in beginsel niet worden vergeleken met de gevallen van schade met vertraging, maar met een 'losse' onrechtmatige daad van na de inwerkingtreding.

Het soort overgangsregel dat lid 2 van artikel 173 Ow I bevat is dat van eerbiediging van het oude recht, en wel voor bepaalde feiten van ná de inwerkingtreding.

\subsection{VERBOD}

Over de andere vorderingen dan schadevergoeding, die op onrechtmatige daad kunnen worden gebaseerd, kan ik kort zijn. De bevoegdheid een verbod te vorderen tot het plegen van een onrechtmatige daad in de toekomst is vanaf de inwerkingtreding aan het nieuwe recht onderworpen, ook indien het gaat om dreiging van herhaling na de invoering van cen voordien begane onrechtmatige gedraging. In plaats van artikel 1401 (oud) BW zijn voor de periode vanaf 1 januari 1992 met name de artikelen 3:296 en 6:168 BW bepalend, in beginsel ook in ten tijde van de inwerkingtreding lopende procedures (vgl. artikelen $68 a$ lid 1 en 74 Ow I). Problemen zal dit niet oproepen, omdat ervan kan worden uitgegaan dat genoemde bepalingen overeenkomen met het voorheen geldende recht ${ }^{84}$.

Dat een vordering tot een verbod door ander recht kan worden beheerst dan een vordering tot schadevergoeding (op grond van een onrechtmatige daad van vóór de inwerkingtreding) is niet 'curieus', immers:

'Schadevergoeding zal inderdaad slechts kunnen worden gevorderd ter zake van een onirechtmatige daad die in het verleden heeft plaatsgevonden. Maar een verbod zal naar zijn aard slechts toekomstige onrechtmatige daden kunnen betreffen. Dat brengt mee dat een onder het nieuwe recht door de rechter te beoordelen vordering tot een verbod slechts toewijsbaar kan zijn als de desbetreffende gedragingen ook naar het nieuwe recht onrechtmatig zijn. Daarbij verdient overigens opmerking dat zich ook hierom geen reëell overgangsprobleem zal voordoen, omdat juist de regeling betreffende onrechtmatige daad in artikel 6.3.1.1 (6:162) niet verschilt van die welke door de huidige rechtspraak op grond van art. $1401 \mathrm{BW}$ is ontwikkeld. Ook waar wel wijzigingen zijn aangebracht (bijv. artikel 6.3.1.2 $a(6: 164)$ ), is niet goed

84. 2le woor artikel 3:296 BW HR 28 juni 1985, NJ 1986, 356 en Asser-Hartkamp III, nr. 118f; voor artikel 6: 168 BW onder meer HR 3 spril 1987, NJ 1987,703 (Van Gastel q.q. -Van den Heuvel); HR 23 september 1988, NJ 1989, 743, Kwartaalbericht Nieuw BW 1989, p 86 m.n. J.H. Kuiper en G.E. van Maanen (zie p. 89) (Kallimijnen); Huijgen, in: BW-krant jaarboek 1988, p. 185 e.v.; Van Maanen, Kwartaalbericht Nieuw BW 1988, p. 40, noot 23; Asser-Hartkamp III, ars: 67, 119. 
denkbaar dat deze voor de bewijsbaarheid (bedoeld zal zijn toewijsbaarheid, HvdB) van een verbodsactie van belang zouden zijn." 85

\subsection{VERKLARING VAN RECHT}

Mits de eiser daarbij belang heeft, kan hij een enkele verklaring van recht vragen dat een gepleegde daad onrechtmatig is. Vanaf de inwerkingtreding is ook op "oude' daden artikel 3:302 BW toepasselijk, dat voorheen geldend recht weergeef ${ }^{86}$. Aan de bepaling komt onmiddellijke werking toe, in beginsel ook in lopende procedures (artikelen 68 a lid 1 en 74 Ow 1 ). De vraag of een wór de inwerkingtreding verrichte gedraging als onrechtmatig moet worden beschouwd, dient te worden beantwoord aan de hand van het oude recht ${ }^{87}$.

\subsection{RECTIFICATIE}

Publicatie van gegevens wan feitelijke aard, die onjuist of door onvolledigheid misleidend zijn, kan aanleiding geven tot veroordeling tot openbaarmaking van een rectificatie. Artikel 6:167 BW bevat een regeling hieromtrent, die voortbouwt op jurisprudentie inzake artikel 1401 (oud) BW. Lid 2 geeft een oplossing voor een moeilijkheid die voorheen bestond ${ }^{88}$. Artikel 6:167 BW kan in beginsel direct vanaf de inwerkingtreding worden toegepast, ook als de daad vốr de inwerkingtreding tot schade heeft geleid (vgl. artikelen 68a lid 1 en (woor lopende procedures) $74 \mathrm{OW}$ 1) ${ }^{89}$. Artikel 6:196 BW (inzake misleidende reclame) stemt overeen met artikel $1416 \mathrm{c}$ (oud) BW en kan derhalve niet tot problemen van overgangsrecht leiden.

\subsection{SLOT}

Door de komst van het nieuwe $B W$ is er niet weinig veranderd op het terrein van de

85. Aluus de minister, Parl. Gesch. Overgangsrecht, p. 161, in antwoord op een vraag (p. 158) natar anlejding wan een opmerking van Spier in Kwartalibericht Nieuw BW 1985, p. 54. Spier (en Sterk) tonen zich ailet overtügd door de minister (zie hun preadv., p. 93). Ik kan hun betoog echter niet wolgen. Ik cit ter."

"Een laatste praktisch bezwar (tegen het stelsel wan de Overgangswet inzake schade met wertraging, HwdB yoor het vorderen wan een verbod van een onrechtnatige daad is niet vereist dat reeds schade fs ont staan. Daut brengt mee dat de onrechtmatigheid wan een gebeurtenis voor de inwerkingtreding met betrekking tot een verbod(sactie) steeds door het oude recht wordt beheerst (dit is in zijn algemeenheid onjuist, zie bovenustaand citaat uit de parlementaire geschiedenis, HvdB). Aldus geldt een verschillend regine ten abinzien wan dezelfide gebeurtenis tussen werschillende "sancties" ingeval de schade eerst nä de inwerkingtreding ontstaat."

Vervolgens geven Spier en Sterk ter sdstructie een voorbeeld waanin de schade direct intreedt (schade toegebracht aam een au to door voetballende tienjarige jongens).

86. Vgl. HR 30 maart 1951, NJ 1952,29 en Asser-Hartkamp II, nr. 117

87. Zie Parl. Gesch. Overgangstecht, P. 152 , sub an, gecilteerd in nr. 6.5.2.1 hiervór.

88. Vgl. Asser-Hartkamp III, nus. $241-243$.

89. Zie Parl. Gesch. Overgangsnecht, p. 315. 
onrechtmatige daad. Meit de hoofdregel van de onmiddellijke werking, de eerbiediging van verkregen rechten (in ruime zin) en de regels voor schade met vertraging kan echter het gros van de overgangskwesties tot een oplossing worden gebracht. 


\section{Tekortkomingen in de nakoming van verbintenissen}

\subsection{INLEIDING}

Het nieuwe vermogensrecht geeft nogal wat verandering te zien ten opzichte wan het oude waar het gaat om het tekortschieten in de nakoming van verbintenissen. Dat is bij voorbeeld het geval bij de regeling van het verzuim en bij die van de ontbinding. Afhankelijk van de temporele 'ligging' van een bepaalde situatie kunnen de wijzigingen die het nieuwe vermogensrecht heeft gebracht voor tekortkomingen in de nakoming van verbintenissen aanleiding geven tot vraagstukken van overgangsrecht. Aan deze laatste is het onderhavige hoofdstuk gewijd. De schijnwerpers zullen met name worden gericht op de artikelen 182, 183 en 196 Ow I.

Ik concentreer mij in het navolgende vooral op de tekortkomingen in de nakoming van die verbintenissen die uit overeenkomst voortvloeien, omdat dat wel de belangrijkste categorie tekortkomingen is.

\subsection{DE BEGRIPPEN 'NIET-NAKOMING' EN 'TEKORTKOMING IN DE NAKOMING'}

Ik ga in dit hoofdstuk uit van het ook in Boek $6 \mathrm{BW}$ gebruikte begrip 'tekortkoming'. Dit staat namelijk eveneens centraal in de relevante bepalingen uit de Overgangswet ${ }^{1}$. Onder genoemde term valt kort gezegd het in het geheel niet, het te laat en het niet behoorlijk presteren, ongeacht of presteren nog mogelijk is en eveneens ongeacht of toerekenbaarheid van de tekortkoming aan de debiteur aanwezig is. Tevens is niet slechts een tekortkoming aanwezig, indien een verschuldigde prestatie niet wordt geleverd, maar ook indien een bepaald, door de debiteur gegarandeerd; resultaat uitblijft ${ }^{2}$. Het ruimere begrip 'niet-nakoming' zal slechts een beperkte rol spelen. Zoals bekend wordt dit in het nieuwe BW doorgaans in een zeer ruime betekenis gebruikt. Onder niet-nakoming valt bij woorbeeld mede het niet voldoen aan een verbintenis die nog niet opeisbaar is, evenals het niet voldoen aan een verbintenis die opeisbaar is, terwijl het verzuim nog niet is ingetreden. Tekortkomingen zijn dan in de regel niet aanwezig. Buiten gevallen van niet-toerekenbaarheid en definitieve niet-nakoming kan immers volgens de nomenclatuur van het nieuwe BW van

1. Ik gebruik zoals ook elders - evenals de overgangswetgever - in beginsel de terminologie van de nienwe wet. Uitgangspunt is immers de vraag of, en zo ja, in hoeverre die nieuwe wet kan en moet werken ten aanziten wan wat is geschied vớr of bestond op het moment vatu haar inwerkingtreding: Overigens lenen systematiek em terminollogie van het nieuwe wetboek zich behoudens enige uitzonderingen ook zeer wel voor een behandeling van het oude recht, aldus Asser-Hartkamp I, nr. 306.

2. Vgl. nader Parl, Gesch. Inv. Boek 6, p. 1247-1250, Asser-Hartkamp $I_{n}$ nr. 307. 
een tekortkoming in beginsel pas worden gesproken, indien de schuldenaar in verzuim is gekomen ${ }^{3}$. Voor dat laatste is weer nodig dat de prestatie uitblijft nadat zij opeisbaar is geworden en aan de eisen van de artikelen 6:82 en $83 \mathrm{BW}$ is voldaan (artikel 6:81 $\mathrm{BW}$ ). Omdat evenwel vanuit het oogpunt van het overgangsrecht ook situaties van belang kunnen zijn als de zoëven genoemde, waarin wel niet-nakoming maar niet tevens een tekortkoming aanwezig is, wordt daaraan in dit hoofdstuk niet geheel voorbijgegaan.

\subsection{ONTSTAAN VAN OVERGANGSKWESTIES BIJ TEKORTKOMINGEN IN DE NAKOMING}

Ook nu weer geef ik slechts schetsmatig aan wat er door het nieuwe BW zoal is veranderd ten aanzien van de tekortkomingen in de nakoming van verbintenissen. Deze veranderingen zullen ook hierna alleen daar in de beschouwing worden betrokken waar dit instructief is voor de behandeling van overgangsrechtelijke problemen ${ }^{4}$.

Voor de voldoening aan een verbintenis kan een termijn zijn gesteld. Onder het oude recht gold zo'n termijn in beginsel niet als fataal, thans is dat juist omgekeerd (artikel 6:83 sub a BW): het verzuim treedt zonder ingebrekestelling in, indien de termijn miet wordt gehaald. Ook treedt volgens artikel $6: 83$ sub b BW verzuim zonder ingebrekestelling in, wanneer de verbintenis voortvloeit uit onrechtmatige daad of strekt tot schadevergoeding als bedoeld in artikel 6:74 lid $1 \mathrm{BW}$ en de verbintenis niet terstond wordt nagekomen. Voorheen gold deze regel niet. Dat de schuldenaar die niet behoorlijk presteert in beginsel in gebreke moet worden gesteld wil verzuim intreden, is evenzeer een afwijking van het oude recht ${ }^{5}$. Vervangende schadevergoeding kon vroeger worden gevorderd zonder dat de verbintenis ten aanzien waarvan de schuldenaar in verzuim was geraakt, was omgezet in één tot vervangende schadevergoeding. Dit wordt nu wel geëist: artikel 6:87 BW.

Ontbinding van wederkerige overeenkomsten kan thans ook geschieden bij tekortkomingen die niet aan de debiteur zijn toe te rekenen (artikel 6:265 BW) en door een schriftelijke verklaring, ook zonder dat partijen dit zijn overeengekomen (artikel 6:267 lid 1 BW). Belangrijk is voorts dat de ontbinding anders dan voorheen in beginsel geen terugwerkende kracht heeft en nimmer zakelijke werking (artikel 6:269 BW).

Het opschortings- en retentierecht en de exceptio non adimpleti contractus waren in de oude wet slechts incidenteel geregeld, maar zijn nu met een algemene regeling bedacht (respectievelijk afdelingen 3.10.4 en 6.1.7 en artikelen 6:262 en 264 BW).

Beperkt gerechtigden kunnen tekortschieten in de nakoming van verplichtingen jeggens de hoofdgerechtigde. In de artikelen 3:221 en 5:87 BW kunnen enkele daarmee verband houdende afwijkingen ten opzichte van het oude recht worden aangetroffen.

3. Zie Asser-Hartkanp $I_{i}$ mr. 307.

4.Zie voor de verschillen tussen oud en nieuw recht bij voorbeeld de desbetreffende hoofdstukken van Asser-Hartkamp I en II.

5. Vgl. Asser-Hartkamp I, nr. 368a. 
Van de wijzigingen in de regeling wan de bijzondere overeenkomsten noem ik hier de herschepping van het recht van reclame in afdeling 7.1.8 BW:

Het spreekt welhaast vanzelf dat zich door de zojuist genoemde nieuwe elementen uit het nieuwe BW transitoire vragen kunnen voordoen. Daarbij kan wat de overgangssituaties betreft met name worden gedacht aan "oude" verbintenissen ten aanzien waarvan de debiteur vóór, bij of na de invoering is tekortgeschoten in de nakoming. Kan en moet aan het nieuwe recht in zulke gevallen werking toekomen? Het antwoord op die vragen kan beslissend zijn voor bij voorbeeld het al dan niet in verzuim verkeren van de schuldenaar, of de mogelijkheid om tot (al dan niet buitengerechtelijke) ontbinding over te gaan.

Bij de beantwoording van de diverse overgangsvragen ga ik als volgt te werk. In nr. 7.6 richt $\mathrm{ik} \mathrm{mij} \mathrm{op} \mathrm{de} \mathrm{tekortkomingen,} \mathrm{geschied} \mathrm{of} \mathrm{aangevangen} \mathrm{vo6r} \mathrm{de} \mathrm{inwer-}$ kingtreding. Na een algemeen deel (nrs. 7.6.1 en 7.6:2) bezie ik wat bij deze tekortkomingen geldt voor de belangrijkste rechtsmiddelen van de crediteur:

- het verlangen van nakoming (nr. 7.6.3);

- het verlangen van schadevergoeding (nr. 7.6.4);

- het bewerkstelligen van ontbinding (nr. 7.6.5);

- het opschorten van de nakoming van de op hem rustende verbintenis (nr. 7.6.6).

Vervolgens ga ik in $\mathrm{mr} .7 .7$ in op tekortkomingen in de nakoming, die dateren van het moment van de inwerkingtreding of daarna. In nr. 7.8 zet ik tegen deze achtergrond af hetgeen geldt voor tekortkomingen bij enige beperkte rechten en bij de koopovereenkomst. Het verschil in systeem tussen het overgangsrecht voor wanprestatie en dat voor onrechtmatige daad stip ik aan in nr. 7.9 .

Thans komt echter eerst aan de orde wat het resultaat zou zijn van onmiddellijke werking van het nieuwe $\mathrm{BW}$ ten aanzien van tekortkomingen in de nakoming van verbintenissen in gevallen van overgangstecht (nr. 7.4), en wat de Overgangswet hieromtrent inhoudt (nr. 7.5).

\subsection{CONSEQUENTIES VAN ONMIDDELLIJKE WERKING VAN HET NIEUWE BW TEN} AANZIEN VAN OVERGANGSSITUATIES BIJ TEKORTKOMINGEN IN DE NAKOMING

Onmiddellijke werking van het nieuwe 'tekortkomingsrecht' zou onder meer de volgende resultaten te zien geven. De termijn die is gesteld voor de voldoening aan een bestaande verbintenis zou vanaf de inwerkingtreding in beginsel fatal zijn. Ook door het (vóór de invoering of daarna) niet terstond nakomen van ten tijde van de invoering aanwezige verbintenissen uit onrechtmatige daad of tot schadevergoeding als bedoeld in artikel 6:74 lid $1 \mathrm{BW}$ zou, zonder dat daarvoor nog een ingebrekestelling nodig is, verzuim ontstaan. De na 31 december 1991 niet behoorlijk presterende schuldenaar zou in beginsel pas na ingebrekestelling in verzuim raken. De ontbinding na de inwerkingtreding van een bestaande wederkerige overeenkomst zou terugwerkende kracht en zakelijke werking ontberen. Opschortingsrechten zouden vanaf de invoering alleen nog uit de nieuwe wet voortvloeien. Bepaalde tekortkomingen (ook die van vớr 1 januari 1992) van vruchtgebruikers en erfpachters zouden vanaf het moment van de invoering onder de artikelen 3:221 en 5:87 BW vallen, en de inroeping na genoemd moment van het recht van reclame onder afdeling 7.1.8 $\mathrm{BW}$. 
De onmiddellijke werking ex artikel 68 a lid 1 Ow I zou bij de onderhavige nogal sterk wan het oude recht afwijkende regels een aantal consequenties hebben, die als onweriselijk voorkomen. Met name wanneer de tekortkoming zich reeds voor de inwerkingtreding voordeed, lijkt het beter om de zaak volgens de oude regels af the whelen:

"Toepasselijkheid van het nieuwe recht zou allicht partijen in verwarring en onzekerheid brengen. 6

Hoe de verstoringen dic de hoofdregel van de onmiddellijke werking teweeg zou brengen worden tegengegaan, zal hierna blijken, evenals de ruimte die bij tekortkomingen in de nakoming nog overblifft voor deze hoofdregel. De belangrijkste voorzieningen van de Overgangswet in deze zal ik thans kort uiteenzetten.

\subsection{DE ONERGANGSWET EN TEKORTKOMINGEN IN DE NAKOMING}

Uitgangspunt bij de regeling van de overgangsproblemen op het gebied van tekortkomingen in de nakoming van verbintenissen is eerbiediging van het oude recht. voor tekortkomingen die voór de inwerkingtreding zijn geschied of aangevangen (artikelen 182 jo. 68 a lid 2 Ow I). Dit impliceert dat het nadien tekortschieten in de nakoming wan een verbintenis, die al onder het voorheen vigerende recht is geboren, in principe naar nieuw recht moet worden beoordeeld. De werking van artikel 182 Ow I is niet beperkt tot het nieuwe BW zelf: op grond van artikel 1 lid 2 Ow II geldt het mede ter regeling van het overgangsrecht in verband met de wijzigingen in de bij de invoering van het nieuwe $\mathrm{BW}$ bestaande wetgeving?.

Voor de automatisch verzuim-regeling van artikel $6: 83$ onder a en b BW geldt een rigoureuzere eerbiediging: deze regeling zal niet toepasselijk worden op verbintenissen die reeds aanwezig waren ten tijde van de inwerkingtreding. Ook de niet-nakoming van zulke verbintenissen, die na de invoering plaatsvindt, valt dus in zoverre onder het oude recht (artikelen 183 jo. 68 a lid 2 Ow I).

Vanaf de inwerkingtreding kunnen opschortingsrechten, waaronder retentierechten, alleen uit het nieuwe BW voortvloeien. Hier gaat de onmiddellijke werking dus wel op: zie artikel 180 Ow I.

De zojuist genoende overgangsbepalingen gelden merendeels voor verbintenissen in het algemeen. Zoals ik reeds eerder aankondigde, zal ik mij echter in beginsel beperken tot de belangrijkste categorie, te weten die van de verbintenissen uit overeenkomst.

De gevolgen van het na de inwerkingtreding tekortschieten in de nakoming wan verbintenissen uit koopovereenkomsten vallen, behalve onder het algemene nietnakomingsrecht, onder titel 7.1 BW: Voor de al dan niet toepasselijkheid van afdeling 7.1.8 BW inzake het recht van reclame is bepalend het tijdstip van uitoefening van dat recht: ligt dat vór de inwerkingtreding, dan blijt daarop het oude recht

7. Zie woor enkele toepassingen Parl, Gesch. Overgangsrecht, p. 331, 332, 333. 
toepasselijk, anders is het nieuwe recht maatgevend. Met deze in lid 3 van artikel 196 Ow I opgenomen overgangsregels wordt afgeweken van de leden 1 en 2, waarin respectievelijk voor koopovereenkomsten, gesloten voor het tijdstip van de inwoering, in een uitgestelde werking van titel 7.1 BW van een jaar is voorzien en woor 'oude' consumentenkoopovereenkomsten in eerbiediging van het oude recht.

In de nrs. 7.6-7.8 hierna zullen de zojwist weergegeven overgangstbepalingen, alsmede enkele andere, aan een analyse worden onderworpen.

\subsection{DE DEBITEUR IS VÓÓR DE INWERKINGTREDING TEKORTGESCHOTEN IN DE NAKOMING}

Conform de indeling zoals deze in nr. 7.3 hiervoor is beschreven, ga ik nu over tot de bespreking van de tekortkoming die is gepleegd of aangevangen onder de vigeur van het oude recht, maar die na de inwerkingtreding van het nieuwe recht nog moet worden afgewikkeld.

\subsection{Algemeen}

De Overgangswet gaat uit van de regel dat, ingeval alle vereisten van de nieuwe wet vónor de invoering zijn vervuld, het oude recht toepasselijk is en anders het nieuwe 8 . Waarom wordt bij tekortkomingen in de nakoming afgeweken van dit uitgangspunt? Met deze vragg belanden we direct bij dle ratio van met name artikel $182 \mathrm{OW}$ $\mathbb{I}$, de belangrijkste overgangsbepaling inzake tekortkomingen in de nakoming. Deze luidt als volgt:

"Indien een schuldenaar vóór het in werking treden van de wet in de nakoming van zijn verbintenis is tekortgeschoten, is op de gevolgen van de tekortkoming de wet niet van toepassing, ook niet indien de tekortkoming nadien wordt voortgezet:

Wolgens de toelichtende stukken is de ratio van deze bepaling de wolgende. Aan een tekortschieten onder de oude wet kan die wet reeds rechtsgevolgen hebben verbonden,

'en het is onpraktisch om die met het nieuwe recht te doorkruisen; het nieuwe recht verschilt immers vrij sterk van het oude in zijn voorschriften omtrent maatregelen voor het bereiken van rechtsgevolgen als verzuim, schadevergoeding en ontbinding",

zodat het de voorkeur verdient om voor de toepasselijkheid van oud of nieuw recht doorslaggevend te laten zijn wanneer de tekortkoming is aangevangen: voor de in- 
werkingtreding of later" Met andere woorden: artikel $182 \mathrm{OW} I$ is vooral ingegeven door het feit dat het nieuwe recht de crediteur ten dele andere routes voorschrijf waarlangs thij moet gaan om gevolgen aan de wanprestatie van zijn debiteur te verbinden. Het zou naar de - als juist voorkomende - mening van de minister niet praktisch zijn om partijen te noodzaken hun rechtsverhouding verder naar nieuw recht af te wikkelen ${ }^{10}$.

Artikel 182 Ow I leidt tot de uitkomst dat de gevolgen van onder het oude recht begane tekortkomingen door oud recht worden beheerst. Dit geldt ook voor zover die gevolgen zich pas na de inwerkingtreding voordoen.

Ik geef ter illustratie een voorbeeld.

A (opdrachtgever) en B (aannemer) sloten in 1991 een aannemingsovereenkomst. Het werk werd opgeleverd vóor de inwerkingtreding. Het had ten tijde van de oplevering een (herstelbaar) verborgen gebrek, dat zich eerst na de inwerkingtreding openbaarde. A wenste aanvankelijk herstel, en naderhand, toen B daartoe niet in staat bleek, ontbinding.

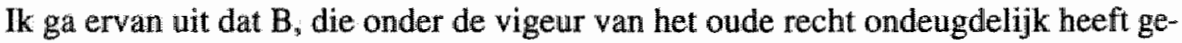
presteerd, naar oud recht ook zonder ingebrekestelling in verzuim zou zijn" ${ }^{11}$, en dat naar nieuw recht daarvoor juist wel een ingebrekestelling nodig zou zijn.

Zonder artikel 182 Ow I zou de hoofdregel van de onmiddellijke werking gelden (artikel $68 a$ lid 1 OW I). Ook voor tekortkomingen in de nakoming van verbintenissen zou de algemene regel opgaan, die inhoudt dat oud recht toepasselijk blijft als alle vereisten die het voor een rechtsgevolg stelt zijn vervuld vóór het moment van de inwerkingtreding, en dat anders het onmiddellijk werkende nieuwe recht vanaf dat moment bepallend wordt. Als gevolg daarvan zou over bij voorbeeld een vordering van $A$ tot vergoeding van de door hem als gevolg van $B$ 's ondeugdelijke prestatie geleden schade aan de hand van nieuw recht moeten worden beslist, voor zover de schade eerst na de invoering is ingetreden ${ }^{12}$.

Zou A (tevens) ontbinding verlangen, dan zou - nog steeds uitgaande van het niet bestaan van artikel 182 Ow I - het oude recht bepalend zijn, indien hij de ontbinding voór de inwerkingtreding zou bewerkstelligen. Zou hij dat later doen, dan zou het nieuwe recht maatgevend zijn voor het al of niet bevoegd zijn tot ontbinding, in welk laatste geval tevens de ontbinding terugwerkende kracht en zakelijke werking zou ontberen. Of een wettelijke bevoegdheid (een rechtsgevolg) als die tot ontbinding bestaat, wordt immers vanaf de invoering in beginsel uitsluitend beoor-

9. Aldus Parl. Gesch. Overgangsrecht, p. 157. Anders dan de tekst van artikel 182 Ow I spreekt de toelichting bijna steeds van 'niet nakoming'. Ik neem aan dat dit laatste begrip hier - zoals wel vaker gebeurt, zie Asser-Hartkamp I, nr. 308 - wordt gebrükt als synonien van "tekortkoming".

10. Parl. Gesch. Overgangsrecht, p. 159 ; zie ook p. 160 en $₫ 78$.

11. Vgl. echter Asser-Hartkamp I, Mr. 368a, alsmede HR 22 mei 1981, NJ 1982, 59 (Van der Gun-Farmex): het geval kan zich yoordoen dat in verband met de eisen van de goede trouw onbehoorlijk presteren eerst wanprestatie oplevert nadat de schuldenaar vergeefs in gebreke is gesteld.

12. Wat overigens in casu niet zou meebrengen dat voor de vordering tot vergoeding van deze na de invoering geleden schade verzuim van B vereist is, nu voor zover het de schade betreft er sprake is van een blijvende onmogelijkheid van correcte nakoming (zie Asser-Hartkaimp I, nr. 359 sub d). 
deeld aan de hand van het nieuwe recht, tenzij de bevoegdheid voordien reeds was uitgeoefend met de daaraan toen verbonden rechtsgevolgen ${ }^{13}$.

Nu zou men kunnen zeggen: als onder de oude wet eenmaal een ontbindingsbeWoegdheid het licht heeft gezien, dan verandert de (onmiddellijk werkende) nieuwe wet die een extra eis daarvoor stelt daar niets meer aan, ook al was die bevoegdheid op het moment van de invoering nog niet uitgeoefend. Dit laatste lijkt echter niet juist. Van een gedane zaak die ook door een onmiddellijk werkende nieuwe regel geen keer meer neemt, is bij een niet uitgeoefende bevoegdheid geen sprake. Dat is bij voorbeeld anders bij een eemmaal ontstaan vorderingsrecht. De bevoegdheid is niet een doel op zich, maar een middel om een zeker resultaat te bereiken. Pas als zij is uitgeoefend, kan er een overgangsrechtelijk 'fait accompli' zijn ontstaan.

Theoretische discussies als deze worden voor het gebied van de tekortkomingen in de nakoming in de kiem gesmoord door de "hard and fast rule" van artikel 182 Ow $I$, die in beginsel alle gevolgen van een tekortkoming ${ }^{14}$ onder én en hetzelfde recht brengt: het oude of het nieuwe. In het gegeven voorbeeld is de tekortkoming er éen van vór de invoering, zodat het oude recht bepalend is, ook voor schade die na het invoeringstijdstip mocht zijn geleden ${ }^{15}$. Ik ga thans nader op artikel $182 \mathrm{Ow}$ I in.

De begrippen 'tekortgeschoten' en 'tekortkoming' in artikel 182 OW I hebben evenals in Boek 6 BW een 'kleurloze' betekenis: zij zien zowel op aan de debiteur toerekenbare als op niet an hem toerekenbare tekortkomingen. Of ten tijde van de inwerkingtreding van een tekortkoming kan worden gesproken, moet worden uitgemaakt aan de hand van het oude recht ${ }^{16}$. Het kan zijn dat niet-nakoming geen tekortkoming oplevert. Dit is bij woorbeeld het geval, indien ten tijde van de inwerkingtreding niet was voldaan aan een verbintenis die nog niet opeisbaar was. In beginsell is ook geen tekortkoming aanwezig, als op genoemd moment niet was voldaan aan een opeisbare verbintenis, maar nog geen verzuim was ingetreden. Indien de debiteur in verzuim raakt, dan zal dat na de inwerkingtreding zijn, zodat in de regel het nieuwe recht bepalend is (artikelen 182 jo. 68 a lid $1 \mathrm{OW}$ I). Op die regel bestaan belangrijke uitzonderingen op grond van artikel $1830 \mathrm{w} \mathrm{I}^{17}$.

Onder het nieuwe recht is anders dan voorheen bij blijvende overmacht voor éen wan de partijen bij een wederkerige overeenkomst een ontbindingsverklaring noodzakelijk, wil de crediteur van zijn verbintenis worden ontheven (artikel $6.265 \mathrm{BW}$ ). Blijyende overmacht, ingetreden onder het oude recht, zall dus wel ontheffing van de crediteur van diens verbintenis tot gevolg hebben gehad. Dat het nieuwe recht daarwoor ontbinding eist, kan dat rechtsgevolg niet meer op losse schroeven zetten, ook al zou dat nieuwe recht direct gaan werken. Dit neemt niet weg dat ook hier ar-

\section{Zile nr 2.5.1.1 sub d hiervobr.}

14. (Uiteraard) ook indien deze gedeeltelijk is: zie Parl. Gesch. Overgangsirecht, p. 159.

15. Vgl, het voorbeeld in Parl. Gesch.. Owergangsrecht; p. 179 sub d en het door de rininaster dienanganande geantwoorde op p. 181 sub d. Zie ook H. Stein, pready., p. 94.

16. Zie Parl. Gesch. Owergangsrecht, p. 157. Zie woor de inhoud van het begrip 'tekontkoming' nader nr. 7.2 hierwor.

17. Zie daarover de nrs. $6.5,1.4$ hierv66r en $7,6.2$ en 7.6 .4 hinema Zie over gelliktijdig met of na de inwerkingtneding platsvindende tekortkomingen in de nakoming van bestaande verbintenissen ook ne. 7.7 hierna. 
tikel 182 Ow I van toepassing is: de niet toerekenbare tekortkoming ${ }^{18}$ van woór de inwerkingtreding blijft beheerst door het oude recht.

Bij een aantal achtereenvolgende tekortkomingen in de nakoming van een verbintenis, sommige plaatswindend vóór de inwerkingtreding en andere daarna (of eventueel tegelijkertijd daarmee), geven gezien artikel 182 Ow I voor de rechtskeuze uiteraard de tijdstippen van de diverse tekortkomingen de doorslag: de anterieure tekortkomingen vallen onder oud recht, de posterieure onder nieuw recht ${ }^{19}$.

Een na de invoering voortgezette tekortkoming die voordien reeds is begonnen blifft ook na de invoering onder de heerschappij van het oude recht vallen; aldus het slot van artikel $182 \mathrm{Ow}$ I. Hierbij zou bij voorbeeld kunnen worden gedacht aan het ook na ingebrekestelling (uitgebracht vó6r de inwerkingtreding) niet opleveren door een aannemer van een door hem aangenomen werk, welke wanprestatie in december 1991 begon en ook na I januari 1992 nog enige tijd voortduurde.

Artikel 182 (jo. $68 a$ lid 2) Ow I houdt tot op zekere hoogte eerbiediging van het oude recht in. Tot op zekere hoogte: deze eerbiediging geldt alleen voor het geval dat ten aanzien van een verbintenis, aanwezig op het moment van het in werking treden van de nieuwe wet, reeds vóór dat moment is tekortgeschoten in de nakoming ${ }^{20}$. Tekortkomingen in de nakoming van zulke verbintenissen, die zich eerst ná de inwerkingtreding voordoen, vallen wel onder het nieuwe recht. In zoverre zou men van "eerbiediging' van de hoofdregel van onmiddellijke werking kunnen spreken: wordt ten aanzien van een bestaande verhouding ná de inwerkingtreding voldaan aan alle vereisten van de nieuwe wet, dan treden de rechtsgevolgen volgens die nieuwe wet in ${ }^{21}$.

Zoals gezegd is in de door artikel $182 \mathrm{OW} I$ bestreken gevallen voor eerbiediging niet voldoende dat een verbintenis dateert van vóór de inwerkingtreding. Dit is anders bij het thans te bespreken artikel 183 Ow I.

\subsubsection{Bijzondere regel voor verzuim}

Stel dat

"tussen A en B als datum voor de levering van bouwplaten is afgesproken 20 december 1991. B levert die dag niet. A staat hem een uitstel toe van uiterlijk 14 dagen, maar ook op die dag blijft B in gebreke. A wil van de koop af. Welk recht is van toepassing?'22

Door partijen afgesproken termijnen voor de voldoening van een prestatie waren

18. Overigens ook als deze tijdelijk was; artikel 182 Ow I maaki hier geen onderscheid.

29. Vigl H. Stein, preadv., 95-96, met voorbeelden. Anders dan Stein meent kan hier naar mijn mening echter niet worden gesproken win een woortdurende, ofwel voortgezette, wanprestatie: het is niet altijd mogelijk om een "voortdurende" wanprestatie te ontleden in samenstellende delen (zie hierna).

20. Vgl Parl Gesch. Overgangstecht, p: 11,179 .

21. Zie nader cle nrs 2.4.1.3 en 2.5.1.1 sub b huervóór en 7.7 hierna,

22. Aldus de Bijzondere Conmissie voor de herziening wan het Burgerlijk Wetboek van de Eerste Kamer in hatr voorlopig verslag, Parl. Gesch Overgangsrecht, $\mathrm{p}$. 179 sub f. De vraag wordt beantwoord op p. $18 \|$ subf. 
volgens het oude recht (artikel $1274 \mathrm{BW}$ ) in beginsel niet fataal. Tenzij uit de rechtsverhouding van partijen anders voortvloeide, kwam de schuldenaar niet in verzuim door het enkele te laat presteren; daarvoor moest eerst een (vergeefse) ingebrekestelling worden uitgebracht ${ }^{23}$. Het nieuwe $\mathrm{BW}$ geeft het ongekeerde te zien: het verzuim treedt (in afwijking van artikel 6:82 lid $1 \mathrm{BW}$ ) zonder ingebrekestelling in, wanneer de voor de voldoening bepaalde termijn verstrijkt zonder dat de verbintenis is nagekomen, tenzij blijkt dat de termijn een andere strekking heeft (artikel $6: 83$ sub a BW).

Voor bovenstaand voorbeeld moet worden bezien of het niet halen van de afgesproken datum door $B$ reeds voldoende was voor het intreden van verzuim. Ik ga er eerst van uit dat de overeenkomst tussen A en B zo kan worden uitgelegd dat B inderdaad in verzuim zal raken door het enkele overschrijden van de termijn. Dit brengt dan met zich mee dat op 21 december 1991 van een tekortkoming sprake was. Daardoor zou ook zonder de hierna te citeren overgangsregel artikel 6:83 sub a BW buiten toepassing blijven (artikel 182 OW I). In het omgekeerde geval (de overeenkomst kan zo worden uitgelegd dat de termijn geen fatale is) is er evenmin een probleem. Weliswaar zou dan (nog steeds afgezien van de zo dadelijk te citeren overgangsbepaling) op grond van de artikelen $182 \mathrm{jo} .68 \mathrm{a}$ lid $1 \mathrm{OW}$ I de nieuwe wet toepasselijk zijn, maar uit die nieuwe wet zelf (artikelen $6: 82$ lid 1 jo. $6: 83$ sub a) zou reeds volgen dat voor verzuim wel een ingebrekestelling benodigd is, nu blijkt dat de termijn geen fatale is.

Als niet is vast te stellen welke strekking de termijn heeft, zou er zonder artikel 183 Ow I echter wel een probleem bestaan. De niet-nakoming door B op 20 december 1991 leverde naar oud recht nog geen verzuim en daarmee ook geen tekortkoming op. Artikel 182 Ow II zou dan onmiddellijke werking van artikel 6:83 sub a BW toelaten, waardoor verzuim en daarmee een tekortkoming vanaf 1 januari 1992 aanwezig zouden zijn. Op die tekortkoming zou het nieuwe recht toepasselijk zijn. Immers, vóór de inwerkingtreding had B's niet-nakoming als gezegd nog niet tot verzuim geleid; ten tijde van de inwerkingtreding was voldaan aan de vereisten die door artikel 6:83 sub a BW worden gesteld voor het zonder ingebrekestelling intreden van verzuim (artikel $68 a$ lid 1 Ow I). Consequenties hiervan zouden onder meer zijn dat het risico voor het onmogelijk worden van nakoming bij $\mathrm{B}$ zou komen te liggen (artikel 6:84 BW), dat A wan rechtswege vergoeding van vertragingsschade zou kunnen vorderen (artikel 6:85 BW) en ook dat $A$ de overeenkomst zou kunnen ontbinden (artikel 6:265 BW). En dat terwijl B,

"die onder huidig (thans: oud, HvdB) recht een verbintenis onder tijdsbepaling op zich nam, er niet op hoefde te rekenen dat hij ook zonder ingebrekestelling in verzuim zou geraken.' 24

Dat een resultaat als dit in de ogen van de overgangswetgever geen genade heeft kunnen vinden zal weinig verbazing wekken. Het wordt voorkomen door artikel 183 (jo. 68 a lid 2) Ow I:

23. Wgl. Asser-Hartkamp I, nr. 367.

24. Aldus Parl. Gesch. Overgangsrecht, p. 162 
'Artikel 83 van Boek 6 is niet van toepassing op het verstrijken van een termijn als bedoeld onder a van dat artikel, die voortvloeit uit een rechtsverhouding welke voór het tijdstip van het in werking treden van de wet is ontstaan $(\ldots)^{25}$.

Wat hier telt is niet wanneer de niet-nakoming plaatsvond of aanving, maar of de verbintenis die niet is nagekomen (vóor het tijdstip van de inwerkingtreding of daarna) al aanwezig was op genoemd tijdstip. De eerbiediging volgens deze overgangsbepaling gaat derhalve verder dan die volgens artikel $182 \mathrm{Ow}$ I: ook posterieure niet-nakoming wordt 'met rust gelaten' door de nieuwe wet ${ }^{26}$. Op alle drie hierboven behandelde varianten is derhalve op grond van de zojuist geciteerde overgangsbepaling artikel 6:83 sub a BW niet toepasselijk. Dit zou niet anders zijn, indien de termijn pas na de invoering zou beginnen te lopen. Voor zover de toepasselijkheid van andere nieuwe bepalingen dan artikel 6:83 sub a BW in het geding is, geeft artikel $182 \mathrm{OW}$ I uitsluitsel.

Indien A aan B geen uitstel toestaat, maar deze sommeert om binnen veertien dagen alsnog tot levering over te gaan op straffe van rechtsmaatregelen, geldt hetzelfde als voor bovenstaand voorbeeld ${ }^{27}$.

Voor zover artikel $183 \mathrm{Ow} \mathrm{I}$ van belang is voor de vordering tot schadevergoeding op grond van wanprestatie behandel ik deze bepaling in nr. 7.6.4 hiema.

\subsubsection{De vordering tot nakoming}

De crediteur kan tegen zijn niet nakomende debiteur een rechtsvordering tot nakoming instellen. Met artikel $182 \mathrm{OW}$ I heeft men alsdan in overgangssituaties niet van doen. De bevoegdheid om nakoming te eisen kan namelijk niet worden aangemerkt als een gevolg van de tekortkoming als bedoeld in artikel $182 \mathrm{Ow} \mathrm{I}$. Deze bevoegdheid komt direct uit de verbintenis voort en bestond dus al vóór de tekortkoming plaatsvond ${ }^{28}$.

Wat betekent dit nu voor het overgangsregime inzake de bevoegdheid nakoming te vorderen? Bepalingen betreffende de vordering tot nakoming zijn in Boek $3 \mathrm{BW}$ te vinden in de artikelen 296-301. Aan deze bepalingen komt - ook in procedures die reeds lopen op het moment van de inwerkingtreding - in de regel onmiddellijke werking toe (artikelen $68 a$ lid 1 en 740 w ${ }^{29}$ ). In Boek $6 \mathrm{BW}$ kan op artikel 38 worden gewezen, dat zegt dlat indien geen tijd voor de nakoming is bepaald, de verbintenis terstond kan worden nagekomen en terstond nakoming kan worden gevorderd. Ook hiervoor geldt de hoofdregel van de onmiddellijke werking ${ }^{30}$. Dat een en ander

25. De Hoge Raad overwoog in zijn arrest van 27 september 1991, NJ 1991, 801 (Groenendijk-Stapel) dat "de regeling wan art, $6: 83$ zozeer afwijkt wan de huidige regeling omtrent verzuim zonder ingebrekestelling; dat voor anticiperende toepassing wan die bepaling geen grond aanwezig is."

26. Zie Parl. Gesch. Overgangsrecht, p. 163.

27. Vgl de desbetreffende vraag in Parl. Gesch. Overgangsrecht, p. 179 sub g en het antwoord opp. 181 subg.

28. Vgl. Asser-Hartkamp I, nrs. 356, 639.

29. Vgl. Parl. Gesch Overgangsrecht, p. 278.

30. Vgl. Parl. Gesch. Overgangsrecht, p. 305. 
tot moeilijkheden aanleiding kan geven lijkt niet erg waarschijnlijk. Voor een deel komen de genoemde bepalingen neer op wat reeds onder het oude BW gold (bij voorbeeld de artikelen $3: 296,297$ en $299 \mathrm{BW}^{31}$. Voor het overige lijken de nieuwe bepalingen zich wel te lenen voor toepassing op overgangsverhoudingen, ook al zou daarover reeds bij de inwerkingtreding een procedure lopen ${ }^{32}$.

Opmerking verdient dat in het stelsel van de Overgangswet de mogelijkheid bestaat, dat in een transitoire casus een nakomingsvordering onder nieuw recht valt en een schadevergoedingsvordering onder oud recht. Reẻle moeilijkheden als gevolg van deze toepasselijkheid van oud en nieuw recht naast elkaar laten zich evenwel niet goed denken.

Voor faillissementen en surséances van betaling moet worden gewezen op artikel 31 Ow II: de oude artikelen $37,38,236$ en 237 FW blijven toepasselijk, indien op grond van artikel 182 Ow I op de gevolgen van een tekortschieten in de nakoming van een overeenkomst het oude recht toepasselijk is ${ }^{33}$.

\subsubsection{De vordering tot schadevergoeding}

Bij de vordering tot schadevergoeding moeten twee categorieën worden onderscheiden: de schadevergoeding wegens een tekortkoming in de nakoming in het algemeen en die wegens vertraging bij de voldoening van schadevergoeding in geld op grond van wanprestatie in het bijzonder.

Wat de eerste categorie betreft is in beginsel onverschillig of het recht op schadevergoeding vóór de inwerkingtreding is ontstaan of later, mits maar sprake is van een tekortkoming voordien, waarop artikel $182 \mathrm{Ow} I$ van toepassing is: steeds is dan het oude recht toepasselijk, en niet bij voorbeeld de afdelingen $6.1 .9,6.1 .10$ en $6.5 .5 \mathrm{BW}^{34}$.

In artikel 182 Ow I wordt zonder beperking 'de wet' niet toepasselijk verklaard op de gevolgen van "oude' tekortkomingen. Uit het verband waarin de woorden 'de wet' worden gebezigd, blijkt niet dat daarmee slechts bepaalde artikelen uit de Boeken 3-8 BW worden bedoeld ${ }^{35}$. Toch zijn volgens de overgangswetgever enkele regels uit 'de wet' toepasselijk, namelijk de artikelen $6: 102,103,105$ en, woor zover dit niet wordt verhinderd door artikel 69 sub c Ow I, 1.04, omdat zij

'de omvang der te vergoeden schade niet beînvloeden'36.

31. Vgl. de aantekeningen over het oude recht bij de genoende artikelen in $\mathrm{T} \& \mathrm{C}$.

32. "De inwoering van artikel $3.11 .2 a(3: 298)$ makt het voor partijen wenselijk hun stellingen aan te scherpen - ook al leent de bepaling zich mogelijk woor anticipatie", ädus cén wan de voorbeelden die de minister noemt bij artikel 74 lid 2 Ow I, in Parl. Gesch. Overgangsrecht, p. 63 onder b.

33. Zie de toelichting, Parl. Giesch. Overgangsrecht, p. 223; Van Huizen, WPNR 6007 (1991),p. 382.

34. Is er een termijn voor de prestatie overeengekomen, dan kunnen ook na de invoering begane tekortkomingen niet leiden tot toepassing van artikel $6: 83$ sub a $\mathrm{BW}$ (zie artikel 183 Ow $\mathrm{I}$, waarover nr. 7.6 .2 hiervóór, en dit nr.).

35. Vgl. artikel 68 Ow I en de toelichting daarop in Parl. Gesch. Overgangsrecht, p. 35. Voor titel 7.1 BW is evenwel artikel 196 lid 3 Ow I maatgevend; zie daarower nr. 7.83 hierna.

36. Aldus Parl. Gesch. Owergangsrecht, p. 308. 
Ik kan dit niet rijmen met de tekst van artikel 182 OW I: daaruit volgt toch dat af deling $6.1 .10 \mathrm{BW}$ in het geheel niet voor toepassing in anmerking komt in geval van een kekortkoming die vór de invoering plaatswond of aanving. Bovendien bevindien de genoemde bepalingen uit afdeling 6.1.10 BW zich nast andere die de omvang van de te vergoeden schade evenmin beïnvloeden, zoals artikel 6: $0101 \mathrm{BW}$ (eigen schuld). Afgezien van de artikelen 6:104 en 106-110 BW wordt genoemde afdeling zelfs als woorheen reeds geldend recht beschouwd ${ }^{37}$. Daarom verbaast het niet dat onmiddellitike werking van afdeling $6.1 .10 \mathrm{BW}$ als uitgangspunt voor 'oudle' tekortkomingen is bepleit, mede omdat dit in het belang van partijen zou $z i j n^{38}$. Aan de andere kant verdient het met het oog op duidelijkheid en overzichtelijkheid wellicht de voorkeur om, zoals in artikel 182 Ow I gebeurt, alle gevolgen van een tekortkoming door hetzelfde recht te laten beheersen.

Apart aandacht verdient de schadevergoeding wegens vertraging in de voldoening van een geldsom die zelf als schadevergoeding wegens wamprestatie versehuldigd is. Deze vergoeding van vertragingsschade bestaat in beginsel alleen uit de wettelijke rente van de hoofdsom over de tijd van het verzuim (artikelen 1286 lid 1 (oud) en 6:119 BW). Vroeger begon deze wettelijke rente in het algemeen pas te lopen vanaf de dag dat deze van de debiteur in rechte was gevorderd, of vanaf de dag waartegen de schuldenaar schriftelijk was aangemaand om aan zijn opeisbare verplichting te voldoen, met mededeling dat de crediteur voor het geval van verdere vertraging aanspraak maakte op vergoeding van de wettelijke rente (artikel 1286 lid 3 (oud) BW).

Artikel 6:119 BW wijkt hierwan af: de wettelijke rente is verschuldigd over de tijd dat de debiteur met de voldoening van de hoofdsom in verzuim is geweest (lid 1) ${ }^{39}$. Dat verzuim begint bij een verbintenis tot vergoeding van schade wegens wanprestatie (artikel $6: 74$ lid $1 \mathrm{BW}{ }^{40}$, indien de verbintenis niet terstond wordt nagekomen (artikel 6:83 sub b BW). Een ingebrekestelling met bijzondere mededeling is dan niet meer nodig 41 .

Stel nu dat een debiteur heeft gewanpresteerd, waardoor diens crediteur schade heeft geleden; beide gebeurtenissen waren reeds geschied vór het tijdstip van de inwerkingtreding van het nieuwe BW en de schade was toen nog niet vergoed. De aammaning en mededeling als bedoeld in artikel 1286 (oud) BW waren nog niet geschied. Van toepassing is dan artikel $183 \mathrm{Ow} \mathrm{I}$ :

Artikel 83 van Boek 6 is niet van toepassing (...) op het niet nakomen van een op dat tijdstip bestaande verbintenis als bedoeld in onderdeel b van dat artikel." 42

37. Aldus Asser-Hartkamp I, nr: 404.

38. Zie H: Stein, preadv, p. 969-97.

39. Voor de werking in de tije wan artikel 6:119 BW is artikel 182 Ow I bepalend zie Parl. Gesch. Over. gangsrecht, $\mathrm{p} .310$ :

40. De schadewergoedingsvordering ex artikel 6:78 BW bij overmacht walt niet onder artikel $6: 83$ sub b BW: vgl. Asser-Tharkimp I, ne 369.

41. Zie voor het voorgande Asser-Harth amp I, nrs: 369, 522-524.

42. Het artikel wordt toegelicht in Parl. Gesch. Overgangsrecht p. 162-163. 
Het oude recht wordt geëerbiedigd voor bestaande schadevergoedingsverbintenissen. Op welk moment een verbintenis tot schadevergoeding ontstaat, hangt onder meer af van de aard van de tekortkoming ${ }^{43}$.

Opmerking verdient dat in de gegeven casus zonder artikel 183 Ow I de door artikel $182 \mathrm{Ow}$ I tot op zekere hoogte toegelaten onmiddellijke werking wèl toepasselijkheid van artikel $6: 83 \mathrm{BW}$ zou hebben opgeleverd, omdat de tekorkkoming in de nakoming van de verbintenis tot schadevergoeding niet reeds vór de invoering was aangevangen ${ }^{44}$. Indien de tekortkoming reeds voordien was begonnen; blijft artikel 6:83 BW evenzeer buiten toepassing; dan wijzen de artikelen 182 en $183 \mathrm{OW}$ I beide toepasselijkheid van deze bepaling af ${ }^{45}$.

Artikel 1:376 BW (van overeenkomstige toepassing verklaard op curatele in artikel 1:385 BW) is bij de invoering van het nieuwe vermogensrecht gelijkgeschakeld met artikel 6:119 BW: Voorheen behoefde de minderjarige die iets aan zijn voogd schuldig was geen rente te vergoeden voordat - na het sluiten van de rekening - aanmaning en mededeling als bedoeld in artikel 1286 lid 3 (oud) BW hadden plaatsgehad. Thans gaat de rente niet lopen zolang de minderjarige niet - na het sluiten van de rekening - met de voldoening van het verschuldigde in verzuim is. Artikel 6 OW II strekt ertoe de oude artikelen 1:376 (jo. 1:385) BW te eerbiedigen ten aanzien van wat de minderjarige op het moment van de invoering aan de voogd na het einde van diens bewind nog schuldig was gebleven ${ }^{46}$.

\subsubsection{De (vordering tot) ontbinding}

Voldoet de schuldenaar niet aan een verbintenis uit een wederkerige overeenkomst, dan zal de schuldeiser in beginsel ontbinding van die overeenkomst kunnen bewerkstelligen. Omdat het hier gaat om één van de gevolgen van een tekoitkoming als bedoeld in artike $182 \mathrm{OW} \mathrm{I}$, wordt ten aanzien van de onthinding(svordering) het oude recht geëerbiedigd, indien de tekortkoming is aangevangen vó́r de inwerkingtreding, ook indien de tekortkoming nadien nog wordt voortgezet (artikelen 182 jo. $68 \mathrm{a}$ lid 2 OW I) ${ }^{47}$. Dit impliceert onder meer dat alsdan:

- ook aan na de inwerkingtreding bewerkstelligde ontbinding terugwerkende kracht en zakelijke werking toekomt;

- bij blijvende overmacht een beroep daarop van de in overmacht verkerende partij reeds voldoende is voor het komen te vervallen van de wederzijdse verbintenissen;

43. Zie nader Asser-Hartkamp I, nrs. 357 e. V., 369.

44. Zie nr. 7.6.2 hiervóón.

45. Artikel 69 sub d Ow I komt hier niet te pas. Anders Brumner, WPNIR 6007 (1991),p. 345 ad d, derde voorbeeld.

46. Vgl. de toelichting, Parl. Gesch. Overgangsrecht, p. 195, alwat naar ik aanmeem in plaats vari artikel 182 Ow I moet worden gelezen artikel $1830 \mathrm{w} \mathrm{I}$.

47. Volgens Lekkerkerker, in: BW-krant Jaarboek 1991, p. 132, zal gezien artikell 182 Ow I in na de inwerkingtreding opgemaakte transportakten inzake registergoederen, waaraan een owereenkomst wan wór de inwerkingtreding ten grondslag ligt, de clausule waarin ontbinding van de overeenkomst op grond van de artikkelen 1302 en 1303 (oud) BW wordt uitgesloten gebruikt blijven worden. 
- aan ontbinding niet kan worden toegekomen, indien ten tijde van de inwerking. treding de wederzijdse verbintenissen reeds waren geschorst wegens tijdelijke overmacht ${ }^{48}$.

Artikel $31 \mathrm{Ow}$ II geeft voor faillissementen en surséances van betaling een overgangswoonziening in verband met de nieuwe artikelen $37,38,236$ en $237 \mathrm{Fw}$. De voorgangers van dit kwartet blijven gelden, indien krachtens artikel $182 \mathrm{Ow}$ I op de gevolgen van een tekortkoming in de nakoming van een overeenkomst het oude rechit toepasselijk is ${ }^{49}$.

\subsubsection{Opschortingsrechten}

"Emmeloord (loonwerker) heeft in opdracht van boer Swifterbant een perceel in augustus 1991 diepgeploegd. Swifterbant betaalt de aanneemsom niet, omdat het werk beweerdelijk gebrekkig is uitgevoerd. Desondanks verstrekt hij aan Emmeloord een tweede opdracht, waarvan Emmeloord de uitvoering telkens uitstelt. In januari 1992 wordt Emmeloord tot nakoming gesommeerd, maar beroept zich op een opschortingsrecht." 50

In deze casus zitten twee vragen van overgangsrecht verscholen. De eerste is welk recht moet worden toegepast op de kwestie van de al dan niet gebrekkige witvoering van het ploegwerk door Emmeloord; de tweede is welk recht moet worden toegepast op diens beroep op een opschortingsrecht. Om met dit laatste te beginnen: artikel 180 OW I wijst hier het nieuwe recht aan:

'De wet bepaalt van haar in werking treden af of een bevoegdheid tot opschorting van de nakoming van een verbintenis, een retentierecht daaronder begrepen, bestaat."

De artikelen 6:52-56 BW bevatten regels omtrent het al dan niet bestaan van een opschortingsrecht. Nu zij krachtens artikel $180 \mathrm{Ow}$ I onmidxlellijk werken, bepalen zij vanaf de inwerkingtreding bij uitsluiting of aan een schuldeiser een opschortingsrecht toekom ${ }^{\$ 1}$. Dit resultaat zou echter ook uit de hoofdregel van de onmiddellijke werking van artikel 68 a lid 1 OW I voortvloeien. De verklaring voor het opnemen van artikel 180 in de Overgangswet is dan ook niet de noodzaak de temporele werking aan te geven van de zoëven genoemde bepalingen uit Boek $6 \mathrm{BW}$. Zij heeft te maken met het retentierecht. Zonder artikel 180 Ow 1 zou namelijk de vraag kumnen rijzen, of op het retentierecht artikel $69 \mathrm{OW}$ I van toepassing is, Aangezien artikel 3:290 $\mathrm{BW}$ voor het al dan niet bestaan van retentierechten werwijst naar de bij de wet aangegeven gevallen, is de hier noodzakelijk geachte voorziening verwat in een overgangsregel voor de opschortingsrechten. In het nieuwe BW wordt het re-

48. Vgl. Parl. Gesch. Overgangsrecht; p. 320-321.

49. Zie de toelichting, Parl. Gesch Owergangsrecht, p. 223; Van Huizen, WPNR 6007 (1991), p. 382.

50. H. Stein geeft dit voorbeeld, in: Liber amicorum NBW, p. 162.

51. Part. Gesch. Owergangsrecht, p. 306. 
tentierecht immers beschouwd als een species van het genus opschortingsrecht ${ }^{52}$.

Opschortingsrechten en de bijzondere vormen daarvan (waaronder bij voorbeeld ook de exceptio non adimpleti contractus van artikel 6:262 BW) kunnen worden beschouwd als bevoegdheden. In het stelsel van de Overgangswet

'gaan en komen zulke bevoegdheden met de wet die hen toekent.' ${ }^{53}$

Artikel $182 \mathrm{Ow}$ I is niet van toepassing op opschortingsrechten, omdat zij geen gevolgen van een tekortkoming zijn als bedoeld in deze bepaling. Zij zijn aanwezig zodra de vordering op de wederpartij, alsmede de eigen schuld, opeisbaar zijn en blijven in stand, zolang de wederpartij zijn verbintenis niet is nagekomen (vgl. artikel 6:52 BW) ${ }^{54}$. Thans is het hoog tijd om weer terug te keren naar de hierboven geciteerde casus van Stein. Emmeloords beroep op een opschortingsrecht moet op grond van artikel 180 Ow I worden beoordeeld aan de hand van het nieuwe recht. Over de beweerdle wanprestatie van Emmeloord echter dient volgens artikel 182 Ow I het oude recht te worden geraadpleegd. Stein ${ }^{55}$ merkt naar aanleiding van onder meer dit voorbeeld op:

'Mijn fantasie schiet te kort om te voorzien of een dergelijke mengelmoes van oud en nieuw recht tot ongelukken leidt, maar het gevaar is bepaald niet denkbeeldig en de kans daarop wordt door de dépeçage van de rechtsverhouding stellig verhoogd. De angstige spanning, waarmee ik - ondanks alle voorbereiding - D-day tegemoet zie, berust voornamelijk op mijn beduchtheid voor dergelijke complicaties.'

Het is mij niet duidelijk waarop Steins angst precies is gebaseerd. Zo kan ik mij niet goed voorstellen, welke bezwaren er zouden kunnen bestaan tegen het in een bepaald overgangsgeval (uiteraard na de inwerkingtreding) toepassen van oud recht op schadevergoedings- en ontbindingsvragen en nieuw recht op de daarvan in beginsel los staande vraag of een opschortingsbevoegdheid aanwezig is. Opschortingsrechten zijn evenals de vordering tot nakoming ${ }^{56}$ geen gevolgen van een tekortkoming in de zin van artikel 182 Ow I, waardoor men bij voorbeeld bij de opschortingsrechten met verzuim als vereiste niet in aanraking zal komen.

Enige bepalingen waaraan op grond van artikel $180 \mathrm{Ow}$ I onmiddellijke werking toekomt zijn de artikelen 5:100 (retentierecht erfpachter), 6:37 (opschortingsrecht schuldentar die twijfelt aan wie hij moet betalen), 6:48 lid 3 en 49 lid 4 (opschortingsrecht schuldenaar ingeval crediteur niet voldoet aan wettelijke voorschriften inzake kwijting), 117 (opschortingsrecht schuldenaar bij wijziging plaats betaling) en 262-264 BW (exceptio non adimpleti contractus en onzekerheidsexceptie) ${ }^{57}$.

52. Vgl. Parll. Gesch. Overgangsrecht, p. 276-277.

53. Aldus (met uitwerking) Parl. Gesch. Overgangsrecht, p. 17; zie ook nr. 2.5.1.1 sub d hierv6or:

54. Vgl, Parl. Gesch. Overgangsrecht, p. 157.

55. In: Liber amicorum NBW, p. 163.

56. Zie nur. 7.6.3 hiervóór.

57. Zie hierover Parl. Gesch. Overgangsrecht, p. 294, 304-305, 309, 320. 
Na hetgeen in nr. 7.6 hiervóór is geschreven, kan ik hier wrij kort blijven. Indien een verbintenis reeds bestond toen het nieuwe $\mathrm{BW}$ werd ingevoerd, maar pas bij de invoering of daarna te tekortkoming in de nakoming van die verbintenis een aanvang nam, geldt in beginsel dat alle gevolgen van dat tekortschieten zijn onderworpen aan het nieuwe recht (artikel 182 Ow I). Hierop bestaat een uitzondering voor zover het gaat om artikel 6:83 sub a (termijn voor prestatie in beginsel fataal) en sub $\mathrm{b} B W$ (verbintenis tot schadevergoeding wegens wanprestatie wordt niet terstond nagekomen). Deze regels komen ook niet tot toepassing, indien vóór de inwerkingtreding van een tekortkoming in de nakoming nog geen sprake was (de verbintenis was nog niet opeisbaar, of de verbintenis was wel opeisbaar, maar de debiteur was nog niet in verzuim geraakt) en eerst daarna aan hun vereisten wordt voldaan (artikel 183 Ow I).

Vermeldenswaard is het volgende voorbeeld uit de parlementaire geschiedenis:

'Gesteld een overeenkomst tussen A en B voor het leveren van bouwplaten omstreeks eind december 1991. Op Kerstdag brandt B's fabriek af. Met man en macht probeert $B$ de produktie weer op te starten c.q. aan zijn leveringsverplichtingen te voldoen. Het heeft er aanvankelijk alle schijn van dat hij in zijn streven zal slagen, maar op zeker moment medio januari 1992 moet desondanks worden vastgesteld dat het hem niet gelukt is en ook niet lukken zal. Moet dan voor het bepalen of sprake is van blijvende onmogelijkheid (overmacht) en van de daaraan verbonden gevolgen het oude of het nieuwe recht worden gehanteerd?'58

Ervan uitgaande dat het tijdstip waarvóór $\mathrm{B}$ ten laatste moest presteren na 31 december 1991 lag, kan niet vór 1 januari 1992 een tekortkoming zijn ontstaan, zodat uit artikel 182 Ow I toepasselijkheid van het nieuwe recht volgt ${ }^{59}$.

Artikel 6:80 BW geeft enkele gevallen aan waarin de gevolgen van niet-nakoming reeds intreden voordat de vordering opeisbaar is geworden. Deze nieuw recht bevattende bepaling kan toepassing vinden in een casus als de volgende:

Orgelbouwer A heeft zich in juli 1989 jegens kerkelijke gemeente B verbonden tot de restauratie van haar monumentale orgel. B zal in september 1992 haar driehonderdjarig bestaan vieren. Bij de jubileumfestiviteiten moet het orgel volgens de plannen van $B$ een belangrijke rol spelen. Het instrument moet daarom uiterlijk op 1 september 1992 geheel speelklaar in het kerkgebouw zijn opgesteld. Zo niet, dan verkeert A volgens de overeenkomst van rechtswege in verzuim. Op 15 december 1991 heeft A aan B medegedeeld dat hij onmogelijk reeds op 1 september 1992 een geheel speelklaar orgel kan opleveren; dat kan pas op zijn vroegst in december 1992 lukken. Enige re- 
search heeft uitgemaakt dat de oorzaken hiervan zijn gelegen in A's niet geheel toereikende planningscapaciteiten en diens overvolle orderportefeuille: $\mathrm{B}$ is zo verbolgen dat zij de overeenkomst met A will ontbinden.

Een tekortkoming was (volgens het oude recht, maar ook volgens het nieuwe) vóór 1 januari 1992 nog allerminst aanwezig. Pas na 1 september 1992 zou er een tekortkoming van A kumnen zijn. Uit artikel 182 Ow I volgt derhalve, dat vanaf 1 januari 1992 het nieuwe recht toepasselijk is. Omdat op 1 januari 1992 is voldaan aan hetgeen artikel 6:80 lid 1 aanhef en sub b BW eist, treden de gevolgen van niet-nakoming reeds met ingang van genoemde datum in, ook al wordt B"s vordering pas op I september 1992 opeisbaar. B zal dus vanaf 1 januari 1992 haar zin kunnen krijgen en tot ontbinding kunnen overgaan (artikel 6:265 lid $1 \mathrm{BW}$ ).

\subsection{TEKORTKOMINGEN IN DE NAKOMING BIJ ENIGE BEPERKTE RECHTEN EN BLI DE KOOPOVEREENKOMST}

Bij enkele figuren is het de moeite waard om nader te bekijken hoe het daarbij is gesteld met het overgangsrecht inzake tekortkomingen in de nakoming. Voor het merendeel gaat het daarbij om bijzondere overgangsbepalingen; een enkele keer tevens om de toepassing van een algemene overgangsbepaling op een specifieke rechtsverhouding. Ik besteed aandacht aan achtereenvolgens vruchtgebruik, gebruik en bewoning (nr. 7.8.1), erfpacht (nr. 7.8.2) en koop (nr. 7.8.3).

\subsubsection{Wuchtgebruik, gebruik en bewoning}

A is vruchtgebruiker van B's woning. A is in december 1991 ernstig tekortgeschoten in de nakoming van zijn verplichtingen als vruchtgebruiker. B heeft in februari 1992 het voornemen opgevat daartegen juridische stappen ondernemen.

Het oude BW (artikelen 862 en 863) gaf B de bevoegdheid tot het vorderen van "vernietiging" van het vruchtgebruik of van onderbewindstelling. Eerstgenoemde mogelijkheid bestaat thans niet meer (artikel $3: 221 \mathrm{BW}$ ). Zonder bijzondere overgangsbepaling zou voor de gegeven casus te rade moeten worden gegaan bij artikel 182 Ow I. Aan toepassing van dit artikel staat niet in de weg dat het is geplaatst tussen de overgangsbepalingen in verband met Boek $6 \mathrm{BW}$ en evenmin dat het spreekt over verbintenissen in plaats van (zoals artikel 3:221 BW) over verplichtingen. Artikel $182 \mathrm{OW} I$ betreft niet slechts Boek $6 \mathrm{BW}$, maar heel algemeen 'de wet', dat wil zeggen: de in werking getreden bepalingen van de Boeken 3-8 BW (artikel 68 OW I; artikel 196 lid 3 Ow I is echter bepalend voor de niet-nakomingsregels uit titel 7.1 BW). Voorts kan het tevens op de verplichtingen van beperkt gerechtigden toepassing vinden, omdat ook deze als verbintenissen kunnen worden aangemerkt ${ }^{60}{ }_{\text {" Ook }}$

60. Vgl. Parl. Gesch. Boek 6, p. 40. 
wordt in artikel 182 Ow I niet een beperking aangebracht ten aanzien van de bron waaruit de verbintenis is voortgevloeid. Artikel $182 \mathrm{OW}$ I zou ertoe leiden dat in casu het oude recht bepalend zou zijn. Dit is door de overgangswetgever onwenselijk geacht met het oog op de in het oude recht bestaande mogelijkheid tot "vemietiging" van het vruchtgebruik ${ }^{61}$. Vandaar dat hij artikel 106 in de Overgangswet heeft opgenomen:

'Artikel 221 van Boek 3 is van toepassing op een vruchtgebruik dat op het tijdstip van het in werking treden van de wet bestaat, ook indien op dat tijdstip de vruchtgebruiker reeds in ernstige mate in de nakoming van zijn verplichtingen is tekortgeschoten.'

In afwijking van artikel $182 \mathrm{OW}$ I komt dus aan artikel 3:221 BW onmiddellijke werking toe en komt het in aanmerking voor toepassing op de gegeven casus, zodat de mogelijkheid van vervallenverklaring door 'vernietiging' niet meer bestaat.

Volgens $\mathrm{H}$. Stein ${ }^{62}$ zou de hoofdgerechtigde die vóór de inwerkingtreding een vordering tot 'vernietiging' heeft ingesteld deze niet gefrustreerd zien worden door artikel $106 \mathrm{Ow}$ I. Zo'n vordering zou naar zijn mening ook na de inwerkingtreding kunnen worden toegewezen, omdat de hoofdgerechtigde door het instellen van de vordering, en daarmee de inroeping van een hem door de wet gegeven bevoegdheid, een door artikel 69 Ow I beschermd vermogensrecht zou hebben verkregen. Ik zie dit niet in. Zo lang de rechtsvordering van de hoofdgerechtigde tot 'vernietiging' van het vruchtgebruik niet door de rechter is toegewezen, heeft hij mijns inziens nog geen vermogensrecht verworven ${ }^{63}$.

Op rechten van gebruik en van bewoning vinden de vruchtgebruikregels overeenkomstige toepassing (artikel 3:226 lid $1 \mathrm{BW}$ ). Artikel $106 \mathrm{Ow} I$ is mede voor deze rechten van belang ${ }^{64}$.

\subsubsection{Erfpacht}

Stel het volgende geval doet zich voor:

Gemeente A heeft op 1 januari 1985 voor de duur van vijftig jaar een erfpachtsrecht gevestigd ten behoeve van B op een aan A toebehorend perceel grond. B is aan A per kalenderjaar een canon van $f 5000$ verschuldigd. In de jaren 1990 en 1991 heeft B de canon niet voldaan. In 1992 wil A daarom het erfpachtsrecht eenzijdlig beëindigen.

Indien in de erfpachtswoorwaarden de onderhavige situatie niet zou zijn geregeld

61. Zie Parl. Gesch. Overgangsrecht, p. 113-114.

62. In: Liber amicorum NBW, p. 158. Anders nog dezelfde auteur in zi.jn NJV-preadvies, p. 197.

63. Zie Asser-Beekhuis II, nr. 424: "Het verval geschiedt niet van rechtswege, maar kan door de rechter worden uitgesproken.'

64. Aldus Parl. Gesch. Overgangsrecht, p. 269. 
(hetgeen niet vaak zal voorkomen), zou onder het oude recht het volgende hebben gegolden. Artikel 780 lid 2 (oud) BW (regelend recht op grond van artikel 782 (oud) $\mathrm{BW}$ ) bepaalde dat vervallenverklaring van de erfpacht kon worden uitgesproken ter zake van wanbetaling van de canon gedurende vijf op elkaar volgende jaren: In casu is aan deze eis niet voldaan. Ook de andere beëindigingsmogelijkheden die het oude BW kende (artikelen 765 en 766 jo. 783) zouden hier geen uitkomst geven. Meer waarschijnlijk zou zijn dat de erfpachtsvoorwaarden wel een voorziening bevatten voor wanbetaling van de canon; bij voorbeeld de mogelijkheid van vervallenverklaring van de erfpacht bij wanbetaling gedurende een periode van langer dan zes maanden ${ }^{65}$. Dan zou eenzijdige beëindiging van de erfpacht wel mogelijk zijn.

Volgens artikel 5:87 lid 2 BW kan de eigenaar de erfpacht opzeggen, indien de erfpachter in verzuim is de canon over twee achtereenvolgende jaren te betalen. Aan dit vereiste is in casu voldaan, zodat opzegging mogelijk zou zijn, behalve in het onwaarschijnlijke geval dat in de erfpachtsvoorwaarden ten gunste van de erfpachter van genoemde bepaling zou zijn afgeweken (afwijking ten nadele van de erfpachter is nietig volgens lid 3). Ik ga voor het vervolg uit van de veronderstelling dat in de onderhavige erfpachtsvoorwaarden niet van de wet is afgeweken op het stuk van sancties ter zake van wanbetaling van de canon ${ }^{66}$.

Wie de parlementaire stukken raadpleegt om te weten te komen welke werking in de tijd toekomt aan artikel 5:87 lid 2 BW krijgt daaruit geen eenduidig beeld. In de toelichting ${ }^{67}$ treft men bij eén van de voorgangers van genoemde bepaling, artikel 5.7.1.8 $a$ \id 4 , de opmerking aan dat, indien bij de inwerkingtreding is voldaan aan de vereisten die genoemd lid 4 stelt, het oude recht toepasselijk blijft op grond van artikel 182 Ow I. In het hierboven gegeven voorbeeld zou derhalve artikel 5:87 lid $2 \mathrm{BW}$ niet toepasselijk zijn. In deze richting wijst ook de toelichting bij artikel 106 OW I inzake de vruchtgebruiker die in ernstige mate is tekortgeschoten in de nakoming van zijn verplichtingen, waarin eveneens wordt gerefereerd aan artikel 182 OW $\mathbb{I}^{68}$.

Later in de parlementaire geschiedenis, als het huidige artikel 5:87 lid $2 \mathrm{BW}$ inmiddels het licht heeft gezien, wordt een voorbeeld gegeven, dat niet goed met de zojuist genoemde aanwijzingen is te verenigen. Dit voorbeeld betreft artikel 74 lid 2 OW I (lopende procedures) en houdt in dat de eigenaar na de inwerkingtreding van artikel 5:87 lid $1^{69} \mathrm{BW}$ de erfpacht opzegt tijdens een lopende procedure inzake wanbetaling van de canon, en wel op een tijdstip waarop de vijfjaarstermijn van artikel 780 lid 2 (oud) BW nog niet was verstreken. Het gaat hier om uitoefening van een nieuwe bevoegdheid tijdens een lopende procedure ${ }^{70}$. Evenals in het voorbeeld dat ik hierboven gaf moet in dit voorbeeld wel, gezien het feit dat het om een

65. Aldus het in nr. 4.5.4 hiervớr geciteerde beding.

66. Zie over het geval dat dit, ten nadele wan de erfpachter, wel is geschied nur. 4.5.4 hiervóór (eerbiediging krachtens artikel $79 \mathrm{Ow}$ D. Alsdan kan de grondeigenaar behalve aan artikel $5: 87$ BW ook aan het gehandhaafde teding in de erfpachtsvoorwaarden een opzeggingsbewoegdheid ontlenen.

67. Parl. Gesch. Overgangsrecht, $\mathrm{p}_{.} 147$.

68. Zie nr. 7.8. 1 hiervón, waar ook is gebleken dat toepassing van artikel 1820 w I bijil beperkte rechten inderdaad mogelijk is.

69. Dit moet lid 2 zi.j.n.

70. Aldus Parl. Gesch. Overgangsrecht, $\mathrm{p}_{4} 63$ sub d en laatste wolle alinea. 
ten tijde van de invoering lopende procedure gaat, bij de invoering reeds zijn voldaan aan de vereisten die artikel 5:87 lid $2 \mathrm{BW}$ voor de bevoegdheid tot opzegging stelt, zodat kennelijk in de visie van de overgangswetgever op grond van de hoofdregel van de onmiddellijke werking (artikel $68 a$ lid 1 Ow 1 ) de opzeggingsbevoegdheid volgens de nieuwe bepaling ontstaat ${ }^{71}$.

Deze laatste uitkomst lijkt te worden ondersteund op een andere plaats in de parlementatre stukken ${ }^{72}$, waar van artikel $5: 87$ lid $2 \mathrm{BW}$ wordt gezegd dat de onniddellijke werking daarvan, die tevens de afschaffing van artikel 780 (oud) BW voor lopende erfpachten betekent, geen bijzondere bepaling behoeft. Tegen toepassing van artikel $182 \mathrm{Ow}$ I pleit voorts nog dat de ratio daarvan voor het onderhavige geval niet opgaat. Deze ratio komt hierop neer dat aan een tekortschieten onder de oude wet die wet reeds rechtsgevolgen kan hebben verbonden, en dat het onpraktisch is om die met het nieuwe recht te doorkruisen, omdat het nieuwe recht ten aanzien van verzuim, schadevergoeding en ontbinding nogal verschilt van het oude ${ }^{73}$. Onder het oude recht was aan de onderhavige tekortkoming van de erfpachter echter juist geen rechtsgevolg verbonden.

Zou men de parlementaire geschiedenis wegdenken en alleen naar de tekst van de Overgangswet zien, dan zou men moeten concluderen dat artikel 182 Ow I en niet artikel $68 \mathrm{a}$ Ow I het hier voor het zeggen heeft. Aantrekkelijk is dit niet ${ }^{74}$ : de grondejgenaar die geen beëindigingsbevoegdheid kan ontlenen aan de erfpachtsvoorwaarden zou in bovenstaand voorbeeld aangewezen blijven op artikel 780 lid 2 (oud) BW met zijn vijfjaarstermijn. Met artikel 75 Ow I kan men hierin geen verandering brengen, omdat daarin niet de mogelijkheid wordt geopend in plaats van het oude recht het nieuwe recht toepasselijk te laten zijn ${ }^{75}$. Artikel 6:248 lid 2 BW kan hier uitkomst bieden. In plaats van artikel 182 Ow I zou men dan artikel $68 a$ lid 1 Ow I kunnen toepassen, met als resultaat onmiddellijke werking van artikel 5:87 lid $2 \mathrm{BW}$.

\subsection{Koop}

Met betrekking tot de nieuwe regeling van de koop- (en de ruil)overeenkomst in titel 7.I BW bevat artikel 196 OW I een aantal overgangsregels, dat hier bespreking verdient. Doordat in het artikel nogal wat uitzonderingen voorkomen, ziet het er tamelijk ungewikkeld uit. Hoofdregel is een uitgestelde werking van één jaar vân titel 7.1 BW als geheel voor koop-en ruilovereenkomsten, die vóof het tijdstip van de inwerkingtreding zijn gesloten (artikel 196 lid 1 Ow I). Op deze uitgestelde werking wordt in lid 2 een uitzondering gemaakt voor consumentenkoopovereenkomsten (gesloten vóor het tijdstip van de inwerkingtreding). Daarvoor geldt in zoverre eer-

71. Vgl : ook hetgeen in de toelichting wordt gezegd over bevoegdheden (Parl. Gesch. Owergangsrecht, $\mathrm{p}$. 17).

72. Parl. Gesch. Overgangsrecht, p. 145; in deze zin ook H. Stein, in: Liber amicorum NBW,p. 1.58.

73. Zie nader ni: 7.6. hiervo6r.

74. Ook niet volgens de minister' 'artikel 780 is wel erg lamkmoedig, althans voor onze tijd' (Parl. Giesch. Overgangsrechi, p. 145).

75. Hierwoor is overigens wel gepleit, zie nr. 2.5.3 hiervóor. 
biediging wan het oude recht, dat de nieuwe regels inzake consumentenkoop daarop niet toepasselijk zullen worden. Zowell in afwijking van lid 1 als van lid 2 is titel 7.1 BW well toepasselijk op de gevolgen van niet-nakoming in het geval dat éen der partijen na de inwerkingtreding tekortschiet in de nakoming van eén van haar verbintenissen. Dit geldt echter weer niet, indien het tekortschieten een voortzetting is van een eerdere tekortkoming (artikel 196 lid 3 eerste zin Ow I). Ik geef een aan de parlementaire geschiedenis ontleend voorbeeld.

'Gesteld dat A ten behoeve van zijn restaurant in oktober 1991 een vaatwasmachine koopt. De machine gaat tengevolge van een verborgen gebrek op 3 januari 1992 stuk. A moet extra kosten maken. Geldt dan voor de gehele afwikkeling van het geschil - verzuim, ingebrekestelling, wanprestatie of verborgen gebreken, ontbinding, schadevergoeding enz. - het huidige recht?' ${ }^{76}$

Indien ervan wordt uitgegaan dat de machine in 1991 is geleverd en toen een gebrek had, dat tot de schade op 3 januari 1992 heeft geleid, is de wanprestatie vór $\mathbb{1}$ januari 1992 aangevangen en geldt op grond van de artikelen 182 en 196 lid 3 Ow I het oude recht voor alle gevolgen van de wanprestatie, ongeacht of deze vóor dan wel op of na 1 januari 1992 intreden ${ }^{77}$. Hetzelfde geldt als de machine vóor en na de inwerkingtreding een aantal malen defect raakt en weer wordt gerepareerd en A na enige tijd zegt van de koop af te willen c.q. een nieuwe machine te wensen ${ }^{78}$.

In het oog dient te worden gehouden dat artikel 182 Ow I alleen betrekking heeft op de algemene regels met betrekking tot tekortkomingen in de nakoming en niet tevens op die betreffende koop (titel 7.1 BW, onder meer afdeling 3): daarvoor geldt artikel 196 lid 3 Ow I. Beide bepalingen bevatten hetzelfde stelsel: op de gevolgen van een tekortkoming die is begaan vóór de inwerkingtreding wordt het nieuwe recht niet toepasselijk, ook niet indien de tekortkoming na de inwerkingtreding wordt voortgezet.

De gedachte achter artikel 196 lid 3 Ow I is de volgende. Voor de uitgestelde werking en de eerbiediging, die de leden 1 en 2 inhouden, is doorslaggevend geweest dat de overgrote meerderheid van de koopovereenkomsten slechts een korte duur heeft en het voor partijen niet aantrekkelijk is om tijdens die korte duur te worden geeonfronteerd met de waarschijnlijk onverwachte werking van een nieuwe wet. Anders is het in de opvatting van de overgangswetgever, indien een partij na de inwerkingtreding tekortschiet in de nakoming van haar verplichtingen, terwijl op dat gebied het nieuwe recht een niet geringe vooruitgang betekent ten opzichte van het oude. Daarom is in lid 3 een uitzondering opgenomen, die op één lijn ligt met artikel 182 Ow I. Hierdoor ontstaat de mogelijkheid dat op ến en hetzelfde geval zowel oud als nieuw recht moet worden toegepast. Dit ontmoet in de ogen van de overgangswetgever geen bezwaar:

'De specifieke regeling der niet nakoming in titel 7.1 vormt een goed afge-

76. Parl. Gesch. Overgangsrectit, p. 179 subd:

77. Vgl. Parl. Gesch. Overgangsrecht, p. 181 sub d.

78. Zie Parl. Gesch. Overgangsrecht, p. 179 sube, 181 sube. 
rond geheel, dat zich voor toepassing leent; ook al worden de wederzijdse verbintenissen van partijen nog door het oude recht geregeld. ${ }^{779}$

De argumentatie van de overgangswetgever inzake artikel 196 lid 3 Ow I komt overtuigend voor, met name de gelijkschakeling met artikel $182 \mathrm{Ow} \mathrm{I}$, dat de algemene tekortkomingsregels betreft. Wel is het zo dat men door deze opzet wordt genoodzaakt een onderscheid te maken tussen regels uit titel $7.1 \mathrm{BW}$ inzake niet-nakoming en andere regels. Dit lijkt echter niet problematisch (regels inzake niet-nakoming zijn met name opgenomen in de afdelingen 7.1.3 en 7.1.5-7 BW) ${ }^{30}$.

Schmitz betoogt dat de toepassing van tweërlei recht in geval van een tekortkoming op of na 1 januari 1992 tot problemen leidt bij koopovereenkomsten betreffende specieszaken. $\mathrm{Zij}$ voert in dit verband de volgende casus ten tonele:

'Op 15 december 1991 verkoopt antiquair B aan de heer Van $Z$ een antieke klok. Zij spreken af dat B deze op 10 januari 1992 zal bezorgen bij Van Z. In de wroege ochtend van 1 januari 1992 brandt het pand waarin de klok hangt uit. Van de klok zijn slechts enige vermoedelijke restanten aangetroffen. ${ }^{81}$

De minister bestrijdt Schmitz' mening met de volgende beschouwing over deze casus, die mij op een enkel punt na juist toeschijnt. De regel 'periculum est emptoris" van artikel 1496 (oud) BW heeft hier tot gevolg dat het risico voor het tenietgaan van de klok door overmacht vóór de levering voor koper Van $Z$ is: hij zal alsdan toch de koopprijs moeten betalen. De invoering van titel 7.1 BW beïnvloedt deze risicoverdeling niet: deze wordt volgens de artikelen 69 sub a en 196 lid 1 of lid 2 Ow I geèerbiedigd ${ }^{82}$. Behalve de gehandhaafde risicoverdeling is in de casus nog een tweede overgangsrechtelijke vraag aanwezig, namelijk onder welk recht B's tekortkoming valt. Op grond van artikel $182 \mathrm{Ow}$ I is het algemene niet-nakomingsrecht van Boek 6 BW toepasselijk en op grond van artikel 196 lid 3 Ow I het niet-nakomingsrecht van titel 7.1 $\mathrm{BW}$ : de tekortkoming is immers eerst na 1 januari 1992 ingetreden. Indien B de overeenkomst ex artikel 6:265 BW ontbindt, worden partijen bevrijd wan de door de ontbinding getroffen verbintenissen (artikel $6: 271 \mathrm{BW}$ ), behalve van de verbintenis waarom het hier juist gaat, namelijk die tot betaling van de koopprijs. Dit laatste volgt uit de tussen partijen geldende risicoverdeling. De minister maakt een treffende vergelijking met de situatie waarin een rịsicoverdeling zou zijn afgesproken door partijen bij een na 31 december 1991 gesloten koopovereenkomst en een volgens deze afspraak voor risico van de koper komende gebeurtenis zich zou verwezenlijken. Het verschil met de onderhavige casus is slechts dat daarin de risicoverdeling bestaat krachtens overgangsrecht, ter-

79. Aldus Parl. Gesch, Overgangsrecht p. 180.

80. Zie over de réchtsgeldigheid van anterieure bedingen ter zake wan niet-nakoming door de verkoper, die de wettelijke rechten van een consument-koper verkorten nr. 4.5 .8 hiervoór.

81, In: BW-krant juarboek 1990, p. 84.

82. Het is niet altijd om het even welke bepaling men hier toepast: zonder artikel 69 sub a Ow I zou krachtens artikel 196 lid 1 Ow I met ingang van 1 januari 1993 alsnog de nieu we risicoverdeling bepalend worden. $\mathrm{Vg}$. Polman, ${ }_{8}$ Overgangswet, deel 1 , p. 37. 
wijl deze in het andere geval uit een contractueel beding zou voortvloeien ${ }^{83}$ :

Artikel 7:23 lid $2 \mathrm{BW}$ houdt een verjaringstermijn van twee jaar in voor rechtsvorderingen en verweren, gegrond op feiten die de stelling zouden rechtvaardigen dat de afgeleverde zaak niet aan de overeenkomst beantwoordt; dit betekent een afwijking van de verborgen gebreken-regeling in artikel 1547 (oud) BW. De termijnbepalingen 72 en $73 a$ Ow I worden hier uitgeschakeld door artikel 196 lid 3 Ow I*4.

Voor het recht van reclame is een aparte overgangsregel geformuleerd in de tweede zin van artikel 196 lid 3 Ow I: afdeling 7.1.8 BW is toepasselijk op het recht van reclame, indien dit na de inwerkingtreding wordt uitgeoefend, ongeacht wanneer de wanprestatie is aangevangen, die tot gebruikmaking van het recht van reclame leidt. Op een vóór de inwerkingtreding uitgeoefend recht van reclame blijft ook nadien het oude recht toepasselijk. Daarmee wijkt artikel 196 lid 3 tweede zin OW I af van artikel 182 Ow I. De speciale regeling voor het recht van reclame is ingegeven door motieven van praktische aard. De eveneens praktische overwegingen die tot artikel $182 \mathrm{Ow}$ I hebben geleid ${ }^{85}$ gelden hier volgens de minister niet. Indien het recht van reclame, hoewel inroeping mogelijk zou zijn geweest, ten tijde van de invoering nog niet was ingeroepen, dan

'heeft het niet weel goede zin de uitoefening na die inwerkingtreding nog aan de regels wan het oude recht te binden. In wezen is er niet veel verschil, afdeling 7.1.8 biedt veeleer een meer moderne en systematische regeling. ${ }^{\circ 6}$

Voor het recht van reclame gaat dus de hoofdregel van de onmiddellijke werking op: de bevoegdheid van de verkoper tot terugvordering van de koopwaar vloeit, ook ingeval de koper reeds vóór de inwerkingtreding is tekortgeschoten in de betaling van de koopprijs, nadien uit de nieuwe wet voort, tenzij de verkoper zijn bevoegdheid reeds had ingeroepen onder het oude recht.

De zoëven weergegeven passage uit de parlementaire geschiedenis gaat uit van de situatie dat het recht van reclame onder het oude recht kon worden aitgeoefend. Afdeling 7.1.8 $\mathrm{BW}$ bevat echter verruimingen ten opzichte van wat voorheen gold $^{87}$. Daardoor kan het voorkomen dat de verkoper vanaf de inwerkingtreding een bevoegdheid verwerft, die hij voorheen niet had. Bezwaarlijk lijkt dit echter niet.

Artikel 196 lid 3 tweede zin Ow I zet de termijnenregeling in de artikelen 72 en $73 a$ Ow I opzij 88 .

De afschaffing van het verkopersprivilege heeft geen gevolg voor zo'n privilege dat vóór de inwerkingtreding reeds aan een vordering was verbonden op grond van artike1 1185 sub 3 (oud) BW (artikel 119 OW I). Tevens worden in genoemde over-

83. Zie Parl. Gesch. Overgangsrecht, p. 180 sub b. Voor de met het risico voor de koopwaar verband houdendle regeling in artikel 263 WwK is een overgangswoorziening getroffen in artikel 14 OW II, die inhoudt dat het rieuwe artikel 263 WvK slechts toepasselijk is, indien voor de koop artikel 7:10 BW (de opvolger van artikel 1496 (oud) BW) geldt; zie de toelichting in Parl. Gesch. Overgangsrecht, p. 199.

84. Aldus ook Parl. Gesch. Overgangsrecht, p. 177; anders Schmitz, in: BW-krant Jaarboek 1990, p. 88-89.

85. Zie nr. 7.6.1 hiervóór.

86. Aldus Parl. Gesch. Overgangsrecht, p. 178.

87. Zie Van der Beek, Kwartaalbericht Nieuw BW 1988, p. 81-82.

88. Aldus ook Parl. Gesch. Overgangsrecht, p. 177, 178; anders Polak, preadv., p. 63. 
gangsbepaling de artikelen 1190 en $1192 a$ (oud) $\mathrm{BW}$ geẻerbiedigd, volgens de toolichling omdat de regeling wan deze beide bepalingen bij dat privilege zou behoren ${ }^{89}$. Voor artikel $1192 a$ (oud) BW gaat dit echter niet op: hierin wordt een regeling gegeven die het recht wan reclame betreft ${ }^{90}$. Zou het recht van reclame na de in werkingtreding worden ingeroepen met betrekking tot een voordien reeds ontstane koopprijswordering, dan zou naast afdeling 7.1.8 BW (zie artikel 196 lid 3 OW I) ook artikel 1192 (oud) BW nog toepasselijk zijn (zie artikel 119 OW I). Ik denk echter niet dat dit tot 'ongelukken' kan leiden. Artikel $1192 a$ (oud) BW heeft betrekking op het recht wan reclame ex artikel 1191 (oud) $\mathrm{BW}$ en hangt zonder deze Jatste bepaling als het ware in de lucht: het recht van de verkoper waarover lid I van artikel $1192 a$ (oud) BW spreekt, bestaat vanaf 1 januari 1992 niet meer ${ }^{91}$.

De bevogdheid van de onbetaalde werkoper om in het faillissement van de koper het bodembeslag van de fiscus te doorbreken door zijn recht van reclame uit te oefenen, bestaat niet meer wolgens de artikelen 22 lid 3 Invorderingswet 1990 en 156 lid 4 Algemene wet inzake de douane en de accijnzen, beide zoals gewijzigd bij de invoeringswetgeving voor het nieuwe $\mathrm{BW}^{92}$. Het oude recht wordt hier echter geeerbiedigd: in artikel 39 lid 2 Ow II $^{93}$ wordt bepaald dat genoemde artikelleden niet toepasselijk zijn op een vóór het tijdstip wan de inwerkingtreding gelegd bodembeslag, voor zover het betreft de rechten van hen die tot aan dat tijdstip reeds op grond van de oude artikelen 230 e.v. WvK bevoegd waren tot de terugvordering vali een in beslag genomen zaak ${ }^{94}$. Wordt het recht van reclame na de inwerkingtreding uitgeoefend, dan is dárop het nieuwe recht toepasselijk (artikel 196 lid 3 Ow $)^{95}$.

\subsection{DE UITEENLOPENDE OVERGANGSREGIMES BUT TEKORTKOMINGEN IN DE} NAKOMING EN BIJ DE ONRFCHTMATIGE DAAD

Bij tekortkomingen in de nakoming wordt uitgegaan van een ander stelsel dan bij schadevergoeding wegens onrechtmatige daad. Kort gezegd: bij tekortkomingen in de nakoming is doorslaggevend voor de toepasselijkheid van oud dan wel nieuw recht, of de tekortkoming al dan niet vór de inwerkingtreding is gepleegd of aan-

39. Zie Parl Gesch. Overgangsrecht, $\mathrm{p}, 123$.

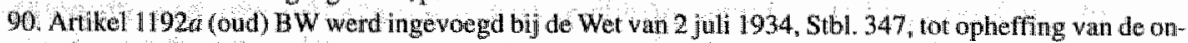
dersoheidhng tossen handelsdaden wh thet handelsdaden en kooplieden en niet-kooplieden. Het is behou dens enige verswhillen in redactie gelijk an het met ingang van 1 januari 1935 uit de regelung van hat recht wan reclame in het wetboek van Koophandel geschrapte artikel 245 en wijkt op meerdere punten ar van de net we regeling van het recht van reclame in afdeling $7.1 .8 \mathrm{BW}$. Zie ook Asser-Mijnssen nrs. 51, 61-62. 91. Tol welke verwarring het noemen van artikel $1192 a$ (oud) BW in artikel 119 Ow 1 kan leiden blikt bij P.A. Sie:n, WPNR 6007 (1991), p. 361 .

92. Re gpetiewelijk her dertiende gedeelte (de zogenoemde "bezemwet", Stbl. 1991, 199) en het megende gedeelte (Stbl 1989,491$)$

93. Loals voongestell in TK, vergaderjaar 1991-1992, 22442 , nr. 2 (wetsvoorstel Correctie en anpassing van de Invoringswet Boeken 3,5 en 6 nieuw B. W. (dertiende gedeelte) voor zover het fiscale wetgeving betretten enige andere correcties). 2 ie ook nr. 5.6.4, noot 62 , hierwór.

94. De eerbiediging van het oude recht volgt uit de artikelen 1 lid 2 Ow II jo: 68 a lid 2 Ow $\mathrm{L}$.

95. Vgi. Parl Gesch. Overgangsrecht, p. 230. 
gevangen. Voor de onrechtmatige daad daarentegen is bepalend, of alle vereisten die de oude wet voor een rechtsgevolg stelde onder de gelding van die wet waren vervuld. Bij samenloop tussen wanprestatie en onrechtmatige daad in gevallen van overgangsrecht is denkbaar dat zowel de artikelen 182 jo. $68 \mathrm{a}$ lid 2 als (de regel waarvan wordt uitgegaan in) $173 \mathrm{Ow}$ I voor toepassing in aanmerking komen. De aansprakelijkheid uit wanprestatie kan dan onder oud recht vallen, terwijl die uit onrechtmatige daad wordt beheerst door het nieuwe. Ik volsta met een verwijzing naar de parlementaire geschiedenis, waarin op beide punten (uiteenlopende overgangsregimes woor onrechtmatige daad en wanprestatie, en samenloop) uitvoerig is ingegaan ${ }^{96}$.

\subsection{SLOT}

Wie wordt geconfronteerd met een overgangsprobleem dat verband houdt met een tekortkoming in de nakoming van verbintenissen, moet niet denken te kunnen volstaan met raadpleging van artikel 182 Ow I met de daarbij behorende parlementaire geschiedenis. Ook andere overgangsbepalingen zullen moeten worden 'gecheckt" met het oog op hun eventuele van toepassing zijn, bij voorbeeld de artikelen 183 en 196 lid 3 Ow II. Voorts moet in het oog worden gehouden dat de mogelijkheid bestaat, dat in een bepaald geval het ene rechtsgevolg (bij voorbeeld schadevergoeding) wordt beheerst door oud recht en het andere (bij voorbeeld opschorting) door nieuw recht. 



\section{HOOFDSTUK 8}

\section{Tot besluit}

Twee vragen staan centraal in dit boek. De eerste is, wanneer overgangsrechtelijke kwesties rijzen en hoe deze kunnen worden opgelost. De tweede is of, en zo ja, in hoeverre het nieuwe vermogensrecht toepasselijk wordt en behoort te worden op overeenkomsten, zekerheidseigendomsrechten en dergelijke; die bij zijn inwerkingtreding aanwezig waren, alsmede wat de gevolgen zijn van dat al dan niet toepasselijk worden (zie nr. 1.1 hiervóór). De beantwoording van genoemde vragen leverde onder meer het volgende op.

Men wordt met kwesties van overgangsrecht geconfronteerd, indien sprake is van een overgangssituatie en van het daarvoor vereiste opeenvolgen van rechtsregels'. Met name inzicht in het begrip 'overgangssituatie' zoals dit door de wetgever wordt gezien is onontbeerlijk voor een juiste toepassing van de Overgangswet en voor een goed begrip van de daarbij behorende toelichtende stukken. Zo"n overgangssituatie is er volgens de wetgever, indien ten tijde wan de inwerkingtreding de vereisten waren vervuld, die de nieuwe wet stelt voor het intreden van haar rechtsgevolg. Uit deze omschrijving blijkt hoe de wetgever aankijkt tegen rechtsregels: deze verbiniden een rechtsgevolg aan de vervulling van de vereisten die zij daarvoor stellen. Voor een rechtsgevolg kunnen toestanden, feiten en juridische waarderingen van toestanden of feiten vereist zijn.

Anders dan de wetgever doet voorkomen, is het werken met alleen overgangssituaties die bestonden op het tijdstip van de inwerkingtreding niet toereikend. Terugwerkende kracht, uitgestelde werking, "onvolledige complexen van rechtsfeiten" etc. laten stuk voor stuk zien dat het uitsluitend kijken naar het moment van de inwerkingtreding niet over de gehele linie vol te houden valt. Problematisch is ook de rol die anterieure feiten spelen als zij voldoen aan de vereisten die de nieuwe wet stelt voor een rechtsgevolg.

Ten aanzien van het 'opeenvolgen van rechtsregels' is met name van belang te weten hoe oude en nieuwe wet zich tot elkaar verhouden ten aanzien van de vereisten die zij stellen en de daarbij behorende rechtsgevolgen. Stemmen oud en nieuw op beide fronten overeen (zoals zich bij het oude en het nieuwe BW niet zelden voordoet), dan brengt dit niet met zich mee dat men dan de 'antikiesregel' zou kunnen toepassen, zoals wel is beweerd. Er moet well degelijk worden gekozen; hier zal in de regel het nieuwe recht toepasselijk zijn.

Telkens als een overgangssituatie en een opeenvolgen van rechtsregels aan de orde zijn, heeft men te maken met de volgende vragen: wordt de nieuwe regel toepasselijk op overgangssituaties, behoort hij daarop toepasselijk te worden, en zo ja, in hoeverre? Het overgangsrecht beoogt deze vragen te beantwoorden.

Het instrumentarium dat de overgangswetgever tot zijn beschikking heeft ter re- 
gulering wan de temporele werking van de nieuwe wet valt uiteen in twee groepen. Yoor de naar verhouding eenvoudige problemen is een verwijzingsregel toereikend. In andere gevallen moet een overbruggingsregel worden opgesteld. Opvallend is dat de temporele werking van het nieuwe BW volgens de overgangswetgever afthankelijk is niet wan het moment warop de vereisten van het nieuwe wetboek zijn vervuld, matar van dat warop zijn rechtsgevolg daaraan wordt verbonden. De onmiddellike werking heeft daardoor een bereik dat naar mijn mening te ruim is: ook als vanaf de inwerkingtreding een rechtsgewolg wordt werbonden aan anterieure feiten is er wolgens de overgangswetgever onmiddellijke werking.

Voor de opllossing van overgangsproblemen is mede van belang de mogelijkheid om het resultat wan toepassing van een overgangsiregel te corrigeren, met name op grond van de derogerende werking van de redelijkheid en billijkheid. Ik acht deze in artikel 75 Ow $\mathbb{I}$ alleen voor een aantal algemene overgangsbepalingen geopende mogelijkheid ook wenselijk voor de bijzondere overgangsbepalingen, evenals het buiten toepassing kumen laten van door de Overgangswet aangewezen oud recht, waarin artikel $75 \mathrm{OW}$ I evenmin voorziet.

De tweede in dit boek aan de orde gestelde vraag betreft, als gezegd, het al dan niet toepasselijk (behoren te) worden van het nieuwe vermogensrecht op bij de inwerkingtreding bestaande overeenkomsten, zekerheidseigendomsrechten en dergelijke en de gevolgen van dat al dan niet toepasselijk worden. Bij de beantwoording van deze vraag wordt uiteraard voortgebouwd op de in het algemeen deel besproken fundamenten. Ik wijs slechts op enkele punten die bij de beantwoording van deze vrag naar voren kwamen. Vooral de geldigheid van rechtshandelingen en de zekerheidseigendom ontpoppen zich als notoür moeilijk. Bij de geldigheid van rechtshandelingen springt in het oog dat de wetgever, zonder dat duidelijk wondt waarom, onaantastbaarheid en nietigheid in tegenstelling tot wernietigbaarheid beschouwt als 'momentele' eigenschappen van rechtshandelingen. Het aantall overgangsproblemen als gevolg van de omzetting van zekerheidseigendom in stil pandrecht (zoals op het vlak van de collisie) blijkt bij nadere bestudering aanvankelijk bijna niet te overzien. Dat wordt met zekerheid veroorzaakt door de grote gecompliceerdheid van het materiele recht op dit stuk.

De inschrijvingen betreffende registergoederen, de onrechtmatige daad en de tekortkomingen in de nakoming van verbintenissen leveren een minder (omvang)rijke overgangsproblematiek op. Evenals bij de geldigheid van rechtshandelingen en bij de zekerheidseigendom zijn de daarop betrekking hebbende overgangsregels echter van eminent belang voor de praktijk. Ten aanzien van de inschrijvingen betheffende registergoederen noem ik bij wijze van voorbeeld de uitgestelde werking van drie jaar van de nieuwe derdenbeschermingsbepalingen $3: 24$ lid 1,25 en 26 BW. Bij de onrechtmatige daad speelt de 'eerbiediging van verkregen rechten' een belangrijke rol. Bij de tekortkomingen in de nakoming springt onder meer de fijnmazige overgangsregeling ten aanzien van de koopovereenkomst in het oog.

Wie het overgangsrecht voor het nieuwe vermogensrecht overziet, kan zich afvragen of het niet eenvoudiger had gekund. Is het wel doelmatig om de overgangsproblematiek die wordt veroorzaakt door de invoering van het nieuwe vermogensrecht te regelen met een zo in detail tredende en op nieuw ontwikkelde uitgangspunten berustende overgangswetgeving? Naar mijn mening is dat wel degelijk 
doelmatig. Om meerdere redenen konden enkele grove overgangsregells niet volstaan bij de invoering van het nieuwe vermogensrecht. De overgangswetgever had te maken met

'het belang van partijen bij een zoveel mogelijk ongestoorde voortzetting (van hun rechtsverhouding, $\mathrm{HvdB}$ ) en het belang van invoering wan nieuw recht over de gehele linie" 1 .

Belangrijk is ook dat het nieuwe BW onderdelen bevat, die op allerlei, soms fundamentele, punten afwijken van het oude recht (denk aan het stille pandrecht). Wie dan volstaat met bij voorbeeld onmiddellijke werking als hoofdregel met daarop wat uitzonderingen, of omgekeerd eerbiediging van het oude recht met enkele afwijkingen, zadelt de praktijk op met te voorziene moeilijkheden die tot op grote hoogte hadden kunnen worden voorkomen.

De onderhavige, gedetailleerde, regeling dient ook de rechtszekerheid. Niet alleen door haar gedetailleerdheid, maar vooral ook door de inhoud van de regeling. Daarbij is de rechtvaardigheid in het concrete geval echter niet uit het oog verloren. De wetgever heeft ook ingezien dat hij niet alle overgangsproblemen kan voorzien. Hij heeft daarom een mogelijkheid tot afwijking van het overgangsrecht geschapen. De zojuist gemaakte opmerkingen nemen niet weg dat men op onderdelen van de systematiek, de uitgangspunten en de toepassingen van het overgangsrecht voor het nieuwe BW kritiek kan hebben (zie de hierboven als voorbeeld genoemde en in de voorgaande hoofdstukken uitgewerkte punten van kritiek). Deze is echter niet wan dien aard dat aan dit overgangsrecht 'exportpretentie' ten aanzien van andere wetgeving, ook buiten privaatrechtelijk terrein, zou moeten worden ontzegd. Integendeel, ontwerpers van andere wetten doen er verstandig aan om bij voorbeeld de terminologie en de inhoud van de verwijzingsregels over te nemen zoals de overgangswetgever nieuw BW deze hanteert. Zo kan het overgangsrecht voor het nieuwe BW ook elders zijn nut bewijzen. Er is tenslotte altijd. strijd tussen oud en nieuw recht. 



\section{Samenvatting}

De invoering van de Boeken 3, 5, 6 en enige delen van Boek 7 BW op 1 januari 1992 werd begeleid door een omvangrijk complex overgangsregels. Systematiek, uitgangspunten en toepassingen van een aantal van deze overgangsregels vormen het onderwerp van dit proefschrift. Na het inleidende hoofdstuk I worden in hoofdstuk 2 systematiek en uitgangspunten van het overgangsrecht voor het nieuwe BW besproken. De centrale vraag in dit algemeen deel is, wanneer kwesties van overgangsrecht ontstaan en hoe deze kunnen worden opgelost. Bedoelde kwesties doen zich in de optiek van de wetgever voor, indien ten tijde van de inwerkingtreding de vereisten waren vervuld, die het nieuwe recht stelt voor een rechtsgevolg. In dat geval was ten tijde van de inwerkingtreding een zogeheten overgangssituatie aanwezig. Er moet dus sprake zijn van een bepaalde feitenconstellatie en van de invoering van nieuw recht: De vereisten die een rechtsregel stelt voor een rechtsgevolg kunnen bestaan uit toestanden, feiten en juridische waarderingen van toestanden of feiten.

In hoofdstuk 2 wordt betoogd dat de wetgever het begrip 'overgangssituatie' te beperkt opvat, aangezien ook het vóór of na de inwerkingtreding vervuld zijn van de vereisten die het nieuwe BW voor een rechtsgevolg stelt tot vragen van overgangsrecht kan leiden. Dit blijkt bij voorbeeld bij de terugwerkende kracht en bij de uitgestelde werking.

Het ingevoerde nieuwe en het afgeschafte oude recht kunnen zich op verschillende manieren tot elkaar verhouden wat betreft de vereisten die zij stellen en de rechtsgevolgen die zij aan de vervulling van die vereisten verbinden. Ook als oud en nieuw recht op deze punten niet van elkaar verschillen dient in overgangssituaties het overgangsrecht te worden toegepast. In de regel zal dan het nieuwe recht toepasselijk zijn.

Overgangssituatie en opeenvolgen van rechtsregels doen de volgende vragen rijzen: wordt de nieuwe regel toepasselijk op overgangssituaties, behoort hij daarop toepasselijk te worden, en zo ja, in hoeverre? Het overgangsrecht beoogt antwoord te geven op deze vragen.

Voor de beantwoording van overgangsrechtelijke vragen kan de wetgever putten uit verschillende mogelijkheden. Hij kan het laten bij een verwijzingsregel. Dat is een regel die zelf geen antwoord geeft op de aan de orde zijnde vraag, maar het rechtsstelsel aanwijst, aan de hand waarvan die oplossing moet worden gevonden. Van deze indirecte regels zijn er vier: onmiddellijke werking, eerbiediging van het oude recht, uitgestelde werking en terugwerkende kracht. In het systeem van de Overgangswet is voor de werking in de tijd van een nieuwe regel bepalend van welk 
tijdstip af het rechtsgevolg intreedt, dat in die regel wordt omschreven. In hoofdstuk 2 wordt het standpunt ingenomen dat een verwijzingsregel als de onmiddellijke werking hierdoor een te ruim toepassingsgebied krijgt. Dit geldt bij voorbeeld, indien onder het oude recht geen aansprakelijkheid aanwezig was in een bepaalde casus, terwijl onder het nieuwe recht wel aansprakelijkheid zou bestaan. De onmiddellijke werking zou hier volgens de overgangswetgever meebrengen dat vanaf de inwerkingtreding aansprakelijkheid zou bestaan (ware het niet dat dit wordt tegengegaan door de eerbiediging van het niet bestaan van verkregen rechten).

De temporele werking van het nieuwe BW is in beginsel de onmiddellijke werking, zoals blijkt uit artikel $68 a$ lid $1 \mathrm{Ow}$ I. Daarop zijn in de overgangswetgeving echter tal van uitzonderingen aangebracht. In vele gevallen gaat het daarbij om uitgestelde werking of eerbiediging van het oude recht. Met name op grond van deze gevallen moet in haar algemeenheid onjuist worden geacht de nogal eens gehoorde mening dat het overgangsrecht woor het nieuwe BW 'wegwerprecht' zou zijn.

In plaats van naar een verwijzingsregel, kan de overgangswetgever ook grijpen naar een zwaarder middel om een probleem van overgangsrecht tot een oplossing te brengen, namelijk een overbruggings- ofwel koppelregel. Daarin wordt wèl rechtstreeks een oplossing gegeven voor dat probleem. Deze directe regels effenen de weg voor toepassing van het nieuwe recht. In het overgangsrecht voor het nieuwe BW zijn in het bijzonder van belang de omzenting, de fictie en de bekrachtiging.

Enkele andere onderwerpen waaraan in hoofdstuk 2 aandacht wordt besteed, zijn de vraag of het overgangsrecht voor het nieuwe $\mathrm{BW}$ al dan niet dwingendrechtelijk van aard is en de verhouding tussen overgangsrecht en anticipatie.

De hoofdstukken 3 tot en met 7 gaan over de toepassing van het overgangsrecht voor het nieuwe BW op een aantal voor de theorie en de praktijk belangrijke rechtsfiguren. Leidraad is de vraag of, en zo ja, in hoeverre het nieuwe BW toepasselijk wordt en behoort te worden op bij de inwerkingtreding aanwezige overeenkomsten, zekerheidseigendomsrechten en dergelijke, alsmede wat de gevolgen zijn van dat all dan niet toepasselijk worden.

Hoofdstuk 3 is gewijd an het overgangsrecht inzake de inschrijwingen betreffende registergoederen. De regeling van deze materie in afdeling 3.1.2 BW is geheel nieuw. De overgangswetgever moest daarom bezien, of de rechtsgevolgen van de nieuwe regeling behoorden te worden werbonden aan bij de inwerkingtreding in de registers aanwezige in- en overschrijvingen en aantekeningen. In beginsel hebben deze anterieure inschrijvingen etc. inderdaad de rechtsgevolgen van de nieuwe regeling gekregen. Een uitzondering hierop geldt bij voorbeeld voor in de registers vóór de inwerkingtreding gepubliceerde akten met bedingen die naar nieuw recht een kwalitatieve verplichting zouden opleveren. Beginsel en uitzonderingen worden in hoofdstuk 3 geanalyseerd. Daarbij blijkt vooral de koppeling van de rechtsgevolgen van de nieuwe wet aan anterieure inschrijvingen etc. van meer (praktisch) belang en van een grotere complexiteit te zijn dan men na een eerste kennismaking zou vermoeden.

Dit laatste gaat ook op voor de geldigheid van rechtshandelingen. Wat de Overgangswet hiervoor in petto heeft wordt bezien in hoofdstuk 4 . De talrijke verschuivingen tussen oud en mieuw recht bevinden zich zowel op goederenrechtelijk als op verbintenisrechtelijk terrein. Voor tal van "overlopende" rechtshandelimgen diende 
te worden uitgemaakt of zij al dan niet mochten worden geraakt door zo'n werschuiving. Aan de regeling in de Overgangswet ligt de gedachte ten grondslag, dat onaantastbaarheid en nietigheid eigenschappen van rechtshandelingen zijin, die sllechts bestaan op en niet langer duren dan het tijdstip van het verrichten van de rechtshandeling, terwijl vernietigbaarheid de rechtshandeling een tijdlang begeleidt. De Overgangswet knoopt aan bij de eigenschap van de rechtshandeling wolgens het oude recht, te weten onaantastbaar, vernietigbaar of nietig. In hoofdstuk 4 wordt dit stramien gevolgd. Daarbij worden vele verschillen tussen oud en nieuw recht als illustratiemateriaal gebruikt.

Grote aantallen duurzame, over de inwerkingtreding heen lopende rechtsverhondingen en ingrijpende verschillen tussen oud en nieuw recht kunnen worden aangetroffen bij de zekerheidsrechten op niet-registergoederen. De voorheen gebruikelijke zekerheidseigendom is bij de inwerkingtreding op enkele uitzonderingen na niet gehandhaafd, maar omgezet in stil pandrecht. Omvangrijk en complex is de overgangsproblematiek die verband houdt met deze omzetting. Deze problematiek wordt aan de orde gesteld in hoofdstuk 5. Daarbij wordt onder meer ingegaan op de wereisten voor de omzetting van zekerheidseigendom in pandrecht, de sterkte van het wettelijke pandrecht en de blokkering van het ontstaan van zekerheidseigendom na de inwerkingtreding. Met name de beoordeling van de sterkte van het wettelijke pandrecht is een ingewikkelde zaak. Dat komt onder meer door het grote aantal (woor)rechten warmee zekerheidseigendom en pandrecht kunnen collideren en doordat onderscheid dient te worden gemaakt tussen reeds vóor de inwerkingtreding bestaande (voor)rechten en eerst nadien ontstane (voor)rechten.

Het overgangsrecht ter zake van de onrechtmatige daad komt aan bod in hoofdstuk 6. Enkele verschillen tussen het oude en het nieuwe onrechtmatige daadsrecht zijn, dat nieuwe aansprakelijkheden zijn gecreëerd, dat oude zijn afgeschaft en dat de omvang van verplichtingen tot schadevergoeding volgens nieuw recht een andere kan zijn dan volgens oud recht. Bij de bespreking van de diverse overgangs" kwesties die deze en andere verschillen kunnen oproepen, wordt een onderscheid gemaakt tussen verschillende rechtsgevolgen die een onrechtmatige daad kan hebben (kort gezegd: schadevergoeding, verbod, verklaring van recht en rectificatie). Bij de aansprakelijkheid tot schadevergoeding wordt onder meer bezien wat in overgangsgevallen geldt voor "schade met vertraging': de schade volgt niet direct na de veroorzaking van de schade, maar laat kortere of langere tijd op zich wachten. De Overgangswet gaat ervan uit dat dat recht toepasselijk is, waaronder de schade intreedt of aanvangt.

Hoofdstuk 7 gaat over het overgangstecht inzake tekortkomingen in de nakoming van verbintenissen. Ook hier heeft het nieuwe BW nogal wat verandering gebracht. Zo is de voor de voldoening aan een verbintenis gestelde termijn anders dan voorheen in beginsel een fatale, zijn vereisten voor en rechtsgevolgen van de ontbinding van wederkerige overeenkomsten gewijzigd en hebben nieuwe regels met. betrekking tot tekortkomingen in de nakoming hun intrede gedaan ten aanzien van beperkte rechten en ten aanzien van de koopovereenkomst. Voor het overgangsrecht roept dit met name de vraag op, of het oude dan wel het nieuwe recht toepasselijk wordt en behoort te worden op een tekortkoming in de nakoming (vór, bij of na de inwerkingtreding) van een anterieure verbintenis. De beantwoording van deze 
vraag staat centraal in hoofdstuk 7. Daarbij wordt afzonderlijk aandacht geschonken aan de rechten van vruchtgebruik, gebruik, bewoning en erfpacht en aan de koopovereenkomst. De hoofdregell is dat het oude recht ook na de inwerkingtreding toepasselijk blijft op de gevolgen van een tekortkoming, indien de tekortkoming dateerr van vóór de inwerkingtreding.

Hoofdstuk 8 ten slotte bevat enkele afsluitende beschouwingen. 
The Transitional Provisions of the new Dutch Civil Code:

Arrangement, General Principles and Application

\section{Summary}

On 1st January 1992 a large part of the new Dutch Civil Code (CC) came into force. The parts which came into force were: Book 3 (the Law of Obligations, Property Law and Commercial Law: the General Part); Book 5 (Property Law); Book 6 (general provisions of the Law of Obligations); and certain sections (titels) of Book 7 (particular types of contract). The implementation of these Books is accompanied by a complex of transitional provisions. This doctoral thesis is a study of the arrangement, general principles, and application of a number of these transitional provisions. Chapter One provides an introduction. In Chapter Two the arrangement and general principles of the transitional provisions of the new $\mathrm{CC}$ are discussed. Central in this general part are two questions: has a situation requiring transitional regulation arisen? and how should the situation be resolved? Such transitional issue is considered by the legislator to have arisen if, at the moment of the coming into force of the $C C$, requirements to which the new legislative provisions attach legal consequences, were already satisfied. Such situation, obtaining at the moment of the Code coming into force, is defined by the legislator as a transitional situation. Essential for the establishment of such situation are the presence of a certain constellation of facts and the implementation of new legislative provisions. The requirements to which legal consequences are attached by the new legislative provisions can comprise a state of affairs, an event and/or a matter of law regulating such state of affairs or event. Ownership is an example of a state of affairs. The causing of damage is an example of an 'event', whilst the fact that the causing of damage may be unllawful is a matter of law regulating an event.

In Chapter Two it is argued that the legislator has defined the concept of a 'transitional situation" too narrowly. This submission is based upon the fact that the legislator confines his definition of a transitional situation to the moment of coming into force of the Code. The submission of the author is that, whether the requirements specified by the new Code are satisfied before or after the moment of the CC coming into force, transitional provision can also be necessary. Such is demonstrated, for example, by the provisions, to be described below, on retrospective effect and delayed applicability.

The relationship, in respect of the requirements specified and the legal consequences flowing from such requirements once satisfied, between the implemented new Code and the repealed old Code, can take various forms. Even when there is no difference between the old and the new Codes in the matters just mentioned, the transitional provisions must still be applied in transitional situations. As a general rule the new Code will be applicable in such cases.

The presence of a transitional situation and the succession of one legal provision 
by another gives rise to the following questions: is the new provision applicable in a transitional situation? should it be applied in such case? and, if it should be so applied, to what extent? The transitional provisions purport to answer these questions, When searching for a solution to a transitional question, the legislator has several options. The legislator can simply suffice with a "choice of law' provision. This is an indirect provision which does not itself resolve the question, but it refers the question to the old or new Code for resolution. There are four types of "choice of law' rules: direct applicability, deference to the old Code, delayed applicability, and retrospective effect.

The general rule under the transitional provisions is that the new $\mathrm{CC}$ is directly applicable. This general rule is formulated in the Transitional Provisions Act, Article 68 a (1):

'The Code [new $\mathrm{CC}$ ] is applicable from the moment of coming into force, if, at the moment of coming into force, the requirements specified by the Code [new $\mathrm{CC}$ ] for a legal consequence are satisfied, unless otherwise required by the following provisions.' [author's addition].

Deference to the old Code obtains when the new Code is wholly inapplicable to a particular transitional situation; instead of applying the new provision, the solution offered by the old provision is maintained. Important examples of such cases are provided by Article 69 of the Transitional Provisions Act, in which, in a number of cases, the principle that acquired rights shall be respected is secured. Delayed applicability is present when the new Code only becomes applicable to transitional situations after a certain time has elapsed after the coming into force of the Code. During the delay period specified the situation according to the old provisions is maintained. Retrospective effect means that the new provisions are deemed, from the moment of the coming into force of the new $\mathrm{CC}$, to have been applicable to transitional situations from a moment which pre-dates the coming into force of the $\mathrm{CC}$.

Under the system of the Transitional Provisions Act, the temporal effect of a new provision is determined according to the moment at which the legal consequence laid down in the provision takes effect. In Chapter Two it is argued that a 'choice of law' provision such as that of direct applicability is hereby given too wide a field of application. Such is the case, for example, on facts which did not give rise to any liability under the old law, but which, under the new provisions; would give rise to liability. According to the legislator of transitional provisions, direct applicability should cause, in such case, liability to arise at the moment that the Code comes into force (were this not prevented by respecting the no-right of the would-be plaintiff and the established freedom from liability of the defendant under the old provisions).

There are a multitude of exceptions in the Transitional Provisions to the general principle of direct applicability. In many of these cases applicability is delayed or there is deference to the old provisions. In particular these cases demonstrate the incorrectness of the not-uneommonly held view that the transitional provisions comprise the 'quick-disposable' element in the legislative package associated with the new CC.

Instead of using a "choice of law' provision the legislator of transitional provisions might deploy a somewhat mightier tool to deal with a transitional problem; 
manely, a bridging- or link-provision. Such provision does provide a direct solution to the problem. These direct provisions pave the way for the application of the new provisions. In the transitional provisions of the new $\mathrm{CC}$ the following legal devices are particularly important: conversion (as in the case of a transfer of ownership by way of security ${ }^{1}$ which is converted into a statutory charge ${ }^{2}$ ); the use of fictions (by which a matter is deemed to have been recorded in the public registers concerning registered rights in accordance with the new Code); and validation (by which a void legal transaction is made unassailable).

Certain other subjects considered in Chapter Two are the questions: whether the transitional provisions of the new $\mathrm{CC}$ are mandatory of application; as to the scope of the "catch-net" provision (Transitional Provisions Act, Article 75) which requires the transitional provisions not to be applied if, inter alia, application would have inequitable results; and as to the relationship between the transitional provisions and judicial interpretation which anticipates the new Code. Such anticipatory interpretation occurs when a court, adjudicating before the new Code is enacted, refers in its judgment to the new Code to support its decision. In particular, the Dutch Supreme Court (Hoge Raad), the highest court in, inter alia, private law cases, made multiple anticipatory references to the new $\mathrm{CC}$ before it came into force. Even after the coming into force of the Code anticipatory interpretation is still conceivable, for example, in cases in which the Transitional Provisions Act provides for delayed applicability of the new Code.

Chapters Three to Seven of the thesis treat the application of the transitional provisions of the new $\mathrm{CC}$ to a number of legal concepts which are of theoretical and practical importance. The golden thread is the question whether, and, if so, to what extent, the new CC should be applied to contracts, tights of security and suclalike in existence at the moment that the Code came into force. Furthermore, the consequences of applying the new CC or not are studied.

Chapter Three is devoted to the transitional provisions concerning the registration of matters pertaining to registered rights in the relevant public registers. Section 3.1.2 of the Civil Code regulates these matters in a completely new way. Accordingly, the legislator of the transitional provisions had to consider whether the legal consequences laid down in the new Code should, from the moment of the Code coming into force, attach to matters which were already registered at that moment. In principle such anterior registrations pertaining to registered land and registered deeds and charges and entries upon such registrations do indeed take effect under the new Code. This has been achieved with the help of the fiction described above. The general rule and the exceptions to it are analysed in Chapter Three. This analysis reveals that the attachment of the legal consequences of the new Code to

1. A form of security by which a debt was secured upon moveable tangible goods, whilst the goods remained in the use and control of the debtor. The creditor was owner, and, in the event of the debtor"s insolwency. could, if certain conditions were satisfied, and subject to some exceptions not relevant here, claim the goods as his property. This form of securify was a non-statutory development which was tolerated under the old $\mathrm{CO}$ de, but which cannot be created under the new Code.

2. As with the transfer of ownership by way of security the debtor retains use and control of the goods but the creditor has a right of security which is granted by an authenticated deed or a deed the moment of deliwery of which is reconded by the inland revenue authorities. 
anterior registrations hass a greater (practical) significance and a greater degree of complexity than one might, at first blush, suspect.

This last remark also applies to the validity of legal transactions. Chapter Four constitutes an examination of what the Transitional Provisions Act has in store for this area of law. The multitude of discrepancies between old and new Codes affect proprietary rights as well as obligations. For numerous 'transitional' transactions it was. necessary for the legislator of the transitional provisions to decide whether or not it was desirable that they were affected by such discrepancies in the law. The Transitional Provisions Act is founded upon the principle that unassailability and nullity are qualities attaching to legal transactions which only obtain at, and do not endure longer tham, the moment needed to complete the legall transaction, whereas voidability accompanies the legal relationship arising from the transaction for a period of time. The Transitional Provisions Act takes as a starting-point the characterisation of the legal transaction according to the old Code as unassailable, voidable or void. This same approach is followed in Chapter Four. In this chapter many differences between. the old and new codes are used as illustrations. The Transitional Provisions Act provides, inter alia, for the respecting of the unassailability of legal transactions which would have otherwise been, contrary to the case under the old Code, void or voidable under the new Code. Furthermore, as indicated above, a transaction which was woid under the old Code will be; if, inter alia, it satifies the requirements laid down in the new Code for an unassailable legal transaction, validated.

Numerous legal relationships of long duration, which traverse the moment of coming into force of the new Code, and drastic differences between the old and new Codes, are encountered in the law of rights secured upon personal property. The previous legal devices for establishing security rights have been, with a few exceptions, not retained under the new Code, but instead have been converted, at the moment of coming into force of the new Code, into the legal device which the new CC offers for the establishment of rights of security; namely, the relationship of statutory charge. Thus, at the moment that the new Code came into force, a proprietary right which was eligible for statutory charging but which under the old law was transferred to another by way of security, was, by virtue of the Transitional Provisions Act, transferred back to the person granting the security (i.e. a debtor or a person giving security for another's debt) but burdened by a statutory charge in favour of the grantee of the security (usually a creditor), who was an owner under the old Code. The transitional difficulties associated with this conversion are both extensive and complicated. These difficulties are the subject of Chapter Five. In this chapter the following matters, inter alia, are considered: the requirements for the conversion of a transfer of ownership by way of security into a statutory charge; the strength of the statutory charge; and the blocking of the transfer of ownership for the purpose of security after the coming into force of the new Code. In particular, evaluation of the strength of the statutory charge is a complicated matter. This complexity is due, inter alia, to the large number of (preferred) ${ }^{3}$ rights with which the

3. Voortechten (preferred rights) are rights which, because of the character of the legal relationship under which they have arisen, afford, to those who hold such rights priority over the general creditors in the event of the debtor's bankruptcy. 
transfer by way of security or the charge may have to compete, and to the need to distinguish between (preferred) rights which were in existence before, and those which were established after, the date at which the Code came into force.

The transitional provisions relating to tort are considered in Chapter Six. Some differences between the law of tort under the old and the new Codes are that new causes of action have been created and old ones abolished, and that the extent of the obligation to pay damages can differ under the old and the new codes. In discussing the various transitional problems which can arise as a result of the above-mentioned, or other, discrepancies, the different legal consequences which can flow from the commission of a tort are distinguished. These legal consequences are the liability to pay, and the right to claim, damages, as well as the power to request, or the power of the court to award, a prohibitory injunction, a declaration or rectification. In respect of liability to pay damages special attention is directed to the transitional provisions concerning, inter alia, "latent damage"; the damage does not set in immediately after the tort is committed, but later. The Transitional Provisions Act is based upon the principle that that Code is applicable which is in force at the moment at which the damage sets in or begins to set in. If it is impossible to establish whether or not the damage set in before the moment that the new Code came into force, then the Code must be applied which was in force at the date that the damage became known.

Chapter Seven is concerned with transitional provisions applicable to failure or inadaquacy of performance. Also in this field the new Code has made considerable amendment. Thus, under the new Code, the failure to meet a contractual deadline for the performance of an obligation is, in contrast with the case under the old Code, generally fatal. Furthermore, the requirements for, and legal consequences of, the termination of bilateral contracts have changed; and there are new provisions regulating failed or inadequate performance of obligation in respect of limited rights ${ }^{4}$ and in respect of contracts of sale. In particular, these changes pose for the transitional provisions the question whether the old or the new Code should be applied to a failed or inadequate performance (when the failed or inadequate performance occurs before, at or after the moment that the Code came into force) in respect of an obligation assumed before the new Code came into force. The answer to this question occupies a central position in Chapter Seven. In this chapter the most important legal remedies available to the creditor in the event that the debtor does not perform the obligation are scrutinised. These rights are, namely: to demand specific performance, to demand damages, to obtain termination of the contract and to suspend performance of the creditor's own obligation until the recalcitrant debtor has performed his part. Furthermore, attention is given successively to the rights of

4. Beperkte rechten: they include serwitudes, rights of security and other proprietary rights which are less than ownership and which burden the owner's title. 
usufruct $^{5}$, use and enjoyment ${ }^{6}$, occupation ${ }^{7}$, lease ${ }^{8}$, and the contract of sale. The general principle is that the old Code remains, after the new Code has come into for$c e$, applicable to the consequences of a failed or inadequate performance of obligation, if the failed or inadequate performance pre-dates the coming into force of the new Code. Conversely if the failed or inadequate performance occurred at or after the moment of the new Code coming into force, the new Cade is, in principle, applicable.

Chapter Eight contains some concluding observations.

5. Recht van vruchtgebruik i.e. a right to use the property of another and to enjoy the fruits thereof, commonly a life interest.

6. Recht wan gebruik i.e. a right to use another person's property, similar to the usufruct, but the right to use and enjoy is restricted to the needs of the user and his/her family.

7. Recht vam bewoning i.e the right to oceupy, with one's family, the dwelling-house of another.

8. Erfpacht: the most extensive limited right which can be granted under Dutch law, broadly comparable with a lease... 
Das Ubergangsrecht für das neue niederländische Bürgerliche Gesetzbuch: Systematik, Grandsätze und Anwendungen

\section{Zusammenfassung}

Am 1. Januar 1992 ist in den Niederlanden ein großer Teil des neuen Bürgerlichen Gesetzbuchs (Burgerlijk Wetboek, BW) in Kraft getreten. Es handelt sich um Buch 3 (Allgemeines Vermögensrecht), Buch 5 (Sachenrechte), Buch 6 (Allgemeiner Teil des Schuldrechts) und einige Titel von Buch 7 (Einzelne Verträge). Die Einführung dieser Bücher wurde von einem umfangreichen Komplex von Übergangsregeln begleitet. Die Systematik, die Grundsätze und die praktische Anwendung des Übergangsrechts sind Gegenstand dieser Abhandlung. Nach einem eïnleitenden ersten Kapitel werden im zweiten Kapitel die Systematik und die Grundsätze des Übergangsrechts für das neue Burgerlijk Wetboek dargestellt. In diesem allgemeinen Teil steht die Frage im Vordergrund, wann Übergangsprobleme entstehen und wie sie gelöst werden können. Nach Ansicht des Gesetzgebers ergeben sich diese Probleme dann, wenn im Zeitpunkt des Inkraftretens die Voraussetzungen, die das neue Recht für eine Rechtsfolge fordert, erfüllt waren. In diesem Fall lag im Zeitpunkt des Inkrafttretens ein sog. Übergangsfall vor. Es müssen also zwei Bedingungen erfüllt sein, eine bestimmte tatsächliche Lage und das Inkrafttreten neuen Rechts. Bei den Voraussetzungen, die nach einer Rechtsregel für eine Rechtsfolge erfüllt sein müssen, kann es sich um Zustände, um Tatsachen und um juristische Bewertungen von Zuständen oder Tatsachen handeln. Ein Zustand in diesem Sinne ist es beispielsweise, Eigentimer zu sein. Eine Tatsache ist es, wenn ein Schaden zugefügt wird; die juristische Bewertung einer Tatsache ist die Unrechtmäßigkeit der Schadenszufügung.

Das zweite Kapitel legt dar, daß der Gesetzgeber den Begriff des 'ÜbergangsfalIs" zu eng verstanden hat. Auch wenn die Voraussetzungen, die das neue Burgerlijk Wetboek für eine Rechtsfolge verlangt, vor oder nach dem Inkrafttreten erfüllt sind, könnnen übergangsrechtliche Fragen entstehen. Dies zeigt sich beispielsweise in den näher zu beschreibenden Fällen, in denen eine Rückwirkung angeordnet ist oder die Wirkung aufgeschoben ist.

Das Verhältnis von neuem Recht und abgeschafftem alten Recht kann hinsichtlich der Voraussetzungen und der an die Erfüllung dieser Voraussetzungen geknüpften Rechtsfolgen zu verschiedenen Konstellationen führen. Auch wern altes und neues Recht sich insoweit nicht unterscheiden, ist in Übergangsfällen das Übergangsrecht anzuwenden. In der Regel wird dann das neue Recht anzuwenden sein. Mit einem Übergangsfall und der Geltung verschiedener Rechtsregeln in zeitlicher Folge stellen sich folgende Fragen: Wird die neue Regel auf den Übergangsfall anwendbar, soll sie hierauf anwendbar werden und wenn ja, inwieweit? Diese Fragen will das Übergangsrecht beantworten.

Der Gesetzgeber hat verschiedene Möglichkeiten, auf übergangsrechtliche Fra- 
gen zu antworten. Er kann sich mit einer Verweisungsregel begnügen. Dies ist eine Regel, die auf die anstehende Frage selbst keine Antwort gibt, die aber auf die Regelung verweist, der die Lösung zu entnehmen ist. Es lassen sich vier derartige indirekte Regeln unterscheiden: unmittelbare Wirkung, Anerkennung des alten Rechts, aufgeschobene Wirkung und rizckwirkende Kraft.

Die unmüttelbare Wikung ist für das neue Burgerlijk Wetboek die Grundregel. Der Gesetzgeber hat diese Grundregel in Art. 68 a Abs. 1 des Übergangsgesetzes folgendermaßen formuliert:

'Das Gesetz ist vom Zeitpunkt seines Inkraftretens an anwendbar, wenn in diesem Zeitpunkt die Voraussetzungen, die das Gesetz für eine Rechtsfolge aufstell, erfullt sind, sofern sich nicht aus den folgenden Artikeln etwas anderes ergibt."

Mit "das Gesetz" sind hier, wie sich aus Art. 68 des Übergangsgesetzes ergibt, die neu eingeführten Bestimmungen der Büicher 3 bis 8 des Burgerlijk Wetboek gemeint. Anerkennung des alten Rechts bedeutet, daß das neue Recht in einem Ubergangsfall insgesamt keine Wirkung entfaltet; anstatt dessen wirkt das alte Recht weiter. Wichtige Beispiele hierfür finden sich in Art. 69 des Übergangsgesetzes, in dem das Prinzip der Anerkennung erworbener Rechte konkretisient ist. Aufgeschobene Wirkung liegt vor, wenn das neue Gesetz erst in einem Zeitpunkt nach seinem Inkraftureten auf Ubergangsfälle anwendbar wird. Während des Aufschubs bleibt in diesen Situationen das alte Recht anwendbar. Rückwirkende Kraft bedeutet, daB man vom Inkrafttreten des neuen Gesetzes an davon ausgeht, daß das neue Gesetz auf Ubergangsfalle schon von einem Zeitpunkt an anwendbar gewesen ist, der vor dem Inkrafttreten des newen Gesetzes liegt.

Im System des Übergangsgesetzes ist es für die zeitliche Wirkung einer neuen Regel entscheidend, von welchem Zeitpunkt an die in dieser Regel vorgesehene Rechtsfolge eintritt. Das Ergebnis des zweiten Kapitels ist, daß eine Verweisungsregel wie die unmittelbare Wirkung hierdurch ein zu weites Anwendungsgebiet erhält. Dies zeigt sich, wenn $z$. B. jemand nach altem Recht in einem bestimmten Fall nicht haftete, während das neue Recht für diesen Fall eine Haftung vorsieht. Nach der Regelung im Ubergangsgesetz wiirde die unmittelbare Wirkung hier dazu fihren, daB vom Inkraftreten des Gesetzes an eine Haftung bestünde (wenn dem nicht der Grundsatz entgegensteht, daB es auch anerkannt wird, wenn nach altem Recht ein Recht nicht erworben worden ist.)

Von der Hauptregel der ummittelbaren Wirkung enthält das Übergangsrecht eine Anzahl von Ausnahmen. In vielen Fällen geht es dabei um aufgeschobene Wirkung oder um die Anerkennung alten Rechts. Namentlich aufgrund dieser Fälle ist der manchmal geâußerten Ansicht, beim Übergangsrecht für das neue Burgerlijk Wetboek handele es sich um nur fur kurze Zeit geltendes "Wegwerfrecht', entgegenzutreten.

Anstelle einer Verweisungsregel kann der Gesetzgeber beim Ubergangsrecht auch zu einem eingreifenderen Mittel greifen, um ein Ubergangsproblem zu lösen, zu einer Überbrückungs- oder Koppelregel. In diesen Fălllen wird das materielle Problen selbst geregelt. Diese direkten Regeln machen den Weg frei für die An- 
wendung des neuen Rechts. Im Übergangsrecht für das neue Burgerlijk Wetboek spielen insbesondere die Umqualifizierung ( stilles Pfandrecht), die Fiktion (z.B. daß eine Tatsache entsprechend der neuen Regelung in die öffentlichen Register für Registergüter als eingetragen gilt) und die Bestätigung (eines nichtigen Rechtsgeschäfts als eimes vollgültigen).

Weitere Probleme, denen im zweiten Kapitel nachgegangen wird, sind die Frage, ob das Übergangsrecht für das neue Burgerlijk Wetboek zwingender Natur ist, die Funktion des Art. 75 des Übergangsgesetzes als Auffangtatbestand in Fallen in denen eine besondere Regel nicht zur Verfügung steht und das Verhältnis zwischen Übergangsrecht und antizipierender Interpretation des neuen Rechts durch den Richter. Eine solche antizipierende Interpretation liegt vor, wenn der Richter - der erwarteten Einführung eines neuen Gesetzes vorausgreifend - in der Begründung seiner Entscheidung auf das neue Gesetz verweist. Vor allem der Hoge Raad der Nederlanden, das höchste Gericht auch in Zivilsachen, hat vielfach schon vor der Einführung des neuen Burgerlijk Wetboek dessen Regelungen vorweggenommen. Auch nachdem das neue Gesetz in Kraft ist, ist eine solche Vorwegnahme noch denkbar, wenn z. B. das Übergangsgesetz die Wirkung des neuen Rechts aufschiebt.

Die Kapitel 3 bis 7 behandeln die Anwendung des Übergangsrechts auf einzelne theoretisch und praktisch wichtige Rechtsinstitute. Richtunggebend ist dabei die Frage ob - und wenn ja, inwieweit - das neue Burgerlijk Wetboek auf u. a. Verträge und Sicherungsübereignungen, die bei Inkraftreten bestehen, anwendbar ist und welche Folgen mit der Entscheidung über die Anwendbarkeit verbunden sind.

Kapitel 3 befaßt sich mit dem Übergangsrecht für Eintragungen in die öffentlichen Register. Die Regelung, die diese Materie in Abteilung 3.1.2 des Burgerlijk Wetboek erhalten hat, ist insgesamt neu. Der Gesetzgeber hatte im Übergangsrecht zu entscheiden, ob die im neuen Recht vorgesehenen Rechtsfolgen auch für Eintragungen gelten sollen, die beim Inkrafttreten des neuen Gesetzes schon vorhanden waren. Grundsätzllich gelten in der Tat für die früheren Eintragungen die Rechtsfolgen des neuen Gesetzes. Das Übergangsrecht erreicht dies mit Hilfe der erwähnten Fiktion. Grundsatz und Ausnahmen werden in Kapitel 3 analysiert. Der Umstand, $\mathrm{daB}$ die Rechtsfolgen des neuen Rechts auch für frühere Eintragungen gelten, erweist sich dabei als praktisch wichtiger und komplizierter als es auf den ersten Blick scheint.

Dies letzte gilt auch für die Wirksamkeit von Rechtsgeschäften. In Kapitel 4 wird untersucht, was das Übergangsgesetz hierzu sagt. Die zahlreichen Unterschiede zwischen altem und neuem Recht betreffen sowohl das Güterrecht als auch das Schuldrecht. Für eine Reihe von Rechtsgeschäften, die im Übergangszeitraum liegen, mußte geklärt werden, ob sie von einem solchen Unterschied betroffen sind. Der Regelung des Übergangsgesetzes liegt der Gedanke zugrunde, daß Geltung und Nichtigkeit Eigenschaften sind, von denen nur im Zeitpunkt der Vornahme des Rechtsgeschäfts gesprochen werden kann, wohingegen die Anfechtbarkeit dem Rechtsgeschäft eine zeitlang anhaftet. Grundlage der Übergangsregelung sind die Begriffe des alten Rechts, nämlich Geltung, Anfechtbarkeit und Nichtigkeit. Diesem Ansatz folgt Kapitel 4. Dabei werden viele Unterschiede zwischen altem und neuem Recht zur Illustration herangezogen. Bas Übergangsgesetz schreibt u.a. die Anerkennung wirksamer Rechtsgeschäfte vor, die nach neuem Recht anfechtbar 
oder nichtig sein würden. Es wird andrerseits, wie oben schon angedeutet, ein früher nichtiges Rechtsgeschäft als wirksam bestätigt, wenn (u.a.) die Voraussetzungen für ein wirksames Rechtsgeschäft nach neuem Recht worliegem.

Bei : den Sicherungsrechten an Nichi-Registergütern finden sich zahlreïche Rechtsverhältnisse, die sich weit uber den Zeitpunkt des Inkrafttretens des neuen Rechts hinweg erstrecken. Dabei ergeben sich zugleich große Unterschiede zwischen altem und neuem Recht. Das fruiher verbreitete Sicherungseigentum hat, abgesehen won Ausnahmefällen, nach Inkrafttreten des neuen Rechts keinen Bestand mehr; es ist in ein Institut umgewandelt worden, das das neue Burgerlijk Wetboek an die Stelle des Sicherungseigentums gesetzt hat, das stille Pfandrecht. Dies ist in der Weise geschehen, daß im Zeitpunkt des Inkrafttretens des neuen Rechts ein Gut; das verpfändet werden kann und das einem anderen zur Sicherheit übereignet war, in das Eigentum des Sicherungsgebers zurückgefallen ist und dort zugunsten des wormaligen Sicherungseigentïmers mit einem Pfandrecht belastet ist. Die mit dieser Umqualifizierung verbundene Übergangsproblematik ist umfangreich und komplex. Sie wird in Kapitel 5 behandelt. Dabei wird vor allem auf die Voraussetzungen einer Umqualifizierung des Sicherungseigentums in ein Pfandrecht eingegangen, auf die Sicherheit, die das gesetzlich vorgesehene Pfandrecht bietet und auf die Maßnahmen, die das Entstehen neuen Sicherungseigentums nach dem Inkrafttreten des neuen Rechts werhindern sollen. Vor allem die Beurteilung der Sicherheit, die das im Gesetz geregelte Pfandrecht bietet, ist schwierig. Grund hierfür ist; daß auch das neue Recht eine große Zahl von Rechten und Privilegien kennt, die nun mit dem Pfandrecht kollidieren können und daß zwischen Rechten und Privilegien, die vor und nach dem Inkrafttreten des neuen Rechts entstanden sind, unterschieden werden muB.

Im sechsten Kapitel geht es um das Übergangsrecht im Deliktsrecht. Zu den wichtigsten Unterschieden zwischen altem und neuem Deliktsrecht gehört, daß neue Tatbestände geschaffen und alte abgeschafft worden sind und daß der Umfang der Schadensersatzpflicht nach neuem Recht von dem nach altem Recht abweichen kann. Die Diskussion der verschiedenen Übergangsprobleme, die sich bei den genannten und anderen Unterschieden ergeben können, geht von den unterschiedli-

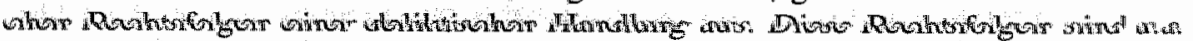
die Verpflichtung zum und das Recht auf Schadensersatz, die Befugnis ein Verbot zu fordern oder auszusprechen und die Feststellung eines Rechts. Bei der Schadensersatzpflicht wird u.a. untersucht, was in Übergangsfallen für den Folgeschaden gilt, dein Schaden also, der nicht unmittelbar durch das Delikt verursacht ist, sondern erst später eintritt. Ausgangspunkt des Übergangsgesetzes ist, daß das Recht zur Zeit des Sehadenseintritts oder -beginns anzuwenden ist. Wenn nicht festzustellen ist, ob dieser Zeitpunkt vor oder nach dem Inkraftreten des neuen Rechts liegt, wird auf den Zeitpunkt des Bekanntwerdens des Schadens abgestellt.

Kapitel 7 behandelt das Übergangsrecht im Rahmen der Leistungsstorungen im Schuldrecht. Awch hier bringt das neue Burgerlijk Wetboek Veränderungen. Geändert sind die Bedeutung des Termins für die Erfüllung einer Verbindlichkeit, die Voraussetzangen und Folgen einer Lösung von gegenseitigen Verträgen und das Recht der Leistungsstörungen bei beschränkten Rechten und beim Kauf. Für das Übergangsrecht stellt sich vor allem die Frage, ob bei einem Schuldverhältnis nach al- 
tem Recht eine Leistungsslörung vor, bei oder nach dem Inkraftreten des neuen Rechts nach altem oder neuem Recht zu behandeln ist. Diese Frage steht im Mittelpunkt des siebenten Kapitels. Dabei werden die wichtigsten Rechtsbehelfe des Gläubigers bei einer Leistungsstörung durch den Schuldner behandelt, der Erfüitlungsanspruch, der Schadensersatzanspruch, der Rücktritt und das Leistungsverweigerungsrecht des Gläubigers. Weiter wird insbesondere auf Gebrauchsrechte, Erbpacht und Kauf eingegangen. Hauptregel ist, daß das alte Recht auf Leistungsstörungen vor dem Inkrafttreten des neuen Rechts anwendbar bleibt, auch wenn die Folgen erst danach eintreten; auf Leistungsstörungen nach diesem Zeitpunkt ist grundsätzlich das neue Recht anzuwenden.

Das achte Kapitel dient abschließenden Betrachtungen. 
Droit transitoire du nouveau Code civil néerlandais:

Systeme, principes et applications

\section{Sommaire}

Aux Pays-Bas, une grande partie du nouveau Code civil est entrée en vigueur le premier janvier 1992. II s'agit des Livres suivants: Livre troisième: Du droit patrimonial en général; Livre cinquième: Des droits réels; Livre sixième: Partie générale du droit des obligations et quelques Titres du Livre septième portant sur les contrats particuliers. L'entrée en vigueur de ces Livres était accompagnée d'un vaste ensemble de règles transitoires. La présente thèse traite du système et des principes fondlant ces règles transitoires et des applications de quelques-unes d'entre elles. Après le premier chapitre introductif, le chapitre 2 traite du système et des principes du droit transitoire accompagnant la mise en vigueur du nouveau Code civil. Cette partie gếnérale de la thèse est axée sur la question de savoir sous quelles conditions il se crée des problèmes de droit transitoire et de quelle manière ils peuvent êtrê résolus. Le législateur estime que ces problèmes se présentent lorsque les conditions pour la production d'un effet juridique prévues par la nouvelle loi étaient déjà remplies au moment de l'entrée en vigueur de cette lot. Si tel est le cas, il existait au moment de l'entrée en vigueur une situation appelée transitoire qui nécessite donc une certaine configuration de faits et l'entrée en vigueur d'une loi nouvelle. Les conditions prévues par la loi quant à la production d'un effet juridique consistent en situations, en faits et en appréciations juridiques de situations ou de faits. A titre d'exemple, le statur de propriétaire est considéré comme une situation, l'acte causant un dommage comme un fait et le caractère illicite de l'acte causant un dommage comme l'appréciation juridique d'un fait.

Il est argumenté dans ce deuxième chapitre que le législateur a une conception trop limitée de la notion de "situation transitoire", étant donné que le droit transitoire peut s'appliquer également aux cas où les conditions prévues par le nouveau Code pour la production d'un effet juridique sont remplies avant ou après le moment de l'entrée en vigueur. Ceci apparaît par exemple pour les notions de "rétroactivité" et d"'effet différé"; ces notions seront discutées ci-après.

Le nouveau droit en vigueur et l'ancien droit aboli peuvent avoir des rapports différents dans le domaine des conditions stipulées et des effets juridiques liés à la réunion de ces conditions. Le droit transitoire doit être appliqué dans les situations transitoires même s'il n'existe aucune différence sur ces points entre le nouveau et 1"ancien droit. En général, le nouveau droit sera applicable dans ces cas.

Plusieurs questions se posent quant à la situation transitoire et à la succession de règles de droit: la nouvelle règle sera-t-elle applicable aux situations transitoires, devra-t-elle être applicable, et si tel est le cas, dans quelle mesure ? Or, la raison d'être du droit transitoire est justement de fournir la réponse à ces questions.

Pour répondre aux questions de droit transitoire, le législateur dispose de plusi- 
eurs possibilités. Il peut se contenter de formuler une règle de conflit, regle indireete qui, sans fournir elle-même de réponse à la question concernee, indique le système de droit à l"aide duquel la réponse doit être trouvée. On distingue quatre règles indirectes: effer immédiat, sumvie de la loi ancienne, effet différé et effer rêtroctiof. Pour le nouveau Code civil, l'effet iwmédiat est devenu la règle principale. Le legislateur a formulé cette règle principale dans $\mathrm{l}^{2}$ article $68 a$, alinéa 1 de la Loi transitoire:

Le Code est applicable dès le moment de son entrée en vigueur, sì à ce moment les conditions prévues par la loi pour la production d'un effet juridique sont remplies, à moins qu'il soit stipule autre chose dans les articles suivants."

Comme il ressort de l'article 68 de la Loi transitoire, les dispositions qui viennent d'entrer en vigueur et qui se trouvent dans les. Livres troisième et suivants du nouveau Code civil sont désignées ici par le terme "Code". La règle de survie de la loi ancienne s"appliquera si la loi nouvelle n'est nullement applicable aux situations transitoires; ces cas sont régis par le droit ancien. L'article 69 de la liol transitoire contient des exemples extrêmement importants. En effet, cet article concrétise le principe du respect des droits acquis. Il sera question d'effet differé dans les situations transitoires pour lesquelles la loi nouvelle n'est pas applicable des le moment de son entrée en vigueur mais plus tard seulement Pendant la durée de ce délai, ces situations relèvent du droil ancien. La règle de l'effet rétroactif est appliqué Lorsque, dès son entrée en vigueur, la loi nouvelle est considérée avoir été applicable aux situations transitoires à partir d'un moment précédant cette entrée en vigueur.

Dans le système de la Lui transitoire, l'effet dans le temps d'une nouvelle règle est déterminé par le moment où l'effet juridique décrit dans cette règle entre en vigueur. Nous estimons que ceci a pour conséquence que le domaine d'application d" une règle de conflit telle que l'effet immédiat est devenu trop large. Ceci vaut par" exemple pour le cas spécifique où selon le droit ancien, il est question d'absence de responsabilité, tandis que pour ce même cas, le droit nouveau reconnaît une responsabilité effectivement présente. Selon le législateur; l'effet immédiat impliquerait l'existence d'une responsabilité dès le moment de l'entrée en vigueur du nouveau Code (le respect de la non-existence de droits acquis va pourtant à l'en= contre de cette responsabilité).

La règle principale de l'effet immédiat connaît une multitude d'exceptions dans la législation transitoire. Dans de nombreux cas, ces exceptions portent sur l'effet différé ou la survie de la loi ancienne. Si plusieurs auteurs considèrent le droit transitoire du nouveau Code civil comme "jetable", c'est surtout en raison de ce grand nombre d'exceptions traitees dans la Loi transitoire que nous estimons que, généralement parlant, il s'agit là d'une opinion erronée.

Au lieu de la règle de conflit, le législateur peut recourir à un moyen plus sévểe pour résoudre un problème de droit transitoire: une règle de soudure ou de liaison. II s'agit là d'une règle directe qui fournit effectivement une solution au problème. Ces règles directes préparent le chemin pour l'application du droit nôvveau. Les règles de soudure particulièrement importantes dans le droit transitoire du nouveau Code eivil sont les suivantes: la transformation (par exemple la propriété pour súreté de la dette transformée en gage sans dépossession), la fiction (par exemple le fait censé être inscrit dans les registres publics des biens immatriculés conformé- 
ment à la nouvelle disposition) et la régularisation (d'un acte juridique nul en un acte juridique valide).

Autres sujets discutés dans le deuxiène chapitre: la question de savoir sil le droit transitoire du nouveau Code civil est ou n'est pas de nature contraignante, les possibilités de corriger les résultats de l'application d'une règle transitoire en vertu de l'article 75 de la Loi transitoire, le rapport entre le droit transitoire et l'interprêtation par anticipation du juge. Il est question d"interprétation par anticipation lorsque le juge, devançant l'entrée en wigueur prévue d'une loi nouvelle, réfère à celle-ci pour étayer son jugement. Avant l'entrếe en vigueur du nouveau Code cívil, c'est. surtout la Hoge Raad der Nederlanden (Cour de Cassation des Pays-Bas) qui a bien souvent devancé le nouveau Code. L'interprétation par anticipation est concevable mềme après l'entrée en vigueur, par exemple dans les cas où la Loi transitoire prévoit un effer différé du droit nouveau.

Les chapitres 3 à 7 inclus de la présente thèse sont consacrés à l'application du droit transitoire du nouveau Code civil à un certain nombre de structures juridiques qui sont importantes d'un point de vue théorique aussi bien que pratique. Les questions suivantes sont traitées successivement: le nouveau Code civil sera-t-il et devra-t-il etre applicable aux contrats, aux droits de propriété pour sâreté de la dette, etc. qui existaient déjà au moment de l'entrée en vigueur; si tel est le cas, dans quelle mesure doit-ill être applicable; quelles sont les conséquences de cette applicabilité ou non-applicabilité.

Le chapitre 3 traite du droit transitoire relatif aux inscriptions de biens immatriculés sur les registres publics concemés. Les dispositions en la matière étant tout à fait nouvelles, le législateur était obligé d'examiner si les effets juridiques des nouvelles dispositions devaient être liés aux inscriptions, transcriptions et notes présenles dans les registres au moment de l'entrée en vigueur du nouveau Code. En principe, ces inscriptions, transcriptions et notes antérieures ont en effet obtenu les effets juridiques des dispositions nouvelles. Ceci a été réalisé à l'aide de la règle de fiction susmentionnée. Le principe et les exceptions en la matière sont analysés au chapitre 3. II ressort de ces analyses que l'application de la loi nouvelle quant aux inscriptions, transcriptions et notes antérieures s"avère jouer un rôle (pratique) plus important et qu'elle est beaucoup plus compliquée qu'on l'aurait supposé à la première lecture.

Il en est de même pour la validité des actes juridiques dont le règlement transitoine est discuté au chapitre 4 . II s"est produit de nombreux glissements entre les deux Codes et ce dans le domaine du droit des biens aussi bien que dans celui du droit des obligations. Pour de nombreux actes juridiques dont l'action s'etend audelà de la date d'entrée en vigueur du nouveau Code, le législateur a dû décider s'ils devaient ou ne devaient pas être touchés par ces glissements. Le règlement prévu par la Loi transitoire est basé sur le principe selon lequel l'intangibilité et la mullité sont des caractéristiques d'actes juridiques qui n'existent qu'au moment de l'exécution de cet acte juridique et ne durent que ce seul moment, alors que l'annulabilité accompagne l'acte juridique pendant quelque temps. Or, le législateur a pris pour point de départ la conception du droit ancien en matière de caractéristiques de l'acte juridique, à savoir l'intangibilitế, l'annulabilitế et la nullitté. La même formule est appliquée dans le chapitre 4 , où la matière est illustrée à l'aide d'un grand 
nombre de differences entre droit ancien et droit nouveau. La Loi tramsitoire prếvoit entre autres le respect de l'intangibilite des actes juridiques qui, selon le droit nouweau, seraient annulables ou nuls, contrairement au droit ancien. En outre, nous l'avons remarqué déjà, un acte juridique nul dans l'ancien système est en principe régularisé pour devenir intangible, si les conditions prévues par la loi nouvelle pour l'intangibilite d'un acte juridique sont remplies.

Dans le domaine des sûretés en matière de biens non immatricullés, il existe une multitude de rapports juridiques durables engagés avant et continués après le premier janvier 1992; en outre, l'on constate des différences profondes entre le droit ancien et le droit nouveau. Ainsi, à quelques exceptions près, la notion de propriété pour sûreté de la dette, usuelle dans l'ancien droit, n'existe plus: en effet "le législateur a converti la propriété pour sûreté de la dette en une autre structure juridique visant à la remplacer, à savoir le gage sans dépossession. Cette conversion a été concrétisée de telie manière qu'au moment de l'entrée en vigueur du nouveau Code civil, un bien susceptible d'être mis en gage et qui avait été remis au creancier pour sûreté de la dette, est transfếré à celui à la charge duquel la sûreté avait été constituée (il s'agit généralement du débiteur) et est chargé d'un droit de gage au profit de l'ancien propriétaire à titre de sûrete de la dette (en général: le créancier). Or, dans le droit transitoire, cette conversion de propriété pour sûreté de la dette en droit de gage est entourée d'un vaste ensemble de problèmes extrêmement com plexes. Ces problèmes sont discutés au chapitre 5, où sont abordés des aspects tels que les conditions auxquelles cette conversion est soumise, la force du droit de gage et l'empêchement à créer, après l'entrée en vigueur de la nouvelle législation, une propriété pour sûreté de la dette. Il s'avère particulièrement difficile d'évaluer la force du droit de gage. En effet, il existe une multitude de droits et privilèges auxquels peuvent se heurter la propriêté pour sûreté de la dette et le droit de gage. II faut ajouter qu'il est nécessaire de distinguer entre les droits et privilèges existant avant et ceux créés après la mise en vigueur du nouveau Code.

Le droit transitoire à l'égard de l'acte illicite est traité au chapitre 6. Les différences entre le droit ancien et le droit nouveau en la matière concernent entre autres les responsabilités civiles: certaines ont été abolies et de nouvelles ont été crées; de même, il existe des différences quant à l'étendue des obligations de réparation du dommage. Dans la discussion des problèmes transitoires qui peuvent se présenter du fait de ces différences, une distinction est faite entre différents effets juridiques découlant d"un acte illicite. Il s'agit des effets suivants: la responsabilité du dommage, le droit à la réparation de dommage, et le pouvoir dle dlemander ou d'adjuger une interdiction, un jugement déclaratoire et une rectification. Quant à la responsabilité du dommage, nous étudions entre autres la question de savoir ce qui est prévu par la Loi transitoire en matière de "dommages réalisés avec un retard", c"est-àdire les dommages qui, au lieu de se présenter dès qu'ils sont causês, ne se produisent qu'après un certain laps de temps indéterminé. La Loi transitoire se base sur le principe de l'applicabilité du droit en vigueur au moment de la réalisation du dommage. S'il est impossible de déterminer si ce moment de réalisation se trouvait avant ou après l'entrée en vigueur du nouveau Code, le droit applicable sera celui qui était en vigueur au moment où le dommage a été constaté.

Le chapitre 7 est consacré au droit transitoire relatif aux manquements dans 
l'exécution des obligations. Dans ce domaine aussi, le nouveau Code civil contient des modifications considérables. Ainsi, conträrement aux dispositions antérieures; le délai fixé pour l'exécution de l'obligation est devenu en principe un délai fatal, les conditions pour la résiliation de contrats synallagmatiques et les effets juridiques de celle-ci ont été modifiées et de nouvelles règles ont été introduites pour les droits démembrés et les contrats de vente. Dans le contexte du droit transitoire se pose la question de savoir quel droit, l'ancien ou le nouveau, sera et devra être applicable en matière de manquement (avant, après ou à la date même d'entrée en vigueur du nouveau Code) dans l'exécution d'une obligation contractée avant cette date. Or, c'est sur la réponse à cette question qu'est axé le chapitre 7 , où sont discutés les principaux instruments dont dispose le créancier au cas où le débiteur manquerait à l'exécution de son obligation. Il s'agit des instruments suivants: la demande de l'exécution, la demande de réparation du dommage, la résiliation du contrat, la suspension de l'exécution de l'obligation engagée par le créancier. Sont abordés en outre les droits d'usufruit, d'usage, d'habitation, et d'emphytéose ainsi que le contrat de vente. Selon la règle principale, le droit ancien restera applicable aux conséquences d'un manquement, même après l'entrée en vigueur du droit nouveau, si ce manquement date d'avant l'entrée en vigueur; en principe, le droit houveau est applicable pour les manquements survenus au moment de l'entrée en vigueur ou après celle-ci.

La thèse se termine par le chapitre 8 qui contient quelques observations finales. 


\section{Lijst van aangehaalde Kamerstukken}

Onderstaande lijst bevat de volledige gegevens van de in de noten verkort aangehaalde Kamerstukken.

Parl, Gesch. Inv. Boek 1

Parl. Gesch. Boek 3

Parl. Gesch. Inv. Boek 3

Parl. Gesch. Boek 5

Parl. Gesch. Boek 6

Parl. Gesch. Inv. Boek 6

Parl. Gesch. Boek 7
C.J. van Zeben en O.W. van Ewijk, Parlementaire Geschiedenis van het nieuwe Burgerlijk Wetboek, Invoeringswet Boek 1. Personen- en familierecht, Deventer 1969.

C.J. van Zeben en J.W. du Pon, m.m.v. M.M. Olthof, Parlementaire Geschiedenis van het nieuwe Burgerlijk Wetboek, Boek 3. Vermogensrecht in het algemeen, Deventer 1981.

W.H.M. Reehuis en E.E. Slob, Parlementaire Geschiedenis van het nieuwe Burgerlijk Wetboek, Invoering Boeken 3, 5 en 6. Boek 3. Vermogensrecht in het algemeen, Deventer 1990.

C.J. var Zeben en J.W. du Pon, m.m.v. M.M. Olthof, Parlementaire Geschiedenis van het nieuwe Burgerlijk Wetboek, Boek 5. Zakelijke rechten, Deventer 1981.

C.J. van Zeben en J.W. du Pon, m.m.v. M.M. Olthof, Parlementaire Geschiedenis van het nieuwe Burgerlijk Wetboek. Boek 6. Algemeen gedeelte van het verbintenissenrecht, Deventer 1981.

W.H.M. Reehuis en E.E. Slob, Parlementaire Geschiedenis van het nieuwe Burgerlijk Wetboek, Invoering Boeken 3, 5 en 6. Boek 6. A]gemeen gedeelte van het verbintenissenrecht, Deventer 1990.

W.H.M. Reehuis en E.E. Slob, Parlementaire 
TK, vergaderjaar 1980-1981, 1.6593 , nr. 3

TK, vergaderjaar 1981-1982, 16593 , nr. 5

Parl. Gesch. Kadasterwet

TK, vergaderjaar 1990-1991, 21830 , nrs. 3 en 5

Parl. Gesch. Overgangsrecht

TK, vergaderjaar 1988-1989, 18998 , nrs. 5 en 8
Geschiedenis van het nieuwe Burgerlijk Wet boek, Invoering Baeken 3, 5 en 6. Boek 7. Bijzondere overeenkomsten, Titels $1,7,9$ en 14 , Deventer 1991.

Tweede Kamer der Staten-Generaal, vergaderjaar 1980-1981, 16 593, Invoeringswet Boeken 3-6 Nieuw B.W. eerste gedeelte, bevattende wijziging van het Wetboek van Burgerlijke Rechtsvordering, de Wet op de rechterlijke organisatie en de Faillissementswet, nr. 3 (memorie van toelichting).

Tweede Kamer der Staten-Generaal, vergaderjaar 1981-1982, 16 593, Invoeringswet Boeken 3-6 Nieuw B.W. eerste gedeelte, bevattende wijziging van het Wetboek van Burgerlijke Rechtsvordering, de Wet op de rechterlijke organisatie en de Faillissementswet, nr. 5 (memorie van antwoord).

W.H.M. Reehuis en E.E. Slob, Parlementaire Geschiedenis van het nieuwe Burgerlijk Wetboek, Invoering Boeken 3, 5 en 6. Kadasterwet (wet houdende regelen met betrekking tot de openbare registers voor registergoederen, alsmede met betrekking tot het kadaster), Deventer 1990.

Tweede Kamer der Staten-Generaal, vergaderjaar 1990-1991, 21 830, Wijziging van de Kadasterwet en van enige andere wetten en regeling van het overgangsrecht in verband met de inwerkingtreding van de Kadasterwet. (Invoeringswet Kadasterwet), nrs. 3 (memorie van toelichting) en 5 (memorie van antwoord).

W.H.M. Reehuis en E.E. Slob, Parlementaire Geschiedenis van het nieuwe Burgerlijk Wetboek, Invoering Boeken 3, 5 en 6 . Overgangsrecht, Deventer 1991.

Tweede Kamer der Staten-Generaal, vergaderjaar 1988-1989, 18 998, Aanvulling van de Overgangswet Nieuw Burgerlijk Wetboek (In- 
TK, vergaderjaar 1990-1991, 22109, nr. 3

TK, vergaderjaar 1991-1992, 22442 , nrs. 2 en 4

TK, vergaderjaar 1988-1989, 21265 , nr. 3

EK, vergaderjaar 1990-1991, 21265 , nr. $90 a$

TK, vergaderjaar 1988-1989, 21202 , nr. 3

TK, vergaderjaar 1990-199॥, 21202 , nr. 6 voeringswet Boeken 3,5 en $6 \mathrm{NBW}$ elfde gedeelte), nrs. 5 (memorie van antwoord) en 8 (nota naar aanleiding van het eindverslag).

Tweede Kamer der Staten-Generaal, vergaderjaar 1990-1991, 22 109, Aanpassing van de Wet op het consumentenkrediet aan de Boeken 3,5 en 6 van het nieuwe Burgerlijk Wetboek alsmede enige correcties in de Invoeringswet Boeken 3, 5 en 6 van het nieuwe Burgerlijk Wetboek, nr. 3 (memorie van toelichting).

Tweede Kamer der Staten-Generaal, vergaderjaar 1991-1992, 22 442, Correctie en aanpassing van de Invoeringswet Boeken 3, 5 en 6 nieuw B.W. (dertiende gedeelte) voor zover het fiscale wetgeving betreft en enige andere correcties, nrs. 2 (voorstel wan wet) en 4 (nota van wijziging).

Tweede Kamer der Staten-Generaal, vergaderjaar 1988-1989, 21 265, Inwoering van Boek 8 van het Burgerlijk Wetboek, vierde gedeelte (Overgangswet Boek 8 nieuw B.W.), nr. 3 (memorie van toelichting).

Eerste Kamer der Staten-Generaal, vergaderjaar 1990-1991, 21 265, Invoering van Boek 8 van het nieuwe Burgerlijk Wetboek, vierde gedeelte (overgangsrecht en correcties), nr. $90 \mathrm{a}$ (memorie van antwoord).

Tweede Kamer der Staten-Generaal, vergaderjaar 1988-1989, 21 202, Aanvulling van de Boeken 3, 6 en 8 nieuw BW met regels betreffende de aansprakelijkheid voor gevaarlijke stoffen en verontreiniging van lucht, water of bodem, hr. 3 (memorie van toelichting).

Tweede Kamer der Staten-Generaal, vergaderjaar 1990-1991, 21 202, Aanwulling van de Boeken 3, 6 en 8 NBW met regels betreffende de aansprakelijkheid voor gevaarlijke stoffen en verontreiniging wan lucht, water of bodem, nr. 6 (memorie van antwoord). 
TK, vergaderjaar 1985-1986, $19529, \mathrm{mr} .3$

TK, vergaderjaar 1985 1986, 19636 , nr. 3

TK, vergaderjaar 1989-1990, 21528 , nr. 1

TK, vergaderjaar 1987-1988, 20588 , nr. 3
Tweede Kamer der Staten-Generaal, vergaderjaar 1985-1986, 19 529, Vaststelling van titel 7.17 (verzekering) en titel 7.18 (lijfrente) van het nieuwe Burgerlijk Wetboek, nr. 3 (memorie van toelichting).

Tweede Kamer der Staten-Generaal, vergaderjaar 1985-1986, 19 636, Aanpassing van het Burgerlijk Wetboek aan de richtlijn van de Raad van de Europese Gemeenschappen inzake de aansprakelijkheid voor produkten met gebreken, nr. 3 (memorie van toelichting).

Tweede Kamer der Staten-Generaal, vergaderjaar 1989-1990, 2l 528, Verkeersaansprakelijkheid, nr. 1 (notitie over de verkeersaansprakelijkheid).

Tweede Kamer der Staten-Generaal, vergaderjaar 1987-1988, 20 588, Invordering van rijksbelastingen, andere dan invoerrechten en accijnzen (Invorderingswet 1989), nr. 3 (memorie van toelichting). 


\section{Lijst van aangehaalde literatuur}

Onderstaande lijst bevat de volledige gegevens van de in de noten verkort aangehaalde literatuur. Noten onder rechterlijke uitspraken zijn niet in de lijst opgenomen.

Abas, WPNR 5970 (1990)

Advies Produktenaansprakelijkheid, Publikatie nr. 4 - 18 januari 1980 Asser-Scholten, Algemeen deel

Asser-Beekhuis I

Asser-Beekhuis II

Asser-Mijnssen, en:

Asser-Van Velten

Asser-Rutten II
P. Abas, Overzicht der Nederlandse rechtspraak, Verbintenissenrecht; De verbintenis uit overeenkomst, Nederlandse Jurisprudentie 1984-1989 (IT), WPNR 5970 (1990), p. 493-496.

Advies van de SER inzake Produktenaansprakelijkheid, uitgebracht aan de minister van Justitie, Publikatie nr. 4 - 18 januari 1980.

Mr. C. Asser's Handleiding tot de beoefening van het Nederlands burgerlijk recht, Algemeen deel, door Paul Scholten, derde druk, met feitelijke gegevens aangevulld door G.J. Scholten, Zwolle 1974.

Mr. C. Asser's Handleiding tot de beoefening van het Nederlands burgerlijk recht, Zakenrecht, Algemeen deel, twaalfde druk, bewerkt door J.H. Beekhuis, F.H.J. Mijnssen en P. de Haan, Zwolle 1985.

Mr. C. Asser"s Handleiding tot de beoefening van het Nederlands burgerlijk recht, Zakenrecht, Tweede deel, Eigendom en beperkte zakelijke genotsrechten, twaalfde druk, bewerkt door J.H. Beekhuis, W.J.M. Davids, F.H.J. Mijnssen en A.A. van Velten, Zwolle 1990.

Mr. C. Asser's Handleiding tot de beoefening van het Nederlands burgerlijk recht, Zakenrecht, Zekerheidsrechten, elfde druk, bewerkt door F.H.I. Mijnssen en A.A. van Velten, Zwolle 1986.

Mr. C. Asser's Handleiding tot de beoefening van het Nederlands burgerlijk recht, Verbintenissenrecht, Tweede deel, Algemene leer der 
Asser-Harkamp I

Asser-Hartkamp II

Asser-Hartkamp III

Asser-Kamphuisen

Asser-Schut

Asser-Coehorst

Asser-Kleijn

Asser-Meijers-Van der Ploeg

Bakels, Kwartaalbericht overeenkomsten, zesde druk, bewerkt door L.E.H. Rutten, Zwolle 1982.

Mr. C. Asser"s Handleiding tot de beoefening van het Nederlands burgerlijk recht, Verbintenissenrecht, deel I, De verbintenis in het algemeen, achtste druk, bewerkt door A.S. Hartkamp, Zwolle 1988.

Mr. C. Asser"s Handleiding tot de beoefening van het Nederlands burgerlijk recht, Verbintenissenrecht, deel II, Algemene leer der overeenkomsten, achtste druk, bewerkt door A.S. Hartkamp, Zwolle 1989.

Mr. C. Asser's Handleiding tot de beoefening van het Nederlands burgerlijk recht, Verbintenissenrecht, deel III, De verbintenis uit de wet, achtste druk, bewerkt door A.S. Hartkamp, Zwolle 1990.

Mr. C. Asser's Handleiding tot de beoefening van het Nederlandsch burgerlijk recht, Verbintenissenrecht, derde stuk, Bijzondere overeenkomsten, derde druk, bewerkt door P.W. Kamphuisen m.m.v. J. van Andel, Zwolle 1960.

Mr. C. Asser"s Handleiding tot de beoefening van het Nederlands burgerlijk recht, Bijzondere overeenkomsten, deel I, Koop en ruil, vierde druk, bewerkt door G.H.A. Schut, Zwolle 1981. Mr. C. Asser's Handleiding tot de beoefening van het Nederlands burgerlijk recht, Bijzondere overeenkomsten, deel III, overeenkomst van opdracht; arbeidsovereenkomst, aanneming van werk, zesde druk, door P.J.M.G. Coehorst, L.J.M. de Leede en H.O. Thunnissen, Zwolle 1988.

Mr. C. Asser's Handleiding tot de beoefening van het Nederlands burgerlijk recht, Bijzondere overeenkomsten, Deel IV, Bewaargeving, bruikleen, verbruikleen, borgtocht, schenking, gevestigde en altijddurende renten, kansovereenkomst en lijfrente, spel en weddenschap, vaststellingsovereenkomst en dading, vierde/vijfde druk, bewerkt door W.M. Kleijn, Zwolle 1988.

Mr. C. Asser's Handleiding tot de beoefening van het Nederlands burgerlijk recht, Erfrecht, tiende druk, bewerkt door P.W. van der: Ploeg, Zwolle 1988.

F.B. Bakels, De Nederlandse Vereniging voor- 
Nieuw BW 1985

Barendrecht, in: BW-krant jaarboek 1991

Van der Beek, Kwartaalbericht Nieuw BW 1986

Van der Beek, RegelMaat 1986

Van der Beek, AA 1988

Van der Beek, Kwartaalbericht Nieuw BW 1988

Bloembergen, in: BWkrant jaarboek 1987

Brahn, studiepocket (zesde druk)

Brahn, studiepocket

Brunner, preadv.

Brunner, in: Verslag NJVvergadering
Rechtspraak over het Ontwerp Overgangswet, Kwartaalbericht Nieuw BW 1985 , p. $54-57$.

J.M. Barendrecht, Toepasselijkheid wan algemene voorwaarden onder het Nieuw BW: een nieuw regime, in: A.G. Castermans e.a. (red), Practicum Nieuw BW. Enkele praktische wenken bij de invoering van het Nieuw Burgerlijk Wetboek, BW-krant jaarboek nr. 7, Arnhem 1991, p. 105-116.

H.L. van der Beek, Enige aspecten van het overgangsrecht Nieuw BW, Kwartaalbericht Nieuw BW 1986, p. 78-82.

H.L. van der Beek, Een aanwijzing afgewezen: punt 74 Aanwijzingen voor de wetgevingstechniek en het overgangsrecht NBW, RegelMaat 1986, p. 158-161.

H.L. van der Beek, Beantwoording rechtsvraag (N)BW (26) overgangsrecht, AA 1988, p. 404412, tevens gepubliceerd in: Rechtsvragen NBW Ars Aequi 1983-1989, Nijmegen 1989, p. 111-119, met naschrift op p. 119-120.

H.L. van der Beek, Het recht van reclame in het Nieuw BW: een geslaagde herschepping?, Kwartaalbericht Nieuw BW 1988, p. 80-86.

A.R. Bloembergen, Het regresrecht van de sociale verzekeraar, in: A.G. Castermans e.a. (red.), Schadeverhaal, BW-krant jaarboek nr. 3, Leiden 1987, p. 13-36.

O.K. Brahn, Fiduciaire overdracht, stille verpanding en eigendomsvoorbehoud naar huidig en komend recht, Studiepockets privaatrecht nr. 13, zesde, herziene en aangevulde druk, Zwolle 1988.

O.K. Brahn, Stille verpanding en eigendomsvoorbehoud volgens het nieuwe Burgerlijk Wetboek, met het overgangsrecht en vergelijkende opmerkingen over het oude recht; Studiepockets privaatrecht nr: 13, zevende, geheel herschreven druk, Zwolle 1991.

C.J.H. Brunner, Rechtsvinding Overgangsrecht Privaatrecht, Preadvies NJV, in: Handelingen 1985 der Nederlandse Juristen-Vereniging, deel 1, eerste stuk, Zwolle 1985, p. 1-61.

C.J.H. Brunner, beantwoording interventies, in: Verslag van de op 14 juni 1985 te Haarlem gehouden algemene vergadering, Handelingen 
Brunner, WPNR 6007 (1991)

Commentaar KNB, Kwartaalbericht Nieuw BW 1985

Commissie-Van Schendel, Trema special $91-2$

Compendium bijzondere overeenkomsten VI (Veldhuis)

Contractenrecht I-E (De Loos-Wijker)

De Die, RMTh 1979

De Die, in: Verslag NJVvergadering

De Die, DD 1989

De Die, Spoedcursus

De Die, AA 1991

Van Dijk, in: Liber amicorum NBW
1985 der Nederlandse Juristen-Vereniging, deel 2. Zwolle 1986, p. 31-37.

C.J.H. Brumner, Algemene beginselen van overgangsrecht nieuw vermogensrecht, WPNR 6007 (1991), p. 342-347.

Commentaar van de Commissie Overgangsrecht van de Koninklijke Notariële Broederschap, Kwartaalbericht Nieuw BW 1985, p. 48-52.

Consequenties invoering NBW voor de werklast van de rechterlijke macht, Tweede tussentijds verslag aan de Minister van Justitie van de Commissie consequenties invoering NBW voor de werklast van de rechterlijke macht, Trema special "91-2.

A.M. Veldhuis, Lastgeving en verrichten van enkele diensten, in: C.J. van Zeben (red.), Compendium bijzondere overeenkornsten, zesde druk, Deventer 1989, p. 271-291.

Hoofdstuk I, Vragen van algemene aard, onderdeel E, Nietigheden, bewerkt door S.A.M. de Loos-Wijker, in: A.R. Bloembergen en W.M. Kleijn (red.), Contractenrecht, losbladige uitgave, Deventer.

B.C. de Die, Overgangsrecht - een herwaardering na vijftig jaar, RMTh 1979, p. 253-285.

B.C. de Die, interventie, in: Verslag van de op 14 juni 1985 te Haarlem gehouden algemene vergadering, Handelingen 1985 der Nederlandse Juristen-Vereniging, deel 2, Zwolle 1986, p. 25-28.

B.C. de Die, Bespreking van G. Knigge, Verandering van wetgeving. Beschouwingen over de artt. 4 A.B. en 1 Sr., diss. Groningen, Arnhem 1984, in: DD 1989, p. 880-886.

B.C. de Die, De aanpak van het overgangsrecht - een spoedcursus, nota d.d. 12 oktober 1990.

B.C. de Die, Beginselen van Overgangsrecht, AA. 1991, p. 818-829.

D. van Dijk, Over Bob de Die, wetgevingsjurist en collega, in: Liber amicorum NBW. Opstellen aangeboden aan $\mathrm{Mr}$ drs B.C. de Die bij zijn aftscheid als hoofd van de Stafafdeling Wetgeving Nieuw Burgerlijk Wetboek van het Ministerie van Justitie, Arnhem/Deventer/Zwolle 1991, p. 3-6. 
Van Driel en Van Maanen, Kwartaalbericht Nieuw BW 1985

Drion-Hijma/Olthof, Compendium

Van Dunné c.s., Kosten en tekortkomingen

Elders, in: Verslag NJVvergadering

Van Erp, studiepocket

Fesevur, Advocatenblad 1990

Folmer, diss.

Van Harinxma thoe Slooten, NJB 1990

Hartkamp, in: Non sine causa

Hartkamp, Compendium

Hartkanp, in: Liber amicorum NBW

Hartkamp, AA 1991
H. van Driel en G.E. van Maanen, Anticiperen op het Nieuw BW, Kwartaalbericht Nieuw BW 1985, p. 109-117.

H. Drion, Compendium van het Nederlands vermogensrecht, bewerkt door Jac. Hijma en M.M. Olthof, achtste druk, Deventer 1991.

J.M. van Dunné, E.A.A. Luijten en P.A. Stein, Kosten en tekortkomingen van het Nieuw Burgerlijk Wetboek (boeken 3, 5 en 6). Rapport uitgebracht aan de vaste Commissie voor justitie van de Tweede Kamer, Serie rechtsvinding deel 7, Arnhem 1990.

J. Elders, interventie, in: Verslag van de op 14 juni 1985 te Haarlem gehouden algemene vergadering, Handelingen 1985 der Nederlandse Juristen-Vereniging, deel 2, Zwolle 1986, p. 3031.

J.H.M. van Erp, Jnternationaal huwelijksvermogensrecht, Studiepockets privaatrecht nr. 38, Zwolle 1985.

J.E. Fesevur, Fiduciaire eigendom, pandrecht en warrantage, Advocatenblad 1990, p. 537-540.

G.J.Ph. Folmer, Ontwikkeling van het Intertemporaal Burgerlijk Recht in theorie en practijk, diss. Leiden, Amsterdam 1928.

L.R. van Harinxma thoe Slooten, Door "warrantage' meer kredietmogelijkheden op handelsgoederen, NJB 1990, p. 1447-1451.

A.S. Hartkamp, Bekrachtiging van nietige rechtshandelingen in het nieuwe Burgerlijk Wetboek, in: Non sine causa. Opstellen aangebodlen aan Prof.Mr. G.J. Scholten ter gelegenheid van zijn afscheid als hoogleraar aan de Universiteit van Amsterdam, Zwolle 1979, p. 115-134.

A.S. Hartkamp, Compendium van het vermogensrecht volgens het nieuwe Burgerlijk Wetboek, vierde druk, Deventer 1990.

A.S. Hartkamp, De redelijkheid en billijkheid in het overgangsrecht (art. $75 \mathrm{Ow}$.), in: Liber amicorum NBW. Opstellen aangeboden aan $\mathrm{Mr}$ drs B.C. de Die bij zijn afscheid als hoofd van de Stafafdeling Wetgeving Nieuw Burgerlijk Wetboek van het Ministerie van Justitie, Arnhem/Deventer/Zwolle 1991, p. 151-155.

M. Hesselink, H. Wattendorff, De tien tafelen 
Hartkamp, WPNR 6030 (1991)

Hartkamp, rede

Hijma, diss.

Hijmans van den Bergh, diss.

Hijmans van den Bergh, preadv.

Hondius, Kwartaalbericht Nieuw BW 1984

Huijgen, in: BW-krant jaarboek 1988

Van Huizen, WPNR 6007 (1991)

Jansen, Kwartaalbericht Nieuw BW 1985

Jessurun d'Oliveira, diss.

De Jong, diss.

Joppe, diss. van de Nederlandse wet. Dat zou toch mooi zijn? Interview met prof.mr. A.S. Hartkamp, AA 1991, p. 1109-1118.

A.S. Hartkamp, Terugwerkende kracht, WPNR 6030 (1991), p. 868-873.

A.S. Hartkamp, Wetsuitleg en rechtstoepassing na de invoering van het nieuwe Burgerlijk Wetboek, rede uitgesproken bij de aanvaarding van het ambt van hoogleraar in het privaatrecht aan de Rijksuniversiteit te Utrecht op 29 januari 1992, Deventer 1992.

Jac. Hijma, Nietigheid en vernietigbaarheid van rechtshandelingen, diss. Leiden, Deventer 1988. L.J. Hijmans van den Bergh, Opeenvolgen van rechtsregels, diss. Utrecht 1928.

L.J. Hijmans van den Bergh, Overgangsrecht, in verband met het ontwerp voor een nieuw Burgerlijk Wetboek, Praeadvies, uitgebracht voor de jaarlijkse algemene vergadering van de Broederschap der Notarissen in Nederland, te houden te Arnhem op 13 September 1956, z.p., z.j..

E.H. Hondius, Operatie stofkam: rol van rechter in Nieuw BW wordt teruggedrongen, Kwartaalbericht Nieuw BW 1984, p. 2-6.

W.G. Huijgen, De situering van art. 6.3.1.5b in het burgerlijk recht, in: A.G. Castermans e.a. (red.), Oud en nieuw, BW-krant jaarboek nr. 4, Leiden 1988, p. 182-189.

Ph.H.J.G. van Huizen, Wijziging Koophandel, Strafvordering, Faillissementswet, en bijzondere wetten (art. 13-14, 28, 29-30). Overgangsrecht, tweede stuk, WPNR 6007 (1991), p. 379383.

H.G.T.J. Jansen, Het Ontwerp Overgangswet vanuit de advocatuur bezien, Kwartaalbericht Nieuw BW 1985, p. 57-59.

H.U. Jessurun d'Oliveira, De antikiesregel. Een paar aspekten van de behandeling van buitenlands recht in het burgerlijk proces, diss. Amsterdam (UvA), Deventer 1971.

G.T. de Jong, Registers, risico en goede trouw, diss. Groningen, Arnhem 1988.

I.S. Joppe, Overgangsrecht in het internationaal privaatrecht en het fait accompli, diss. Leiden, Arnhem 1.987. 
Knigge, diss.

Konings, diss.

Konings, WPNR 6002 (1991)

Kortmann, in: Met grond verbonden

Leijten, NJB 1972

Leijten, NJB 1985

Lekkerkerker, in: BW-krant jaarboek 1991

Van Maanen, NJB 1984

Van Maanen, Kwartaalbericht Nieuw BW 1988

Van Maanen ${ }_{*}$ Kwartaalbericht Nieuw BW 1990

R.S. Meijer, preadv.

W.R. Meijer, WPNR 6007 (1991)

Mezas, diss.

Van Mierlo, diss.
G. Knigge, Verandering van wetgeving. Beschouwingen over de artt. 4 A.B. en 1 Sr., diss. Groningen, Arnhem 1984.

P.G.H.T. Konings, De openbare registers ten hypotheekkantore, diss. Nijmegen, Deventer 1990. P.G.H.T. Konings, Het dagregister, beslissend voor de rangorde?, WPNR 6002 (1991), p. 269271.

S.C.J.J. Kortmann, Een misverstand met een dure lange staart. Bunde/Erckens c.s., in: Met grond verbonden. Opstellen aangeboden aan Mr. J.P. Wijn en Mr. J.J. Stael, Deventer 1991, p. $89-99$.

J.C.M. Leijten, Overgangsrecht, NJB 1972, p. 364-373, 389-400.

J.C.M. Leijten, Overgangsrecht in het privaatrecht, NJB 1985, p. 733-739.

G.J.C. Lekkerkerker, De afstand 1302/1303; opkomst en ondergang van een toverformule, in: A.G. Castermans e.a. (red.), Practicum Nieuw BW. Enkele praktische wenken bij de invoering van het Nieuw Burgerlijk Wetboek, BW-krant jaarboek nr. 7, Arnhem 1991, p. 117 . 136 , in enigszins gewijzigde vorm tevens gepubliceerd in: WPNR 6030 (1991), p. 905-910.

G.E. van Maanen, Operatie 'stofkam' of stofkam-operette?, NJB 1984, p. 173.

G.E. van Maanen, De onrechtmatige daad (titel 6.3) in het Nieuw BW anno 1988. Terugblik en vooruitzicht, Kwartaalbericht Nieuw BW 1988, p. $37-46$.

G.E. van Maanen, Vooruitlopen op de invoering van het Nieuw BW, Kwartaalbericht Nieuw BW 1990, p. 69-72.

R.S. Meijer, Nakoming en niet nakoming van overeenkomsten; As Time Goes By..., in: Capita Overgangsrecht NBW, Preadviezen, uitgebracht voor de Vereniging voor Burgerlijk Recht, Lelystad 1991, p. 9-27.

W.R. Meijer, Het overgangsrecht met betrekking tot het goederenrecht, WPNR 6007 (1991), p. $350-355$.

B.M. Mezas, Eigendomsvoorbehoud naar huidig en komend Nederlands recht, diss. Nijmegen, Zwolle 1985.

A.I.M. van Mierlo, Fiduciaire zekerheid, vuist- 
Van Mierlo, preadv.

Molenaar, Kwartaalbericht Nieuw BW 1990 loos en stil pand. Enige beschouwingen omtrent het rechtskarakter van de fiduciaire zekerheidsoverdracht naar huidig recht en wan de haar opvolgende regeling in het Nieuwe Burgerlijk Wetboek, diss. Nijmegen, Deventer 1988.

A.I.M. van Mierlo, Over zekerheidsrechten, het overgangsrecht en conversie ex lege transitoria, in: Capita Overgangsrecht NBW, Preadviezen, uitgebracht voor de Vereniging voor Burgerlijk Recht, Lelystad 1991, p. 29-50.

F. Molenaar, Bespreking van W.H.M. Reehuis, Stille verpanding van roerende zaken en vorderingen volgens het NBW, overeenkomsten en verschillen met zekerheidsoverdracht, met beschrijving van het overgangsrecht, diss. Groningen, Arnhem 1987, in: Kwartaalbericht Nieuw BW 1990, p. 49-56.

Mon. Nieuw BW A-1 (Hartkamp) A.S. Hartkamp, Aard en opzet van het nieuwe vermogensrecht, Monografieën Nieuw BW deel A-1, tweede druk, Deventer 1990.

Mon. Nieuw BW A-23 (Van Buchem)

Mon. Nieuw BW A-25 (De

Vries Lentsch-Kostense)

Mon. Nieuw BW B-10 (Kleijn)

Mon. Nieuw BW B-12a

(Molenaar)

Mon. Nieuw BW B-28 (De

Jong)

Mon. Nieuw BW B-78

(Blomkwist)

Pabbruwe, RMTh 1985

Paquay, AA 1986

Paquay, AA 1987
A.M.J. van Buchem-Spapens, Anticipatie, Monografieën Nieuw BW deel A-23, Deventer 1986.

C.L. de Vries Lentsch-Kostense, Overgangsrecht, Monografieën Nieuw BW deel A-25, Deventer 1992.

W.M. Kleijn, Vruchtgebruik, Monografieën Nieuw BW deel B-10, Deventer 1990.

F. Molenaar, Pandrecht, Monografieën Nieuw BW deel B-12a, tweede druk, Deventer 1991.

J. de Jong, Erfpacht en opstal, Monografieèn Nieuw BW deel B-28, Deventer 1986.

J.W.H. Blomkwist, Borgtocht, Monografieèn Nieuw BW deel B-78, Deventer 1991.

H.J. Pabbruwe, Bespreking van O.K. Brahn, Fiduciaire overdracht, stille verpanding en eigendomsvoorbehoud naar huidig en komend recht, Studiepockets privaatrecht nr. 13 , vierde, geheel herziene en aangevulde druk, Zwolle 1983, in: RMTh 1985, p. 386-387.

G.B.A. Paquay, Nieuwe regels voor algemene voorwaarden uitgesteld. Een kritische beschouwing over artt. 71 en 191 van de Overgangswet NBW, AA 1986, p. 517-524.

G.B.A. Paquay, Het arrest Van der Meer/gem. Smilde en art. 191 Overgangswet NBW, AA 1987, p. 70-71. 
Pitlo-Bolweg

Polak, WPNR 5744 (1985)

Polak, preadv.

Polman, diss.

Polman, Overgangswet, deel 1, en: Reinsma, Overgangswet, deel 1 Reehuis, diss.

Reehuis, AA 1991

Reinsma, Kwartaalbericht Nieuw BW 1985

Reinsma, AA 1991

Rijken, TVVS 1986

Rijken, Bb 1991

Rijken, in: Wegwijzer nieuw BW, deel 2

Van Rijn van Alkemade, in: Liber amicorum NBW
A. Pitlo, Het Nederlands Burgerlijk Wetboek, deel 3, Algemeen deel van thet verbintenissenrecht, achtste druk, bewerkt door M.F.H.J. Bolweg, Arnhem 1979.

M.V. Polak, Van oud naar nieuw. Ontwikkelingen in het overgangsrecht (II, slot), WPNR 5744 (1985), p. 434-437.

M.V. Polak, Wegwerprecht op termijn: verjaring en verval in het overgangsrecht NBW, in: Capita Overgangsrecht NBW, Preadviezen, uitgebracht voor de Vereniging voor Burgerlijk Recht, Lelystad 1991, p. 51-84.

J.J.R. Polman, Temporele werkingen van wetten. Op het burgerlijk recht georiënteerde beschouwingen van theoretische aard over en naar aanleiding van een visie op het overgangsrechtelijke deelprobleem van de mogelijke functies van een nieuwe wet, diss. Amsterdam (VU) 1984.

J.J.R. Polman en M. Reinsma, Aanvulling Overgangswet Nieuw Burgerlijk Wetboek, deel 1, Algemeen, Arnhem 1991.

W.H.M. Reehuis, Stille verpanding van roerende zaken en vorderingen volgens het NBW, overeenkomsten en verschillen met zekerheidsoverdracht, met beschrijwing van het overgangsrecht diss. Groningen, Arnhem 1987.

W.H.M. Reehuis, Beantwoording rechtsvraag (204) burgerlijk recht, AA 1991, p. 507- 512.

M. Reinsma, Nieuw overgangsrecht, Kwartaalbericht Nieuw BW 1985, p. 41-48.

M. Reinsma, De Overgangswet Nieuw Burgerlijk Wetboek, AA 1991, p. 652-656.

G.J. Rijken, De komende wettelijke regeling van de algemene voorwaarden, TVVS 1986, $\mathrm{p}$. 265-270.

G.J. Rijken, Opnieuw: een onredelijk bezwarend arbitragebeding in algemene voorwaarden, Bb 1991 , p. 96.

G.J. Rijken, Overeenkomst en algemene voorwaarden, in: Wegwijzer nieuw $B W$, deel 2, Zwolle 1992, p. 27-44.

J. van Rijn van Alkemade, Artikel 2 Boek 6 Nieuw Burgerlijk Wetboek en het international privaatrecht, in: Liber amicorum NBW. OpstelJen aangeboden aan Mr drs B.C. de Die bij zijn afscheid als hoofd van de Stafafdeling 
Van Rooij en Polak, Private International Law

Salomons, VA 1990

Schepel, in: Verslag NJVvergadering

Schmitz, in: BW-krant jaarboek 1990

Schoordijk, Boek 3

Schuttevâer-Hermans

Sijmonsma, in: Om wille van de consument

Snijders, AA 1991

Spier, Kwartaalbericht Nieuw BW 1985

Spier, rede

Spier en Sterk, preadv.
Wetgewing Nieuw Burgerlijk Wetboek van het Ministerie van Justitie, Arnhem/Deventer/Zwolle 1991, p. 105-110.

R. van Rooij en M.V. Polak, Private International Law in the Netherlands, Deventer 1987.

R.A. Salomons, Anticipatie op het verzekeringsrecht in het NBW, VA 1990, p. 121-134.

J. Schepel, interventie, in: Verslag van de op 14 juni 1985 te Haarlem gehouden algemene vergadering, Handelingen 1985 der Nederlandse Juristen-Vereniging, deel 2, Zwolle 1986, p. 1419.

T.W.H.E. Schmitz, Artikel 196 overgangswet NBW, een al te bijzondere regeling?, in: A.G. Castermans e.a. (red.), Rechterlijke macht en Nieuw BW, BW-krant jaarboek nr. 6, Arnhem 1990 , p. 79-93.

H.C.F. Schoordijk, Vermogensrecht in het algemeen naar Boek 3 van het nieuwe B.W. (titel 1 $\mathrm{t} / \mathrm{m} 5$, titel 11), Deventer 1986.

H. Schuttevâer en F.M.J. Hermans, Kort begrip van rechtswerkeersbelastingen en registratie, derde druk, Arnhem 1981.

J.R. Sijmonsma, Bunde-Erckens, de geschiedenis van een stuk grond. Een stuk grond is een stuk grond is een stuk grond ... totdat er geld bij komt, in: Om wille van de consument. Rechtsgeleerde opstellen aangeboden aan Prof. Mr. P. Clausing, Zwolle 1990, p. 165-175.

W. Snijders, Enkele hoofdpunten van de Boeken $3,5,6,7$ en $8 \mathrm{NBW}$, voor zover deze op $\mathbb{1}$ januari 1992 in werking zijn, AA 1991, p. 10881099.

J. Spier, Kanttekeningen van het Nederlands Genootschap van Bedrijfsjuristen bij het Ontwerp Overgangsrecht, Kwartaalbericht Nieuw BW 1985, p. 52-54.

J. Spier, Sluipende schade, rede uitgesproken bij de aanvaarding van het ambt van hoogleraar in het privaatrecht aan de Katholieke Universiteit Brabant op 21 september 1990, Deventer 1990. J. Spier en C.H.W.M. Sterk, Onrechtmatige daad en schadevergoeding, in: Capita overgangsrecht NBW, Preadviezen, witgebracht voor de Vereniging voor Burgerlijk Recht, Lelystad 1991, p. 85-101. 
H. Stein, Plaats en tijd

H. Stein, preadv.

H. Stein, in: Verslag NJVvergadering

H. Stein, in: Liber amicorum NBW

P.A. Stein, WPNR 6007 (11991)

Van Straaten, WPNR 5979. 5981 (1990)

Van Straaten, Kadaster

$\mathrm{T} \& \mathrm{C}$

Tekstra, preadv.

Van der Ven, in: Met eerbiedigende werking
H. Stein, Plaats en tijd in het IPR. De lex causae is gewijzigd - wat nu?, Studiekring 'Prof.Mr. J. Offerhaus', reeks Internationaal Privaatrecht, no. 16, Deventer 1984.

H. Stein, Brood-NODI-gheden bij de toepassing van de owergangswet Boeken 3,5 en 6 NBW, Preadvies NJV, in: Handelingen 1985 der Nederlandse Juristen-Vereniging, deel 1, eerste stuk, Zwolle 1985, p. 63-266.

H. Stein, beantwoording interventies, in: Verslag van de op 14 juni 1985 te Haarlem gehouden algemene vergadering, Handelingen 1985 der $\mathrm{Ne}$ derlandse Juristen-Vereniging, deel 2 , Z wolle 1.986, p. $37-40$.

H. Stein, Het ongrijpbare overgangsrecht, in: Liber amicorum NBW. Opstellen aangeboden aan Mr drs B.C. de Die bij zijn afscheid als hoofd van de Stafafdeling Wetgeving Nieuw Burgerlijk Wetboek van het Ministerie van Justitie, Amhem/Deventer/ Zwolle 1991, p. 157165.

P.A. Stein, Voorrechten en zekerheidsrechten in de overgang, WPNR 6007 (1991), p. 355 361.

J.C. van Straaten, Doorhaling van hypothecaire inschrijvingen volgens het NBW, WPNR 5979 5981 (1990), respectievelijk p. 691-693, 710$712,724-726$.

J.C. van Straten, Kadaster, openbare registers en derdenbescherming. Serie Recht en Praktijk nr. 59, Deventer 1992.

J.H. Nieuwenhuis e.a. (red.), Nieuw Burgerlijk Wetboek. Tekst \& Commentaar. De tekst van de Boeken 3, 5 en 6, en de titels 1, 7, 9 en 14 van Boek 7, voorzien van commentatar, Deventer 1990.

A.J. Tekstra, Transitoria; overeenkomsten met uitzondering van nakoming en tekortkoming, in: Capita Overgangsrecht NBW, Preadviezen uitgebracht voor de Vereniging voor Burgerlijk Recht, Lelystad 1991, p. 103-112.

J.J.M. van der Ven, Overgangswetgeving als rechtsverschijnsel, in: Met eerbiedigende werking. Opstellen aangeboden aan Prof.mr. L.J. Hijmans van den Bergh, Deventer 1971, p. 3341 , tevens gepubliceerd in: De mens in zijn 
Verbintenissenrecht

(Hondius)

Verhelij, RegelMaat 1986

Versteeg, preadv.

De Vries Lentsch-Kostense, in: BW-krant jaarboek 1990

De Vries Lentsch-Kostense, in: Liber amicorum NBW

De Vries Lentsch-Kostense, WPNR 6007 (1991)

De Vries Lentsch-Kostense, in: Quod licet

Vriesendorp, Advocatenblad 1985

Vriesendorp, WPNR 6025 (1991) rechtsorde. Verzamelde opstellen van J.J.M. van der Ven, Deventer 1981, p. 224-231.

Titel 5, Overeenkomsten in het algemeen, afdeling 3, Algemene voorwaarden, bewerkt door E.H. Hondius, in: C.J.H. Brunner en E.H. Hondius (red.), Verbintenissenrecht, losbladige uitgave, Deventer.

N. Verheij, Wetten die niet werken, RegelMaat 1986, p. 143-149.

Th.A. Versteeg, Overgangsrecht, mede in verband met de invoering van het nieuwe Burgerlijk Wetboek, Prae-advies, uitgebracht voor de jaarlijkse algemene vergadering van de Broederschap der Notarissen in Nederland, te houden te Arnhem op 13 September 1956, z.p., z.j..

C.L. de Vries Lentsch-Kostense, De systematiek van het overgangsrecht Nieuw BW, in: A.G. Castermans e.a. (red.), Rechterlijke macht en Nieuw BW, BW-krant jaarboek nr. 6, Arnhem 1990, p. 59-77, in enigszins gewijzigde vorm tevens gepubliceerd in: Wegwijzer nieuw BW, deel 1, Zwolle 1992; p. 33-52.

C.L. de Vries Lentsch-Kostense, Met onmiddellijke werking, in: Liber amicorum NBW. Opstellen aangeboden aan $\mathrm{Mr}$ drs B.C. de Die bij zijn afscheid als hoofd van de Stafafdeling Wetgeving Nieuw Burgerlijk Wetboek van het Ministerie van Justitie, Arnhem/Deventer/Zwolle 1991 , p. 167-173.

C.L. de Vries Lentsch-Kostense, Hoofdstuk 6 art. 173-190 Overgangswet: overgangsbepalingen in verband met titel 1-4 van Boek 6 nieuw BW, WPNR 6007 (1991), p. 366-372.

C.L. de Vries Lentsch-Kostense, Aansprakelijkheidsrecht in de overgang, in: Quod licet. Bundel aangeboden aan prof.mr. W.M. Kleijn ter gelegenheid van zijn afscheid als hoogleraar burgerlijk recht en notarieel recht aan de Rijksuniversiteit te Leiden op 21 februari 1992, Deventer 1992, p. $469-478$.

R.D. Vriesendorp, Het eigendomsvoorbehoud en het overgangsrecht NBW, Advocatenblad 1985 , p. $434-442$.

R.D. Vriesendorp, Enige opmerkingen over het lot van afhankelijke (zekerheids)rechten bij ver- 
Waaldijk, RegelMaat 1987

Wessels, Kort bestek

Wessels, Advocatenblad 1990

Wessels, Advocatenblad 1991

Wessels/Jongeneel, Algemene voorwaarden panding wan vorderingen naar NBW, WPNR 6025 (1991), p. 767-772.

C. Waaldijk, Kritiek op de Aanwijzingen voor de wetgevingstechniek, RegelMaat 1987, p. 2-8. B. Wessels, Overgangsrecht nieuw BW in kort bestek, tweede herziene druk, Lelystad 1990.

B. Wessels, Doorwerking van "oud" recht onder nieuw BW, Advocatenblad 1990, p. 473476.

B. Wessels, Zijn uw contracten NBW-compatible?, Advocatenblad 1991, p. 322-325.

B. Wessels en R.H.C. Jongeneel, Algemene voorwaarden. De nieuwe regeling in afd. 6.5.2A, toegelicht voor de praktijk, Zwolle 1987. 



\section{Trefwoordenregister}

Verwezen wordt naar pagina's.

aansprakelijkheid 25,203 e.v.

- ter zake van registers voor registergoederen 70-71

schrapping van - 210-211

verschuiving van $-211-212$

wijziging van de omvang van -213

aantekening $69,71,72,78-80$

aanvaring 218,219

aanvullend recht

zie: regelend recht

Aanwijzingen voor de regelgeving 13, 29, 37, 47

Aanwijzingen voor de wetgevingstechniek 19, 29, 37, 47

absoluut recht 7,36

actio Pauliana 118

afhankelijk recht 146

algemene voorwararden $9,21-22,30,45,60-61,62,98$ e. $v_{m}, 156,200$

informatieplicht bij $-100-102$

anticipatie/anticiperende interpretatie $1,3,54,55$ e.ฬ., 239

antikiesregel $24,27,255$

appartementsrecht 116

bedreiging 94

bedrog $94-95$

beheersbeding 95

bekrachtiging $50,66,108,110$

zie ook: convalescentie

beslag $43,153,189,192$

bodem- 142- 144,252

bevoegdheid $7,20,32,35,36,89,104,117,118,119,234-235,238,243,247-248$,

251

bevoorrechting van vordering 39

zie ook: privilege

bewoning

recht van $-245-246$

bodembeslag

zie: beslag

bodemzaak 181-182

boete(beding) 98 
borgtocht 146

burenrecht 18

buurweg 84

cessie $20,24,32,39,89$

collisie 157 e.v., 256

compensatie $58-59$

consumentenkoop

zie: koop

convalescentie $108-109,110,111,115,116$

conversie

zie: omzetting

definitie

zie: omschrijving

derdenbeding $24,40,116$

derdenbescherming 110

- bij registergoederen $45-46,81-83,111$ e.v., 256

doorhaling

zie: inschrijvingen betreffende registergoederen

dwingend recht 14-16, 102, 103, 154, 155

eerbiedigende werking 37

zie verder: eerbiediging van het oude recht

eerbiediging van het oude recht $11-12,21,22,28,37$ e.v., 66, 96, 226, 232, 236,

$241,248-249,252,257$

- en anticipatie $56-58,62$

eerbiediging van verkregen rechten $11,36,39,40-41,93,107,110,115,147-148$,

$188,205-206,208-209,211,222,238,256$

eigendom 160-162, 186

voorbehouden - 162-163, 186

- tot zekerheid

zie: zekerheidseigendom

eigenschap $7,32,35,36,89,90,91,104,106,117$

eigen schuld 207,240

erfdienstbaarheid $85,95,115$

erfpacht(srecht) $16,21,54,58,95,96,115-116,211-212,246-248$

opzegging van - 95-96, 97-98, 247-248

exceptio non adimpleti contractus $35,230,243$

exclusieve werking 29

zie verder: onmiddellijke werking

executie 43,129

zie ook: uitwinning

faillissement 140-142, 143, 151-152, 190, 192-193, 239, 242, 252

-saanvrage 141 
feit $7,18,19-21,25,32$ e.v., $39-40,45-46,49,70,72,73,74,75,76,77,78,79,81$, $82,83,84,255,256$

voldongen $-17,20,23,40,45,80,89,90,101,111,114,120,127$

feitelijke onbekwaamheid 107, 119-120

fictie $49,66,72,73,74,75,117,128,195,197$

fiduciaire eigendom(soverdracht) tot zekerheid

zie: zekerheidseigendom en -overdracht

fiscus

privilege van de $-180-182$

zie ook: bodembeslag

gebruik

recht van $-245-246$

gelden 8,9

geldigheid

zie: rechtshandelingen

gemeenschap

overgang van goed uit -89

verdeling van -120

goede trouw $60,61,70,234$

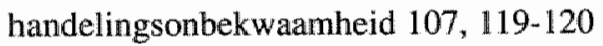

handelingsonbevoegdheid 94, 111

handelskoop

zie: koop

hoedanigheid

zie: eigenschap

hoofdelijkheid 204, 206-207

huurbeding $95,96-97$

hypotheek(recht) 76, 96, 146

imprévision

zie: onvoorziene omstandigheden

informatieplicht

zie: algemene voorwaarden

ingebrekestelling 213-214, 230, 234, 236, 237, 240

inschrijvingen betreffende registergoederen 69 e.v., 256

doorhaling van $-75,76,78-80$

rangorde van $-80-81$

waardeloze $-75-76$

internationaal privaatrecht $3,5-6,9,13,24,27,51,52$

intertemporeel recht

zie: overgangsrecht

invoering 8

inwerkingtreding 8,9 
juridische waardering $7,18,36,40,46,216,255$

kettingbeding 85,86

koop(overeenkomst) 105-106, 107-108, 116, 248 e.v., 256

consumenten-103,116, 248-249

handels- 44

koppelregel $35,48-50,117$

zie ook: overbruggingsxegel

kosten wegens bearbeiding

privilege ter zake van - 177-179, 192

kosten tot behoud

privilege ter zake van - 174 e.v., 193

kosten van lijkbezorging 213

kwalitatieve verplichting $85-86$

kwekersrecht

zekerheidseigendom van - 129

lastgeving(sovereenkomst) 103, 116-117

levensverzekering

- en pandrecht 201-202

- en zekerheidseigendom 201-202

levering

zie: pandrecht en zekerheidsoverdracht

matiging(sbevoegdheid) 98,208

milieuschade 217

minderjarige 241

misbruik van omstandigheden $25,83,118-119,120$

nakoming $21,238-239$

nietigheid

zie: rechtshandelingen

niet-nakoming $35,37,229-230,234,235,237,238,244-245,249-250$

omschrijving $8,32,35,36,44$

omzetting $49,66,117,128,129,130$ e.v., 190 e.v., 195, 197, 256

onaantastbaarheid

zie: rechtshandelingen

onmiddellijke werking $13,22,24,28$ e.v., 52, 71-72, 88-90, 126-127, 205 e.v., 231-

$232,234,236,238-239,241,242,246,248,256,257$

onrechtmatige daad $22,24,25,33-35,36,40,203$ e.v., $230,231,252-253,256$

onrechtmatigheid 216,225

onroerende zaken 69,151

ontbinding $25,39,66,67,163$ e.v., 186, 230, 231, 233, 234, 235, 237, 241-242,

$243,245,250$

ontruimingsbeding 95 
onverschuldigde betaling 107

onvolledig complex van rechtsfeiten $22,31,35-36,40,45-46,209,215-216,255$

onvoorziene omstandigheden $31,57-58,61$

openbare registers

zie: registers voor registergoederen

opschortingsrecht $230,231,232,242-243$

opstal(recht) 95

opzegging van $-97-98$

oude zakelijke rechten

zie: zakelijke rechten

overbruggingsregel $13,15,26,27,48-50,72,108,130,197,256$

zie ook: koppelregel

overdracht 24,111 e.v.

- tot zekerheid

zie: zekerheidsoverdracht

overeenkomst

voortbouwende -121

overgangsrecht $2-3,5-7,10$ e.v., 257

- en anticipatie 55 e.v.

beginselen van -5

- Kadasterwet 7,69

- rweede stuk 6-7

vragen van -25 e.v., 71

overgangssituatie 5,16 e.v., $26,27,29,30-31,33,34,36,38,39,44,47,64,66,71$, $99,127,193-194,255$

Overgangswet 6 e.v.

toepassing van de -63 e.v.

overmacht $235-236,240,241-242,250$

overschrijving $69,71,72,73,74,77,78,80$

'paardesprong' 214

pandrecht $125,146,149$ e.v.

akte van vestiging van $-148,152-153$

levering bij voorbaat tot vestiging van $-163,170,171$, 196 e.v., 201

rangorde van $-145,146,171$ e.v.

- en rente 150

stil $-25,49,66,123$ e.v., 256

verbintenis tot vestiging van $-194-195,201$

wettelijk -148 e.v., 157 e.v.

wettelijk - en overeengekomen bedingen 154 e.v.

privilege 171 e.v., 189,192

produktenaansprakelijkheid 218,219

rangorde $84,190-191,192$

zie ook: inschrijvingen betreffende registergoederen en pandrecht 
rechtsfeit

zile: feit

rechtsgevollg $7-8,9,18,19,20-21,22,24-25,26,29,30,31,32,33,34,35,36-37$, $38,40,42,44,46,47,48,71,89,102,117,233,234,236,255,256$

rechtshandelingen

geldigheid van -87 e.v., 256

nietigheid van -87 e.v. 256

onaantastbaarheid van -87 e.v., 256

vernietigbaarheid van -87 e.v., 256

rechtstoestand

zie: toestand

rechtszekerheid $15,41,219-220,221,257$

reclame

misleidende -227

recht van - 166, 187, 190, 192-193, 231, 232-233, 251-252

verlengstuk van het recht van-166-168, 187

rectificatie 227

redelijkheid en billijkheid $51-52,53-55,58,61,256$

regelend recht 14-16, 103, 154, 155

registergoederen 69

zekerheidseigendom van $-131,151$

registers (voor registergoederen) $69,71,72,81,82,83,84,85,86$

kenbaarheid uit de -73 e.v.

rente 241

wettelijke -240

retentierecht $182-184,189,230,232,242-243$

voorrang in kader van $-183,184$

revindicatie 107

risico $237,250-251$

samenloop 253

schade

opeenvolgende - $\mathrm{n} 222$ e.w.

oplopende -222 e.v.

- met vertraging 215 e.v., 226

vertragings- 237,240

schadevergoedling 203 e.v., 233, 239-241, 243

privilege ter zake van - 179-180

vervangende -230

schadeveroorzakende gebeurtenis 218,219

schenking 110-111, 116-117, 121

schuld

overgang van -212

servituut

zie: erfdienstbaarheid 
stil pandrecht

zie: pandrecht

surséance van betaling 239,242

teboekgestelde luchtvaartuigen 69

teboekgestelde schepen 69

tekortkoming in de nakoming $25,42,66,229$ e.v., 256

termijn $118-119,230,231,236-238,239,244$

terugwerkende kracht $13,17,22-23,26-27,28,29,34,35,46-48,66,106,145,255$

toepasselijkheid 8-9

toepassing

van - zijn 8-9

toestand $17-19,20-21,24,25,26,32,34,36,37,38,44,47,49,80,222,225,255$

transitoir recht

zie: overgangsrecht

unitgestelde werking $12-13,22,23,28,42$ e.w., $66,82-83,99,248-249,255$

- en anticipatie 59-61, 62

ütwinning 131 e.v., 143,152

aanzegging van - 131 e.v., 173, 190, 191

zie ook: executie

verbintenis $7,36,204$ e.v., 229 e.v.

niet opeisbare - $235,244-245$

toevallig samenlopende - sen 204, 206-207

verbod $226-227$

verborgen gebreken 251

vereiste $7-8,9,18-19,20,21,22,23-24,25,26,29,30,31,32,33,34,35,36,37$, $38,42,44,47,48,71,89,215-216,233,236,255,256$

verhaal

beperking van -115

tijdelijke regeling -srechten 203

verjaring(stermijn) $24,226,251$

verklaring van recht 227

verklaring van waardeloosheid $75-76,80$

verkopersprivilege $172-173,251-252$

vernietigbaarheid

zie: rechtshandelingen

verplichting 7

verwijzingsregel 22,27 e.v., 117,256

verzekerbarheid $219-220$

verzekering $2 \rrbracket 7$

verzuim $213-214,230,231,232,233,234,235,236-238,240,241,243,244$

voldongen feit

zie: feit

woogd 241 
voorrecht

zie: privilege

vruchtgebruik $95,96,97,111,115,245-246$

wanprestatie $234,236,238,239,240,243,244,249,251,253$

warrantage 1.46

wegwerprecht 10 e.w.

werken 8-9

werking $7,35,36,97$

zaaksvervanging $149,168,173-174,188$

zaaks vorming 62-63

zakelijke rechten

oude -84

zekerheidseigendom $23,25,66,123$ e.v, 256

- "in tweede verband" 168 e.v.

zekerheidsoverdracht $23,49,123$ e.w.

aanpassing van overeenkomst verplichtend tot - 199-201

levering bij voorbaat tot - 124, 126, 127, 128, 163, 170, 193, 195 e.v., 201

relativering van $-161,162,175,176,178$

verbintenis tot $-124,126,127,128,193,194-195,201$ 


\section{Wetsartikelenregister}

Verwezen wordt naar hoofdstukken en (onderdelen van) paragrafen.

Ow I

68-75 2.3 .1

$68-220 \quad 2.2 .1$

68

$68 a-75$

2.2.1, 2.5.1.1 sub a, 2.5.3, 7.6.4, 7.8.1

$68 a$

69

4.4

$68 a$

2.2.1, 2.2.4, 2.5.1, 2.5.1.2 sub c, 2.5.1.2 sub e, 2.5.3, 4.5.6, $5.6 .3 .2,6.1,6.4,7.8 .2$

lid $1 \quad 2.3 .1,2.4 .1 .1,2.4 .1 .2,2.5 .1 .1,2.5 .1 .1$ sub $b, 2.5 .1 .1$ sub $c$, 2.5.1.1 sub e, 2.5.1.2 sub e, 2.5.1.2 sub f, 2.5.3, 2.7, $3.6,4.8 .1,5.4,5.6 .3 .3,5.6 .3 .8,5.7 .2 .1,5.8 .2 .1,5.8 .2 .7,5.9 .3$, $6.3,6.4,6.5 .1 .1,6.5 .1 .2,6.5 .2 .1,6.5 .3,6.6,6.7,6.8,7.4$, $7.6 .1,7.6 .2,7.6 .3,7.6 .6,7.8 .2$

lid $2 \quad 2.3 .1,2.3 .2,2.5 .1 .2$ sub b, 2.5.1.2 sub c, 2.5.1.3 sub b, 2.5.3; $3.5 .1,3.6,3.7,4.5 .6,5.6 .4,5.8 .1 .6,7.5,7.6 .2,7.6 .5,7.8 .3$, 7.9

2.2.1, 2.2.4, 2.3.1, 2.5.1.1 sub c, 2.5.1.1 sub d, 2.5.1.2 sub c, 2.5.1.2 sub e, $2.5 .3,2.7,3.7,4.5 .1,4.5 .6,4.8 .1,4.9 .1,4.9 .3$, $5.6,5.6 .3 .2,5.6 .7,6.1,6.3,6.4,6.5 .1 .5,7.6 .6,7.8 .1$

sub a 2.4.1.2, 2.5.1.1 sub c, 2.5.1.2 sub c, 2.5.1.2 sub e, 5.6.7, 5.7.2.1, 5.8.1.6, 5.8.2.5, 5.8.3.5, 6.3, 6.5.1.1, 6.5.1.2, 6.5.2.1, $6.5 .2 .2,7.8 .3$

sub b $\quad 6.5 .1 .2,6.5 .2 .1,6.5 .2 .2,6.5 .2 .3$

sub c $\quad 5.7 .2 .1,6.3,6.5 .1 .3,6.5 .2 .1,6.5 .2 .2,6.5 .2 .3,7.6 .4$

sub d $\quad 2.4 .1 .2,2.5 .1 .1$ sub $\mathrm{c}, 2.5 .1 .2$ sub c, 5.7.2.1, 6.5.1.2, 6.5.2.1, $6.5 .2 .2,6.5 .2 .3,6.5 .3,7.6 .4$

sub e $\quad 5.6 .7,5.8 .1 .6,5.8 .3 .5$

71

72

$2.2 .1,2.5 .2,2.5 .3,4.5 .4,4.5 .6,5.6 .3 .2$

lid $1 \quad 2.3 .2$

lid $2 \quad 4.5 .4$

73

$2.2 .1,2.5 .3,2.7,4.5 .6,4.10 .1,5.6 .3 .2,7.8 .3$

$2.2 .1,2.5 .3,2.7,4.5 .6,4.10 .1,5.6 .3 .2,5.8 .2 .4,6.5 .1$

lid $1 \quad 2.2 .4,2.3 .1$

lid 2 4.10.1

$73 a$

74

lid 1

$2.2 .1,2.5 .3,2.7,4.5 .6,4.10 .1,4.12,5.6 .3 .2,7.8 .3$

4.10.1

$2.2 .1,4.7 .1,4.8 .1,6.6,6.7,6.8,7.6 .3$ 
lid $1 \quad 2.2 .4$

lid $2 \quad 7.6 .3,7.8 .2$

lid $3 \quad 2.2 .4$

lid $4 \quad 2.2 .4,2.6$

76

77

78

79

80

81

85

86

$1,2.2 .1,2.3 .2,2.5,2.5 .3,2.7,4.5 .6,5.6 .3 .2,5.6 .3 .4,5.6 .3 .6$, $5.8 .5,6.5 .2 .1,7.8 .2,8$

lid ]. $\quad 2.5 .3,6.5 .2 .1$

lid $2 \quad 2.5 .3$

5.7 .2 .1

$2.5 .2,5.7 .1,5.7 .2 .1,5.8 .2$

$2.7,3.3,3.4,3.5 .1,3.5 .2,3.7$

lid $1 \quad 2.2 .3,2.3 .1,2.5 .1 .3$ sub $c, 2.5 .2,3.4,3.5 .1,3.5 .2,3.8 .5,3.9$

lid $2 \quad 3.4,3.6,3.8 .1$

lid $3 \quad 2.5 .1 .3$ sub $c, 3.4,3.5 .2,3.7,3.8 .2,3.8 .3$

$2.3 .1,2.5 .1 .2$ sub e, $2.5 .3,2.7,4.1,4.3,4.4,4.5 .1,4.5 .2$, $4.5 .3,4.5 .4,4.5 .5,4.5 .6,4.5 .7,4.5 .8,4.6,4.12,5.7 .3,5.9 .4$, 7.8 .2

lid $1 \quad 4.4,4.7 .1,4.7 .2,4.97,4.12$

lid $2 \quad 2.5 .1 .4,4.4,4.8 .1,4.8 .2,4.8 .3,4.12$

$2.5 .3,2.7,4.1,4.4,4.6,4.9 .1,4.9 .4,4.9 .5,4.9 .6,4.9 .7$, $4.10 .2,5.8 .1 .7$

lid $1 \quad 2.5 .1 .4,2.5 .1 .4$ sub $b, 2.5 .2,4.4,4.9 .1,4.9 .2,4.9 .3,4.9 .5$, $4.10 .1,4.12,5.8 .1 .7$

lid $2 \quad 2.2 .3,2.2 .4,4.4,4.9 .1,4.10 .1,4.10 .2,4.10 .3,4.11,4.12$

lid $3 \quad 4.9 .1,4.9 .3,4.10 .1,4.10 .2$

2.2 .3

$2.3 .1,2.4 .1 .3,2.7,4.9 .3,5.1,5.4,5.6,5.6 .2,5.6 .4,5.6 .5$, $5.6 .7,5.7 .1,5.7 .2,5.7 .2 .1,5.7 .3,5.8,5.8 .1 .1,5.8 .1 .3,5.8 .1 .4$, $5.8 .1 .7,5.8 .4 .1,5.8 .4 .3,5.8 .5,5.11$

lid $\| \quad 2.5 .2,5.5,5.6,5.6 .2,5.6 .3,5.6 .3 .1,5.6 .3 .2,5.6 .3 .3,5.6 .3 .5$, 5.6.3.6, 5.6.3.7, 5.6.4, 5.6.5, 5.6.6, 5.6.7, 5.8, 5.8.1.1, 5.8.1.3, $5.8 .1 .5,5.8 .1 .6,5.8 .1 .7,5.8 .2 .1,5.8 .2 .2,5.8 .2 .5,5.8 .2 .6$, $5.8 .2 .7,5.8 .3 .1,5.8 .3 .2,5.8 .3 .3,5.8 .3 .4,5.8 .5,5.9 .1,5.9 .2$, $5.9 .3,5.9 .4$

lid $2 \quad 2.5 .2,5.5,5.6 .6,5.8 .1 .3,5.8 .2 .1,5.8 .2 .3,5.8 .2 .4,5.8 .2 .6$, $5.8 .2 .7,5.8 .3 .1,5.8 .3 .3,5.8 .3 .4,5.9 .1,5.9 .2,5.9 .3$

lid $3 \quad 2.5 .2,5.5,5.6 .5,5.7 .1,5.8 .1,5.8 .1 .1,5.8 .1 .5,5.8 .1 .7,5.8 .2$, $5.8 .2 .1,5.8 .2 .2,5.8 .2 .3,5.8 .2 .4,5.8 .2 .5,5.8 .2 .6,5.8 .2 .7$, $5.8 .3,5.8 .5$

lid $4 \quad 5.6 .2,5.10$

lid $5 \quad 2.5 .2,2.7,5.5,5.6 .3,5.6 .3 .1,5.6 .3 .2,5.6 .3 .3,5.6 .3 .4,5.6 .3 .5$, 5.6.3.6, 5.6.3.7, 5.6.3.9, 5.6.4, 5.6.6, 5.8.1.1, 5.8.2.1, 5.8.2.3, $5.8 .2 .6,5.8 .5,5.10$

lid $6 \quad 5.5,5.6 .3 .2,5.7 .1,5.7 .2 .1,5.7 .3,5.8 .3,5.8 .4 .2,5.9 .4$

lid $7 \quad 2.2 .3,2.5 .2,5.5,5.8 .1 .2,5.8 .1 .7,5.8 .3 .5,5.9,5.9 .1,5.9 .2$, 
$5.9 .3,5.9 .4$

88

lid $8 \quad 5.5,5.7 .3,5.9 .4$

2.2 .4

lid $1 \quad 2.2 .3,2.3 .1$

89

$2.5 .2,5.1,5.5,5.7 .2 .1$

lid $1 \quad 5.6 .5,5.7 .1,5.8 .1 .2$

lid $3 \quad 2.2 .4,5.5,5.6 .5,5.8 .1 .2$

2.4.1.2

2.2 .4

2.3.1

2.4.1.2

$2.2 .3,2.3 .1$

2.2 .4

$2.2 .4,2.5 .1,2.5 .1 .2$ sub $\mathrm{f}$

$2.2 .4,2.3 .1$

$2.2 .4,2.3 .1$

2.2 .4

$2.2 .4,7.8 .1,7.8 .2$

$5.6 .5,5.7 .2 .1,5.9 .4$

5.7 .2 .1

$5.6 .3 .8,5.7 .2 .1,5.7 .3$

2.3.1

2.3.1

114

115

117

lid $1 \quad 2.3 .1,4.5 .4$

lid $2 \quad 2.3 .1,3.7$

$3.8 .1,5.1,5.8 .1,5.8 .2 .4,5.8 .3 .5,5.8 .5$

lid 1. $\quad 5.8 .2 .1,5.8 .2 .3,5.8 .2 .4,5.8 .2 .5,5.8 .2 .6,5.8 .2 .7,5.8 .5$

lid $2 \quad 2.5 .1 .2$ sub c, $5.8 .2 .6,5.8 .2 .7,5.8 .5$

lid $3 \quad 2.5 .1 .2$ sub c, $5.8 .2 .6,5.8 .2 .7,5.8 .5$

lid $4 \quad 2.5 .1 .2$ sub c, $5.8 .2 .6,5.8 .2 .7,5.8 .5$

118

2.3.1, 2.5.1.2 sub c, 5.1, 5.8.1, 5.8.2.2, 5.8.5

119

121

$1: 50$

2.3.1, 2.5.1.2 sub c, $5.1,5.8 .1,5.8 .1 .4,5.8 .1 .5,5.8 .2 .1,5.8 .5$, 7.8 .3

lid $2 \quad 2.2 .3,2.2 .4$

lid $1 \quad 3.8 .2$

lid $2 \quad 2.3 .1,3.8 .2,3.8 .4$

lid $3 \quad 2.2 .3,2.3 .1$

lid $4 \quad 2.2 .3,2.3 .1$

lid $5 \quad 2.2 .3$

lid $6 \quad 2.2 .4$

lid $7 \quad 2.2 .3$

156

2.3.1.

159

2.4.1.1

160

$2.3 .1,3.8 .3$

161

2.5 .2

$162 \quad$ lid $1 \quad 2.4 .1 .5$ 
182

183

184

185

190

191

192

193

194

195

196

220

224

251-258

Ow II

\section{$2.3 .1,2.3 .2$ \\ $4.9 .5,4.12$ $6.5 .2 .2,7.9$ \\ lid $2 \quad 6.4,6.5 .4$ \\ 6.3 \\ 5.8 .1 \\ 2.3 .1 \\ 2.6.1 \\ 2.3 .2 \\ 2.3.1, 4.8.1 \\ 4.5.7, 6.5.1.5 \\ 2.3 .1 \\ 2.5.1.3 subc \\ 2.2 .1}

$2.3 .2,4.5 .4$

$2.4 .1 .3,2.5 .1 .2$ sub $\mathrm{f}, 2.6 .1$

2.5 .1 .2 sub f, 2.6.1., 4.5.4

2.5.1.1 sub b, 2.5.1.2 sub c, 2.5.3, 2.7, 6.1, 6.4, 6.5.2, 6.5.2.1,

lid $1 \quad 2.2 .4,6.4,6.5 .2 .2,6.5 .2 .3,6.5 .4$

2.5.1.1 sub c, $2.5 .2,4.5 .4,5.8 .2 .7,7.5,7.6 .6$

$2.3 .1,2.4 .1 .3,2.5 .1,2.5 .1 .2$ sub c, 2.5.1.2 sub $f, 2.5 .3,2.7$, $4.5 .5,5.8 .1 .3,5.8 .3 .2,6.4,6.5 .2 .3,7.1,7.5,7.6 .1,7.6 .2$, $7.6 .3,7.6 .4,7.6 .5,7.6 .6,7.7,7.8 .1,7.8 .2,7.8 .3,7.9,7.10$

$2.3 .1,2.4 .1 .3,2.5 .1 .2$ sub a, 2.5.1.2 sub c, 6.5.1, 6.5.1.4, 7.1, $7.5,7.6 .1,7.6 .2,7.6 .4,7.7,7.10$

2.4.1.3, 2.5.1.3 sub c, $2.7,3.7,4.5 .4,4.5 .6,5.7 .3$

lid $1 \quad 2.3 .1,2.5 .1 .1$ sub a, 2.6.2, 5.7.3, 5.9.4

lid $2 \quad 4.5 .6,4.5 .8,5.7 .3$

$2.2 .3,3.4,3.8 .5$

2.3.1, 2.5.1.2 sub c, 4.9 .6

2.5.1, 2.5.1.1 sub b, 2.5.1.2 sub f, 2.6.1, 2.6.2, 4.5.7

$2.7,4.9 .7 .7 .1,7.8 .3$

lid I $\quad 2.3 .1,2.5 .1 .3$ sub c, $2.6 .2,7.5,7.8 .3$

lid $2 \quad 2.3 .1,4.5 .8,4.9 .7,7.5,7.8 .3$

lid $3 \quad 2.3 .1,2.5 .1 .3 \mathrm{sub} c, 5.8 .1 .4,5.8 .1 .5,5.8 .3 .3,5.8 .5,7.5,7.6 .4$, 7.8.1, 7.8.3, 7.10

lid $2 \quad 2.5 .1 .1$ sub $b, 2.5 .3,3.4,4.4,5.6 .3 .8,5.6 .4,5.8 .2 .6,6.4 .7 .5$, 7.8 .3 7.6 .4 
lid $1 \quad 5.6 .4$

$20 \quad 3.5 .1$

21 lid $1 \quad 5.6 .3 .8$

$22 \quad 5.7 .2 .3$

$23 \quad 2.5 .1 .3 \mathrm{sub}$ a

lid $2 \quad 3.5 .1$

lid $4 \quad 3.5 .1$

29

5.7 .2 .2

lid $1 \quad 5.6 .3 .9$

31

33

$7.6 .3,7.6 .5$

$39 \quad 2.5,5.1,5.5$

lid $1 \quad 5.6 .4,5.8 .2 .6$

lid $2 \quad 7.8 .3$

Besiuit van 17 april 1991, Stbl. 200, tot inwerkingtreding van her elfde, twaalfde en dertiende gedeelte van de Inwoeringswet Boeken 3,5 en $6 \mathrm{NBW}$

$1 \quad$ lid $2 \quad 2.5$

Wetsvoorstel 22442 (Correctie en aanpssing van onder meer de Invoeringswet Boeken 3, 5 en 6 nieuw B.W. (dertiende gedeelte))

VI $\quad$ lid $1 \quad 2.5,5.6 .4$

Ow Kadasterwet

$\begin{array}{lll}\text { IV } & & 3.5 .1 \\ \text { VI } & \text { lid 1 } & 3.5 .1 \\ & \text { lid 2 } & 3.5 .1 \\ & \text { lid 3 } & 3.5 .1 \\ \text { VII } & \text { lid } 1 & 3.5 .1,3.5 .2 \\ \text { X } & & 2.5 .1 .3 \text { sub a } \\ \text { XV } & & 2.5 .1 .3 \text { sub a } \\ \text { XVII } & & 2.5 .1 .3 \text { sub a }\end{array}$

Ow 1829 
BW

Boek I

1:376

7.6.4

h:385

7.6.4

Boek 3

3:8

3:10

afd. 3.1.2

3:16

3:17

$3: 18$

3:19

$3: 20$

$3: 21$

$3: 23$

$3: 24$

3:25

3:26

$3: 27$

$3: 28$
5.8

3.1

2.5.1.3 sub c, 3.1, 3.4, 3.5.1, 3.5.2, 3.8.5, 4.9.3

3.1

$3.3,3.5 .2$

lid $1 \quad 3.2,3.5 .1,3.7$

lid $2 \quad 3.5 .1$

3.5 .2

3.5 .2

lid $2 \quad 3.6$

$3.2,3.3,3.5 .2$

lid $1 \quad 3.5 .1$

lid $2 \quad 3.5 .1$

lid $3 \quad 3.5 .1$

lid 4 3.5.1

lid $5 \quad 3.5 .1$

lid $6 \quad 3.5 .1$

lid $1 \quad 3.6$

lid $2 \quad 3.6$

$3.2,3.3,3.5 .1,3.5 .2$

$3.2,3.3,3.5 .2,3.7$

lid $1 \quad 2.3 .1,2.5 .1 .3$ sub c, $3.4,3.7,3.8 .2,3.8 .3,8$

lid $2 \quad 2.5 .1 .3$ sub c, 3.7

lid $3 \quad 2.5 .1 .3$ sub c, 3.7

$2.3 .1,2.5 .1 .3$ sub c, $3.2,3.3,3.4,3.5 .2,3.7,8$ $2.3 .1,2.5 .1 .3$ subc, $3.2,3.3,3.4,3.5 .2,3.7,8$ 3.5 .2

$3.2,3.3,3.5 .2$

lid $1 \quad 3.5 .1$

lid $2 \quad 3.5 .1$ 

$3.2,3.3,3.5 .2$

$3: 32$

lid $2 \quad 4.8 .2,4.10 .2$

$3: 34$

$3: 36$

$3: 37$

$3: 43$

lid $2 \quad 4.8 .2,4.10 .2$

5.9 .3

lid $3 \quad 5.6 .3 .3$

4.8 .3

lid $1 \quad 4.5 .2,4.9 .2$

lid $2 \quad 4.9 .2$

3:44 lid $2 \quad 4.5 .3$

lid $4 \quad 4.10 .3$

lid $5 \quad 4.5 .3$

3:45 lid I 2.4.1.4

lid $4 \quad 2.4 .1 .4$

3:51 lid $3 \quad 4.10 .1$

$3: 52$

$3: 58$

4.10 .1

4.9 .1

lid $1 \quad 4.9 .1$

lid $3 \quad 4.9 .1$

$3: 67$

2.2 .2

3:69

4.9 .1

$3: 84$

$3: 86$

$3: 88$

$3: 89$

$3: 90$

$3: 92$

$3: 94$

$3: 97$

$3: 98$

$3: 99$

3:105

3:120

$3: 121$

3:122

$\begin{array}{ll}\text { lid } 1 & 2.2 .2,2.4 .1 .4,4.3,4.9 .3,5.3 \\ \text { lid } 3 & 2.7,5.3,5.4,5.6 .7,5.9,5.9 .2\end{array}$

2.3 .1

lid $2 \quad 5.8 .1 .1,5.8 .3 .2,5.9 .3$

$3.2,3.7,4.9 .3$

3.5.1

lid $2 \quad 5.8 .1 .1,5.8 .1 .3$

lid $2 \quad 5.5,5.8 .1 .2$

lid $1 \quad 2.4 .1 .4,2.5 .1 .2 \mathrm{sub} c$

lid $2 \quad 5.9 .3$

$4.5 .2,5.9 .3$

3.2

2.3.1

2.4.1.2

2.4.1.2

2.4 .1 .2

3:123

$3: 177$

2.4.1.2

$3: 181$

$3: 189$

lid $3 \quad 2.3 .1$

2.5.1.2 sub $\mathrm{f}$

3:194

3:195

afd. 3.7 .3

$3: 212$

3:2 15

lid 2 2.3.1

lid $2 \quad 2.3 .1$

lid $1 \quad 4.10 .4$

4.4

4.9 .5

4.9 .5 


\begin{tabular}{|c|c|c|}
\hline $3: 217$ & lid 3 & 4.5 .4 \\
\hline & lid 4 & 4.5 .4 \\
\hline & lid 5 & 4.5 .4 \\
\hline $3: 221$ & & $7.3,7.4,7.8 .1$ \\
\hline $3: 226$ & & 7.8 .1 \\
\hline afd. 3.9.1 & & 5.3 \\
\hline $3: 227$ & & 5.6 .2 \\
\hline & lid 1 & $5.7 .2 .1,5.8$ \\
\hline & lid 2 & 5.7 .2 .1 \\
\hline $3: 228$ & & $5.6 .2,5.7 .2 .1$ \\
\hline $3: 229$ & & $5.7 .2 .1,5.8 .3 .5,5.8 .5$ \\
\hline & lid 1 & $5.7 .1,5.8 .1 .6,5.8 .3 .5$ \\
\hline & $\operatorname{lid} 2$ & $5.8 .1 .6,5.8 .3 .5,5.8 .5$ \\
\hline $3: 230$ & & 5.7 .2 .1 \\
\hline $3: 231$ & & 5.7 .2 .1 \\
\hline $3: 232$ & & 5.7 .2 .1 \\
\hline $3: 233$ & & 5.7 .2 .1 \\
\hline $3: 234$ & & 5.7 .2 .1 \\
\hline $3: 235$ & & 5.7 .2 .1 \\
\hline afd. 3.9 .2 & & 5.3 \\
\hline $3: 236$ & & $5.6 .6,5.7 .2 .1$ \\
\hline & lid 1 & 5.6 .6 \\
\hline $3: 237$ & & $2.4 .1 .4,5.7 .2 .1,5.8 .2 .1,5.8 .2 .3,5.8 .5$ \\
\hline & lid 1 & $5.2 .2,5.3,5.6 .6,5.7 .1,5.9 .1$ \\
\hline & lid 2 & $5.7 .1,5.9 .1$ \\
\hline & lid 3 & $5.6 .6,5.7 .2 .1,5.7 .2 .3,5.7 .3,5.8 .2 .1,5.9 .4$ \\
\hline & lid 4 & 5.7 .2 .1 \\
\hline & lid 5 & 5.7 .2 .1 \\
\hline $3: 238$ & & $5.7 .2 .1,5.8 .5$ \\
\hline & lid 1 & 5.9 .3 \\
\hline $3: 239$ & & $2.4 .1 .4,5.7 .2 .1$ \\
\hline & lid 1 & $5.2 .2,5.3,5.6 .6,5.7 .1,5.9 .1,5.9 .2$ \\
\hline & lid 2 & $5.7 .1,5.9 .1$ \\
\hline & lid 3 & $5.6 .6,5.7 .2 .1,4.7 .3,5.9 .4$ \\
\hline & lid 4 & 5.7 .2 .1 \\
\hline $3: 241$ & & 5.7 .2 .1 \\
\hline $3: 242$ & & 5.7 .2 .1 \\
\hline $3: 243$ & & 5.7 .2 .1 \\
\hline & lid 1 & 5.7 .2 .1 \\
\hline & lid 2 & 5.7 .2 .1 \\
\hline $3: 244$ & & $5.7 .2 .1,5.9 .4$ \\
\hline $3: 245$ & & 5.7 .2 .1 \\
\hline $3: 246$ & & 5.7 .2 .1 \\
\hline $3: 247$ & & 5.7 .2 .1 \\
\hline $3: 248$ & & 5.7 .2 .1 \\
\hline $3: 249$ & & $5.5,5.6 .3 .8,5.7 .2 .1,5.7 .3$ \\
\hline
\end{tabular}


lid $1 \quad 5.9 .4$

$3: 250$

$3: 251$

$3: 252$

3:253

3:254

3.255

3:256

$3: 257$

3:258

$3: 259$

3:261

3:262

$3: 264$

3:266

3:267

3:273

$3: 274$

$3: 276$

3:278

3:279

$3: 283$

$3: 284$

$3: 285$

$3: 287$

afd. 3.10.4

3:290

3:291

3:292

3:296

$3: 297$
$5.5,5.6 .3 .8,5.7 .2 .1,5.7 .3,5.9 .4$

$5.5,5.6 .3 .8,5.7 .2 .1,5.7 .3,5.9 .4$

lid $1 \quad 5.7 .3$

$5.5,5.6 .3 .8,5.7 .2 .1,5.7 .3,5.9 .4$

$5.5,5.6 .3 .8,5.7 .2 .1,5.7 .3$

lid $1 \quad 5.6 .3 .2$

5.7 .2 .1

5.7 .2 .1

5.7 .2 .1

5.7 .2 .1

5.7 .2 .1

lid $2 \quad 5.7 .1$

3.6

3.6

lid $4 \quad 2.3 .1,4.5 .4$

lid $5 \quad 2.3 .1,4.5 .4$

lid $6 \quad 2.3 .1,4.5 .4$

lid $7 \quad 2.3 .1,4.5 .4$

lid $8 \quad 2.3 .1,4.5 .4$

2.3.1

4.5 .4

3.5.1, 3.5.2

$3.2,3.3,3.5 .2$

lid $1 \quad 3.5 .1$

lid $2 \quad 3.5 .1$

lid $3 \quad 3.5 .1$

lid $4 \quad 3.5 .1$

4.9 .4

5.8 .3

$5.8 .2 .2,5.8 .2 .6,5.8 .3$

$2.3 .1,5.8 .2 .2$

$5.8 .2 .3,5.8 .2 .4$

lid $2 \quad 5.8 .2 .3,5.8 .3,5.8 .5$

lid $1 \quad 5.8 .2 .4$

lid $2 \quad 5.8 .2 .4,5.8 .3,5.8 .5$

5.8 .3

lid $1 \quad 5.8 .2 .5$

lid $2 \quad 5.8 .2 .5$

7.3

$5.8 .2 .7,7.6 .6$

lid $1 \quad 5.8 .2 .7$

lid $2 \quad 5.8 .2 .7,5.8 .3$

$5.8 .2 .7,5.8 .3$

$6.6,7.6 .3$

7.6 .3 


$\begin{array}{ll}3: 298 & 7.6 .3 \\ 3: 299 & 7.6 .3 \\ 3: 300 & 7.6 .3 \\ 3: 301 & 7.6 .3 \\ 3: 302 & 6.7 \\ 3: 310 & 6.5 .1,6.5 .4\end{array}$

\section{Boek 5}

$\begin{array}{lll}5: 2 & & 4.8 .1 \\ 5: 16 & \text { lid 2 } & 2.6 .3 \\ 5: 70 & & 4.9 .5 \\ 5: 71 & & 4.9 .5 \\ 5: 77 & \text { lid 1 } & 4.5 .4 \\ & \text { lid 2 } & 4.5 .4 \\ & \text { lid 3 } & 4.5 .4 \\ 5: 85 & \text { lid 2 } & 4.5 .4,4.9 .5 \\ 5: 87 & & 4.5 .4,7.3,7.4 \\ & \text { lid 1 } & 7.8 .2 \\ & \text { lid 2 } & 4.5 .4,7.8 .2 \\ & \text { lid 3 } & 4.5 .4,4.6,7.8 .2 \\ 5: 88 & & 4.5 .4 \\ 5: 90 & \text { lid 1 } & 4.5 .4 \\ 5: 91 & & 4.9 .5 \\ 5: 92 & \text { lid 2 } & 4.5 .4 \\ & \text { lid 3 } & 4.5 .4 \\ 5: 97 & & 2.6 .1 \\ & \text { lid 1 } & 2.4 .1 .3 \\ 5: 98 & & 4.5 .4 \\ & \text { lid 1 } & 4.5 .4 \\ & \text { lid 2 } & 4.5 .4,4.6 \\ 5: 99 & & 2.3 .1,2.3 .2 \\ 5: 100 & & 4.5 .4,7.6 .6 \\ & \text { lid 1 } & 4.5 .4 \\ & \text { lid 2 } & 4.5 .4 \\ 5: 104 & \text { lid 1 } & 4.5 .4 \\ & \text { lid 2 } & 4.5 .4 \\ 5: 110 & \text { lid 1 } & 4.9 .5\end{array}$

Boek 5 (oud)

5.7.1.8 $a$ lid $4 \quad 7.8 .2$ 
Boek 6

$\begin{array}{lll}6: 2 & \text { lid } 2 & 2.3 .2,2.5 .3,2.6 .2,2.7,6.5 .4 \\ 6: 27 & & 6.5 .3 \\ 6: 37 & & 7.6 .6 \\ 6: 38 & & 7.6 .3 \\ 6: 41 & \text { sub b } & 2.3 .1 \\ 6: 48 & \text { lid } 3 & 7.6 .6 \\ 6: 49 & \text { lid } 4 & 7.6 .6 \\ \text { afd. } 6.1 .7 & & 7.3 \\ 6: 52 & & 5.8 .2 .7,7.6 .6 \\ 6: 53 & & 7.6 .6 \\ 6: 54 & & 7.6 .6 \\ 6: 55 & & 7.6 .6 \\ 6: 56 & & 7.6 .6 \\ \text { afd. } 6.1 .9 & & 7.6 .4 \\ 6: 74 & \text { lid } 1 & 7.3,7.4,7.6 .4 \\ 6: 78 & & 7.6 .4 \\ 6: 80 & & 7.7\end{array}$

lid 1

sub b $\quad 7.7$

$6: 811$

7.2

$6: 82$

7.2

lid $1 \quad 7.6 .2$

$6: 83$

2.3.1, 2.5.1.2 sub $c_{1} 7.2,7.6 .4$

sub a $\quad 2.4 .1 .3,7.3,7.5,7.6 .2,7.6 .4,7.7$

sub b $\quad 6.5 .1 .4,7.3,7.5,7.6 .4,7.7$

$6: 84$

7.6 .2

$6: 85$

7.6 .2

$6: 87$

7.3

$6: 94$

4.5 .5

lid $1 \quad 4.5 .5$

lid $3 \quad 4.5 .5$

$\begin{array}{ll}\text { afd. } 6.1 .10 & 6.3,6.5 .4,7.6 .4 \\ 6: 101 & 6.3,7.6 .4 \\ 6: 102 & 6.2,6.3,6.5 .4,7.6 .4 \\ 6: 103 & 6.3,6.5 .4,7.6 .4 \\ 6: 104 & 6.3,6.5 .1 .3,6.5 .4,7.6 .4 \\ 6: 105 & 6.3,6.5 .2 .1,6.5 .4,7.6 .4 \\ 6: 106 & 6.3,7.6 .4 \\ 6: 107 & 6.3,7.6 .4 \\ 6: 108 & 6.3,7.6 .4\end{array}$

lid 1

sub c $\quad 2.5 .3$

lid $2 \quad 6.3,6.5 .1 .3$

lid $3 \quad 6.5 .4$ 


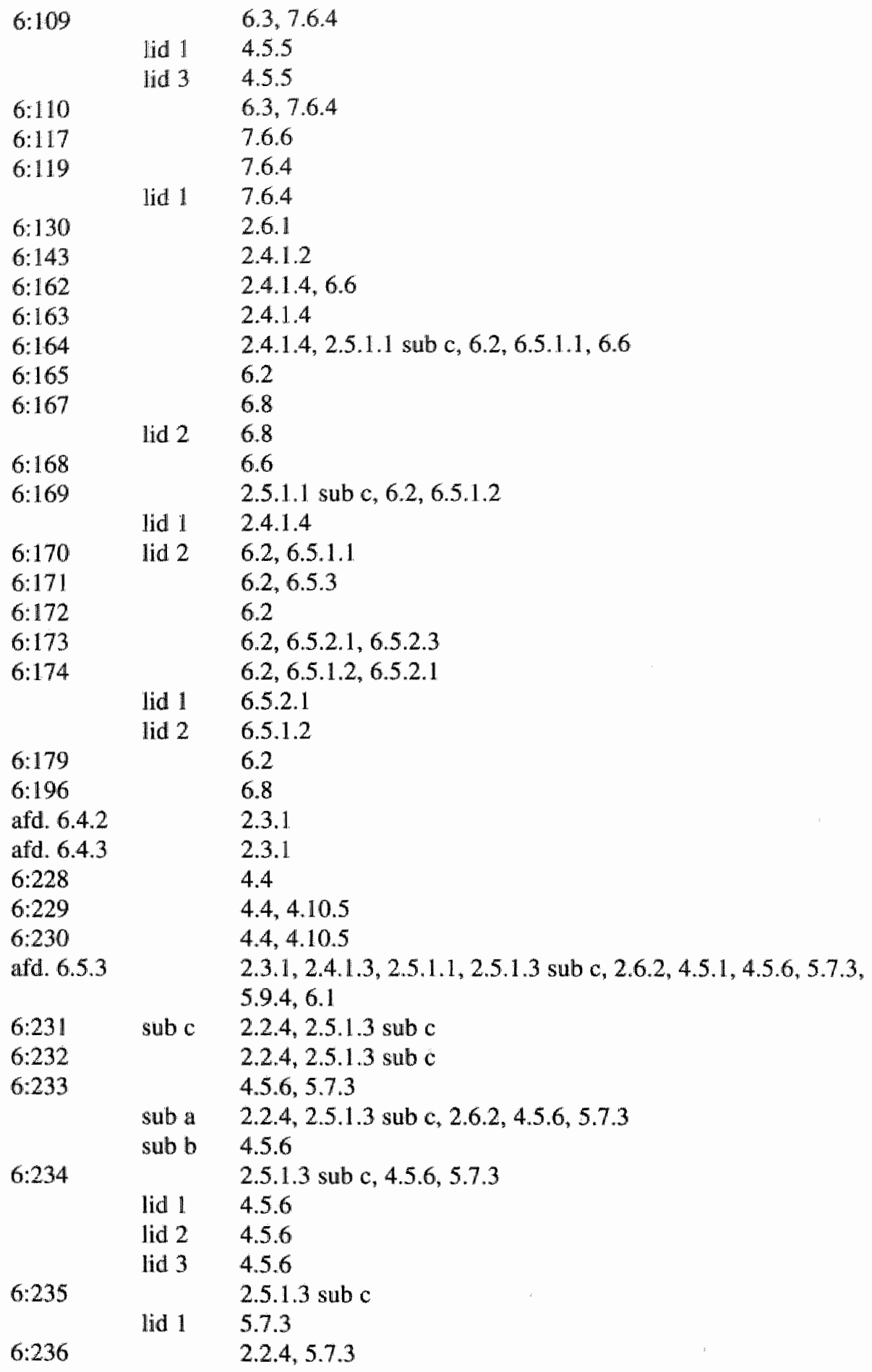

6.234

$6: 235$

$6: 236$

6.2

6.8

2.3.1.

2.3.1

4.4

$4.4,4.10 .5$ $4.4,4.10 .5$ $2.3 .1,2.4 .1 .3,2.5 .1 .1,2.5 .1 .3$ sub c, $2.6 .2,4.5 .1,4.5 .6,5.7 .3$, $5.9 .4,6.1$ 


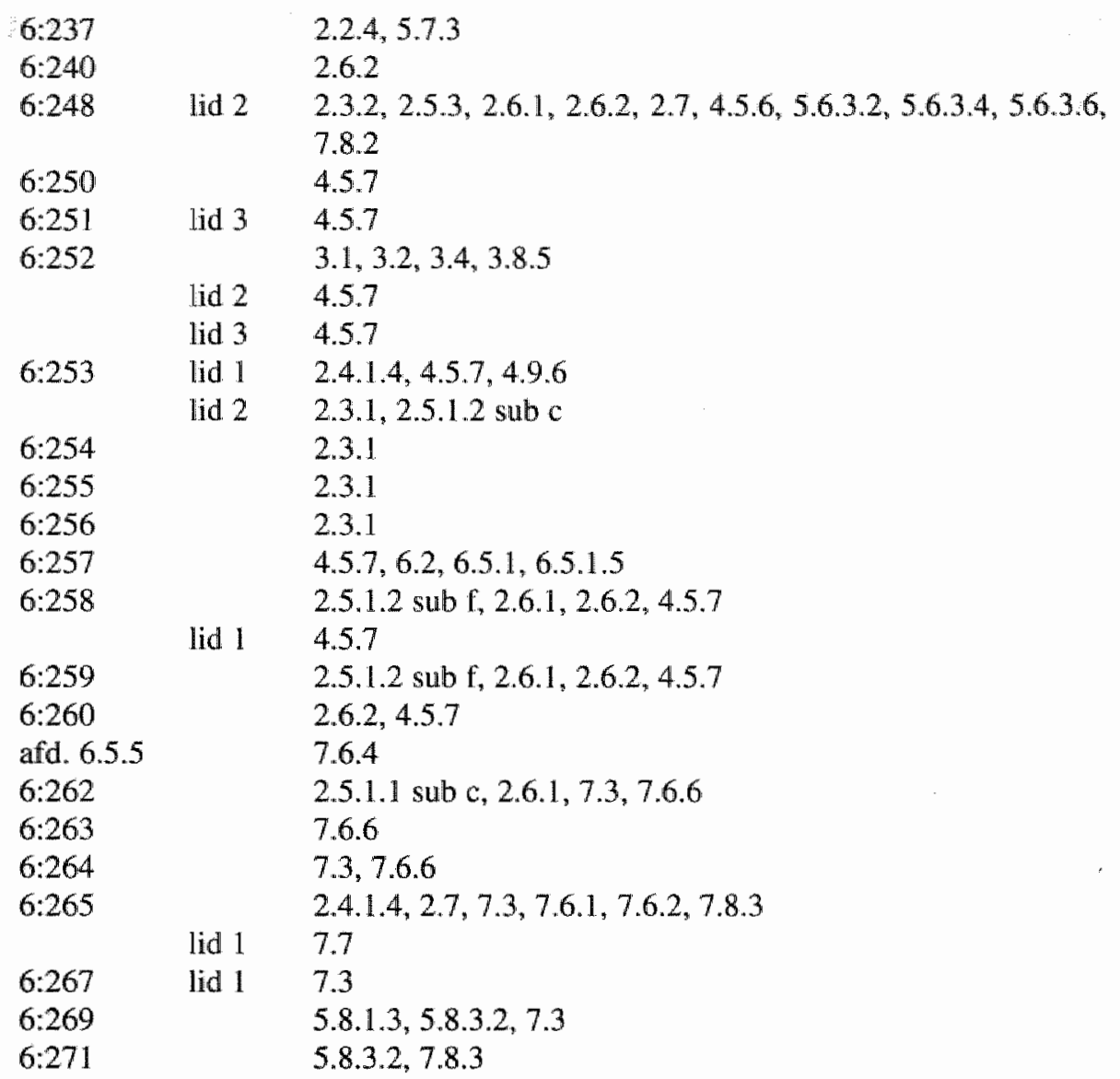

$6: 240 \quad 2.6 .2$

$6.248 \quad$ lid $2 \quad 2.3 .2,2.5 .3,2.6 .1,2.6 .2,2.7,4.5 .6,5.6 .3 .2,5.6 .3 .4,5.6 .3 .6$, 7.8 .2

$6: 250 \quad 4.5 .7$

$6: 251 \quad$ lid $3 \quad 4.5 .7$

$6: 252 \quad 3.1,3.2,3.4,3.8 .5$

lid $2 \quad 4.5 .7$

lid $3 \quad 4.5 .7$

$6: 253 \quad$ lid $1 \quad 2.4 .1 .4,4.5 .7,4.9 .6$

lid $2 \quad 2.3 .1,2.5 .1 .2$ sub c

$6: 254 \quad 2.3 .1$

$6: 255 \quad 2.3 .1$

$6: 256 \quad 2.3 .1$

$6: 257 \quad 4.5 .7,6.2,6.5 .1,6.5 .1 .5$

$6: 258$

lid $1 \quad 4.5 .7$

$6: 259$

2.5.1.2 sub f, 2.6.1, 2.6.2, 4.5.7

$6: 260$

afd. 6.5 .5

$2.6 .2,4.5 .7$

7.6 .4

$6: 262$

2.5.1.1 sub c, $2.6 .1,7.3,7.6 .6$

$6: 263$

7.6 .6

$6: 264$

$7.3,7.6 .6$

$6: 265$

$2.4 .1 .4,2.7,7.3,7.6 .1,7.6 .2,7.8 .3$

lid $1 \quad 7.7$

$6: 267 \quad$ lid $1 \quad 7.3$

$6: 269 \quad 5.8 .1 .3,5.8 .3 .2,7.3$

$6: 271 \quad 5.8 .3 .2,7.8 .3$

Boek 6 (oud)

$\begin{array}{ll}6.5 .2 \mathrm{~A} .2 \quad & \operatorname{lid} 2 \\ & \text { sub b } \quad 4.5 .6\end{array}$

Wet van 11 september 1991, Stbl. 470, tot aampassing van Boek 6 BW aan de EG. richtlijn inzake produktenaansprakelijkheid

II

6.5 .2 .3

Wetsvoorstel 21202 (Aansprakelijkheid voor gevaarlijke stoffen en verontreiniging van lucht, water of bodem)

$\begin{array}{lll}\mathrm{V} \quad & \text { lid } \Perp & 6.5 .2 .1,6.5 .2 .3 \\ & \text { lid } 2 & 6.5 .2 .3\end{array}$ 


\section{Boek 7}

$\begin{array}{lll}7: 4 & & 4.9 .7 \\ 7: 6 & & 4.5 .8 \\ & \text { lid 1 } & 4.9 .7 \\ 7: 10 & & 7.8 .3 \\ \text { afd. } 7.1 .3 & & 4.5 .8,7.8 .3 \\ 7: 23 & \text { lid 2 } & 7.8 .3 \\ \text { afd. } 7.1 .5 & & 7.8 .3 \\ \text { afd. } 7.1 .6 & & 7.8 .3 \\ \text { afd. } 7.1 .7 & & 7.8 .3 \\ \text { afd. } 7.1 .8 & & 7.3 .7 .4,7.5,7.8 .3 \\ 7: 39 & \text { lid 1 } & 5.8 .3 .3 \\ 7: 42 & & 5.8 .3 .3 \\ 7: 44 & & 5.8 .3 .3 \\ 7: 406 & & 4.5 .8 \\ 7: 409 & \text { lid 3 } & 4.5 .8 \\ 7: 414 & \text { lid 1 } & 4.5 .8 \\ & \text { lid 3 } & 4.5 .8 \\ 7: 415 & \text { lid 1 } & 4.5 .8,4.9 .7 \\ & \text { lid 2 } & 4.5 .8 \\ 7: 416 & \text { lid 3 } & 4.5 .8\end{array}$

Boek 7 (ontwerp)

afd. 7.17 .3

5.10

7.17.3.20

5.10

7.17.3.20a

5.10

7.17.3.20b

5.10

Boek 8

$\begin{array}{lll}8: 541 & & 6.5 .2 .3 \\ 8: 610 & \text { lid } 1 & 2.5 .1 .3 \text { sub c } \\ 8: 1002 & & 6.5 .2 .3\end{array}$

Wet van 25 februari 1991, Stbl. 75, houdende invoering van Boek 8 van het nieuwe $B W$ vierde gedeelte

Hfdst. III

1

2.2.1 


\section{Kadasterwet}

$\begin{array}{lll}11 & \text { lid 1 } & 3.1 \\ 12 & \text { lid 1 } & 3.1 \\ & \text { lid } 4 & 3.1 \\ 36 & \text { lid 2 } & 3.8 .2 \\ & \text { lid 3 } & 3.8 .4\end{array}$

$B W($ oud)

563

592

630

631

632

633

634

635

636

639

658

659

660

661

668

671

721

736

743

760

765

766

767

773

779

780

781

782

783

804

807

862

863
2.2 .2

5.8.1.1, 5.8.1.7

2.4.1.2

2.4.1.2

2.4.1.2

2.4.1.2

2.4.1.2

2.4.1.2

2.4.1.2

2.4.1.4, 5.8.1.1

2.4.1.2

2.4 .1 .2

2.4.1.2

2.6 .3

2.4.1.4

3.5 .1

4.9 .5

4.9 .5

3.5 .1

3.5 .1

7.8 .2

$4.5 .4,7.8 .2$

3.5.1, 4.5.4

lid $1 \quad 4.9 .5$

2.3.2

4.5.4

$4.5 .4,7.8 .2$

lid $2 \quad 7.8 .2$

4.5 .4

$2.3 .2,4.5 .4,7.8 .2$

4.5.4, 7.8.2

2.3 .1

lid $1 \quad 3.5 .1$

7.8 .1

7.8 .1 
1117

1185

1190

1191

$1192 a$

1196

1198

1199

1200

1201

1203

1204

1205

1210

1212

1224

1226

1227

1.229

1230

1239

1240

1241

1266

1267

1268

1274

1286

1302

1303

1318

1353

1361

1364

1371

1373
2.5.1.2 sub f

sub $3 \quad 7.8 .3$

$5.8 .2 .1,7.8 .3$

$5.8 .1 .4,5.8 .1 .5,7.8 .3$

7.8 .3

lid $1 \quad 5.8 .1 .4,5.8 .1 .5,7.8 .3$

lid $2 \quad 5.8 .1 .5$

5.8 .2 .3

5.3

lid $5 \quad 5.8 .5$

5.3

5.7 .3

5.7 .2 .1

lid $1 \quad 5.7 .2 .1$

lid $2 \quad 5.7 .2 .1$

lid $1 \quad 5.7 .2 .1$

lid $1 \quad 5.7 .2 .1$

lid $2 \quad 2.3 .1$

sub I 5.7.2.1

5.6 .2

3.5 .1

3.6

lid $1 \quad 3.6$

lid $2 \quad 3.6$

3.6

3.6

2.3 .1

4.5 .4

3.5.1

3.5.1

3.5.1

3.2

3.2

3.2

7.6.2

7.6 .4

lid $1 \quad 7.6 .4$

lid $3 \quad 7.6 .4$

2.4.1.4, 5.8.1.3, 5.8.1.4, 7.6.5

2.4.1.4, 7.6.5

6.3

lid $12.4 .1 .4,4.9 .6$

4.5 .3

4.5 .3

$2.4 .1 .4,4.10 .3,4.10 .5$

$2.4 .1 .4,4.10 .3$ 
1374

$1376 a$

1377

1401

1403

1404

1405

1406

$1416 c$

1490

1496

1501

1503

1504

1505

1506

1507

1547

1582

1652

1719

1850

1910 (oud)

2000

2004

2014
$2.6 .1,2.6 .2$

lid $3 \quad 4.5 .5$

$3.7,4.9 .3,5.8 .1 .1,5.8 .1 .3$

$$
4.10 .1
$$

lid. $1 \quad 4.10 .1$

lid $2 \quad 2.4 .1 .4$

lid $3 \quad 6.5 .1 .1$

lid $5 \quad 2.4 .1 .4,6.5 .1 .2$

6.2

$6.2,6.5 .1 .2,6.5 .2 .1$

6.5 .1 .3

6.8

lid $2 \quad 4.10 .1$

7.8 .3

4.9 .7

4.7 .2

$4.5 .2,4.8 .3$

$4.5 .2,4.8 .3,4.9 .2$

$4.5 .2,4.8 .3$

4.7.2

7.8 .3

4.7 .2

5.8 .2 .7

$4.9 .1,4.9 .7,4.11$

sub $3 \quad 4.5 .8,4.9 .7$

4.9 .3

lid $1 \quad 4.9 .3$

6.5 .1

$4.9 .3,5.8 .1 .1,5.8 .1 .3,5.8 .1 .7$

Wet van 13 september 1990, Stbl. 784, tot aanpassing van het BW (oud) aan de EGrichtlijn inzake produktenaansprakelijkheid

II

$$
6.5 .2 .3
$$

Algemene wet inzake de douane en de accijnzen

$\begin{array}{lll}152 & \text { lid 2 } & 5.6 .4 \\ 156 & & 5.6 .4 \\ & \text { lid 4 } & 5.6 .4,7.8 .3 \\ 220 c & & 5.6 .4\end{array}$


Failissementswet

$\begin{array}{lll}33 & \text { lid 2 } & 5.6 .4 \\ 35 & \text { lid 2 } & 5.8 .1 .7,5.9 .2 \\ & \text { lid 3 } & 5.8 .5 \\ 37 & & 7.6 .3,7.6 .5 \\ 38 & & 7.6 .3,7.6 .5 \\ 63 a & \text { lid 1 } & 5.7 .3 \\ 108 & & 5.8 .5 \\ 236 & & 7.6 .3,7.6 .5 \\ 237 & & 7.6 .3,7.6 .5\end{array}$

Invorderingswet 1845
12
5.6 .4
16
5.6 .4

Invorderingswet 1990

21

$5.8 .2,5.8 .2 .6$

22

lid $2 \quad 5.6 .4,5.8 .2 .6$

5.6 .4

70

lid $3 \quad 5.6 .4,5.8 .2 .6,7.8 .3$

5.6 .4

WAM

6

5.8 .2 .5

Wet $A B$

4

2.5.1, 2.5.1.1 sub c, 2.5 .1 .4 sub b

Wet bodembescherming

47

6.5 .2 .3 
Wetsvoorstel 21556 (Uibreiding van de Wet bodembescheming ner een regeling inzake sanering van de bodem)

$\mathrm{V} \quad$ lid $1 \quad 6.5 .2 .3$

Wet op het consumentenkrediet

$\begin{array}{ll}40 & 5.6 .5 \\ 41 & 5.6 .5 \\ 42 & 5.6 .5 \\ 43 & 5.6 .5\end{array}$

Wet tot aanpassing wan de Wet op het consumentenkrediet (Stbl. 1991, 630)

V lid $1 \quad 4.4$

lid $2 \quad 5.6 .5$

Wet kadastraal recht (vervallen)

4

Wetboek van Burgerlije Rechtsvordering

$\begin{array}{lll}461 a & & 5.7 .2 .3,5.8 .5 \\ & \text { lid } 1 & 5.7 .2 .3 \\ 480-490 d & & 5.7 .3 \\ 483 a & & 5.6 .3 .2 \\ 490 b & & 5.7 .2 .3 \\ 492 & & 5.7 .2 .3 \\ 496 & & 5.7 .1,5.7 .2 .3 \\ & \text { lid 1. } & 5.7 .2 .3 \\ & \text { lid 2 } & 5.7 .2 .3 \\ & \text { lid 3 } & 5.7 .2 .3,5.8 .5 \\ 513 a & & 3.5 .1 \\ 730 \text { e.v. } & & 5.7 .2 .3\end{array}$

Wetboek van Burgerlijke Rechtswordering (oud)

$\begin{array}{rll}505 & \text { lid } 2 & 3.5 .1,3.6 \\ & \text { lid } 3 & 3.6 \\ \text { lid } 4 & 3.5 .1 \\ & \text { lid } 5 & 3.5 .1\end{array}$


Wetboek van Koophandel (oud)

230 e.v.

245

263

297
7.8 .3

7.8 .3

7.8 .3

$5.8 .1 .6,5.8 .3 .5$

Zaaizaad-en Plantgoedwet

$49 a$ 5.5

Voorstel voor een EG-richtlijn inzake dienstenaansprakelijkheid. PbEG I8 januari 1991, nr. C 12/11

11<smiles>[194Sn]</smiles> 


\section{Jurisprudentieregister}

Verwezen wordt naar pagina's.

Hoge Raad

HR 25 januari 1929, NJ 1929, 616 (Bierbrouwerij) 125

HR 21 juni 1929, NJ 1929, 1096 (Autoverhuuronderneming) 125

HR 22 december 1950, NJ 1951, 222 (Lemmerboot) 225

HR 30 maart 1951, NJ 1952, $29 \quad 227$

HR 30 maart 1951, NJ 1952, $697 \quad 10$

HR 22 mei 1953, NJ 1954, 189 (Sio) 160

HR 25 juni 1954, NJ 1955, 685 (doorverkochte rogge) 167

HR 29 september 1961, NJ 1962, 14 (Picus-Smallingerland) 160

HR 25 april 1969, NJ 1970,3 3

HR 6 maart 1970, NJ 1970, 433 (Van Wessem-Traffic ofwel Pluvier) 164, 172, 175

HR 8 juni 1973, NJ 1974, 346 (Kamphuis-Nationaal Grondbezit) $\quad 160$

HR 7 maart 1975, NJ 1976, 91 (Van Gend \& Loos) 164.

HR 10 oktober 1975, NJ 1976, 567

HR 17 december 1976, NJ 1977, 241. (Bunde-Erckens) $\quad 111 ; 112$

HR 16 december 1977, NJ 1978, 156 (Ziekenfonds) 57

HR 3 oktober 1980, NJ 1981, $60 \quad 143$

HR 24 oktober 1980, NJ 1981, 265 (Solleveld, Romijn \& Co. B.V. II) 195, 196

HR 22 mei 1981, NJ 1982, 59 (Van der Gun-Farmex) 234

HR 20 november 1981, NJ 1982, 517 (Holleman-De Klerk) 45

HR 27 april 1984, NJ 1984, 679 (NVB-Helder)

$57,58,61,98$

HR 25 mei 1984, RvdW 1984, 110 (Berggren-De Wit) 105

HR 19 oktober 1984, NJ 1985, 213 (CBI-IFN) 58

HR 21 juni 1985, NJ 1986, 306 (LDM-Brock) 164

HR 28 juni 1985, NJ 1986, $356 \quad 226$

HR 29 november 1985, NJ 1987, 291 (Van Amsterdam-Van den Hurk) 204

HR 25 april 1986, NJ 1986, 714 (Van der Meer-Gemeente Smilde) 60

HR 25 april 1986, NJ 1987, 742 (Consumentenbond-Gemeente Smilde) 60

HR 5 december 1986, NJ 1987, 382 (Bunde-Erckens) 112

HR 16 januari 1987, NJ 1987, 553 (Hooijen-De Tilburgsche Hypotheekbank) 60

HR 3 april 1987, NJ 1987, 703 (Van Gastel q.q.-Van den Heuvel) 226

HR 10 april 1987, NJ 1987, 829 143

HR 12 juni 1987, NJ 1988, 150 (Kriek-Smit) 57

HR 18 september 1987, NJ 1988, 983 (Berg \& Sons-De Bary) 173

HR 23 september 1988, NJ 1989, 743 (Kalimijnen) 226

HR 19 mei 1989, NJ 1990, 745 (IFN-CBI) 170 
HR 8 december 1989, NJ 1990,747 (WUH-Union Alantique)

HR 5 oktober 1990, RvdW 1990, 167 (Breda-Antonius)

HR 14 december 1990, NJ 1992, 20

HR 8 februari 1991, NJ 1992, 21

HR 15 maart 1991, RvdW 1991, 79 (Veenendaal q.q.-Hogeslag)

170,196

HR 8 juli 1991, NJ 1991, 691 (Kunst- en antiekstudio Lelystad)

57,60

HR 27 september 1991, NJ 1991, 80 I (Groenendijk-Stapel)

\section{Gerechtshoven}

Hof "s-Gravenhage 15 maart 1950, NJ 1950, 764

Hof 's-Gravenhage 16 mei 1962, NJ 1963, 203

Hol Arnhem 23 juni 1964, NJ 1965, 378

Hof Amsterdam 16 mei 1974, kenbaar uit HR 10 oktober 1975, NJ 1976, 56711

Hof Arnhem 9 november 1982, NJ 1987, 714 (Erckens-Bunde)

Hof 's-Hertogenbosch 30 oktober 1989 , rolnummer 196/89/Ma

(niet gepubliceerd) (Meerssen-Erckens)

\section{Arrondissementsrechtbanken}

Rb. Almelo 7 april 1948, NJ 1949, 50

Rb. Breda 24 december 1957, NJ 1958, 383

Rb. Middelburg 3 februari 1960, NJ 1960, 467

Rb. Rotterdam 15 mei 1962, NJ 1962, 433

Rb. Utrecht 25 mei 1966, kenbaar uit HR 25 april 1969, NJ 1970, 3

Rb. Utrecht 17 november 1971, kenbaar uit HR 10 oktober 1975, NJ 1976, 56711

Rb. Alkmaar 25 mei 1978, NJ 1979, 331.

Pres. Rb. Maastricht 22 december 1987, rolnummer 356/1987

(niet gepubliceerd) (Meerssen-Erckens)

Rb. Maastricht 5 januari 1989, rolnummer 1169/88 (niet gepubliceerd)

(Meerssen-Erckens)

Pres. Rb. Maastricht 15 november 1989, rolnummer 498/1989

(niet gepubliceerd) (Meerssen-Erckens)

112,113

Rb. Zwolle 6 juni 1990, BR 1990, p. 861 


\section{Curriculum vitae}

H.L. van der Beek werd op 19 februari 1961 geboren te Elburg. Hij bezocht vanaf 1973 de Rijksscholengemeenschap Ooststellingwerf te Oosterwolde (Frl.), alwaar hij in 1979 het diploma Atheneum-B behaalde. Van 1979 tot 1981 studeerde hij rechten aan de Rijksuniversiteit te Groningen. Na aldaar het kandidaatsexamen met goed gevolg te hebben afgelegd, zette hij zijn rechtenstudie voort aan de toenmalige Katholieke Hogeschool Tilburg, Op 23 november 1984 studeerde hij aldaar cum laude af in de privaatrechtelijke afstudeerrichting.

Vanaf 1 november 1984 tot heden is hij werkzaam aan de Rijksuniversiteit Limburg, aanvankelijk als wetenschappelijk assistent privaatrecht en vanaf 1 januari 1987 als universitair docent privaatrecht. Hij publiceerde over uiteenlopende onderwerpen, onder meer op het gebied van het overgangsrecht en het bouwrecht. 